\title{
Povećanje raspoloživosti mrežnih uređaja primjenom upravljačkoga konfiguracijskoga standarda
}

Valenčić, Davorin

Doctoral thesis / Disertacija

2020

Degree Grantor / Ustanova koja je dodijelila akademski / stručni stupanj: University of Zagreb, University of Zagreb, Faculty of Humanities and Social Sciences / Sveučilište u Zagrebu, Filozofski fakultet

https://doi.org/10.17234/diss.2020.8667

Permanent link / Trajna poveznica: https://urn.nsk.hr/urn:nbn:hr:131:006473

Rights / Prava: In copyright/Zaštićeno autorskim pravom.

Download date / Datum preuzimanja: 2023-04-26

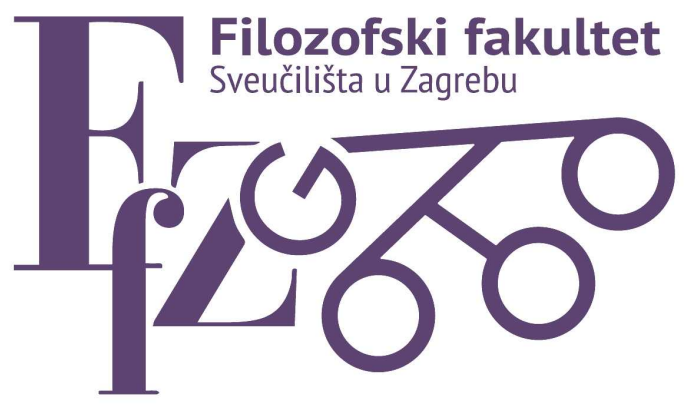

Repository / Repozitorij:

ODRAZ - open repository of the University of Zagreb Faculty of Humanities and Social Sciences
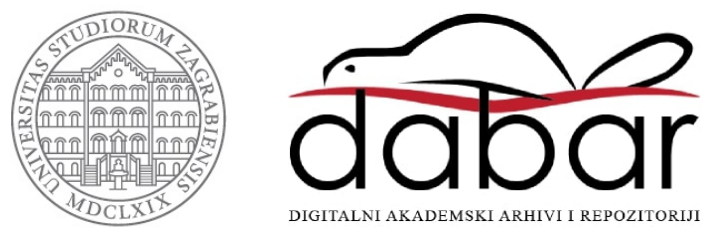


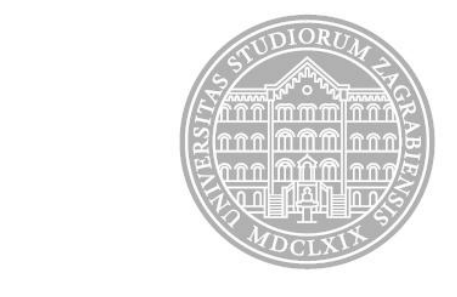

Sveučilište u Zagrebu

FILOZOFSKI FAKULTET

Davorin Valenčić

\section{POVEĆANJE RASPOLOŽIVOSTI MREŽNIH UREĐAJA PRIMJENOM UPRAVLJAČKOGA KONFIGURACIJSKOGA STANDARDA}

DOKTORSKI RAD

Zagreb, 2020. 



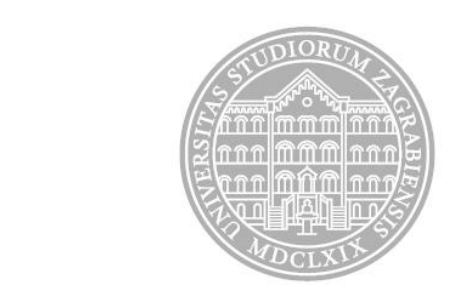

Sveučilište u Zagrebu

FILOZOFSKI FAKULTET

Davorin Valenčić

\title{
POVEĆANJE RASPOLOŽIVOSTI MREŽNIH
}

\section{UREĐAJA PRIMJENOM UPRAVLJAČKOGA}

KONFIGURACIJSKOGA STANDARDA

\author{
DOKTORSKI RAD \\ Mentor: \\ dr. sc. Vladimir Mateljan, red. prof.
}

Zagreb, 2020. 


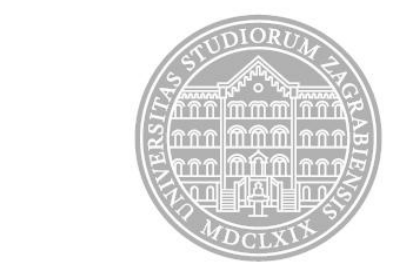

University of Zagreb

FACULTY OF HUMANITIES AND SOCIAL SCIENCES

Davorin Valenčić

\title{
INCREASING THE AVAILABILITY OF NETWORK DEVICES BY IMPLEMENTING THE COMMAND CONFIGURATION STANDARD
}

\author{
DOCTORAL THESIS \\ Supervisor: \\ Ph. D. Vladimir Mateljan, full professor
}

Zagreb, 2020 


\section{INFORMACIJE O MENTORU}

Prof. dr. sc. Vladimir Mateljan (matični broj znanstvenika 188826) je informacijski stručnjak, sveučilišni profesor u trajnom zvanju. Diplomirao je na Prirodoslovnomatematičkom fakultetu $\mathrm{u}$ Zagrebu, smjer: primijenjena matematika $\mathrm{s}$ temom iz područja parcijalnih diferencijalnih jednadžbi, s diplomskim radom Hiperbolički sistemi i stekao zvanje diplomirani inženjer matematike (1981). Predavao matematiku i informatiku na raznim školama u Zadru i Zagrebu (1981-1983). Radio kao informacijski i računalni stručnjak u 'GEOTEHNICI' u Zagrebu, kao projektant i programer matematičkih-tehničkih modela i aplikacija za istraživanje podzemnih voda $i$ zona utjecaja bunara (1983-1987). Radio u tvornici računskih strojeva 'TRS' i 'INI' u Zagrebu, kao voditelj softwareskih projekata (1987-1990). Bio rukovodilac Elektroničkog računskog centra u poduzeću 'MONTER' u Zagrebu (1991).Upisao postdiplomski studij 'Projektiranje informacijskih sustava' na Fakultetu organizacije i informatike u Varaždinu (1989). Magistrirao i stekao znanstveni stupanj magistra informacijskih znanosti s tezom Upotreba matričnog prikaza u postupku dobivanja grafa skupa funkcijskih ovisnosti i modifikacija Bernsteinovog algoritma za normalizaciju sintezom (1992). Za višeg asistenta na Odsjeku za informacijske znanosti Filozofskog fakulteta u Zagrebu izabran je 1992.Godine. Prijavio doktorat na Filozofskom fakultetu u Zagrebu (1993). Doktorirao na Filozofskom fakultetu s tezom Utjecaj redundancije u bazi podataka na brzinu obrade (1996). Godine 1997. izabran je za docenta, 2002. god. za izvanrednog profesora, 2006. za redovitog profesora, a 2011. za redovitog profesora u trajnom zvanju, na Filozofskom fakultetu u Zagrebu na Odsjeku za informacijske i komunikacijske znanosti. Predaje na Odsjeku za informacijske znanosti na dodiplomskom i poslijediplomskom studiju. Voditelj je poslijediplomskog studija društveno humanističke informatike na Odsjeku za informacijske znanosti od 2002. god. Predstojnik je Katedre za društveno humanističku informatiku na istom Odsjeku u periodu 2004. 2009. Ponovo je izabran za predstojnika Katedre 2013. god. Pročelnik Odsjeka za informacijske i komunikacijske znanosti je bio od 2009. do 2013. godine, od 2015. do 2017. s novim mandatom od 2017. do 2019. godine. Od 2010. godine je član Matičnog odbora za informacijske i komunikacijske znanosti. Predavao predmete iz područja informatike, i programiranja baza podataka na Tehničkom veleučilištu u 
Zagrebu (od 1997), Agronomskom fakultetu (od 2004), Tehničkom veleučilištu u Velikoj gorici (od 2005), u Sarajevu i Mostaru (BIH), Visokoj školi za poslovanje i upravljanje u Zaprešiću (od 2010). Senat u Novom Sadu (RS) izabrao ga je 2008. u zvanje gostujućeg profesora iz znanstvenog područja Informatike sa metodikom nastave na Pedagoškom fakultetu u Somboru, gdje je iste godine kao gostujući profesor predavao preko projekta međunarodne suradnje (Basileus). Odlukom Izbornog vijeća Fakulteta za ekonomiju i inženjerski menadžment Univerziteta Privredna akademija u Novom Sadu izabran je 11.10.2013. za gostujućeg profesora za predmete Alati i metode softverskog inženjerstva i predmet Logičko programiranje na master akademskim studijima, na studijskom programu Informatika. Bio je voditelj i sudjelovao je na više znanstvenih projekata. Objavio je više znanstvenih i stručnih radova.

Znanstveni interes prof.dr.sc. Vladimira Mateljana usmjeren je prema logici, logičkom programiranju i logičkom oblikovanju baza podataka, istraživanju odnosa između predikatnog računa i računa funkcijskih zavisnosti te postavljanje teorijskih osnova za njihovu primjenu u problemskim područjima baza podataka i baza znanja. U svojim se znanstvenim radovima bavi problemima logičkog oblikovanja baza podataka i logike.

Do listopada 2019. na studiju informacijskih I komunikacoijskih znanosti na Filozofskom fakultetu Sveučilišta u Zagrebu predaje kolegije Matematika, Logika za informatičare, Kombinatorika i grafovi, Vjerojatnost i statistika, Logičko programiranje i Baze podataka. Na poslijediplomskom doktorskom studiju informacijskih znanosti predaje kolegije Teorija oblikovanja baze podataka i Modalna logika. U listopadu 2019. godine, prof.dr.sc. Vladimir Mateljan je otišao u mirovinu. Od 01.11.2019. zaposlen je na Veleučilištu s pravom javnosti, Baltazar-Adam-Krčelić, na pola radnog vremena i tamo predaje kolegije: Baze poataka, Uvod u kriptografiju, Mobilne aplikacije, Sistemski inženjering. 


\section{SAŽETAK}

Administriranje i konfiguriranje mrežnih uređaja (usmjernika i preklopnika) od početka računalnog umrežavanja uglavnom se izvršava pomoću operacijskih sustava proizvođača mrežne opreme koji koriste svoje nestandardno komandno i tekstualno korisničko sučelje (engl. Command Line Interface - CLI). To se pokazuje kao vrlo složeno i neefikasno rješenje, pogotovo stoga što se računalne mreže sve više razvijaju i postaju složenije.

IETF (Internet Engineering Task Force) standardna organizacija je 2006. godine kreirala protokol NETCONF s ciljem definiranja standardnog komandnog korisničkog CLI sučelja za konfiguriranje mrežnih uređaja različitih proizvođača.

Osim u klasičnim računalnim mrežama, važnost NETCONF standarda se pojavljuje i u primjeni novih i nadolazećih mrežnih arhitektura, kao na primjer softverski definiranih mreža (engl. Software Defined Networking - SDN) i internetu stvari (engl. Internet of Things - IoT), a pogotovo u sustavima koji traže visoku raspoloživost (na primjer $\mathrm{u}$ bolnicama, zračnim lukama ili podatkovnim centrima).

Danas, nakon više od deset godina od nastanka standarda NETCONF, postavlja se pitanje kolika je stvarna prihvaćenost i primjena NETCONF standarda $u$ današnjim mrežama i kakva je njegova zrelost.

Tema doktorskog rada je određivanje prednosti NETCONF standarda u odnosu na dosadašnje nestandardne metode komandne konfiguracije s ciljem postizanja veće raspoloživosti mrežnih uređaja. Osim toga, odredit će se stupanj nekorištenja NETCONF standarda od strane svjetskih proizvođača mrežne opreme i predložiti preporuke za povećanje i poboljšanje implementacije. Također, odredit će se stupanj nekorištenja od strane korisnika mrežne opreme i predložiti model rada (aktivnosti) s korisnicima koji će osigurati povećanje korištenja NETCONF standarda sa svim njegovim prednostima.

\section{Ključne riječi}

NETCONF, usmjernik, preklopnik, komandno korisničko sučelje, mrežno upravljanje, standard, raspoloživost 


\section{ABSTRACT}

Since the beginning of computer networking the administration and configuration of network devices (routers and switches) have been usually performed by using the vendors' operating systems and their non-standard user CLI (Command Line Interface). This has proven to be a very complex and ineffective solution, especially with fast development and more complexity in the computer networking area.

IETF (Internet Engineering Task Force) standard organization created in 2006 the NETCONF protocol in order to define the standard solution for command-oriented CLI user interface for the configuration of network devices of different vendors.

Apart from classical computer networks, the importance of NETCONF standard occurs also in the application of new upcoming network architectures, such as Software Defined Networking (SDN) and Internet of Things (IoT), and especially in systems requiring high availability (e.g. hospitals, airports and Data Centers).

Today, more than ten years after the creation of the NETCONF standard there is the question about the actual acceptance of NETCONF protocol in current networks and about the actual maturity of NETCONF standard.

The topic of the doctoral dissertation deals with defining of advantages of the NETCONF standard in order to obtain higher availability of network devices. Besides, the current state of non-implementation of NETCONF standard by world vendors of networking equipment will be defined and recommendations for increase and improvement in implementation will be proposed. Also, the level of nonimplementation by the network equipment users will be determined and the operation model (activities) with the users will be proposed that will assure an increase in the usage of NETCONF standard with all its advantages.

\section{Keywords}

NETCONF, router, switch, Command Line Interface, network management, standard, availability 


\section{Sadržaj}

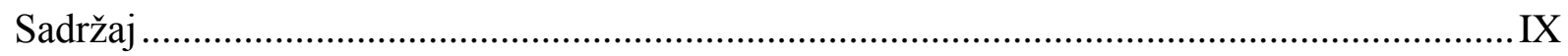

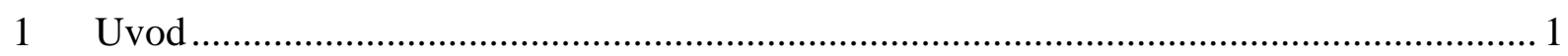

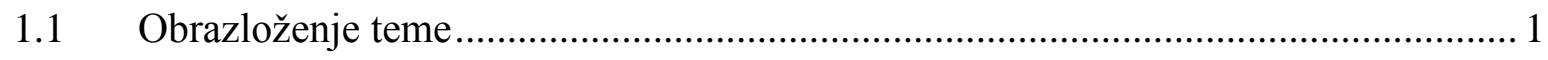

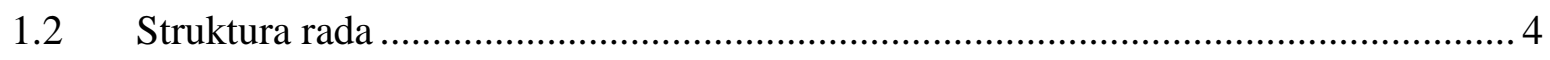

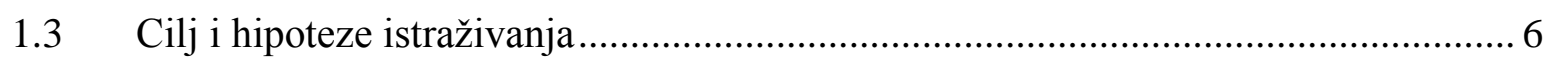

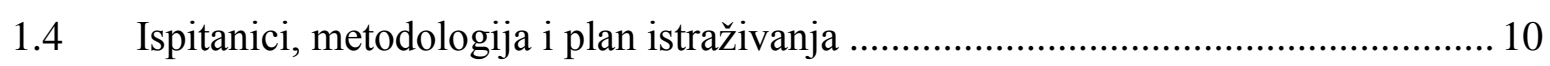

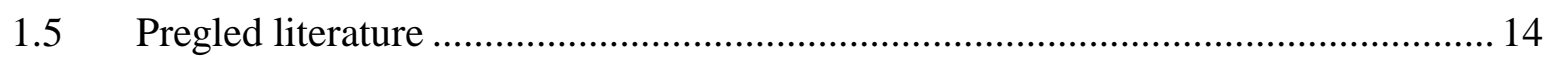

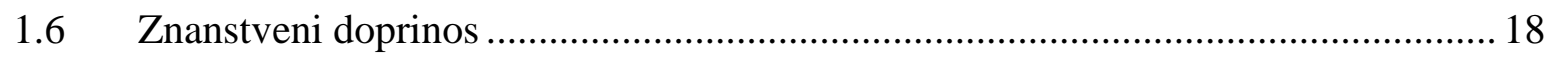

2 Upravljanje sistemskim podacima uređaja računalnih mreža ..................................... 19

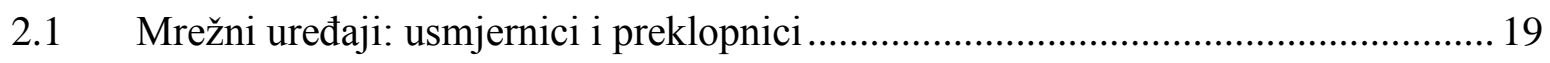

2.2 Upravljanje računalnim mrežama .................................................................. 22

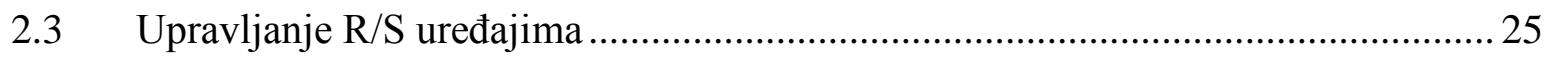

2.3.1 Tradicionalan način upravljanja R/S uređajima ............................................... 26

2.3.2 Upravljanje operacijskim podacima R/S uređaja ........................................... 27

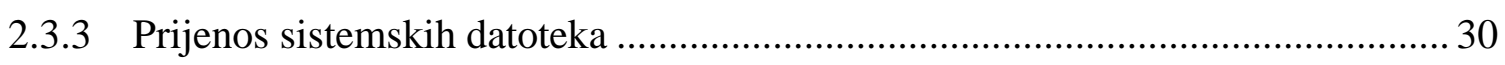

2.4 Upravljanje konfiguracijskim podacima R/S uređaja ...................................... 31

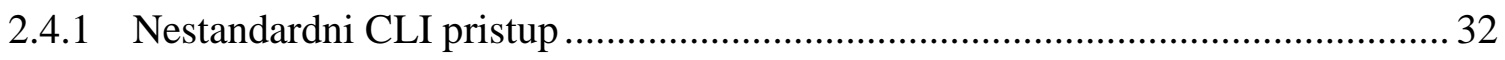

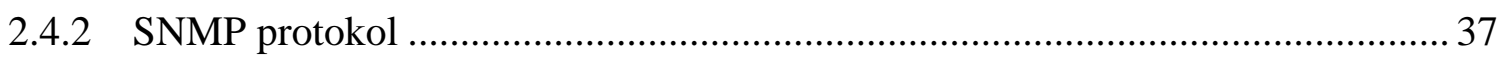

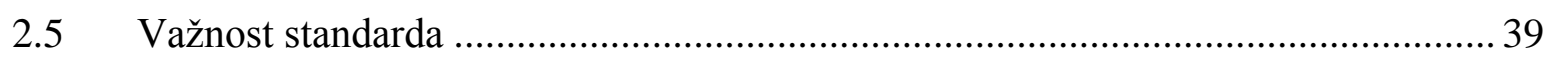

2.6 Trendovi u upravljanju mrežnim uređajima: SDN mreže ................................... 42

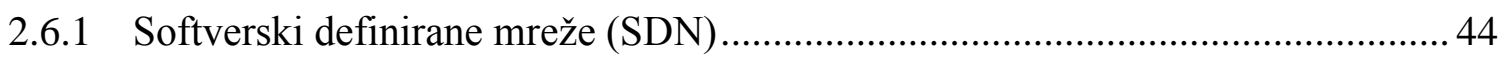

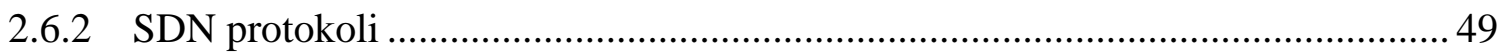

2.6.3 Primjena SDN tehnologije na mrežnim uređajima .......................................52 
2.6.4 Važnost SDN mreža 54

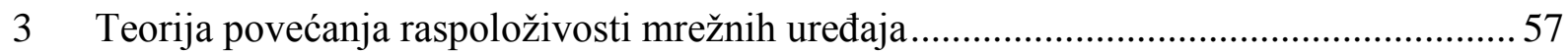

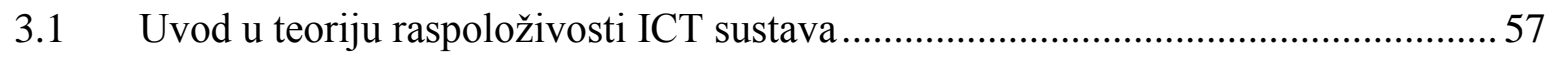

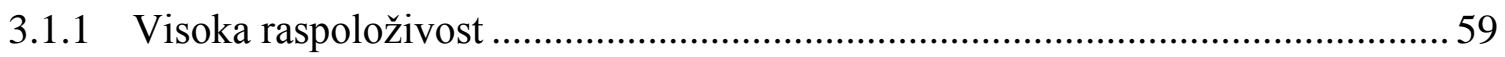

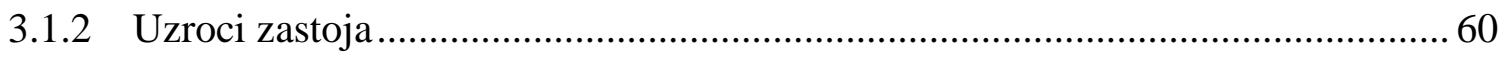

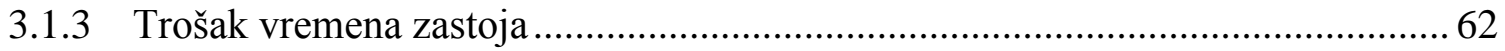

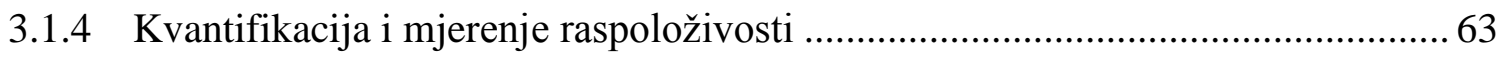

3.2 Povećanje raspoloživosti mrežnih sustava i uređaja. ......................................... 68

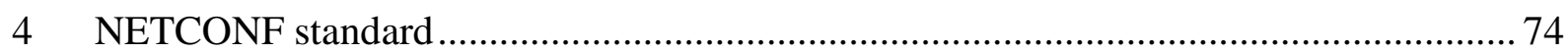

4.1 Uvod u NETCONF standard i njegov nastanak ........................................... 74

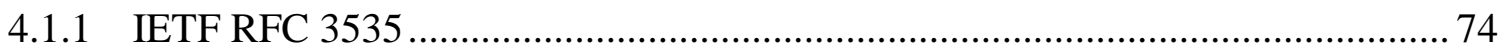

4.2 Osnovna svojstva i prednosti NETCONF standarda ............................................. 77

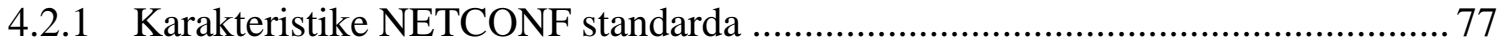

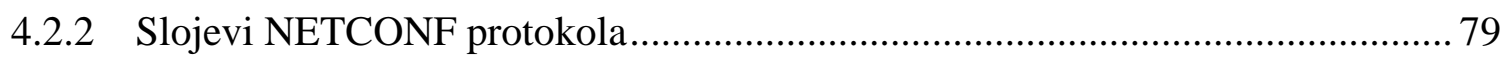

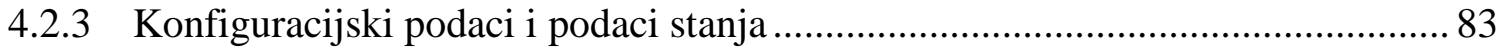

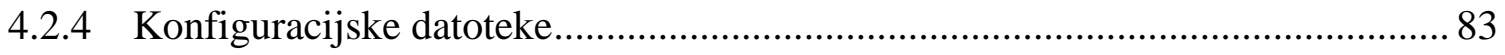

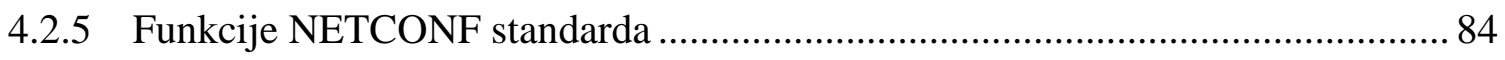

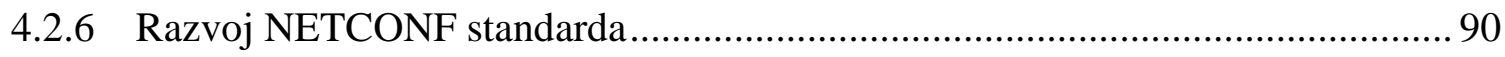

4.3 Današnji status NETCONF protokola kao standarda.......................................... 90

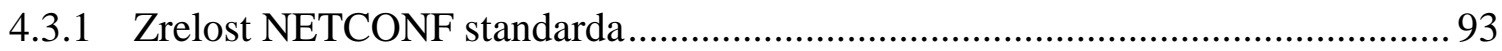

5 NETCONF standard i povećanje raspoloživosti mrežnih uređaja .............................. 96

5.1 Usporedba metoda konfiguriranja mrežnih uređaja ........................................ 97

5.1.1 Svojstva NETCONF standarda za povećanje raspoloživosti ........................... 102

5.2 Informacije proizvođača o implementaciji NETCONF standarda ........................ 104

5.3 Testiranje funkcija NETCONF standarda u laboratoriju ................................... 105

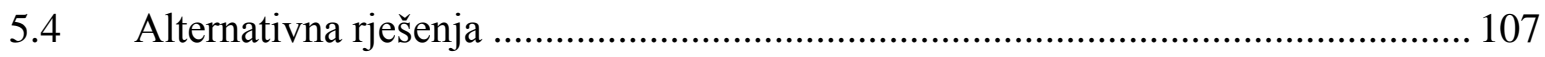

6 Povećanje raspoloživosti pomoću NETCONF standarda i primjena u Hrvatskoj ......... 110

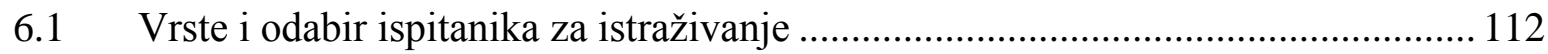


6.1.1 Odnos proizvođača, partnera i krajnjih korisnika mrežnih uređaja .................. 112

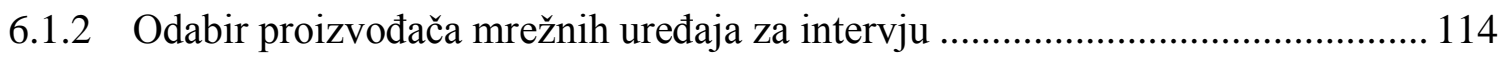

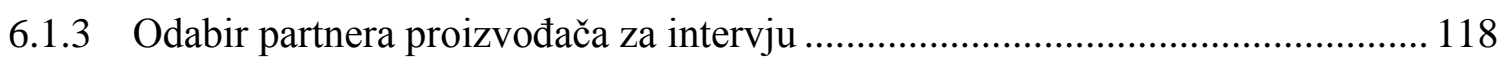

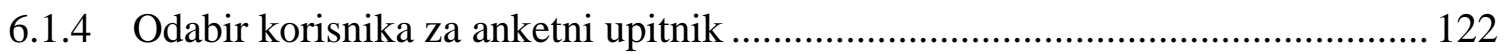

6.1.5 Provedba istraživanja pomoću intervjua i anketnog upitnika ........................... 123

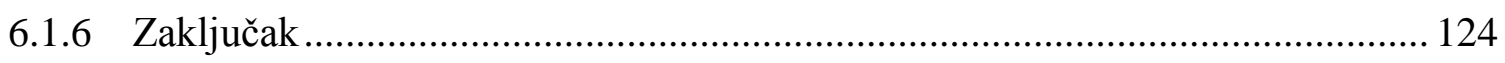

6.2 Dobiveni podaci od ispitanika (intervju s proizvođačima) .................................... 126

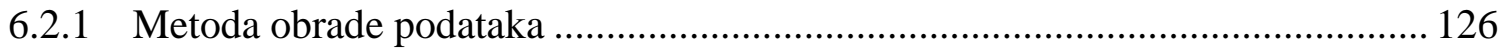

6.2.2 Primjena NETCONF standarda kod proizvođača R/S uređaja ........................ 127

6.2.3 NETCONF i povećanje raspoloživosti R/S uređaja ........................................ 135

6.2.4 Karakteristike i povećanje primjene NETCONF standarda ............................. 137

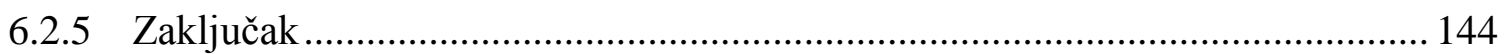

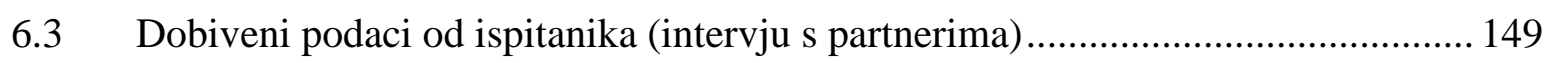

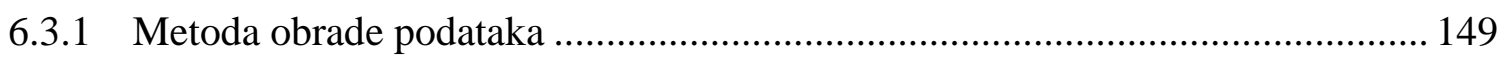

6.3.2 Primjena NETCONF standarda kod proizvođača R/S uređaja ......................... 150

6.3.3 Primjena NETCONF standarda od strane korisnika u Hrvatskoj ..................... 153

6.3.4 Poznavanje NETCONF standarda od strane korisnika u Hrvatskoj .................. 160

6.3.5 NETCONF i povećanje raspoloživosti R/S uređaja ........................................ 165

6.3.6 Karakteristike i povećanje primjene NETCONF standarda ............................. 170

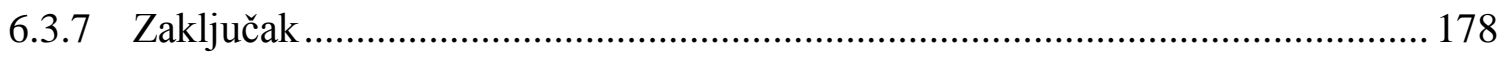

6.4 Dobiveni podaci od ispitanika (anketni upitnik korisnika) .................................. 185

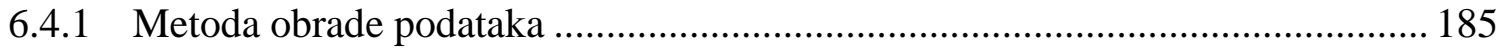

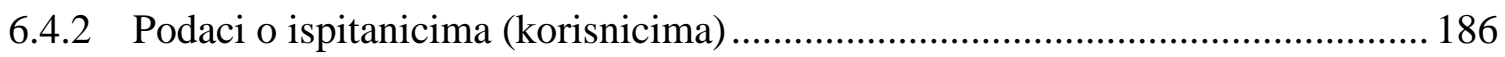

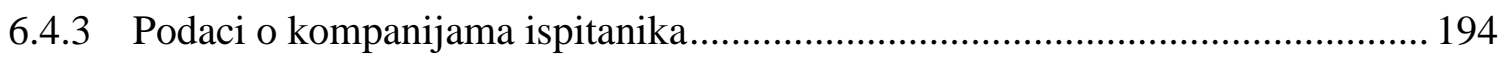

6.4.4 Primjena NETCONF standarda kod proizvođača R/S uređaja ......................... 200

6.4.5 Primjena NETCONF standarda od strane korisnika u Hrvatskoj ...................... 208

6.4.6 Poznavanje NETCONF standarda od strane korisnika u Hrvatskoj .................. 216

6.4.7 NETCONF i povećanje raspoloživosti R/S uređaja ....................................... 218

6.4.8 Karakteristike i povećanje primjene NETCONF standarda ............................. 223

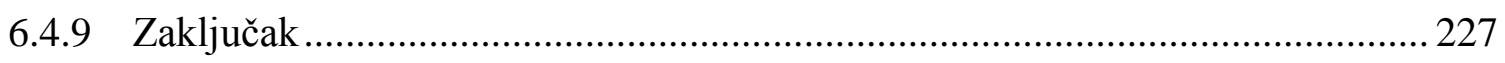

$7 \quad$ Usporedba i dodatna analiza dobivenih rezultata istraživanja .................................... 236 
8 Testiranje hipoteza 258

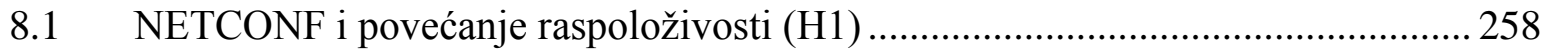

8.2 Primjena NETCONF standarda od proizvođača R/S uređaja $(\mathrm{H} 2)$....................... 260

8.3 Primjena NETCONF standarda u kompaniji korisnika $(\mathrm{H} 3)$.............................. 262

8.4 Poznavanje NETCONF standarda od strane korisnika $(\mathrm{H} 4)$................................ 263

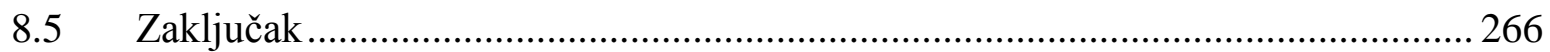

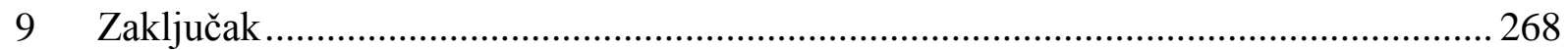

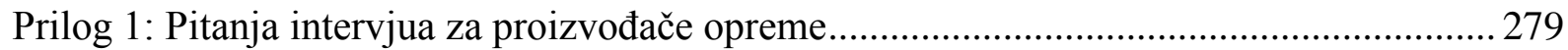

Prilog 2: Pitanja intervjua za partnere u Hrvatskoj ......................................................... 289

Prilog 3: Pitanja anketnog upitnika za krajnje korisnike u Hrvatskoj .................................. 307

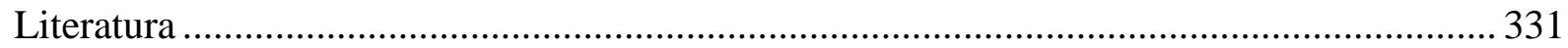

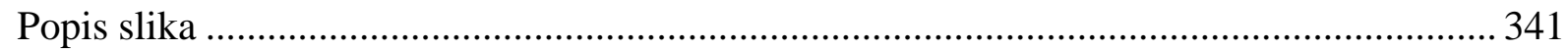

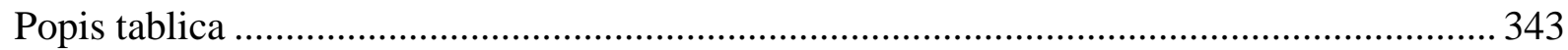

Popis hrvatskih naziva za osnovne pojmove računalnih mreža na engleskom jeziku ........... 349

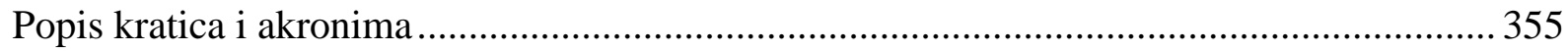

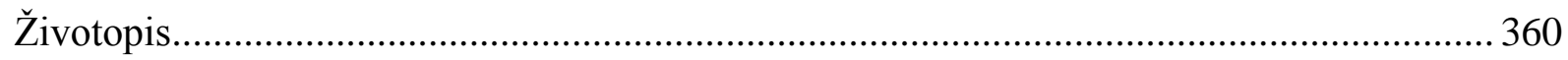

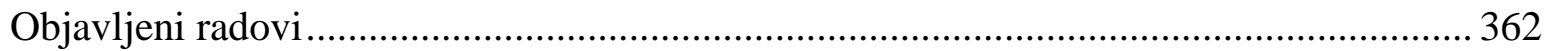




\section{Uvod}

\subsection{Obrazloženje teme}

Osnovicu današnjih računalnih mreža i Interneta čini TCP/IP grupa protokola i posredovni mrežni uređaji usmjernici (engl. router) i preklopnici (engl. switch). Upravljanje računalnim mrežama (engl. Network Management - NM) i mrežnim uređajima bavi se uglavnom operacijama obavljenim sa sistemskim (konfiguracijskim i operativnim) podacima računalnih mrežnih uređaja. Konfiguriranje mrežnih uređaja (usmjernika i preklopnika) danas se uglavnom izvršava pomoću operacijskih sustava (OS) proizvođača opreme (npr. Cisco IOS, Juniper JUNOS, Extreme EXOS i drugi), koji su međusobno različiti, ali svi koriste svoje nestandardno komandno korisničko sučelje (engl. Command Line Interface - CLI).

Konfiguriranje mrežnih uređaja pomoću nestandardnog CLI sučelja proizvođača opreme ima svoje brojne nedostatke, kao na primjer (a) različitu strukturu komandi, (b) različitu strukturu podataka, (c) različitu strukturu poruka (greške, obavijesti i drugo), koje za posljedicu imaju (a) obaveznu edukaciju mrežnih administratora za različite OS proizvođača, (b) praktično nemoguće postizanje automatizacije upravljanja i (c) složeni prijelaz na novi sustav drugog proizvođača u slučaju prekida rada i drugo. Na taj se način znatno smanjuje otpornost, stabilnost i fleksibilnost mrežnih sustava u kriznim situacijama i njihova raspoloživost.

IETF (Internet Engineering Task Force) standardna organizacija (koja definira današnji Internet i njegovu bazu TCP/IP grupu protokola) od početka je pokušala pomoću svojih RFC dokumenata standardizirati i ovo područje, posebno sa SNMP (Simple Network Management Protocol) standardom.

SNMP standard je vrlo raširen protokol za nadzor mreže, odnosno za dobivanje konfiguracije i operativnog stanja mrežnih uređaja, kao i za javljanje promjene stanja. Iako je u tu svrhu bio 
inicijalno i razvijen, SNMP se u praksi rijetko ili uopće ne koristi za konfiguriranje mrežnih uređaja. Najveći uzrok je što SNMP ne sadrži komandno CLI sučelje koje je puno preglednije i praktičnije za mrežnog administratora. Zbog toga se, umjesto SNMP standarda, uglavnom koriste nestandardna komandna CLI sučelja proizvođača uređaja koja su različita za svakog proizvođača.

U lipnju 2002. godine održan je sastanak IETF zajednice za mrežno upravljanje s mrežnim operatorima gdje su definirani zahtjevi (u RFC 3535) za standardnim komandnim CLI sučeljem. Na temelju tih zahtjeva nastao je NETCONF protokol.

NETCONF je standard za komandno orijentirani pristup (CLI) konfiguraciji mrežnih uređaja i definiran je 2006. godine u RFC 4741, a kasnije poboljšan 2011. godine u RFC 6241. NETCONF koristi YANG kao modelirajući jezik za definiranje semantike operacijskih podataka, konfiguracijskih podataka, notifikacija i operacija. YANG je definiran u RFC 6020 u listopadu 2010. godine.

Cilj definiranja NETCONF standarda je postizanje standardiziranog, jednostavnijeg i efikasnijeg konfiguriranja mrežnih uređaja. Mogućnost primjene NETCONF standarda je izuzetno široka i važna za budući razvoj računalnih mreža.

Novi trendovi razvoja računalnih mreža (virtualizacija, centralizacija i programabilnost upravljanja, kao i mobilnost uređaja) su osnova nastanka računalstva u oblaku sa SDN (engl. Software Defined Networking) arhitekturom, kao i IoT (engl. Internet of Things) arhitekture. SDN nudi programabilni pristup računalnim mrežama i omogućava efikasniju i jednostavniju instalaciju, upravljanje i praćenje stanja računalnih mreža.

Obje ove napredne arhitekture (SDN i IOT) izražavaju potrebu za standardnim sučeljem za komandnu konfiguraciju svojih uređaja. Tako SDN arhitektura (definirana od strane IETF-a u RFC 7426 u siječnju 2015.) koristi dva osnovna protokola za upravljanje konfiguracijom mrežnih uređaja: komandno orijentirani NETCONF i podatkovno orijentiran SNMPv3.

Primjena NETCONF standarda je posebno važna u mrežnim sustavima koji zahtijevaju visoku raspoloživost (kao na primjer u podatkovnim centrima). 
Nakon više od deset godina od nastanka NETCONF standarda postavlja se pitanje kolika je stvarna prihvaćenost i primjena ovog standarda u današnjim mrežama i kolika je njegova zrelost.

IETF definira u RFC 6410 postojanje dvaju nivoa zrelosti RFC standarda: “predloženi” (engl. proposed) i "Internet standard". Da bi standard prešao u najviši nivo (status "Internet standard"), trebala bi postojati široka upotreba tog standarda u korisničkoj praksi, odnosno RFC treba biti prihvaćen u svakodnevnoj primjeni. Trenutni status NETCONF standarda je "predložen”, a SNMPv3 ima status "Internet standard".

Budući da korisnici (administratori, sistemski inženjeri, arhitekti mrežnih sustava i drugi) odabirom i instalacijom nekog protokola u svojim mrežama određuju važnost i zrelost RFC standarda, potrebno je ispitati širinu i način primjene NETCONF standarda u Hrvatskoj (više od deset godina nakon što je prva verzija standarda objavljena, što je vrlo dug period u ICT području).

Što je neka tehnologija promijenjenija, dostići će se i viši stupanj njene zrelosti. Pod zrelošću se podrazumijeva koliki je stupanj primjene proizvođača, funkcije koje su primijenjene, učestalost programskih grešaka (engl. bug) koje se pojavljuju, interoperabilnost između različitih proizvoda i proizvođača, dokumentacija i edukacija proizvođača i drugo. Izuzetno važan faktor hoće li neki standard uspjeti u ICT primjeni i biti široko primijenjen u računalnim sustavima su korisnici i njihovo (subjektivno) prihvaćanje i primjena tehnologije. Povećanje primjene standarda rezultira povećanjem njegove zrelosti, a s time i povećanjem raspoloživosti mrežnih uređaja i cijelog mrežnog sustava.

Značajan utjecaj na definiranje istraživačkog pitanja u doktorskoj disertaciji bilo je autorovo dugogodišnje (više od 25 godina) iskustvo rada s mrežnim uređajima kao zaposlenika kod različitih proizvođače mrežne opreme (Cisco, Extreme Networks i 3Com) i više korisnika u Hrvatskoj i Europi, kao i trenutnog rada u edukaciji u tom području (kao predavač na Visokoj školi i voditelj Cisco mrežne akademije). Autor se cijelo to vrijeme susretao sa svim nedostatcima nestandardnog CLI komandnog konfiguracijskog sučelja i neuspjelom primjenom SNMP standarda u tom području. Zbog toga autor potpuno shvaća potrebu za zrelim i široko primijenjenim standardom za komandno konfiguracijsko CLI sučelje (kao što 
je NETCONF) koji bi znatno pojednostavio i optimizirao rad s mrežnim uređajima, a time i povećao njihovu raspoloživost. Međutim, kroz trenutno dostupne informacije i razgovore s kolegama, postavlja se ključno pitanje koliko je NETCONF standard uistinu prihvaćen i primijenjen i od strane proizvođača i od strane korisnika, i što bi trebalo napraviti i poboljšati da dođe do njegove šire primjene.

\subsection{Struktura rada}

Rad je organiziran u devet poglavlja.

U prvom poglavlju daju se osnove znanstvenog istraživanja ovog rada određene u Prijavi teme doktorskog rada (Dr.Sc.-01 dokumentu): znanstveni problem, predmet znanstvenog istraživanja, objekti istraživanja, hipoteze istraživanja, svrha i ciljevi istraživanja, istraživačka pitanja, uzorak istraživanja, metodologija istraživanja, znanstveni doprinos i plan istraživanja. Osim toga, dan je kratak pregled vrsta korištene literature.

Od drugog do petog poglavlja napravljen je teoretski uvod u temu istraživanja, odnosno prikazani su rezultati sekundarnog istraživanja.

U drugom su poglavlju ukratko objašnjeni osnovni pojmovi iz računalnih mreža važni za ovaj rad: vrste mrežnih uređaja, svrha i način rada usmjernika i preklopnika, kao i najčešći modeli upravljanja računalnim mrežama. Osim toga, objašnjen je tradicionalan način upravljanja sistemskim podacima usmjernika i preklopnika (uobičajene metode i protokoli koji se koriste), a detaljno je opisano upravljanje konfiguracijskim podacima. Zatim je u ovom poglavlju opisana i naglašena važnost standarda u primjeni računalnih mreža. U drugom dijelu ovog poglavlja prikazani su trendovi u upravljanju računalnim mrežama, odnosno softverski definirane mreže koje uvode izuzetno značajne promjene u računalnim mrežama. Prikazana je arhitektura SDN mreža (čiji je sastavni dio i NETCONF), osnovni protokoli koje koristi, kao i primjeri implementacije različitih vodećih proizvođača na tržištu.

U trećem je poglavlju objašnjen pojam raspoloživosti, kao i ostali pojmovi iz tog područja (visoka raspoloživost, prekid, vrijeme zastoja). Prikazani su primjeri najčešćih uzroka zastoja 
ICT uređaja, kao i pregled i važnost troška vremena zastoja za različite ICT usluge. Osim toga, prikazana je formula za izračunavanje raspoloživosti i najčešći način prikaza raspoloživosti pomoću „n-devetki“. U drugom dijelu ovog poglavlja prikazani su osnovni uzroci neraspoloživosti računalne mreže, kao i načini i komponente za povećanje raspoloživosti mrežnih uređaja i računalne mreže.

U četvrtom poglavlju je detaljno prikazan NETCONF standard: razlog i način nastanka, osnovna svojstva i prednosti, slojevi protokola i njegove funkcije. Osim toga, prikazan je i današnji status standarda kao sastavni dio NM i SDN standarda definiranih u RFC dokumentima, a razmatra se i njegova zrelost i primjena od strane proizvođača i korisnika.

U petom se poglavlju razmatra NETCONF standard i njegova primjena u povećanju raspoloživosti R/S uređaja. U prvom dijelu ovog poglavlja uspoređuju se i analiziraju metode konfiguriranja R/S uređaja (CLI, SNMP i NETCONF) i razmatra se primjena NETCONF standarda. Ovaj dio rada nastao je kao priprema za primarno istraživanje i objavljen je (uz male izmjene) u članku na konferenciji Mipro 2019. U nastavku ovog poglavlja autor definira osnovna svojstva (mogućnosti) NETCONF standarda kojima se povećava raspoloživost R/S uređaja, a koja se razmatraju u primarnom istraživanju. U drugom dijelu ovog poglavlja prikazani su primjeri informacija proizvođača o implementaciji NETCONF standarda na njihovim uređajima, a ukratko su navedena i alternativna/slična rješenja NETCONF standardu koja se trenutno koriste na tržištu. Prikazani su i rezultati laboratorijskog testa u kojem se vidi interoperabilnost uređaja različitih proizvođača i koje NETCONF funkcije (NETCONF capabilities) podržavaju.

Od šestog do osmog poglavlja prikazani su rezultati provedenog primarnog istraživanja.

U prvom dijelu šestog poglavlja prikazan je uzorak istraživanja (proizvođači, partneri i krajnji korisnici) i njihov međusobni odnos. Detaljno je prikazan način odabira proizvođača i partnera te njihovih zaposlenika za intervjue. Sve su intervjuirane osobe vrlo iskusne u radu s $\mathrm{R} / \mathrm{S}$ uređajima, imaju položene najviše stupnjeve certifikata i vodeći su stručnjaci $u \mathrm{R} / \mathrm{S}$ području u Hrvatskoj (partneri) i regiji (proizvođači). Nakon toga je prikazan i odabir korisnika za ispitivanje pomoću anketnog upitnika. U drugom dijelu ovog poglavlja detaljno su prikazani rezultati dobiveni od ispitanika pomoću intervjua (proizvođači i partneri) i 
pomoću anketnog upitnika (korisnici u Hrvatskoj). Zbog preglednosti su dobiveni rezultati prikazani za svaku vrstu ispitanika (proizvođači, partneri i korisnici) u četiri dijela: (a) primjena NETCONF standarda kod proizvođača, (b) primjena NETCONF standarda kod korisnika, (c) poznavanje NETCONF standarda od strane korisnika i (d) NETCONF i povećanje raspoloživosti $\mathrm{R} / \mathrm{S}$ uređaja. Osim toga, prikazani su podaci o ispitanicima $\mathrm{i}$ njihovim kompanijama dobiveni anketnim upitnikom. Većina dobivenih rezultata $\mathrm{u}$ ovom poglavlju je testirana upotrebom Wilcoxonovog testa i prezentirana upotrebom metoda deskriptivne statistike.

U sedmom je poglavlju napravljena usporedba dobivenih rezultata različitim metodama (i primarnog i sekundarnog) istraživanja i od različitih ispitanika (zaposlenici proizvođača, zaposlenici partnera i korisnici u Hrvatskoj). Zbog preglednosti prikaza rezultata koristi se SWOT analiza NETCONF standarda.

U osmom se poglavlju prikazuju rezultati testiranja postavljenih hipoteza istraživanja upotrebom Hi kvadrat $\left(\chi^{2}\right)$ testa.

U devetom je poglavlju iznesen zaključak i dani su prijedlozi za daljnje istraživanje.

\subsection{Cilj i hipoteze istraživanja}

Znanstveni problem ovog istraživanja je odrediti kolika je stvarna prihvaćenost i primjena NETCONF standarda $u$ današnjim mrežama i koliki je utjecaj NETCONF standarda na povećanje raspoloživosti mrežnih uređaja.

Opisani i determinirani znanstveni problem istraživanja o međuodnosu NETCONF standarda i povećanja raspoloživosti mrežnih uređaja odredili su znanstvenu paradigmu za postavljanje predmeta znanstvenoga istraživanja: utvrditi koje su prednosti NETCONF standarda u povećanju raspoloživosti mrežnog uređaja u odnosu na nestandardne metode konfiguriranja mrežnih uređaja, kolika je primjena NETCONF standarda u praksi od strane proizvođača mrežne opreme i kolika je primjena NETCONF standarda u praksi od strane korisnika u 
njihovim mrežama. Nadalje, potrebno je i odrediti preporuke kako da korisnici primjenjuju NETCONF standard češće na svojim mrežnim uređajima.

Znanstveni problem istraživanja i predmet znanstvenog istraživanja odnose se na sljedeće objekte istraživanja: NETCONF standard, mrežni uređaji usmjernici (engl. router) i preklopnici (engl. switch), proizvođači mrežnih uređaja, korisnici mrežnih uređaja, upravljanje konfiguracijom mrežnih uređaja, raspoloživost mrežnih uređaja.

Na temelju znanstvenog problema istraživanja, predmeta i objekta znanstvenog istraživanja određene su temeljne znanstvene hipoteze:

- H1: NETCONF standard povećava raspoloživost mrežnog uređaja u odnosu na nestandardne metode konfiguriranja mrežnih uređaja.

- H2: proizvođači mrežne opreme ne implementiraju NETCONF standard na svojim uređajima.

- H3: korisnici mrežne opreme ne implementiraju NETCONF standard na svojim mrežnim uređajima.

- H4: korisnici nedovoljno poznaju prednosti NETCONF standarda u povećanju raspoloživosti mrežnih uređaja.

Na temelju znanstvenog problema istraživanja, predmeta i objekta znanstvenog istraživanja, postavljanjem radnih hipoteza određeni su svrha i ciljevi znanstvenog istraživanja.

Svrha je znanstvenog istraživanja istražiti trenutnu primjenu NETCONF standarda i utvrditi prijedloge za povećanje primjene te analizirati i ocijeniti doprinos NETCONF standarda povećanju raspoloživosti mrežnih uređaja.

Glavni je cilj pokazati da se primjenom NETCONF standarda utječe na povećanje raspoloživosti mrežnih uređaja. Pomoćni su ciljevi sljedeći:

- Pomoćni cilj 1. Na temelju istraživanja prikazati podatke o primjeni NETCONF standarda za komandnu konfiguraciju mrežnih uređaja od strane korisnika i 
proizvođača mrežne opreme (učestalost primjene kao i pozitivne i negativne čimbenike koje utječu na primjenu NETCONF standarda).

- Pomoćni cilj 2. Postići da se NETCONF standard više koristi zbog svojih prednosti.

- Pomoćni cilj 3. Povećanjem korištenja NETCONF standarda postići će se viša razina zrelosti standarda (od sadašnjeg statusa „predloženi standard“ na „Internet standard" najviše zrelosti).

- Pomoćni cilj 4: Utvrditi aktivnosti koje je potrebno obaviti da bi NETCONF standard bio više korišten.

Kako bi se primjereno riješio znanstveni problem istraživanja, ostvario predmet znanstvenog istraživanja, dokazala postavljena radna hipoteza i pomoćne hipoteze te postigla svrha i ciljevi istraživanja, potrebno je dati odgovore na sljedeća istraživačka pitanja:

- 1. pitanje: Koje su prednosti NETCONF standarda u povećanju raspoloživosti mrežnog uređaja $\mathrm{u}$ odnosu na nestandardne metode konfiguriranja mrežnih uređaja?

○ Pomoćna pitanja su sljedeća:

- Koje su nestandardne metode konfiguriranja mrežnih uređaja koje se danas koriste? Koje su njihove karakteristike (prednosti i nedostaci)?

- Koji su razlozi nastanka NETCONF standarda? Koje su karakteristike NETCONF standarda?

- Koji su trenutačni trendovi razvoja računalnih mreža i kakav je status NETCONF standarda u njima? Postoje li alternativna rješenja (ili se radi na njima) koja bi mogla zamijeniti NETCONF standard?

- Na koji način NETCONF standard utječe na povećanje raspoloživosti mrežnih uređaja? 
Odgovorom na ovo pitanje i potpitanja određuju se teoretski moguće prednosti NETCONF standarda za povećanje raspoloživosti mrežnih uređaja.

- 2. pitanje: Kolika je primjena NETCONF standarda u praksi od strane proizvođača mrežne opreme?

- Pomoćna pitanja su sljedeća:

- Koji važniji proizvođači i na kojim mrežnim uređajima implementiraju NETCONF standard?

- Koji su razlozi implementiranja i neimplementiranja NETCONF standarda na pojedinim vrstama mrežnih uređaja?

- Podržavaju li proizvođači veću primjenu NETCONF standarda kod korisnika i na koji način (dokumentacija, edukacija, sudjelovanje u razvoju standarda i drugo)?

- Na koji način povećati primjenu NETCONF standarda od strane proizvođača?

Odgovorom na ovo pitanje i potpitanja određuje se koja su od mogućih prednosti NETCONF standarda primijenjena od strane proizvođača mrežnih uređaja i na kojim uređajima.

- 3. pitanje: Kolika je primjena NETCONF standarda u praksi od strane korisnika u njihovim mrežama?

- Pomoćna pitanja su sljedeća:

- Koje tipovi korisnika i na kojim uređajima koriste NETCONF standard?

- Koji su razlozi zašto se NETCONF koristi (ili ne koristi) na uređajima? 
- Koja je razina znanja korisnika o NETCONF standardu? Poznaju li korisnici prednosti NETCONF standarda u povećanju raspoloživosti mrežnog sustava? Da li predlažu moguća poboljšanja?

- Na koji način povećati primjenu NETCONF standarda od strane korisnika?

Odgovorom na ovo pitanje i potpitanja određuje se jesu li korisnici upoznati s prednostima NETCONF standarda i koje je njihovo viđenje NETCONF standarda $u$ svakodnevnoj primjeni.

\subsection{Ispitanici, metodologija i plan istraživanja}

U sklopu znanstvenog istraživanja za potrebe izrade doktorske disertacije bit će provedeno primarno i sekundarno istraživanje te kvalitativno, kvantitativno i kombinirano istraživanje.

Uzorak istraživanja, odnosno osnovni skup za potrebe primarnog istraživanja činit će najveći svjetski proizvođači mrežnih uređaja (usmjernika i preklopnika) i odabrani korisnici tih mrežnih uređaja u Hrvatskoj.

Synergy Research Group objavila je podatke u veljači 2016. godine o najvećim svjetskim proizvođačima mrežne opreme: Cisco je najveći proizvođač usmjernika i preklopnika i ima 56\% udjela na tržištu, dok ostali proizvođači (Juniper, Hewlett Packard Enterprise, Huawei, Alcatel-Lucent, F5, Arista, Extreme Networks i drugi) imaju preostali udjel. Po područjima primjene Cisco ima 69\% udjela na tržištu usmjernika za tvrtke, oko 64\% udjela na tržištu u području Ethernet preklopnika u tvrtkama i 42\% na tržištu usmjernika za davatelje usluga.

Zbog toga će Cisco biti jedan od uzoraka istraživanja, a osim njega to će biti i Juniper, Hewlett Packard Enterprise, F5 i Huawei, tako da zajedno pokrivaju minimalno 80\% svjetskog tržišta usmjernika i preklopnika.

Korisnici mrežne opreme mogu se podijeliti na partnere proizvođača i krajnje korisnike. 
Partneri proizvođača prodaju mrežnu opremu krajnjim korisnicima i tehnički su odgovorni (zajedno s krajnjim korisnicima) za dizajn i svakodnevni rad računalnih mreža. Partneri proizvođača intenzivno i blisko surađuju s proizvođačima i vrlo su često specijalizirani za određena područja i tehnologije računalnih mreža te su zbog toga tehnički educiraniji i s više iskustva od krajnjih korisnika. Proizvođači određuju važnost partnera (između ostalog i na temelju tehničke obučenosti i certificiranja) i dodjeljuju im određeni stupanj. Osnovni uzorak istraživanja bit će najveći partneri u Hrvatskoj gore navedenih proizvođača, a njihov odabir bit će na temelju tržišnog udjela proizvođača s kojim surađuju i njihovog stupnja važnosti dodijeljenog od proizvođača. Očekivani ukupan broj ispitanih partnera je 60\% partnera najvećeg stupnja važnosti za gore navedeni uzorak proizvođača.

Krajnji korisnici su odgovorni za svakodnevni rad mreže, ali i poznaju trenutne zahtjeve i određuju budući razvoj mreže. To su vrlo često složene i zahtjevne računalne mreže (na primjer bolnice, banke, zračne luke, sveučilišta, i slično). Osnovni uzorak istraživanja krajnjih korisnika bit će određen od strane proizvođača i partnera na temelju njihove veličine i važnosti što se tiče raspoloživosti računalnih mreža. Očekivani broj ispitanih krajnjih korisnika je oko 100 (s očekivanim odgovorom od minimalno 50\%), a to će uglavnom biti veće i važnije računalne mreže (bolnice, državne i obrazovne ustanove, banke, zračne luke i sl.) koje zahtijevaju veću raspoloživost.

Primarno istraživanje provodit će se u tri dijela.

U prvom će se dijelu prikupljati podaci od strane proizvođača mrežnih uređaja metodom polustrukturiranog intervjua. Intervju će se provesti s najznačajnijim proizvođačima mrežne opreme, odnosno njihovim stručnjacima u području upravljanja mrežnim uređajima.

Odabrani proizvođači su najveći svjetski proizvođači mrežne uređaja: Cisco, Juniper, Hewlett Packard Enterprise, F5 i Huawei koji zajedno pokrivaju više od $80 \%$ tržišta usmjernika i preklopnika u svijetu. Intervjuima će se ispitati njihovo viđenje sadašnjeg stanja primjene NETCONF standarda i budućeg razvoja i primjene. Ispitat će se koja su osnovna obilježja primjene NETCONF standarda u mrežnim uređajima, na kojim vrstama uređaja i zašto je primijenjen (ili nije) NETCONF standard, koji dijelovi NETCONF standarda su podržani (ili nisu), koje su povratne informacije od strane inženjera/arhitekata proizvođača, s kojim 
problemima se suočavaju proizvođači, kakva je strategija implementacije NETCONF standarda u odnosu na uređaje i vrste mreža (posebno u području povećanja raspoloživosti sustava), kakva je vizija buduće implementacije i razvoja NETCONF standarda (pogotovo u odnosu na nove implementacije SDN, IoT i Green IT) i drugo. Također će se dobiti informacije o tome koji su koraci napravljeni za veću primjenu standarda (na primjer o organiziranoj internoj edukaciji o NETCONF standardu i edukaciji prema korisnicima), kao i informacije o tome kakva je međusobna suradnja proizvođača oko primjene i postizanja veće uporabe NETCONF standarda i problemima koji se pojavljuju s tim u vezi.

Intervjui će se provoditi izlaskom na teren, a u slučaju nemogućnosti odlaska na lokaciju intervju će se provesti telefonom ili drugim dostupnim komunikacijskim alatima.

U drugom će se dijelu prikupljati podaci od strane partnera mrežnih uređaja metodom polustrukturiranog intervjua. Intervjui će se provesti s najvećim partnerima proizvođača i njihovim vodećim mrežnim arhitektima koji dizajniraju mreže krajnjih korisnika te s glavnim inženjerima koje te mreže održavaju. Očekivani ukupan broj ispitanih partnera je 60\% partnera najvećeg stupnja važnosti za gore odabrane proizvođače.

Intervjuima će se ispitati njihovo viđenje samog standarda NETCONF (prednosti, nedostaci, moguća poboljšanja), koja je širina primjene NETCONF standarda na mrežnim uređajima, na kojim vrstama mreža se koristi NETCONF standard, kakva je interoperabilnost uređaja različitih proizvođača, kakva je jednostavnost migracije na NETCONF i drugo. Dobit će se informacije od partnera o zadovoljstvu dokumentiranosti, edukaciji i podršci NETCONF standarda od strane proizvođača. Naglašena tema u ispitivanju bit će povećanje raspoloživosti mrežnih sustava s NETCONF standardom.

Intervjui će se provoditi izlaskom na teren, a u slučaju nemogućnosti odlaska na lokaciju intervju će se provesti telefonom ili drugim dostupnim komunikacijskim alatima.

U trećem će se dijelu prikupljati podaci od strane krajnjih korisnika mrežnih uređaja metodom strukturiranog upitnika. Upitnik će biti poslan odabranim krajnjim korisnicima od strane proizvođača i partnera, a na osnovi veličine i značaja krajnjih korisnika i zahtjevom za visoku raspoloživost. Očekivani broj ispitanih krajnjih korisnika je oko 100 (s očekivanim 
odgovorom od minimalno 50\%), a to će uglavnom biti veće i važnije računalne mreže (bolnice, banke, državne i obrazovne ustanove, ...) s potrebom veće raspoloživosti.

Upitnicima će se ispitati koliko su krajnji korisnici upoznati s NETCONF standardom, da li ga koriste (i gdje i kako) na svojim mrežnim uređajima, kako krajnji korisnici vide kvalitetu samog standarda NETCONF (prednosti, nedostaci, moguća poboljšanja) i drugo. Dobit će se informacije od krajnjih korisnika o zadovoljstvu dokumentiranosti, edukaciji i podršci NETCONF standarda od strane partnera i proizvođača. Naglašena tema u ispitivanju bit će povećanje raspoloživosti mrežnih sustava s NETCONF standardom. Dodatne teme ispitivanja bit će odlučene temeljem intervjua s proizvođačima i partnerima.

Upitnici će biti poslani e-poštom.

Sekundarno istraživanje odnosit će se na analizu opsežne relevantne literature i dostupnih informacija iz područja upravljanja konfiguracijskim podacima mrežnih uređaja i NETCONF standarda. Osnovni izvori potrebnih podataka su dosadašnja znanstvena istraživanja vezana uz NETCONF standard, web-stranice NETCONF standarda i IETF organizacije, web-stranice i dokumentacija proizvođača mrežnih uređaja, web-stranice vezane uz novije trendove razvoja računalnih mreža (SDN i IoT) i literatura s temama mrežnog upravljanja i raspoloživosti sustava.

Analiza literature počela se provoditi u listopadu 2015. godine. Znanstvene metode na kojima se zasniva analiza relevantne literature su metoda analize i sinteze, induktivna i deduktivna metoda, metoda uzorka, metoda intervjua, statistička metoda, metoda apstrakcije i konkretizacije, generalizacije i specijalizacije, metoda kompilacije, komparativna metoda, povijesna metoda, metoda dokazivanja i opovrgavanja.

Osim toga, NETCONF standard će biti testiran i u laboratoriju na mrežnom uređaju od jednog (najvećeg) proizvođača koji potpuno podržava standard. Svrha testiranja je provjera osnovnih karakteristika NETCONF standarda i njegova usporedba (primjeri pokazatelja su brzina, jednostavnost, dostupnost i sl. ) s nestandardnom CLI metodom konfiguriranja mrežnih uređaja. Biti će određene i ispitane prednosti (i eventualni nedostaci) NETCONF standarda $u$ postizanju veće raspoloživosti mrežnih uređaja. 
Uz korištenje odgovarajućih metoda istraživanje će se provesti kroz sljedeće četiri etape (svaka u trajanju od oko 60 dana):

1. Istraživanje trenutnog stanja NETCONF standarda.

- Pregled i analiza objavljenih IETF standarda za NETCONF; kao i trenutni rad i zadaci IETF radne grupe za NETCONF standard.

- Istraživanje primjene NETCONF standarda od strane proizvođača mrežne opreme kroz objavljenu dokumentaciju i materijale proizvođača.

- Testiranje NETCONF standarda u laboratoriju i usporedba s nestandardnim CLI pristupom u postizanju povećanja raspoloživosti mrežnih uređaja.

Osnovne metode istraživanja su sljedeće kvalitativne metode: metoda kvalitativne analize i komparativna metoda.

2. Istraživanje primjene NETCONF standarda od strane proizvođača mrežnih uređaja i njihovih partnera.

Osnovna metoda istraživanja je kvalitativna: intervju.

3. Istraživanje primjene NETCONF standarda od strane krajnjih korisnika mrežnih uređaja.

Osnovna metoda istraživanja je kvantitativna: anketa pomoću upitnika.

4. Obrada prikupljenih podataka.

Osnovne metode istraživanja su statistička obrada kvantitativnih podataka i kvalitativne metode:metoda kvalitativne analize, komparativna metoda i metoda SWOT-analize.

\subsection{Pregled literature}

Literatura korištena u ovom radu može se prema sadržaju podijeliti u tri grupe. 
U prvoj grupi nalazi se literatura u kojoj se govori općenito o upravljanju računalnim mrežama i mrežnim uređajima, upravljanju sistemskim podacima uređaja računalnih mreža i novim trendovima u ovom području (posebno softverski definirane mreže). Također, ovoj grupi pripada literatura koja opisuje pojam raspoloživosti te opisuje teoriju, različite modele i važnost povećanja raspoloživosti kod računalnih mreža.

U drugoj se grupi nalazi literatura i internetski izvori koji detaljnije opisuju standard NETCONF i njegov nastanak, svojstva, arhitekturu i implementaciju.

Treću grupu čini literatura i internetski izvori na kojima se nalaze dokumenti i alati korišteni u istraživanju. Također, ovoj grupi pripada literatura koja je vezana uz metodologije i tehnologije istraživanja i statističku obradu podataka.

Uz ostalu literaturu, u radu je korištena i literatura u kojoj je koautor i autor ovog doktorskog rada:

- za uvodni (teoretski dio rada):

○ udžbenici u kojima su obrađeni osnovni pojmovi i protokoli računalnih mreža:

- Lebinac, V., Valenčić, D. 2013. Računalne mrě̌e, izdavač Veleučilište Velika Gorica, ISBN 978-953-7716-45-5.

- Valenčić, D., Valić, B. 2019. Usmjernici i preklopnici: osnovni protokoli i konfiguracija, izdavač Veleučilište Velika Gorica, ISBN 978-953-7716-88-2, (u tisku).

○ objavljeni znanstveni radovi i radovi na međunarodnim konferencijama koji su bliski temi doktorskog rada:

- Marković, S., Valenčić, D., Valić, B. 2018. Visoka raspoloživost preklopnika u troslojnom hijerarhijskom modelu računalnih mreža, Zbornik radova, 11. Međunarodna konferencija "Dani kriznog 
upravljanja“, Veleučilište Velika Gorica, Velika Gorica, 2018., (pregledni rad, znanstveni).

- Kažović D., Valenčić, D., Radošević, I. 2016. Primjena ITIL standarda и upravljanju kriznim situacijama IT sustava, Zbornik radova, 11. Međunarodna konferencija "Dani kriznog upravljanja“, Veleučilište Velika Gorica, Velika Gorica.

- Galac, M., Valenčić, D.. 2015. Trendovi u izgradnji podatkovnih centara $u$ Hrvatskoj, Proceedings of the 38th International Convention, Croatian Society for Information and Communication Technology, Electronics and Microelectronics - MIPRO, Rijeka, (članak, znanstveni).

- Valenčić, D., Lebinac, V., Skendžić, A. 2013. Developments and current trends in Ethernet technology, Proceedings of the 36th International Convention, Croatian Society for Information and Communication Technology, Electronics and Microelectronics MIPRO, Rijeka, str. 507 - 512, ISBN: 978-953-233-074-8, (članak, znanstveni).

- Valenčić, D., Ćavar, I., Lebinac, V. 2012. Provedba oporavka od katastrofe u računalstvu u oblaku, Zbornik radova, 5. Međunarodna konferencija "Dani kriznog upravljanja“, Veleučilište Velika Gorica, Velika Gorica, str. 675 - 693, ISBN 978-953-7716-31-8., (pregledni rad, znanstveni).

- Valenčić D., Ćavar I., Zimet J. 2012. Visoka raspoloživost računalnih mreža, Zbornik radova, 5. Međunarodna konferencija "Dani kriznog upravljanja“, Veleučilište Velika Gorica, Velika Gorica, str. 695 - 719, ISBN 978-953-7716-31-8., (pregledni rad, znanstveni).

- za teoretski i istraživački dio rada: 
○ objavljen znanstven rad (čiji rezultati su nastali tijekom istraživanja i rada na doktorskom radu):

- Valenčić, D., Mateljan, V. 2019. Implementation of NETCONF Protocol, Proceedings of the 42nd International Convention, Croatian Society for Information and Communication Technology, Electronics and Microelectronics - MIPRO, Rijeka, (članak, znanstveni). 


\subsection{Znanstveni doprinos}

Na temelju izabranih istraživačkih metoda dokazat će se zašto je NETCONF standard bolji u odnosu na dosadašnje nestandardne metode komandne konfiguracije s ciljem postizanja veće raspoloživosti mrežnih uređaja. Osim toga, odredit će se stupanj nekorištenja NETCONF standarda od strane proizvođača mrežne opreme i predložiti preporuke za povećanje implementacije. Također, odredit će se stupanj nekorištenja od strane korisnika mrežne opreme i predložiti model rada (aktivnosti) s korisnicima koji će osigurati povećanje korištenja NETCONF standarda sa svim njegovim prednostima. 


\section{Upravljanje sistemskim podacima uređaja računalnih mreža}

\subsection{Mrežni uređaji: usmjernici i preklopnici}

Internet i njegova arhitektura osnovani su na TCP/IP grupi protokola (engl. protocol suite). TCP/IP grupa protokola omogućuje međusobnu komunikaciju između računala različitih tehničkih karakteristika (proizvođač, operacijski sustav i slično). Jedan od najvažnijih uzroka brzog rasta Interneta jest karakteristika TCP/IP grupe protokola da je to potpuno otvoren sustav (engl. open system) tako da je većina implementacija besplatno raspoloživa ${ }^{1}$.

Danas se računalne mreže najčešće opisuju pomoću ISO OSI arhitekture. ISO (International Organization for Standardization) OSI (Open System Interconnection) višeslojna arhitektura definirana je u sedam slojeva ${ }^{2}$ :

1. Fizički sloj (engl. physical layer): definira fizičke, električne, mehaničke i funkcionalne procedure i standarde za pristup fizičkom mediju.

2. Podatkovni sloj (engl. data link layer): osigurava pouzdani prijenos podataka preko medija između dvaju susjednih čvorova.

3. Mrežni sloj (engl. network layer): brine se o transparentnom prijenosu podataka mrežom između krajnjih stanica.

4. Transportni sloj (engl. transport layer): brine se o redoslijedu slanja i potvrdi prijema, odnosno da svi podaci višeg sloja stignu točno s kraja na kraj mreže.

5. Sjednički sloj (engl. session layer): provjerava cjelovitost poruke i isporučuje poruku na pravo odredište unutar računala.

\footnotetext{
${ }^{1}$ Stevens, R. 1996. TCP/IP Illustrated, Volume 1: The Protocols, Addison Wesley, e-book, section 1.1.

${ }^{2}$ Tanenbaum, A. 2003. Computer Networks, Fourth Edition, Prentice Hall, e-book, section 1.4..
} 
6. Prezentacijski sloj (engl. presentation layer): bavi se i sintaksom i semantikom podataka koji se prenose.

7. Aplikacijski sloj (engl. application layer): pruža mrežne usluge aplikacijama (programima) i upućuje zahtjev za usluge prezentacijskog sloja.

Razlikuju se dvije vrste uređaja u računalnim mrežama:

- $\quad$ krajnji uređaj (engl. end device): primjeri su računalo, server ili IP telefon;

- posredovni uređaj (engl. intermediate device): primjeri su koncentrator, preklopnik, usmjernik, vatrozid (engl. firewall) ili pristupnik (engl. gateway).

Sve današnje računalne mreže osnovane su na dvjema najraširenijim vrstama posredovnih uređaja: preklopniku i usmjerniku.

Svoje osnovne funkcije preklopnik (engl. switch) obavlja na podatkovnom sloju OSI modela, dok usmjernik (engl. router) svoje osnovne funkcije izvršava na mrežnom sloju.

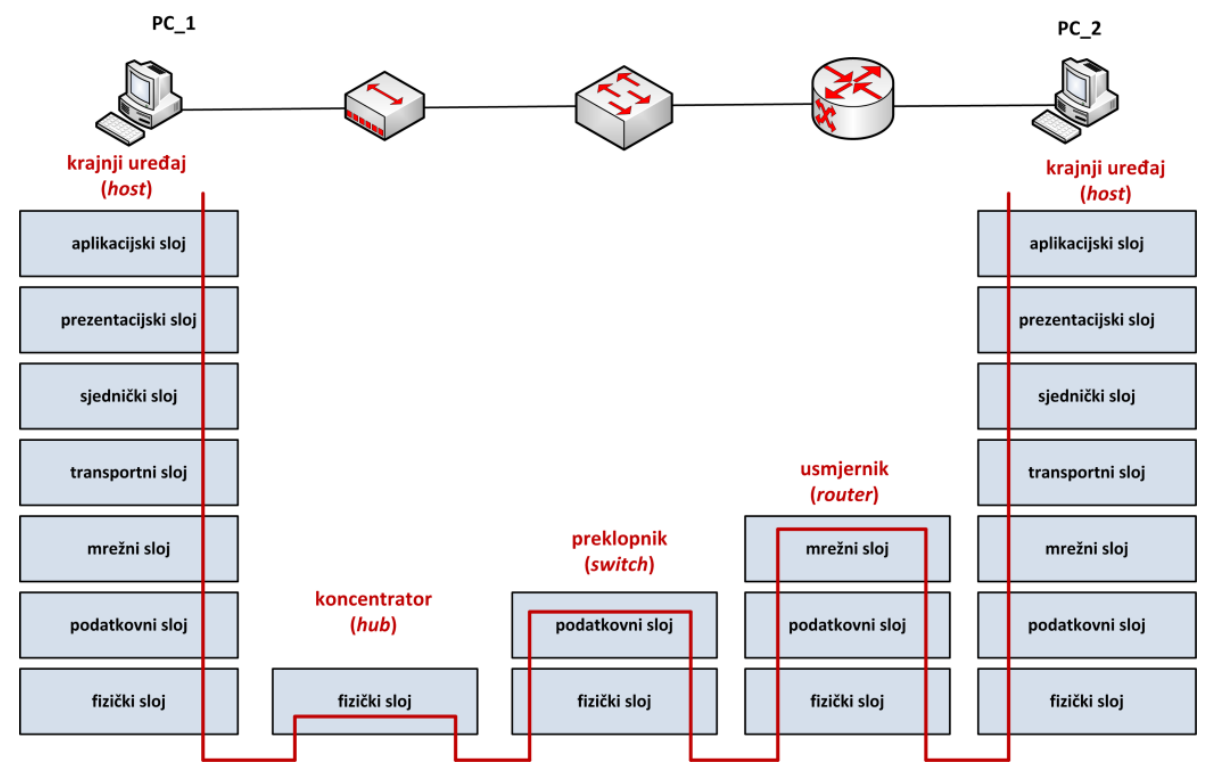

Slika 2-1. OSI model, preklopnik i usmjernik ${ }^{3}$

\footnotetext{
${ }^{3}$ Lebinac V., Valenčić D. 2013. Računalne mreže, izdavač Veleučilište Velika Gorica, ISBN 978-953-7716-455., 210-212.
} 
Osnovne funkcije podatkovnog sloja (i preklopnika) su sljedeće ${ }^{4}$ :

- definirati strukture okvira (engl. framing);

- prepoznavati prvi i zadnji bit u okviru - sinkronizacija okvira (engl. synchronization);

- omogućiti prijenos bilo koje duljine okvira do maksimalne veličine;

- omogućiti prijenos informacijskog niza bilo koje sekvence bita (engl. pattern);

- kontrolirati pogreške (engl. error control) u prijenosu preko prijenosnog linka;

- osigurati da ni jedan okvir ne bude izgubljen;

- kontrola prometnim tokovima (engl. flow control);

- u konfiguracijama 'jedan prema više' (multidrop) osigurati adresiranje primatelja i pošiljatelja te rješavati konflikte istovremenog odašiljanja više stanica

- $\quad$ kontrolirati pristup prijenosnom mediju (engl. Media Access Control - MAC)

Osnovne funkcije mrežnog sloja (i usmjernika) su sljedeće ${ }^{5}$ :

- $\quad$ adresiranje uređaja (dodavanje logičke adrese za uređaje koji čine mrežu računala)

- inkapsulacija (dodavanje zaglavlja mrežnog sloja na izvorišnom krajnjem uređaju)

- usmjeravanje i prosljeđivanje paketa kroz mrežu od jednog do drugog krajnjeg uređaja

- dekapsulacija (uklanjanje zaglavlja paketa na odredišnom uređaju i prosljeđivanje podataka na transportni sloj za dalju obradu).

Od ostalih posredovnih uređaja važno je razlikovati ${ }^{6}$ :

\footnotetext{
${ }^{4}$ Lebinac V., Valenčić D. 2013. Računalne mreže, izdavač Veleučilište Velika Gorica, ISBN 978-953-7716-455., 88-90.

${ }^{5}$ Cisco CCNA Routing/switching course, Cisco Academy v4.0 e-learning (2009.), https://www.netacad.com/ (11.05.2012).
} 
- koncentrator (engl. hub): osnovne funkcije izvršava na fizičkom sloju, ne koristi adresiranje, već sav promet prosljeđuje na sva sučelja (osim dolaznog). Danas se vrlo rijetko koristi u računalnim mrežama.

- pristupnik (engl. gateway): uređaj koji radi na aplikacijskom sloju, odnosno na svim slojevima OSI modela gdje međusobno povezuje različite grupe protokola (na primjer TCP/IP i IBM SNA) za neku određenu aplikaciju (na primjer e-mail ili prijenos podataka).

- vatrozid (engl. firewall): uređaj koji brine o sigurnosti računalnih mreža i uređaja, a radi na svim slojevima OSI modela.

Pod mrežnom opremom, danas se uglavnom smatraju uređaji 2. i 3. sloja OSI modela, odnosno usmjernici i preklopnici, za koje se često koristi skraćenica R/S.

\subsection{Upravljanje računalnim mrežama}

Upravljanje mrežama odnosi se na aktivnosti, metode, procedure i alate pomoću kojih se postiže izvršavanje, administracija, održavanje i isporuka usluga mrežnih sustava ${ }^{7}$.

Mogućnost upravljanja mrežom potrebna je za konfiguriranje sustava, nadzor njegovog statusa, pravovremene reakcije na preopterećenje i zastoje u radu, kao i za inteligentno širenje mreže ${ }^{8}$.

Slika 2-2. prikazuje osnovne elemente sustava upravljanja računalnim mrežama.

\footnotetext{
${ }^{6}$ Isto.

${ }^{7}$ Clemm, A. 2006. Network management fundamentals, Cisco Press, str. 8.

${ }^{8}$ Stallings, W. 2003. Data and computer communications, Fifth Edition, Pearson Education, Inc., Pearson Prentice Hall, str.5.
} 


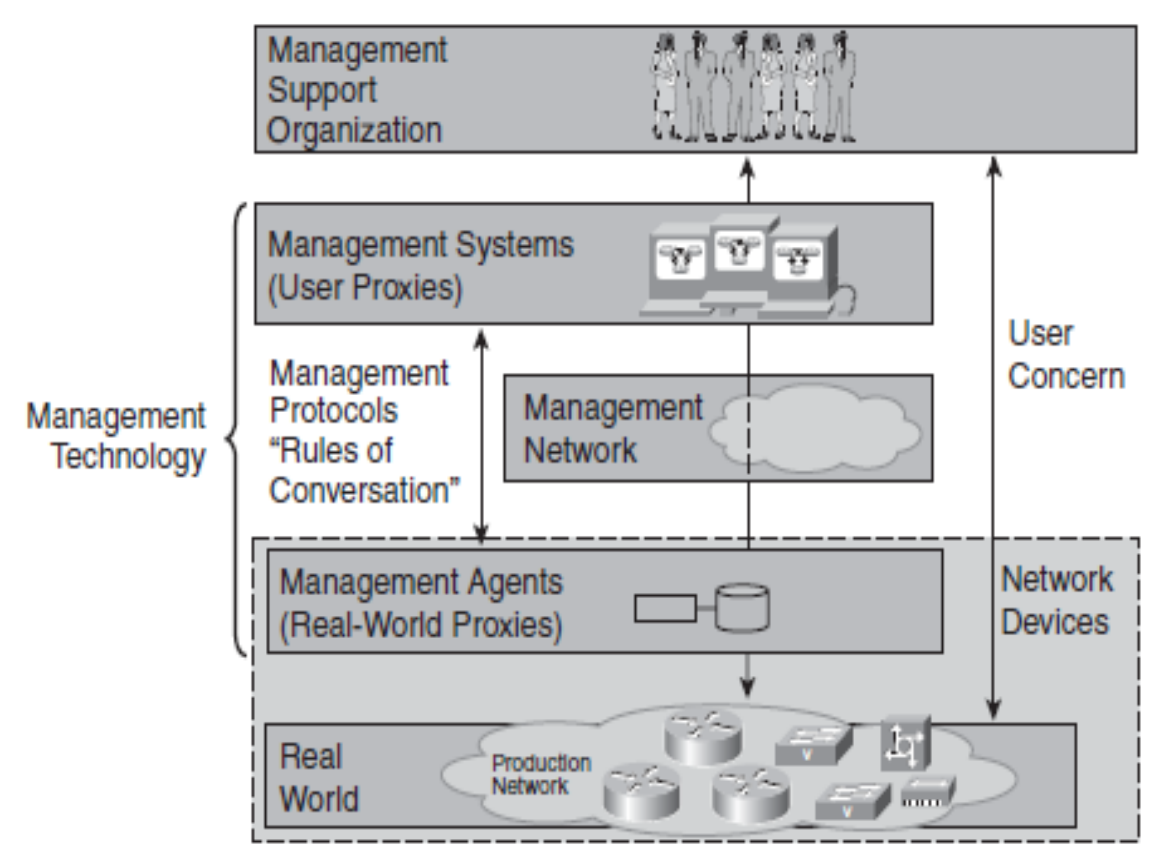

\section{Slika 2-2. Osnovni elementi NM sustava ${ }^{9}$}

\section{TMN model}

TMN (Telecommunications Management Network) se odnosi na grupu standarda za telekomunikacijske mreže definiranih od strane ITU-T. Jedna od najvećih dobrobiti TMN modela je definiranje jasne i općeprihvaćene terminologije u području upravljanja mrežama ${ }^{10}$. Osim toga TMN definira hijerarhijski referentni model koji se sastoji od sljedećih slojeva ${ }^{11}$ :

- Upravljanja mrežnim elementom (engl. element management) - upravljanje pojedinih mrežnih elemenata, kao na primjer upravljanje alarmima, obrada informacija, sigurnosne kopije, logiranje poruka i održavanje hardvera i softvera.

- Mrežno upravljanje (engl. network management) - dodjeljuje mrežne resurse, izvršava zadatke konfiguracije, kontrole i nadzora mreže.

\footnotetext{
${ }^{9}$ Clemm, A. 2006. Network management fundamentals, Cisco Press, str. 83.

${ }^{10}$ Clemm, A. 2006. Network management fundamentals, Cisco Press, 118-123.

${ }^{11}$ Telecommunications Management Network, https://en.wikipedia.org/wiki/Telecommunications_Management_Network (21.04.2019).
} 
- Upravljanje uslugom (engl. service management) - manipulira uslugama mreže: definiranje, administracija i naplata usluga.

- Poslovno upravljanje (engl. business management) - odnosi se na poslovne funkcije, na primjer definira strategiju i investicije.

Iako u praksi ti slojevi nisu uvijek jasno odvojeni, sam hijerarhijski referentni model je vrlo važan i koristan.

\section{FCAPS}

ISO je definirao model upravljanja računalnim mrežama poznat pod nazivom FCAPS (Fault, Configuration, Accounting, Performance, Security) ${ }^{12}$.

FCAPS se sastoji od sljedećih funkcija ${ }^{13}$ :

- Upravljanje kvarovima (engl. fault management) - obuhvaća skup funkcija za detektiranje, izoliranje, obavještavanje i ispravljanje kvarova i grešaka koje su nastupile u mreži kao i za održavanje zapisnika.

- Upravljanje konfiguracijama (engl. configuration management) - uključuje konfiguraciju mrežnih uređaja, upravljanje inventarom i upravljanje softverom.

- Računovodstveno upravljanje (engl. accounting management) - prikupljanje podataka o uporabi mrežnih resursa.

- Upravljanje performansama (engl. performance management) - uključuje nadzor i mjerenje mrežnih radnih parametara, sakupljanje statističkih informacija, održavanje i pregled zapisa aktivnosti.

- Upravljanje sigurnošću (engl. security management) - bavi se zaštitom mreže i sustava od nedopuštenog pristupa.

\footnotetext{
${ }^{12}$ Clemm, A. 2006. Network management fundamentals, Cisco Press, 131-161.

${ }^{13}$ IETF RFC 6632 An Overview of the IETF Network Management Standards (2012), https://tools.ietf.org/html/rfc6632 (21.04.2019).
} 
Slika 2-3. prikazuje odnos između TMN i FCAPS modela, odnosno spajanje funkcionalnosti FCAPS modela sa slojevima TMN modela.

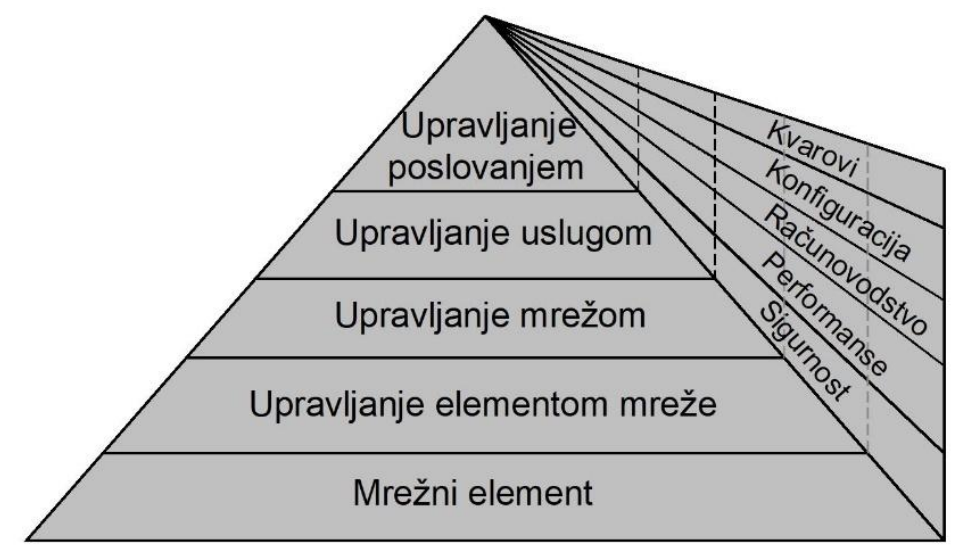

\section{Slika 2-3. Odnos između TMN i FCAPS modela ${ }^{14}$}

Osnovne prednosti efikasnog mrežnog upravljanja su ${ }^{15}$ :

- Smanjenje troškova: osnovni cilj je smanjiti i minimalizirati ukupan trošak posjedovanja (engl. Total Cost of Ownership - TCO). TCO se sastoji od troškova opreme (koji se amortiziraju tijekom vremena) i operacijskih troškova (ljudi, električna energija, prostor, $\mathrm{i}$ dr.).

- Poboljšanje kvaliteta mrežnih usluga: odnosi se na kvalitetu mrežnih i komunikacijskih usluga. Osim brzine prijenosa, važni faktori su raspoloživost i pouzdanost računalne mreže i mrežne usluge.

- Povećanje prihoda: upravljanje mrežama može generirati i prihod, kao na primjer kod internetskih davatelja usluga (engl. Internet Service Provider - ISP).

\subsection{Upravljanje R/S uređajima}

Tržište računalnih mreža diktira koji proizvodi i tehnologije opstaju i ono se vrlo često pokazalo nepredvidivim. Od početka razvoja računalnih mreža najčešće su proizvođači

\footnotetext{
${ }^{14}$ Clemm, A. 2006. Network management fundamentals, Cisco Press, str.130.

${ }^{15}$ Clemm, A. 2006. Network management fundamentals, Cisco Press, 13-16.
} 
mrežnih uređaja (engl. vendors) predvodili i donosili tehnološke invencije i nove protokole, dok su standardi najčešće dolazili naknadno sa zakašnjenjem od nekoliko godina. Ipak, zadnjih se desetak godina veliki proizvođači mrežne opreme često udružuju u radne grupe za određene tehnologije. Te radne grupe definiraju nove tehnologije i njihove standarde koji bi zadovoljili i korisnike i proizvođače.

Unatoč svim ogromnim napredcima u računalstvu i računalnim mrežama, područje upravljanja R/S (router/switch) uređajima i upravljanje računalnim mrežama (network management $-\mathrm{NM}$ ) razvijalo se vrlo polako.

Primjer zastarjelog pristupa je okruženje za rad s mrežnim uređajima. Tako se i danas za konfiguraciju mrežnih uređaja (usmjernika i preklopnika) najčešće koriste CLI (engl. Command Line Interface) korisnička sučelja, a za prijenos operacijskog softvera i konfiguracijskih podataka i datoteka mrežnih uređaja koriste se FTP i TFTP protokoli. Jedan od mogućih razloga je jednostavnost i praktičnost rada s mrežnim uređajima koji su se često pokazali značajnim, a često i odlučujućim faktorom, u tržišnom natjecanju. Primjer za ovu tvrdnju je neuspjeh proizvođača koji su probali CLI sučelje zamijeniti s „menu-driven“ i grafičkim korisničkim sučeljem (engl. Graphical User Interface - GUI), iako su im proizvodi bili jednako uspješni u glavnim zadacima mrežnog uređaja (usmjeravanju podataka).

Ipak u nekoliko zadnjih godina i područje upravljanja računalnim mrežama doživljava velike promjene. Pojava virtualizacije, računalstva u oblaku i potrebe za programabilnim upravljanjem uzrokovali su implementaciju R/S funkcija u softveru (bez potrebe za odvojenim fizičkim uređajem) i nov pristup izgradnji računalnih mreža i podatkovnih centara.

\subsubsection{Tradicionalan način upravljanja $R / S$ uređajima}

Upravljanje računalnim mrežama (engl. Network Management - NM) za osnovni zadatak ima upravljanje R/S mrežnim uređajima te se uglavnom bavi operacijama obavljenim sa sistemskim podacima računalnih R/S mrežnih uređaja.

Osnovni sistemski podaci mrežnih uređaja mogu se podijeliti u dvije osnovne skupine: 
- Konfiguracijski podaci služe za konfiguriranje uređaja, odnosno za određivanje koje će funkcije mrežni uređaji izvršavati i na koji način (na primjer koji je protokol aktiviran na nekom sučelju).

- Operacijski podaci govore o trenutnom operacijskom stanju mrežnog uređaja (da li je određeno sučelje aktivno ili ne) te daju statističke podatke (na primjer o broju paketa koji prolaze kroz sučelje).

Sistemskim podacima se upravlja pomoću operacijskog sustava mrežnog uređaja i pomoću mrežnog protokola za prijenos tih podataka na udaljenu lokaciju, najčešće je to računalo za upravljanje mrežom (engl. Network Management Station - NMS).

Najčešće se mrežnim uređajima i njihovim sistemskim podacima, nakon inicijalne instalacije i konfiguracije, pristupa s udaljene lokacije. Zbog toga se koriste različiti protokoli za komunikaciju, najčešće standardizirani i definirani od strane IETF organizacije.

U sljedeća dva poglavlja ukratko će se obraditi upravljanje operacijskim podacima i prijenos sistemskih podataka, dok će se nakon toga detaljno obraditi upravljanje konfiguracijskim podacima.

\subsubsection{Upravljanje operacijskim podacima $R / S$ uređaja}

Nadzor mrežnih uređaja vrši se pomoću operacijskih podataka mrežnih uređaja. Operacijski podaci govore o trenutnom stanju mrežnog uređaja i linkova, a sadrže i razne alarme i upozorenja koja govore mrežnom administratoru o eventualnim problemima na mreži.

Operacijski podaci se šalju na centralno NMS računalo, gdje se sakupljaju, analiziraju i često vizualno prezentiraju na GUI korisničkom sučelju.

Osnovni protokoli za prijenos sistemskih operacijskih podataka mrežnih uređaja su:

- $\quad$ SNMP (Simple Network Management Protocol),

- $\quad$ ICMP (Internet Control Message Protocol),

- Syslog, 


\section{- $\quad$ RMON i}

\section{- $\quad$ Netflow}

ICMP (Internet Control Message Protocol) je protokol koji koriste mrežni uređaji (na primjer usmjernici) da bi javili grešku ili operacijske informacije. Prva definicija protokola ICMP za IPv4 objavljena je u RFC 792. Upotrebom ICMP protokola i zaglavlja IP paketa u nadzoru računalne mreže moguće je provjeravati dostupnost uređaja, gubitak paketa i praćenje razine latencije između radne stanice i nadziranog uređaja. Najpoznatiji administrativni alat za provjeru dostupnosti uređaja koji koristi ICMP je ping. Ping odašilje ICMP echo request pakete prema udaljenom uređaju i očekuje ICMP echo reply. Nakon što proces završi, prikazuje se statistika obrađenih paketa ${ }^{16}$.

Syslog standard koristi se za logiranje poruka (engl. message logging). Syslog protokol je definiran 2001. godine u RFC 3164, a zatim je u ožujku 2009. godine ažuriran u RFC $5424^{17}$. Protokol sakuplja poruke od mrežnih uređaja poslane preko mreže i sprema ih u kolektor poruka (koji se naziva syslog server). Syslog protokol koristi UDP protokol (port 514) za komunikaciju, tako da server neće slati potvrdu o primitku poruke.

RMON ili nadzor na daljinu (engl. remote network monitoring) definiran je u RFC 2819, dok je druga poboljšana verzija RMONv2 definirana u RFC $4502^{18}$. Prva verzija omogućuje NMS računalu vođenje statistike na razini paketa za cijelu mrežu, dok druga verzija omogućuje vođenje statistike na mrežnoj i aplikacijskoj razini. Ti se podaci mogu prikupljati pomoću RMON sondi (probe) koje se mogu implementirati na svaki upravljani mrežni uređaj koji želimo nadzirati. Pomoću RMON protokola upravljačka stanica više ne mora prozivati uređaje kako bi prikupljala podatke, već se podaci spremaju u RMON MIB, kojemu u svakom trenutku može pristupiti NMS računalo i dohvatiti željene podatke. ${ }^{19}$

\footnotetext{
${ }^{16}$ Lebinac V., Valenčić D. 2013. Računalne mreže, izdavač Veleučilište Velika Gorica, ISBN 978-953-771645-5., 232-234.

${ }^{17}$ IETF RFC 5424 The Syslog Protocol (2009), https://tools.ietf.org/html/rfc5424 (11.3.2019).

18 IETF RFC 4502 Remote Network Monitoring Management Information Base Version 2 (2006), https://tools.ietf.org/html/rfc4502 (11.3.2019).

${ }^{19}$ Cisco CCNA Routing/switching course, Cisco Academy v6.0 e-learning (2017.), https://www.netacad.com/ (11.03.2019).
} 
NetFlow je protokol razvijen 1996. godine u kompaniji Cisco i sličan je RMON-u. NetFlow omogućava prikupljanje informacija o mrežnom prometu i izradu statističkih prikaza. Usmjernici i preklopnici koji podržavaju NetFlow mogu prikupljati statistiku IP prometa na svim sučeljima na kojima je omogućen NetFlow, a kasnije ih izvoziti kao NetFlow zapise prema barem jednom NetFlow kolektoru, obično poslužitelju koji obavlja stvarne analize prometa. Informacije o toku prometa (engl. traffic flow) koje se šalju sa sučelja mrežnog uređaja jako su korisne za razumijevanje ponašanja mrežnog prometa. Izvorišna adresa omogućuje razumijevanje tko stvara promet, odnosno destinacijska adresa govori o tome kome je promet namijenjen, izvorišni i odredišni portovi (UDP ili TCP) ukazuju na to koja aplikacija vrši komunikaciju. ${ }^{20}$

Cisco je objavio NetFlow u informacijskom dokumentu RFC $3954^{21}$. Ostali proizvođači su razvijali slične protokole pod različitim imenima, na primjer Jflow (Juniper Networks), NetStream (Huawei, 3Com/HP), Rflow (Ericsson), sFlow (AT, Alcatel, Brocade, Extreme, Arista, F5 i drugi). Cisco je najzastupljeniji proizvođač mrežnih uređaja pa je zbog toga danas vrlo raširen naziv NetFlow i za sve slične protokole drugih proizvođača. ${ }^{22}$

Danas se najčešće koriste dvije verzije NetFlow protokola, verzija 5 (podržava samo IPv4) i verzija 9. Uslijed potrebe za univerzalnim standardom od strane IETF organizacije definiran je IPFIX (Internet Protocol Flow Information Export) standard. IPFIX se često naziva Netflow verzija 10, iako nema direktne veze i nije kompatibilan sa Cisco Netflow protokolom $^{23}$.

IPFIX protokol (Internet Protocol Flow Information Export) definiran je 2008. godine od strane IETF u RFC 5101 i 5102 i poslije je ažuriran 2013. godine u RFC 7011 i $7012^{24}$. IPFIX je izgrađen na idejama Cisco NetFlow $v 9$ verzije i polako dobiva sve širu primjenu. IPFIX je stvoren zbog potrebe za standardnim načinom eksporta informacija o IP mrežnom prometu, u

\footnotetext{
${ }^{20}$ Isto

${ }^{21}$ IETF RFC 3954 Cisco Systems NetFlow Services Export Version 9 (2004), https://tools.ietf.org/html/rfc3954 (11.3.2019).

${ }^{22}$ Netflow, https://en.wikipedia.org/wiki/NetFlow (21.1.2019).

${ }^{23}$ Isto

${ }^{24}$ IETF RFC 7011 Specification of the IP Flow Information Export (IPFIX) Protocol for the Exchange of Flow Information (2013), https://tools.ietf.org/html/rfc7011 (11.3.2019).
} 
kojem mogu biti mrežni uređaji različitih proizvođača te omogućava uvid u puno veći broj podataka za svaki tok mrežnog prometa. IPFIX protokol omogućava mrežnim administratorima prikupljanje podataka sa preklopnika, usmjernika ili drugih mrežnih uređaja koji podržavaju taj protokol. Kod IPFIX protokola mrežni administratori imaju mogućnost prikupljanja puno više informacija koje mogu biti korisne za praćenje i unaprjeđenje mreže ${ }^{25}$.

\subsubsection{Prijenos sistemskih datoteka}

Jedna od najvažnijih stavki za mrežnog administratora je udaljeno upravljanje sistemskim datotekama na različitim mrežnim uređajima. To uključuje sigurnosnu kopiju (engl. backup) operacijskog sustava i konfiguracijskih datoteka mrežnog uređaja, kao i slanje novije verzije tih datoteka na mrežne uređaje.

Većina mrežnih uređaja preko CLI sučelja omogućava dobavljanje i slanje kopija datoteka na TFTP (Trivial File Transfer Protocol) i FTP (File Transfer Protocol) servere.

Konfiguracijske datoteke se spremaju na centralni server preko FTP/TFTP protokola. U slučaju brisanja ili promjene konfiguracije na neželjeni način, administrator može vratiti sigurnosnu kopiju konfiguracije preuzimanjem s FTP/TFTP servera.

FTP/TFTP prijenos se isto tako može koristiti kao autoinstalacijska metoda za mrežne uređaje. Nakon spajanja na WAN mrežu, mrežni uređaj se automatski može konfigurirati preuzimanjem konfiguracijskih podataka s FTP/TFTP servera koji se nalazi na udaljenoj centralnoj lokaciji.

FTP protokol (File Transfer Protocol) je protokol aplikacijskog sloja koji omogućuje prijenos datoteka između klijenta i poslužitelja. FTP klijent je aplikacija na računalu (najčešće računalo mrežnog administratora) koja se koristi za stavljanje datoteka na poslužitelj (mrežni uređaj) i skidanje datoteka s poslužitelja na kojemu se nalazi FTP daemon (FTPd). FTP je

\footnotetext{
${ }^{25}$ Cisco CCNA Routing/switching course, Cisco Academy v6.0 e-learning (2017.), https://www.netacad.com/ (11.03.2019).
} 
najprije bio specificiran u RFC 114, zatim ažuriran nekoliko puta, a današnji standard nalazi se u RFC $959^{26}$.

TFTP protokol (Trivial File Transfer Protocol) jednostavniji je protokol za prijenos datoteka od FTP protokola. TFTP koristi UDP protokol na transportnom sloju, dok FTP koristi TCP. Osim toga, TFTP ne koristi posebnu konekciju za kontrolne naredbe tako da se ne mogu izvršiti neke osnovne funkcije koje se koriste u FTP protokolu. Na primjer, na klijentu se ne može ispisati popis mapa i datoteka na poslužitelju i ne podržava autentikaciju korisnika pri spajanju na poslužitelj. TFTP omogućuje samo prijenos datoteka između mapa. TFTP (verzija 2) definiran je u RFC 1350 i koristi UDP port $69^{27}$. Primjer korištenja TFTP protokola jest prijenos datoteka i softvera s TFTP poslužitelja na R/S uređaje.

\subsection{Upravljanje konfiguracijskim podacima $R / S$ uređaja}

Unatoč svim ogromnim napredcima u računalstvu i računalnim mrežama, okruženje za rad s mrežnim uređajima vrlo se malo promijenilo i ostalo je skoro isto kao prije pedesetak godina, odnosno sedamdesetih i osamdesetih godina prošlog stoljeća. Tako se i danas za konfiguraciju mrežnih uređaja (usmjernika i preklopnika) najčešće koriste CLI korisničko sučelje koje je vrlo slično DOS i UNIX sučelju.

Mrežni uređaji dostavljaju se korisnicima s početnom definiranom (default) konfiguracijom, koja je najčešće prazna pa se zbog toga svaki uređaj mora prilagoditi potrebama mreže.

Promjena (modifikacija) konfiguracije mrežnog uređaja može se izvršiti na različite načine. Uređaji se mogu konfigurirati pomoću ${ }^{28}$ :

- lokalnog spajanje preko management sučelja (na primjer spajanje na CON ili AUX sučelja na Cisco router),

\footnotetext{
${ }^{26}$ IETF RFC 959 FILE TRANSFER PROTOCOL (FTP) (1985), https://tools.ietf.org/html/rfc959 (11.3.2019).

${ }^{27}$ IETF RFC 1350 THE TFTP PROTOCOL (REVISION 2) (1985), https://tools.ietf.org/html/rfc1350 (11.3.2019).

${ }^{28}$ Valenčić D., Mateljan V. 2019. Implementation of NETCONF Protocol, Proceedings of the 42nd International Convention, Croatian Society for Information and Communication Technology, Electronics and Microelectronics - MIPRO, Rijeka.
} 
- udaljenog spajanja preko TCP/IP protokola, najčešće pomoću Telnet/SSH i SNMP protokola. Svaki mrežni uređaj mora imati konfiguriranu IP adresu da bi se moglo pristupiti s udaljene lokacije.

Tradicionalan (engl. legacy) način upravljanja i konfiguriranja mrežnih uređaja koristi sljedeće metode:

- CLI pristup s SSH protokolom i

- Simple Network Management Protocol (SNMP) protokol.

\subsubsection{Nestandardni CLI pristup}

Administriranje mrežnih uređaja izvršava se pomoću operacijskih sustava proizvođača opreme (npr. Cisco IOS, Juniper JUNOS, Extreme EXOS i drugi), koji su međusobno različiti, ali svi koriste tekstualno komandno korisničko sučelje (CLI - Command Line Interface).

CLI pristup nastao je s ciljem pojednostavljenja interakcije mrežnih administratora s mrežnim uređajima. Takav pristup je vrlo sličan znakovnom komandnom sučelju (engl. character-based command-line interface) koji se koristi u prvim operacijskim sustavima, kao što su UNIX i DOS. 


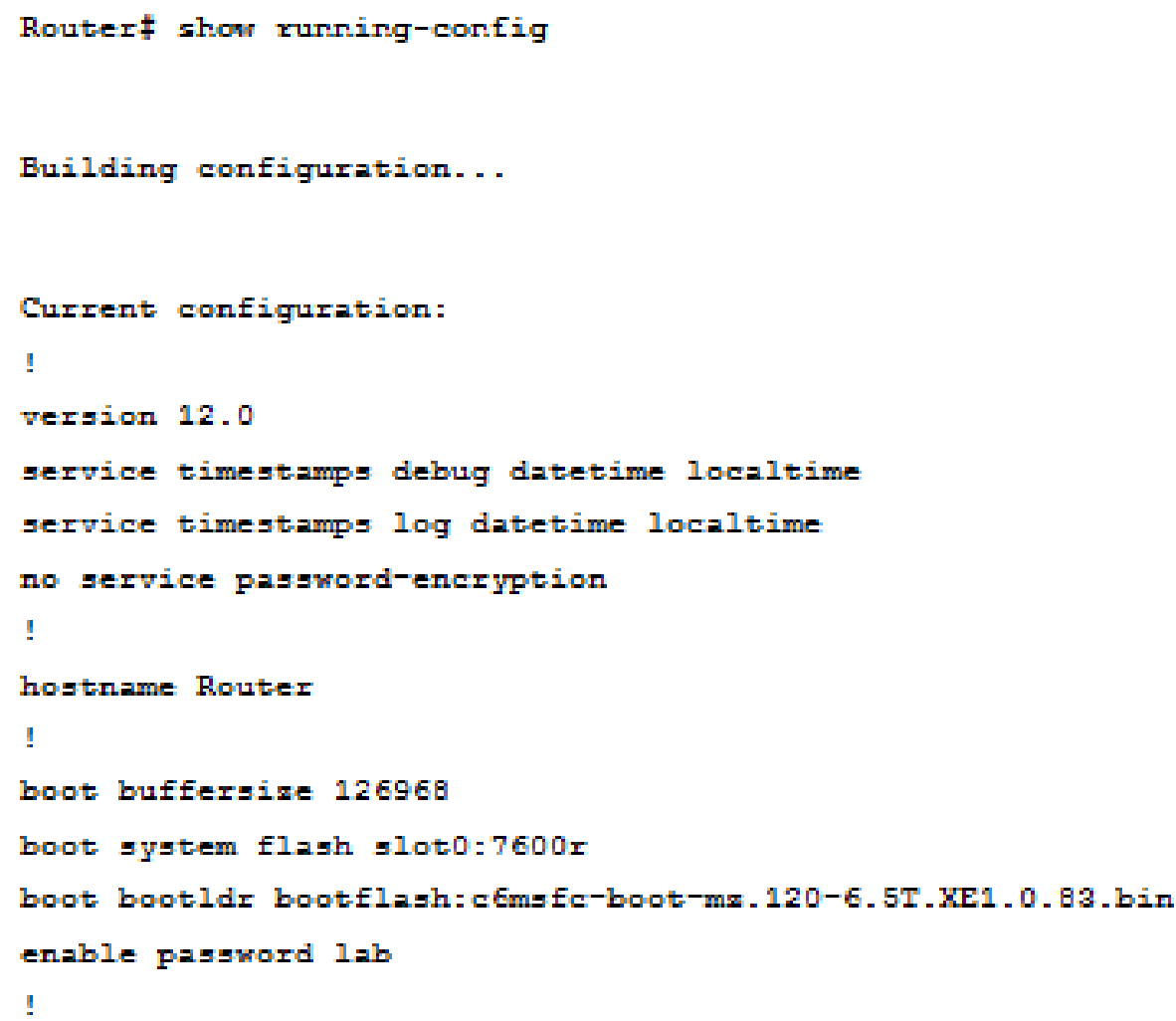

Slika 2-4. Cisco IOS CLI ${ }^{29}$

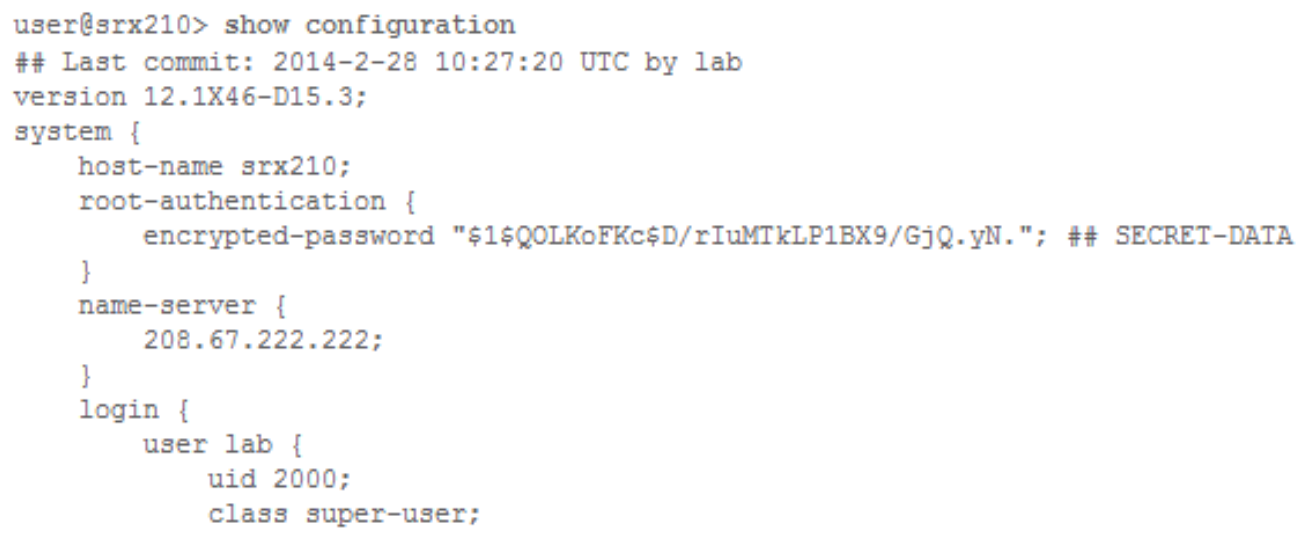

Slika 2-5. Juniper JUNOS CLI ${ }^{30}$

\footnotetext{
${ }^{29}$ Valenčić D., Mateljan V. 2019. Implementation of NETCONF Protocol, Proceedings of the 42nd International Convention, Croatian Society for Information and Communication Technology, Electronics and Microelectronics - MIPRO, Rijeka.
} 
CLI komande su organizirane na hijerarhijski način. Komande koje izvršavaju slične funkcije su grupirane $\mathrm{u}$ istom nivou i pod zajedničkim imenom. Takva hijerarhija može imati nekoliko nivoa. Takva hijerarhijska struktura je jedan od glavnih čimbenika zašto je mrežnim administratorima jednostavno koristiti CLI pristup. Također, skup CLI komandi nije fiksan, tako da je uvijek moguće dodati novu funkciju s njenim komandama i konfiguracijskim parametrima.

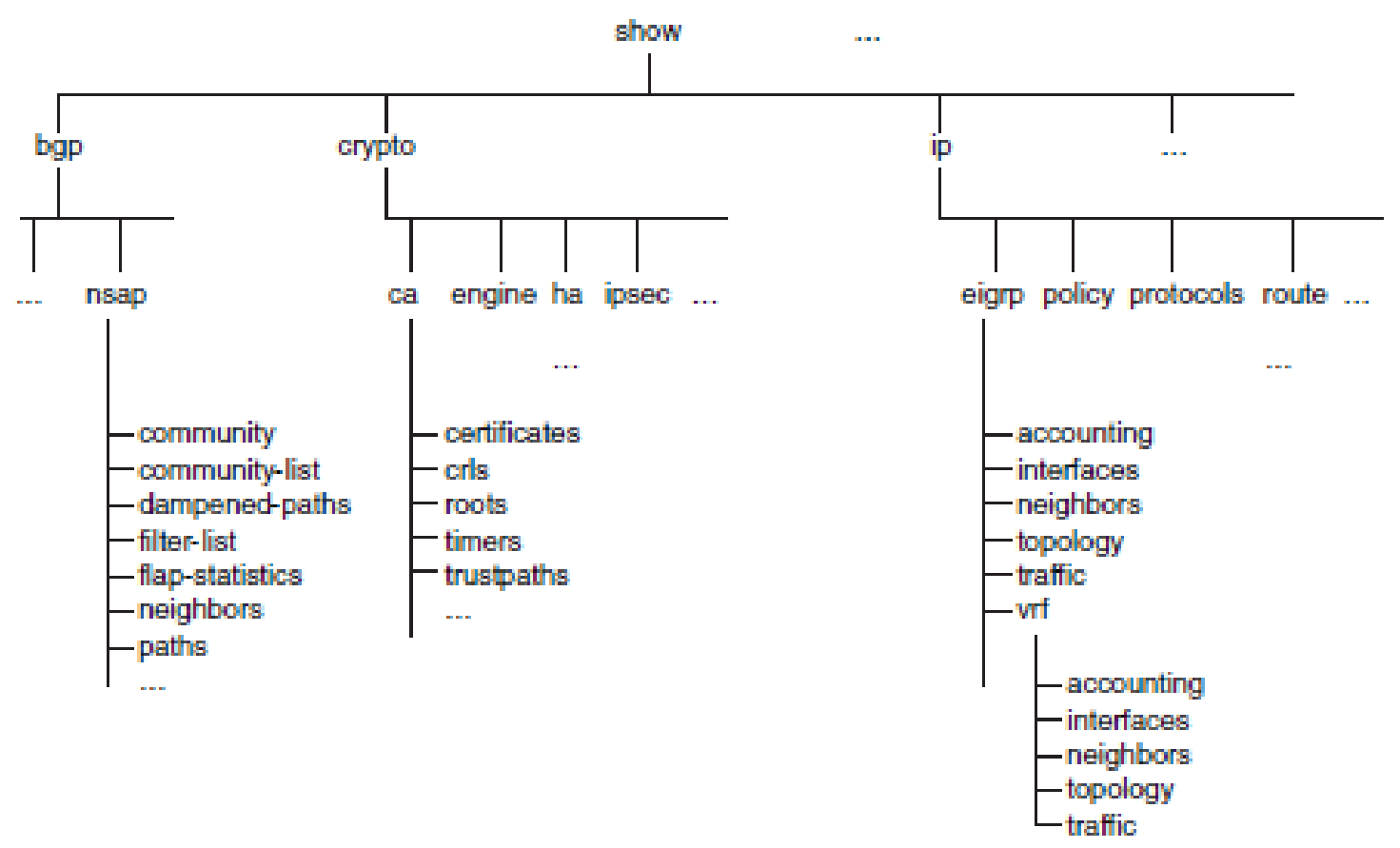

\section{Slika 2-6. Hijerarhija CLI komande show ${ }^{31}$}

Svaki mrežni uređaj mora imati konfiguriranu IP adresu da bi se moglo pristupiti s udaljene lokacije. Zbog toga je najčešće neophodno prvo dodijeliti IP konfiguraciju pomoću lokalnog pristupa preko konzole (engl. console), a zatim se mrežnom uređaju može pristupiti i pomoću odgovarajućeg protokola po izboru iz TCP/IP grupe protokola s udaljenih lokacija.

\footnotetext{
${ }^{30}$ Valenčić D., Mateljan V. 2019. Implementation of NETCONF Protocol, Proceedings of the 42nd International Convention, Croatian Society for Information and Communication Technology, Electronics and Microelectronics - MIPRO, Rijeka.

${ }^{31}$ Clemm, A. 2006. Network management fundamentals, Cisco Press, str.265.
} 
Protokoli Telnet i SSH koriste se za konfiguriranje uređaja pomoću CLI korisničkog sučelja, dok se HTTP/HTTPS i SNMP protokoli koriste za grafička korisnička sučelja (GUI).

Telnet i danas češće korištena sigurna verzija SSH uglavnom se koriste od strane mrežnih administratora za pristup i izvršavanje zadataka konfiguracije i dijagnostike nad udaljenim mrežnim uređajima (na primjer preklopnicima, usmjernicima).

\section{Telnet/SSH protokol}

Telnet je klijent/poslužitelj protokol aplikacijskog sloja TCP/IP grupe protokola koji omogućuje pristup terminalu na udaljeni računalni sustav. Telnet je definiran u RFC $854^{32}$.

Telnet je razvijen 1969. godine i jedan je od najstarijih protokola i servisa TCP/IP grupe protokola na aplikacijskom sloju. U to vrijeme korisnici su sa svog terminala (koji se nazivao i ,dummy terminal“ i nije imao ni radnu memoriju, ni tvrdi disk ni CPU) pristupali direktno spojenom centralnom računalu (mainframe) korištenjem tekstualnog sučelja. U to vrijeme nije se još koristilo grafičko korisničko sučelje (GUI - Graphical User Interface), već se pristup vršio preko tekstualnog sučelja (CLI - Command Line Interface) $)^{33}$.

Nakon nastanka računalnih mreža javila se potreba za pristupom udaljenim centralnim računalima onako kako se pristupalo uz pomoć direktno spojenih terminala. Namjena telnet protokola jest omogućivanje takva pristupa. Danas se telnet najčešće koristi za omogućivanje korisniku jednog računala uspostavljanja sesije za korištenje CLI sučelja na drugom računalu.

Imenom telnet nazivamo i protokol koji se koristi i programsku aplikaciju kao servis.

Telnet je klijent/poslužitelj aplikacija koja omogućuje emulirani pristup CLI terminala udaljenim uređajima na računalnoj mreži. Umjesto da se uređaj fizički spaja direktno na poslužitelj, koristi se telnet softver za kreiranje virtualnog terminala (engl. Virtual Terminal -

\footnotetext{
${ }^{32}$ IETF RFC 854 Telnet Protocol Specification (1983), https://tools.ietf.org/html/rfc854 (21.1.2019).

${ }^{33}$ Valenčić D., Mateljan V. 2019. Implementation of NETCONF Protocol, Proceedings of the 42nd International Convention, Croatian Society for Information and Communication Technology, Electronics and Microelectronics - MIPRO, Rijeka.
} 
VT) koji ima iste mogućnosti kao direktno fizički spojen terminal koji pristupa poslužitelju uz pomoć CLI sučelja ${ }^{34}$.

Secure Shell (SSH) protokol jest protokol koji nudi iste mogućnosti kao telnet, ali na mnogo sigurniji način. SSH ima implementiranu sigurniju autentikaciju i enkripciju podataka tijekom prijenosa. Zbog toga se preporučuje korištenje SSH umjesto telnet aplikacija i protokola kad god je to moguće ${ }^{35}$. SSH je definiran u RFC $4253^{36}$.

\section{CLI kao nestandardni pristup}

Tablica 2-1. prikazuje neke osnovne CLI naredbe JUNOS i IOS operacijskih sustava za upravljanje R/S mrežnim uređajima. Kao što se može vidjeti, neke su naredbe iste, ali većina je različita.

Konfiguriranje mrežnih uređaja pomoću nestandardnog CLI sučelja proizvođača opreme ima svoje brojne nedostatke, kao na primjer:

- različita struktura komandi,

- različita struktura podataka,

- različita struktura poruka (greške, obavijesti, i drugo),

koje za posljedicu imaju:

- obaveznu edukaciju mrežnih administratora za različite OS proizvođača,

- praktično nemoguće postizanje automatizacije upravljanja i

- složeni prijelaz na novi sustav drugog proizvođača u slučaju prekida rada i drugo.

Na taj način se znatno smanjuje otpornost, stabilnost i fleksibilnost mrežnih sustava u kriznim situacijama i njihova raspoloživost.

\footnotetext{
${ }^{34}$ Lebinac V., Valenčić D. 2013. Računalne mreže, izdavač Veleučilište Velika Gorica, ISBN 978-953-771645-5., 279-281.

35 Isto

${ }^{36}$ IETF RFC 4253 The Secure Shell (SSH) Transport Layer Protocol (2006), https://tools.ietf.org/html/rfc4253 (21.1.2019).
} 
Tablica 2-1. Usporedba osnovnih JUNOS i IOS naredbi

\begin{tabular}{ll}
\hline JUNOS naredba & IOS naredba \\
\hline ping & ping \\
\hline request message & send \\
\hline request support information & show tech-support \\
\hline request system reboot & reload \\
\hline set date & clock set \\
\hline show chassis environment & show environment \\
\hline show cli history & show history \\
\hline show configuration & show running config \\
\hline show logshow log file name & show logging \\
\hline show system processes & show processes \\
\hline show system statistics & show ip traffic \\
\hline show system uptime & show clock \\
\hline show system users & show users \\
\hline
\end{tabular}

\subsubsection{SNMP protokol}

Simple Network Management Protocol (SNMP) jest protokol za upravljanje mrežnim uređajima. SNMP omogućuje upravljanje uređajima (dobivanje konfiguracije, konfiguriranje itd.) mrežnih uređaja s udaljenog računala.

Kod primjene SNMP protokola jedno ili više NMS (Network Management Station) računala izvršava promatranje i upravljanje mrežnim uređajima. Upravljani uređaji (usmjernici, preklopnici, poslužitelji) kojima se upravlja uz pomoć SNMP protokola sadrže softverski proces (SNMP agent) koji se neprekidno izvršava. Agent prikuplja i sprema informacije s lokalnog računalnog sustava te omogućuje NMS-u njihovu dostupnost. NMS koristi naredbe 
read i write za dobivanje i mijenjanje informacija na SNMP agentu. Te naredbe koriste UDP port 161. SNMP agenti prikazuju podatke kao varijable na upravljanom uređaju. Varijable su organizirane u hijerarhiju (stablo podataka), a hijerarhija podataka i sam opis podataka naziva se MIB (Management Information Base). MIB koristi notaciju definiranu u ASN.1. Neki uređaji mogu biti konfigurirani za slanje poruka (trap) prema NMS-u u slučaju prestanka rada nekog sučelja ili drugog predodređenog slučaja. Te poruke šalju se prema NMS-u kao SNMP trap koji koristi UDP port 162.

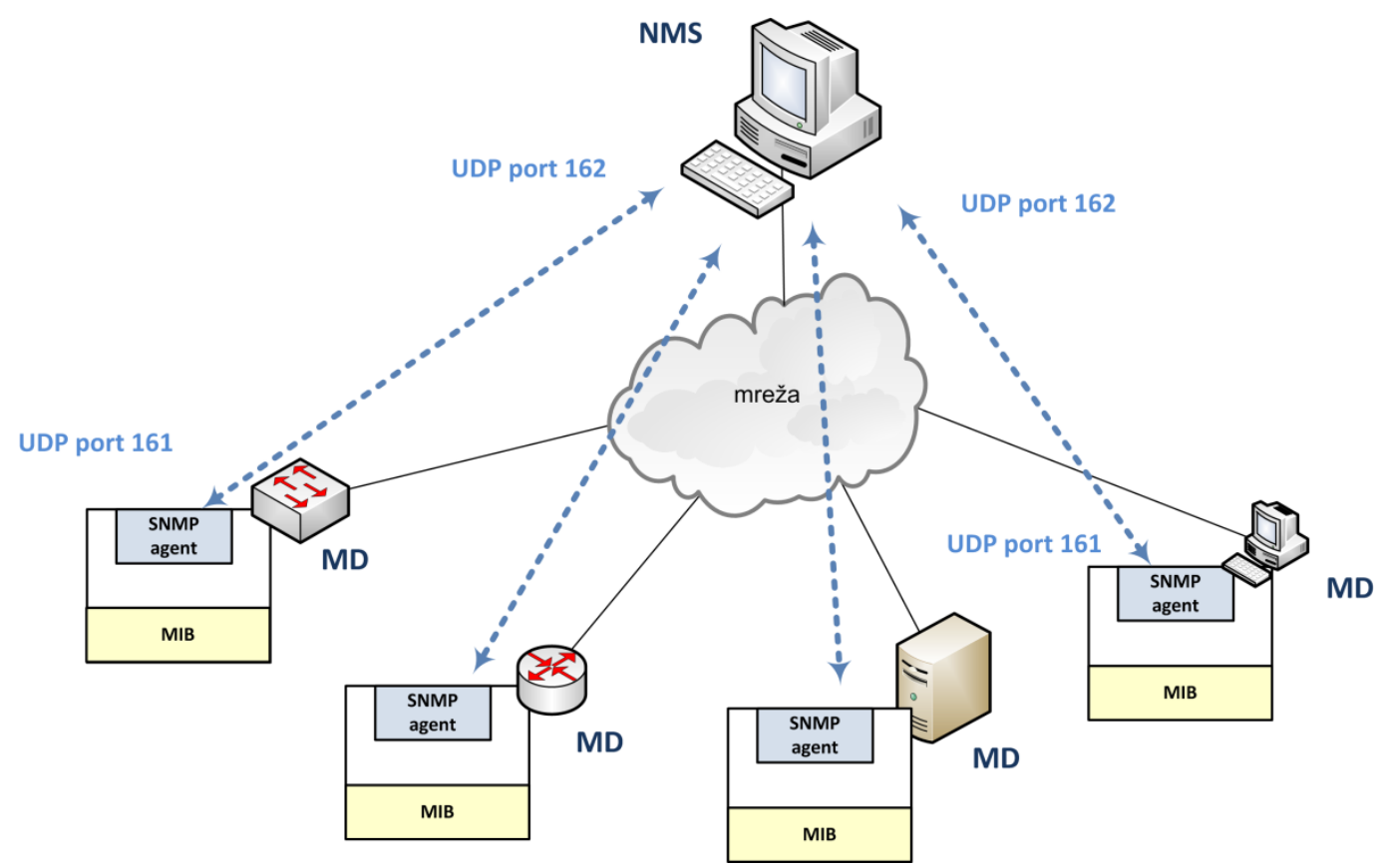

Slika 2-7. SNMP arhitektura ${ }^{37}$

Verzije SNMP protokola jesu sljedeće ${ }^{38}$ :

- SNMPv1 (SNMP version 1) prva je implementacija SNMP protokola i nastala je 1988. godine.

- $\quad$ SNMPv2 i jednostavnija verzija SNMPv2c poboljšali su performanse SNMPv1.

\footnotetext{
${ }^{37}$ Lebinac V., Valenčić D. 2013. Računalne mreže, izdavač Veleučilište Velika Gorica, ISBN 978-953-771645-5., 281-283.

${ }^{38}$ Isto.
} 
- SNMPv3: od početka je sigurnost bila najveća slabost SNMP protokola, pa je SNMPv3 bitno poboljšao sigurnost, kao i mogućnost udaljene konfiguracije. SNMPv3 je bitno promijenio i terminologiju i koncept SNMP protokola.

IETF je 2004. godine proglasio SNMPv3 (definirano u RFC 3411-RFC 3418) standardom, a verzije 1 i 2 proglasio je zastarjelima ${ }^{39}$. Zbog kompatibilnosti s već instaliranim i starijim uređajima, danas u svakodnevnoj primjeni SNMP implementacije podržavaju više verzija SNMP protokola: najčešće SNMPv1, SNMPv2c i SNMPv3 ${ }^{40}$.

\subsection{Važnost standarda}

Mrežni uređaji međusobno se razlikuju po:

- vrsti uređaja (na primjer usmjernik, preklopnik)

- veličini (kapacitetu) uređaja (na primjer mali kućni usmjernik, backbone ISP usmjernik),

- $\quad$ proizvođaču (na primjer Cisco, Juniper, ...)

- operacijskom sustavu uređaja (IOS, JUNOS, ...)

- verziji operacijskog softvera.

Da bi mrežni uređaji mogli međusobno komunicirati, njihove poruke i način obrade podataka (protokoli komunikacije) moraju biti standardizirani.

Svi standardi koji su povezani s Internetom i TCP/IP grupom protokola objavljeni su kao RFC standardi. Ima dosta RFC (Request for Comment) dokumenata koji nisu standardi, već služe za davanje dodatnih informacija i preporuka. RFC dokumenti označavaju se brojem, na primjer RFC 1009, pri čemu veći broj označava noviji RFC dokument.

\footnotetext{
${ }^{39}$ IETF RFC 3411 An Architecture for Describing Simple Network Management Protocol (SNMP) Management Frameworks (2002), https://tools.ietf.org/html/rfc3411 (21.01.2019).

${ }^{40}$ Lebinac V., Valenčić D. 2013. Računalne mreže, izdavač Veleučilište Velika Gorica, ISBN 978-953-771645-5., 281-283.
} 
Udruženje Internet Engineering Task Force (IETF) i njegove radne grupe objavljuju RFC dokumente. Tako na primjer RFC 791 (objavljen u rujnu 1981. godine) objašnjava IP verziju 4 protokola na osnovi kojega je izgrađen Internet. Sljedeća verzija IP protokola jest IP verzija 6 i opisana je u RFC 2460 koji je objavljen 1998. godine.

Svi RFC dokumenti dostupni su bez naknade (na internetskoj stranici: http://www.ietf.org/rfc.html). Kod traženja odgovarajućeg RFC dokumenta za neki protokol važno je vidjeti koji je RFC najnoviji i koji su prethodni RFC dokumenti zastarjeli.

Ostali standardi koji se koriste u računalnim mrežama (posebno na fizičkom i podatkovnom sloju OSI modela) definirani su od strane slijedećih organizacija:

- ISO (International Organization for Standardization),

- IEEE (Institute of Electrical and Electronics Engineers),

- ANSI (American National Standards Institute),

- ITU (International Telecommunication Union),

- EIA/TIA (The Electronics Industry Alliance/Telecommunications Industry Association).

Postoje i novije organizacije koje nastaju udruživanjem proizvođača i drugih zainteresiranih strana s ciljem promoviranja određene tehnologije i postizanja interoperabilnosti između različitih proizvoda. Primjer su:

- ONF (Open Networking Foundation) organizacija koja je nastala 2011. godine s ciljem promoviranja SDN tehnologije i OpenFlow protokola ${ }^{41}$.

- OpenConfig je neformalna radna grupa mrežnih operatera. Nastala je s ciljem promoviranja računalnih mreža s dinamičnom i programabilnom infrastrukturom koja

\footnotetext{
${ }^{41}$ ONF, https://www.opennetworking.org/ (15.8.2019).
} 
je bazirana na softverski definiranim mrežama. Trenutni osnovni fokus je izgradnja standardnih YANG podatkovnih modela ${ }^{42}$.

U dosadašnjem dijelu rada prikazani su različiti najvažniji protokoli koji se koriste u mrežnom upravljanju. Tablica 2-2. prikazuje pregled tih protokola i ukratko njihovu svrhu i zadnji osnovni standard u kojem su definirani. Za NetFlow protokol (vlasnički Cisco protokol) postoji informativni RFC, koji je kreirao Cisco s namjerom da se uporaba protokola proširi na ostale proizvođače. Na temelju NetFlow protokola nastao je IPFIX kao standard koji bi ga trebao zamijeniti. Jedino za CLI pristup konfiguraciji uređaja ne postoji standard, ali bi ga trebao zamijeniti NETCONF standard koji će biti obrađen kasnije.

Tablica 2-2. NM protokoli i standardi

\begin{tabular}{lll}
\hline Protokol & Svrha (ukratko) & Standard \\
\hline ICMP & Javljanje kontrolnih informacija & RFC 792 \\
\hline Syslog & Logiranje poruka & RFC 5424 \\
\hline RMON & Nadzor na daljinu & RFC 4502 \\
\hline NetFlow & Prikupljanje informacija o mrežnom prometu & RFC 3954 \\
\hline IPFIX & & (informational) \\
\hline FTP & Prikupljanje informacija o mrežnom prometu & RFC 7011 \\
\hline TFTP & Prijenos datoteka (koristi TCP) & RFC 959 \\
\hline CLI & Prijenos datoteka (koristi UDP) & RFC 1350 \\
\hline Telnet & Konfiguracija uređaja & - \\
\hline SSH & Pristup terminalu & RFC 854 \\
\hline SNMP & Siguran pristup terminalu & RFC 4253 \\
\hline & Konfiguracija i nadzor mrežnih uređaja & RFC 3411 \\
\hline
\end{tabular}

\footnotetext{
${ }^{42}$ OpenConfig, http://www.openconfig.net/ (15.8.2019).
} 
Uspjeh standarda ne ovisi o onome što ,radi na papiru“, već o tome je li on zapravo prihvaćen na tržištu. Općenito, standardi za mrežno upravljanje su uspješni ako ispunjavaju sljedeće kriterije $^{43}$ :

- Oni su "univerzalni" po tome što sadrže optimalni skup funkcija koje podržavaju svi proizvođači. Njihov opseg stoga može biti donekle ograničen, ali unutar svog opsega oni su cjeloviti.

- Proširivi su ili nude način mogućeg proširenja kako bi se zadovoljili novi zahtjevi. To nudi mogućnost unaprjeđivanja standarda u budućnosti.

- Jednostavni su za implementaciju. Ova funkcionalnost olakšava njihovo prihvaćanje i preduvjet je da se dobije kritična masa kako bi standard postao ne samo „de iure standard“ (odnosno standard samo na papiru), nego i „de facto standard“, odnosno standard koji je zapravo implementiran, koji se široko primjenjuje, i tržište ( proizvođači i korisnici) ga prihvaća.

\subsection{Trendovi u upravljanju mrežnim uređajima: SDN mreže}

Usmjernici i preklopnici obavljaju funkcije koje se mogu podijeliti u podatkovnu i kontrolnu cjelinu. Podatkovna cjelina je zaslužna za prosljeđivanje paketa između ulaznih i izlaznih sučelja ovisno o informacijama koje sadrže tablice prosljeđivanja dok kontrolna cjelina procesuira cijelu topologiju, skuplja informacije i kreira tablicu prosljeđivanja ${ }^{44}$.

U tradicionalnim mrežama podatkovna i kontrolna cjelina su spojene što rezultira time da je svaki mrežni uređaj zadužen za obje te funkcionalnosti. Kontrolna cjelina zadužena je za konfiguraciju mrežnih uređaja i određivanje najboljeg puta. Nakon što se odredi put, podatkovna cjelina preuzima ostali dio posla. Primjer mrežnog uređaja koji radi na ovaj način je usmjernik. Usmjernik sadrži podatkovnu i kontrolnu cjelinu i njegova osnovna funkcija je rad na mrežnom sloju, trećem sloju OSI modela. Sučelja na usmjerniku koriste se kako bi se poslužili dolazeći (engl. inbound) i odlazeći (engl. outbound) promet i predstavljaju

\footnotetext{
${ }^{43}$ Clemm, A. 2006. Network management fundamentals, Cisco Press, 113-114.

${ }^{44}$ Lebinac V., Valenčić D. 2013. Računalne mreže, izdavač Veleučilište Velika Gorica, ISBN 978-953-771645-5., 220-223.
} 
podatkovnu cjelinu. Ista ta sučelja kontroliraju se od strane kontrolne logike. Važna stavka kontrolne logike je tablica usmjeravanja koja sadrži zapise o najboljim putanjama prema određenim IP podmrežama.

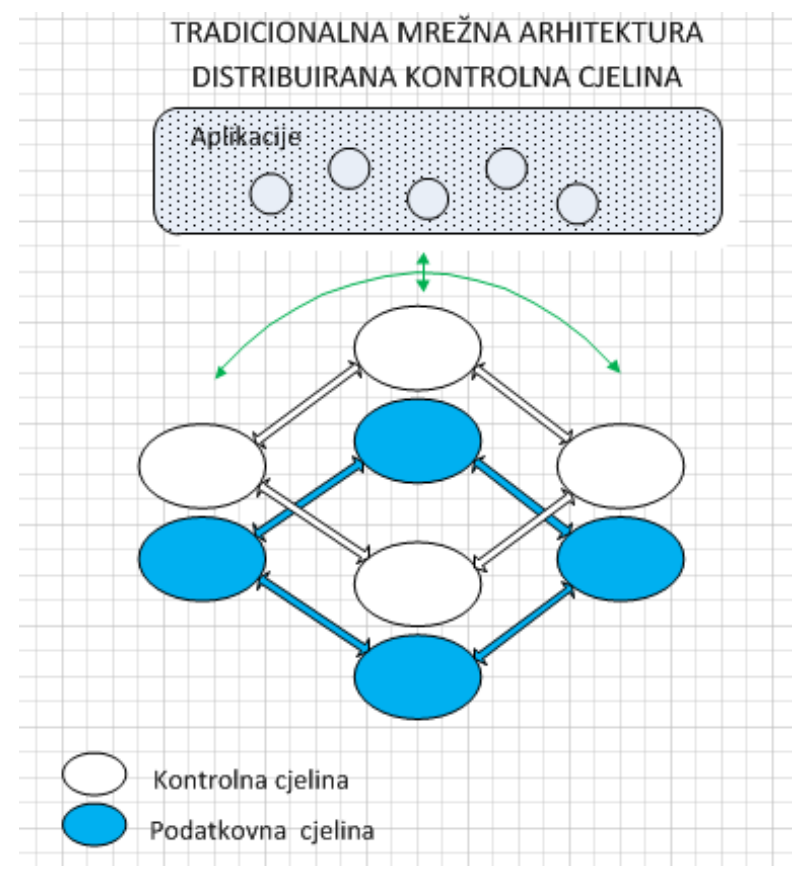

\section{Slika 2-8. Tradicionalna mrežna arhitektura}

Sve veća uporaba pametnih mobilnih uređaja koji su spojeni na Internet, virtualizacija servera i podatkovnih centara gdje su podaci smješteni, sve veća uporaba usluga računalstva u oblaku, potreba za programabilnim upravljanjem, sve to su osnovni trendovi koji uzrokuju da mrežna industrija preispita tradicionalnu mrežnu arhitekturu. Tradicionalne mreže imaju troslojnu hijerarhijsku arhitekturu (engl. three-tiered hierarchical architecture) i izgrađene su na tri sloja mrežnih uređaja (ethernet preklopnicima/usmjernicima), gdje su slojevi pristupni (engl. access layer), distribucijski (engl. distribution layer) i jezgreni (engl. core layer). Ovaj dizajn ima smisla kada je dominira klijent-server odnos između računala, ali takva statička arhitektura nije podobna za nove trendove dinamičkog mobilnog računalstva sa sve većom virtualizacijom i potrebama današnjih poduzeća, podatkovnih centara, kampusa i poslužitelja internetskih usluga. Tako nova arhitektura u podatkovnim centrima, koja se naziva leaf-spine arhitektura, ima tri sloja (leaf, spine, core) gdje su preklopnici u leaf sloju spojeni na sve 
preklopnike u spine sloju (a ne samo na dva kao u troslojnom hijerarhijskom modelu), tako da su svi preklopnici udaljeni jedan od drugoga samo jednim preklopnikom ${ }^{45}$.

Virtualizacija mrežnih funkcija (engl. Network Functions Virtualization - NFV) ili je mrežni koncept koji koristi tehnologije virtualizacije kako bi virtualizirao mrežne funkcije raznih mrežnih uređaja i pretvorio ih u osnovne elemente koji se mogu povezati i stvoriti komunikacijske usluge. NFV se može odnositi i na premještanje usluga, kao što su balansiranje opterećenja (engl. load balancing) i funkcije vatrozida, s fizičkog hardvera u virtualizirano okruženje. Rješenja koja koriste NFV su većinom implementirani unutar podatkovnih centara za razne platforme računalstva u oblaku.

Kako se mijenja arhitektura računalnih mreža, tako se mijenja i potreba za promjenom načina upravljanja tim mrežama i mrežnim uređajima koji sačinjavaju te mreže.

\subsubsection{Softverski definirane mreže (SDN)}

Softverski definirane mreže (engl. Software-Defined Networking - SDN) je termin za paradigmu programabilnih mreža ${ }^{4647}$. Ukratko, SDN se odnosi na sposobnost dinamičkog programiranja softverskih aplikacija pojedinačnih mrežnih uređaja i na taj način kontrolira ponašanje mreže u cjelini ${ }^{48}$. U RFC 7149 je istaknuto da je SDN skup tehnika koje se koriste kako bi se olakšalo projektiranje, isporuka i rad mrežnih usluga na deterministički, dinamičan i podesiv način ${ }^{49}$.

\footnotetext{
${ }^{45}$ Techtarget: Data center network design moves from tree to leaf (2013) https://searchdatacenter.techtarget.com/feature/Data-center-network-design-moves-from-tree-to-leaf (21.01.2019).

${ }^{46}$ Campbell, A., De Meer, H., Kounavis, M., Miki, K., Vicente, J., and D. Villela, 1992. A Survey of Programmable Networks, ACM SIGCOMM Computer Communication Review, Volume 29, Issue 2, 7-23.

${ }^{47}$ McKeown, N., Anderson, T., Balakrishnan, H., Parulkar, G., Peterson, L., Rexford, J., Shenker, S., and J. Turner, 2008. OpenFlow: Enabling Innovation in Campus Networks, ACM SIGCOMM Computer Communication Review, Volume 38, Issue 2, 69-74.

${ }^{48}$ Chowdhury, N. and R. Boutaba, 2009. Network Virtualization:State of the Art and Research Challenges, Communications Magazine, IEEE, Volume 47, Issue 7, 20-26.

${ }^{49}$ IETF RFC 7149 Software-Defined Networking: A Perspective from within a Service Provider Environment (2014), https://tools.ietf.org/html/rfc7149 (21.01.2019).
} 
SDN je programabilni mrežni pristup koji podržava odvajanje kontrolne ravnine i podatkovne ravnine putem standardiziranih sučelja ${ }^{50}$. Ključni element u SDN-u je uvođenje apstrakcije između (tradicionalne) podatkovne ravnine i kontrolne ravnine kako bi ih odvojili te osigurali aplikaciju sredstvima potrebnim za programsko kontroliranje mreže. Cilj je tu razdvojenost i pripadajuća programiranja iskoristiti kako bi se smanjila kompleksnost i omogućile brže inovacije na obje ravnine ${ }^{51}$.

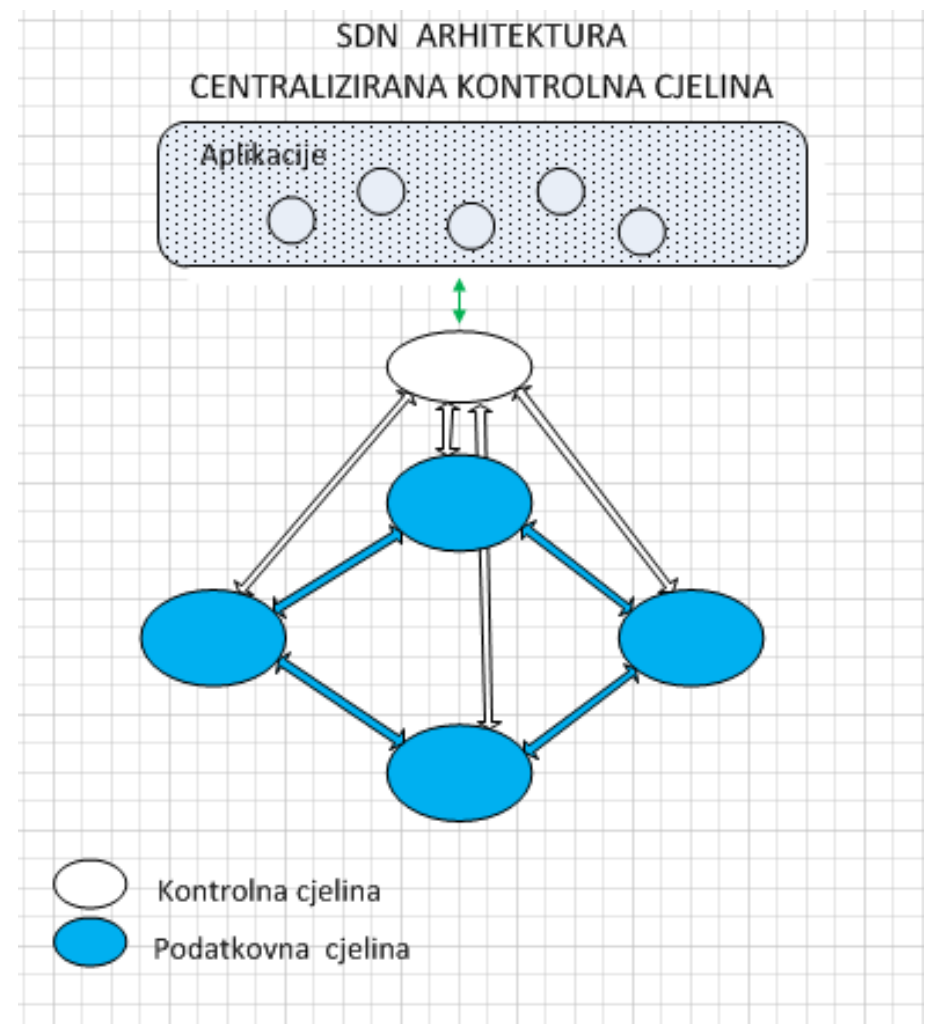

Slika 2-9. SDN mrežna arhitektura

NFV i SDN su vrlo usko povezane tehnologije te se vrlo često dopunjuju. Većina današnjih NFV platformi ima u sebi SDN kontrolere. Iako se NFV mogućnosti mogu ostvariti bez korištenja SDN mehanizama, korištenjem tih mehanizama dobiva se na performansama, pojednostavljuje se kompatibilnost s postojećim razvojem i olakšavaju se postupci za rad i

${ }^{50}$ IETF RFC 7426 Software-Defined Networking (SDN): Layers and Architecture Terminology (2015), https://tools.ietf.org/html/rfc7426 (21.01.2019).

${ }^{51}$ Greenberg, A., Hjalmtysson, G., Maltz, D., Myers, A., Rexford, J., Xie, G., Yan, H., Zhan, J., and H. Zhang, 2005. A CleanSlate 4D Approach to Network Control and Management, ACM SIGCOMM Computer Communication Review, Volume 35, Issue 5, 41-54. 
održavanje. NFV može podržati SDN pružajući infrastrukturu na kojoj se može izvoditi SDN softver. Očekuje se da se ova rješenja spoje sa sustavima zaduženim za upravljanje kao što su platforme za upravljanje računalnim oblakom ili platforme za upravljanje mrežnim uslugama. Prednosti NFV i SDN tehnologije su slične, što ne čudi s obzirom na to da u većini slučajeva NFV ovisi o SDN kontroleru kako bi ostvario svoje ciljeve.

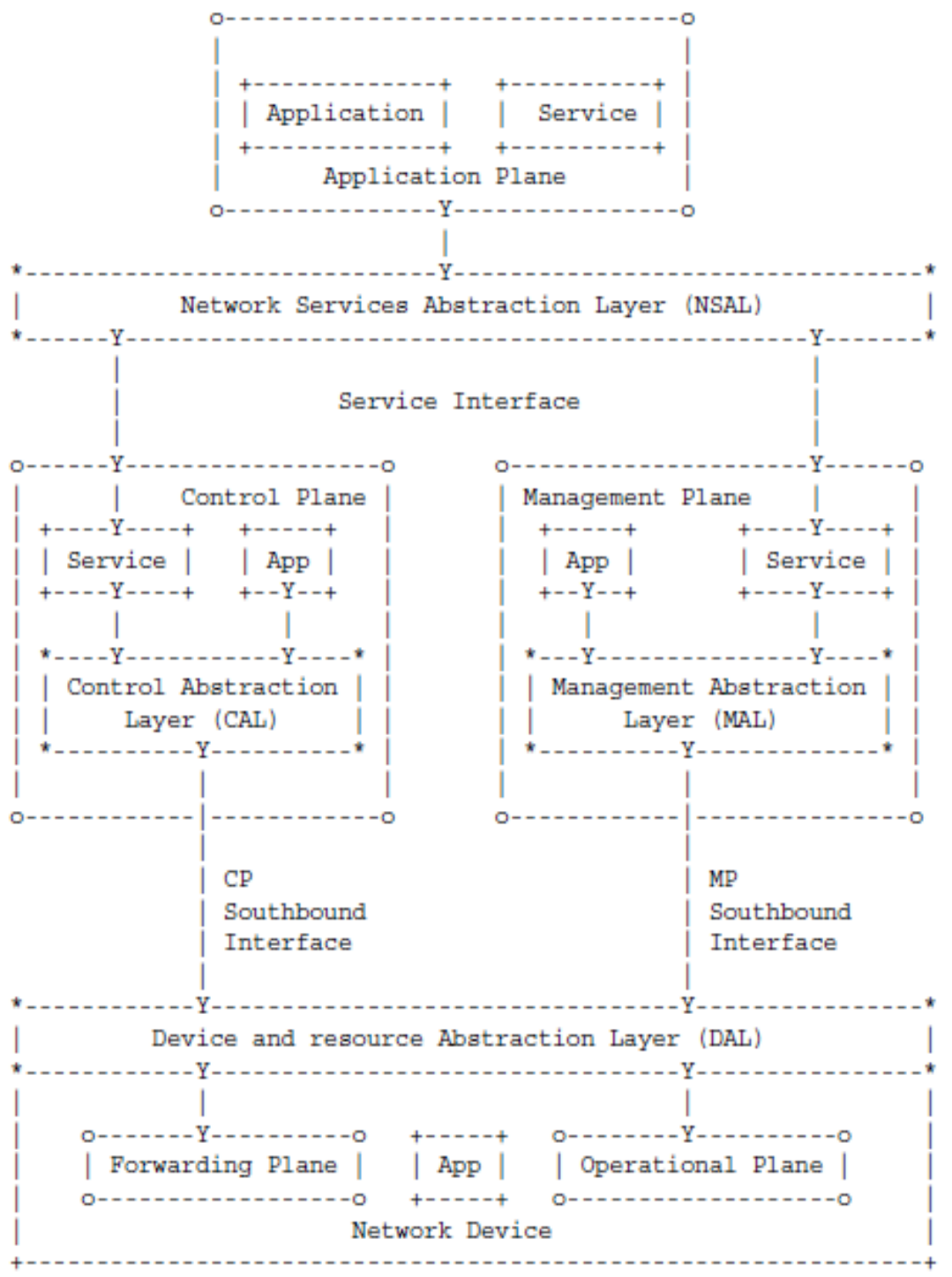

Slika 2-10. Slojevi SDN arhitekture ${ }^{52}$

${ }^{52}$ IETF RFC 7426 Software-Defined Networking (SDN): Layers and Architecture Terminology (2015), https://tools.ietf.org/html/rfc7426 (21.01.2019). 
Slika 2-10. prikazuje SDN protezanje na više ravnina (engl. plane) koje se nazivaju ${ }^{53}$ :

- Aplikacijska ravnina (engl. Application Plane - AP): u kojoj se nalaze aplikacije i usluge koji definiraju ponašanje mreže.

- Upravljačka ravnina (engl. Management Plane - MP): odgovorna je za praćenje, konfiguriranje i održavanje mrežnih uređaja, na primjer za donošenje odluka u vezi sa stanjem mrežnog uređaja. Upravljačka ravnina se uglavnom usredotočuje na operativnu ravninu uređaja, a manje na podatkovnu.

- Kontrolna ravnina (engl. Control Plane - CP): odgovorna je za donošenje odluka o tome kako paketi trebaju biti poslani jednom ili više mrežnih uređaja i šalje takve odluke sve do mrežnih uređaja za izvršenje. Kontrolna ravnina se obično usredotočuje na podatkovnu ravninu te manje na operativnu.

- Operativna ravnina (engl. Operational Plane - OP): odgovorna je za upravljanje operativnim stanjem mrežnog uređaja, na primjer je li uređaj aktivan ili neaktivan, koliko je priključaka na raspolaganju, kakav je status svakog sučelja i tako dalje. Operativna ravnina se odnosi na resurse mrežnih uređaja kao što su sučelja, memorija i tako dalje.

- Podatkovna ravnina (engl. Forwarding Plane - FP) odgovorna je za rukovanje paketima na podatkovnom putu temeljem uputa primljenih iz kontrolne ravnine. Djelovanja podatkovne ravnine uključuju prosljeđivanje, ispuštanje i promjenu paketa, ali nisu ograničeni na njih.

Sve navedene ravnine su spojene preko sučelja (označeno s "Y" na slici). Sučelje može preuzeti više uloga, ovisno o tome nalaze li se povezane ravnine na istom (fizičkom ili virtualnom) uređaju.

Aplikacije (Applications) su programi koji obavljaju određene zadatke koji koriste usluge bez pružanja pristupa drugim aplikacijama i mogu se implementirati u ravninu ili mogu obuhvaćati više ravnina. Usluge (Services) su programi koji pružaju API drugim aplikacijama

\footnotetext{
${ }^{53}$ Isto.
} 
i uslugama, i također se mogu implementirati u određene ravnine. Usluge koje se nalaze u više ravnina pripadaju također i aplikacijskoj ravnini.

Osim toga, definirana su četiri sloja apstrakcije ${ }^{54}$ :

- The Device and resource Abstraction Layer (DAL) odvaja resurse podatkovne i operativne ravnine uređaja od kontrolne i upravljačke ravnine.

- The Control Abstraction Layer (CAL) odvaja CP Southbound sučelje i DAL od aplikacija i usluga kontrolne ravnine.

- The Management Abstraction Layer (MAL) odvaja MP Southbound sučelje i DAL od aplikacija i usluga upravljačke ravnine.

- The Network Services Abstraction Layer (NSAL) pruža apstrakcijske usluge na korištenje aplikacijama i drugim uslugama.

Mrežni uređaj (Network device) na slici je entitet koji prima pakete na svojim sučeljima i obavlja jednu ili više mrežnih funkcija nad njima. Na primjer, mrežni uređaj može proslijediti primljeni paket, ispustiti ga, mijenjati zaglavlje paketa, proslijediti paket i tako dalje. Mrežni uređaj je agregacija više resursa, kao što su sučelja, CPU, memorija i redovi. Resursi su ili jednostavni ili mogu biti u obliku složenih resursa koji se mogu vidjeti kao jedan resurs. Mrežni uređaj je sam po sebi složen resurs. Primjeri mrežnih uređaja uključuju preklopnike i usmjernike. Mrežni uređaji mogu biti implementirani u hardver ili softver, a mogu biti ili fizički ili virtualni ${ }^{55}$.

Podatkovna ravnina, često zvana i "podatkovni put" (Data path), odgovorna je za rukovanje i prosljeđivanje paketa. Ona osigurava preklapanje, usmjeravanje, transformacije paketa i funkcije filtriranja.

Operativna ravnina odgovorna je za operativno stanje mrežnog uređaja, na primjer, s obzirom na status mrežnih sučelja. Resursi operativne ravnine uključuju memoriju, CPU, sučelja i redove, ali nisu ograničeni na njih. Podatkovna i operativna ravnina su izložene putem uređaja i resursa apstrakcijskog sloja (DAL) koji može biti izražen s više apstrakcijskih modela.

\footnotetext{
${ }^{54}$ Isto.

55 Isto.
} 
Primjeri apstrakcijskog modela podatkovne ravnine su Forwarding and Control Element Separation (ForCES) (definiran u RFC 5812), OpenFlow, YANG model (definiran u RFC 6020) i SNMP MIB (RFC 3418). Primjeri apstrakcijskog modela operativne ravnine uključuju ForCES model (RFC 5812), YANG model (RFC 6020) i SNMP MIB (RFC 3418$)^{56}$.

Kontrolna ravnina je uobičajeno distribuirana i odgovorna je uglavnom za konfiguraciju podatkovne ravnine pomoću CPSI (Control-Plane Southbound Interface) sučelja s DAL-om kao referentnom točkom. Kontrolna ravnina je odgovorna za upućivanje podatkovne ravnine o tome što da radi s mrežnim paketima. Komunikacija između entiteta kontrolne ravnine, kolokvijalno se naziva i "istok-zapad" sučelje, obično se implementira kroz gateway protokol kao što je BGP (definiran u RFC 4271). CPSI se može implementirati korištenjem protokola, API-a ili čak i međuprocesnom komunikacijom. Primjeri CPSI sučelja su ForCES (RFC 5810) i OpenFlow protokol ${ }^{57}$.

Upravljačka ravnina je obično centralizirana i njezin je cilj osigurati da mreža u cijelosti radi optimalno, a to postiže komunikacijom s mrežnim uređajima s operativne ravnine koristeći MPSI (Management-Plane Southbound Interface) sučelje s DAL-om kao referentnom točkom. MPSI je u pravilu bliži ljudskoj interakciji od CPSI sučelja i zbog toga je ključan uvjet jednostavnost korištenja, a ne performanse (poruke su rjeđe nego u CPSI sučelju). MPSI može biti u rasponu od protokola, do API-a ili čak izvanprocesne komunikacije. Ako upravljačka ravnina nije ugrađena u mrežni uređaj, MPSI je svakako protokol. Primjeri MPSI sučelja su ForCES (definiran u RFC 5810), NETCONF (RFC 6241), IP Flow Information Export (IPFIX) (RFC 7011), Syslog (RFC 5424), Open vSwitch Database (OVSDB) (RFC 7047) i SNMP (RFC 3411) ${ }^{58}$.

\subsubsection{SDN protokoli}

SDN koristi protokole koji se koriste i u tradicionalnom pristupu mrežama, kao što su SNMP, IPFIX i Syslog koji su ukratko prikazani u prethodnim poglavljima.

\footnotetext{
${ }^{56}$ Isto.

${ }^{57}$ Isto.

${ }^{58}$ Isto.
} 
Primjeri protokola koji su noviji i rijetko se koriste u tradicionalnim mrežama, a često se koriste u softverski definiranim mrežama su sljedeći:
- $\quad$ NETCONF,
- $\quad$ YANG,
- OpenFlow

NETCONF i YANG će biti detaljno prikazani u zasebnom poglavlju, dok će se ovdje ukratko prikazati osnovne karakteristike OpenFlow protokola.

\section{OpenFlow protokol}

ONF (Open Networking Foundation) je organizacija koja je nastala 2011. godine s ciljem promoviranja SDN tehnologije i OpenFlow protokola. ONF grupe stručnjaka rade s ostalim stručnjacima iz područja SDN tehnologije kako bi razvili nove SDN koncepte, arhitekture i standarde ${ }^{59}$.

OpenFlow protokol je standard koji je neovisan o proizvođačima te služi za komunikaciju između kontrolne i podatkovne ravnine u SDN arhitekturi, odnosno služi za komunikacija između SDN kontrolera i mrežnih uređaja preko southbound API sučelja.

Prva verzija 1.1 OpenFlow protokola je izdana od strane organizacije ONF u veljači 2011. Trenutna verzija koja je dostupna svima je v1.5.1, dok je verzija 1.6 (izašla u rujnu 2016.) dostupna samo članovima ONF organizacije $e^{60}$.

OpenFlow protokol može biti uspoređen s instrukcijskim skupom CPU-a. OpenFlow protokol određuje osnovne funkcije (Slika 2-11) koje mogu korištene od strane vanjske softverske aplikacije da bi se programirala podatkovna ravnina mrežnog uređaja, baš kako bi CPU instrukcijski skup programirao računalni sustav.

\footnotetext{
${ }^{59}$ Open Networking Fundation, 2012 Software-defined networking: The new norm for networks, ONF White Paper.

${ }^{60}$ OpenFlow, https://en.wikipedia.org/wiki/OpenFlow (21.3.2019).
} 


\section{SDN Controller Software}

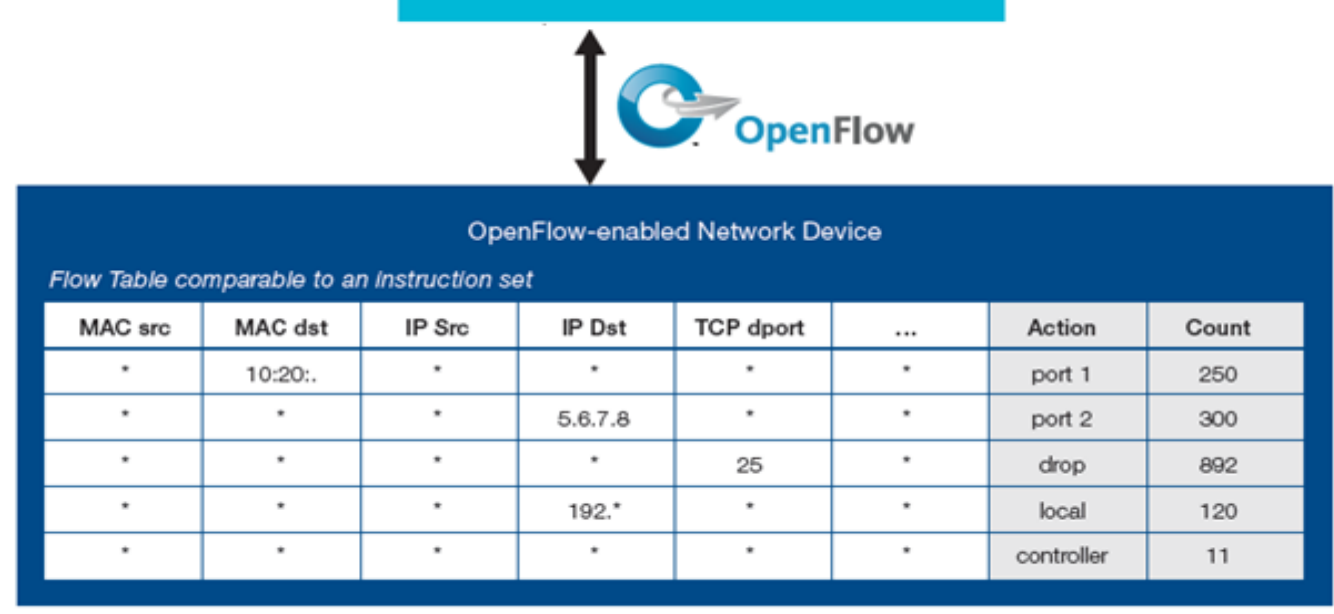

\section{Slika 2-11. Primjer OpenFlow skupa instrukcija ${ }^{61}$}

OpenFlow ne zahtijeva hardverske promjene, što u principu znači da proizvođači mrežne opreme ne moraju mijenjati svoje sustave kako bi ga podržavali, potrebno je otvoriti nekoliko dobro poznatih portova kako bi se ostvarila komunikacija podatkovne s kontrolnom cjelinom. Tako, na primjer, OpenFlow preklopnik ima vrlo slične karakteristike kao i standardni hardverski preklopnik. Obje vrste preklopnika koriste tablice tokova te izvršavaju prosljeđivanje paketa. Razlika je u tome na koji se način pravila protoka umetnu i ažuriraju unutar tablice tokova. Tradicionalni preklopnik može imati statička pravila koja su već unesena ili može raditi na principu učenja MAC adresa gdje preklopnik umeće pravila unutar tablice tokova svaki puta kada na svom sučelju dobije informaciju o novom uređaju. OpenFlow preklopnik s druge strane koristi vanjski kontroler kako bi umetnuo pravila unutar tablice tokova.

OpenFlow protokol radi iznad TCP (Transmission Control Protocol) protokola i koristi se TLS (Transport Layer Security) protokolom za sigurnost. Kontroler uči o OpenFlow preklopnicima osluškujući na TCP portu 6653.

\footnotetext{
${ }^{61}$ Open Networking Fundation, 2012 Software-defined networking: The new norm for networks, ONF White Paper.
} 


\subsubsection{Primjena SDN tehnologije na mrežnim uređajima}

U posljednjih se nekoliko godina pojavilo mnogo različitih implementacija SDN arhitekture. Najčešće se SDN primjenjuje u računalnim mrežama podatkovnih centara, najviše zbog njihove karakteristike intenzivne virtualizacije i velike koncentracije mrežnih uređaja na malom prostoru, kao i zbog velike potrebe za programabilnim pristupom upravljanju. SDN je zbog toga osnovni sastavni dio podatkovnih centara novije generacije nazvanih SDDN (Software-Defined Data Center) ili VDC (Virtual Data Center).

U ovom će se poglavlju ukratko prikazati nekoliko primjera implementacija SDN onih proizvođača koje imaju najveći utjecaj na tržištu mrežnih uređaja u ovom području.

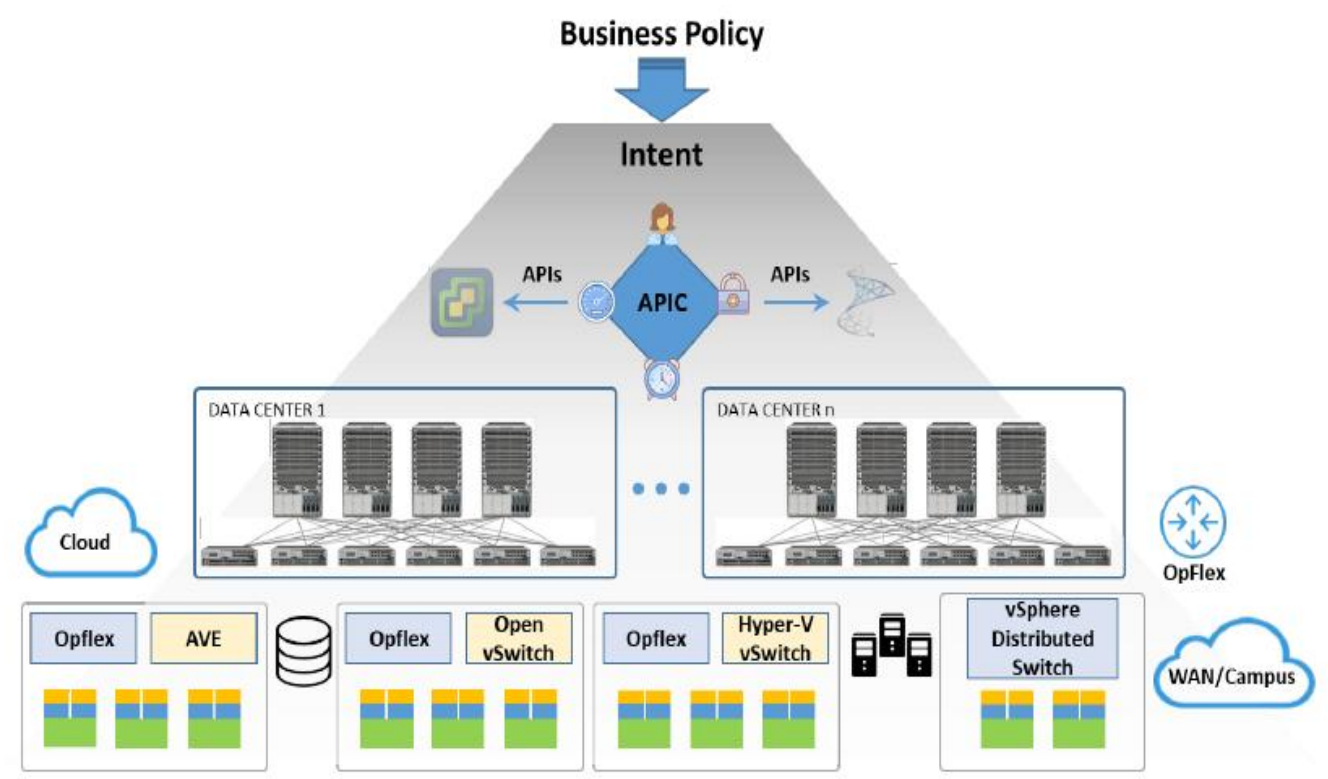

Slika 2-12. ACI infrastruktura ${ }^{62}$

\section{Cisco ACI}

Cisco ACI (Application Centric Infrastructure) sastoji se od Nexus 9K serije preklopnika, Cisco kontrolera APIC (Application Policy Infrastructure Controller), virtualnih preklopnika i skupa proizvoda Cisco partnera. Cisco ACI je građena na osnovi leaf/spine arhitekture i čini programabilnu cjelinu za konfiguraciju i upravljanje.

62 Cisco ACI, https://www.cisco.com/c/dam/en/us/solutions/collateral/data-center-virtualization/applicationcentric-infrastructure/esg-lab-validation-aci.pdf (21.3.2019). 
Cisco APIC čine grupa (engl. cluster) od tri servera koji zajedno izvršavaju sve funkcije SDN kontrolera $^{63}$. Slika 2-12. prikazuje ACI infrastrukturu.

\section{VMware NSX Data Center}

VMware NSX Data Center je mrežna virtualizacijska platforma za SDDC (Software-Defined Data Center) koja omogućava umrežavanje i sigurnosti primijenjene u cijelosti u softveru, i koja je potpuno neovisna o fizičkoj infrastrukturi.

VMware NSX je softver koji sadrži podatkovnu ravninu i logički integrira funkcije preklopnika, usmjernika i vatrozida. NSX kontroler djeluje na kontrolnoj ravnini, a omogućava upravljanje logičkim mrežnim uređajima i definiranje protokola kontrolne ravnine za prosljeđivanje prometa. NSX menadžer djeluje na upravljačkoj ravnini i predstavlja cjeloviti konfiguracijski portal za SDDC. Osnovni zahtjev za NSX je mogućnost IP spajanja unutar podatkovnog centra, tako da je podržana bilo koja mrežna konfiguracija i arhitektura (leaf/spine ili troslojna hijerarhijska). Osim toga NSX omogućava enkapsuliranje prometa u podatkovnom centru i na taj način dozvoljava da VM (Virtual Machines) ostanu u istoj ravnini iako su fizički smještene u različitim broadcast domenama, odnosno između njih se nalazi usmjernik kao L3 uređaj ${ }^{64}$.

Detaljne informacije o VMware NSX softveru i tehnologijama može se naći na VMware web stranicama.

\section{Big Switch Networks Big CLoud Fabric}

Big Switch Networks je predstavio proizvod Big CLoud Fabric. To je platforma za mreže velikih razmjera, telekome i podatkovne centre. Ova platforma omogućava upravljanje fizičkim i virtualnim mrežnim uređajima. Daje potreban uvid i nadzor nad cijelom mrežom i time olakšava prilagođavanje mreže potrebama ${ }^{65}$.

\footnotetext{
${ }^{63}$ Cisco ACI infrastruktura, https://www.cisco.com/c/en/us/solutions/data-center-virtualization/applicationcentric-infrastructure/index.html\# $\sim$ stickynav=4 (21.3.2019).

${ }^{64}$ VMware NSX https://www.vmware.com/products/nsx.html, (21.3.2019).

${ }^{65}$ Big Switch Networks Big CLoud Fabric, https://www.bigswitch.com/products/big-cloud-fabric, (21.3.2019).
} 


\section{Floodlight}

Floodlight kontroler je SDN kontroler otvorenog koda (engl. open source) i jedan je od najpopularnijih besplatno dostupnih SDN kontrolera. Floodlight kontroler je razvijen pomoću Java programskog jezika i licenciran je od strane ASF (Apache Software Foundation). Floodlight kontroler radi s većinom fizičkih i virtualnih preklopnika s kojima može komunicirati pomoću OpenFlow protokola. Razvijen je od strane otvorene zajednice što omogućuje doprinose aktivnih sudionika (neki od njih su inženjeri iz kompanije Big Switch Networks) te su informacije o projektu razvoja ovog kontrolera svima dostupne. Floodlight kontroler je vrlo jednostavan za instalaciju i za korištenje, a arhitektura kontrolera je modularna što omogućuje jednostavno proširenje pomoću dodatnih modula ${ }^{66}$.

\section{Ostali proizvođači}

Primjeri ostalih proizvođača i njihovih proizvoda koji su vezani uz SDN su sljedeći:

- Juniper Networks Contrail Networking,

- $\quad$ Arista Software Defined Cloud Networking,

- Huawei CloudFabric,

- $\quad$ Extreme Networks ExtremeControl,

- $\quad$ F5 BIG-IQ,

- Alcatel-Lucent Enterprise SDN,

- Hewlett Packard Enterprise SDN Controller,

- Dell SDN Solution.

\subsubsection{Važnost SDN mreža}

U zadnjih nekoliko godina došlo je do značajne potrebe za promjenom u upravljanju R/S uređajima uzrokovane virtualizacijom i mobilnošću današnjih mreža pa su nastale softverski definirane mreže (SDN). SDN se odnosi na sposobnost dinamičkog programiranja softverskih aplikacija pojedinačnih mrežnih uređaja i na taj način kontrolira ponašanje mreže u cjelini.

\footnotetext{
${ }^{66}$ Floodlight, http://www.projectfloodlight.org/floodlight, (21.3.2019).
} 
SDN može pojednostaviti upravljanje mrežom, ubrzati proces isporuke novih usluga i potencijalno smanjiti troškove. Osim toga, jedna od glavnih značajki SDN arhitekture u današnjim mrežama predstavlja agilnost mreže. Mogućnost brze promjene na čitavoj mreži, bez potrebe za poznavanjem komandi i operacijskih sustava opreme u mreži, može posebno biti bitno u mrežama koje imaju uređaje različitih proizvođača.

Trenutno mnogi proizvođači mrežne opreme ulažu u SDN tehnologiju kako bi odgovorili na sve veće zahtjeve svojih klijenata. Većina većih proizvođača mrežne opreme prisutna je na tržištu sa SDN proizvodima (s više ili manje uspjeha), a javljaju se i nove brzorastuće kompanije kojima je SDN osnovni proizvod. Većina SDN proizvoda je za sada fokusirana na podatkovne centre, međutim nude se SDN rješenja i za ostale vrste računalnih mreža, na primjer za LAN mreže velikih poduzeća, WAN mreže, mreže davatelja usluga, IoT mreže i druge.

Ipak SDN ima i svojih nedostataka. SDN je sa svojim centraliziranim načinom upravljanja pogodan za računalne mreže gdje se SDN kontroler nalazi vrlo blizu mrežnim uređajima (kao na primjer u LAN mrežama i mrežama podatkovnih centara). SDN način upravljanja tek se treba dokazati u WAN mrežama, gdje su uređaji udaljeni od SDN kontrolera. Važno je osigurati i redundantnost SDN kontrolera da se izbjegnu SPoF točke, pa i međusobno povezivanje i komunikaciju između SDN kontrolera u različitim računalnim mrežama. SDN tehnologije se brzo razvijaju s više strana (od različitih proizvođača) pa je važna i međusobna operabilnost SDN uređaja, za što će biti potrebno donošenje novih odgovarajućih standarda $u$ tom području. Odličan primjer je RFC 7426 koji je sistematizirao dosadašnji razvoj SDN terminologije i arhitekture.

Osim toga, sam prijelaz na SDN način upravljanja ne može se izvršiti u kratkom vremenskom roku. Kako se većina tradicionalnih tehnologija i protokola koristi i u današnjim mrežama, zbog troškova i kompleksnosti može se očekivati polagani prijelaz na SDN tehnologiju koji će trajati dulji vremenski period i koji se može usporediti s polaganim i dugotrajnim prijelazom iz IPv4 na IPv6 računalne mreže. 
Tako se, unatoč svim prednostima SDN upravljanja i dalje može očekivati primjena tradicionalnih protokola (koji su ukratko prikazani u ovom radu), s postupnom primjenom i daljnjim razvojem novijeg centraliziranog SDN pristupa.

SDN je detaljnije prikazan u ovom radu jer je NETCONF važan sastavni dio SDN arhitekture. Korisnici koji koriste SDN mreže, vrlo često primjenjuju i NETCONF protokol (kao sastavni dio SDN proizvoda), a da toga nisu ni svjesni. NETCONF izvršava svoje funkcije u pozadini i prikriven je SDN korisničkom aplikacijom. 


\section{Teorija povećanja raspoloživosti mrežnih uređaja}

U današnjem poslovanju računalna mreža vrlo često mora biti raspoloživa 24 sata na dan tijekom kojih najvažnije aplikacije i podaci moraju biti raspoloživi.

Nekoliko sekundi zastoja rada, koji je unaprijed planiran ili se dogodi zbog kvara, može izazvati ogromne financijske gubitke. U nekim primjenama računalnih mreža prestanak rada mreže računala može prouzrokovati još i teže posljedice (na primjer zračne luke, bolnice) iako se gubitak ne može mjeriti kroz financije.

Zbog toga je izgradnja računalnih mreža veće raspoloživosti sve važnija.

\subsection{Uvod u teoriju raspoloživosti ICT sustava}

Pojam raspoloživost (engl. availability) u području računalnih sustava i mreža određuje zahtjev da računalni sustav bude raspoloživ za pristup autoriziranim korisnicima ${ }^{67}$.

Odabrane definicije raspoloživosti su sljedeće:

- mogućnost pristupa računalnom sustavu autoriziranim korisnicima kada za to imaju $\operatorname{potrebu}^{68}$.

- mjera koja određuje koliko dugo (ili koliko često) je usluga ili komponenta sustava raspoloživa za uporabu ${ }^{69}$.

- proces optimiziranja spremnosti proizvodnog sustava pomoću preciznog mjerenja i analiziranja i smanjivanja prekida rada tog proizvodnog sustava ${ }^{70}$.

\footnotetext{
${ }^{67}$ Stallings, W. 2003. Data and computer communications, Fifth Edition, Pearson Education, Inc., Pearson Prentice Hall, 623-626.

${ }^{68}$ NIST (US National Institute of Standards and Technology) Glossary, under NIST SP 800-113 (2008.), https://csrc.nist.gov/glossary/term/availability (11.05.2019).

${ }^{69}$ Schmidt, K. 2006. High availability and disaster recovery: concepts, design, implementation. Springer Science \& Business Media, ISBN-13 978-3-540-24460-8, 34-35.
} 
- uloženi trud na prevenciji prekida rada usluge i proizvodnje $\mathrm{e}^{71}$,

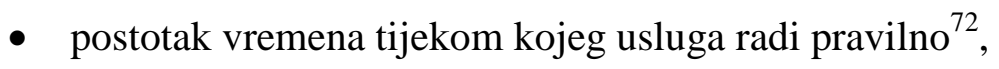

- kvaliteta (osobina, sposobnost) koja je dostupna kada je potrebna ${ }^{73}$,

- sposobnost IT usluge ili konfiguracijske jedinice da izvršava dogovorene funkcije kada je to potrebno ${ }^{74}$,

Raspoloživost je jedan od triju osnovnih zahtjeva mreža (uz tajnost i integritet) za sigurnost računalnih sustava i mreža, zbog čega se često u ICT području koristi skraćenica CIA (Confidentiality, Integrity, Availability) ${ }^{75}$.

Prekid (engl. interruption) nastaje ako dođe do uništavanja jednog dijela sustava ili dio sustava postane neraspoloživ ili neupotrebljiv. Prekid direktno utječe na raspoloživost. Primjer prekida može biti uništavanje hardvera računala ili prekid komunikacije između dvaju računala. Ako korisnik nije u mogućnosti pristupiti sustavu, tada se kaže da je sustav neraspoloživ (engl. unavailable). Općenito se koristi pojam vrijeme zastoja (engl. downtime) za period vremena kada sustav nije raspoloživ ${ }^{76}$. Vrijeme zastoja predstavlja potpuni zastoj hardverskog uređaja, softvera ili neke druge kritične komponente koji rezultira prekidom rada proizvodne aplikacije ${ }^{77}$.

\footnotetext{
${ }^{70}$ Schiesser, R. 2010. IT systems management, Pearson Education, 2nd edition, ISBN-13: 978-0-137-02506-0, 128-129.

${ }^{71}$ Hernandez, S. 2013. Official (ISC)2 ${ }^{2}$ Guide to the CISSP ${ }^{\circledR}$ CBK $®$, 3rd edition, CRC Press, ISBN-13: 978-14665-9793-8, 38-39.

${ }^{72}$ Clemm, A. 2006. Network management fundamentals, Cisco Press, 421-422.

${ }^{73}$ Marcus, E., Stern, H. 2003. Blueprints for high availability. John Wiley \& Sons, 2nd. edition, 31-32.

${ }^{74}$ Menken, I. 2011. Itil ${ }^{\circledR}$ Foundation Complete Certification Kit - Study Book and eLearning Program - 4th edition, Publisher: Emereo Pty Ltd, 139-142.

${ }^{75}$ Hernandez, S. 2013. Official (ISC)2 ${ }^{\circledR}$ Guide to the CISSP ${ }^{\circledR}$ CBK $®$, 3rd edition, CRC Press, ISBN-13: 978-14665-9793-8, 38-39..

76 Valenčić D., Ćavar I., Zimet J. 2012. Visoka raspoloživost računalnih mreža, Zbornik radova, 5. Međunarodna konferencija "Dani kriznog upravljanja“, Veleučilište Velika Gorica, Velika Gorica, str. 695 719, ISBN 978-953-7716-31-8., znanstveni rad.

${ }^{77}$ Schiesser, R. 2010. IT systems management, Pearson Education, 2nd edition, ISBN-13: 978-0-137-02506-0, $131-132$
} 


\subsubsection{Visoka raspoloživost}

Visoka raspoloživost označava da su sustav ili aplikacija raspoloživi tijekom određenih radnih sati bez neplaniranog prekida $\operatorname{rada}^{78}$.

Visoka raspoloživost je karakteristika sustava da se oporavi ili zaštiti od manjih gubitaka (engl. minor outages) u kratkom vremenskom roku na visoko automatiziran način ${ }^{79}$.

Visoka raspoloživost se smatra dizajnom produkcijskog sustava koji sve svoje SPoF točke rješava pomoću redundancije $\mathrm{s}$ ciljem izbjegavanja prekida rada. Takav tip sustava se često naziva i tolerantnim na greške (engl. fault tolerant) ${ }^{80}$.

U ICT sustavima, pojam oporavka od katastrofe (engl. Disaster Recovery - DR) razlikuje se od pojma visoke raspoloživosti (engl. High Availability - HA). Oba su pojma vezana uz neprekidnost poslovanja (engl. Business Continuity - BC). Visoka raspoloživost bavi se kontinuitetom operacija bez prekida, dok oporavak od katastrofe uključuje i period prekida rada koji može iznositi od nekoliko sekundi do nekoliko dana. Drugim riječima, metode visoke raspoloživosti imaju za cilj izbjegavanje prekida rada, dok se procedure oporavka od katastrofe bave što bržim povratkom u normalan način rada uz što manje štete, u slučaju da do prekida ipak dođe ${ }^{81}$.

Ugovori o razinama usluga (engl. Service Level Agreements - SLA) su sredstva pomoću kojih definiramo uvjete isporuke IT usluga, tj. to su ugovori između vlasnika tvrtki (korisnika) i IT odjela (davatelja usluge) ${ }^{82}$. SLA je dogovoreni sporazum između korisnika i davatelja usluge u kojem se formalno definira vrsta i kvaliteta usluge koju je davatelj usluge obavezan pružiti svom korisniku. Ako su usluge IT održavanja dogovorene s vanjskim izvođačem, tada se sklapa pravi pravni ugovor između dviju tvrtki. Međutim, najčešći je

\footnotetext{
${ }^{78}$ Piedad, F., Hawkins, M. 2000. High Availability: Design, Techniques, and Processes, Prentice Hall, str.16.

${ }^{79}$ Schmidt, K. 2006. High availability and disaster recovery: concepts, design, implementation. Springer Science \& Business Media, ISBN-13 978-3-540-24460-8, str. 32.

${ }^{80}$ Schiesser, R. 2010. IT systems management, Pearson Education, 2nd edition, ISBN-13: 978-0-137-02506-0, str.132.

81 Valenčić D., Ćavar I., Zimet J. 2012. Visoka raspoloživost računalnih mreža, Zbornik radova, 5. Međunarodna konferencija "Dani kriznog upravljanja“, Veleučilište Velika Gorica, Velika Gorica, str. 695 719, ISBN 978-953-7716-31-8., znanstveni rad.

${ }^{82}$ Schmidt, K. 2006. High availability and disaster recovery: concepts, design, implementation. Springer Science \& Business Media, ISBN-13 978-3-540-24460-8, 31-32.
} 
slučaj da su vlasnik tvrtke i IT odjel iz iste tvrtke. SLA uobičajeno sadrži definiciju usluge, kvalitetu usluge i način mjerenja, proceduru upravljanja eventualnim problemima, odgovornosti korisnika, podatke o garanciji, krizno upravljanje i procedure i uvjete prekida ugovora. Valjano napisani SLA je prednost za obje strane - vlasnici tvrtke znaju što dobivaju, a IT odjel zna što mora biti isporučeno i poštivano.

Visoka raspoloživost ne znači da sustav mora neprekidno raditi (što je nerealno očekivati i nemoguće ostvariti). Visoka raspoloživost nam ipak daje prostora za planiranje vremena zastoja, sve dok se vrijeme zastoja nalazi izvan dogovorenog i određenog vremena kada sustav mora biti raspoloživ. Na primjer, na osnovi SLA može se pružiti usluga visoke raspoloživosti za vrijeme uobičajenog radnog vremena (na primjer od 9 do 17 sati), a računalni sustav može imati dogovoreni prekid rada tijekom noći za obavljanje redovitog održavanja računala i mreže. Ono što garantira visoka raspoloživost sustava je osiguravanje pouzdanog rada tijekom dogovorenog perioda u kojem raspoloživosti mora biti visoka (i koje je određeno u SLA dokumentu).

Najveći izazov i cilj ovakvih sustava je potpuno eliminirati moguće probleme i prekide, ili ih bar učiniti nevidljivim za korisnike, odnosno bez utjecaja na njihov rad i pristup. U slučaju kvara ili prekida na jednom dijelu računalnog sustava visoke raspoloživosti, korisnik nastavlja koristiti sustav bez primjećivanja bilo kakvih promjena, a sustav mora sam naći rješenje.

\subsubsection{Uzroci zastoja}

Primjeri uzroka zastoja ICT sustava su dobiveni kroz dva istraživanja sa sljedećim rezultatima ${ }^{83}$ :

1. Gartner (Dataquest) istraživanje:

- $\quad$ sistemski softver $27 \%$,

- hardver $23 \%$,

- ljudska greška $18 \%$,

- greška u mreži 17\%,

\footnotetext{
${ }^{83}$ Marcus, E., Stern, H. 2003. Blueprints for high availability. John Wiley \& Sons, 2nd. edition, 15-16.
} 
- prirodna katastrofa $8 \%$,

- nepoznato $7 \%$.

2. CNT istraživanje:

- greška u hardveru $44 \%$,

- ljudska greška $32 \%$,

- softverska greška $14 \%$,

- virusi $7 \%$,

- prirodna katastrofa 3\%.

Slika 3-1. prikazuje rezultate dobivene istraživanjem 2008. godine (Freeform Dynamics).

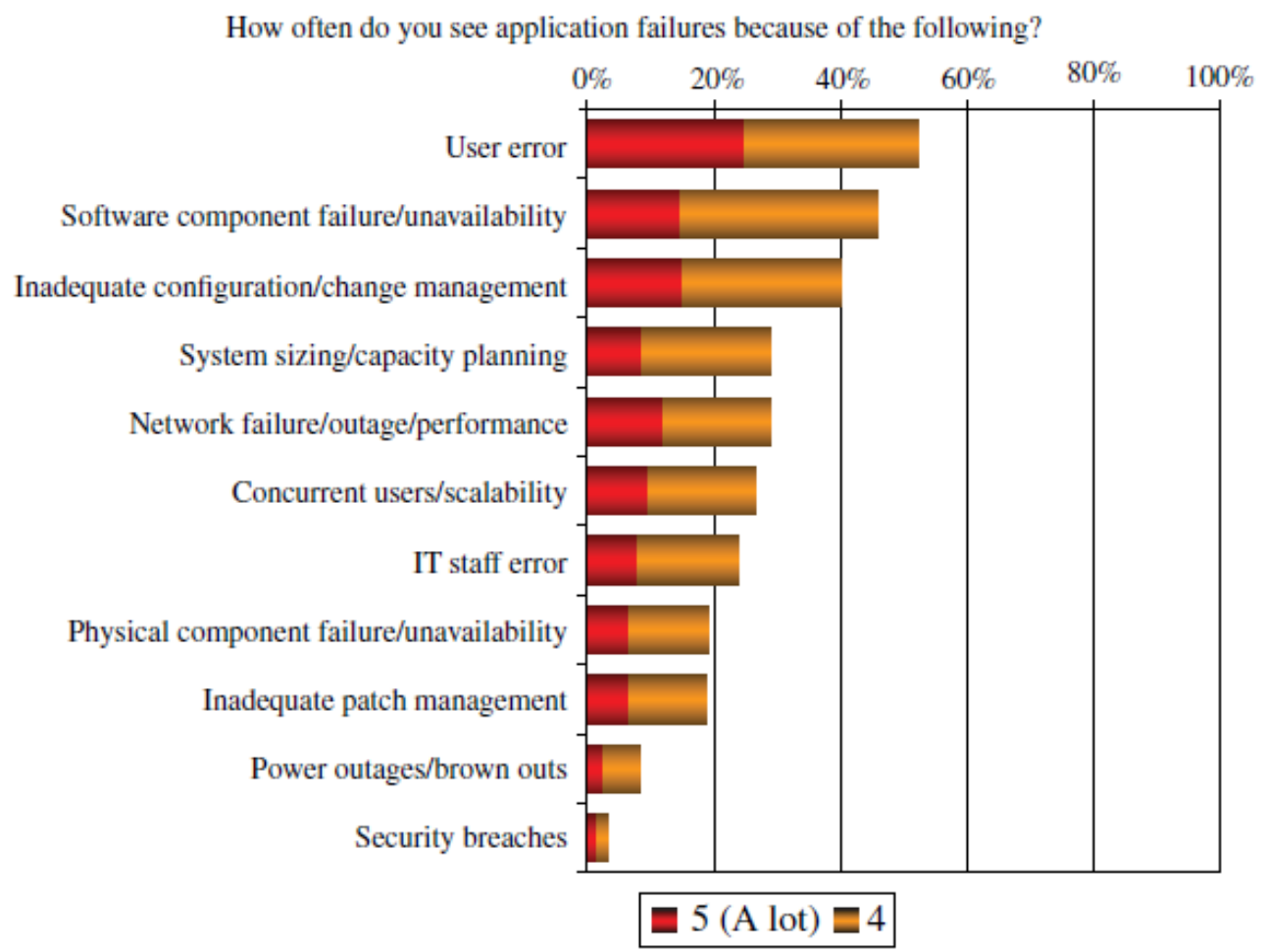

\section{Slika 3-1. Pregled uzroka zastoja aplikacija ${ }^{84}$}

U gornjim istraživanjima ljudska je greška jedan od glavnih uzroka zastoja. Ljudi uzrokuju zastoje uslijed dvaju razloga, koja su međusobno i povezana. Prvi razlog je da ponekad naprave glupu ili nepažljivu grešku. Drugi razlog je da često potpuno ne razumiju kako sistem

\footnotetext{
${ }^{84}$ Geng, H. 2015. Data Center Handbook, Wiley, ISBN 978-1-118-43663-9. str. 648.
} 
funkcionira. Najbolji način izbjegavanja ljudskih pogrešaka je kombinacija edukacije i jednostavnog dizajna sustava. Slanje ljudi na edukaciju da bi ažurirali svoja znanja i održavanje ažurirane dokumentacije značajno pomažu pri smanjenju ljudske pogreške.

\subsubsection{Trošak vremena zastoja}

Termin trošak vremena zastoja (engl. cost of downtime) vrlo se često koristi da bi se objasnio utjecaj prekida rada ICT sustava na poslovanje neke organizacije.

Iako je prekid rada ICT usluga nepoželjan za sve vrste poslovanja, ipak je financijski značajniji za neke vrste industrije i tipove usluga.

Tablica 3-1. prikazuje rezultate istraživanja organizacije Gartner Group (Dataquest) iz 1998. godine. U tablici je prikazan trošak vremena zastoja za primjere pojedinih IT usluge koje pružaju različite vrste organizacija. Trošak je prikazan u američkim dolarima (USD) za period od jedne minute i od jednog sata. Iz tablice se može vidjeti da je financijski utjecaj prekida rada na neke sustave nizak, a na druge je izuzetno visok. Zbog toga najviši nivo raspoloživosti nije potreban za sve aplikacije i industrije.

Primjer visokog utjecaja je burzovno posredništvo. Ako dođe do prekida rada sustava na IT sustavu burze, trošak vremena zastoja je veći od 100000 USD po minuti. Zbog toga će banke zahtijevati da vrijeme prekida bude minimalno i tražit će postizanje najviše razine raspoloživosti tih IT sustava.

U slučaju sustava isporuke paketa, trošak zastoja je nizak. Izgradnja i primjena sustava visoke raspoloživosti može tražiti više financijskog ulaganja nego što se može izgubiti u slučaju prekida rada, pa čak i na dulje vrijeme (nekoliko dana). 
Tablica 3-1. Trošak vremena zastoja ${ }^{858687}$

\begin{tabular}{|c|c|c|c|}
\hline \multirow{2}{*}{ Industrija } & \multirow{2}{*}{ IT usluga } & \multicolumn{2}{|c|}{ Trošak vremena zastoja } \\
\hline & & po minuti & po satu \\
\hline Financijska & Burzovno posredništvo & 107500 & 6450000 \\
\hline Financijska & $\begin{array}{l}\text { Kreditne kartice/autorizacija } \\
\text { prodaje }\end{array}$ & 43333 & 2600000 \\
\hline Financijska & Bankomat/ naknada korištenja & 241 & 14500 \\
\hline Mediji & Video na zahtjev & 2500 & 150000 \\
\hline Mediji & Teleprodaja & 1150 & 69000 \\
\hline Prodaja & Kupovina od kuće & 1883 & 113000 \\
\hline Prodaja & Prodaja po katalogu & 1500 & 90000 \\
\hline Transport & $\begin{array}{l}\text { Rezervacija zrakoplovnih } \\
\text { karata }\end{array}$ & 1483 & 89000 \\
\hline \multirow[t]{2}{*}{ Transport } & Isporuka paketa & 466 & 28000 \\
\hline & $\begin{array}{l}\text { Srednji trošak vremena } \\
\text { zastoja (USD) }\end{array}$ & 17784 & 1067040 \\
\hline
\end{tabular}

\subsubsection{Kvantifikacija i mjerenje raspoloživosti}

Raspoloživost se uobičajeno promatra kao postotak vremena kada je sustav raspoloživ od ukupnog vremena kada bi sustav trebao biti raspoloživ ${ }^{88}$. Formula za izračunavanje raspoloživosti je sljedeća ${ }^{89}$ :

\footnotetext{
${ }^{85}$ Marquis, H. The Paradox of the 9s (2006), ITSM Solutions, http://www.itsmsolutions.com/newsletters/DITYvol2iss47.htm (10.1.2012.).

${ }^{86}$ Marcus, E., Stern, H. 2003. Blueprints for high availability. John Wiley \& Sons, 2nd. edition, 31-32

${ }^{87}$ IBM Global Service: Improving Systems Availability (1998) http://www.cs.cmu.edu/ priya/hawht.pdf (10.1.2012.).
} 


$$
A=\frac{U-Z}{U} \times 100
$$

gdje je:

$$
\begin{aligned}
& \text { A - raspoloživost (\%) } \\
& U \text { - dogovoreno vrijeme pružanja usluge } \\
& Z \text { - neplanirano vrijeme zastoja }
\end{aligned}
$$

Raspoloživost se može izračunati i na sljedeći način ${ }^{90}$ :

$$
A=\frac{M T B F}{M T B F+M T T R}
$$

gdje je:

$$
\text { A - raspoloživost }
$$

MTBF - srednje vrijeme između zastoja (engl. Mean Time Before Failures)

MTTR - srednje vrijeme popravka (engl. Mean Time To Repair)

Ova formula ukazuje nam da je vrlo lako povećati raspoloživost smanjujući vrijeme potrebno da se rad sustava ponovno uspostavi. To se u praksi postiže boljom organizacijom sustava održavanja.

U svakodnevnoj primjeni u IT industriji, pogotovo u marketingu, za prikazivanje raspoloživosti sustava koristi se termin "n-devetki" (gdje je $n$ broj: dva, tri, četiri, pet ili šest). Što je $n$ veći, veća je raspoloživost sustava.

\footnotetext{
${ }^{88}$ Schmidt, K. 2006. High availability and disaster recovery: concepts, design, implementation. Springer Science \& Business Media, ISBN-13 978-3-540-24460-8, 24-25.

${ }^{89}$ Valenčić D., Ćavar I., Zimet J. 2012. Visoka raspoloživost računalnih mreža, Zbornik radova, 5. Međunarodna konferencija "Dani kriznog upravljanja“, Veleučilište Velika Gorica, Velika Gorica, str. 695 719, ISBN 978-953-7716-31-8., znanstveni rad.

${ }^{9}$ Schmidt, K. 2006. High availability and disaster recovery: concepts, design, implementation. Springer Science \& Business Media, ISBN-13 978-3-540-24460-8, 24-25.
} 
Tablica 3-2. prikazuje izračunate vrijednosti raspoloživosti sustava dobivene gornjim formulama.

Tablica 3-2. Vrijeme zastoja u odnosu na raspoloživost ${ }^{91}$

\begin{tabular}{llll}
\hline Raspoloživost \% & Godišnje & Mjesečno & Tjedno \\
\hline $55.5555555 \%$ & 162,22 dana & 13,33 dana & 74,67 sati \\
\hline $90 \%$ & 36,5 dana & 72 sati & 16,8 sati \\
\hline $95 \%$ & 18,25 dana & 36 sati & 8,4 sati \\
\hline $97 \%$ & 10,96 dana & 21,6 sati & 5,04 sati \\
\hline $98 \%$ & 7,30 dana & 14,4 sati & 3,36 sati \\
\hline $99 \%$ & 3,65 dana & 7,20 sati & 1,68 sati \\
\hline $99.5 \%$ & 1,83 dana & 3,60 sati & 50,4 sati \\
\hline $99.8 \%$ & 17,52 sati & 86,23 minuta & 20,16 minuta \\
\hline $99.9 \%$ & 8,76 sati & 43,2 minuta & 10,1 minuta \\
\hline $99.95 \%$ & 4,38 sati & 21,56 minuta & 5,04 minuta \\
\hline $99.99 \%$ & 52,56 minuta & 4,32 minuta & 1,01 minuta \\
\hline $99.999 \%$ & 5,26 minuta & 25,9 sekundi & 6.05 sekundi \\
\hline $99.9999 \%$ & 2,59 sekundi & 0,605 sekundi \\
\hline & 31,5 sekundi & & \\
\hline & & & \\
\hline
\end{tabular}

Upotreba termina "n-devetki" omogućava opisivanje raspoloživost s tehničke strane i vrlo je koristan način za prikazivanje raspoloživosti sustava i izvrsna osnovica za poslovno odlučivanje.

\footnotetext{
${ }^{91}$ High Availability, https://en.wikipedia.org/wiki/High_availability (10.5.2019)
} 
Koristeći gore navedene podatke iz prethodnih dviju tablica, mogu se izračunati i vrijednosti troškova za neplanirane ICT zastoje.

Tablica 3-3. prikazuje srednju vrijednost troška (u USD) neplaniranih zastoja za period od jedne godine za servise s ,tri devetke“ (odnosno 99,9\% raspoloživosti).

Tablica 3-3. Srednja vrijednost troška (raspoloživost 99,9\%) $)^{92}$

\begin{tabular}{llll}
\hline & & \multicolumn{2}{c}{ Trošak vremena zastoja } \\
Industrija & IT usluga & po minuti & godišnje \\
\hline Financijska & Burzovno posredništvo & 107500 & 58050000 \\
\hline Financijska & Kreditne kartice/autorizacija prodaje & 43333 & 23399820 \\
\hline Mediji & Video na zahtjev & 2500 & 1350000 \\
\hline Prodaja & Kupovina od kuće & 1883 & 1016820 \\
\hline Prodaja & Prodaja po katalogu & 1500 & 810000 \\
\hline Transport & Rezervacija zrakoplovnih karata & 1483 & 800820 \\
\hline Mediji & Teleprodaja & 1150 & 621000 \\
\hline Transport & Isporuka paketa & 466 & 251640 \\
\hline Financijska & Bankomat - naknada korištenja & 241 & 130140 \\
\hline
\end{tabular}

Iz gornjih podataka možemo vidjeti zašto poslovne organizacije traže visoku raspoloživost. Ne mogu svi poslovni sustavi raditi s raspoloživosti “pet devetki” jer bi jednostavno cijena ulaganja bila previsoka. Ako je trošak za postizanje sustava s "četiri devetke" (raspoloživost 99,99\%) ili "pet devetki” (raspoloživost 99,999\%) veći od mogućeg gubitka (odnosno troška zastoja sustava), tada jednostavno nema potrebe za gradnjom takvog sustava.

92 Valenčić D., Ćavar I., Zimet J. 2012. Visoka raspoloživost računalnih mreža, Zbornik radova, 5. Međunarodna konferencija "Dani kriznog upravljanja“, Veleučilište Velika Gorica, Velika Gorica, str. 695 719, ISBN 978-953-7716-31-8., znanstveni rad. 
Jednako tako, postizanje „visoke raspoloživosti“ ovisi o ICT industriji i usluzi na koju se odnosi. Raspoloživost od „četiri devetke“ (99,99\%) je sigurno visoka raspoloživost za isporuku paketa (u transportu), ali niska za burzovno posredništvo (u financijama) koja traži puno veću raspoloživost (bar ,„pet devetki“ ili 99,999\% raspoloživosti).

Zbog svega gore navedenog, Gartner (Dataquest) je napravio podjelu raspoloživosti u pet stupnjeva $^{93}$ :

- Neprekidan rad (engl. continuous processing)

- Tolerantnost na grešku (engl. fault tolerant)

- Otpornost na grešku (engl. fault resilient)

- Visoka raspoloživost (engl. high availability)

- Normalna komercijalna raspoloživost (engl. normal commercial availability)

Tablica 3-4. prikazuje stupnjeve raspoloživosti i odgovarajuću vrijednost raspoloživosti i godišnje vrijeme zastoja.

Tablica 3-4. Stupnjevi raspoloživosti ${ }^{94}$

\begin{tabular}{llc}
\hline Stupanj raspoloživosti & Raspoloživost (\%) & Godišnje vrijeme zastoja \\
\hline Neprekidan rad & $100 \%$ & 0 \\
\hline Tolerantnost na grešku & $99,999 \%$ & 5 minuta \\
\hline Otpornost na grešku & $99,99 \%$ & 53 minute \\
\hline Visoka raspoloživost & $99,9 \%$ & 8,8 sati \\
\hline $\begin{array}{l}\text { Normalna komercijalna } \\
\text { raspoloživost }\end{array}$ & $99-99,5 \%$ & $87.6-43.8$ sati \\
\hline
\end{tabular}

\footnotetext{
${ }^{93}$ Marquis, H. The Paradox of the 9s (2006), ITSM Solutions, http://www.itsmsolutions.com/newsletters/DITYvol2iss47.htm (10.1.2012.). ${ }^{94}$ Isto.
} 
Ipak gore definirani stupnjevi raspoloživosti nisu definirani standardom. U svakodnevnoj uporabi se koriste nazivi gore navedenih stupnjeva raspoloživosti, ali bez značenja odgovarajućih vrijednosti raspoloživosti, već više kao marketinški nazivi.

U istraživačkom dijelu ovog rada će se pojam Visoke raspoloživosti koristiti za sustave koji imaju raspoloživost od 99,9\% ili veću, odnosno za sve sustave koji zahtijevaju veću raspoloživost od Normalne komercijalne raspoloživosti. Drugim riječima, istraživanje će se raditi na mrežnim uređajima koji imaju raspoloživost od „tri devetke“ ili veću.

\subsection{Povećanje raspoloživosti mrežnih sustava i uređaja.}

ICT sustavi se sastoje od raznih aplikacija koje su međusobno povezane preko računalnih mreža. Računalna mreža se sastoji od krajnjih uređaja (računala, servera, pametnih telefona itd.), posredovnih uređaja (usmjernika, preklopnika, vatrozida itd.) i različitih vrsta linkova (žični, bežični) koji su povezani na različitim udaljenostima (LAN, WAN, MAN). Kada se govori o raspoloživosti računalnih mreža, ne razmatraju se krajnji uređaji, već posredovni uređaji, linkovi koji ih fizički povezuju i prva četiri sloja OSI modela na kojima oni rade.

Osnovni uzroci neraspoloživosti mreže računala su sljedeći ${ }^{95}$ :

- Planirani zastoj:

○ instaliranje i ažuriranje softvera,

○ zamjena ili nadogradnja hardvera;

- Neplanirani zastoj:

o prekid rada mreže - prekid prouzročen od strane elemenata mreže ili zbog sigurnosnog napada,

○ prekid sustava - prekid prouzročen zbog prekida rada softvera, greške u radu softvera ili zbog kvara u hardveru,

○ operativna greška inženjera koji održavaju mrežu.

\footnotetext{
${ }^{95}$ Valenčić D., Ćavar I., Zimet J. 2012. Visoka raspoloživost računalnih mreža, Zbornik radova, 5. Međunarodna konferencija "Dani kriznog upravljanja“, Veleučilište Velika Gorica, Velika Gorica, str. 695 719, ISBN 978-953-7716-31-8., znanstveni rad.
} 
Svi gore navedeni prekidi mogu se ili izbjeći ili se može umanjiti njihov utjecaj s robusnim hardverom i softverom tako da se kao krajnji cilj ima povećanje raspoloživosti.

Osnovno pitanje kojim se bave dizajneri mreža računala visoke raspoloživosti je sljedeće: „Kako mogu povećati opću raspoloživost određene usluge ili aplikacije, i što moram napraviti da bih eliminirao mogućnost prekida na najosjetljivijim mjestima u mreži?“‘

Dizajniranje takvog sustava traži temeljito planiranje na svih sedam slojeva ISO-OSI referentnog modela i uklanjanje najosjetljivijih mjesta za prekid gdje god je to moguće. Ovdje vrijedi pravilo da je lanac onoliko čvrst koliko je čvrsta njegova najslabija karika.

Zbog toga je uvijek preporučljivo imati bar jedan zamjenski sustav, link ili resurs koji će biti na raspolaganju (ako bude potreba za njim) tijekom uobičajenog rada.

Visoka raspoloživost je cilj kojim sprječavamo ili barem minimaliziramo ispade u mreži. Dobiti visoku raspoloživost u mrežama nije jednostavan posao, potrebno je bez prestanka unaprjeđivati i nadograđivati više komponenti u samoj mreži kao što su ${ }^{96}$ :

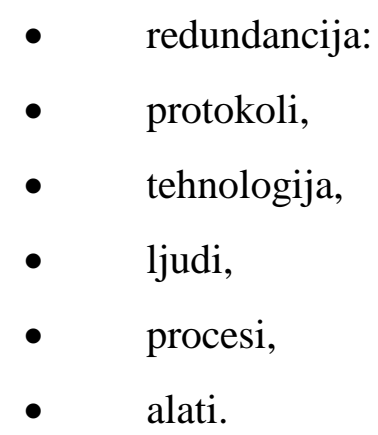

\section{Redundancija}

Osnovni princip i osnovica dizajna mreže visoke raspoloživosti je redundancija mrežnih linkova i redundancija hardvera (mrežnih elemenata). Cilj redundancije je eliminirati točke u mreži zbog kojih bi moglo doći do ispada rada mreže. Te točke mogu biti uređaji, komponente unutar uređaja, linkovi, pojedine geografske lokacije ili sami servisi.

\footnotetext{
96 Valenčić D., Ćavar I., Zimet J. 2012. Visoka raspoloživost računalnih mreža, Zbornik radova, 5. Međunarodna konferencija "Dani kriznog upravljanja“, Veleučilište Velika Gorica, Velika Gorica, str. 695 719, ISBN 978-953-7716-31-8., znanstveni rad.
} 
Prilikom dizajna redundantne mreže važno je izbjegavanje jedinstvenih točaka prekida (engl. Single Point of Failure - SPoF). SPoF točke su najosjetljivije u radu mreže jer nemaju zamjensko rješenje. Zbog toga se mora obratiti pažnja na sljedeće elemente ${ }^{97}$ :

- ostvarivanje geografske različitosti i različitosti tipova linkova između pojedinih lokacija,

- korištenje dvostrukih uređaja i linkova,

- korištenje barem dvaju internetskih davatelja usluga,

- dvostruki podatkovni centri koji su geografski dislocirani,

- dvostruki telefonski sustavi i dvostruki sustavi napajanja.

Redundancija je skupa zbog gotovo pa udvostručivanja mrežnih uređaja i komponenti te linkova između njih. S druge strane, ispad u mreži zbog prestanka funkcioniranja pojedinog uređaja, linka, gubitka podataka ili veze s internetskim davateljem usluga može nositi i višestruko veći novčani gubitak negoli je cijena redundantne mreže. Pristup redundanciji mora biti shvaćen kao pristup osiguranju jer redundancijom osiguravamo funkcioniranje mreže. Neki su dijelovi u mreži, odnosno servisi, kritični i zahtijevaju posebnu pažnju prilikom dizajna redundancije.

Uređaji u pripremi (engl. standby equipment) su jedan od načina povećanja raspoloživosti mreža. Za razliku od uređaja koji su stalno uključeni u mrežu, ovi će uređaji po potrebi biti instalirani (u određenom roku, na primjer 4 ili 8 sati). Ovim načinom se povećava vrijeme neraspoloživosti sustava, ali se i značajno smanjuje cijena opreme i održavanja.

\section{Protokoli}

Redundancija na fizičkom sloju OSI modela (redundantni linkovi i čvorovi odnosno redundantna topologija) zahtijeva i protokole koji podržavaju redundanciju na ${ }^{98}$ :

- podatkovnom sloju OSI modela- na primjer, protokoli RSTP, UDLD;

- mrežnom sloju OSI modela - na primjer protokoli za dinamičko usmjeravanje (OSPF, EIGRP, BGP) i protokoli za izlazak u druge mreže (VRRP, HSRP).

\footnotetext{
${ }^{97}$ Isto.

${ }^{98}$ Isto.
} 


\section{Tehnologija}

Razni proizvođači mrežne opreme nude i razne tehnologije kojima omogućavaju visoku raspoloživost svojih uređaja. Tako na primjer tvrtka Cisco Systems na nekim svojim uređajima nudi tehnologije Nonstop Forwarding (NSF) i Stateful Switchover (SSO) ${ }^{99}$ kojima nudi internu redundanciju unutar samog uređaja te servis koji će omogućiti da uslijed kvara glavne upravljačke jedinice, zamjenska nastavi posao kao da se ništa nije dogodilo. Takvim se tehnologijama izbjegavaju ispadi na samim linkovima i dobiva se kontinuirani tok paketa kroz mrežu i održavanje svih uspostavljenih odnosa između mrežnih uređaja.

\section{Ljudi}

Visoka raspoloživost uređaja i linkova te naprednije tehnologije dio su povećanja raspoloživosti. Međutim, bitna je i sljedeća komponenta - ljudi. Primjeri su sljedeći:

- Radne navike: posvećenost detaljima povećava raspoloživost dok zanemarivanje smanjuje. Tako je, na primjer, na uredno kabliranoj mreži i s uredno postavljenim i naznačenim konfiguracijama puno lakše detektirati kvar.

- Razina obrazovanja i tehničkih vještina je ključan element za ostvarenje više raspoloživosti.

\section{Procesi}

Korištenje ponavljajućih procesa unutar nekog sustava vodi do povećanja raspoloživosti same mreže. Kontinuirano poboljšanje procesa korištenjem neke od metodologija upravljanja uslugama informacijske tehnologije (engl. Information Technology Service Management ITSM) igra ključnu ulogu u poboljšanju mrežne raspoloživosti.

\footnotetext{
${ }^{99}$ Cisco Campus Network for High Availability Design Guide (2008) http://www.cisco.com/en/US/docs/solutions/Enterprise/Campus/HA_campus_DG/hacampusdg.html\#wp110881 $\underline{7}$ (10.1.2012.)
} 
ITSM se obavlja od strane IT pružatelja usluga kroz prikladnu kombinaciju ljudi, procesa i informacijskih tehnologija ${ }^{100}$. Iako se prednosti upotrebe ITSM vještina razlikuju ovisno o potrebama organizacije, neke opće prednosti uključuju ${ }^{101}$ :

- poboljšanje kvalitete pružanja usluga,

- postizanje odgovarajućeg omjera cijene i kvalitete usluga,

- dizajn usluga koji ispunjavaju poslovne zahtjeve davatelja usluge, kao i zahtjeve kupca i korisnika,

- integrirane i centralizirane procese,

- transparentnost uloga i odgovornosti pri pružanju usluga,

- kontinuirani napredak i stjecanje znanja za buduće zadatke i

- dobivanje mjerljivih parametara kvalitete, performansi i efikasnosti.

ITIL (Information Technology Infrastructure Library) je međunarodni industrijski standard koji predstavlja zbirku najboljih praksi za upravljanje IT uslugama. ITIL označava skup alata i metoda koji omogućavaju kvalitetno upravljanje i razvoj IT usluga unutar neke organizacije, te predstavlja standard najboljih praksi za upravljanje IT okolinom.

ITIL definira proces Upravljanje raspoloživosti (engl. availability management) koji se nalazi u fazi dizajna. Raspoloživost se definira kao sposobnost IT usluge ili druge konfiguracijske stavke da obavlja svoju funkciju, kada je to potrebno. Svrha procesa Upravljanja raspoloživosti je osiguravanje ugovorene razine raspoloživosti svim IT uslugama, odnosno postizanje definirane ciljane razine usluge. To mora biti učinjeno na ekonomičan način i uz optimalne troškove.

Upravljanje raspoloživošću uključuje dva ključna elementa ${ }^{102}$ :

\footnotetext{
${ }^{100}$ Kažović D., Valenčić D., Radošević I. 2016. Primjena ITIL standarda u upravljanju kriznim situacijama IT sustava, Zbornik radova, 11. Međunarodna konferencija "Dani kriznog upravljanja“, Veleučilište Velika Gorica, Velika Gorica.

${ }^{101}$ Menken, I. 2011. Itil ${ }^{\circledR}$ Foundation Complete Certification Kit - Study Book and eLearning Program - 4th edition, Publisher: Emereo Pty Ltd, 11-12.

${ }^{102}$ Menken, I. 2011. Itil ${ }^{\circledR}$ Foundation Complete Certification Kit - Study Book and eLearning Program - 4th edition, Publisher: Emereo Pty Ltd, 142-143.
} 
- Reaktivne aktivnosti: ove aktivnosti uključuju praćenje, mjerenje, analizu, upravljanje svim događajima, incidentima i problemima vezanim uz neraspoloživost. Normalnim obavljanjem operativnih uloga u IT-u, aktivnosti su usredotočene na identifikaciju ometanja raspoloživosti usluga i rješavanja poremećaja u dovoljnoj mjeri da bi opet mogli obnoviti uslugu.

- Proaktivne aktivnosti: ove aktivnosti uključuju planiranje, dizajniranje, te poboljšavanje raspoloživosti kako bi se osiguralo da su usluga i povezane komponente dostupne kada je to korisniku potrebno. Aktivnosti izvode pojedinci ili skupine koji su uključeni u planiranje i dizajn usluge.

\begin{abstract}
Alati
Korištenjem raznih alata za konfiguraciju, automatizaciju i nadzor mreže moguće je povećati raspoloživost mreže. Alati za konfiguraciju i automatizaciju smanjuju ljudsku pogrešku. Alati za nadzor omogućavaju brzu reakciju na kvar u mreži. Bez konstantnog nadzora u mreži mogući su duži ispadi ukoliko redundantna komponenta ne preuzme ulogu primarne komponente koju treba zamijeniti uslijed kvara. Alati za nadzor također mogu na vrijeme upozoriti na svaku anomaliju u mreži kao što su neuobičajeno povećanje potrošnje resursa na mrežnim uređajima (CPU i memorija), smanjena propusnost na linkovima, povećano kašnjenje ili varijaciju u kašnjenju te gubitak paketa u mreži. Ti parametri mogu biti prve indikacije o potencijalnim problemima u mreži te se mogu koristiti složeniji alati za automatizaciju za izvršavanje procesa samoizlječenja mreže prekonfiguriranjem mrežnih uređaja i/ili prebacivanjem prijenosa paketa kroz druge linkove i mrežne uređaje.
\end{abstract}




\section{NETCONF standard}

\subsection{Uvod u NETCONF standard i njegov nastanak}

Od kada je IETF organizacija sredinom 80 -ih razvila SNMP, on se pokazao kao vrlo raširen i popularan protokol upravljanja mrežama.

Ipak, pokazalo se u praksi da se SNMP protokol uglavnom ne koristi za konfiguriranje mrežnih uređaja (iako je u tu svrhu bio inicijalno razvijen, koristeći SNMP komandu set), već se uglavnom koristi za nadzor mreža (engl. network monitoring) koristeći trap i get komande.

\subsubsection{IETF RFC 3535}

U lipnju 2002. godine Internet Architecture Board i najvažniji članovi IETF zajednice za mrežno upravljanje održali su sastanak s mrežnim operatorima. Rezultati sastanka su dokumentirani u RFC 3535. Pokazalo se da mrežni operatori koriste CLI korisnička sučelja proizvođača mrežne opreme za konfiguraciju uređaja, odnosno konzolni način rada i telnet/SSH protokole. Prednost takvog načina rada je da je tekstualno orijentiran, za razliku od BER (Basic Encoding Rules), odnosno ASN.1 kodiranog načina SNMP protokola ${ }^{103}$.

Zahtjevi koji su označeni u RFC 3535 su sljedeći ${ }^{104}$ :

- Jednostavna uporaba tehnologije upravljanja mrežama je osnovni zahtjev mrežnih operatera.

\footnotetext{
103 Valenčić D., Mateljan V. 2019. Implementation of NETCONF Protocol, Proceedings of the 42nd International Convention, Croatian Society for Information and Communication Technology, Electronics and Microelectronics - MIPRO, Rijeka.

${ }^{104}$ IETF RFC 3535 Overview of the 2002 IAB Network Management Workshop (2002), https://tools.ietf.org/html/rfc3535 (21.1.2019).
} 
- Potrebno je načiniti jasnu razliku između konfiguracijskih podataka (configuration data), podataka koji opisuju operacijsko stanje (operational state) i statističkih podataka (statistics). Na nekim uređajima vrlo je teško razlikovati koji podaci su administrativno konfigurirani, a koji su dobiveni od strane drugih mehanizama (na primjer od protokola usmjeravanja).

- Potrebno je biti u mogućnosti odvojeno preuzeti (engl. fetch) konfiguracijske, operacijske i statističke podatke s uređaja i biti u mogućnosti usporediti te podatke između uređaja.

- Potrebno je omogućiti operaterima konfiguriranje mreže kao jedne cjeline, umjesto konfiguriranja svakog pojedinog uređaja.

- Ako postoje konfiguracije A i B, treba biti moguće doći od stanja A u stanje B, s najmanje moguće promjena stanja i utjecaja na stanje mreže i sustava. Važno je minimalizirati utjecaj na stanje mreže pri promjeni konfiguracije.

- Mogućnost prijenosa konfiguracije s jednog na drugi mrežni uređaj značajno bi pojednostavio upravljanje mrežnim konfiguracijama (engl. network configuration management).

- Mehanizam brisanja (dump) i ponovnog aktiviranja (restore) konfiguracije bi trebao biti jednostavan. Poželjan je standard koji bi podržao pull i push funkcije na i sa mrežnog uređaja.

- Treba biti moguće jednostavno provjeriti konzistentnost (engl. consistency) konfiguracije tijekom vremena na nekom mrežnom uređaju, kao i između susjednih mrežnih uređaja na istom linku. Cilj je postići mogućnost provjere promjene između konfiguracija i jesu li promjene konzistentne.

- Konfiguracije za cijelu mrežu su najčešće spremljene na centralnu (master) bazu podataka i transformirane $\mathrm{u}$ formate koji mogu biti poslani (push) na uređaje (ili generiranjem sekvenci CLI komandi ili slanjem kompletne konfiguracijske datoteke koje su poslane uređajima). Trenutno nema zajedničke sheme baze 
podataka za mrežne konfiguracije, iako su modeli korišteni od strane različitih operatera vjerojatno vrlo slični. Poželjno je izvući, dokumentirati i standardizirati zajedničke dijelove tih shema baza podataka mrežnih konfiguracija.

- Izrazito je poželjno da se mogu koristiti alati tekstualnog procesiranja (na primjer diff) i alati upravljanja verzijama (na primjer CVS i RCS) za procesiranje konfiguracija, što znači da mrežni uređaji ne bi trebali promijeniti poredak podataka - na primjer kod pristupnih kontrolnih listi (engl. Access Control Lists ACL).

- Zrnatost (engl. granularity) pristupne kontrole (engl. access control) na upravljačkom sučelju (engl. management interfaces) mrežnog uređaja mora odgovarati operacijskim potrebama. Tipični zahtjevi su „role-based access control model" i „principle of least privilege”, gdje se korisniku dodjeljuje samo minimalan pristup potreban za izvršavanje potrebnog zadatka.

- Treba biti moguće provjeriti konzistentnost pristupnih ACL listi između različitih mrežnih uređaja.

- Važno je razlikovati između distribucije konfiguracija i aktivacije određene konfiguracije. Uređaji trebaju imati mogućnost spremanja više konfiguracija.

- SNMP komandni pristup je podatkovno orijentiran (engl. data-oriented), dok je CLI komandni pristup uobičajeno komandno orijentiran (engl. command/task oriented). Ovisno o funkciji upravljanja, ponekad podatkovno ili komandno orijentiran pristup ima više smisla. Zbog toga, potrebno je imati podršku i mogućnost oba komandna pristupa.

$\mathrm{Na}$ temelju zadovoljavanja tih zahtjeva razvijena je prva verzija NETCONF protokola definirana u RFC $4741^{105}$ objavljena u prosincu 2006. godine. NETCONF protokol zatim je poboljšan u lipnju 2011. godine u RFC $6241^{106}$.

${ }^{105}$ IETF: RFC 4741 Network Configuration Protocol (NETCONF) (2006), https://tools.ietf.org/html/rfc4741 (21.1.2019). 


\subsection{Osnovna svojstva i prednosti NETCONF standarda}

NETCONF (Network Configuration Protocol) osigurava mehanizam instaliranja, manipulacije i brisanja konfiguracije mrežnih uređaja ${ }^{107}$. NETCONF protokol jednostavno definira mehanizam pomoću kojeg $^{108}$ :

- mrežni uređaj može biti upravljan,

- konfiguracijski podaci mogu biti preuzeti s mrežnog uređaja,

- nova konfiguracija može biti instalirana i manipulirana na mrežnom uređaju.

- omogućava automatiziranu i programabilnu konfiguraciju i pristup mrežnom uređaju preko API (Application Programming Interface) sučelja.

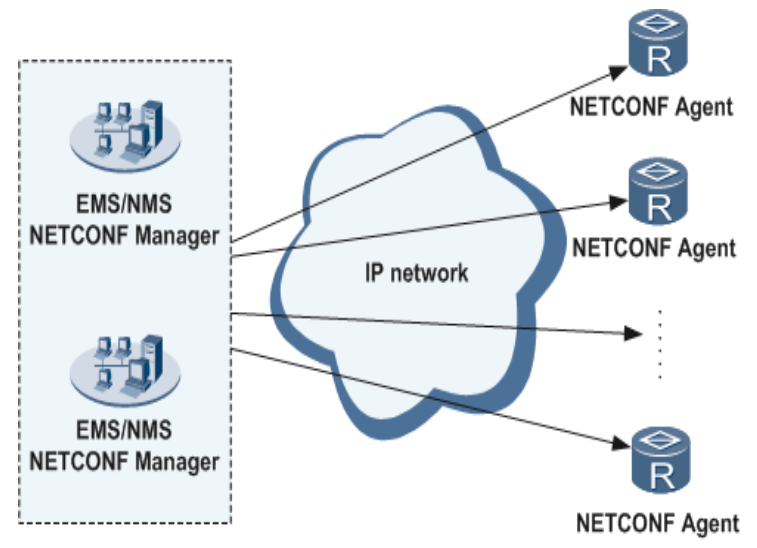

Slika 4-1. NETCONF ${ }^{109}$

\subsubsection{Karakteristike NETCONF standarda}

Operacije NETCONF protokola su realizirane pomoću jednostavnog sloja udaljenih poziva procedure (engl. Remote Procedure Call - RPC) ${ }^{110}$.

\footnotetext{
106 IETF: RFC 6241 Network Configuration Protocol (NETCONF) (2011), https://tools.ietf.org/html/rfc6241 (21.1.2019), str.6.

107 Valenčić D., Mateljan V. 2019. Implementation of NETCONF Protocol, Proceedings of the 42nd International Convention, Croatian Society for Information and Communication Technology, Electronics and Microelectronics - MIPRO, Rijeka.

${ }^{108}$ IETF: RFC 6241 Network Configuration Protocol (NETCONF) (2011), https://tools.ietf.org/html/rfc6241 (21.1.2019).

${ }^{109}$ Huawei www.huawei.com (21.1.2019).
} 
RPC je međuprocesna komunikacija (engl. Inter-Process Communication - IPC) koja omogućava računalnom programu da izvrši potprogram ili proceduru na drugom adresnom prostoru (najčešće na drugom računalu povezanom pomoću računalne mreže) bez da je programer eksplicitno programirao detalje komunikacije između računala. Drugim riječima, programer piše isti programski kod bez obzira da li se potprogram izvršava lokalno ili na udaljenoj lokaciji. RPC se inicira od strane klijenta koji šalje poruku zahtjeva (request) prema udaljenom poslužitelju za izvršavanje određene procedure s poslanim parametrima. Dok poslužitelj izvršava svoj zadatak, klijent je blokiran i čeka odgovor (osim ako klijent pošalje asinkroni zahtjev, kao na primjer XHTTP poziv). Nakon što poslužitelj odgovori klijentu s rezultatima, klijent nastavlja izvršavanje aplikacije. U upotrebi su različite varijacije RPC protokola koje međusobno nisu kompatibilne.

NETCONF koristi RPC mehanizam da omogući komunikaciju između klijenta i servera. Klijent može biti skripta ili aplikacija koja je najčešće dio aplikacije mrežnog upravljanja, a server je najčešće mrežni uređaj.

NETCONF sesija (session) je logička veza između mrežnog administratora (ili aplikacije za mrežnu konfiguraciju) i mrežnog uređaja. Mrežni uređaj mora podržavati uspostavljanje najmanje jedne sesije, iako treba imati mogućnost uspostavljanja istovremeno više sesija [6]

NETCONF protokol koristi XML (Extensible Markup Language) za kodiranje konfiguracijskih podataka i poruka protokola. Poruke protokola se izmjenjuju pomoću sigurnog transportnog protokola ${ }^{111}$.

Postoje različiti softverski alati koji se koriste za jednostavniju upotrebu NETCONF protokola, kao na primjer ncclient ${ }^{112}$ i MG-SOFT NETCONF Browser ${ }^{113}$.

\footnotetext{
${ }^{110}$ IETF RFC 6241 Network Configuration Protocol (NETCONF) (2011) https://tools.ietf.org/html/rfc6241 (21.1.2019), 13-19.

111 Valenčić D., Mateljan V. 2019. Implementation of NETCONF Protocol, Proceedings of the 42nd International Convention, Croatian Society for Information and Communication Technology, Electronics and Microelectronics - MIPRO, Rijeka.

${ }^{112}$ NETCONF central, http://netconfcentral.org/ (15.8.2019).

113 MG-SOFT NETCONF and YANG applications, https://www.mg-soft.si/mgProductsNetConf.html, (15.8.2019).
} 


\subsubsection{Slojevi NETCONF protokola}

NETCONF protokol se dijeli u četiri sloja ${ }^{114}$ :

- sloj sigurnog prijenosa (engl. secure transport layer),

- $\quad$ sloj poruka (engl. messages layer),

- operacijski sloj (engl. operations layer) i

- $\quad$ sloj sadržaja (engl. content layer).

Sloj sigurnog prijenosa omogućava siguran i pouzdan prijenos poruka između klijenta i poslužitelja. Sloj sigurnog prijenosa omogućava komunikaciju između klijenta i servera. NETCONF može koristiti bilo koji transportni protokol koji zadovoljava osnovne uvjete sigurnog prijenosa: autentikaciju (engl. authentication), cjelovitost podataka (engl. data integrity), tajnost (engl. confidentiality) i replay zaštitu. Obavezna implementacija sigurnog prijenosa je „NETCONF over SSH“ (RFC 6242).

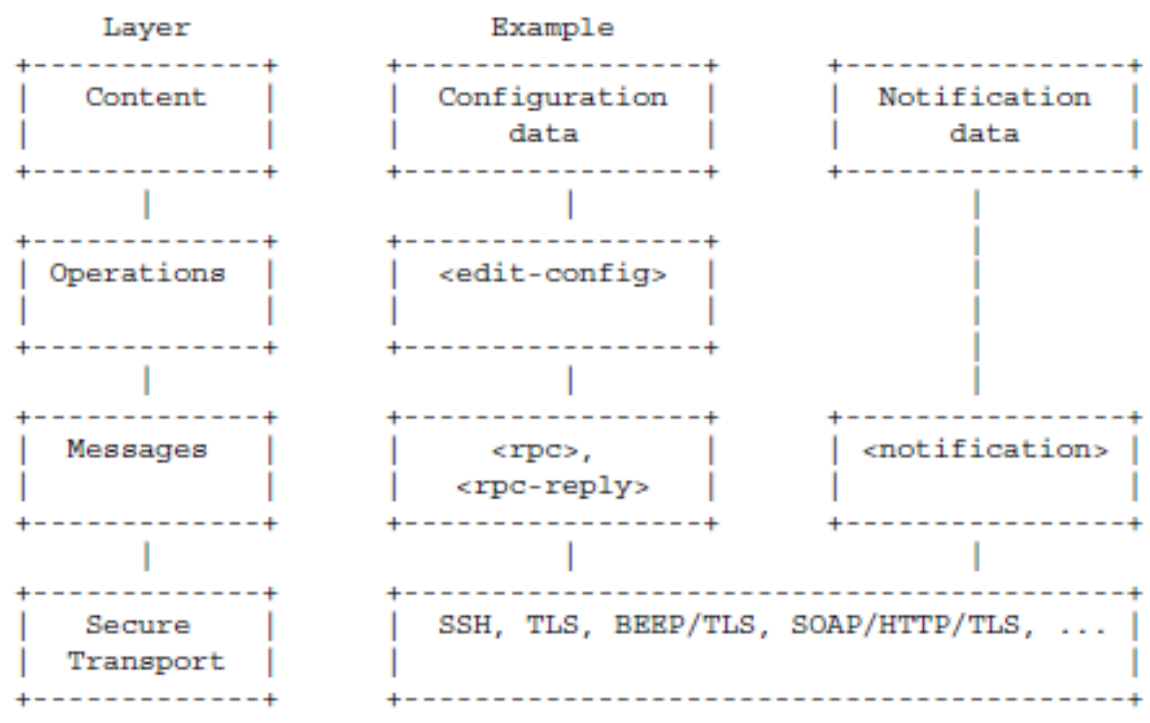

Slika 4-2. Slojevi NETCONF protokola ${ }^{115}$

${ }^{114}$ IETF RFC 6241 Network Configuration Protocol (NETCONF) (2011) https://tools.ietf.org/html/rfc6241 (21.1.2019), str.9. 
Sloj poruka opisuje mehanizam kodiranja udaljenih poziva procedure (engl. Remote Procedure Call - RPC) i notifikacija.

Sloj poruka omogućava jednostavan i neovisan (o transportnom sloju) mehanizam kodiranja RPC poruka i notifikacija. RFC 6241 definira RPC poruke, dok RFC 5277 definira notifikacije $\mathrm{e}^{116}$.

Osnovne NETCONF poruke su sljedeće:

- $\quad$ RPC zahtjev ( $\langle r p c\rangle$ poruka),

- $\quad$ RPC odgovor (<rpc-reply > poruka),

- notifikacija (<notification > poruka).

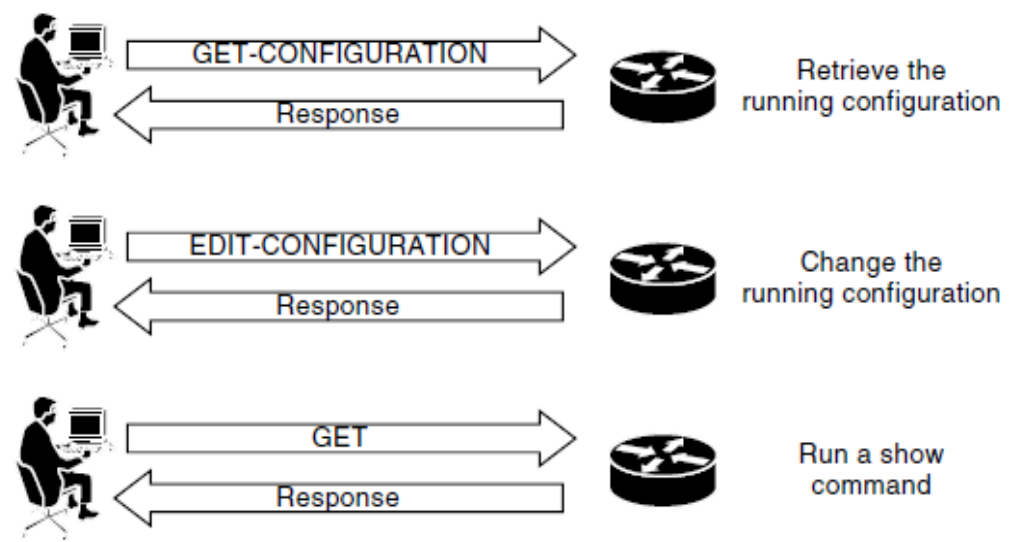

\section{Slika 4-3. Primjer implementacije NETCONF protokola ${ }^{117}$}

Operacijski sloj definira grupu osnovnih operacija protokola koji omogućavaju dohvat i editiranje konfiguracijskih podataka.

Tablica 4-1. prikazuje osnovne operacije NETCONF protokola. Osnovne NETCONF operacije mogu biti proširene definiranjem dodatnih mogućnosti u obliku funkcija (engl. capabilities) tijekom uspostavljanja sesije između klijenta i servera.

115 IETF RFC 6241 Network Configuration Protocol (NETCONF) (2011) https://tools.ietf.org/html/rfc6241 (21.1.2019), str.9.

${ }^{116}$ IETF RFC 5277 NETCONF Event Notifications (2008), https://tools.ietf.org/html/rfc5277 (21.1.2019).

${ }^{117}$ Cisco Systems www.cisco.com (21.1.2019). 
Mogućnosti pretplate i primanja asinkronih notifikacija događaja od strane mrežnog uređaja su definirane u RFC 5277, dok je mogućnost djelomičnog zaključavanja radne konfiguracije definirana u RFC $5717^{118}$.

Tablica 4-1. Osnovne operacije NETCONF protokola ${ }^{119}$

\begin{tabular}{|c|c|}
\hline Operacija & Opis \\
\hline$<$ get $>$ & $\begin{array}{l}\text { Preuzimanje running konfiguracije i operacijskih } \\
\text { podataka o stanju uređaja }\end{array}$ \\
\hline$<$ get-config > & $\begin{array}{l}\text { Preuzimanje svih dijelova odabrane konfiguracijske } \\
\text { datoteke (engl. configuration datastore) }\end{array}$ \\
\hline$<$ edit-config > & $\begin{array}{l}\text { Mogućnost izmjene konfiguracijske datoteke: } \\
\text { kreiranje, brisanje, spajanje ili zamjena sadržaja }\end{array}$ \\
\hline$<$ copy-config > & $\begin{array}{l}\text { Kopiranje cijele jedne konfiguracijske datoteke u } \\
\text { drugu }\end{array}$ \\
\hline <delete-config > & Brisanje konfiguracijske datoteke \\
\hline$<$ lock $>$ & $\begin{array}{l}\text { Zaključavanje cijele konfiguracijske datoteke na } \\
\text { uređaju }\end{array}$ \\
\hline <unlock> & $\begin{array}{l}\text { Otključavanje cijele konfiguracijske datoteke na } \\
\text { uređaju }\end{array}$ \\
\hline$<$ close-session > & Zahtjev za graciozan završetak NETCONF sesije \\
\hline$<$ kill-session $>$ & Prisilno prekidanje NETCONF sesije \\
\hline
\end{tabular}

118 IETF RFC 6241 Partial Lock Remote Procedure Call (RPC) for NETCONF (2009) https://tools.ietf.org/html/rfc5717 (21.1.2019).

${ }_{119}$ IETF RFC 6241 Network Configuration Protocol (NETCONF) (2011) https://tools.ietf.org/html/rfc6241 (21.1.2019), 35-51. 
Mogućnost nadzora NETCONF protokola je objavljena u RFC $6022^{120}$ gdje se objašnjava YANG model za spremanje podataka, sesija, zaključavanja i statistike te koji omogućava upravljanje NETCONF servera.

Sloj sadržaja se sastoji od konfiguracijskih podataka (engl. configuration data) i podataka notifikacije (engl. notification data).

NETCONF protokol se ne bavi slojem sadržaja u svojim RFC dokumentima, već je napravljen odvojeni protokol koji je nazvan YANG. NETMOD radna grupa IETF organizacije odredila je modelirajući jezik za definiranje semantike operacijskih podataka, konfiguracijskih podataka, notifikacija i operacija i nazvala ga je YANG. YANG je definiran u RFC $6020^{121}$, a u RFC $6021^{122}$ prikazani su tipovi podataka.

YANG protokol je razvijen od strane NETMOD radne grupe IETF organizacije i objavljen u RFC 6020 u listopadu 2010. godine. YANG je jezik pomoću kojeg se modeliraju podaci NETCONF protokola. YANG definira hijerarhiju podataka koji se koriste od strane NETCONF operacija, uključujući konfiguraciju, podatke stanja (engl. state data), RPC pozive i notifikacije. YANG omogućava potpuni opis podataka koji se razmjenjuju između klijenta i poslužitelja.

YANG je modularni jezik koji prikazuje strukturu podataka u XML formatu stabla. YANG kao jezik za modeliranje podataka ima neke unaprijed ugrađene i određene vrste podataka (engl. data types) ${ }^{123}$.

YANG modelira hijerarhijsku organizaciju podataka u obliku stabla, u kojem svaki čvor (engl. node) ima svoje ime i neku vrijednost, ili grupu child čvorova. YANG omogućava jasan i kratak opis svakog čvora, kao i međusobnu interakciju između čvorova.

\footnotetext{
${ }^{120}$ IETF RFC 6022 YANG Module for NETCONF Monitoring (2010) https://tools.ietf.org/html/rfc6022 (21.1.2019).

${ }^{121}$ IETF RFC 6020 YANG - A Data Modeling Language for the Network Configuration Protocol (NETCONF) (2010) https://tools.ietf.org/html/rfc6020 (21.1.2019).

${ }^{122}$ IETF RFC 6021 Common YANG Data Types (2010) https://tools.ietf.org/html/rfc6021 (21.1.2019).

${ }^{123}$ IETF RFC 6020 YANG - A Data Modeling Language for the Network Configuration Protocol (NETCONF) (2010) https://tools.ietf.org/html/rfc6020 (21.1.2019).
} 
YANG model se može prikazati i opisati u raznim formatima, ovisno o trenutnim potrebama. Neke opcije za opisivanje YANG modela uključuju YANG jezik, čisti tekst (engl. plain tekst), XML, JSON i HTML/JavaScript. Iako svatko može napisati YANG model, najčešće korišteni modeli dolaze od:

- $\quad$ standardnih tijela ili udruženja, kao što su IETF i OpenConfig ${ }^{124}$;

- proizvođača mrežne opreme i proizvođača softvera, kao što su Cisco, Juniper Networks, Huawei i drugi.

\subsubsection{Konfiguracijski podaci i podaci stanja}

Informacije koje se preuzimaju s mrežnog uređaja podijeljene su u dvije vrste ${ }^{125}$ :

- konfiguracijski podaci (engl. configuration data): skup podataka koji je potreban za promjenu stanja uređaja iz početnog u trenutno stanje. Mrežni administrator može mijenjati konfiguracijske podatke

- podaci stanja (engl. state data): dodatni podaci na uređaju, poput podataka o statusu i prikupljene statistike prometa. Podaci stanja se mogu samo čitati i mrežni administrator ih ne može mijenjati.

\subsubsection{Konfiguracijske datoteke}

NETCONF definira postojanje jedne ili više konfiguracijskih datoteka (engl. configuration datastore) na kojima se vrše konfiguracijske operacije. Konfiguracijska datoteka je definirana kao kompletan skup konfiguracijskih podataka koji su potrebni da bi se uređaj iz zadanog početnog stanja doveo u željeno operativno stanje. Podaci stanja nisu uključeni u konfiguracijsku datoteku. NETCONF razlikuje tri vrste konfiguracijskih datoteka ${ }^{126}$ :

\footnotetext{
${ }^{124}$ OpenConfig, http://www.openconfig.net/ (15.8.2019).

${ }^{125}$ IETF RFC 6241 Network Configuration Protocol (NETCONF) (2011) https://tools.ietf.org/html/rfc6241 (21.1.2019), str.10.

${ }^{126}$ IETF RFC 6241 Network Configuration Protocol (NETCONF) (2011) https://tools.ietf.org/html/rfc6241 (21.1.2019), 19-20.
} 
- Running: konfiguracijska datoteka koja sadrži kompletnu konfiguraciju koja se trenutno aktivno izvodi na uređaju. Samo jedna konfiguracijska datoteka ovog tipa se nalazi na uređaju, i uvijek mora postojati. Označava se s <running>.

- Candidate: konfiguracijska datoteka kojom se može manipulirati bez utjecaja na trenutno aktivnu konfiguraciju uređaja. Označava se s <candidate>. Operacijom <commit> se izvršava promjena na trenutno aktivnu <running> konfiguraciju. Candidate konfiguracijska datoteka je podržana kod uređaja koji podržavaju :candidate NETCONF funkciju.

- Startup: konfiguracijska datoteka u koju se pohranjuje konfiguracija koja se učita prilikom pokretanja uređaja. Označava se s <startup>. Startup konfiguracijska datoteka je podržana kod uređaja koji podržavaju :startup NETCONF funkciju.
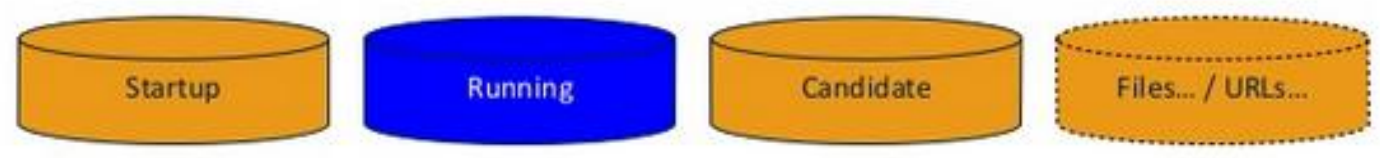

\section{Slika 4-4. NETCONF konfiguracijske datoteke $\mathrm{d}^{127}$}

\subsubsection{Funkcije NETCONF standarda}

NETCONF definira inicijalni osnovni skup operacija i dodatne funkcije (engl. capabilities). Funkcije su dodatne sposobnosti NETCONF uređaja (klijenta i servera) koje oni mogu, ali ne moraju implementirati.

NETCONF definira listu funkcija u svom standardu RFC 6241, a dodatne funkcije se mogu definirati koristeći definirani predložak (engl. template).

\footnotetext{
127 Tail-f Systems: NETCONF Tutorial: https://www.slideshare.net/tailfsystems/04-netconftutorial?next_slideshow=3 (10.2.2019.)
} 
Tablica 4-2. Funkcije NETCONF protokola ${ }^{128}$

\begin{tabular}{llll}
\hline Funkcija & Oznaka & Standard \\
\hline :writable-running & urn:ietf:params:netconf:capability:writable-running:1.0 & [RFC6241] \\
\hline :candidate & urn:ietf:params:netconf:capability:candidate:1.0 & [RFC6241] \\
\hline :confirmed-commit & urn:ietf:params:netconf:capability:confirmed- & [RFC4741] \\
& commit:1.0 & \\
\hline :confirmed- & urn:ietf:params:netconf:capability:confirmed- & [RFC6241] \\
commit:1.1 & commit:1.1 & \\
\hline :rollback-on-error & urn:ietf:params:netconf:capability:rollback-on-error:1.0 & [RFC6241] \\
\hline :validate & urn:ietf:params:netconf:capability:validate:1.0 & [RFC4741] \\
\hline :validate:1.1 & urn:ietf:params:netconf:capability:validate:1.1 & [RFC6241] \\
\hline :startup & urn:ietf:params:netconf:capability:startup:1.0 & [RFC6241] \\
\hline :url & urn:ietf:params:netconf:capability:url:1.0 & [RFC6241] \\
\hline :xpath & urn:ietf:params:netconf:capability:xpath:1.0 & [RFC6241] \\
\hline :notification & urn:ietf:params:netconf:capability:notification:1.0 & [RFC5277] \\
\hline :interleave & urn:ietf:params:netconf:capability:interleave:1.0 & [RFC5277] \\
\hline :partial-lock & urn:ietf:params:netconf:capability:partial-lock:1.0 & [RFC5717] \\
\hline :with-defaults & urn:ietf:params:netconf:capability:with-defaults:1.0 & [RFC6243] \\
\hline :base:1.0 & urn:ietf:params:netconf:base:1.0 & [RFC4741] \\
\hline :base:1.1 & urn:ietf:params:netconf:base:1.1 & [RFC6241] \\
\hline :time:1.0 & urn:ietf:params:netconf:capability:time:1.0 & [RFC6241] \\
\hline :yang-library & urn:ietf:params:netconf:capability:yang-library:1.0 & [RFC7950] \\
\hline :yang-library:1.1 & urn:ietf:params:netconf:capability:yang-library:1.1 & [RFC8526] \\
\hline :with-operational- & urn:ietf:params:netconf:capability:with-operational- & [RFC8526] \\
defaults & defaults:1.0 & \\
\hline
\end{tabular}

${ }^{128}$ IANA: Network Configuration Protocol (NETCONF) Capability URNs (2019) https://www.iana.org/assignments/netconf-capability-urns/netconf-capability-urns.xml, (20.5.2019) 
NETCONF klijent i server izmjenjuju svoje podržane funkciju tijekom uspostavljanja sesije. Nakon uspostavljanja NETCONF sesije, klijent i poslužitelj odmah razmjenjuju „hello“ poruke s elementom $<$ hello $>$ koji sadrži skup NETCONF funkcija koje lokalno podržavaju. NETCONF funkcije se identificiraju pomoću URI metode koja je definirana u RFC $3553^{129}$.

Funkcije se označavaju jedinstvenim identifikatorom resursa (engl. Uniform Resource Identifier - URI) pomoću formata:

urn:ietf:params:netconf:capability:\{name\}:1.x

gdje \{name $\}$ označava ime funkcije. Često se u dokumentaciji koristi skraćena oznaka formata kratice :\{name\} ili :\{name\}:\{verzija\}. Skraćena oznaka, npr. :validate:1.1, koristi se samo u dokumentaciji, ali se ne smije koristiti unutar NETCONF protokola.

Tablica 4-2. prikazuje trenutno postojeće funkcije NETCONF protokola po IETF standardu.

U RFC 6241 su definirane sljedeće funkcije s njihovim osnovnim svojstvima ${ }^{130}$ :

- Writable-Running

○ Oznaka je :writable-running.

○ Označava da uređaj podržava izravno zapisivanje $u$ <running> konfiguracijsku datoteku. Drugim riječima, uređaj podržava <edit-config> i <copy-config> operacije gdje je <running> konfiguracijska datoteka destinacija.

\section{- Candidate Configuration}

○ Oznaka je :candidate

- Označava da uređaj podržava Candidate konfiguracijsku datoteku pomoću koje se može manipulirati s konfiguracijskim podacima bez utjecaja na trenutno aktivnu konfiguraciju uređaja. Candidate konfiguracija je kompletan skup konfiguracijskih podataka koji služi kao radni prostor za kreiranje i upravljanje konfiguracijskim podacima uređaja. Moguće je dodavati, brisati ili mijenjati te podatke s ciljem izrade željene konfiguracije.

\footnotetext{
${ }^{129}$ IETF RFC 3553 An IETF URN Sub-namespace for Registered Protocol Parameters (2003) https://tools.ietf.org/html/rfc3553 (21.3.2019).

${ }^{130}$ IETF RFC 6241 Network Configuration Protocol (NETCONF) (2011) https://tools.ietf.org/html/rfc6241 (21.1.2019), 53-67.
} 
○ Nove operacije:

- <commit>: postavlja trenutno aktivnu konfiguraciju uređaja (Running) na trenutni sadržaj Candidate konfiguracije.

- <discard-changes>: ako klijent odluči da ne želi izvršenje Candidate konfiguracije, može koristiti ovu operaciju za vraćanje na trenutnu Running konfiguraciju.

\section{- Confirmed Commit}

○ Oznaka je :confirmed-commit:1.1.

- Označava da će poslužitelj podržavati operaciju <cancel-commit > te parametre <confirmed>, <confirm-timeout>, <persist> i <persist-id> za <commit> operaciju. Operacija confirmed <commit> mora biti vraćena na prethodno stanje ukoliko potvrda izvršenja nije primljena unutar zadanog vremenskog intervala. Prema zadanim postavkama taj vremenski interval iznosi 600 sekundi.

○ Nova operacija:

- <cancel-commit>: pomoću ove operacije klijent može eksplicitno poništiti operaciju koja zahtijeva potvrdu izvršenja i vratiti konfiguraciju u početno stanje prije isteka vremenskog intervala za potvrdu izvršenja.

\section{- Rollback-on-Error}

○ Oznaka je :rollback-on-error.

○ Označava da poslužitelj podržava „rollback-on-error“ vrijednost za <erroroption> parametar <edit-config> operacije. Ako se tijekom izvršavanja <editconfig> operacije dogodi neka pogreška, ciljana konfiguracijska datoteka (obično Running konfiguracija) ostat će nepromijenjena. To osigurava "sve ili ništa" način uređivanja konfiguracije za svaki <edit-config> zahtjev. Izrazita preporuka je kod uporabe ove funkcije koristiti zaključavanje (koje onemogućava pristup konfiguracijskoj datoteci od strane druge NETCONF, SNMP ili CLI sesije u vremenu dok je zaključana).

\section{- Validate}

○ Oznaka je :validate:1.1. 
- Validacija se sastoji od provjere cijele konfiguracije za sintaktičke i semantičke pogreške prije primjene konfiguracije na uređaj. Ako oglašava ovu funkciju, uređaj podržava <validate> operaciju i provjerava barem sintaktičke pogreške. Dodatno, ova funkcija podržava <test-option> parametar <editconfig> operacije i, kada je parametar zadan, provjeravaju se i sintaktičke pogreške.

○ Nova operacija:

- <validate>: pomoću ove operacije provjerava se sadržaj specificirane konfiguracije. Parametrom <source> definirano je ime konfiguracijske datoteke za koju se provjerava valjanost, kao što je npr. $<$ candidate $>$ ili $<$ config $>$ element koji sadrži cjelovitu konfiguraciju za provjeru valjanosti.

\section{- Distinct Startup}

○ Oznaka je :startup.

- Označava da uređaj podržava zasebne Running i Startup konfiguracijske datoteke. Konfiguracija koja se aktivno izvodi na uređaju naziva se Running, dok se konfiguracija koja se učitava prilikom pokretanja uređaja naziva Startup. Operacije koje utječu na Running konfiguraciju neće se automatski kopirati u Startup konfiguraciju. Eksplicitna operacija <copy-config> iz $<$ running $>\mathrm{u}<$ startup $>$ koristi se za ažuriranje konfiguracije koja se učitava prilikom pokretanja uređaja (Startup) na trenutne vrijednosti konfiguracije koja se aktivno izvodi na uređaju (Running).

- URL

○ Oznaka je :url.

○ Označava mogućnost prihvaćanja <url> elementa in $<$ source $>\mathrm{i}<$ target> parametrima.

- XPath

○ Oznaka je :xpat.

- Označava da NETCONF poslužitelj podržava korištenje XPath izraze (engl. expression) $\mathrm{u}<$ filter $>$ elementu. 
Tablica 4-3. Trenutno aktivni NETCONF standardi ${ }^{131}$

\begin{tabular}{|c|c|c|c|}
\hline Standard & Naziv standarda & Godina & Status \\
\hline RFC 5277 & NETCONF Event Notifications & 2008. & Proposed \\
\hline RFC 5381 & Experience of Implementing NETCONF over SOAP & 2008. & Informational \\
\hline RFC 5717 & Partial Lock Remote Procedure Call (RPC) for NETCONF & 2009. & Proposed \\
\hline RFC 6020 & $\begin{array}{l}\text { YANG - A Data Modeling Language for the Network } \\
\text { Configuration Protocol (NETCONF) }\end{array}$ & 2010. & Proposed \\
\hline RFC 6022 & YANG Module for NETCONF Monitoring & 2010. & Proposed \\
\hline RFC 6110 & $\begin{array}{l}\text { Mapping YANG to Document Schema Definition Languages } \\
\text { and Validating NETCONF Content }\end{array}$ & 2011. & Proposed \\
\hline RFC 6241 & Network Configuration Protocol (NETCONF) & 2011. & Proposed \\
\hline RFC 6242 & Using the NETCONF Protocol over Secure Shell (SSH) & 2011. & Proposed \\
\hline RFC 6243 & With-defaults Capability for NETCONF & 2011. & Proposed \\
\hline RFC 6244 & $\begin{array}{l}\text { An Architecture for Network Management Using NETCONF } \\
\text { and YANG }\end{array}$ & 2011. & Informational \\
\hline RFC 6470 & $\begin{array}{l}\text { Network Configuration Protocol (NETCONF) Base } \\
\text { Notifications }\end{array}$ & 2012. & Proposed \\
\hline RFC 7589 & $\begin{array}{l}\text { Using the NETCONF Protocol over Transport Layer Security } \\
\text { (TLS) with Mutual X.509 Authentication }\end{array}$ & 2015. & Proposed \\
\hline RFC 7758 & Time Capability in NETCONF & 2016. & Experimental \\
\hline RFC 7803 & $\begin{array}{l}\text { Changing the Registration Policy for the NETCONF } \\
\text { Capability URNs Registry }\end{array}$ & 2016. & $\begin{array}{l}\text { Best Current } \\
\text { Practice }\end{array}$ \\
\hline RFC 8040 & RESTCONF Protocol & 2017. & Proposed \\
\hline RFC 8071 & NETCONF Call Home and RESTCONF Call Home & 2017. & Proposed \\
\hline RFC 8072 & YANG Patch Media Type & 2017. & Proposed \\
\hline RFC 8341 & Network Configuration Access Control Model & 2018. & Proposed \\
\hline RFC 8525 & YANG Library & 2019. & Proposed \\
\hline RFC 8526 & $\begin{array}{l}\text { NETCONF Extensions to Support the Network Management } \\
\text { Datastore Architecture }\end{array}$ & 2019. & Proposed \\
\hline RFC 8527 & $\begin{array}{l}\text { RESTCONF Extensions to Support the Network Management } \\
\text { Datastore Architecture }\end{array}$ & 2019. & Proposed \\
\hline
\end{tabular}

${ }^{131}$ IETF Datatracker,

ttps://datatracker.ietf.org/doc/search?name=NETCONF\&sort=\&rfcs=on\&activedrafts=on \&by=group\&group= (15.8.2019) 


\subsubsection{Razvoj NETCONF standarda}

Od svog nastanka i prvog dokumenta u kojem je definiran (RFC 4741) u prosincu 2006. godine, NETCONF standard se stalno ažurira i dalje razvija. Neki RFC su zastarjeli, neki su zamijenjeni novima (na primjer RFC 4741 s RFC 6241), a kreirani su i novi RFC koji pružaju dodatne NETCONF funkcionalnosti ili su bliski NETCONF protokolu (na primjer RFC 8040 o RESTCONF protokolu). Jednako tako, trenutno se radi na novim poboljšanjima NETCONF standarda u 23 dokumenta koji imaju status nacrta (engl. draft) ${ }^{132}$.

Tablica 4-3. prikazuje trenutno aktivne RFC dokumente vezane uz NETCONF standard, godinu njihovog nastanka i trenutni status.

\subsection{Današnji status NETCONF protokola kao standarda}

ISO model upravljanja računalnim mrežama je poznat pod akronimom FCAPS (Fault, Configuration, Accounting, Performance, Security). FCAPS je danas sastavni dio ITU-T referentnog modela TMN (Telecommunications Management Network). TMN predstavlja koncept generičkog modela za upravljanje mrežom davatelja usluge, ali je isto tako primjenjiv u ostalim poslovnim okruženjima

Cilj FCAPS modela je pružanje zajedničke osnove koordiniranog razvoja upravljačkih standarda.

FCAPS kao koncept uvodi kategorizaciju upravljačkih funkcija ${ }^{133}$ :

- Upravljanje greškama (engl. fault management),

- Upravljanje konfiguracijama (engl. configuration management),

- Upravljanje naplatom (engl. accounting management),

- Upravljanje performansama (engl. performance management) i

- Upravljanje sigurnošću (engl. security management).

\footnotetext{
${ }^{132}$ IETF Datatracker, ttps://datatracker.ietf.org/doc/search?name=NETCONF\&sort=\&rfcs=on\&activedrafts=on\&by=group\&group= (15.8.2019)

${ }^{133}$ Clemm, A. 2006. Network management fundamentals, Cisco Press, 131-161.
} 
Funkcija Upravljanje konfiguracijama služi za konfiguriranje mrežnih uređaja, upravljanje konfiguracijskim datotekama i programskom podrškom.

IETF je u RFC 6632 napravio klasifikaciju protokola mrežnog upravljanja i pozicionirao ih u FCAPS model kao što prikazuje Slika 4-5, a za funkciju Upravljanje konfiguracijama odredio je SNMP i NETCONF protokole ${ }^{134}$.

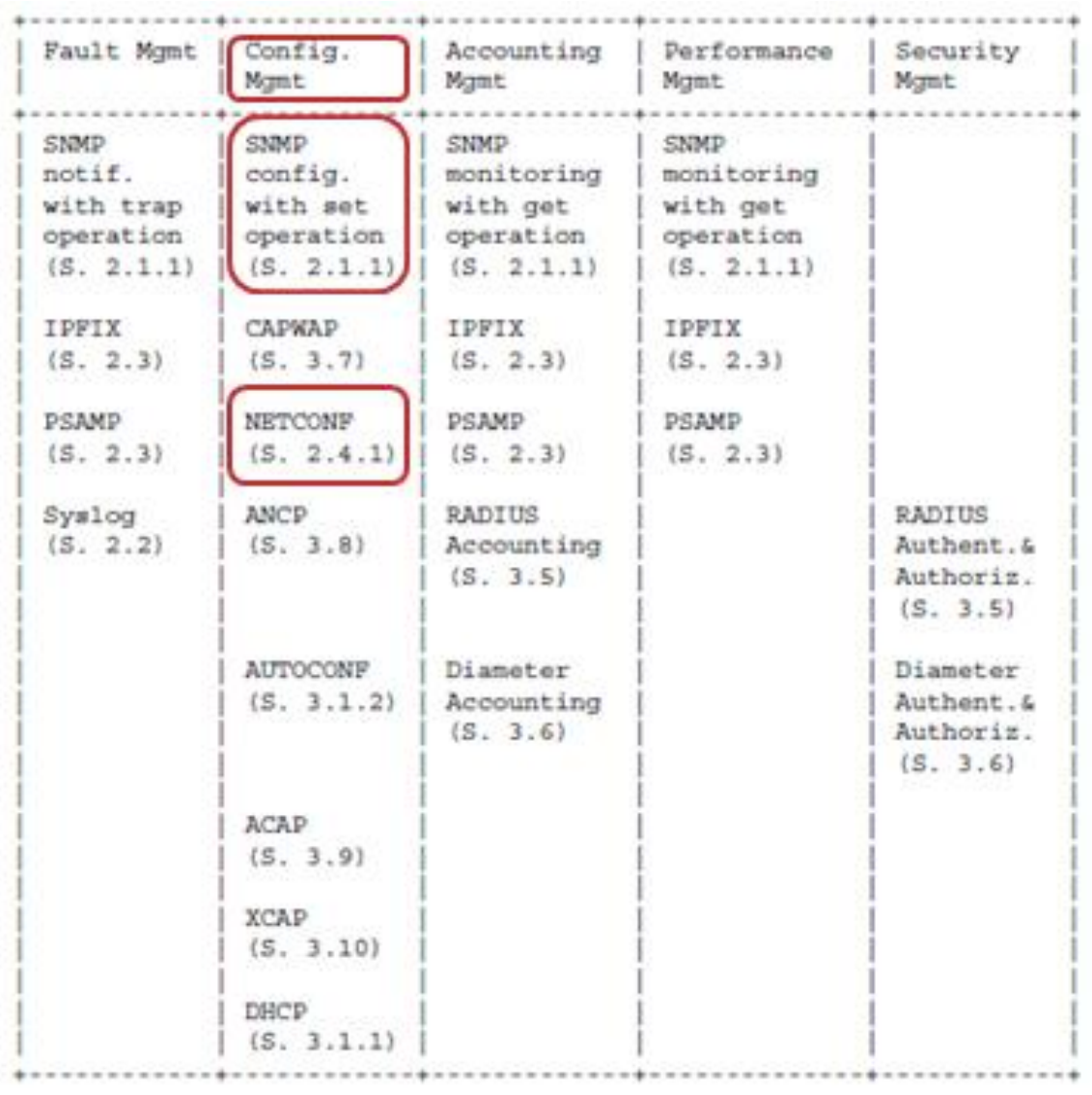

\section{Slika 4-5. FCAPS i protokoli mrežnog upravljanja ${ }^{135}$}

Na taj način su SNMP i NETCONF definirani kao osnovni protokoli za funkciju Upravljanja konfiguracijama FCAPS modela.

\footnotetext{
${ }^{134}$ IETF RFC 6632 An Overview of the IETF Network Management Standards (2012) https://tools.ietf.org/html/rfc6632 (21.1.2019).

${ }^{135}$ IETF RFC 6632 An Overview of the IETF Network Management Standards (2012) https://tools.ietf.org/html/rfc6632 (21.1.2019).
} 
Novi trendovi razvoja računalnih uređaja i mreža (virtualizacija, centralizacija i mobilnost uređaja) su osnova nastanka računalstva u oblaku koji sve češće koristi arhitekturu softverski definiranih mreža za upravljanje računalnim mrežama. SDN nudi programabilni pristup upravljanja računalnim mrežama i omogućava efikasniju i jednostavniju instalaciju, upravljanje i praćenje stanja računalnih mreža.

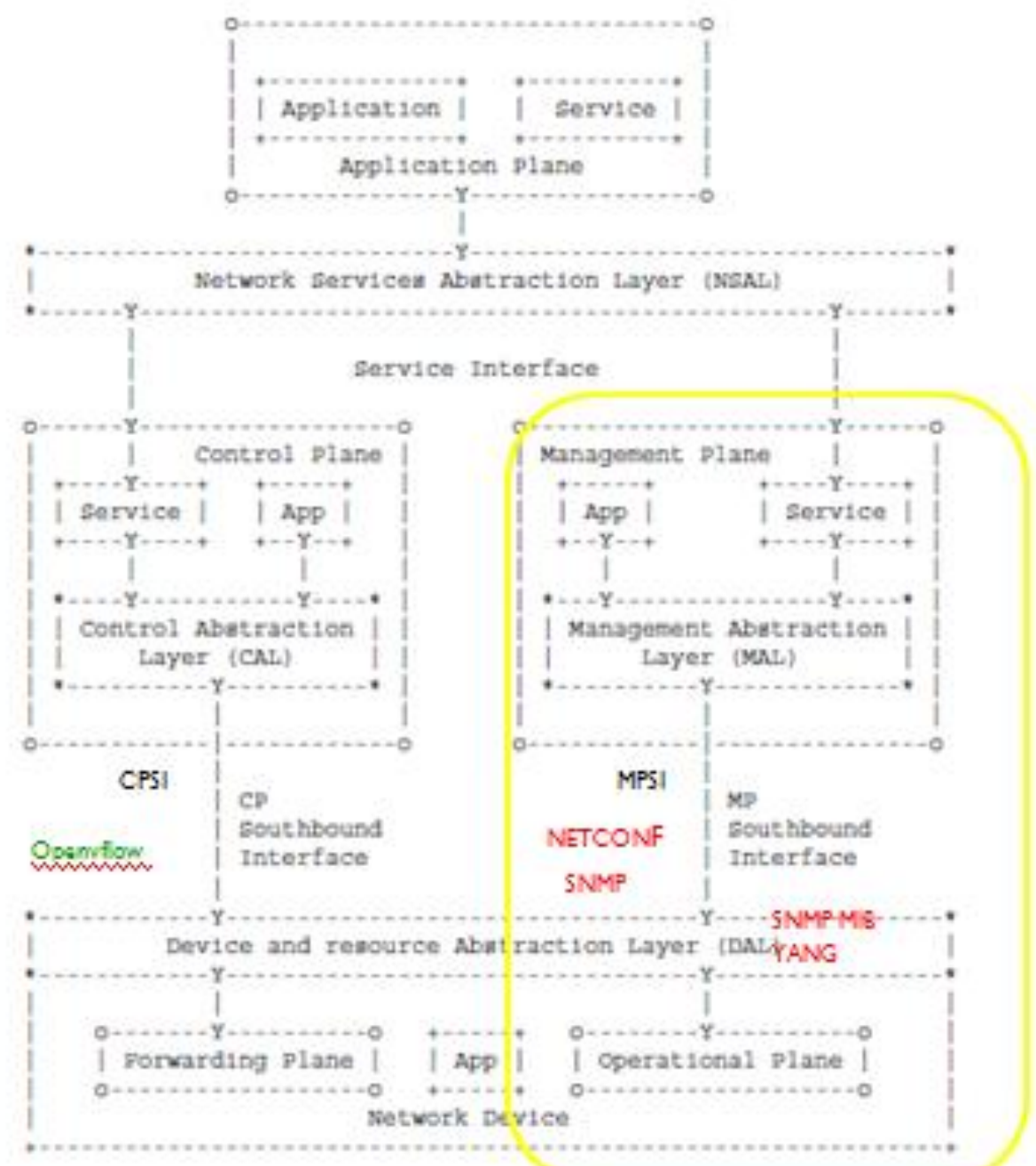

Slika 4-6. Slojevi SDN arhitekture ${ }^{136}$

${ }^{136}$ IETF RFC 7426 Software-Defined Networking (SDN): Layers and Architecture Terminology (2015) https://tools.ietf.org/html/rfc7426 (21.1.2019). 
Budući da se SDN pristup mrežnom upravljanju brzo razvijao i nastajao iz različitih izvora, IETF je objavio RFC 7426 u siječnju 2015. u kojem je napravio pregled i sistematizaciju razvoja SDN arhitekture te definirao smjernice za budući razvoj.

SDN arhitektura ima potrebu za standardnim sučeljem za komandnu konfiguraciju mrežnih uređaja pa RFC 7426 koristi dva osnovna protokola za upravljanje konfiguracijom mrežnih uređaja (sučelje MPSI):

- komandno orijentirani NETCONF i

- podatkovno orijentiran SNMPv3

kao što prikazuje Slika 4-6. Za CPSI sučelje preporuča se Openflow protokol.

Na taj način su i NETCONF i SNMP definirani kao osnovni protokoli za upravljanje u računalnim mrežama budućnosti, kao dva kompatibilna protokola koja se međusobno nadopunjuju.

Može se zaključiti da je NETCONF protokol uključen kao osnovni dio tradicionalnog FCAPS modela mrežnog upravljanja, ali i kao osnovni dio nadolazeće i sve više primjenjivane SDN arhitekture mrežnog upravljanja.

\subsubsection{Zrelost NETCONF standarda}

Nakon više od deset godina od nastanka NETCONF standarda postavlja se pitanje kolika je stvarna prihvaćenost i primjena ovog standarda u današnjim mrežama i kolika je njegova zrelost.

IETF definira u RFC 6410 postojanje dva nivoa zrelosti RFC standarda: "predloženi” (engl. proposed) i "Internet standard". Da bi standard prešao u najviši nivo (status "Internet standard") trebala bi postojati široka upotreba tog standarda u praksi od strane korisnika, odnosno RFC treba biti prihvaćen u svakodnevnoj primjeni ${ }^{137}$. Trenutni status NETCONF standarda je "predložen”, a SNMPv3 ima status “Internet standard".

137 IETF RFC 6410 Reducing the Standards Track to Two Maturity Levels (2011) https://tools.ietf.org/html/rfc6410 (21.1.2019). 
Budući da korisnici (administratori, sistemski inženjeri, arhitekti mrežnih sustava i drugi) odabirom i instalacijom nekog protokola u svojim mrežama određuju važnost i zrelost RFC standarda, potrebno je ispitati širinu i način primjene NETCONF standarda u Hrvatskoj (više od deset godina nakon što je prva verzija standarda objavljena, što je vrlo dug period u ICT području).

Što je neka tehnologija više primijenjena, dostići će se i viši stupanj svoje zrelosti. Pod zrelošću se podrazumijeva koliki je stupanj primjene proizvođača, funkcije koje su primijenjene, učestalost programskih grešaka (engl. bug) koje se pojavljuju, interoperabilnost između različitih proizvoda i proizvođača, dokumentacija i edukacija proizvođača i drugo. Izuzetno važan faktor hoće li neki standard uspjeti u ICT primjeni i biti široko primijenjen u računalnim sustavima su korisnici i njihovo (subjektivno) prihvaćanje i primjena tehnologije. Povećanje primjene standarda kao rezultat ima povećanje njegove zrelosti, a time i povećanje raspoloživosti mrežnih uređaja i cijelog mrežnog sustava ${ }^{138}$.

Tablica 4-4. Primjeri implementacije NETCONF protokola ${ }^{139}$

\begin{tabular}{ll}
\hline Proizvođač & Platforma/OS \\
\hline Cisco & IOS 12.4(9)T and later \\
& IOS XE 2.1 and later \\
\hline Juniper Networks & JUNOS 7.5 and later \\
\hline Brocade & NETIRON XMR, CES and CER \\
& MLX series \\
& VDX \\
\hline Huawei & AR3200/2200 Enterprise routers \\
\hline Ericsson & SEA 20 \\
\hline
\end{tabular}

\footnotetext{
${ }^{138}$ IETF RFC 6410 Reducing the Standards Track to Two Maturity Levels (2011) https://tools.ietf.org/html/rfc6410 (21.1.2019).

139 Valenčić D., Mateljan V. 2019. Implementation of NETCONF Protocol, Proceedings of the 42nd International Convention, Croatian Society for Information and Communication Technology, Electronics and Microelectronics - MIPRO, Rijeka
} 
Tablica 4-4. prikazuje primjere primjene NETCONF standarda nekih proizvođača mrežnih uređaja.

Važno je napomenuti da su u tablici prikazani samo primjeri implementacije jer nije moguće napraviti potpunu i ažuriranu listu za sve proizvođače (pa i najveće) i njihove R/S uređaje, a neki od važnijih razloga su sljedeći:

- lista modela mrežnih R/S uređaja za svakog proizvođača je često vrlo velika,

- ponuda R/S uređaja nekog proizvođača se vrlo često mijenja (dodaju se novi modeli dok se stariji brišu),

- verzije softvera za R/S uređaje se vrlo često mijenjaju,

- funkcije raspoložive za određene verzije softvera se isto mijenjaju (dodaju se na zahtjev korisnika)

- vrlo često je teško dobiti ažurirane informacije i od samog proizvođača.

Ipak, i iz ove se liste može vidjeti da proizvođači mrežne opreme implementiraju NETCONF u određenim verzijama svojeg operacijskog sustava, i na određenim platformama, tako da se ne nalazi na svim uređajima za određenu verziju OS. Zbog toga je stvarno pitanje koliko je uistinu zastupljena implementacija NETCONF protokola (na kojim uređajima i na kojoj verziji OS za svakog pojedinog proizvođača). 


\section{NETCONF standard i povećanje raspoloživosti mrežnih uređaja}

Kao i u dosadašnjem dijelu rada, i u ovom poglavlju prikazani su rezultati sekundarnog istraživanja.

Do sada su u radu prikazani:

- teoretski pregled osnovnih pojmova iz područja računalnih mreža,

- osnovne karakteristike NETCONF protokola i

- teoretski uvod u raspoloživost ICT uređaja.

Svi do sada razmatrani i prikazani pojmovi i tehnologije potrebni su za razumijevanje primarnog istraživanja koje je prikazano u sljedećim poglavljima.

Ovo se poglavlje bavi istraživačkim pitanjima definiranim u Prijavi teme doktorskog rada, a koja su prikazana i u ovom radu u poglavlju 1.3. Cilj i hipoteze istraživanja.

U prvom dijelu ovog poglavlja napravljena je usporedba metoda konfiguriranja mrežnih uređaja (CLI, SNMP i NETCONF) u odnosu na povećanje raspoloživosti. Ovaj dio rada je nastao kao priprema za primarno istraživanje i objavljen je (uz male izmjene) u članku pod nazivom Implementation of NETCONF protocol na konferenciji Mipro 2019.

U drugom dijelu ovog poglavlja prikazani su primjeri informacija proizvođača o implementaciji NETCONF standarda na njihovim uređajima, a ukratko su navedena i alternativna/slična rješenja NETCONF standardu koja se trenutno koriste na tržištu. Prikazani su i rezultati laboratorijskog testa $\mathrm{u}$ kojem se vidi interoperabilnost uređaja različitih proizvođača i koje NETCONF funkcije (NETCONF capabilities) podržavaju. 


\subsection{Usporedba metoda konfiguriranja mrežnih uređaja}

U ovom poglavlju usporedit će se tri načina konfiguriranja mrežnih uređaja: nestandardni CLI pristup, SNMP standard i NETCONF standard. Sadržaj ovog poglavlja nastao je na temelju autorovog (u suradnji s mentorom) objavljenog rada pod nazivom Implementation of NETCONF protocol na konferenciji Mipro $2019^{140}$.

Slika 5-1. prikazuje usporedbu protokola za konfiguriranje mrežnih uređaja.

\begin{tabular}{|c|c|c|c|}
\hline Feature & $C L I$ & SNMP & NETCONF \\
\hline Human readable & Yes & No & Yes \\
\hline Standard & No & $\begin{array}{c}\text { Yes } \\
\text { (IETF) }\end{array}$ & $\begin{array}{c}\text { Yes } \\
\text { (IETF) }\end{array}$ \\
\hline Data Models & Proprietary & Defimed in MIBs & YANG Core Models \\
\hline Data Modeling Language & Proprietary & SMI & YANG \\
\hline Encoding & Proprietary & BER & $\mathrm{XML}$ \\
\hline Resources & Proprietary & OIDs & Paths \\
\hline Remote access & $\begin{array}{c}\text { Yes } \\
\text { (TelnetSSH) }\end{array}$ & Yes & $\begin{array}{c}\text { Yes } \\
\text { (SSH) }\end{array}$ \\
\hline Transport Stack & $\mathrm{TCP}$ & UDP & $\mathrm{TCP}$ \\
\hline Secure protocol & Yes & $\begin{array}{c}\text { Not(v1, } 2 \text { and } 2 c) \\
\text { Yes (v3) but not strong } \\
\text { security }\end{array}$ & Yes \\
\hline Programmability & $\begin{array}{c}\text { No } \\
\text { (Only scripts could be used) }\end{array}$ & Yes & Yes \\
\hline $\begin{array}{l}\text { Distinguish configurational and } \\
\text { operational data. }\end{array}$ & No & No & Yes \\
\hline Get collection of status fields & Yes (with scripts) & Yes & Yes \\
\hline Set collection of configuration fields & Yes (with scripts) & Yes & Yes \\
\hline $\begin{array}{c}\text { Transactions across multiple network } \\
\text { elements }\end{array}$ & No & No & Yes \\
\hline Send event notification & $\begin{array}{l}\text { Yes (by using Syslog } \\
\text { protocol) }\end{array}$ & Yes & $\begin{array}{l}\text { Yes (but must be } \\
\text { connected) }\end{array}$ \\
\hline Backup and restore configuration & No & No & Yes \\
\hline Test configuration before final commit & No & No & Yes \\
\hline
\end{tabular}

\section{Slika 5-1. Usporedba metoda konfiguriranja mrežnih uređaja ${ }^{141}$}

SNMP nije čitljiv (engl. human readable) i to je osnovni razlog što se od svoga nastanka vrlo rijetko koristi za konfiguriranje uređaja. CLI pristup je nastao kako bi se ljudskim operaterima i administratorima olakšala interakcija s mrežnom opremom. CLI podsjeća na komandna

140 Valenčić D., Mateljan V. 2019. Implementation of NETCONF Protocol, Proceedings of the 42nd International Convention, Croatian Society for Information and Communication Technology, Electronics and Microelectronics - MIPRO, Rijeka.

${ }^{141}$ Isto 
sučelja temeljenog na znakovima koja se koriste na UNIX operacijskim sustavima (Slika 2-4. i Slika 2-5.)

Mnoge knjige i priručnici iz područja računalnih mreža sadrže u sebi upute (konfiguraciju s komandama) za mrežne administratore kako se može konfigurirati određena softverska mogućnost (engl. feature) mrežnog uređaja. Takva uputa sadrži slijed odgovarajućih CLI komandi koje trebaju biti upisane u uređaj pomoću konzolnog pristupa. Prikazan slijed CLI komandi na vrlo jasan i pregledan način prikazuje i objašnjava operabilnost i funkcionalnost određene softverske mogućnosti. To je izrazito važna prednost CLI pristupa i jedan od najvažnijih razloga zašto je CLI pristup tako široko prihvaćen od početka.

CLI pristup konfiguriranja nije definiran standardom i to u primjeni ima velikih nedostataka.

Mrežni administratori skoro uvijek moraju održavati računalnu mrežu koja se sastoji od međusobno različitih mrežnih uređaja. Najvažnije razlike između uređaja su sljedeće:

- vrste uređaja: usmjernici, preklopnici, vatrozidovi i drugi;

- model, veličina i kapacitet uređaja: različit broj i vrsta sučelja, kapacitet usmjeravanja i preklapanja i drugo;

- proizvođač uređaja: korisnici vrlo često imaju odabrane proizvođače za određene vrste mrežnih uređaja u svojoj mreži. Tako je jedan vrlo raširen pristup instalacija 90\% određene vrste uređaja (na primjer core usmjernik) od jednog proizvođača, a $10 \%$ od drugog proizvođača.

- operacijski sustav uređaja: svaki proizvođač ima svoj operacijski sustav, a neki proizvođači imaju i više vrsta (ovisno o vrsti i modelu mrežnog uređaja).

- verzija operacijskog sustava: čak uređaji istog modela i proizvođača mogu biti instalirani s različitom softverskom verzijom softvera i zakrpom (engl. patch), ovisno o potrebi korisnika i računalne mreže.

- grupa podržanih funkcionalnosti (engl. feature set) verzije operacijskog sustava: ovisno o traženim mogućnostima (engl. feature), koristi se određena vrsta operacijskog softvera. 
Zbog uporabe uređaja različitih proizvođača u svojim računalnim mrežama, mrežni administratori suočavaju se s problemom interoperabilnosti, odnosno s velikim brojem različitih komandi istog ili sličnog značenja (svaki OS proizvođača ima svoje komande), različitim vrstama upravljačkih funkcija i varijantama prikaza upravljačkih informacija.

Svaki proizvođač koristi svoj model podataka (engl. data model) za spremanje konfiguracije mrežnog uređaja i CLI prikaz.

Postoje različite vrste operacijskih sustava, gdje svaki proizvođač ima svoj operacijski sustav za svoje mrežne uređaje, a neki proizvođači imaju i više operacijskih sustava (na primjer Cisco ima IOS, IOS XR, NX OS).

Slika 2-4. pokazuje Cisco IOS komandu show running-config, dok Slika 2-5. prikazuje Juniper JUNOS komandu show configuration. Obje komande imaju isti cilj (prikazati kompletnu konfiguraciju mrežnog uređaja, i kako se vidi na slikama, sintaksa komandi je različita, a različit je i ispis rezultata komandi.

Različite komande i sintaksa tih komandi postoje u operacijskim sustavima različitih proizvođača, ali i u različitim OS istog proizvođača, u verzijama softvera za različite platforme koji koriste isti OS i čak u različitim verzijama softvera za istu platformu nekog proizvođača.

Popis komandi se stalno mijenja kod dodavanja novih mogućnosti uređajima pa je vrlo naporno za mrežnog administratora poznavati sve komande za mrežne uređaje, pogotovo ako je mreža sastavljena od uređaja različitih proizvođača.

Iako je različit ispis, mrežni administrator može razumjeti informacije koje su prikazane (naravno, ako poznaje komande oba operacijska sustava). Ipak, zbog uporabe različitih komandi i ostalih znakova koje koriste operacijski sustavi, CLI pristup je vrlo teško koristiti za mrežnu automatizaciju (korištenje skripti i aplikacija). 
Svrha svakog računalnog standarda je uspostavljanje zajedničkih pravila koje trebaju primjenjivati svi proizvođači na svojim mrežnim uređajima. Što se tiče mrežnog upravljanja, standard određuje sve parametre vezane uz interoperabilnost ${ }^{142}$ :

- pravila međusobne razmjene upravljačkih poruka (engl. management message), kao i način kako su upravljačke poruke prikazane i kodirane;

- cjelovit i konzistentan skup upravljačkih funkcija, od kojih svaka ima svoje definirano: značenje, parametre i poruke;

- definirani model podataka (engl. data model), odnosno upravljačke informacije za sve upravljane elemente.

SNMP i NETCONF su standardni upravljački protokoli koji zadovoljavaju navedene zahtjeve.

Na tradicionalan način se mrežnim uređajima upravlja pomoću CLI pristupa: konfigurira se uređaj pomoću config komandi i vrši kontrola operacijskog stanja uređaja pomoću show komandi. Kada se koristi CLI pristup, potreban je mrežni administrator da bi pročitao i interpretirao dobivene rezultate.

Korištenjem softverskih programa (koji zamjenjuju CLI manualni pristup) za konfiguriranje mrežnih uređaja, dobiva se jednostavnije i efikasnije rješenje. NETCONF omogućava takve programabilne i automatizirane mrežne operacije.

Važno svojstvo NETCONF protokola je omogućavanje istovremene konfiguracije više mrežnih uređaja pomoću transakcija (engl. transaction-based). Sljedeće četiri karakteristike definiraju transakciju ${ }^{143}$ :

- Atomnost (engl. atomicity): svaka transakcija je nedjeljiva, ona se potpuno izvrši ili se ne izvrši.

\footnotetext{
${ }^{142}$ Clemm, A. 2006. Network management fundamentals, Cisco Press, 111-113.

143 Valenčić D., Mateljan V. 2019. Implementation of NETCONF Protocol, Proceedings of the 42nd International Convention, Croatian Society for Information and Communication Technology, Electronics and Microelectronics - MIPRO, Rijeka.
} 
- Konzistentnost (engl. consistency) što znači da se cijela transakcija prenese u cjelini. Isto tako ne postoji interni poredak izmjena (engl. change) unutar transakcije, odnosno svaka je transakcija skup izmjena, a ne slijed. Drugim riječima, slijed izmjena je važan za izvršenje, ali mrežni administrator ne mora brinuti o transakcijskom sustavu.

- Nezavisnost (engl. independence): paralelne transakcije ne utječu jedna na drugu.

- Trajnost (engl. durability): isporučeni podaci uvijek ostanu u sustavu, čak i u slučajevima fail-over, padu električnog napajanja, restarta sustava ili sličnih situacija.

NETCONF omogućava mrežnom administratoru slanje skupa konfiguracijskih izmjena (ili kompletne konfiguracije) na jedan ili više mrežnih uređaja pomoću jednostavne <editconfig > transakcije. Kada to čini, mrežni administrator ne mora:

- razmišljati u kojem slijedu treba slati konfiguracijske izmjene prema mrežnom uređaju. Različiti sljedovi konfiguracijskih izmjena se na uređaju obrađuju i izvršavaju na jednak način.

- Izvršavati oporavak sustava u slučaju da transakcija ne bude uspješna. U slučaju neuspjeha primjene transakcije zbog nekonzistentnosti konfiguracije, nedostatka raspoložive memorije ili drugih razloga, nijedan dio sadržaja transakcije neće biti izvršen i aktiviran. U tom slučaju transakcija nije napravila roll-back funkciju, već jednostavno nije nikada bila aktivirana. Istovremene transakcije za više mrežnih uređaja (engl. network-wide transactions) je izuzetno važna funkcija zbog toga što mrežni administratori ne moraju više brinuti o slijedu zadataka (engl. sequencing tasks) i oporavku od greške (engl. error recovery). Na taj način se konfiguriraju mrežni servisi koje je potrebno aktivirati istovremeno na više uređaja u mreži (na primjer SNMP community string na uređajima neke mreže). Detaljan primjer istovremene konfiguracije više uređaja pomoću NETCONF standarda prikazan je u samom standardu ${ }^{144}$.

${ }^{144}$ IETF RFC 6241 Network Configuration Protocol (NETCONF) (2011) https://tools.ietf.org/html/rfc6241 (21.1.2019), 106-111. 


\subsubsection{Svojstva NETCONF standarda za povećanje raspoloživosti}

Kako je Clemm naveo, efikasno mrežno upravljanje povećava kvalitetu mrežnih i komunikacijskih usluga, a time povećava raspoloživost i pouzdanost računalne mreže i mrežnih usluga ${ }^{145}$. Autor je ovog rada proučavajući NETCONF standard odredio sljedeća najvažnija svojstva (mogućnosti) NETCONF standarda kojima se povećava kvaliteta mrežnog upravljanja (a time se i povećava raspoloživost R/S mrežnih uređaja):

1. NETCONF kao standardni način konfiguracije preko udaljenog pristupa na IP adresu uređaja gdje je za sve proizvođače ista struktura komandi i podataka.

2. NETCONF kao standard omogućava programabilnost (automatiziranje) koja značajno smanjuje učestalost ljudske pogreške.

3. NETCONF standard koristi jasnu razliku u strukturi između konfiguracijskih i operacijskih podataka.

4. Mogućnost parcijalnog konfiguriranja uređaja pomoću NETCONF standarda

- NETCONF postiže pomoću XML jezika i „XML subtree filtering“ funkcije)

5. Mogućnost provjere konfiguracije prije primjene kod NETCONF načina konfiguriranja uređaja.

- NETCONF postiže provjeru konfiguracijske datoteke pomoću funkcije $\langle$ validate $>$

6. Mogućnost zaključavanja konfiguracijske datoteke koje nudi NETCONF.

- NETCONF pomoću operacija „,lock“ i ,unlock“ onemogućava istovremenu promjenu konfiguracijske datoteke iz više izvora (na primjer istovremena druga NETCONF sesija, CLI pristup ili pristup pomoću SNMP protokola).

7. „Backup \& restore“ mogućnost koju nudi NETCONF standard.

- NETCONF postiže pomoću (1) manipulacije konfiguracijskih datoteka (〈running>, 〈candidate>, 〈startup〉 i backup) i (2) pomoću funkcije „Rollback-on-Error“.

8. Mogućnost istovremenog i koordiniranog konfiguriranja svih ili više uređaja $u$ mreži.

\footnotetext{
${ }^{145}$ Clemm, A. 2006. Network management fundamentals, Cisco Press, 13-16.
} 
- NETCONF postiže pomoću manipulacije konfiguracijskih datoteka (〈running>, 〈candidate>, <startup> i backup) i pomoću operacija ,,lock“ i ,unlock“.

U intervjuima $\mathrm{i}$ anketnom upitniku postavljena su pitanja proizvođačima, partnerima $\mathrm{i}$ korisnicima mrežnih uređaja, tako da mogu iznijeti svoje mišljenje o:

- važnosti pojedinog svojstva NETCONF standarda za primjenu od strane proizvođača i od strane korisnika,

- važnosti pojedinog svojstva NETCONF standarda za povećanje raspoloživosti mrežnog uređaja i

- poznavanje svakog od navedenih svojstava NETCONF standarda (ovo pitanje je postavljeno samo u anketnom upitniku za korisnike).

Važno je napomenuti da je na početku istraživanja postavljena još jedno svojstvo (mogućnost) NETCONF protokola:

- NETCONF kao standardni način konfiguracije preko lokalnog konzolnog pristupa povećava raspoloživost zato jer je za sve proizvođače ista struktura komandi i podataka.

Međutim, tijekom intervjua i pažljivijom analizom NETCONF standarda zaključeno je da nije moguć direktni pristup preko lokalnog konzolnog pristupa, već je uvijek prvo potrebno konfigurirati uređaj (dodijeliti IP adresu i aktivirati NETCONF i SSH protokole) da bi se NETCONF mogao koristiti. Ta početna konfiguracija uređaja izvršava se pomoću komandi i OS sustava proizvođača opreme, a nakon toga uređaj se može dalje konfigurirati pomoću NETCONF standarda spajanjem preko udaljenog pristupa na IP adresu uređaja. Zbog toga spajanje preko lokalnog konzolnog pristupa pomoću NETCONF-a nije moguće i izbačeno je iz istraživanja. 


\subsection{Informacije proizvođača o implementaciji NETCONF standarda}

Proizvođači imaju različite mrežne uređaje koji se, kako je prije navedeno, međusobno razlikuju (vrsta uređaja, model uređaja, vrsta operacijskog sustava, verzija operacijskog sustava, grupa podržanih funkcionalnosti operacijskog sustava).

Podrška nekog uređaja za NETCONF ovisi o parametrima tog uređaja (vrsta uređaja, model uređaja, vrsta operacijskog sustava, verzija operacijskog sustava, grupa podržanih funkcionalnosti operacijskog sustava).

Zbog čestih promjena tih parametara vrlo je složeno odrediti koji mrežni uređaji podržavaju NETCONF i u kojoj verziji softvera, a rezultati se skoro svakodnevno mijenjaju.

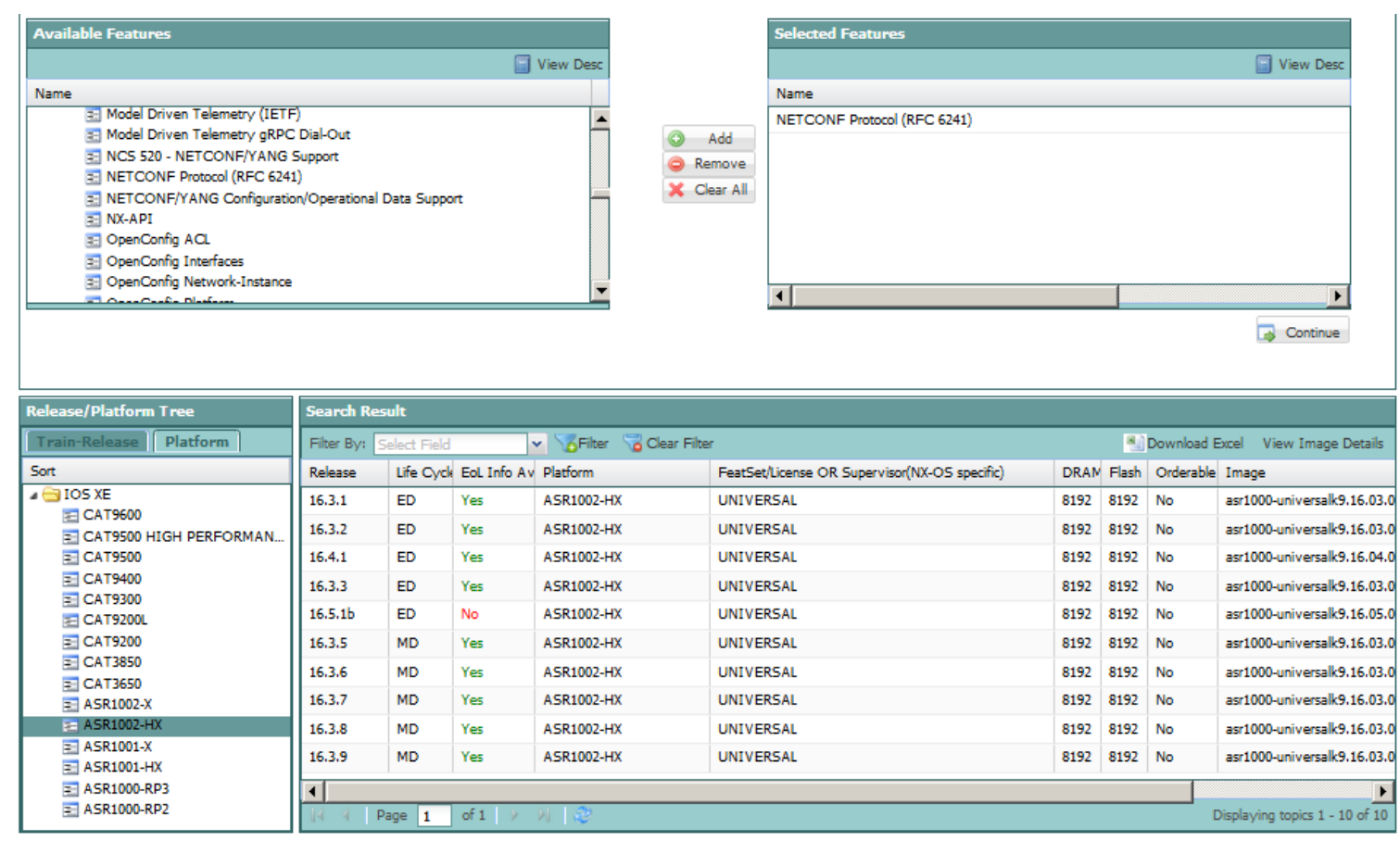

\section{Slika 5-2. Cisco Feature Navigator ${ }^{146}$}

Većina proizvođača ne implementira NETCONF na svim svojim uređajima. Kao primjer će se pokazati podrška za NETCONF za Cisco uređaje ${ }^{147}$. Cisco koristi aplikaciju Cisco Feature Navigator pomoću koje je moguće odrediti koji uređaji podržavaju NETCONF standard ${ }^{148}$.

\footnotetext{
${ }^{146}$ Cisco Feature Navigator: NETCONF https://cfn.cloudapps.cisco.com/ITDIT/CFN/jsp/by-featuretechnology.jsp (17.08.2019).
} 
Slika 5-2. prikazuje primjer uporabe Cisco Feature Navigator aplikacije u određivanju implementacije NETCONF standarda na Cisco uređajima. Od svih sposobnosti (Feature) koje su dostupne u donjem lijevom prozoru, odabran je NETCONF Protocol (6241). Donji lijevi prozor prikazuje koje sve Platforme (vrste i modeli uređaja) podržavaju NETCONF u IOS XE vrsti operacijskog sustava. Za odabranu Platformu uređaja (usmjernik, model ASR1002-HX) $\mathrm{u}$ donjem desnom prozoru prikazane su sve verzije softvera (Release) koje podržavaju NETCONF, njihove zahtjeve za DRAM i Flash memorijom, kao i naziv softvera (Image).

Popis svih uređaja i njihovih verzija softvera koji podržavaju NETCONF od strane proizvođača je skoro svakodnevno promjenjiv zbog velikog broja modela uređaja i verzija softvera (na primjer vrlo često se neki Feature dodaje u određene verzije softvera i uređaje na zahtjev važnijih korisnika). Zbog toga nije moguće na kvantitativan način odrediti implementaciju NETCONF standarda na uređajima proizvođača (na primjer postotak uređaja koji podržavaju NETCONF) pomoću informacija dobivenih od proizvođača, već će se odrediti na temelju informacija dobivenih od korisnika u anketnom upitniku.

\subsection{Testiranje funkcija NETCONF standarda u laboratoriju}

Nakon proučavanja NETCONF standarda, razgovora s inženjerima proizvođača i dostupnih objavljenih radova (kao na primjer članak NETCONF Interoperability lab ${ }^{149}$ ) moglo se zaključiti da različiti modeli i verzije softvera R/S uređaja, iako podržavaju standard, ne moraju podržavati većinu njegovih funkcija koje povećavaju raspoloživost.

Zbog toga je odlučeno napraviti test u kojem bi se vidjelo trenutno stanje softvera i uređaja različitih proizvođača i koje NETCONF funkcije (NETCONF capabilities) podržavaju.

NETCONF funkcije su detaljno objašnjene u teoretskom dijelu ovog rada u poglavlju 4.2.5 Funkcije NETCONF standarda.

\footnotetext{
${ }^{147}$ Cisco Systems, Preston Hank (2018) YANG, NETCONF, RESTCONF Demos. Which Cisco devices are supported? (verzije SW na 33,40) https://www.youtube.com/watch?v=cooE3wZ7O4I (20.1.2019).

${ }^{148}$ Cisco Feature Navigator https://cfn.cloudapps.cisco.com/ITDIT/CFN/jsp/index.jsp (17.08.2019).

149 Bajpai, V., Schönwälder, J. 2014. NETCONF Interoperability Lab, Conference paper, 14th IEEE/IFIP Network Operations and Management Symposium (NOMS 2014), At Krakow, Poland.
} 
Test se sastojao od spajanja na uređaj pomoću MG-SOFT NETCONF Browser aplikacije i prikaza podržanih NETCONF funkcija na uređaju.

Slika 5-3. prikazuje testirane R/S uređaje: proizvođača, model uređaja, OS koji se koristi na testiranom uređaju, testiranu verzija OS softvera (i njezin datum izdavanja). Testirana su tri uređaja proizvođača Cisco, s tim da je svaki uređaj imao instaliranu različitu vrstu OS (trenutno Cisco ima tri vrste OS za svoje uređaje: IOS XE, IOS XR i NX-IOS). Sve verzije testiranog softvera su novije iz 2019. godine, osim HPE softvera koji je iz 2017. godine (ali je zadnja verzija izdanog softvera za testiranu HPE platformu).

\begin{tabular}{|l|l|l|l|l|}
\hline Vendor & Sistem & OS & Verzija OS-a & OS datum \\
\hline Cisco & Cloud Services Router 1000v (CSR 1000v) & Cisco IOS XE & Version 16.9.3 & Mar 20 2019 \\
\hline Cisco & Cisco IOS XRv 9000 & Cisco IOS XR & Version 6.5.3 & Mar 26 2019 \\
\hline Cisco & Nexus 9000v & Cisco NX-OS & Version 7.0(3)I7(6) & Mar 05 2019 \\
\hline Juniper & Juniper vMX & JUNOS OS & Version 19.1R1.6 & Apr 17 2019 \\
\hline HPE & HPE VSR1001 & HPE Comware Software & Version 7.1.064 & Jun 13 2017 \\
\hline
\end{tabular}

Slika 5-3. Lab test: testirani R/S uređaji ${ }^{150}$

Slika 5-4. prikazuje dobivene rezultate testa, odnosno sve podržane funkcije za svaki od testiranih $\mathrm{R} / \mathrm{S}$ uređaja.

Iz provedenog testa može se zaključiti sljedeće:

- svi uređaji podržavaju samo :base1.0 funkciju,

- ni jedan uređaj ne podržava sve dostupne funkcije NETCONF protokola,

- uređaji različitih proizvođača ne podržavaju iste funkcije pa čak i

- različiti uređaji istog proizvođača ne podržavaju iste funkcije.

Zbog gore navedenog nije bilo moguće izvesti test usporedbe NETCONF i CLI konfiguriranja $\mathrm{R} / \mathrm{S}$ uređaja u povećanju raspoloživosti sustava.

${ }^{150}$ Pupovac, V. 2019. Primjena funkcija NETCONF standarda, diplomski rad (u izradi, mentor D. Valenčić), Veleučilište Velika Gorica, 


\begin{tabular}{|l|c|c|c|c|c|}
\cline { 2 - 6 } & $\begin{array}{c}\text { Cisco } \\
\text { Nexus } \\
9000 \mathrm{v}\end{array}$ & $\begin{array}{c}\text { Cisco } \\
\text { IOS XRv } \\
9000\end{array}$ & $\begin{array}{c}\text { Cisco } \\
\text { CSR } \\
\text { 1000v }\end{array}$ & $\begin{array}{c}\text { Juniper } \\
\text { Networks } \\
\text { vMX }\end{array}$ & $\begin{array}{c}\text { HPE } \\
\text { VSR1001 }\end{array}$ \\
\hline :writable-running & $\checkmark$ & $\mathbf{X}$ & $\checkmark$ & $\mathbf{X}$ & $\checkmark$ \\
\hline :candidate & $\checkmark$ & $\checkmark$ & $\mathbf{X}$ & $\checkmark$ & $\mathbf{X}$ \\
\hline :confirmed-commit & $\checkmark$ & $\checkmark$ & $\mathbf{X}$ & $\checkmark$ & $\mathbf{X}$ \\
\hline :confirmed-commit:1.1 & $\checkmark$ & $\checkmark$ & $\mathbf{X}$ & $\mathbf{X}$ & $\mathbf{X}$ \\
\hline :rollback-on-error & $\checkmark$ & $\checkmark$ & $\checkmark$ & $\mathbf{X}$ & $\checkmark$ \\
\hline :validate & $\checkmark$ & $\checkmark$ & $\checkmark$ & $\checkmark$ & $\checkmark$ \\
\hline :validate:1.1 & $\checkmark$ & $\checkmark$ & $\checkmark$ & $\mathbf{X}$ & $\mathbf{X}$ \\
\hline :startup & $\mathbf{X}$ & $\mathbf{X}$ & $\mathbf{X}$ & $\mathbf{X}$ & $\mathbf{X}$ \\
\hline :url & $\mathbf{X}$ & $\mathbf{X}$ & $\mathbf{X}$ & $\checkmark$ & $\mathbf{X}$ \\
\hline :xpath & $\mathbf{X}$ & $\mathbf{X}$ & $\checkmark$ & $\mathbf{X}$ & $\mathbf{X}$ \\
\hline :notification & $\mathbf{X}$ & $\checkmark$ & $\checkmark$ & $\mathbf{X}$ & $\checkmark$ \\
\hline :interleave & $\mathbf{X}$ & $\checkmark$ & $\checkmark$ & $\mathbf{X}$ & $\checkmark$ \\
\hline :partial-lock & $\mathbf{X}$ & $\mathbf{X}$ & $\mathbf{X}$ & $\mathbf{X}$ & $\mathbf{X}$ \\
\hline :with-defaults & $\mathbf{X}$ & $\mathbf{X}$ & $\checkmark$ & $\mathbf{X}$ & $\mathbf{X}$ \\
\hline :base:1.0 & $\checkmark$ & $\checkmark$ & $\checkmark$ & $\checkmark$ & $\checkmark$ \\
\hline :base:1.1 & $\checkmark$ & $\checkmark$ & $\checkmark$ & $\mathbf{X}$ & $\mathbf{X}$ \\
\hline :time:1.0 & $\mathbf{X}$ & $\mathbf{X}$ & $\mathbf{X}$ & $\mathbf{X}$ & $\mathbf{X}$ \\
\hline :yang-library & $\mathbf{X}$ & $\mathbf{X}$ & $\checkmark$ & $\mathbf{X}$ & $\mathbf{X}$ \\
\hline :yang-library:1.1 & $\mathbf{X}$ & $\mathbf{X}$ & $\mathbf{X}$ & $\mathbf{X}$ \\
\hline :with-operational-defaults & $\mathbf{X}$ & $\mathbf{X}$ & $\mathbf{X}$ & $\mathbf{X}$ & $\mathbf{X}$ \\
\hline & & & & & \\
\hline
\end{tabular}

\section{Slika 5-4. Rezultati testa: podržane NETCONF funkcije na uređajima ${ }^{151}$}

\subsection{Alternativna rješenja}

Područje automatiziranja i programiranja računalnih mreža izuzetno je aktivno posljednjih godina. Tako je na primjer Cisco uspostavio DevNet tim koji na svojim stranicama daje detaljne besplatne informacije o različitim MDP (Model-Driven Programmability) tehnologijama, a dostupna je i oprema na kojoj se može raditi laboratorijsko testiranje ${ }^{152}$.

I mnogi drugi proizvođači su uvidjeli potrebu za novim načinom konfiguriranja mrežnih uređaja te su razvili svoja API sučelja. Međutim, većina korisnika, partnera i programera slažu se da je bolje imati standardno sučelje mrežnih uređaja nego nestandardno.

U ovom će se poglavlju ukratko prikazati druga alternativna ili slična rješenja NETCONF-u.

\footnotetext{
151 Isto

${ }^{152}$ Cisco DevNet: Cisco APIs, SDKs, Sandbox and Community for Cisco Developers:, https://developer.cisco.com/ (20.5.2019)
} 
RESTCONF je definiran u RFC 8040 u siječnju 2017. godine ${ }^{153}$ i nastao je na temelju NETCONF standarda. RESTCONF je protokol koji omogućava programabilnost i koristi HTTPS za prijenos. Usko je vezan uz YANG protokol i njegove podatkovne modele, a koristi JSON i XML formate podataka.

Tablica 5-1. prikazuje slojeve RESTCONF standarda.

\section{Tablica 5-1. RESTCONF standard ${ }^{154}$}

\begin{tabular}{|l|l|l|}
\hline Sadržaj (content) & $\begin{array}{l}\text { Konfiguracijski i operacijski } \\
\text { podaci }\end{array}$ & XML ili JSON \\
\hline Operacije (operations) & Akcija koju treba izvršiti & $\begin{array}{l}\text { GET, POST, PUT. PATCH, } \\
\text { DELETE }\end{array}$ \\
\hline Prijenos (transport) & TCP/IP protokoli & HTTPS \\
\hline
\end{tabular}

REST API koriste CRUD (Create, Retrieve, Update, Delete) operacije na osnovi raspoloživih HTTP metoda. Tablica 5-2. prikazuje kako RESTCONF mapira NETCONF operacije u te HTTP metode.

Tablica 5-2. RESTCONF i NETCONF operacije $\mathrm{e}^{155}$

\begin{tabular}{|l|l|}
\hline \multicolumn{1}{|c|}{ RESTCONF } & \multicolumn{1}{c|}{ NETCONF } \\
\hline GET & <get>, <get-config> \\
\hline POST & <edit-config> (operation="create") \\
\hline PUT & <edit-config> (operation="create/replace") \\
\hline PATCH & <edit-config> (operation="merge") \\
\hline DELETE & <edit-config> (operation="delete") \\
\hline
\end{tabular}

\footnotetext{
${ }^{153}$ IETF RFC 8040 RESTCONF Protocol (2017) https://tools.ietf.org/html/rfc8040 (15.8.2019).

${ }^{154}$ Cisco DevNet: RESTCONF https://developer.cisco.com/learning/modules/intro-device-level-interfaces/introrestconf/step/2 (20.8.2019)

${ }^{155}$ Isto
} 
IETF $^{156}$ i Cisco ${ }^{157}$ ne smatraju da je RESTCONF zamjena za NETCONF, već da se mogu koristiti istovremeno u različitim prilikama, ovisno o potrebama korisnika. RESTCONF omogućava API sučelje koje je usklađeno s ostalim API sučeljima web aplikacija i na taj način omogućava jednostavan pristup programerima. RESTCONF u ovom trenutku nema sva svojstva i prednosti NETCONF standarda, ali postoji mogućnost da će RESTCONF tijekom vremena biti nadograđen i dalje razvijan. RESTCONF (kao i NETCONF i gRPC) dostupan je na pojedinim modelima proizvođača mrežne opreme, a za Cisco se informacije mogu naći na njihovim DevNet web stranicama ${ }^{158}$.

gRPC je RPC otvorenog koda koji je razvijen od kompanije Google. gRPC koristi HTTP/2 za prijenos i omogućava dodatne mogućnosti (na primjer autentikaciju, dvosmjerni streaming i kontrolu toka i drugo). Detaljne informacije o gRPC-u se mogu naći na web stranici https://www.grpc.io/. Cisco, na primjer, u svoja MDP rješenja uvrštava NETCONF, RESTCONF i gRPC.

JSON (JavaScript Object Notation) je format koji se koristi za razmjenu podataka između sustava. JSON koristi key/value parove u svrhu opisivanja objekata koji se koriste u aplikaciji $^{159}$. JSON je format podataka koji se često koristi u programske svrhe i teži biti razumljiviji od XML formata. JSON je definiran u RFC7158 $8^{160}$, a detaljne informacije o JSON-u se mogu naći na web stranici https://www.json.org/.

ZTP (Zero Touch Provisioning) je svojstvo mrežnog uređaja koje omogućava automatsku konfiguraciju uređaja kod instalacije i spajanja na mrežu. Kada se koristi ZTP, potrebna je minimalna manualna konfiguracija uređaja od strane mrežnog administratora. ZTP automatizira i ažuriranje verzije operacijskog sustava. ${ }^{161} 162$

\footnotetext{
${ }^{156}$ IETF RFC 8040 RESTCONF Protocol (2017) https://tools.ietf.org/html/rfc8040 (15.8.2019).

${ }^{157}$ Cisco DevNet: RESTCONF https://developer.cisco.com/learning/modules/intro-device-level-interfaces/introrestconf/step/2 (20.8.2019)

${ }^{158}$ Cisco DevNet: Model Driven Programmability https://developer.cisco.com/site/standard-network-devices/ (15.8.2019).

${ }^{159}$ Cisco DevNet: JSON https://developer.cisco.com/learning/help (20.8.2019)

${ }^{160}$ IETF RFC 7158 The JavaScript Object Notation (JSON) Data Interchange Format (2013) https://tools.ietf.org/html/rfc7158 (15.8.2019).

${ }^{161}$ Juniper Zero Touch Provisioning https://www.juniper.net/documentation/en_US/junos/topics/topic-map/zerotouch-provision.html\#id-zero-touch-provisioning (15.8.2019).
} 


\section{Povećanje raspoloživosti pomoću NETCONF standarda i primjena u Hrvatskoj}

Ovo poglavlje se bavi primarnim istraživanjem i istraživačkim pitanjima definiranim u Prijavi teme doktorskog rada (prikazanim i u ovom radu u poglavlju 1.4. Ispitanici, metodologija $i$ plan istraživanja pomoću sljedećih znanstvenih metoda:

- metoda polustrukturiranog intervjua s (a) proizvođačima mrežne opreme i (b) njihovim partnerima u Hrvatskoj;

- metoda strukturiranog upitnika za korisnike mrežne opreme u Hrvatskoj i

- statistička obrada kvantitativnih podataka.

U ovom poglavlju prvo su prikazane vrste i odabir ispitanika za istraživanje, a zatim i osnovni podaci o ispitanicima i njihovim kompanijama koji su dobiveni istraživanjem pomoću:

- intervjua s odabranim svjetskim proizvođačima R/S mrežne opreme,

- intervjua s odabranim partnerima proizvođača R/S mrežne opreme u Hrvatskoj i

- anketnog upitnika koji su popunili odabrani korisnici R/S mrežne opreme u Hrvatskoj.

U svakom od ovih istraživanja dobiveni odgovori su prikazani redom po sljedećim područjima:

- primjena NETCONF standarda kod proizvođača R/S uređaja koja je povezana uz područje ispitivanja hipoteze $\mathrm{H} 2$;

- primjena NETCONF standarda od strane korisnika u Hrvatskoj koja je povezana uz područje ispitivanja hipoteze $\mathrm{H} 3$;

- poznavanje NETCONF standarda od strane korisnika u Hrvatskoj koja je povezana uz područje ispitivanja hipoteze $\mathrm{H} 4$;

\footnotetext{
${ }^{162}$ Cisco Zero Touch Provisioning https://www.cisco.com/c/en/us/td/docs/switches/lan/catalyst3850/software/release/165/configuration_guide/prog/b_165_prog_3850_cg/zero_touch_provisioning.pdf (15.8.2019).
} 
- NETCONF i povećanje raspoloživosti R/S uređaja koje je povezano uz područje ispitivanja hipoteze $\mathrm{H} 1$;

- karakteristike i povećanje primjene NETCONF standarda koje pokriva ostala pitanja vezana uz NETCONF standard i povećanje raspoloživosti R/S uređaja. 


\subsection{Vrste i odabir ispitanika za istraživanje}

U ovom poglavlju su prikazani podaci o izvršenom odabiru ispitanika.

U poglavlju 1.4. Ispitanici, metodologija i plan istraživanja prikazan je dio Prijave teme doktorskog rada (Dr.Sc.-01 dokumenta) koji objašnjava:

- uzorak istraživanja:

○ ispitanici su podijeljeni u tri grupe: proizvođači, partneri i korisnici R/S uređaja,

- planirani način odabira uzorka ispitanika,

- metode istraživanja:

○ polustrukturirani intervju (proizvođači R/S uređaja i njihovi partneri $u$ Hrvatskoj),

○ anketni upitnik (korisnici R/S uređaja u Hrvatskoj)

i njihov način provođenja;

- plan provođenja istraživanja kroz četiri etape (1. teoretsko istraživanje, 2. intervjui s proizvođačima i partnerima, 3. anketni upitnik za korisnike i 4. obrada podataka).

Odabir ispitanika i istraživanje su izvedeni kako je određeno i planirano u Prijavi teme doktorskog rada.

\subsubsection{Odnos proizvođača, partnera i krajnjih korisnika mrežnih uređaja}

Uzorak istraživanja, odnosno, osnovni skup za potrebe primarnog istraživanja čine najveći svjetski proizvođači mrežnih uređaja (usmjernika i preklopnika) i odabrani korisnici (partneri i krajnji korisnici) tih mrežnih uređaja u Hrvatskoj.

Korisnici se mogu podijeliti na partnere proizvođača mrežne opreme i krajnje korisnike. Slika 6-1. prikazuje odnos između proizvođača mrežne opreme i njihovih korisnika.

Primjeri proizvođača mrežne opreme su Cisco, Juniper, HPE i drugi, koji su svjetski lideri u proizvodnji R/S uređaja.

Primjeri partnera u Hrvatskoj su Combis, CS, King ICT, Kodeks, S\&T, Storm, Verso i drugi. 
Krajnji korisnici se dijele u dvije skupine: davatelji usluga (engl. Internet Service Provider ISP) i poduzeća (engl. enterprise). Podjela se najčešće izvršava u te dvije skupine zbog različitog načina korištenja računalnih mreža, odnosno različite arhitekture računalnih mreža korisnika.

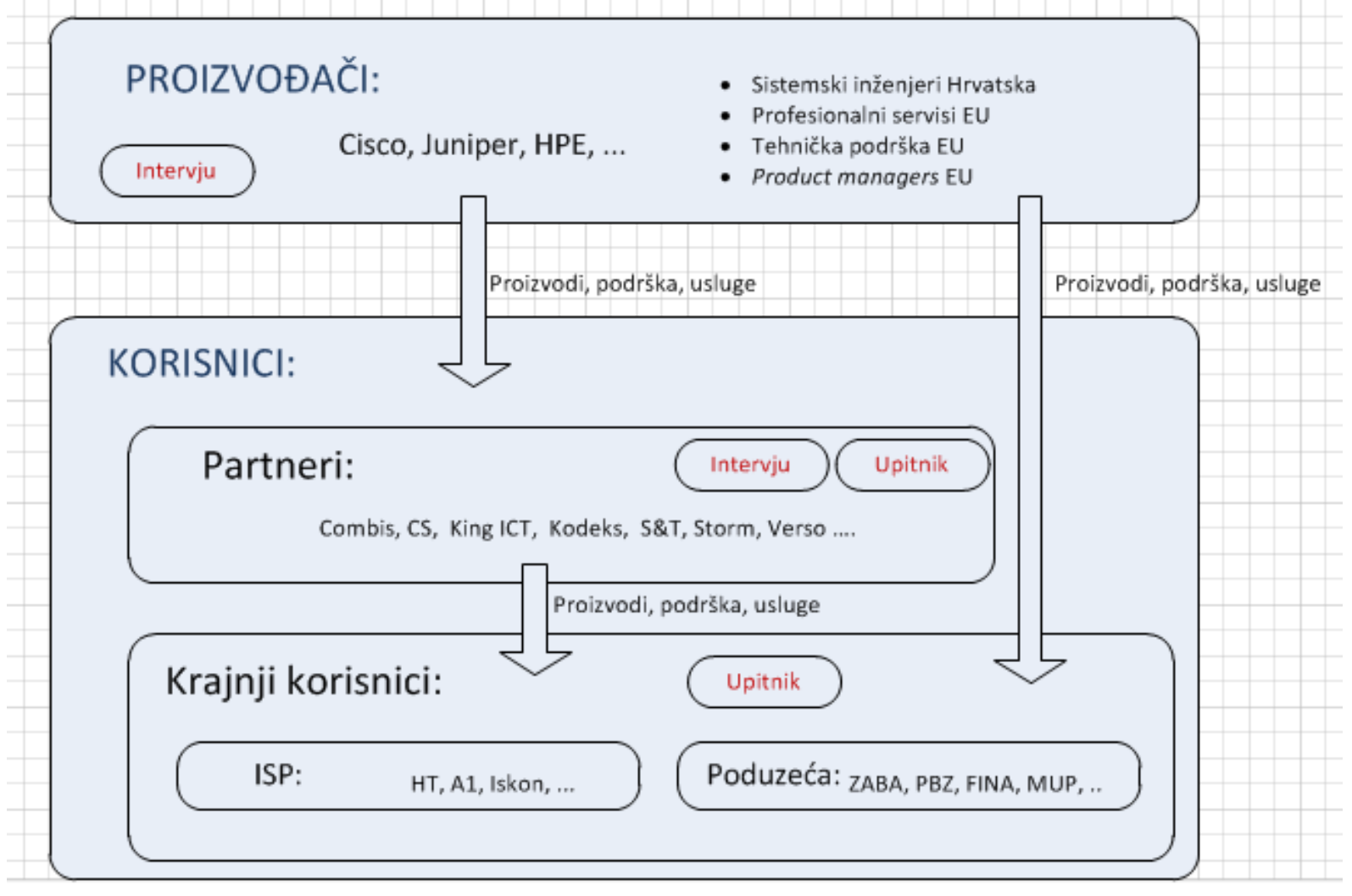

\section{Slika 6-1. Odnos proizvođača, partnera i krajnjih korisnika}

Partneri su najčešće posrednici između proizvođača i krajnjih korisnika pa izvršavaju poslove prodaje mrežnih uređaja, tehničke podrške, savjetovanja, edukacije i drugih usluga prema krajnjim korisnicima. Proizvođači vrlo rijetko direktno posluju i imaju kontakt s krajnjim korisnicima, i to se događa jedino s najvećim krajnjim korisnicima u nekim slučajevima većih projekata ili poslova.

Zbog toga proizvođači vrlo rijetko imaju predstavništvo u manjim zemljama kao što je Hrvatska, ili su ti uredi vrlo mali. U Hrvatskoj tako manja predstavništva imaju Cisco, HPE i Huawei, dok Juniper nema svoje predstavništvo. 
Većinu poslova za proizvođače izvršavaju partneri, kod kojih se često nalazi grupa inženjera za računalne mreže. U takvoj grupi, inženjeri su specijalizirani za pojedina područja računalnih mreža (na primjer $\mathrm{R} / \mathrm{S}$ uređaji, sigurnost, bežične mreže, i drugo). Zbog vrlo visoke cijene i kompleksnosti sustava, vrlo često krajnji korisnici (osim ISP korisnika i najvećih poduzeća) nemaju specijalizirane inženjere za računalne mreže, već se oslanjaju na tehničku podršku od strane partnera. Zbog toga se kod partnera nalazi veća koncentracija znanja što se tiče računalnih mreža. Iznimka su veći davatelji usluga (ISP) kojima je pružanje mrežnih usluga osnova njihovog posla i oni imaju vrlo visoko kvalificirano osoblje za računalne mreže.

Tijekom istraživanja proveden je:

1. intervju s odabranim svjetskim proizvođačima mrežne opreme,

2. intervju s odabranim partnerima proizvođača mrežne opreme u Hrvatskoj i

3. anketni upitnik s korisnicima (partnerima i krajnjim korisnicima) u Hrvatskoj.

\subsubsection{Odabir proizvođača mrežnih uređaja za intervju}

Danas postoji veći broj proizvođača mrežne opreme na svjetskom tržištu. Pod mrežnom opremom, kao što je već rečeno, danas se uglavnom smatraju uređaji 2. i 3. sloja OSI modela, odnosno usmjernici i preklopnici, za koje se često koristi skraćenica R/S.

Slika 6-2. prikazuje stanje 2015. godine na tržištu R/S mrežnih uređaja u svijetu koje je objavila Synergy Research Group. Cisco je najveći proizvođač usmjernika i preklopnika i ima oko 56\% udjela na tržištu, dok ostali proizvođači (Juniper, Hewlett Packard Enterprise, Huawei, Alcatel-Lucent, F5, Arista, Extreme Networks i drugi) imaju preostali udio. Po područjima primjene, Cisco ima oko 69\% udjela na tržištu usmjernika za tvrtke, oko $64 \%$ udjela na tržištu u području Ethernet preklopnika u tvrtkama i 42\% na tržištu usmjernika za davatelje usluga. 


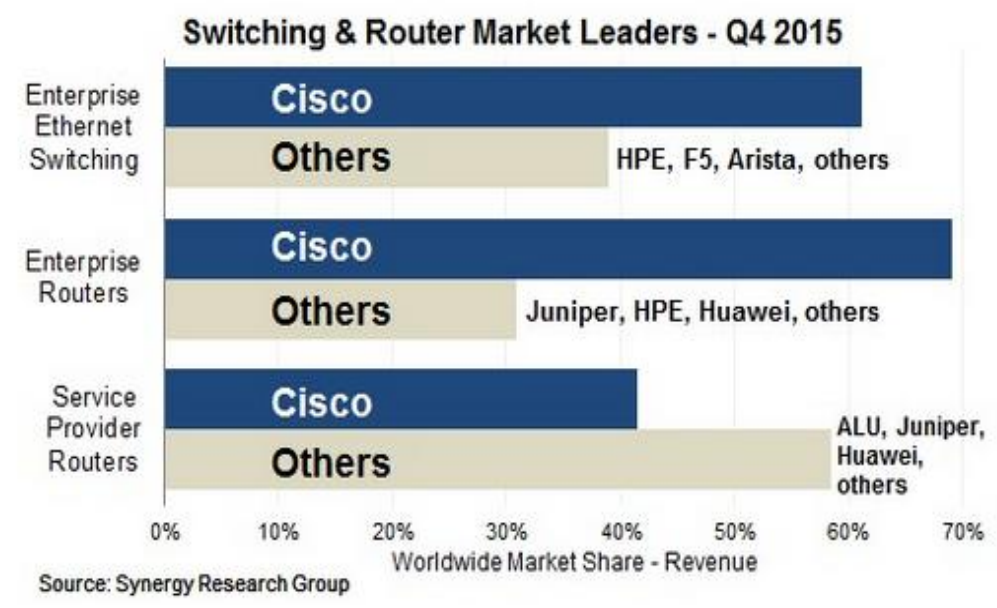

\section{Slika 6-2. Proizvođači R/S mrežnih uređaja u svijetu ${ }^{163}$}

Slika 6-3. prikazuje stanje na tržištu R/S mrežnih uređaja u Hrvatskoj na temelju istraživanja provedenog pomoću anketnog upitnika (10. pitanje) za korisnike.

Za svakog proizvođača izračunati su bodovi prisutnosti na tržištu množenjem stupnja postotka s brojem korisnika koji su odabrali taj stupanj. Tako se, na primjer, za Cisco dobije 268 $(7 * 1+14+7 * 2+12 * 3+14 * 4+31 * 5)$ i odgovarajući postotak $(268 / 541 * 100=49,54 \%)$.

\begin{tabular}{|c|c|c|c|c|c|c|c|c|c|c|c|c|c|c|}
\hline & \multicolumn{2}{|c|}{$\begin{array}{c}0 \\
0 \%\end{array}$} & \multicolumn{2}{|c|}{$\begin{array}{c}1 \\
1-20 \% \\
\end{array}$} & \multicolumn{2}{|c|}{$\begin{array}{c}2 \\
21-40 \% \\
\end{array}$} & \multicolumn{2}{|c|}{$\begin{array}{c}3 \\
41-60 \% \\
\end{array}$} & \multicolumn{2}{|c|}{$\begin{array}{c}4 \\
61-80 \% \\
\end{array}$} & \multicolumn{2}{|c|}{$\begin{array}{c}5 \\
81-100 \% \\
\end{array}$} & \multicolumn{2}{|c|}{ Ukupno } \\
\hline & $\%$ & $\mathbf{N}$ & $\%$ & $\mathbf{N}$ & $\%$ & $\mathbf{N}$ & $\%$ & $\mathbf{N}$ & $\%$ & $\mathbf{N}$ & $\%$ & $\mathbf{N}$ & $\%$ & $\mathbf{N}$ \\
\hline Arista & 86.84 & 33 & 10.53 & 4 & 0.00 & 0 & 2.63 & 1 & 0.00 & 0 & 0.00 & 0 & 100 & 38 \\
\hline Cisco Systems & 1.39 & 1 & 9.72 & 7 & 9.72 & 7 & 16.67 & 12 & 19.44 & 14 & 43.06 & 31 & 100 & 72 \\
\hline Extreme Networks & 78.05 & 32 & 7.32 & 3 & 2.44 & 1 & 4.88 & 2 & 2.44 & 1 & 4.88 & 2 & 100 & 41 \\
\hline F5 & 43.75 & 21 & 31.25 & 15 & 12.50 & 6 & 10.42 & 5 & 0.00 & 0 & 2.08 & 1 & 100 & 48 \\
\hline $\begin{array}{l}\text { Hewlett Packard } \\
\text { Enterprise }\end{array}$ & 28.00 & 14 & 34.00 & 17 & 12.00 & 6 & 14.00 & 7 & 8.00 & 4 & 4.00 & 2 & 100 & 50 \\
\hline Huawei & 48.89 & 22 & 22.22 & 10 & 6.67 & 3 & 13.33 & 6 & 4.44 & 2 & 4.44 & 2 & 100 & 45 \\
\hline Juniper Networks & 44.00 & 22 & 34.00 & 17 & 14.00 & 7 & 2.00 & 1 & 2.00 & 1 & 4.00 & 2 & 100 & 50 \\
\hline $\begin{array}{l}\text { Nokia (Alcatel- } \\
\text { Lucent) }\end{array}$ & 79.49 & 31 & 15.38 & 6 & 5.13 & 2 & 0.00 & 0 & 0.00 & 0 & 0.00 & 0 & 100 & 39 \\
\hline
\end{tabular}

Slika 6-3. Proizvođači R/S mrežnih uređaja u Hrvatskoj

${ }^{163}$ IDC, Worldwide Ethernet Switch and Router 3Q15 Market Share Update (2016), https://www.idc.com/getdoc.jsp?containerId=US40444915 (10.05.2016) 
Tablica 6-1. prikazuje izračun za sve proizvođače. U tablici se vidi da su četiri proizvođača najviše zastupljena kod korisnika u Hrvatskoj: Cisco (49,54\%), HPE (14,05\%), Huawei $(9,61 \%)$ i Juniper Networks $(8,87)$ i s njima je obavljen intervju. Oni zajedno pokrivaju $82 \%$ tržišta R/S uređaja u Hrvatskoj pa je ispunjen plan istraživanja (pokrivenost 80\% proizvođača) određen u Dr.Sc.-01 dokumentu.

Tablica 6-1. Proizvođači R/S mrežnih uređaja u Hrvatskoj

\begin{tabular}{|c|c|c|}
\hline \multirow{2}{*}{ Proizvođač } & \multicolumn{2}{|c|}{ Prisutnost na tržištu } \\
\hline & Bodovi & Postotak \\
\hline Arista & 7 & 1,29 \\
\hline Cisco Systems & 268 & 49,54 \\
\hline Extreme Networks & 25 & 4,62 \\
\hline F5 & 47 & 8,69 \\
\hline Hewlett Packard Enterprise (HPE) & 76 & 14,05 \\
\hline Huawei & 52 & 9,61 \\
\hline Juniper Networks & 48 & 8,87 \\
\hline Nokia (Alcatel-Lucent) & 18 & 3,33 \\
\hline Ukupno: & 541 & $100 \%$ \\
\hline
\end{tabular}

Razgovor (intervju) je obavljen sa specijaliziranim inženjerima koji posjeduju najvišu razinu znanja i iskustva za R/S uređaje i tehnologije u svojim kompanijama za područje Hrvatske i regiju.

Ukupno je obavljeno 5 intervjua: $2 \mathrm{~s}$ inženjerima kompanije Cisco (zbog visoke zastupljenosti na tržištu od oko 50\%), i po jedan s HPE, Juniper i Huawei inženjerima. Dva su razgovora obavljena uživo, dok su tri obavljena preko Skype veze i mobitela (dva na engleskom jeziku s 
inženjerima zaposlenima u Nizozemskoj) za koje su se koristila pitanja intervjua objavljena na web stranici https://easy-feedback.com/ ${ }^{165}$.

U intervjuu sa specijaliziranim inženjerima partnera dobiveni su sljedeći njihovi podaci:

- godine iskustva rada $\mathrm{s}$ računalnim mrežama i mrežnim uređajima (1. pitanje intervjua),

- najviši stupanj položenog certifikata iz računalnih mreža (koji je položen, a ne mora biti aktivan) (2. pitanje intervjua),

Tablica 6-2. Godine iskustva rada s računalnim mrežama (intervju proizvođači)

\begin{tabular}{|c|c|c|}
\hline & $\mathbf{N}$ & $\%$ \\
\hline 0 - 5 godina & 0 & 0,00 \\
\hline $5-10$ godina & 1 & 20,00 \\
\hline 10 - 15 godina & 0 & 0,00 \\
\hline $15-20$ godina & 1 & 20,00 \\
\hline 20 - 25 godina & 1 & 20,00 \\
\hline Više od 25 godina & 2 & 40,00 \\
\hline Ukupno ispitanika & 5 & 100,00 \\
\hline
\end{tabular}

Tablica 6-3. Najviši stupanj certifikata iz računalnih mreža (intervju proizvođači)

\begin{tabular}{c|c|c|}
\hline & N & $\%$ \\
\hline Osnovni (Associate level) & 0 & 0,00 \\
\hline Srednji (Professional level) & 2 & 40,00 \\
Najviši (Expert level) & 3 & 60,00 \\
Ukupno & 5 & 100,00 \\
\hline
\end{tabular}

\footnotetext{
${ }^{164}$ Easy-feedback: NETCONF Protocol: Interview (vendors) (2019) https://indivsurvey.com/customer/survey/ $1176497(10.06 .2019)$

${ }^{165}$ Easy-feedback: NETCONF Protocol: Interview (vendors) (2019) https://indivsurvey.com/customer/survey/ $1176497(10.06 .2019)$
} 
Tablica 6-2. prikazuje odgovore na 1. pitanje intervjua: može se vidjeti da četiri od pet ispitanika ima više od 15 godina iskustva rada s računalnim mrežama, a njih dvojica (40,00\%) čak više od 25 godina.

Tablica 6-3. prikazuje odgovore na 2. pitanje intervjua: svi ispitanici koji su sudjelovali u intervjuu imaju položen vrlo visoki stupanj certifikata iz računalnih mreža.

Veći broj ispitanika ima položen najviši (Expert level) certifikata iz računalnih mreža (3 ispitanika; 60\%) u odnosu na ispitanike (2 ispitanika, 40\%) koji imaju položen srednji (Professional level).

\subsubsection{Odabir partnera proizvođača za intervju}

Za kvalitativno istraživanje pomoću intervjua odabrani su najveći partneri proizvođača mrežne opreme u Hrvatskoj. Cilj je bio pokriti 60\% tržišta mrežnih uređaja u Hrvatskoj.

Partneri koji se bave računalnim mrežama surađuju većinom s više proizvođača.

Zbog svoje široke zastupljenosti u Hrvatskoj, kompanija Cisco surađuje i sa svim najvećim partnerima. Cisco ima određene stupnjeve suradnje s partnerima, gdje se partnerima dodjeljuje status koji se određuje na temelju:

- napravljenog financijskog rezultata,

- educiranosti partnera, odnosno broja certificiranih inženjera (CCIE, CCNP, CCNA inženjera),

- specijalnostima po određenim područjima tehnologija

- i drugim parametrima.

Ciscovi stupnjevi za partnere su sljedeći (od najnižeg do najvišeg) ${ }^{166}$ :

- Select

- Premier

- Gold

166 Cisco: Select, Premier, and Gold Certifications https://www.cisco.com/c/en/us/partners/partner-withcisco/channel-partner-program/certifications/select-premier-gold.html (16.08.2010). 
Gold partneri imaju najdublje i najšire znanje iz svih mrežnih tehnologija i mogu prodavati i implementirati rješenja u područjima sigurnosti, računalnih mreža, podatkovnih centara, kolaboracije, kao i hibridne IT usluge.

Ciscovi Gold partneri u Hrvatskoj su sljedeći (ima ih ukupno 11): Combis d.o.o, Computech d.o.o, CS Computer Systems d.o.o, IBM, KING ICT d.o.o., KODEKS d.o.o, S\&T, Sedam IT, Smart Innovation LLC, Storm Computers i Mrežne tehnologije VERSO ${ }^{167}$.

Obavljen je intervju sa sedam (od ukupno 11) Ciscovih Gold partnera u Hrvatskoj, što iznosi 64\% (planirano je 60\%).

Svi odabrani partneri podržavaju i ostale proizvođače, što se može vidjeti i na temelju odgovora na 5. pitanje intervjua s partnerima (Od kojih proizvođača dolaze $R / S$ mrežni uređaji i u kojem su postotku instalirani u mrežama Vaših korisnika?).

Tablica 6-4. prikazuje odgovore na 5. pitanje intervjua s partnerima (ukupan broj ispitanika $\mathrm{N}=7$ ).

Tablica 6-4. Primjena R/S mrežnih uređaja po proizvođačima (rezultati intervju partneri)

\begin{tabular}{|c|c|c|c|c|c|c|c|c|c|c|c|c|}
\hline & \multicolumn{2}{|c|}{$\begin{array}{c}0 \\
(0 \%) \\
\end{array}$} & \multicolumn{2}{|c|}{$\begin{array}{c}1 \\
(1-20 \%)\end{array}$} & \multicolumn{2}{|c|}{$\begin{array}{c}2 \\
(21-40 \%) \\
\end{array}$} & \multicolumn{2}{|c|}{$\begin{array}{c}3 \\
(41-60 \%) \\
\end{array}$} & \multicolumn{2}{|c|}{$\begin{array}{c}4 \\
(61-80 \%) \\
\end{array}$} & \multicolumn{2}{|c|}{$\begin{array}{c}5 \\
(81-100 \%) \\
\end{array}$} \\
\hline & $\mathrm{N}$ & $\%$ & $\mathrm{~N}$ & $\%$ & $\mathrm{~N}$ & $\%$ & $\mathrm{~N}$ & $\%$ & $\mathrm{~N}$ & $\%$ & $\mathrm{~N}$ & $\%$ \\
\hline Arista & 4 & 57,14 & 3 & 42,86 & 0 & 0,00 & 0 & 0,00 & 0 & 0,00 & 0 & 0,00 \\
\hline Cisco Systems & 0 & 0,00 & 0 & 0,00 & 0 & 0,00 & 0 & 0,00 & 1 & 14,29 & 6 & 85,71 \\
\hline $\begin{array}{l}\text { Extreme } \\
\text { Networks }\end{array}$ & 5 & 71,43 & 0 & 0,00 & 2 & 28,57 & 0 & 0,00 & 0 & 0,00 & 0 & 0,00 \\
\hline F5 & 2 & 28,57 & 1 & 14,29 & 1 & 14,29 & 2 & 28,57 & 1 & 14,29 & 0 & 0,00 \\
\hline $\begin{array}{l}\text { Hewlett } \\
\text { Packard } \\
\text { Enterprise }\end{array}$ & 1 & 14,29 & 3 & 42,86 & 2 & 28,57 & 1 & 14,29 & 0 & 0,00 & 0 & 0,00 \\
\hline Huawei & 2 & 28,57 & 4 & 57,14 & 0 & 0,00 & 1 & 14,29 & 0 & 0,00 & 0 & 0,00 \\
\hline $\begin{array}{l}\text { Juniper } \\
\text { Networks }\end{array}$ & 3 & 42,86 & 3 & 42,86 & 0 & 0,00 & 1 & 14,29 & 0 & 0,00 & 0 & 0,00 \\
\hline
\end{tabular}
167 Cisco: Find a Cisco Partner https://locatr.cloudapps.cisco.com/WWChannels/LOCATR/openBasicSearch.do
(25.01.2019) 
Za svakog proizvođača izračunati su bodovi prisutnosti R/S uređaja kod korisnika množenjem stupnja postotka s brojem partnera koji su odabrali taj stupanj.

Tablica 6-5. prikazuje izračun za sve proizvođače.

Tablica 6-5. R/S uređaji kod korisnika (ocjena njihovog partnera)

\begin{tabular}{|c|c|c|c|}
\hline \multirow{2}{*}{\multicolumn{2}{|c|}{ Proizvođač }} & \multicolumn{2}{|c|}{ Prisutnost kod korisnika } \\
\hline & & Bodovi & Postotak \\
\hline Arista & & 3 & 3,90 \\
\hline Cisco Systems & & 34 & 44,16 \\
\hline Extreme Networks & & 4 & 5,19 \\
\hline F5 & & 13 & 16,88 \\
\hline Hewlett Packard Enterprise & & 10 & 12,99 \\
\hline Huawei & & 7 & 9,09 \\
\hline Juniper Networks & & 6 & 7,79 \\
\hline & Ukupno: & 77 & $100 \%$ \\
\hline
\end{tabular}

Može se vidjeti da je odabir Ciscovih Gold partnera za intervju, osim proizvođača Cisco, pokrio i ostale proizvođače R/S uređaja koji su prisutni na tržištu u Hrvatskoj.

Razgovor (intervju) je obavljen sa specijaliziranim inženjerima (s jednim za svakog odabranog partnera) koji posjeduju najviši nivo znanja i iskustva za R/S uređaje i tehnologije u svojim kompanijama. Svi razgovori su provedeni uživo.

U intervjuima sa specijaliziranim inženjerima partnera dobiveni su sljedeći njihovi podaci:

- godine iskustva rada $s$ računalnim mrežama i mrežnim uređajima (1. pitanje intervjua),

- najviši stupanj položenog certifikata iz računalnih mreža (koji je položen, a ne mora biti aktivan) (2. pitanje intervjua). 
Tablica 6-6. Godine iskustva rada s računalnim mrežama (intervju partneri)

\begin{tabular}{|c|c|c|}
\hline & $\mathbf{N}$ & $\boldsymbol{\%}$ \\
\hline 0 - 5 godina & 0 & 0,00 \\
\hline $5-10$ godina & 3 & 42,86 \\
\hline $10-15$ godina & 2 & 28,57 \\
\hline $15-20$ godina & 1 & 14,29 \\
\hline 20 - 25 godina & 1 & 14,29 \\
\hline Više od 25 godina & 0 & 0,00 \\
\hline Ukupno ispitanika & 7 & 100,00 \\
\hline
\end{tabular}

Tablica 6-6. prikazuje odgovore na 1. pitanje intervjua: tri ispitanika $(42,86 \%)$ imaju 5 do 10 godina iskustva rada s računalnim mrežama, dva ispitanika $(28,57 \%)$ imaju 10 do 15 godina iskustva rada s računalnim mrežama, dok jedan ispitanik (14,29\%) ima 15 do 20 odnosno 20 do 25 godina iskustva rada s računalnim mrežama.

Tablica 6-7. Najviši stupanj certifikata iz računalnih mreža (intervju partneri)

\begin{tabular}{c|c|c|}
\hline & N & $\%$ \\
\hline Osnovni (Associate level) & 0 & 0,00 \\
\hline Srednji (Professional level) & 1 & 14,29 \\
Najviši (Expert level) & 6 & 85,71 \\
Ukupno & 7 & 100,00 \\
\hline
\end{tabular}

Tablica 6-7. prikazuje odgovore na 2. pitanje intervjua: svi ispitanici koji su sudjelovali u intervjuu imaju položen vrlo visoki stupanj certifikata iz računalnih mreža. Gotovo svi ispitanici (6 ispitanika, 85,71\%) imaju položen najviši (Expert level) stupanj certifikata iz računalnih mreža. Jedan ispitanik (14,29\%) ima položen srednji (Professional level) certifikat iz računalnih mreža.

Važno je napomenuti da jedini ispitanik koji trenutno nema najviši (Expert level) stupanj certifikata, ima položena dva certifikata srednjeg stupnja (CCNP R/S i CCDP) i položeni pismeni dio CCIE (Expert level) certifikata (lab test je planiran za jesen ove godine). To 
pokazuje da je i taj ispitanik izuzetno visokog znanja u području računalnih mreža. Osim toga, odabran je od strane partnera zbog njegove specijaliziranosti za područje kojim se bavi ovo ispitivanje.

Jedan od ispitanika ima položena četiri ispita najvišeg stupnja certifikata: CCIE R/S, CCIE Data Center, CCIE Security i CCIE Service Provider.

\subsubsection{Odabir korisnika za anketni upitnik}

Za popunjavanje anketnog upitnika odabrani su zaposlenici kompanija u Hrvatskoj koji imaju ili održavaju veće ili važnije računalne mreže u Hrvatskoj.

Sudionici istraživanja su izravno kontaktirani na temelju odabira:

- istraživača,

- intervjuiranih zaposlenika proizvođača ili

- intervjuiranih zaposlenika partnera u Hrvatskoj.

Osnovni kriteriji odabira ispitanika su sljedeći:

1. korisnici mrežne opreme koji rade sa R/S uređajima i poznaju tehnologiju računalnih mreža i

2. korisnici koji rade u Hrvatskoj s računalnim mrežama i R/S opremom koja zahtijeva veću raspoloživost (raspoloživost $\geq 99.9 \%$, odnosno vrijeme zastoja godišnje $\leq 8.76$ sati).

Iz popunjavanja upitnika isključeni su inženjeri koji su već sudjelovali u intervjuima kao zaposlenici partnera u Hrvatskoj. Razlog njihovog isključivanja za istraživanje pomoću upitnika je sljedeći: oni su odabrani za intervju kao specijalizirane osobe u području R/S uređaja i ne predstavljaju ,prosječnog“ korisnika jer je razina njihovog znanja puno viša.

Anketni upitnik kreiran je i objavljen na web stranici https://easy-feedback.com/ ${ }^{168}$.

\footnotetext{
${ }^{168}$ NETCONF upitnik https://indivsurvey.com/customer/survey/1175461 (10.06.2019)
} 
Anketni upitnik bio je aktivan u periodu od 23. lipnja do 31.srpnja 2019. godine. Do 1. srpnja anketni upitnik je popunjavan u testnoj fazi od odabranih 7 ispitanika, a nakon toga su informirani i ostali sudionici ispitivanja.

Ukupno je popunjavano 89 anketnih upitnika, od kojih za istraživanje nisu uzeti u obzir:

- upitnici nepotpuno popunjeni ili

- upitnici popunjeni od osoba koji se trenutno direktno ne bave računalnim mrežama (6. pitanje anketnog upitnika) ili

- upitnici popunjeni od osoba koji rade na mrežama niže raspoloživosti (raspoloživost manja od 99,9\%) (9. pitanje anketnog upitnika).

Preostali broj od 73 potpuno odgovorenih upitnika se koristi kao temelj za analiziranje rezultata. Od tih 73 upitnika korisnika, njih 20 su partneri, a 53 su krajnji korisnici (planirano minimalno 50 u Dr.Sc.-01 dokumentu).

\subsubsection{Provedba istraživanja pomoću intervjua i anketnog upitnika}

Intervjui s proizvođačima i partnerima su započeli 17. travnja 2019. godine i većina razgovora je obavljena prije aktiviranja anketnog upitnika za korisnike (23.lipnja). $\mathrm{Na}$ temelju teoretskog istraživanja i dobivenih odgovora proizvođača i partnera kreirana su pitanja za anketni upitnik.

Potrebno je naglasiti da su se tijekom provedbe istraživanja pojavili sljedeći izazovi:

- pronalazak odgovarajućeg ispitanika kod proizvođača i partnera koji ima najviši stupanj znanja u traženom području;

- nedostupnost za intervju ispitanika kod partnera zbog njihovih radnih obaveza i projekata;

- izrazita nedostupnost ispitanika kod proizvođača zbog njihovih radnih obaveza i putovanja, a osim toga neki proizvođači nemaju ured u Hrvatskoj (pa je razgovor obavljen pomoću Skype aplikacije); 
- zaposlenici nekih kompanija nisu mogli sudjelovati u ispitivanju zbog internih pravila zaštite podataka o računalnoj mreži i složene procedure dobivanja odgovarajuće dozvole (na primjer banke i MUP);

- nedostupnost nekih zaposlenika za sudjelovanje u anketnom upitniku zbog preopterećenosti i rada na većim projektima.

Prikupljanju dovoljnog broja ispitanika pripomogao je dugogodišnji rad (skoro 25 godina) ispitivača $u$ području računalnih mreža i poznanstva koja je u tom periodu stekao (i u Hrvatskoj i u inozemstvu). Skoro svi kontaktirani ispitanici vrlo su se rado odazvali pozivu za sudjelovanje i smatrali su temu istraživanja vrlo zanimljivom.

\subsubsection{Zaključak}

Tablica 6-8. prikazuje ukratko pregled odabira ispitanika za istraživanje.

Može se vidjeti da su ispunjeni svi zahtjevi za uzorak ispitanika postavljeni u Prijavi teme doktorskog rada (Dr.Sc-01).

Što se tiče tablice, potrebno je objasniti i certificiranost ispitanika:

- najvišu certificiranost imaju partneri proizvođača (6 ispitanika od 7 ima najvišu certificiranost). Uzrok tome je što proizvođači uvjetuju svojim partnerima da moraju imati određeni broj zaposlenika s najvišim certifikatom: tako na primjer za Ciscov Gold status njihov partner mora imati 5 zaposlenika s najvišim CCIE certifikatom. U isto vrijeme, za svoje specijaliste proizvođači ne uvjetuju posjedovanje tog certifikata, već vrlo često traže veće iskustvo rada s računalnim mrežama (čak 40\% ispitanika kod proizvođača ima više od 25 godina iskustva rada s računalnim mrežama) i kvalitetno obavljanje svoga posla.

- Certificiranost korisnika pokazuje da su u ispitivanju sudjelovali „prosječni“ korisnici:

○ neki od njih (ukupno 5) imaju najviši certifikat (i većina njih radi u ISP kompanijama ili kod partnera),

○ nešto veći broj (ukupno 14) nema certifikata (jer rade uglavnom na poslovima sistemskog administratora kod krajnjih korisnika gdje im certifikat nije toliko potreban), 
○ dok većina ispitanika ima osnovni (26) ili certifikat srednjeg nivoa (27).

Tablica 6-8. Odabir ispitanika za istraživanje

\begin{tabular}{|c|c|c|c|}
\hline $\begin{array}{l}\text { Metoda istraživanja } \\
\text { /vrsta podataka }\end{array}$ & Intervju proizvođači & Intervju partneri & Upitnik korisnici \\
\hline $\begin{array}{l}\text { Kompanija } \\
\text { ispitanika: }\end{array}$ & $\begin{array}{l}\text { Najveći svjetski proizvođači } \\
\text { R/S uređaja. }\end{array}$ & $\begin{array}{l}\text { Najveći partneri } \\
\text { proizvođača R/S uređaja u } \\
\text { Hrvatskoj. }\end{array}$ & $\begin{array}{l}\text { Kompanije u } \\
\text { Hrvatskoj koje imaju } \\
\text { ili održavaju veće i } \\
\text { važnije računalne } \\
\text { mreže. }\end{array}$ \\
\hline $\begin{array}{l}\text { Uvjet koje odabrane } \\
\text { kompanije moraju } \\
\text { zadovoljiti } \\
\text { (tražena vrijednost u } \\
\text { Dr.Sc.-01): }\end{array}$ & $\begin{array}{l}\text { Pokrivenost R/S tržišta: } \\
\text { min } \mathbf{8 0 \%}\end{array}$ & $\begin{array}{l}\text { Pokrivenost R/S tržišta: } \\
\text { min } 60 \%\end{array}$ & $\begin{array}{l}\text { Min } 50 \text { krajnjih } \\
\text { korisnika koji imaju } \\
\text { raspoloživost } \geq \\
\mathbf{9 9 , 9 \%} \text { (vrijeme } \\
\text { zastoja godišnje } \leq 8,76 \\
\text { sati). }\end{array}$ \\
\hline $\begin{array}{l}\text { Uvjet koje odabrane } \\
\text { kompanije moraju } \\
\text { zadovoljiti } \\
\text { (ispunjena } \\
\text { vrijednost): }\end{array}$ & $\begin{array}{l}\text { Pokrivenost R/S tržišta: } \\
\mathbf{8 2 \%}\end{array}$ & $\begin{array}{l}\text { Pokrivenost R/S tržišta: } \\
\mathbf{6 4 \%}\end{array}$ & 53 krajnjih korisnika \\
\hline $\begin{array}{l}\text { Opis odabranih } \\
\text { kompanija: }\end{array}$ & $\begin{array}{l}\text { Četiri svjetska proizvođača } \\
\text { najveće zastupljenosti u } \\
\text { Hrvatskoj }\end{array}$ & $\begin{array}{l}\text { Sedam od } 11 \text { najvećih } \\
\text { partnera u Hrvatskoj }\end{array}$ & $\begin{array}{l}73 \text { kompanije od kojih } \\
\text { su } 20 \text { partneri (sistem } \\
\text { integratori) i } 53 \\
\text { krajnjih korisnika. }\end{array}$ \\
\hline $\begin{array}{l}\text { Broj dobivenih } \\
\text { intervjua/upitnika: }\end{array}$ & 5 & 7 & 73 \\
\hline $\begin{array}{l}\text { Uvjet koji ispitanici } \\
\text { ispunjavaju: }\end{array}$ & $\begin{array}{l}\text { Specijalizirani inženjeri koji } \\
\text { posjeduju najviši nivo znanja } \\
\text { i iskustva za R/S uređaje i } \\
\text { tehnologije u svojim } \\
\text { kompanijama za područje } \\
\text { Hrvatske i regiju. }\end{array}$ & $\begin{array}{l}\text { Specijalizirani inženjeri } \\
\text { koji posjeduju najviši nivo } \\
\text { znanja i iskustva za R/S } \\
\text { uređaje i tehnologije u } \\
\text { svojim kompanijama. }\end{array}$ & $\begin{array}{l}\text { Rad na tehničkim } \\
\text { poslovima vezanim uz } \\
\text { računalne mreže. }\end{array}$ \\
\hline $\begin{array}{l}\text { Znanje } \\
\text { (certificiranost) } \\
\text { ispitanika iz područja } \\
\text { računalnih mreža: }\end{array}$ & $\begin{array}{l}3 \text { najvišeg (CCIE) nivoa, } 2 \\
\text { srednjeg (CCNP) nivoa. }\end{array}$ & $\begin{array}{l}6 \text { najvišeg (CCIE) nivoa, } 1 \\
\text { srednjeg (CCNP) nivoa. }\end{array}$ & $\begin{array}{l}5 \text { najvišeg }(\mathrm{CCIE}) \\
\text { nivoa, } 27 \text { srednjeg } \\
(\mathrm{CCNP}) \text { nivoa, } 26 \\
\text { osnovnog (CCNA) } \\
\text { nivoa, } 14 \text { bez } \\
\text { položenih certifikata. }\end{array}$ \\
\hline
\end{tabular}




\subsection{Dobiveni podaci od ispitanika (intervju s proizvođačima)}

U ovom poglavlju su prikazani odgovori dobiveni tijekom intervjua s R/S specijaliziranim inženjerima koji su zaposleni kod odabranih svjetskih proizvođača R/S mrežnih uređaja.

Odgovori su podijeljeni po područjima:

- primjena NETCONF standarda kod proizvođača R/S uređaja (pitanja 3., 5., 6., 7. i 9.) koja je povezana uz područje ispitivanja hipoteze $\mathrm{H} 2$.

- Primjena NETCONF standarda od strane korisnika u Hrvatskoj (koja je povezana uz područje ispitivanja hipoteze $\mathrm{H} 3$ ) nije razmatrana.

- Poznavanje NETCONF standarda od strane korisnika u Hrvatskoj (koje je povezano uz područje ispitivanja hipoteze $\mathrm{H} 4$ ) nije razmatrano.

- NETCONF i povećanje raspoloživosti R/S uređaja (pitanja 4. i 16.) koje je povezano uz područje ispitivanja hipoteze $\mathrm{H} 1$.

- Karakteristike i povećanje primjene NETCONF standarda (pitanja 8., 10., 11., 12., 13., 14., 15. i 17.) koje pokriva ostala pitanja vezana uz NETCONF standard i povećanje raspoloživosti $\mathrm{R} / \mathrm{S}$ uređaja.

\subsubsection{Metoda obrade podataka}

U ovom poglavlju se upotrebom metoda tabelarnog prikazivanja prezentira struktura odgovora na pitanja intervjua od strane ispitanika (zaposlenika proizvođača), dok se upotrebom metoda deskriptivne statistike prezentiraju srednje vrijednosti (aritmetička sredina, medijan i mod) kao i disperzija oko srednjih vrijednosti (standardna devijacija kao prosječno odstupanje od aritmetičke sredine, te interkvartilni raspon (IQR) kao pokazatelj disperzije oko srednje vrijednosti medijana). Testiranje razlika u odnosu na teorijsku vrijednost provodi se upotrebom Wilcoxonovog testa za jedan nezavisan uzorak. Opravdanost upotrebe Wilcoxonovog testa proizlazi iz malih veličina uzorka, te ranga obilježja brojčanih vrijednosti čime nisu zadovoljeni uvjeti za provođenje parametrijskih inačica testa. 
Analiza je rađena u statističkom softveru SPSS 25 te se zaključci donose pri graničnoj signifikantnosti od $5 \%$.

\subsubsection{Primjena NETCONF standarda kod proizvođača $R / S$ uređaja}

U ovom poglavlju se razmatra primjena NETCONF standarda od strane proizvođača na svojim R/S uređajima.

Treće pitanje intervjua glasi: „Implementira li Vaša kompanija NETCONF standard definiran u RFC?“.

Tablica 6-9. Implementacija NETCONF standarda (intervju proizvođači)

\begin{tabular}{c|c|c}
\hline & $\mathbf{N}$ & $\%$ \\
\hline $\mathrm{Ne}$ & 0 & 0,00 \\
$\mathrm{Da}$ & 5 & 100,00 \\
\hline
\end{tabular}

Tablica 6-9. prikazuje odgovore na 3. pitanje intervjua: svi proizvođači implementiraju NETCONF protokol definiran u RFC standardu.

Dodatna zapažanja ispitanika na ovo pitanje su sljedeća:

- $\quad$ ispitanik navodi da njegova kompanija (HPE) ima dvije vrste proizvoda:

- Aruba Networks koja koristi REST API,

○ HPE FlexNetwork (H3C) koja koristi NETCONF ili REST API.

Peto pitanje intervjua glasi: „U kojim vrstama mreža je NETCONF implementiran na R/S uređajima i u kojem postotku od strane Vaše kompanije?“. Ispitanici su iskazivali mišljenje vrijednostima razreda od 0 do 5 , gdje je 0 označavalo $0 \%$, dok je 5 označavalo $100 \%$.

Testiranje se provodi Wilcoxonovim testom za jedan nezavisan uzorak gdje će se utvrditi postojanje visoke razine upotrebe samo ako je srednja vrijednost (medijan) veća od 3,00 (41\%-60\%) uz empirijsku p vrijednost manju od 0,05. U slučaju da je empirijska p vrijednost veća od 0,05 riječ je o srednjoj razini primjene (41\%-60\%), dok u slučaju da je srednja 
vrijednost (medijan) manja od 3 (41-60\%) te se utvrdi empirijska p vrijednost manja od 0,05, postoji niska razina upotrebe.

Tablica 6-10. prikazuje rezultate dobivene pomoću deskriptivne statistike na temelju odgovora na 5. pitanje intervjua s proizvođačima. Podaci u tablici su uređeni od najveće do najmanje prosječne vrijednosti.

Tablica 6-10. Implementacija NETCONF standarda na $R / S$ uređajima po vrstama mreža (intervju proizvođači)

\begin{tabular}{lcccccccc}
\hline & $\mathrm{N}$ & Prosjek & Std.Dev. & Mode & Medijan & IQR & Z & $\mathrm{P}^{*}$ \\
\hline $\begin{array}{l}\text { Mreže davatelja usluga } \\
\text { (Internet Servise Provider }-\end{array}$ & 4 & 4,75 & 0,50 & 5,00 & 5,00 & $\begin{array}{c}(4,50- \\
5,00)\end{array}$ & 1,89 & 0,059 \\
\begin{tabular}{l} 
ISP)* \\
\hline $\begin{array}{l}\text { Mreže podatkovnih centara } \\
\text { (Data Center - DC) }\end{array}$
\end{tabular} & 5 & 4,60 & 0,89 & 5,00 & 5,00 & $\begin{array}{c}(5,00- \\
5,00)\end{array}$ & 2,00 & 0,046 \\
\hline $\begin{array}{l}\text { WAN mreže većih poduzeća } \\
\text { (Enterprise Networks) }\end{array}$ & 5 & 4,20 & 1,30 & 5,00 & 5,00 & $\begin{array}{c}(4,00- \\
5,00)\end{array}$ & 1,66 & 0,098 \\
\hline $\begin{array}{l}\text { LAN mreže malih i srednjih } \\
\text { poduzeća (Small Medium } \\
\text { Business - SMB) }\end{array}$ & 4 & 3,50 & 2,38 & 5,00 & 4,50 & $\begin{array}{c}(2,00- \\
5,00)\end{array}$ & 0,37 & 0,713 \\
\hline $\begin{array}{l}\text { LAN mreže većih poduzeća } \\
\text { (Enterprise Networks) }\end{array}$ & 5 & 3,20 & 2,05 & Multiple & 4,00 & $\begin{array}{c}(1,00- \\
5,00)\end{array}$ & 0,14 & 0,888 \\
\hline $\begin{array}{l}\text { Mreže internet stvari (IoT) } \\
\text { Ukupno }\end{array}$ & 4 & 2,25 & 2,06 & 4,00 & 2,50 & $\begin{array}{c}(0,50- \\
4,00)\end{array}$ & 0,74 & 0,461 \\
\hline
\end{tabular}

* Wilcoxonov test za jedan nezavisan uzorak

Iz tablice se može vidjeti da proizvođači najviše implementiraju NETCONF za R/S uređaje koji se primjenjuju u mrežama (svi imaju prosječnu vrijednost veću od 4):

- mrežama davatelja usluga (ISP) (prosječna vrijednost odgovora 4,75 (95\%); std.dev. $0,50)$.

- mrežama podatkovnih centara (prosječna vrijednost odgovora 4,60 (92\%); std.dev. $0,89)$.

- WAN mrežama većih poduzeća $(4,20$ (84\%), std.dev. 1,30$)$.

dok manje u SMB mrežama $(3,50,70 \%)$ i LAN mrežama manjih poduzeća $(3,20,64 \%)$.

Ispitanici pak najmanje koriste NETCONF na R/S mrežnim uređajima u mrežama Internet stvari (IoT) (prosječna vrijednost odgovora 2,25 (45\%); std.dev.2,06). 
Ukupna razina implementiranja NETCONF standarda na R/S uređajima od strane kompanija bilježila je visoku prosječnu vrijednost 3,75 (75\%) s prosječnim odstupanjem od aritmetičke sredine 1,50 . Testiranjem nije utvrđena visoka razina implementiranja $(Z=0,94 ; p=0,345)$.

Tijekom intervjua s proizvođačima dobivene su informacije o niskoj zastupljenosti NETCONF standarda na uređajima u IoT mrežama i u području Zelenog umrežavanja (engl. green networking).

Dodatna zapažanja ispitanika na ovo pitanje su sljedeća:

- ispitanik (Juniper) ističe:

○ da je NETCONF dio JUNOS operacijskog sustava i zbog toga je implementiran na sve R/S proizvode,

○ da se NETCONF koristi najviše zbog primjene automatizacije i

○ da Juniper trenutno nema IoT proizvode.

- Ispitanik (Huawei) navodi da je implementacija određene funkcije (capability) ovisna o tehnologiji tj. uređaju, odnosno da nisu iste funkcije implementirane na svim uređajima. Jedan od razloga su različiti razvojni timovi za različite uređaje.

- Ispitanik (Cisco) ističe da se kao sistemski inženjer bavi ISP korisnicima i njihovim mrežama. Njegovi kolege pokrivaju Enterprise korisnike.

Šesto pitanje intervjua glasi: „Koji su glavni razlozi implementacije NETCONF standarda na R/S mrežnim uređajima Vaše kompanije?“. Ispitanici su iskazivali mišljenje vrijednostima razreda od 1 do 5 , gdje je 1 označavalo nevažno, dok je 5 označavalo izuzetno važno.

Testiranje se provodi Wilcoxonovim testom za jedan nezavisan uzorak gdje će se utvrditi postojanje važnosti samo ako je srednja vrijednost (medijan) veća od 2,00 uz empirijsku p vrijednost manju od 0,05. U slučaju da je empirijska $p$ vrijednost veća od 0,05 riječ je o indiferentnom stavu, dok u slučaju da je srednja vrijednost (medijan) manja od 2 te se utvrdi empirijska $\mathrm{p}$ vrijednost manja od 0,05 , postoji nevažnost s ponuđenim tvrdnjama.

Tablica 6-11. prikazuje rezultate dobivene pomoću deskriptivne statistike na temelju odgovora na 6. pitanje intervjua s proizvođačima. Podaci u tablici su uređeni od najveće do najmanje prosječne vrijednosti. 
Tablica 6-11. Razlozi implementacije NETCONF standarda na R/S uređajima (intervju proizvođači)

\begin{tabular}{|c|c|c|c|c|c|c|c|c|}
\hline & $\mathrm{N}$ & Prosjek & Std.Dev. & Mode & Median & IQR & $\mathrm{Z}$ & $\mathrm{P}^{*}$ \\
\hline $\begin{array}{l}\text { Mogućnost parcijalnog } \\
\text { konfiguriranja uređaja pomoću } \\
\text { NETCONF standarda. }\end{array}$ & 5 & 5,00 & 0,00 & 5,00 & 5,00 & $\begin{array}{l}(5,00- \\
5,00)\end{array}$ & 2,24 & 0,025 \\
\hline $\begin{array}{l}\text { Mogućnost provjere } \\
\text { konfiguracije prije primjene } \\
\text { kod NETCONF načina } \\
\text { konfiguriranja uređaja. }\end{array}$ & 5 & 5,00 & 0,00 & 5,00 & 5,00 & $\begin{array}{l}(5,00- \\
5,00)\end{array}$ & 2,24 & 0,025 \\
\hline $\begin{array}{l}\text { NETCONF kao standardni } \\
\text { način konfiguracije preko } \\
\text { udaljenog pristupa na IP adresu } \\
\text { uređaja zato jer je za sve } \\
\text { proizvođače ista struktura } \\
\text { komandi i podataka. }\end{array}$ & 5 & 4,80 & 0,45 & 5,00 & 5,00 & $\begin{array}{l}(5,00- \\
5,00)\end{array}$ & 2,21 & 0,034 \\
\hline $\begin{array}{l}\text { NETCONF kao standard koji } \\
\text { omogućava programabilnost } \\
\text { (automatiziranje) koja značajno } \\
\text { smanjuje učestalost ljudske } \\
\text { pogreške. }\end{array}$ & 5 & 4,80 & 0,45 & 5,00 & 5,00 & $\begin{array}{l}(5,00- \\
5,00)\end{array}$ & 2,21 & 0,034 \\
\hline $\begin{array}{l}\text { NETCONF standard koristi } \\
\text { jasnu razliku u strukturi između } \\
\text { konfiguracijskih i operacijskih } \\
\text { podataka. }\end{array}$ & 5 & 4,80 & 0,45 & 5,00 & 5,00 & $\begin{array}{l}(5,00- \\
5,00)\end{array}$ & 2,21 & 0,034 \\
\hline $\begin{array}{l}\text { „Backup \& restore“ mogućnost } \\
\text { koju nudi NETCONF standard. }\end{array}$ & 5 & 4,80 & 0,45 & 5,00 & 5,00 & $\begin{array}{l}(5,00- \\
5,00)\end{array}$ & 2,21 & 0,034 \\
\hline $\begin{array}{l}\text { Mogućnost istovremenog i } \\
\text { koordiniranog konfiguriranja } \\
\text { svih ili više uređaja u mreži. }\end{array}$ & 5 & 4,80 & 0,45 & 5,00 & 5,00 & $\begin{array}{l}(5,00- \\
5,00)\end{array}$ & 2,21 & 0,034 \\
\hline $\begin{array}{l}\text { Mogućnost zaključavanja } \\
\text { konfiguracijske datoteke koje } \\
\text { nudi NETCONF. }\end{array}$ & 5 & 4,60 & 0,89 & 5,00 & 5,00 & $\begin{array}{l}(5,00- \\
5,00)\end{array}$ & 2,21 & 0,034 \\
\hline
\end{tabular}

* Wilcoxonov test za jedan nezavisan uzorak

Najvažniji razlozi za implementaciju NETCONF standarda na R/S uređajima proizvođača su (prosječna vrijednost odgovora 5,00; std.dev.0,00):

- mogućnost parcijalnog konfiguriranja uređaja pomoću NETCONF standarda te

- mogućnost istovremenog i koordiniranog konfiguriranja svih ili više uređaja u mreži.

Sva navedena svojstva su dobila izuzetno visoke vrijednosti važnosti. Najnižu vrijednost važnosti je dobila Mogućnost zaključavanja konfiguracijske datoteke (prosječna vrijednost odgovora 4,60; std.dev.0,89):.

Dodatna zapažanja ispitanika na ovo pitanje su sljedeća: 
- $\quad$ ispitanik (Cisco) navodi:

○ RESTCONF nema lock funkcije,

- IOS XR usmjernici podržavaju rollback funkciju (što znači da su neki CLI preuzeli određene funkcije iz NETCONF-a),

- NETCONF je transaction-based protokol (što mu je velika prednost u odnosu na CLI).

- Ispitanik (Juniper) navodi:

- Juniper JUNOS ima već sve NETCONF mogućnosti implementirane u svoj CLI, kao što su candidate, locking, backup/restore i druge (važno je napomenuti da je NETCONF nastao na osnovama JUNOS operacijskog sustava $\left.^{169}\right)$.

- NETCONF donosi homogenu implementaciju i koristi se za API automatizaciju kod različitih proizvođača.

Sedmo pitanje intervjua glasi: „Koji su glavni razlozi neimplementacije NETCONF standarda na R/S mrežnim uređajima Vaše kompanije?“. Ispitanici su iskazivali mišljenje vrijednostima razreda od 1 do 5 , gdje je 1 označavalo nevažno, dok je 5 označavalo izuzetno važno.

Testiranje se provodi Wilcoxonovim testom za jedan nezavisan uzorak gdje će se utvrditi postojanje važnosti samo ako je srednja vrijednost (medijan) veća od 2,00 uz empirijsku p vrijednost manju od 0,05. U slučaju da je empirijska $p$ vrijednost veća od 0,05 riječ je o indiferentnom stavu, dok u slučaju da je srednja vrijednost (medijan) manja od 2 te se utvrdi empirijska $\mathrm{p}$ vrijednost manja od 0,05 , postoji nevažnost s ponuđenim tvrdnjama.

Tablica 6-12. prikazuje rezultate dobivene pomoću deskriptivne statistike na temelju odgovora na 7. pitanje intervjua s proizvođačima.

169 Tail-f Systems: NETCONF and YANG Tutorial part 1a: NETCONF and YANG Overview (2014) https://www.youtube.com/watch?v=Vr4kB1_6fLQ (10.1.2016.) 
Tablica 6-12. Razlozi neimplementacije NETCONF standarda na R/S uređajima (intervju proizvođači)

\begin{tabular}{|c|c|c|c|c|c|c|c|c|}
\hline & $\mathrm{N}$ & Prosjek & Std.Dev. & Mode & Medijan & IQR & $\mathrm{Z}$ & $\mathrm{P}^{*}$ \\
\hline $\begin{array}{l}\text { 1. Naš CLI je jednostavniji od } \\
\text { NETCONF standarda }\end{array}$ & 5 & 1,80 & 1,30 & 1,00 & 1,00 & $\begin{array}{l}(1,00- \\
2,00)\end{array}$ & 0,38 & 0,725 \\
\hline $\begin{array}{l}\text { 2. NETCONF nije potreban jer } \\
\text { su naši korisnici navikli na naš } \\
\text { OS i CLI }\end{array}$ & 5 & 2,80 & 1,64 & 2,00 & 2,00 & $\begin{array}{l}(2,00- \\
4,00)\end{array}$ & 1,07 & 0,285 \\
\hline $\begin{array}{l}\text { 3. NETCONF koristi XML } \\
\text { sintaksu koja je redundantna i } \\
\text { opširna što može zamarati i } \\
\text { zbunjivati korisnika. }\end{array}$ & 5 & 2,20 & 1,30 & 1,00 & 2,00 & $\begin{array}{l}(1,00- \\
3,00)\end{array}$ & 0,38 & 0,705 \\
\hline $\begin{array}{l}\text { 4. NETCONF ne daje dovoljno } \\
\text { prednosti da bi se } \\
\text { implementirao }\end{array}$ & 5 & 1,60 & 1,34 & 1,00 & 1,00 & $\begin{array}{c}(1,00- \\
1,00)\end{array}$ & 0,71 & 0,480 \\
\hline $\begin{array}{l}\text { 5. NETCONF nije prihvaćen od } \\
\text { korisnika i rijetko se koristi }\end{array}$ & 5 & 3,20 & 1,48 & 3,00 & 3,00 & $\begin{array}{c}(3,00- \\
4,00) \\
\end{array}$ & 1,51 & 0,131 \\
\hline $\begin{array}{l}\text { 6. Koristimo RESTCONF koji } \\
\text { je bolje standardno rješenje od } \\
\text { NETCONF-a }\end{array}$ & 5 & 1,40 & 0,55 & 1,00 & 1,00 & $\begin{array}{l}(1,00- \\
2,00)\end{array}$ & 1,73 & 0,083 \\
\hline
\end{tabular}

* Wilcoxonov test za jedan nezavisan uzorak

Glavni razlog za neimplementaciju NETCONF standarda na R/S uređajima je neprihvaćenost NETCONF standarda od korisnika (prosječna vrijednost odgovora 3,20; std.dev.1,48), dok je najmanje važan razlog korištenje RESTCONF kao boljeg standardnog rješenja (prosječna vrijednost odgovora 1,40; std.dev.0,55).

Dodatna zapažanja ispitanika na ovo pitanje i potpitanja su sljedeća:

- ispitanik (Cisco) smatra sljedeće:

○ težnja kompanije je implementacija NETCONF-a na svim uređajima,

- Ciscova implementacija protokola je sljedeća: RESTCONF više na Northbound API, NETCONF više na Southbound API;

○ većina korisnika je naviknuta na CLI.

- Ispitanik (HPE) navodi da se odgovori korisnika razlikuju: neki korisnici smatraju uporabu programabilnih alata (kao NETCONF) izuzetno važnim, pogotovo u situacijama gdje postoji puno promjena konfiguracije u mreži. U statičkim mrežnim okruženjima nema zahtjeva za NETCONF protokolom. Zbog toga, manje interesa za NETCONF protokolom ima kod Enterprise korisnika koji koriste tradicionalan 
FCAPS softver za upravljanje mrežama. Ispitanik u praksi vidi primjenu NETCONF protokola kod ISP korisnika.

- Ispitanik (Juniper) navodi:

○ JUNOS ima ugrađenu podršku za NETCONF u sam operacijski sustav i zbog toga je NETCONF podržan na svim Juniper R/S proizvodima. JUNOS podržava i RESTCONF s ciljem ponude alternativnog rješenja.

- NETCONF se uobičajeno ne koristi za manualnu CLI implementaciju. CLI je korisniku jednostavniji za uporabu (engl. user friendly), a NETCONF se koristi kao infrastruktura za izgradnju svojih API rješenja kao što su PYez, Jsnapy, Ansible, Saltstacks i dr.

Na deveto pitanje ispitanici su iskazivali slaganje s tvrdnjama koje se odnose na raspoloživu dokumentaciju i edukaciju (o primjeni i korištenju NETCONF standarda) od strane njihove kompanije. Ispitanici su iskazivali mišljenje ocjenama od 1 do 5 , gdje je 1 označavala neslaganje s tvrdnjom, a 5 potpuno slaganje s tvrdnjom.

Testiranje se provodi Wilcoxonovim testom za jedan nezavisan uzorak gdje će se utvrditi postojanje slaganja samo ako je srednja vrijednost (medijan) veća od 2,00 uz empirijsku p vrijednost manju od 0,05 . U slučaju da je empirijska $p$ vrijednost veća od 0,05 riječ je o indiferentnom stavu, dok u slučaju da je srednja vrijednost (medijan) manja od 2 te se utvrdi empirijska p vrijednost manja od 0,05 postoji neslaganje s ponuđenim tvrdnjama.

Tablica 6-13. prikazuje rezultate dobivene pomoću deskriptivne statistike na temelju odgovora na 9. pitanje intervjua s proizvođačima.

Ispitanici (zaposlenici proizvođača) se najviše slažu s tvrdnjama:

- da postoji detaljna dokumentacija koja objašnjava rad i primjenu NETCONF standarda (prosječna vrijednost odgovora 4,80; std.dev.0,45) i

- da postoje tečajevi proizvođača za samostalno učenje (prosječna vrijednost odgovora 4,60; std.dev.0,89),

dok se najmanje slažu s tvrdnjom da postoje certifikacijski ispiti (prosječna vrijednost odgovora 4,20; std.dev. 1,75). 
Tablica 6-13. Raspoloživa dokumentacija i edukacija o NETCONF standardu (intervju proizvođači)

\begin{tabular}{|c|c|c|c|c|c|c|c|c|}
\hline & $\mathrm{N}$ & Prosjek & Std.Dev. & Mode & Medijan & IQR & $\mathrm{Z}$ & $\mathrm{P}^{*}$ \\
\hline $\begin{array}{l}\text { Postoji detaljna dokumentacija koja } \\
\text { objašnjava rad i primjenu NETCONF } \\
\text { standarda na mrežnim uređajima } \\
\text { Vašeg proizvođača: upute (manuals), } \\
\text { preporuke za uporabu (white papers), } \\
\text { i slično. }\end{array}$ & 5 & 4,80 & 0,45 & 5,00 & 5,00 & $\begin{array}{c}(5,00- \\
5,00)\end{array}$ & 2,12 & 0,034 \\
\hline $\begin{array}{l}\text { Postoje tečajevi za samostalno učenje } \\
\text { (CBT, Webinar, i slično) koji u } \\
\text { potpunosti podučavaju korisnike } \\
\text { uporabi i primjeni NETCONF } \\
\text { standarda na mrežnim uređajima } \\
\text { Vašeg proizvođača. }\end{array}$ & 5 & 4,60 & 0,89 & 5,00 & 5,00 & $\begin{array}{c}(5,00- \\
5,00)\end{array}$ & 2,12 & 0,034 \\
\hline $\begin{array}{l}\text { Postoje organizirani tečajevi vođeni } \\
\text { od instruktora koji detaljno } \\
\text { podučavaju korisnike uporabi i } \\
\text { primjeni NETCONF standarda na } \\
\text { mrežnim uređajima Vašeg } \\
\text { proizvođača. }\end{array}$ & 5 & 4,40 & 1,34 & 5,00 & 5,00 & $\begin{array}{c}(5,00- \\
5,00)\end{array}$ & 2,00 & 0,046 \\
\hline $\begin{array}{l}\text { Postoje certifikacijski ispiti (i } \\
\text { pripadajući tečajevi) koji detaljno } \\
\text { osposobljavaju korisnike uporabi i } \\
\text { primjeni NETCONF standarda na } \\
\text { mrežnim uređajima Vašeg } \\
\text { proizvođača. }\end{array}$ & 5 & 4,20 & 1,79 & 5,00 & 5,00 & $\begin{array}{c}(5,00- \\
5,00)\end{array}$ & 1,84 & 0,066 \\
\hline Ukupno & 5 & 4,50 & 1,12 & 5,00 & 5,00 & $\begin{array}{c}(3,75- \\
5,00) \\
\end{array}$ & 2,12 & 0,034 \\
\hline
\end{tabular}

* Wilcoxonov test za jedan nezavisan uzorak

Ukupna razina raspoloživosti dokumentacije i edukacija o primjeni i korištenju NETCONF standarda od strane proizvođača opreme bilježila je prosječnu vrijednost $4,50 \mathrm{~s}$ prosječnim odstupanjem od aritmetičke sredine 1,12. Testiranjem je utvrđeno postojanje visoke razine važnosti $(Z=2,12 ; p=0,0334)$.

Dodatna zapažanja ispitanika uz ovo pitanje su sljedeća:

- ispitanik (Cisco) navodi da Cisco pruža detaljne informacije (svoje Config Guide) i na Github (Opensource) (komentar istraživača: Cisco stavlja svoje materijale na Opensource web stranice što značajno poboljšava širenje informacija o implementaciji NETCONF standarda).

- Ispitanik (HPE) navodi da HPE nudi dovoljno dokumentacije i edukacije za ovo područje. 


\subsubsection{NETCONF i povećanje raspoloživosti R/S uređaja}

$\mathrm{U}$ ovom poglavlju se razmatra povećanje raspoloživosti mrežnih $\mathrm{R} / \mathrm{S}$ uređaja pomoću NETCONF standarda (u odnosu na nestandardne metode konfiguriranja).

Četvrto pitanje intervjua glasi: „Povećava li NETCONF standard raspoloživost mrežnih uređaja u odnosu na nestandardne metode konfiguriranja (CLI) koje koriste proizvođači sa svojim operacijskim sustavima (na primjer JUNOS, IOS, EXOS, itd.) i na koji način?““. Ispitanici su iskazivali slaganje s tvrdnjama o povećanju raspoloživosti mrežnih uređaja primjenom NETCONF standarda skalom od 1 do 5, gdje je 1 označavala izrazito neslaganje, a 5 izrazito slaganje s tvrdnjom.

Testiranje se provodi Wilcoxonovim testom za jedan nezavisan uzorak gdje će se utvrditi postojanje slaganja s ponuđenim tvrdnjama samo ako je srednja vrijednost (medijan) veća od 3,00 uz empirijsku p vrijednost manju od 0,05. U slučaju da je empirijska p vrijednost veća od 0,05 riječ je o indiferentnom stavu, dok u slučaju da je srednja vrijednost (medijan) manja od 3 te se utvrdi empirijska $p$ vrijednost manja od 0,05 postoji neslaganje s ponuđenim tvrdnjama.

Tablica 6-14. prikazuje rezultate dobivene pomoću deskriptivne statistike na temelju odgovora na 4. pitanje intervjua s proizvođačima. Podaci u tablici su uređeni od najveće do najmanje prosječne vrijednosti.

Ispitanici su iskazali najveću razinu slaganja s tvrdnjom:

- mogućnost parcijalnog konfiguriranja uređaja pomoću NETCONF standarda povećava raspoloživost mrežnih uređaja (prosječna vrijednost odgovora 5,00; std.dev.0,00),

dok se najmanje i jednako slažu s tvrdnjama (prosječna vrijednost odgovora 4,60; std.dev.0,55):

- NETCONF kao standardni način konfiguracije preko udaljenog pristupa na IP adresu uređaja povećava raspoloživost mrežnih uređaja zato što je za sve proizvođače ista struktura komandi i podataka,

- NETCONF standard povećava raspoloživost mrežnih uređaja zbog toga što koristi jasnu razliku u strukturi između konfiguracijskih i operacijskih podataka i 
- mogućnost zaključavanja konfiguracijske datoteke koje nudi NETCONF povećava raspoloživost mrežnih uređaja.

Tablica 6-14. NETCONF standard i povećanje raspoloživosti (intervju proizvođači)

\begin{tabular}{|c|c|c|c|c|c|c|c|c|}
\hline & $\mathrm{N}$ & Prosjek & Std.Dev. & Mode & Medijan & IQR & Z & $\mathrm{P}^{*}$ \\
\hline $\begin{array}{l}\text { Mogućnost parcijalnog } \\
\text { konfiguriranja uređaja pomoću } \\
\text { NETCONF standarda povećava } \\
\text { raspoloživost mrežnih uređaja. }\end{array}$ & 5 & 5,00 & 0,00 & 5,00 & 5,00 & $\begin{array}{c}(5,00- \\
5,00)\end{array}$ & 2,24 & 0,025 \\
\hline $\begin{array}{l}\text { NETCONF kao standard } \\
\text { povećava raspoloživost jer } \\
\text { omogućava programabilnost } \\
\text { (automatiziranje) konfiguriranja } \\
\text { mrežnih uređaja koja značajno } \\
\text { smanjuje učestalost ljudske } \\
\text { pogreške. }\end{array}$ & 5 & 4,80 & 0,45 & 5,00 & 5,00 & $\begin{array}{c}(5,00- \\
5,00)\end{array}$ & 2,12 & 0,034 \\
\hline $\begin{array}{l}\text { Mogućnost provjere } \\
\text { konfiguracije prije primjene kod } \\
\text { NETCONF načina konfiguriranja } \\
\text { uređaja povećava raspoloživost } \\
\text { mrežnih uređaja. }\end{array}$ & 5 & 4,80 & 0,45 & 5,00 & 5,00 & $\begin{array}{c}(5,00- \\
5,00)\end{array}$ & 2,12 & 0,034 \\
\hline $\begin{array}{l}\text { „Backup \& restore“ mogućnost } \\
\text { koju nudi NETCONF standard } \\
\text { povećava raspoloživost mrežnih } \\
\text { uređaja. }\end{array}$ & 5 & 4,80 & 0,45 & 5,00 & 5,00 & $\begin{array}{c}(5,00- \\
5,00)\end{array}$ & 2,12 & 0,034 \\
\hline $\begin{array}{l}\text { Mogućnost istovremenog i } \\
\text { koordiniranog konfiguriranja svih } \\
\text { ili više uređaja u mreži koje nudi } \\
\text { NETCONF povećava } \\
\text { raspoloživost mrežnih uređaja. }\end{array}$ & 5 & 4,80 & 0,45 & 5,00 & 5,00 & $\begin{array}{c}(5,00- \\
5,00)\end{array}$ & 2,12 & 0,034 \\
\hline $\begin{array}{l}\text { NETCONF kao standardni način } \\
\text { konfiguracije preko udaljenog } \\
\text { pristupa na IP adresu uređaja } \\
\text { povećava raspoloživost mrežnih } \\
\text { uređaja zato jer je za sve } \\
\text { proizvođače ista struktura } \\
\text { komandi i podataka }\end{array}$ & 5 & 4,60 & 0,55 & 5,00 & 5,00 & $\begin{array}{c}(4,00- \\
5,00)\end{array}$ & 2,07 & 0,038 \\
\hline $\begin{array}{l}\text { NETCONF standard povećava } \\
\text { raspoloživost mrežnih uređaja } \\
\text { zbog toga što koristi jasnu razliku } \\
\text { u strukturi između } \\
\text { konfiguracijskih i operacijskih } \\
\text { podataka }\end{array}$ & 5 & 4,60 & 0,55 & 5,00 & 5,00 & $\begin{array}{c}(4,00- \\
5,00)\end{array}$ & 2,07 & 0,038 \\
\hline $\begin{array}{l}\text { Mogućnost zaključavanja } \\
\text { konfiguracijske datoteke koje } \\
\text { nudi NETCONF povećava } \\
\text { raspoloživost mrežnih uređaja. }\end{array}$ & 5 & 4,60 & 0,55 & 5,00 & 5,00 & $\begin{array}{c}(4,00- \\
5,00)\end{array}$ & 2,07 & 0,038 \\
\hline Ukupno & 5 & 4,75 & 0,34 & 5,00 & 5,00 & $\begin{array}{c}(4,38- \\
5,00)\end{array}$ & 2,07 & 0,038 \\
\hline
\end{tabular}

* Wilcoxonov test za jedan nezavisan uzorak 
Ukupna razina povećanja raspoloživosti mrežnih uređaja pomoću svojstava NETCONF standarda bilježila je vrlo visoku prosječnu vrijednost 4,75 s prosječnim odstupanjem od aritmetičke sredine 0,34 . Testiranjem je utvrđena visoka razina povećanja $(Z=2,07 ; p=0,038)$.

Dodatna zapažanja ispitanika na ovo pitanje su sljedeća:

- ispitanik ističe da je značajna prednost NETCONF protokola njegova stateful karakteristika, za razliku od REST API pristupa koji je stateless, ali koji je postao vrlo popularan zadnjih godina. Prednost REST API pristupa je njegova jednostavnost primjene.

- Drugi ispitanik se potpuno slaže sa svim prikazanim svojstvima i njegova kompanija koristi navedene mogućnosti NETCONF protokola na dnevnoj bazi.

Šesnaesto pitanje intervjua glasi: "Molimo Vas da izložite svoja dodatna zapažanja i mišljenje vezano uz primjenu NETCONF standarda i povećanje raspoloživosti mrežnih uređaja, a koja nisu obrađena u prethodnim pitanjima.".

Dobiven je sljedeći odgovor ispitanika:

- ispitanik (Cisco) navodi da Software defined (WAN, LAN, Data Center, Network, i drugo) potiču primjenu NETCONF-a.

\subsubsection{Karakteristike i povećanje primjene NETCONF standarda}

U ovom poglavlju se razmatraju ostale teme o NETCONF standardu (karakteristike, budući razvoj i primjena, i drugo) koje nisu pokrivene $\mathrm{u}$ prethodnim pitanjima intervjua $\mathrm{s}$ proizvođačima.

Osmo pitanje intervjua glasi: „Molim Vas da izrazite svoje mišljenje o nedostacima NETCONF standarda“. Ispitanici su iskazivali slaganje s tvrdnjama o nedostacima NETCONF standarda skalom od 1 do 5 , gdje je 1 označavala izrazito neslaganje, a 5 izrazito slaganje s tvrdnjom.

Testiranje se provodi Wilcoxonovim testom za jedan nezavisan uzorak gdje će se utvrditi postojanje slaganja s ponuđenim tvrdnjama samo ako je srednja vrijednost (medijan) veća od 3,00 uz empirijsku p vrijednost manju od 0,05. U slučaju da je empirijska p vrijednost veća od 0,05 riječ je o indiferentnom stavu, dok u slučaju da je srednja vrijednost (medijan) manja od 
3 te se utvrdi empirijska $\mathrm{p}$ vrijednost manja od 0,05 , postoji neslaganje s ponuđenim tvrdnjama.

Tablica 6-15. prikazuje rezultate dobivene pomoću deskriptivne statistike na temelju odgovora na 8. pitanje intervjua s proizvođačima.

Tablica 6-15. Nedostatci NETCONF standarda (intervju proizvođači)

\begin{tabular}{|c|c|c|c|c|c|c|c|c|}
\hline & $\mathrm{N}$ & Prosjek & Std.Dev. & Mode & Medijan & IQR & $\mathrm{Z}$ & $\mathrm{P}^{*}$ \\
\hline $\begin{array}{l}\text { 1. NETCONF standard daje } \\
\text { mogućnost proizvođačima da } \\
\text { ne podržavaju sve funkcije } \\
\text { (capability), na primjer } \\
\text { „Candidate“, „Startup“, } \\
\text { „Validate“, „Rollback-on- } \\
\text { Error" i druge pa se ne može } \\
\text { iskoristiti većina prednosti } \\
\text { standarda. }\end{array}$ & 5 & 3,00 & 1,00 & Multiple & 3,00 & $\begin{array}{c}(2,00- \\
4,00)\end{array}$ & 0,00 & $>0,999$ \\
\hline $\begin{array}{l}\text { 2. NETCONF standard daje } \\
\text { mogućnost da se koriste } \\
\text { nestandardni (proprietary) } \\
\text { modeli podataka (data models). }\end{array}$ & 5 & 2,40 & 1,14 & 2,00 & 2,00 & $\begin{array}{c}(2,00- \\
3,00)\end{array}$ & 1,13 & 0,257 \\
\hline $\begin{array}{l}\text { 3. NETCONF standard daje } \\
\text { mogućnost da se definiraju i } \\
\text { koriste nestandardne } \\
\text { (proprietary) funkcije } \\
\text { (capabilities). }\end{array}$ & 5 & 2,00 & 0,71 & 2,00 & 2,00 & $\begin{array}{c}(2,00- \\
2,00)\end{array}$ & 1,89 & 0,059 \\
\hline $\begin{array}{l}\text { 4. NETCONF standard koristi } \\
\text { XML jezik i njegovu sintaksu } \\
\text { koja je redundantna i opširna } \\
\text { što može zamarati i zbunjivati } \\
\text { korisnika. }\end{array}$ & 5 & 2,60 & 0,89 & 2,00 & 2,00 & $\begin{array}{c}(2,00- \\
3,00)\end{array}$ & 1,00 & 0,317 \\
\hline $\begin{array}{l}\text { 5. Za korištenje NETCONF } \\
\text { protokola potrebno je } \\
\text { poznavanje programskih jezika. }\end{array}$ & 5 & 2,00 & 0,71 & 2,00 & 2,00 & $\begin{array}{c}(2,00- \\
2,00)\end{array}$ & 1,89 & 0,059 \\
\hline Ukupno & 5 & 2,40 & 0,62 & 2,40 & 2,40 & $\begin{array}{c}(1,90- \\
2,90)\end{array}$ & 1,76 & 0,078 \\
\hline
\end{tabular}

* Wilcoxonov test za jedan nezavisan uzorak

Prema mišljenju ispitanika glavni nedostatak NETCONF standarda je taj što daje mogućnost proizvođačima da ne podržavaju sve funkcije (capability) (prosječna vrijednost odgovora 3,00; std.dev.1,00), dok se najmanje slažu s tvrdnjom da je nedostatak što standard daje mogućnost da se definiraju i koriste nestandardne funkcije (prosječna vrijednost odgovora 2,00; std.dev.0,71). 
Ukupna razina važnosti nedostataka NETCONF standarda na R/S uređajima je bilježila prosječnu vrijednost $2,40 \mathrm{~s}$ prosječnim odstupanjem od aritmetičke sredine 0,62 . Testiranjem nije utvrđeno postojanje visoke razine važnosti $(Z=1,76 ; p=0,078)$.

Dodatna zapažanja ispitanika su sljedeća na:

- potpitanje 8.1.:

- Ispitanik smatra da je NETCONF RFC vrlo jasno i određeno definiran. U slučaju da proizvođač ne odluči implementirati opcionalne funkcije, to postaje ograničenje njegovih $\mathrm{R} / \mathrm{S}$ uređaja. U svakom slučaju NETCONF RFC omogućava podršku i primjenu opcionalnih funkcija na standardan način. U stvari, zaključuje ispitanik, dobro je imati ponuđenu fleksibilnost primjene.

- Potpitanje 8.5.:

○ Ispitanik smatra da stariji inženjeri (korisnici) potencijalno imaju problema sa snalaženjem i učenjem programskih jezika (najčešće nisu dovoljno zainteresirani).

- Drugi ispitanik smatra da postoji dovoljno javno dostupnih API aplikacija koje koriste NETCONF tako da nema potrebe za razvojem vlastitih aplikacija za automatizaciju pomoću NETCONF-a.

U desetom pitanju su ispitanici iskazivali svoje mišljenje o različitim tvrdnjama vezanim uz NETCONF standard i povećanje raspoloživosti R/S uređaja. Ispitanici su iskazivali slaganje s ponuđenim tvrdnjama skalom od 1 do 5 , gdje je 1 označavala izrazito neslaganje, a 5 izrazito slaganje s tvrdnjom.

Testiranje se provodi Wilcoxonovim testom za jedan nezavisan uzorak gdje će se utvrditi postojanje slaganja s ponuđenim tvrdnjama samo ako je srednja vrijednost (medijan) veća od 3,00 uz empirijsku p vrijednost manju od 0,05. U slučaju da je empirijska p vrijednost veća od 0,05 riječ je o indiferentnom stavu, dok u slučaju da je srednja vrijednost (medijan) manja od 3 te se utvrdi empirijska p vrijednost manja od 0,05 , postoji neslaganje s ponuđenim tvrdnjama.

Tablica 6-16. prikazuje rezultate dobivene pomoću deskriptivne statistike na temelju odgovora na 10. pitanje intervjua s proizvođačima. 
Tablica 6-16. NETCONF standard i povećanje raspoloživosti R/S uređaja (intervju proizvođači)

\begin{tabular}{|c|c|c|c|c|c|c|c|c|}
\hline & $\mathrm{N}$ & Prosjek & Std.Dev. & Mode & Medijan & IQR & Z & $\mathrm{P}^{*}$ \\
\hline $\begin{array}{l}\text { 1. Primjena NETCONF } \\
\text { standarda na R/S uređajima } \\
\text { našeg proizvođača je važna za } \\
\text { konkurentnost na tržištu. }\end{array}$ & 5 & 4,80 & 0,45 & 5,00 & 5,00 & $\begin{array}{c}(5,00- \\
5,00)\end{array}$ & 2,12 & 0,034 \\
\hline $\begin{array}{l}\text { 2. NETCONF standard bi se } \\
\text { trebao više koristiti od strane } \\
\text { Vaših korisnika na R/S } \\
\text { uređajima. }\end{array}$ & 5 & 4,80 & 0,45 & 5,00 & 5,00 & $\begin{array}{c}(5,00- \\
5,00)\end{array}$ & 2,12 & 0,034 \\
\hline $\begin{array}{l}\text { 3. Korištenjem NETCONF } \\
\text { standarda povećava se } \\
\text { raspoloživost mrežnih uređaja i } \\
\text { sustava. }\end{array}$ & 5 & 4,80 & 0,45 & 5,00 & 5,00 & $\begin{array}{c}(5,00- \\
5,00)\end{array}$ & 2,12 & 0,034 \\
\hline $\begin{array}{l}\text { 4. NETCONF standard bi se } \\
\text { trebao više koristiti od strane } \\
\text { Vaših korisnika na R/S } \\
\text { uređajima da bi povećali } \\
\text { raspoloživost uređaja i sustava. }\end{array}$ & 5 & 4,80 & 0,45 & 5,00 & 5,00 & $\begin{array}{l}(5,00- \\
5,00)\end{array}$ & 2,12 & 0,034 \\
\hline $\begin{array}{l}\text { 5. RESTCONF standard } \\
\text { (definiran u RFC } 8040 \text { u } \\
\text { siječnju 2017.) je bolje rješenje } \\
\text { za konfiguraciju mrežnih } \\
\text { uređaja od NETCONF } \\
\text { standarda. }\end{array}$ & 5 & 3,00 & 0,71 & 3,00 & 3,00 & $\begin{array}{c}(3,00- \\
3,00)\end{array}$ & 0,00 & $>0,999$ \\
\hline
\end{tabular}

* Wilcoxonov test za jedan nezavisan uzorak

Ispitanici su iskazali jednaku vrlo visoku razinu slaganja s ponuđenim tvrdnjama (prosječna vrijednost odgovora 4,80; std.dev.0,45):

- primjena NETCONF standarda je važna za konkurentnost na tržištu,

- NETCONF standard bi se trebao više koristiti od strane korisnika na R/S uređajima,

- korištenjem NETCONF standarda povećava se raspoloživost mrežnih uređaja i sustava,

- NETCONF standard bi se trebao više koristiti od strane korisnika kako bi povećali raspoloživost uređaja i sustava,

osim s tvrdnjom da je RESTCONF bolje rješenje od NETCONF standarda (prosječna vrijednost odgovora 3,00; std.dev.0,71) koja ima neutralan rezultat.

Dodatna zapažanja ispitanika na ovo pitanje su sljedeća:

- $\quad$ na potpitanje 10.5 . 
○ ispitanik smatra da ima više RESTCONF stručnjaka među IT inženjerima (na primjer poznavatelji VMware tehnologije).

- Drugi ispitanik smatra da oba standarda (RESTCONF i NETCONF) imaju svojih nedostataka i prednosti, tako da nijedan od njih nije bolji, već sve ovisi o trenutnoj situaciji i zahtjevima korisnika.

Jedanaesto pitanje intervjua glasi: "Slažete li se s tvrdnjom da sve vrste R/S uređaja (na primjer od malih SMB uređaja do velikih ISP uređaja) trebaju imati implementiran NETCONF standard?".

Tablica 6-17. Implementacija NETCONF standarda na svim vrstama R/S uređaja (intervju proizvođači)

\begin{tabular}{cc|c}
\hline & $\mathbf{N}$ & $\%$ \\
\hline $\mathrm{Ne}$ & 2 & 40,00 \\
$\mathrm{Da}$ & 3 & 60,00 \\
\hline
\end{tabular}

Tablica 6-17. prikazuje rezultate dobivene na 11. pitanje intervjua s proizvođačima: tri ispitanika (60\%) se slažu s tvrdnjom da NETCONF standard treba implementirati u sve vrste $\mathrm{R} / \mathrm{S}$ uređaja, a dva se ispitanika (40\%) ne slažu.

O implementaciji NETCONF standarda na svim vrstama R/S uređaja ispitanici su iznijeli sljedeća zapažanja:

- ispitanici (Cisco) smatraju:

○ u porastu je trend u kojem ISP upravlja malim SMB uređajem, to su takozvane upravljane usluge (engl. managed services),

○ u idealnom slučaju NETCONF bi trebao biti prisutan kao sučelje na svim uređajima.

- Ispitanik (Huawei) smatra:

o da NETCONF olakšava administraciju uređaja pogotovo s alatima kakve ima Huawei (u2000, eSight i drugi). 
- Ispitanik (Juniper) smatra da za automatizaciju moraju biti prisutne unificirane metode.

- Ispitanik (HPE) smatra da ovisi o vrsti uređaja i načinu implementacije. Na primjer, postoje dostupna rješenja na tržištu gdje su R/S uređaji instalirani u trgovinama (dakle SMB vrsta proizvoda) i kojima ISP upravlja pomoću centralne upravljačke platforme (uobičajeno u oblaku). Ako je SMB proizvod instaliran kao samostalan uređaj, ispitanik smatra da nema nikakve potrebe za primjenom NETCONF protokola. U slučaju upravljanih usluga (engl. managed services) ispitanik uglavnom vidi primjenu drugih protokola (kao što je REST) koji se koriste za konfiguraciju SMB uređaja.

Dvanaesto pitanje intervjua glasi: "Na koji način mislite da bi se mogla povećati primjena NETCONF standarda?".

Dobiveni su sljedeći odgovori ispitanika:

- primjenom na upravljane usluge.

- Jednaka implementacija NETCONF sučelja na svim uređajima različitih proizvođača. Također u open-source projektima, npr. OpenWrt.

- Kod prodaje uređaja više promovirati NETCONF.

- Ispitanik smatra da je NETCONF vrlo robustan protokol, ali da treba bolje alate koji će jednostavnije kreirati predloške (engl. template) jer su NETCONF predlošci u XML formatu. NETCONF bi bilo jednostavnije koristiti da postoji grafičko sučelje za kreiranje predložaka. Za uporabu NETCONF protokola, potrebno je znanje programiranja ili rad sa skriptama.

Trinaesto pitanje intervjua glasi: "Na koji način mislite da bi se mogao poboljšati NETCONF standard?".

Dobiveni su sljedeći odgovori ispitanika:

- većom primjenom NETCONF-a u praksi.

- proglašavanjem sadašnjih opcionalnih funkcija NETCONF standarda obaveznima.

- razgovorima s korisnicima, razmatranjem njihovih želja i uvidom u njihovu infrastrukturu.

Četrnaesto pitanje intervjua glasi: "Na koji način $\mathrm{Vi}$ vidite buduću primjenu i razvoj NETCONF standarda?". 
Dobiveni su sljedeći odgovori ispitanika:

- ispitanik smatra pomoću upravljanih usluga u kojima ISP upravlja uslugama, uređajima i konekcijama u paketu (kao jedna usluga).

- Drugi ispitanik smatra kroz primjenu na opremi različitih proizvođača na isti/standardizirani način.

- Treći ispitanik nije siguran kakva je budućnost NETCONF standarda. U slučaju da NETCONF standard postane jednostavniji za primjenu, imat će svoju budućnost. Međutim, danas je NETCONF previše teoretski (engl. academic) u usporedbi, primjerice, s REST API koji je puno jednostavniji za primjenu. Korisnici vole jednostavnost. U pravilu, IT odjeljenja su većinom fokusirana na servere i storage opremu, a manje na računalne mreže. Ispitanik vidi veće znanje korisnika o mrežama samo u većim poduzećima (na primjer sveučilišta, bolnice, multinacionalne kompanije). Korisnici koji su fokusirani na servere i storage opremu imaju vrlo malo znanje o računalnim mrežama i obično imaju vrlo jednostavnu arhitekturu svoje računalne mreže (i u takvim mrežama NETCONF ne može iskazati sve svoje prednosti).

- Četvrti ispitanik smatra da će NETCONF sve više zamjenjivati zastarjele načine konfiguriranja (poput CLI, SNMP).

- Peti ispitanik (Juniper) smatra da je trenutna baza i infrastruktura primjene NETCONF standarda dobra. NETCONF se intenzivno koristi u JUNOS proizvodima. Sve aplikacije automatizacije koje Juniper isporučuje svojim korisnicima moraju sadržavati NETCONF standard.

Petnaesto pitanje intervjua glasi: "Molimo Vas da izložite svoja dodatna zapažanja i mišljenje vezano uz primjenu NETCONF standarda, a koja nisu obrađena u prethodnim pitanjima.".

Dobiveni su sljedeći odgovori ispitanika:

- ispitanik smatra sljedeće:

○ ISP korisnici primjenjuju NETCONF, dok Enterprise i SMB ne primjenjuju.

○ mrežni administratori ne koriste u svakodnevnom radu API i XML i zbog toga pokazuju otpor prema NETCONF-u. 
○ događalo se da korisnici nakon višestrukih prezentacija prednosti NETCONF-a potvrde njegove prednosti, međutim odgode implementaciju zbog izlaska iz ugodne zone poznatih tehnologija.

- Drugi ispitanik ističe sljedeće:

○ NETCONF ovisi o raspoloživim YANG modelima. Trenutno postoji velika količina YANG modela definirana $u$ tri grupacije (a) nestandardni (proprietary) (b) IETF, (c) Open Config. OpenConfig je nastao udruživanjem proizvođača kao zamjena/dopuna za sporije IETF standarde.

○ U standardnoj konfiguraciji za aktivaciju NETCONF-a potrebno je aktivirati SSH i NETCONF agenta. Npr. na 64-bitnom XR danas se to rješava kroz automatiziranu DayO konfiguraciju putem Golden ISO XR imagea (u kojem je moguće dodati kod koji automatski konfigurira sve što je potrebno za NETCONF, tako da se nije potrebno spajati preko CLI sučelja).

Sedamnaesto pitanje intervjua glasi: "Imate li Vi kakvih pitanja za mene ili dodatna opažanja?".

Dobiveni su sljedeći odgovori ispitanika:

- ispitanik smatra:

○ da je NETCONF vrlo robustan protokol koji minimizira ljudske pogreške i zbog toga posebno ima smisla koristiti NETCONF u mrežama koje zahtijevaju česte promjene.

- Ipak, primjena NETCONF protokola vrlo je složena. Korisnici vrlo često nisu ažurirani s njegovim karakteristikama/prednostima i odlučuju se za jednostavnija alternativna rješenja (REST) ili jednostavno primjenjuju CLI (pogotovo u slučaju kada nemaju puno promjena konfiguracija u svojoj mreži).

- Drugi ispitanik smatra da bi se NETCONF više koristio boljim razvojem aplikacija za NETCONF, što bi rezultiralo pojednostavljeno upravljanje R/S uređajima.

\subsubsection{Zaključak}

Na osnovi odgovora dobivenih tijekom intervjua sa zaposlenicima proizvođača R/S mrežnih uređaja može se zaključiti sljedeće: 


\section{Primjena NETCONF standarda kod proizvođača R/S uređaja:}

- Svi intervjuirani proizvođači implementiraju NETCONF standard definiran u RFC dokumentu.

- NETCONF se najviše implementira (ponuđene vrijednosti su od 0 do 5 , gdje 5 označava $100 \%$ ) na R/S mrežnim uređajima (svi imaju prosječnu vrijednost veću od 4):

○ mrežama davatelja usluga (ISP) (prosječna vrijednost odgovora 4,75 (95\%); std.dev. 0,50).

○ mrežama podatkovnih centara (prosječna vrijednost odgovora 4,60 (92\%); std.dev. 0,89).

○ WAN mrežama većih poduzeća $(4,20$ (84\%), std.dev. 1,30$)$.

dok manje u SMB mrežama $(3,50,70 \%)$ i LAN mrežama manjih poduzeća $(3,20$, 64\%). Ispitanici pak najmanje koriste NETCONF na R/S mrežnim uređajima $u$ mrežama:

○ Internet stvari (IoT) (prosječna vrijednost odgovora 2,25 (45\%); std.dev.2,06). Ukupna razina implementiranja NETCONF standarda na R/S uređajima za različite vrste mreža je bilježila visoku prosječnu vrijednost 3,75 (75\%) s prosječnim odstupanjem od aritmetičke sredine 1,50.

- Najvažniji razlozi za implementaciju NETCONF standarda na R/S uređajima proizvođača su sljedeći (ponuđene vrijednosti od 1 do 5 , gdje 5 označava izuzetno važno):

- mogućnost parcijalnog konfiguriranja uređaja pomoću NETCONF standarda (prosječna vrijednost odgovora 5,00; std.dev.0,00) te

- mogućnost istovremenog $i$ koordiniranog konfiguriranja svih ili više uređaja $u$ mreži (prosječna vrijednost odgovora 5,00; std.dev.0,00).

Sva navedena svojstva NETCONF standarda su dobila izuzetno visoke vrijednosti važnosti. Najnižu vrijednost je dobila Mogućnost zaključavanja konfiguracijske datoteke (prosječna vrijednost odgovora 4,60; std.dev.0,89):

- Glavni razlog za neimplementaciju NETCONF standarda na R/S uređajima je neprihvaćenost NETCONF standarda od korisnika (prosječna vrijednost odgovora 
3,20; std.dev.1,48), dok je najmanje važan razlog korištenje RESTCONF standarda kao boljeg rješenja (prosječna vrijednost odgovora 1,40; std.dev.0,55).

- Što se tiče raspoložive dokumentacije i edukacije od strane proizvođača (ponuđene vrijednosti su od 1 do 5 , gdje je 5 potpuno slaganje s tvrdnjom), ispitanici (zaposlenici proizvođača) se najviše slažu s tvrdnjama (prosječna vrijednost odgovora 4,80; std.dev.0,45):

○ da postoji detaljna dokumentacija koja objašnjava rad i primjenu NETCONF standarda i

O da postoje tečajevi proizvođača za samostalno učenje,

dok se najmanje slažu s tvrdnjom da postoje certifikacijski ispiti (prosječna vrijednost odgovora 4,20; std.dev. 1,75). Ukupna razina raspoloživosti dokumentacije i edukacija o primjeni i korištenju NETCONF standarda od strane proizvođača opreme vrlo je visoka i bilježi prosječnu vrijednost $4,50 \mathrm{~s}$ prosječnim odstupanjem od aritmetičke sredine 1,12 .

\section{NETCONF i povećanje raspoloživosti R/S uređaja:}

- Što se tiče povećanja raspoloživosti primjenom svojstava NETCONF standarda (ponuđene vrijednosti su od 1 do 5 , gdje je 5 izrazito slaganje), ispitanici su iskazali najveću razinu slaganja s tvrdnjom:

- mogućnost parcijalnog konfiguriranja uređaja pomoću NETCONF standarda povećava raspoloživost mrežnih uređaja (prosječna vrijednost odgovora 5,00; std.dev.0,00),

dok se najmanje i jednako slažu s tvrdnjama (prosječna vrijednost odgovora 4,60; std.dev.0,55):

- NETCONF kao standardni način konfiguracije preko udaljenog pristupa na IP adresu uređaja povećava raspoloživost mrežnih uređaja zato jer je za sve proizvođače ista struktura komandi i podataka,

- NETCONF standard povećava raspoloživost mrežnih uređaja zbog toga što koristi jasnu razliku u strukturi između konfiguracijskih $i$ operacijskih podataka i 
- mogućnost zaključavanja konfiguracijske datoteke koje nudi NETCONF povećava raspoloživost mrežnih uređaja.

Ukupna razina povećanja raspoloživosti mrežnih uređaja pomoću navedenih svojstava NETCONF standarda je bilježila vrlo visoku prosječnu vrijednost 4,75 s prosječnim odstupanjem od aritmetičke sredine 0,34 .

\section{Karakteristike i povećanje primjene NETCONF standarda:}

- Prema mišljenju ispitanika (ponuđena skala od 1 do 5 , gdje je 5 izrazito slaganje) glavni nedostatak NETCONF standarda je taj što daje mogućnost proizvođačima da ne podržavaju sve funkcije (capability) (prosječna vrijednost odgovora 3,00; std.dev.1,00), dok se najmanje slažu s tvrdnjom da je nedostatak što standard daje mogućnost da se definiraju i koriste nestandardne funkcije (prosječna vrijednost odgovora 2,00; std.dev.0,71). Ukupna razina važnosti predloženih nedostataka NETCONF standarda na R/S uređajima je bilježila prosječnu vrijednost 2,40 $\mathrm{s}$ prosječnim odstupanjem od aritmetičke sredine 0,62 .

- U desetom pitanju su ispitanici iskazivali svoje mišljenje o različitim tvrdnjama vezanim uz NETCONF standard i povećanje raspoloživosti R/S uređaja (ponuđena skala od 1 do 5 , gdje je 5 izrazito slaganje). Ispitanici su iskazali jednaku vrlo visoku razinu slaganja sa svim ponuđenim tvrdnjama (prosječna vrijednost odgovora 4,80; std.dev.0,45):

○ primjena NETCONF standarda je važna za konkurentnost na tržištu,

- NETCONF standard bi se trebao više koristiti od strane korisnika na R/S uređajima,

○ korištenjem NETCONF standarda povećava se raspoloživost mrežnih uređaja i sustava,

- NETCONF standard bi se trebao više koristiti od strane korisnika da bi povećali raspoloživost uređaja i sustava,

osim s tvrdnjom da je RESTCONF bolje rješenje od NETCONF standarda (prosječna vrijednost odgovora 3,00; std.dev.0,71) koja ima neutralan rezultat. 
- O implementaciji NETCONF standarda na svim vrstama R/S uređaja tri ispitanika (60\%) se slažu s tvrdnjom da NETCONF standard treba implementirati na sve vrste $\mathrm{R} / \mathrm{S}$ uređaja, a dva ispitanika (40\%) se s ponuđenom tvrdnjom ne slažu.

Ispitanici su dali i svoje mišljenje o budućem razvoju i primjeni NETCONF standarda.

Na temelju odgovora dobivenih tijekom intervjua sa zaposlenicima proizvođača R/S uređaja, kreirana su i pitanja anketnog upitnika za korisnike mrežne opreme u Hrvatskoj. 


\subsection{Dobiveni podaci od ispitanika (intervju s partnerima)}

U ovom poglavlju su prikazani odgovori dobiveni tijekom intervjua s R/S specijaliziranim inženjerima koji su zaposleni kod odabranih partnera u Hrvatskoj.

Odgovori su podijeljeni po područjima:

- primjena NETCONF standarda kod proizvođača R/S uređaja (pitanja 6. i 10.) koja je povezana uz područje ispitivanja hipoteze $\mathrm{H} 2$.

- Primjena NETCONF standarda od strane korisnika u Hrvatskoj (pitanja 4., 5., 7. i 8.) koja je povezana uz područje ispitivanja hipoteze H3.

- Poznavanje NETCONF standarda od strane korisnika u Hrvatskoj (pitanja 20. i 21.) koje je povezano uz područje ispitivanja hipoteze H4.

- NETCONF i povećanje raspoloživosti R/S uređaja (pitanja 6. i 10.) koje je povezano uz područje ispitivanja hipoteze $\mathrm{H} 1$.

- Karakteristike i povećanje primjene NETCONF standarda (pitanja 6. i 10.) koje pokriva ostala pitanja vezana uz NETCONF standard i povećanje raspoloživosti R/S uređaja.

\subsubsection{Metoda obrade podataka}

U ovom poglavlju se upotrebom metoda tabelarnog prikazivanja prezentira struktura odgovora na pitanja intervjua od strane ispitanika (zaposlenika partnera proizvođača), dok se upotrebom metoda deskriptivne statistike prezentiraju srednje vrijednosti (aritmetička sredina, medijan i mod) kao i disperzija oko srednjih vrijednosti (standardna devijacija kao prosječno odstupanje od aritmetičke sredine te interkvartilni raspon (IQR) kao pokazatelj disperzije oko srednje vrijednosti medijana). Testiranje razlika u odnosu na teorijsku vrijednost se provodi upotrebom Wilcoxonovog testa za jedan nezavisan uzorak. Opravdanost upotrebe Wilcoxonovog testa proizlazi uz malih veličina uzorka, te ranga obilježja brojčanih vrijednosti čime nisu zadovoljeni uvjeti za provođenje parametrijskih inačica testa.

Analiza je rađena u statističkom softveru SPSS 25 te se zaključci donose pri graničnoj signifikantnosti od 5\%. 


\subsubsection{Primjena NETCONF standarda kod proizvođača $R / S$ uređaja}

U ovom poglavlju se razmatra primjena NETCONF standarda od strane proizvođača na svojim R/S uređajima.

Šesto pitanje intervjua glasi: „Na R/S (router/switch) uređajima kojih proizvođača koristite NETCONF i u kojem postotku?“‘. Ispitanici su iskazivali mišljenje vrijednostima razreda od 0 do 5 , gdje je 0 označavalo $0 \%$ dok je 5 označavalo $100 \%$.

Testiranje se provodi Wilcoxonovim testom za jedan nezavisan uzorak gdje će se utvrditi postojanje visoke razine upotrebe samo ako je srednja vrijednost (medijan) veća od 3,00 (41\%-60\%) uz empirijsku p vrijednost manju od 0,05. U slučaju da je empirijska p vrijednost veća od 0,05 riječ je o srednjoj razini primjene (41\%-60\%), dok u slučaju da je srednja vrijednost (medijan) manja od $3(41-60 \%)$ te se utvrdi empirijska p vrijednost manja od 0,05, postoji niska razina upotrebe.

Tablica 6-18. prikazuje rezultate dobivene pomoću deskriptivne statistike na temelju odgovora na 6. pitanje intervjua s partnerima. Podaci u tablici uređeni su od najveće do najmanje prosječne vrijednosti.

Tablica 6-18. Primjena NETCONF standarda na R/S uređajima korisnika (intervju partneri)

\begin{tabular}{lcccccccc}
\hline & N & Prosjek & Std.Dev. & Mod & Medijan & IQR & Z & P* \\
\hline Cisco Systems & 7 & 1,00 & 0,58 & 1,00 & 1,00 & $(1,00-1,00)$ & 2,45 & 0,014 \\
\hline Huawei & 5 & 1,00 & 1,73 & 0,00 & 0,00 & $(0,00-1,00)$ & 1,79 & 0,074 \\
\hline F5 & 4 & 0,75 & 0,96 & 0,00 & 0,00 & $(0,00-1,50)$ & 1,84 & 0,066 \\
\hline Juniper Networks & 4 & 0,75 & 0,96 & 0,00 & 0,00 & $(0,00-1,50)$ & 1,84 & 0,066 \\
\hline Arista & 3 & 0,33 & 0,58 & 0,00 & 0,00 & $(0,00-1,00)$ & 1,63 & 0,102 \\
\hline $\begin{array}{l}\text { Hewlett Packard } \\
\text { Enterprise }\end{array}$ & 6 & 0,17 & 0,41 & 0,00 & 0,00 & $(0,00-0,00)$ & 2,33 & 0,020 \\
\hline Extreme Networks & 2 & 0,00 & 0,00 & 0,00 & 0,00 & $(0,00-0,00)$ & 1,41 & 0,157 \\
\hline Ukupno & 7 & 0,61 & 0,51 & 0,50 & 0,50 & $(0,14-1,00)$ & 2,37 & 0,018 \\
\hline
\end{tabular}

* Wilcoxonov test za jedan nezavisan uzorak 
NETCONF se najčešće koristi kod korisnika na R/S uređajima proizvođača Cisco Systems (prosječna vrijednost odgovora 1,00, korištenje kod 20\% korisnika; std.dev.0,58) i uređajima proizvođača Huawei (prosječna vrijednost odgovora 1,00 (20\%); std.dev. 1,73).

Ukupna razina odgovora ispitanika je bilježila prosječnu vrijednost $0,61 \mathrm{~s}$ prosječnim odstupanjem od aritmetičke sredine 0,51 , što pokazuje vrlo nisku prosječnu implementaciju $(12,2 \%)$ NETCONF standarda na R/S uređajima proizvođača.

Dodatna zapažanja ispitanika na ovo pitanje su sljedeća:

- ispitanik navodi da se implementacija NETCONF-a uglavnom izvodi na R/S uređajima kod SP korisnika.

- Drugi ispitanik je do sada vidio implementaciju NETCONF standarda na R/S uređajima korisnika samo u laboratorijskim uvjetima.

Na deseto pitanje su ispitanici iskazivali slaganje s tvrdnjama koje se odnose na raspoloživu dokumentaciju o primjeni i korištenju NETCONF standarda od strane proizvođača opreme. Ispitanici su iskazivali mišljenje ocjenama od 1 do 5 , gdje je 1 označava neslaganje s tvrdnjom, a 5 potpuno slaganje s tvrdnjom.

Testiranje se provodi Wilcoxonovim testom za jedan nezavisan uzorak gdje će se utvrditi postojanje slaganja s ponuđenim tvrdnjama samo ako je srednja vrijednost (medijan) veća od 1,00 uz empirijsku p vrijednost manju od 0,05 . U slučaju da je empirijska p vrijednost veća od 0,05 riječ je o neslaganju.

Tablica 6-19. prikazuje rezultate dobivene pomoću deskriptivne statistike na temelju odgovora na 10. pitanje intervjua s partnerima.

Ispitanici se najviše slažu s tvrdnjom da postoje tečajevi proizvođača za samostalno učenje (CBT, Webinar, i slično) koji u potpunosti podučavaju korisnike uporabi i primjeni NETCONF standarda na mrežnim uređajima (prosječna vrijednost odgovora 2,71; std.dev.1,38) dok se najmanje slažu s tvrdnjom da postoje certifikacijski ispiti (prosječna vrijednost odgovora 1,57; std.dev. 0,53). 
Tablica 6-19. Raspoloživa dokumentacija i edukacija o NETCONF standardu (intervju partneri)

\begin{tabular}{|c|c|c|c|c|c|c|c|c|}
\hline & $\mathrm{N}$ & Prosjek & $\begin{array}{c}\text { Std.D } \\
\text { ev. }\end{array}$ & Mod & Medijan & IQR & Z & $\mathrm{P}^{*}$ \\
\hline $\begin{array}{l}\text { Postoji detaljna dokumentacija } \\
\text { proizvođača koja objašnjava } \\
\text { rad i primjenu NETCONF } \\
\text { standarda na mrežnim } \\
\text { uređajima: upute (manuals), } \\
\text { preporuke za uporabu (white } \\
\text { papers) i slično. }\end{array}$ & 7 & 2,29 & 1,38 & 2,00 & 2,00 & $(1,00-3,00)$ & 2,06 & 0,039 \\
\hline $\begin{array}{l}\text { Postoje tečajevi proizvođača } \\
\text { za samostalno učenje (CBT, } \\
\text { Webinar i slično) koji u } \\
\text { potpunosti podučavaju } \\
\text { korisnike uporabi i primjeni } \\
\text { NETCONF standarda na } \\
\text { mrežnim uređajima }\end{array}$ & 7 & 2,71 & 1,38 & 2,00 & 2,00 & $(2,00-4,00)$ & 2,23 & 0,026 \\
\hline $\begin{array}{l}\text { Postoje organizirani tečajevi } \\
\text { proizvođača vođeni od } \\
\text { instruktora koji detaljno } \\
\text { podučavaju korisnike uporabi } \\
\text { i primjeni NETCONF } \\
\text { standarda na mrežnim } \\
\text { uređajima. }\end{array}$ & 7 & 2,57 & 1,62 & 1,00 & 3,00 & $(1,00-4,00)$ & 1,84 & 0,066 \\
\hline $\begin{array}{l}\text { Postoje certifikacijski ispiti (i } \\
\text { pripadajući tečajevi) } \\
\text { proizvođača koji detaljno } \\
\text { osposobljavaju korisnike } \\
\text { uporabi i primjeni NETCONF } \\
\text { standarda na mrežnim } \\
\text { uređajima. }\end{array}$ & 7 & 1,57 & 0,53 & 2,00 & 2,00 & $(1,00-2,00)$ & 2,00 & 0,046 \\
\hline Ukupno & 7 & 2,29 & 1,05 & 2,00 & 2,00 & $(1,50-2,75)$ & 2,21 & 0,027 \\
\hline
\end{tabular}

* Wilcoxonov test za jedan nezavisan uzorak

Ukupna razina odgovora ispitanika o raspoloživoj NETCONF dokumentaciji i edukaciji je bilježila prosječnu vrijednost 2,29 s prosječnim odstupanjem od aritmetičke sredine 1,05.

Dodatna zapažanja ispitanika na ovo pitanje su sljedeća:

- Cisco izrazito promovira NETCONF.

- Postoje besplatni resursi (upute, labovi, softver, Youtube) - pogotovo od proizvođača Cisco i Juniper.

- Cisco dosta promovira DevNet i srodne tehnologije u zadnje 3 godine. 
- Ispitanik navodi da rijetko nailazi na R/S uređaje za koje postoje izdvojeni NETCONF konfiguracijski vodiči (engl. configuration guide).

\subsubsection{Primjena NETCONF standarda od strane korisnika u Hrvatskoj}

U ovom se poglavlju razmatra primjena NETCONF standarda od strane korisnika na svojim $\mathrm{R} / \mathrm{S}$ uređajima.

Četvrto pitanje intervjua glasi: "U kojim vrstama mreža koristite NETCONF na R/S mrežnim uređajima i u kojem postotku od strane Vaših korisnika?" Ispitanici su iskazivali mišljenje vrijednostima razreda od 0 do 5 , gdje je 0 označavalo $0 \%$ dok je 5 označavalo $100 \%$.

Tablica 6-20. Implementacija NETCONF standarda na R/S uređajima od strane korisnika (intervju partneri)

\begin{tabular}{|c|c|c|c|c|c|c|c|c|}
\hline & $\mathrm{N}$ & Prosjek & $\begin{array}{l}\text { Std. } \\
\text { Dev. }\end{array}$ & Mod & Medijan & IQR & $\mathrm{Z}$ & $\mathrm{P}^{*}$ \\
\hline $\begin{array}{l}\text { Mreže davatelja usluga } \\
\text { (Internet servise provider - } \\
\text { ISP). Uključuje sve vrste ISP } \\
\text { mreža, na primjer broadband, } \\
\text { bežične, core, access }\end{array}$ & 3 & 3,33 & 1,15 & 4,00 & 4,00 & $(2,00-4,00)$ & 0,58 & 0,564 \\
\hline $\begin{array}{l}\text { Mreže podatkovnih centara } \\
\text { (Data Center - DC) }\end{array}$ & 6 & 1,50 & 1,05 & $\mathrm{n} / \mathrm{a} * *$ & 1,50 & $(1,00-1,50)$ & 2,04 & 0,041 \\
\hline $\begin{array}{l}\text { WAN mreže većih poduzeća } \\
\text { (Enterprise Networks) }\end{array}$ & 7 & 0,57 & 0,53 & 1,00 & 1,00 & $(0,00-1,00)$ & 2,43 & 0,015 \\
\hline $\begin{array}{l}\text { LAN mreže malih i srednjih } \\
\text { poduzeća (Small Medium } \\
\text { Business-SMB) }\end{array}$ & 7 & 0,14 & 0,38 & 0,00 & 0,00 & $(0,00-0,00)$ & 2,53 & 0,011 \\
\hline Mreže internet stvari (IoT) & 4 & 0,00 & 0,00 & 0,00 & 0,00 & $(0,00-0,00)$ & 2,00 & 0,046 \\
\hline $\begin{array}{l}\text { LAN mreže većih poduzeća } \\
\text { (Enterprise Networks) }\end{array}$ & 7 & 0,71 & 0,49 & 1,00 & 1,00 & $(0,00-1,00)$ & 2,46 & 0,014 \\
\hline Ukupno & 7 & 0,94 & 0,84 & 0,00 & 0,75 & $(0,00-1,75)$ & 2,37 & 0,018 \\
\hline
\end{tabular}

Testiranje se provodi Wilcoxonovim testom za jedan nezavisan uzorak gdje će se utvrditi postojanje visoke razine upotrebe samo ako je srednja vrijednost (medijan) veća od 3,00 (41\%-60\%) uz empirijsku p vrijednost manju od 0,05. U slučaju da je empirijska p vrijednost veća od 0,05 riječ je o srednjoj razini primjene (41\%-60\%), dok u slučaju da je srednja 
vrijednost (medijan) manja od 3 (41-60\%) te se utvrdi empirijska p vrijednost manja od 0,05, postoji niska razina upotrebe.

Tablica 6-20. prikazuje rezultate dobivene pomoću deskriptivne statistike na temelju odgovora na 4. pitanje intervjua s partnerima.

Ispitanici najviše koriste NETCONF na R/S mrežnim uređajima u mrežama davatelja usluga (prosječna vrijednost odgovora 3,33 (66,6\%); std.dev. 1,15). Ispitanici, pak, ne koriste NETCONF u IoT mrežama na što ni jedan ispitanik nije dao odgovor.

Ukupna razina odgovora ispitanika je bilježila prosječnu vrijednost 0,94 s prosječnim odstupanjem od aritmetičke sredine 0,84 što pokazuje vrlo nisku prosječnu implementaciju $(18,8 \%)$ NETCONF standarda u različitim vrstama mreža.

Dodatna zapažanja ispitanika na ovo pitanje su sljedeća:

- najvažnija prednost NETCONF-a je automatizacija. NETCONF je najbolje primjenjiv u SP i tzv. Cloud okruženjima.

- NETCONF se koristi uglavnom na većim mrežama kako bi se pojednostavilo konfiguriranje (automatizacija).

- Ispitanik smatra sljedeće:

- dodatna područja koja nisu navedena u pitanju su Cisco SD-WAN i SDAccess. Cisco SD-WAN i SD-Access konfiguriraju sve servise pomoću NETCONF-a.

- Za sada se rijetko koristi NETCONF, ali Cisco jako promiče tu tehnologiju. Cisco bi htio da CLI postane prošlost, ali s obzirom na naviku današnjih mrežnih inženjera u radu s CLI rješenjem, to ide sporo.

Važno je napomenuti da su inženjeri vrlo često specijalizirani u jednom od dva velika područja primjene R/S uređaja: ISP ili Enterprise. Ispitanici koje rade u ISP području imaju veća znanja i iskustva o NETCONF standardu, dok ispitanici u Enterprise mrežama puno manje (zbog rjeđe primjene i manje potrebe korisnika). 
Peto pitanje intervjua glasi: „Od kojih proizvođača dolaze R/S mrežni uređaji i u kojem postotku su instalirani u mrežama Vaših korisnika?“. Ispitanici su iskazivali mišljenje vrijednostima razreda od 0 do 5 , gdje je 0 označavalo $0 \%$, dok je 5 označavalo $100 \%$.

Testiranje se provodi Wilcoxonovim testom za jedan nezavisan uzorak gdje će se utvrditi postojanje visoke razine upotrebe samo ako je srednja vrijednost (medijan) veća od 3,00 (41\%-60\%) uz empirijsku p vrijednost manju od 0,05. U slučaju da je empirijska p vrijednost veća od 0,05 riječ je o srednjoj razini primjene (41\%-60\%), dok u slučaju da je srednja vrijednost (medijan) manja od 3 (41-60\%) te se utvrdi empirijska p vrijednost manja od 0,05, postoji niska razina upotrebe.

Tablica 6-21. prikazuje rezultate dobivene pomoću deskriptivne statistike na temelju odgovora na 5. pitanje intervjua s partnerima.

Tablica 6-21. Primjena R/S mrežnih uređaja po proizvođačima (intervju partneri)

\begin{tabular}{lcccccccc}
\hline & $\mathrm{N}$ & Prosjek & Std.Dev. & Mod & Medijan & IQR & $\mathrm{Z}$ & $\mathrm{P}^{*}$ \\
\hline Arista & 7 & 0,43 & 0,53 & 0,00 & 0,00 & $(0,00-1,00)$ & 2,43 & 0,015 \\
\hline Cisco Systems & 7 & 4,86 & 0,38 & 5,00 & 5,00 & $(5,00-5,00)$ & 2,53 & 0,011 \\
\hline $\begin{array}{l}\text { Extreme } \\
\text { Networks }\end{array}$ & 7 & 0,57 & 0,98 & 0,00 & 0,00 & $(0,00-2,00)$ & 2,46 & 0,14 \\
\hline F5 & 7 & 1,86 & 1,57 & $\mathrm{n} / \mathrm{a}^{* *}$ & 2,00 & $(0,00-3,00)$ & 1,63 & 0,102 \\
\hline $\begin{array}{l}\text { Hewlett Packard } \\
\text { Enterprise }\end{array}$ & 7 & 1,43 & 0,98 & 1,00 & 1,00 & $(1,00-2,00)$ & 2,23 & 0,026 \\
\hline Huawei & 7 & 1,00 & 1,00 & 1,00 & 1,00 & $(0,00-1,00)$ & 2,27 & 0,023 \\
\hline $\begin{array}{l}\text { Juniper Networks } \\
7\end{array}$ & 0,86 & 1,07 & $\mathrm{n} / \mathrm{a}^{* *}$ & 1,00 & $(0,00-1,00)$ & 2,25 & 0,024 \\
\hline
\end{tabular}

* Wilcoxonov test za jedan nezavisan uzorak

** multimodalna distribucija, mod se ne može prikazati

R/S uređaji koji su instalirani u mrežama korisnika ispitanika najčešće dolaze od proizvođača Cisco (prosječna vrijednost odgovora 4,86 (97,2\%); std.dev.0,38), dok su najrjeđi R/S uređaji od proizvođača Arista (prosječna vrijednost odgovora 0,43 (8,6\%), sa standardnom devijacijom 0,53).

Dodatna zapažanja ispitanika na ovo pitanje su sljedeća: 
- F5 (kod korisnika tog ispitanika) nema R/S uređaje, već ima uglavnom load balancer uređaje ADC (Application Delivery Control).

- Dodatna vrsta uređaja koja je zastupljena kod korisnika je Nokia (bivši Alcatel).

Sedmo pitanje intervjua glasi: „Koji su glavni razlozi implementacije NETCONF standarda na R/S mrežnim uređajima Vaših korisnika?“. Ispitanici su iskazivali mišljenje vrijednostima razreda od 1 do 5 , gdje je 1 označavalo nevažan razlog, a 5 izuzetno važan razlog.

Testiranje se provodi Wilcoxonovim testom za jedan nezavisan uzorak gdje će se utvrditi postojanje važnosti samo ako je srednja vrijednost (medijan) veća od 2,00 uz empirijsku p vrijednost manju od 0,05 . U slučaju da je empirijska $p$ vrijednost veća od 0,05 riječ je o indiferentnom stavu, dok u slučaju da je srednja vrijednost (medijan) manja od 2 te se utvrdi empirijska $p$ vrijednost manja od 0,05 , postoji nevažnost s ponuđenim tvrdnjama.

Tablica 6-22. prikazuje rezultate dobivene pomoću deskriptivne statistike na temelju odgovora na 7. pitanje intervjua s partnerima.

Najvažniji razlozi za implementaciju NETCONF standarda na R/S uređajima korisnika su (prosječna vrijednost odgovora 4,14; std.dev. 1,46):

- omogućavanje programabilnosti (automatiziranja),

- mogućnosti "Backup \& restore" te

- mogućnost istovremenog i koordiniranog konfiguriranja svih ili više uređaja u mreži. Najmanje važni razlozi implementacije prema ispitanicima su:

- razlikovanje između konfiguracijskih i operacijskih podataka (prosječna vrijednost 3,43; std.dev. 1,51) i

- mogućnost parcijalnog konfiguriranja (prosječna vrijednost 3,43; std.dev. 1,27)

Ukupna prosječna razina razloga implementacija NETCONF standarda na R/S uređajima od strane korisnika je 3,79 s prosječnim odstupanjem od aritmetičke sredine 1,33 te je riječ o visokoj razini povećanja $(Z=2,20 ; p=0,028)$. 
Tablica 6-22. Razlozi implementacije NETCONF standarda na R/S uređajima korisnika (intervju partneri)

\begin{tabular}{|c|c|c|c|c|c|c|c|c|}
\hline & $\mathrm{N}$ & Prosjek & $\begin{array}{l}\text { Std. } \\
\text { Dev. }\end{array}$ & Mod & Medijan & IQR & Z & $\mathrm{P}^{*}$ \\
\hline $\begin{array}{l}\text { NETCONF kao standardni } \\
\text { način konfiguracije preko } \\
\text { udaljenog pristupa na IP } \\
\text { adresu uređaja zato jer je za } \\
\text { sve proizvođače ista struktura } \\
\text { komandi i podataka. }\end{array}$ & 7 & 3,57 & 1,40 & $\mathrm{n} / \mathrm{a}^{* *}$ & 4,00 & $(4,00-3,00)$ & 2,05 & 0,040 \\
\hline $\begin{array}{l}\text { NETCONF kao standard jer } \\
\text { omogućava programabilnost } \\
\text { (automatiziranje) koja } \\
\text { značajno smanjuje učestalost } \\
\text { ljudske pogreške. }\end{array}$ & 7 & 4,14 & 1,46 & 5,00 & 5,00 & $(5,00-4,00)$ & 2,24 & 0,025 \\
\hline $\begin{array}{l}\text { NETCONF standard koristi } \\
\text { jasnu razliku u strukturi } \\
\text { između konfiguracijskih i } \\
\text { operacijskih podataka. }\end{array}$ & 7 & 3,43 & 1,51 & $\mathrm{n} / \mathrm{a}^{* *}$ & 4,00 & $(4,00-2,00)$ & 1,90 & 0,057 \\
\hline $\begin{array}{l}\text { Mogućnost parcijalnog } \\
\text { konfiguriranja uređaja } \\
\text { pomoću NETCONF } \\
\text { standarda. }\end{array}$ & 7 & 3,43 & 1,27 & 4,00 & 4,00 & $(4,00-3,00)$ & 2,06 & 0,040 \\
\hline $\begin{array}{l}\text { Mogućnost provjere } \\
\text { konfiguracije prije primjene } \\
\text { kod NETCONF načina } \\
\text { konfiguriranja uređaja. }\end{array}$ & 7 & 3,71 & 1,38 & 4,00 & 4,00 & $(4,00-3,00)$ & 2,14 & 0,033 \\
\hline $\begin{array}{l}\text { Mogućnost zaključavanja } \\
\text { konfiguracijske datoteke koje } \\
\text { nudi NETCONF. }\end{array}$ & 7 & 3,71 & 1,50 & 5,00 & 4,00 & $(4,00-3,00)$ & 2,06 & 0,040 \\
\hline $\begin{array}{l}\text { „Backup \& restore“ } \\
\text { mogućnost koju nudi } \\
\text { NETCONF standard. }\end{array}$ & 7 & 4,14 & 1,46 & 5,00 & 5,00 & $(5,00-4,00)$ & 2,24 & 0,025 \\
\hline $\begin{array}{l}\text { Mogućnost istovremenog i } \\
\text { koordiniranog konfiguriranja } \\
\text { svih ili više uređaja u mreži }\end{array}$ & 7 & 4,14 & 1,46 & 5,00 & 5,00 & $(5,00-4,00)$ & 2,24 & 0,025 \\
\hline Ukupno & 7 & 3,79 & 1,33 & 4,88 & 4,00 & $(3,63-4,88)$ & 2,20 & 0,028 \\
\hline
\end{tabular}

Dodatna zapažanja ispitanika na ovo pitanje su sljedeća:

- NETCONF, za razliku od CLI, pruža puno jednostavniju implementaciju automatizacije zbog već ugrađenih mehanizama (na primjer Rollback, mogućnost konfiguriranja više uređaja, i drugo). 
- Ispitanik navodi da su iz njegovog iskustva najvažniji (a) mogućnost istovremenog i koordiniranog konfiguriranja svih ili više uređaja u mreži i (b) automatizacija. Automatizacija je vrlo bitna jer ako nadzor stalno mora mijenjati konfiguracije uređaja, to ne želi raditi ručno ili kroz predloške (engl. template). Osim ponuđenih, isti ispitanik navodi dvije dodatne mogućnosti:

- Multi-tenant, Zero Touch, automatizacija (segment usmjeravanja kao dio SDNa).

○ brisanje konfiguracije, odnosno uklanjanje konfiguracije (engl. change management): nakon prestanka rada usluge, konfiguraciju na uređajima treba obrisati ili dovesti u prethodno stanje. To je ogromni trenutni operativni problem SP-a, a rješenje je moguće pomoću SDN-a (i NETCONF-a).

- Ispitanik navodi da se NETCONF ne koristi kod njegovih korisnika (koji su svi Enterprise korisnici).

Osmo pitanje intervjua glasi: „Koji su glavni razlozi neimplementacije NETCONF standarda na R/S mrežnim uređajima Vaših korisnika?“. Ispitanici su iskazivali mišljenje vrijednostima razreda od 1 do 5 , gdje je 1 označavalo nevažan razlog, a 5 izuzetno važan razlog.

Testiranje se provodi Wilcoxonovim testom za jedan nezavisan uzorak gdje će se utvrditi postojanje važnosti samo ako je srednja vrijednost (medijan) veća od 2,00 uz empirijsku p vrijednost manju od 0,05. U slučaju da je empirijska $p$ vrijednost veća od 0,05 riječ je o indiferentnom stavu, dok u slučaju da je srednja vrijednost (medijan) manja od 2 te se utvrdi empirijska p vrijednost manja od 0,05 , postoji nevažnost s ponuđenim tvrdnjama.

Tablica 6-23. prikazuje rezultate dobivene pomoću deskriptivne statistike na temelju odgovora na 8 . pitanje intervjua s partnerima.

Glavni razlozi neimplementacije NETCONF standarda na uređajima korisnika su:

- nepoznavanje programskih jezika od strane korisnika (prosječna vrijednost odgovora 4,43; std.dev. 0,53),

- nedostupnost na starijim uređajima i operacijskim sustavima (prosječna vrijednost 4,29; std.dev. 0,76),

- navika korisnika na CLI i OS proizvođača (prosječna vrijednost 4,00; std.dev. 1,00). 
- proizvođači ne podržavaju sve funkcije pa se ne može iskoristiti većina prednosti standarda (prosječna vrijednost 3,71; std.dev. 1,25) i

- $\quad$ strah od novih tehnologija (prosječna vrijednost 3,71; std.dev. 1,11).

\section{Tablica 6-23. Razlozi neimplementacije NETCONF standarda na R/S uređajima korisnika (intervju partneri)}

\begin{tabular}{|c|c|c|c|c|c|c|c|c|}
\hline & $\mathrm{N}$ & Prosjek & $\begin{array}{l}\text { Std. } \\
\text { Dev. }\end{array}$ & Mod & Medijan & IQR & $\mathrm{Z}$ & $\mathrm{P}^{*}$ \\
\hline $\begin{array}{l}\text { 1. CLI proizvođača je } \\
\text { jednostavniji od NETCONF } \\
\text { standarda }\end{array}$ & 7 & 2,57 & 1,27 & 2,00 & 2,00 & $(2,00-3,00)$ & 1,13 & 0,257 \\
\hline $\begin{array}{l}\text { 2. NETCONF nije potreban } \\
\text { jer su krajnji korisnici } \\
\text { navikli na OS i CLI } \\
\text { proizvođača }\end{array}$ & 7 & 4,00 & 1,00 & $\mathrm{n} / \mathrm{a}^{* *}$ & 4,00 & $(4,00-5,00)$ & 2,40 & 0,016 \\
\hline $\begin{array}{l}\text { 3. NETCONF koristi XML } \\
\text { sintaksu koja je redundantna } \\
\text { i opširna što može zamarati } \\
\text { i zbunjivati korisnika. }\end{array}$ & 7 & 2,29 & 1,60 & 1,00 & 2,00 & $(2,00-4,00)$ & 0,41 & 0,680 \\
\hline $\begin{array}{l}\text { 4. Krajnji korisnici koriste } \\
\text { RESTCONF koji je bolje } \\
\text { standardno rješenje od } \\
\text { NETCONF-a }\end{array}$ & 7 & 1,71 & 0,76 & $\mathrm{n} / \mathrm{a}^{* *}$ & 2,00 & $(2,00-2,00)$ & 1,00 & 0,317 \\
\hline $\begin{array}{l}\text { 5. NETCONF nije dostupan } \\
\text { na starijim uređajima i } \\
\text { starijem OS koji ga ne } \\
\text { podržavaju }\end{array}$ & 7 & 4,29 & 0,76 & $\mathrm{n} / \mathrm{a}^{* *}$ & 4,00 & $(4,00-5,00)$ & 2,40 & 0,016 \\
\hline $\begin{array}{l}\text { 6. Nepoznavanje } \\
\text { programskih jezika od } \\
\text { strane korisnika }\end{array}$ & 7 & 4,43 & 0,53 & 4,00 & 4,00 & $(4,00-5,00)$ & 2,43 & 0,015 \\
\hline $\begin{array}{l}\text { 7. Proizvođači ne } \\
\text { podržavaju sve funkcije } \\
\text { (capability), na primjer } \\
\text { „Candidate“, „Startup“, } \\
\text { „Validate“, „Rollback-on- } \\
\text { Error“ i druge pa se ne } \\
\text { može iskoristiti većina } \\
\text { prednosti standarda. }\end{array}$ & 7 & 3,71 & 1,25 & 4,00 & 4,00 & $(4,00-5,00)$ & 2,07 & 0,038 \\
\hline $\begin{array}{l}\text { 8. Potrebni dodatni alati (na } \\
\text { primjer NETCONF browser } \\
\text { ili aplikacija u Pythonu) }\end{array}$ & 7 & 3,00 & 1,29 & 4,00 & 4,00 & $(4,00-4,00)$ & 1,84 & 0,066 \\
\hline $\begin{array}{l}\text { 9. Strah od novih } \\
\text { tehnologija }\end{array}$ & 7 & 3,71 & 1,11 & $\mathrm{n} / \mathrm{a}^{* *}$ & 4,00 & $(4,00-5,00)$ & 2,22 & 0,026 \\
\hline
\end{tabular}

* Wilcoxonov test za jedan nezavisan uzorak

** multimodalna distribucija, mod se ne može prikazati 
Najmanje važan razlog neimplementacije NETCONF standarda na uređajima korisnika je da krajnji korisnici koriste RESTCONF kao bolje standardno rješenje od NETCONF-a (prosječna vrijednost odgovora 1,71; std.dev. 0,76).

Dodatna zapažanja ispitanika na ovo pitanje su sljedeća:

- korisnici su naučeni na CLI, a i Enterprise okruženja ne zahtijevaju toliku automatizaciju.

- Ispitanik smatra da korisnici uglavnom ne implementiraju NETCONF zbog::

- nekompatibilnosti svih uređaja s NETCONF standardom (stariji uređaji ne podržavaju NETCONF, neki proizvođači također) te

○ zbog straha od automatizacije, makar je ona (ukoliko je kvalitetno implementirana) sigurnija (nego kada čovjek konfigurira) zbog mogućnosti ljudske greške. Strah od automatizacije dolazi zato što korisnici imaju osjećaj da nemaju kontrolu nad uređajima.

- Navika na CLI način konfiguracije i nepoznavanje NETCONF standarda glavni su razlozi slabe implementacije.

- Jedan od ispitanika navodi sljedeće:

- vrlo je važan faktor navika korisnika na CLI;

○ korisnici razumiju CLI, ali još ne razumiju NETCONF;

○ vrlo često prvo pitanje tehničkih direktora je: "Što ću sa svojim inženjerima ako će stroj konfigurirati servise?".

- Korisnici nisu upoznati s prednostima NETCONF-a.

\subsubsection{Poznavanje NETCONF standarda od strane korisnika u Hrvatskoj}

U ovom poglavlju se razmatra poznavanje mogućnosti NETCONF standarda i njegove primjene.

U dvadesetom pitanju su ispitanici iskazivali svoje mišljenje o znanju svojih korisnika o NETCONF standardu. Ispitanici su davali svoje ocjene znanja korisnika od 1 (nedovoljno) do 5 (izvrsno). 
Testiranje se provodi Wilcoxonovim testom za jedan nezavisan uzorak gdje će se utvrditi postojanje prolazne ocjene na ponuđene tvrdnje samo ako je srednja vrijednost (medijan) veća od 1,00 uz empirijsku p vrijednost manju od 0,05. U slučaju da je empirijska p vrijednost veća od 0,05 riječ je o neprolaznoj ocjeni (nedovoljan).

Tablica 6-24. prikazuje rezultate dobivene pomoću deskriptivne statistike na temelju odgovora na 20. pitanje intervjua s partnerima.

Tablica 6-24. Znanje korisnika o NETCONF standardu (intervju partneri)

\begin{tabular}{lcccccccc}
\hline & $\mathrm{N}$ & Prosjek & $\begin{array}{c}\text { Std. } \\
\text { Dev. }\end{array}$ & Mod & Medijan & IQR & Z & P* \\
\hline $\begin{array}{l}\text { 1. Savladana teoretska } \\
\text { znanja o radu NETCONF } \\
\text { protokola i razumiju } \\
\text { njegove karakteristike i } \\
\text { prednosti }\end{array}$ & 7 & 1,14 & 0,38 & 1,00 & 1,00 & $(1,00-1,00)$ & 1,00 & 0,317 \\
\hline $\begin{array}{l}\text { 2. Savladana praktična } \\
\text { znanja NETCONF } \\
\text { protokola i koriste ga s } \\
\text { lakoćom }\end{array}$ & 7 & 1,00 & 0,00 & 1,00 & 1,00 & $(1,00-1,00)$ & 0,00 & $>0,999$ \\
\hline $\begin{array}{l}\text { 3. Poznavanje prednosti } \\
\text { NETCONF protokola u } \\
\text { povećanju raspoloživosti } \\
\text { mrežnih uređaja }\end{array}$ & 7 & 2,00 & 1,53 & 1,00 & 1,00 & $(1,00-3,00)$ & 1,60 & 0,109 \\
\hline
\end{tabular}

* Wilcoxon test za jedan nezavisan uzorak

Ispitanici smatraju da njihovi korisnici imaju izrazito nisku razinu znanja o NETCONF standardu što je vidljivo u prosječnim ocjenama za pojedine tvrdnje koje se odnose na znanje.

Najveću razinu znanja korisnici imaju u poznavanju prednosti NETCONF protokola $\mathrm{u}$ povećanju raspoloživosti mrežnih uređaja (prosječna ocjena 2,00; std.dev. 1,53).

Ispitanici (partneri) smatraju da njihovi korisnici imaju izuzetno nisko znanje o NETCONF standardu.

Dodatna zapažanja ispitanika na ovo pitanje su sljedeća:

- ispitanik smatra da:

○ je dužnost partnera promovirati NETCONF standard kod njihovih korisnika, što ne ide jednostavno zbog njihove navike na CLI; 
○ neki (pogotovo SP) korisnici su već dobro upoznati s NETCONF standardom, ali se boje implementacije (smatraju da gube kontrolu, a u stvarnosti dobivaju puno bolju kontrolu).

- Drugi ispitanik smatra da korisnici imaju jako malo teoretskog i praktičnog znanja, odnosno premalo za produkcijsko okruženje.

U 21. pitanju su ispitanici iskazivali svoje mišljenje o teoretskom znanju svojih korisnika o NETCONF standardu po pojedinim njegovim svojstvima. Ispitanici su davali svoje ocjene znanja korisnika od 1 (nedovoljno) do 5 (izvrsno).

Tablica 6-25. Teoretska znanja korisnika o NETCONF standardu (intervju partneri)

\begin{tabular}{|c|c|c|c|c|c|c|c|c|}
\hline & $\mathrm{N}$ & Prosjek & $\begin{array}{l}\text { Std. } \\
\text { Dev. }\end{array}$ & Mod & Medijan & IQR & $\mathrm{Z}$ & $\mathrm{P}^{*}$ \\
\hline $\begin{array}{l}\text { NETCONF kao standardni } \\
\text { način konfiguracije preko } \\
\text { udaljenog pristupa na IP } \\
\text { adresu uređaja }\end{array}$ & 7 & 1,86 & 1,46 & 1,00 & 1,00 & $(1,00-2,00)$ & 1,63 & 0,102 \\
\hline $\begin{array}{l}\text { NETCONF kao standard } \\
\text { koji omogućava } \\
\text { programabilnost } \\
\text { (automatiziranje). }\end{array}$ & 7 & 2,00 & 1,53 & 1,00 & 1,00 & $(1,00-3,00)$ & 1,60 & 0,109 \\
\hline $\begin{array}{l}\text { NETCONF standard koristi } \\
\text { jasnu razliku u strukturi } \\
\text { između konfiguracijskih i } \\
\text { operacijskih podataka. }\end{array}$ & 7 & 1,71 & 1,50 & 1,00 & 1,00 & $(1,00-2,00)$ & 1,34 & 0,180 \\
\hline $\begin{array}{l}\text { Mogućnost parcijalnog } \\
\text { konfiguriranja uređaja } \\
\text { pomoću NETCONF } \\
\text { standarda. }\end{array}$ & 7 & 1,71 & 1,50 & 1,00 & 1,00 & $(1,00-2,00)$ & 1,34 & 0,180 \\
\hline $\begin{array}{l}\text { Mogućnost provjere } \\
\text { konfiguracije prije primjene } \\
\text { kod NETCONF načina } \\
\text { konfiguriranja uređaja. }\end{array}$ & 7 & 1,57 & 1,51 & 1,00 & 1,00 & $(1,00-1,00)$ & 1,00 & 0,317 \\
\hline $\begin{array}{l}\text { Mogućnost zaključavanja } \\
\text { konfiguracijske datoteke } \\
\text { koje nudi NETCONF. }\end{array}$ & 7 & 1,57 & 1,51 & 1,00 & 1,00 & $(1,00-1,00)$ & 1,00 & 0,317 \\
\hline $\begin{array}{l}\text { „Backup \& restore“ } \\
\text { mogućnost koju nudi } \\
\text { NETCONF standard. }\end{array}$ & 7 & 1,71 & 1,50 & 1,00 & 1,00 & $(1,00-2,00)$ & 1,34 & 0,180 \\
\hline $\begin{array}{l}\text { Mogućnost istovremenog i } \\
\text { koordiniranog konfiguriranja } \\
\text { svih ili više uređaja u mreži. }\end{array}$ & 7 & 1,86 & 1,46 & 1,00 & 1,00 & $(1,00-2,00)$ & 1,63 & 0,102 \\
\hline Ukupno & 7 & 1,75 & 1,46 & 1,00 & 1,13 & $(1,00-1,63)$ & 1,83 & 0,068 \\
\hline
\end{tabular}

* Wilcoxonov test za jedan nezavisan uzorak 
Testiranje se provodi Wilcoxonovim testom za jedan nezavisan uzorak gdje će se utvrditi postojanje prolazne ocjene na ponuđene tvrdnje samo ako je srednja vrijednost (medijan) veća od 1,00 uz empirijsku p vrijednost manju od 0,05 . U slučaju da je empirijska p vrijednost veća od 0,05 riječ je o neprolaznoj ocjeni (nedovoljan).

Tablica 6-25. prikazuje rezultate dobivene pomoću deskriptivne statistike na temelju odgovora na 21. pitanje intervjua s partnerima.

Teoretska znanja korisnika o NETCONF standardu po pojedinim mogućnostima su izrazito niska.

Korisnici su najviše upoznati s tim da NETCONF standard omogućava programabilnost (automatiziranje) (prosječna ocjena 2,00; std.dev. 1,53).

Prosječna razina teorijskog znanja korisnika o NETCONF standardu po pojedinim njegovim mogućnostima iznosi 1,75 s prosječnim odstupanjem od aritmetičke sredine 1,46. Testiranjem nije utvrđeno postojanje statistički značajne razlike u odnosu na vrijednost 1 (nedovoljno; $\mathrm{Z}=1,83 ; \mathrm{p}=0,068)$.

Dodatna zapažanja ispitanika na ovo pitanje su sljedeća:

- u velikim organizacijama gdje se preko 100 ljudi bavi mrežom, NETCONF koriste možda njih 3 do 4;

- korisnici ne poznaju NETCONF tehnologiju jer proizvođači ne inzistiraju na primjeni, a onda ni integratori ne educiraju ("guraju") korisnike;

- SP korisnici imaju neka znanja o NETCONF standardu i njegovoj primjeni, dok Enterprise korisnici izuzetno mala.

U 22. pitanju su ispitanici iskazivali svoje mišljenje o praktičnom znanju svojih korisnika o NETCONF standardu po pojedinim njegovim svojstvima. Ispitanici su davali svoje ocjene znanja korisnika od 1 (nedovoljno) do 5 (izvrsno).

Testiranje se provodi Wilcoxonovim testom za jedan nezavisan uzorak gdje će se utvrditi postojanje prolazne ocjene na ponuđene tvrdnje samo ako je srednja vrijednost (medijan) veća 
od 1,00 uz empirijsku p vrijednost manju od 0,05. U slučaju da je empirijska p vrijednost veća od 0,05 riječ je o neprolaznoj ocjeni (nedovoljan).

Tablica 6-26. prikazuje rezultate dobivene na temelju odgovora na 22. pitanje intervjua s partnerima.

\section{Tablica 6-26. Praktična znanja korisnika o NETCONF standardu (intervju partneri)}

\begin{tabular}{|c|c|c|c|c|c|c|c|c|}
\hline & $\mathrm{N}$ & Prosjek & $\begin{array}{l}\text { Std. } \\
\text { Dev. }\end{array}$ & Mod & Medijan & IQR & $\mathrm{Z}$ & $\mathrm{P}^{*}$ \\
\hline $\begin{array}{l}\text { NETCONF kao standardni } \\
\text { način konfiguracije preko } \\
\text { udaljenog pristupa na IP } \\
\text { adresu uređaja }\end{array}$ & 7 & 1,29 & 0,49 & 1,00 & 1,00 & $(1,00-2,00)$ & 1,41 & 0,157 \\
\hline $\begin{array}{l}\text { NETCONF kao standard } \\
\text { koji omogućava } \\
\text { programabilnost } \\
\text { (automatiziranje). }\end{array}$ & 7 & 1,29 & 0,49 & 1,00 & 1,00 & $(1,00-2,00)$ & 1,41 & 0,157 \\
\hline $\begin{array}{l}\text { NETCONF standard } \\
\text { koristi jasnu razliku u } \\
\text { strukturi između } \\
\text { konfiguracijskih i } \\
\text { operacijskih podataka. }\end{array}$ & 7 & 1,14 & 0,38 & 1,00 & 1,00 & $(1,00-1,00)$ & 1,00 & 0,317 \\
\hline $\begin{array}{l}\text { Mogućnost parcijalnog } \\
\text { konfiguriranja uređaja } \\
\text { pomoću NETCONF } \\
\text { standarda. }\end{array}$ & 7 & 1,29 & 0,49 & 1,00 & 1,00 & $(1,00-2,00)$ & 1,41 & 0,157 \\
\hline $\begin{array}{l}\text { Mogućnost provjere } \\
\text { konfiguracije prije } \\
\text { primjene kod NETCONF } \\
\text { načina konfiguriranja } \\
\text { uređaja. }\end{array}$ & 7 & 1,29 & 0,76 & 1,00 & 1,00 & $(1,00-1,00)$ & 1,00 & 0,317 \\
\hline $\begin{array}{l}\text { Mogućnost zaključavanja } \\
\text { konfiguracijske datoteke } \\
\text { koje nudi NETCONF. }\end{array}$ & 7 & 1,29 & 0,76 & 1,00 & 1,00 & $(1,00-1,00)$ & 1,00 & 0,317 \\
\hline $\begin{array}{l}\text { „Backup \& restore“ } \\
\text { mogućnost koju nudi } \\
\text { NETCONF standard. }\end{array}$ & 7 & 1,29 & 0,76 & 1,00 & 1,00 & $(1,00-1,00)$ & 1,00 & 0,317 \\
\hline $\begin{array}{l}\text { Mogućnost istovremenog i } \\
\text { koordiniranog } \\
\text { konfiguriranja svih ili više } \\
\text { uređaja u mreži. }\end{array}$ & 7 & 1,43 & 0,79 & 1,00 & 1,00 & $(1,00-2,00)$ & 1,34 & 0,180 \\
\hline Ukupno & 7 & 1,29 & 0,55 & 1,00 & 1,00 & $(1,00-1,38)$ & 1,60 & 0,109 \\
\hline
\end{tabular}

Praktična znanja korisnika o NETCONF standardu po pojedinim mogućnostima su izrazito niska. 
Korisnici su najviše upoznati $\mathrm{s}$ tim da NETOCONF ima mogućnost istovremenog $\mathrm{i}$ koordiniranog konfiguriranja svih ili više uređaja u mreži (prosječna ocjena 1,43; std. 0,79).

Prosječna razina praktičnog znanja korisnika o NETCONF standardu po pojedinim mogućnostima je 1,29 s prosječnim odstupanjem od aritmetičke sredine 0,55 . Testiranjem nije utvrđeno postojanje statistički značajne razlike u odnosu na vrijednost 1 (nedovoljno; $Z=1,60$; $\mathrm{p}=0,109)$.

Dodatna zapažanja ispitanika na ovo pitanje su sljedeća:

- Premali se broj inženjera kod korisnika služi NETCONF-om, a oni koji ga koriste i razumiju njegove prednosti.

\subsubsection{NETCONF i povećanje raspoloživosti R/S uređaja}

$\mathrm{U}$ ovom poglavlju se razmatra povećanje raspoloživosti mrežnih $\mathrm{R} / \mathrm{S}$ uređaja pomoću NETCONF standarda (u odnosu na nestandardne metode konfiguriranja).

Treće pitanje intervjua glasi: "Povećava li NETCONF standard raspoloživost mrežnih uređaja u odnosu na nestandardne metode konfiguriranja (CLI) koje koriste proizvođači sa svojim operacijskim sustavima (na primjer JUNOS, IOS, EXOS, itd.) i na koji način?"

Ispitanici su iskazivali stupanj slaganja na ponuđene tvrdnje ocjenama od 1 do 5 , gdje je 1 označavala izrazito neslaganje s tvrdnjom, dok je 5 označavala izrazito slaganje s tvrdnjom. Kao granična vrijednost se koristi vrijednost 3,00 gdje u slučaju da vrijednosti slaganja prelaze graničnu vrijednost 3,00 postoji slaganje s ponuđenim tvrdnjama, dok vrijednosti niže od granične vrijednosti 3,00 upućuju na indiferentnost, dok vrijednosti manje od 3 upućuju na neslaganje s ponuđenim tvrdnjama. Testiranje se provodi Wilcoxonovim testom za jedan nezavisan uzorak gdje će se utvrditi postojanje slaganja s ponuđenim tvrdnjama samo ako je srednja vrijednost (medijan) veća od 3,00 uz empirijsku p vrijednost manju od 0,05. U slučaju da je empirijska $p$ vrijednost veća od 0,05 riječ je o indiferentnom stavu, dok u slučaju da je srednja vrijednost (medijan) manja od 3 te se utvrdi empirijska p vrijednost manja od 0,05 postoji neslaganje s ponuđenim tvrdnjama.

Tablica 6-27. prikazuje odgovore na 3. pitanje pomoću deskriptivne statistike. 
Tablica 6-27. Povećanje raspoloživosti pomoću NETCONF standarda (intervju partneri)

\begin{tabular}{|c|c|c|c|c|c|c|c|c|}
\hline & $\mathbf{N}$ & Prosjek & $\begin{array}{l}\text { Std. } \\
\text { Dev. }\end{array}$ & Mod & Medijan & IQR & $\mathbf{Z}$ & $\mathbf{P}^{*}$ \\
\hline $\begin{array}{l}\text { NETCONF kao standardni način } \\
\text { konfiguracije preko udaljenog } \\
\text { pristupa na IP adresu uređaja } \\
\text { povećava raspoloživost mrežnih } \\
\text { uređaja zato jer je za sve } \\
\text { proizvođače ista struktura komandi } \\
\text { i podataka. }\end{array}$ & 7 & 4,57 & 0,53 & 5,00 & 5,00 & $(4,00-4,00)$ & 2,43 & 0,015 \\
\hline $\begin{array}{l}\text { NETCONF kao standard povećava } \\
\text { raspoloživost jer omogućava } \\
\text { programabilnost (automatiziranje) } \\
\text { konfiguriranja mrežnih uređaja } \\
\text { koja značajno smanjuje učestalost } \\
\text { ljudske pogreške. }\end{array}$ & 7 & 5,00 & 0,00 & 5,00 & 5,00 & $(5,00-5,00)$ & 2,65 & 0,008 \\
\hline $\begin{array}{l}\text { NETCONF standard povećava } \\
\text { raspoloživost mrežnih uređaja zbog } \\
\text { toga što koristi jasnu razliku u } \\
\text { strukturi između konfiguracijskih i } \\
\text { operacijskih podataka. }\end{array}$ & 7 & 4,00 & 0,82 & 4,00 & 4,00 & $(3,00-3,00)$ & 2,07 & 0,038 \\
\hline $\begin{array}{l}\text { Mogućnost parcijalnog } \\
\text { konfiguriranja uređaja pomoću } \\
\text { NETCONF standarda povećava } \\
\text { raspoloživost mrežnih uređaja. }\end{array}$ & 7 & 4,86 & 0,38 & 5,00 & 5,00 & $(5,00-5,00)$ & 2,53 & 0,011 \\
\hline $\begin{array}{l}\text { Mogućnost provjere konfiguracije } \\
\text { prije primjene kod NETCONF } \\
\text { načina konfiguriranja uređaja } \\
\text { povećava raspoloživost mrežnih } \\
\text { uređaja. }\end{array}$ & 7 & 4,86 & 0,38 & 5,00 & 5,00 & $(5,00-5,00)$ & 2,53 & 0,011 \\
\hline $\begin{array}{l}\text { Mogućnost zaključavanja } \\
\text { konfiguracijske datoteke koje nudi } \\
\text { NETCONF povećava raspoloživost } \\
\text { mrežnih uređaja. }\end{array}$ & 7 & 4,71 & 0,49 & 5,00 & 5,00 & $(4,00-4,00)$ & 2,46 & 0,014 \\
\hline $\begin{array}{l}\text { „Backup \& restore“ mogućnost } \\
\text { koju nudi NETCONF standard } \\
\text { povećava raspoloživost mrežnih } \\
\text { uređaja }\end{array}$ & 7 & 4,86 & 0,38 & 5,00 & 5,00 & $(5,00-5,00)$ & 2,53 & 0,011 \\
\hline $\begin{array}{l}\text { Mogućnost istovremenog i } \\
\text { koordiniranog konfiguriranja svih } \\
\text { ili više uređaja u mreži koje nudi } \\
\text { NETCONF povećava raspoloživost } \\
\text { mrežnih uređaja }\end{array}$ & 7 & 4,71 & 0,49 & 5,00 & 5,00 & $(4,00-4,00)$ & 2,46 & 0,014 \\
\hline Ukupno & 7 & 4,70 & 0,30 & $\mathrm{n} / \mathrm{a}$ & 4,75 & $(4,50-4,88)$ & 2,38 & 0,018 \\
\hline
\end{tabular}

*Wilcoxonov test za jedan nezavisan uzorak

Ispitanici su najveću razinu slaganja iskazali na tvrdnju NETCONF kao standard povećava raspoloživost jer omogućava programabilnost (automatiziranje) (prosječna ocjena 5,00; std.dev. 0,00), dok su najnižu razinu slaganja iskazali na tvrdnju NETCONF standard 
povećava raspoloživost mrežnih uređaja zbog toga što koristi jasnu razliku u strukturi između konfiguracijskih i operacijskih podataka (prosječna ocjena 4,00; std.dev. 0,82).

Ukupna razina povećanja raspoloživosti mrežnog uređaja u odnosu na nestandardne metode konfiguriranja (CLI) primjenom različitih svojstava NETCONF standarda je 4,70 $\mathrm{s}$ prosječnim odstupanjem od aritmetičke sredine 0,30 te se može donijeti zaključak da je riječ o visokoj razini povećanja $(Z=2,38 ; p=0,018)$.

Dodatna zapažanja ispitanika na ovo pitanje su sljedeća:

- „atomnost“ konfiguracije (transaction-based karakteristika) je najvažnije svojstvo NETCONF protokola. Protokol dovodi sistem u definirano (željeno) stanje ili ga vraća u prethodno stanje. Ne može se dogoditi polovična konfiguracija R/S uređaja. I zbog toga je NETCONF izvrsno rješenje.

Jedanaesto pitanje intervjua glasi: „Koji postotak po vrstama mreža Vaših korisnika po Vašem mišljenju zahtijeva raspoloživost jednaku ili veću od „tri devetke“ ( $\geq$ raspoloživosti od 99,9\%), odnosno vrijeme zastoja manje od 8,76 sati godišnje ili 43,2 minute mjesečno ili 10,1 minutu tjedno)?““. Mišljenje su vrednovali vrijednostima od 0 do 5 , gdje je 0 označavala $0 \%$, dok je vrijednost 5 ukazivala na potpuno zahtijevanje visoko raspoložive mreže ( $100 \%)$.

Testiranje se provodi Wilcoxonovim testom za jedan nezavisan uzorak gdje će se utvrditi postojanje visoke razine upotrebe samo ako je srednja vrijednost (medijan) veća od 3,00 (41\%-60\%) uz empirijsku p vrijednost manju od 0,05. U slučaju da je empirijska p vrijednost veća od 0,05 riječ je o srednjoj razini primjene (41\%-60\%), dok u slučaju da je srednja vrijednost (medijan) manja od 3 (41-60\%) te se utvrdi empirijska p vrijednost manja od 0,05, postoji niska razina upotrebe.

Tablica 6-28. prikazuje rezultate dobivene na temelju odgovora na 11. pitanje intervjua s partnerima.

Najvišu traženu raspoloživost mreža prema mišljenju ispitanika zahtijevaju podatkovni centri (prosječna vrijednost mišljenja 5,00 (100\%); std.dev. 0,00), dok po mišljenju ispitanika najnižu raspoloživost zahtijevaju rezidencijalni korisnici (prosječna vrijednost mišljenja 2,17 $(43,4 \%)$; std. dev.1,33). 
Tablica 6-28. Visoko raspoložive mreže korisnika (intervju partneri)

\begin{tabular}{|c|c|c|c|c|c|c|c|c|}
\hline & $\mathrm{N}$ & Prosjek & Std.Dev. & Mod & Medijan & IQR & $\mathrm{z}$ & $\mathrm{P}^{*}$ \\
\hline $\begin{array}{l}\text { Financijske ustanove } \\
\text { (banke i slično) }\end{array}$ & 7 & 4,86 & 0,38 & 5,00 & 5,00 & $(5,00-5,00)$ & 2,53 & 0,011 \\
\hline Podatkovni centri & 7 & 5,00 & 0,00 & 5,00 & 5,00 & $(5,00-5,00)$ & 2,65 & 0,008 \\
\hline $\begin{array}{l}\text { Internet davatelji usluga } \\
\text { (na primjer T-com, A1, } \\
\text {...) }\end{array}$ & 7 & 4,71 & 0,76 & 5,00 & 5,00 & $(5,00-5,00)$ & 2,45 & 0,014 \\
\hline $\begin{array}{l}\text { Medijske ustanove (TV, } \\
\text { radio, časopisi, ....) }\end{array}$ & 6 & 4,67 & 0,52 & 5,00 & 5,00 & $(4,00-5,00)$ & 2,27 & 0,023 \\
\hline $\begin{array}{l}\text { Edukacijske ustanove } \\
\text { (škole, fakulteti, ...) }\end{array}$ & 7 & 2,86 & 1,46 & 4,00 & 3,00 & $(2,00-4,00)$ & 0,00 & $>0,999$ \\
\hline $\begin{array}{l}\text { Trgovine (trgovački lanci, } \\
\text { trgovački centri, ...) }\end{array}$ & 7 & 4,43 & 0,79 & 5,00 & 5,00 & $(4,00-5,00)$ & 2,27 & 0,023 \\
\hline $\begin{array}{l}\text { On-line trgovine (e-kupi, } \\
\text { „ulaznice.hr“, ...) }\end{array}$ & 6 & 4,83 & 0,41 & 5,00 & 5,00 & $(5,00-5,00)$ & 2,33 & 0,020 \\
\hline $\begin{array}{l}\text { Transport (zračne luke, } \\
\text { željeznica, ...) }\end{array}$ & 6 & 4,17 & 1,60 & 5,00 & 5,00 & $(4,00-5,00)$ & 1,44 & 0,149 \\
\hline $\begin{array}{l}\text { Zdravstvene ustanove } \\
\text { (bolnice, ambulante, ...) }\end{array}$ & 7 & 4,00 & 1,53 & 5,00 & 5,00 & $(3,00-5,00)$ & 1,44 & 0,149 \\
\hline $\begin{array}{l}\text { Državne ustanove (vojska, } \\
\text { policija }, . . .)\end{array}$ & 7 & 4,00 & 1,15 & 5,00 & 4,00 & $(3,00-5,00)$ & 1,82 & 0,068 \\
\hline $\begin{array}{l}\text { Rezidencijalni (kućni) } \\
\text { korisnici }\end{array}$ & 6 & 2,17 & 1,33 & 3,00 & 3,00 & $(1,00-3,00)$ & 1,34 & 0,180 \\
\hline $\begin{array}{l}\text { Mala i srednja poduzeća } \\
\text { (Small Medium Business - } \\
\text { SMB) }\end{array}$ & 7 & 2,71 & 1,25 & 3,00 & 3,00 & $(1,00-4,00)$ & 0,74 & 0,458 \\
\hline
\end{tabular}

* Wilcoxon test za jedan nezavisan uzorak

Dodatna zapažanja ispitanika na ovo pitanje su sljedeća:

- ispitanik dodatno navodi poduzeća od izrazite važnosti (po EU regulativi) koja moraju imati visoko raspoložive mreže (ocjena 5 u skali).

Na dvanaesto pitanje su ispitanici iskazivali svoje mišljenje o visoko raspoloživim mrežama (raspoloživost $\geq 99,9 \%$ ) njihovih korisnika i NETCONF standardu. Mišljenje su vrednovali vrijednostima od 0 do 5 gdje je 0 označavala $0 \%$, dok je vrijednost 5 ukazivala na potpuno zahtijevanje visoko raspoložive mreže (100\%).

Testiranje se provodi Wilcoxonovim testom za jedan nezavisan uzorak gdje će se utvrditi postojanje visoke razine upotrebe samo ako je srednja vrijednost (medijan) veća od 3,00 (41\%-60\%) uz empirijsku p vrijednost manju od 0,05. U slučaju da je empirijska p vrijednost veća od 0,05 riječ je o srednjoj razini primjene (41\%-60\%), dok u slučaju da je srednja 
vrijednost (medijan) manja od 3 (41-60\%) te se utvrdi empirijska p vrijednost manja od 0,05, postoji niska razina upotrebe.

Tablica 6-29. prikazuje rezultate dobivene na temelju odgovora na 12. pitanje intervjua s partnerima.

Tablica 6-29. Visoko raspoložive mreže korisnika i NETCONF (intervju partneri)

\begin{tabular}{|c|c|c|c|c|c|c|c|c|}
\hline & $\mathrm{N}$ & Prosjek & $\begin{array}{c}\text { Std. } \\
\text { Dev. }\end{array}$ & Mod & Medijan & IQR & $\mathrm{Z}$ & $\mathrm{P}^{*}$ \\
\hline $\begin{array}{l}\text { 1. Koji postotak Vaših } \\
\text { korisnika ima visoko } \\
\text { raspoložive mreže (jednaku } \\
\text { ili veću od „tri devetke“)? }\end{array}$ & 7 & 4,00 & 1,00 & 4,00 & 4,00 & $(4,00-5,00)$ & 1,93 & 0,053 \\
\hline $\begin{array}{l}\text { 2. Koji postotak R/S uređaja } \\
\text { Vaših korisnika koristi } \\
\text { NETCONF za } \\
\text { konfiguriranje u mrežama } \\
\text { visoke raspoloživosti } \\
\text { (jednaku ili veću od „tri } \\
\text { devetke“)? }\end{array}$ & 7 & 0,71 & 0,49 & 1,00 & 1,00 & $(0,00-1,00)$ & 2,46 & 0,014 \\
\hline
\end{tabular}

* Wilcoxonov test za jedan nezavisan uzorak

Prema ispitanicima 80\% njihovih korisnika (prosječna vrijednost odgovora 4,00; std.dev. 1,00) ima visoko raspoloživu mrežu (raspoloživost $\geq 99,9 \%$ ).

NETCONF u tim visoko raspoloživim mrežama koristi 14,6\% (prosječna vrijednost odgovora 0,73; std.dev. 0,49) njihovih korisnika, što je vrlo nizak iznos.

Dodatna zapažanja ispitanika na ovo pitanje su sljedeća:

- za sada većina primjena NETCONF-a koje je ispitanik vidio bile su u laboratorijskim uvjetima.

- Drugi ispitanik navodi da su rijetko imali korisnike koji koriste NETCONF, ali standard se polako probija na tržište. Korisnici ispitanika su Enterprise korisnici.

- Treći ispitanik navodi da su po njegovom iskustvu korisnici koji primjenjuju NETCONf standard uglavnom ISP korisnici.

Devetnaesto pitanje intervjua glasi: "Molimo Vas da izložite svoja dodatna zapažanja i mišljenje vezanu uz primjenu NETCONF standarda i povećanje raspoloživosti mrežnih 
uređaja, a koja nisu obrađena u prethodnim pitanjima:". Dobivena su sljedeća mišljenja i prijedlozi ispitanika:

- veća primjena NETCONF-a dolazi i kroz proprietary sustave za konfiguraciju i nadzor mrežne opreme za specifična rješenja (kao na primjer SD-WAN, SD-LAN i sl.) koji mogu u potpunosti iskoristiti prednosti NETCONF-a.

- Visoka raspoloživost je izuzetno važna jer se u procesu konfiguracije gotovo isključuje ljudska greška koja je najveći uzrok prekida rada sustava, odmah iza fizičkog kvara veza. Ljudska greška obično uzrokuje puno teže prekide, pogotovo danas kada je teško i skupo naći kvalificirani kadar.

\subsubsection{Karakteristike i povećanje primjene NETCONF standarda}

U ovom poglavlju se razmatraju ostale teme o NETCONF standardu (karakteristike, budući razvoj i primjena, i drugo) koje nisu pokrivene u prethodnim pitanjima intervjua s partnerom proizvođača.

Deveto pitanje intervjua glasi: „Molim Vas da izrazite svoje mišljenje o nedostacima NETCONF standarda.“. Ispitanici su iskazivali ocjenama od 1 do 5 svoje mišljenje o nedostacima NETCONF standardima. Vrijednost 1 je označavala izrazito neslaganje $s$ tvrdnjom, dok je vrijednost 5 označavala izrazito slaganje s tvrdnjom.

Testiranje se provodi Wilcoxonovim testom za jedan nezavisan uzorak gdje će se utvrditi postojanje slaganja s ponuđenim tvrdnjama samo ako je srednja vrijednost (medijan) veća od 3,00 uz empirijsku p vrijednost manju od 0,05. U slučaju da je empirijska p vrijednost veća od 0,05 riječ je o indiferentnom stavu, dok u slučaju da je srednja vrijednost (medijan) manja od 3 te se utvrdi empirijska $\mathrm{p}$ vrijednost manja od 0,05 , postoji neslaganje s ponuđenim tvrdnjama.

Tablica 6-30. prikazuje rezultate dobivene na temelju odgovora na 9. pitanje intervjua s partnerima.

Prema mišljenju ispitanika glavni nedostatak NETCONF standarda je taj što je za korištenje NETCONF protokola potrebno poznavati programske jezike (prosječna vrijednost odgovora 3,71; std.dev.0,95), dok se najmanje slažu da je nedostatak mogućnost korištenja nestandardnih modela podataka (prosječna vrijednost odgovora 2,71 ; std.dev.0,95). 
Tablica 6-30. Nedostatci NETCONF standarda (intervju partneri)

\begin{tabular}{|c|c|c|c|c|c|c|c|c|}
\hline & $\mathrm{N}$ & Prosjek & $\begin{array}{l}\text { Std. } \\
\text { Dev. }\end{array}$ & Mod & Medijan & IQR & $\mathrm{Z}$ & $\mathrm{P}^{*}$ \\
\hline $\begin{array}{l}\text { 1. NETCONF standard daje } \\
\text { mogućnost proizvođačima da ne } \\
\text { podržavaju sve funkcije } \\
\text { (capability), na primjer } \\
\text { "Candidate“, „Startup““, „Validate“, } \\
\text { „Rollback-on-Error“i i druge pa se } \\
\text { ne mogu iskoristiti većina prednosti } \\
\text { standarda. }\end{array}$ & 7 & 3,43 & 1,27 & 4,00 & 4,00 & $\begin{array}{c}(3,00- \\
4,00)\end{array}$ & 0,83 & 0,408 \\
\hline $\begin{array}{l}\text { 2. NETCONF standard daje } \\
\text { mogućnost da se koriste } \\
\text { nestandardni (proprietary) modeli } \\
\text { podataka (data models). }\end{array}$ & 7 & 3,14 & 1,07 & $\mathrm{n} / \mathrm{a}$ & 3,00 & $\begin{array}{c}(3,00- \\
4,00)\end{array}$ & 0,38 & 0,705 \\
\hline $\begin{array}{l}\text { 3. NETCONF standard daje } \\
\text { mogućnost da se definiraju i koriste } \\
\text { nestandardne (proprietary) funkcije } \\
\text { (capabilities). }\end{array}$ & 7 & 2,71 & 0,95 & 3,00 & 3,00 & $\begin{array}{c}(4,00- \\
3,00)\end{array}$ & 0,82 & 0,414 \\
\hline $\begin{array}{l}\text { 4. NETCONF standard koristi } \\
\text { XML jezik i njegovu sintaksu koja } \\
\text { je redundantna i opširna što može } \\
\text { zamarati i zbunjivati korisnika. }\end{array}$ & 7 & 3,43 & 1,51 & $\mathrm{n} / \mathrm{a}$ & 4,00 & $\begin{array}{c}(2,00- \\
5,00)\end{array}$ & 0,75 & 0,453 \\
\hline $\begin{array}{l}\text { 5. Za korištenje NETCONF } \\
\text { protokola potrebno je poznavanje } \\
\text { programskih jezika. }\end{array}$ & 7 & 3,71 & 0,95 & 4,00 & 4,00 & $\begin{array}{c}(4,00- \\
4,00)\end{array}$ & 1,67 & 0,096 \\
\hline Ukupno & 7 & 3,25 & 0,63 & 3,25 & 3,25 & $\begin{array}{c}(3,25- \\
3,75)\end{array}$ & 1,29 & 0,196 \\
\hline
\end{tabular}

* Wilcoxonov test za jedan nezavisan uzorak

** multimodalna distribucija, mod se ne može prikazati

Ukupna razina slaganja ispitanika o predloženim nedostacima NETCONF standarda je bilježila prosječnu vrijednost 3,25 s prosječnim odstupanjem od aritmetičke sredine 0,63 .

Dodatna zapažanja ispitanika su sljedeća na:

- potpitanje 9.1.:

- Ispitanik smatra da je to svojstvo prednost NETCONF-a jer ga u suprotnom ne bi bilo moguće implementirati na velik broj uređaja (povećava širinu uređaja na kojima može biti implementiran NETCONF).

○ Drugi ispitanik smatra suprotno, da bi to svojstvo trebalo biti zabranjeno, odnosno da bi sve funkcije morale biti obavezne.

- Potpitanje 9.2.: 
- Ispitanik smatra da je u nekim slučajevima to prednost (podržavanje proprietary funkcionalnosti proizvođača) dok je u nekima nedostatak (teža je automatizacija).

- Drugi ispitanik smatra da time proizvođači unapređuju postojeće funkcionalnosti.

- Potpitanje 9.3.:

- Ispitanik smatra da je u nekim slučajevima to prednost (podržavanje proprietary funkcionalnosti proizvođača) dok je u nekima nedostatak (teža je automatizacija). Ima isti stav kao u prethodnom potpitanju.

- Drugi ispitanik smatra da $\mathrm{s}$ time proizvođači unapređuju postojeće funkcionalnosti. Ima isti stav kao u prethodnom potpitanju.

- Potpitanje 9.4.:

- Ispitanik smatra da je XML možda opširan, ali je standard koji nije previše kompliciran.

○ Drugi ispitanik smatra da bi bolje rješenje bilo JSON (parsing). Ipak, i kod XML-a konfiguraciju može čitati i čovjek i stroj.

- Potpitanje 9.5.:

○ Pri implementaciji automatizacije uvijek se koristi neki od programskih jezika pri čemu NETCONF pojednostavljuje komunikaciju i izvlačenje podataka i konfiguriranje opreme.

○ Potrebno je osnovno poznavanje UNIX-a (skripte, Shell)

○ Mrežni administratori nisu često upoznati s programskim jezicima.

U trinaestom pitanju su ispitanici iskazivali svoje mišljenje o različitim tvrdnjama vezanim uz NETCONF standard i povećanje raspoloživosti R/S uređaja. Ispitanici su iskazivali slaganje ocjenama od 1 do 5 gdje je 1 označavala izrazito neslaganje, a 5 izrazito slaganje $s$ tvrdnjom.

Testiranje se provodi Wilcoxonovim testom za jedan nezavisan uzorak gdje će se utvrditi postojanje slaganja s ponuđenim tvrdnjama samo ako je srednja vrijednost (medijan) veća od 3,00 uz empirijsku p vrijednost manju od 0,05. U slučaju da je empirijska p vrijednost veća od 0,05 riječ je o indiferentnom stavu, dok u slučaju da je srednja vrijednost (medijan) manja od 
3 te se utvrdi empirijska $\mathrm{p}$ vrijednost manja od 0,05 , postoji neslaganje $\mathrm{s}$ ponuđenim tvrdnjama.

Tablica 6-31. prikazuje rezultate dobivene na temelju odgovora na 13. pitanje intervjua s partnerima.

Tablica 6-31. NETCONF standard i povećanje raspoloživosti R/S uređaja (intervju partneri)

\begin{tabular}{|c|c|c|c|c|c|c|c|c|}
\hline & $\mathrm{N}$ & Prosjek & $\begin{array}{l}\text { Std. } \\
\text { Dev. }\end{array}$ & Mod & Medijan & IQR & $\mathrm{Z}$ & $\mathrm{P}^{*}$ \\
\hline $\begin{array}{l}\text { 1. NETCONF pomaže } \\
\text { korisnicima u radu kada su } \\
\text { u mreži prisutni R/S } \\
\text { uređaji različitih } \\
\text { proizvođača }\end{array}$ & 7 & 4,43 & 0,53 & 4,00 & 4,00 & $(4,00-5,00)$ & 2,43 & 0,015 \\
\hline $\begin{array}{l}\text { 2. Dostupnost NETCONF } \\
\text { standarda na uređajima } \\
\text { proizvođača je važna za } \\
\text { njihovu konkurentnost na } \\
\text { tržištu }\end{array}$ & 7 & 4,43 & 0,79 & 5,00 & 5,00 & $(4,00-5,00)$ & 2,27 & 0,023 \\
\hline $\begin{array}{l}\text { 3. NETCONF standard bi } \\
\text { se trebao više koristiti od } \\
\text { strane Vaših korisnika na } \\
\text { R/S uređajima. }\end{array}$ & 7 & 4,29 & 0,95 & 5,00 & 5,00 & $(3,00-5,00)$ & 2,12 & 0,034 \\
\hline $\begin{array}{l}\text { 4. Korištenjem NETCONF } \\
\text { standarda povećava se } \\
\text { raspoloživost mrežnih } \\
\text { uređaja i sustava. }\end{array}$ & 7 & 4,71 & 0,49 & 5,00 & 5,00 & $(4,00-5,00)$ & 2,46 & 0,014 \\
\hline $\begin{array}{l}\text { 5. NETCONF standard bi } \\
\text { se trebao više koristiti od } \\
\text { strane Vaših korisnika na } \\
\text { R/S uređajima da bi } \\
\text { povećali raspoloživost } \\
\text { uređaja i sustava. }\end{array}$ & 7 & 4,57 & 0,53 & 5,00 & 5,00 & $(4,00-5,00)$ & 2,43 & 0,015 \\
\hline $\begin{array}{l}\text { 6. RESTCONF standard } \\
\text { (definiran u RFC } 8040 \text { u } \\
\text { siječnju 2017.) je bolje } \\
\text { rješenje za konfiguraciju } \\
\text { mrežnih uređaja od } \\
\text { NETCONF standarda. }\end{array}$ & 7 & 3,00 & 0,00 & 3,00 & 3,00 & $(3,00-3,00)$ & 0,00 & $>0,999$ \\
\hline $\begin{array}{l}\text { 7. Rad s nestandardnim } \\
\text { CLI sučeljem i njegovim } \\
\text { konfiguracijskim } \\
\text { datotekama je više „human } \\
\text { readable“ nego kada se } \\
\text { koristi NETCONF } \\
\text { standard. }\end{array}$ & 7 & 4,14 & 1,07 & 5,00 & 5,00 & $(3,00-5,00)$ & 2,00 & 0,046 \\
\hline
\end{tabular}


Ispitanici se izrazito slažu sa sljedećim tvrdnjama:

- korištenjem NETCONF standarda povećava se raspoloživost mrežnih uređaja (prosjek 4,71; std.dev. 0,49),

- NETCONF standard bi se trebao više koristiti od strane korisnika zbog povećanja raspoloživosti (prosjek 4,57; std.dev. 0,53),

- NETCONF pomaže korisnicima u radu kada su u mreži prisutni R/S uređaji različitih proizvođača (prosjek 4,43; std. dev.0,53)

- dostupnost NETCONF standarda na uređajima proizvođača je važna za njihovu konkurentnost na tržištu(prosjek 4,43; std.dev. 0,79),

- NETCONF standard bi se trebao više koristiti od strane korisnika na R/S uređajima (prosjek 4,29; std.dev. 0,95),

- $\operatorname{rad} \mathrm{s}$ nestandardnim CLI sučeljem i njegovim konfiguracijskim datotekama je više „human readable“ nego kada se koristi NETCONF standard (prosjek 4,14; std.dev. $1,07)$,

dok se vrlo malo slažu s tvrdnjom da je RESTCONF bolje rješenje za konfiguraciju mrežnih uređaja od NETCONF standarda (prosjek 3,00; std.dev.0,00).

Dodatna zapažanja ispitanika su sljedeća na:

- potpitanje 13.5.:

○ ispitanik navodi da veća primjena NETCONF standarda ovisi o tipu korisnika i njegovim potrebama.

- Potpitanje 13.6.:

- Isti ispitanik navodi da odabir NETCONF ili RESTCONF standarda isto ovisi o tipu korisnika i njegovim potrebama.

○ Jedan ispitanik navodi da nema iskustva rada s RESTCONF standardom.

- Potpitanje 13.7.:

- Ispitanik navodi da su korisnici naviknuti na CLI, makar nije niti NETCONF u odnosu na CLI toliko „nečitljiv“.

- Dva ispitanika ističu da je vrlo važna navika korisnika (u odabiru između CLI i NETCONF-a).

- Za cijelo pitanje 13.: 
- U SDN mrežama korisnik niti ne zna da sustav koristi NETCONF (u pozadini svu konfiguraciju obavlja kontroler).

Četrnaesto pitanje intervjua glasi: „Slažete li se s tvrdnjom da sve vrste R/S uređaja (na primjer od malih SMB uređaja do velikih ISP uređaja) trebaju imati implementiran NETCONF standard?“.

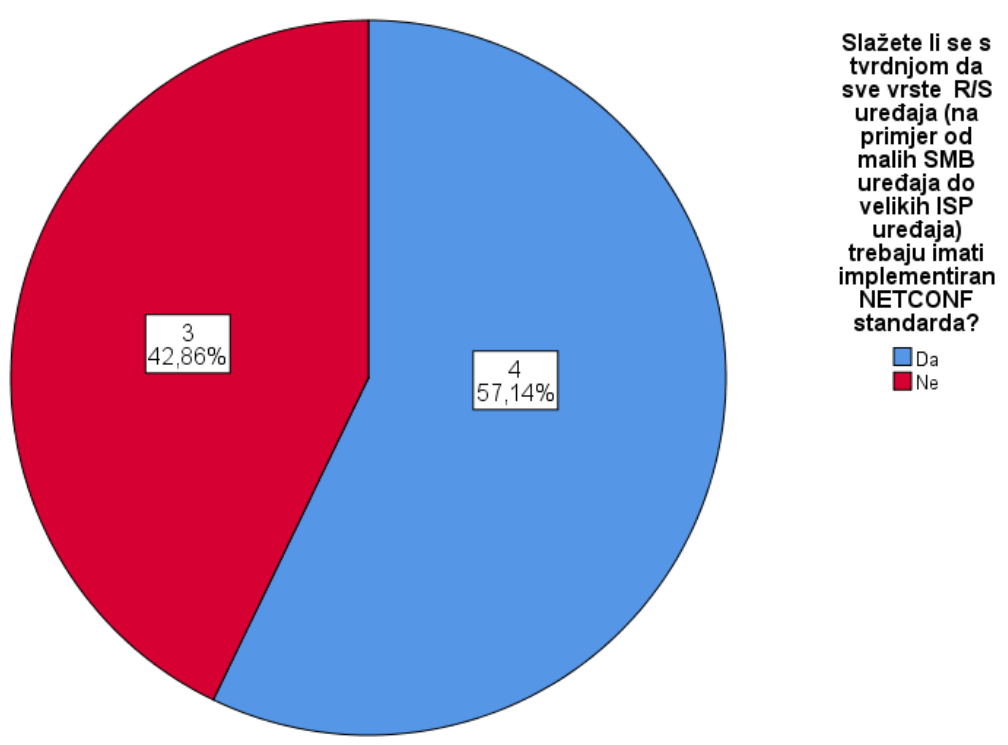

\section{Slika 6-4. Implementacija NETCONF standarda na svim vrstama R/S uređaja (intervju partneri)}

Slika 6-4. prikazuje graf dobiven na temelju odgovora na 14. pitanje intervjua s partnerima. Na grafu je vidljivo da se više od polovice ispitanika (4 ispitanika; 57,14\%) slaže s tvrdnjom da NETCONF standard treba implementirati u sve vrste R/S uređaja, dok se tri ispitanika $(42,86 \%)$ s ponuđenom tvrdnjom ne slažu.

O implementaciji NETCONF standarda na svim vrstama uređaja neki ispitanici su se slagali sa sljedećim zapažanjima:

- primjena na svim uređajima je važna, pogotovo ako se ide u smjeru SDN implementacije; 
- NETCONF bi olakšao korisnicima automatizaciju cjelokupne mreže, a automatizacija bi se u tom slučaju i češće koristila;

a neki bili protiv navodeći:

- da će u SMB mrežama prednosti dobivene od uvođenja NETCONF-a biti poništene povećanjem kompleksnosti same mreže.

- da je za SMB mreže dovoljno Web sučelje, jedino u SP okruženjima treba ZTP.

- SMB i SOHO uređaji nemaju potrebu za NETCONF-om.

Petnaesto pitanje intervjua glasi: "Na koji način mislite da bi se mogla povećati primjena NETCONF standarda?". Dobiveni su sljedeći odgovori ispitanika:

- uvođenjem više cjelovitih sustava za nadzor i konfiguraciju mrežne opreme koji bi u pozadini koristili NETCONF.

- Boljom podrškom proizvođača opreme i više edukacijskih resursa.

- Implementacija u IoT tehnologijama.

- Povećana primjena ovisi o samim proizvođačima koji bi trebali pružati veću podršku za NETCONF na svojim uređajima i povećati ponudu edukacije i dokumentacije na tu temu.

- Proizvođači trebaju više inzistirati na korištenju NETCONF standarda.

- Povećana primjena bi se postigla pomoću organizacije interesne udruge (foruma) za NETCONF protokol.

- Potreban je angažman proizvođača u pružanju podrške korištenja NETCONF-a na novoj opremi te pružanju migracijske strategije prema NETCONF-u.

Šesnaesto pitanje intervjua glasi: "Na koji način mislite da bi se mogao poboljšati NETCONF standard?". Dobiveni su sljedeći odgovori ispitanika:

- prelaskom sa XML u JSON format koji je više "human readable" i sve više standard koji potiskuje XML.

- Brža standardizacija temeljnih servisa: na primjer MPLS VPN treba konfigurirati na isti način kod svih proizvođača opreme.

Sedamnaesto pitanje intervjua glasi: "Na koji način Vi vidite buduću primjenu i razvoj NETCONF standarda?". Dobivena su sljedeća mišljenja i prijedlozi ispitanika: 
- kroz veći stupanj automatizacije mreža doći će i do veće potrebe za standardom kao što je NETCONF.

- Bolja informiranost partnera i krajnjih korisnika o NETCONF standardu od strane proizvođača opreme.

- S povećanjem NFV-a i standardizacijom usluga i protokola.

- Postoji puno API-ja (REST) koji su možda u zadnje vrijeme i češće korišteni od samog NETCONF-a. Na primjer, kod Cisco ACI proizvoda se ne koristi NETCONF za komunikaciju kontrolera i uređaja već koriste protokol OPFLEX. Pitanje je da li će NETCONF preživjeti ili će prevladati neki drugi standard (tržište i vrijeme će pokazati).

- Veća primjena SDN-a bi trebala doprinijeti učestalosti primjene NETCONF-a u mrežama svih vrsta.

- Automatizacija servisa će se temeljiti na NETCONF-u. Mogućnost povezivanja sa umjetnom inteligencijom (kada stroj počne automatski konfigurirati servise, a u to će se sigurno uključiti umjetna inteligencija).

Osamnaesto pitanje intervjua glasi: "Molimo Vas da izložite svoja dodatna zapažanja i mišljenje vezano uz primjenu NETCONF standarda, a koja nisu obrađena u prethodnim pitanjima:". Dobivena su sljedeća mišljenja i prijedlozi ispitanika:

- prva verzija NETCONF-a se pojavila puno prije nego alati koji su ga mogli i znali iskoristiti. Stupanj edukacije inženjera u prošlosti po pitanju mrežne programabilnosti i automatizacije bio je vrlo nizak. Tek se zadnjih godina počela dizati svijest ljudi o prednostima i potrebi automatizacije i programabilnosti mreža, a čiji je sastavni dio i NETCONF.

- Ispitanik je naveo da:

- NETCONF zahtijeva znanja i iz mrežnih tehnologija i iz programiranja. Većina njegovih kolega je orijentirana na mrežne tehnologije. Zbog toga:

- potrebno je dulje vrijeme da se savlada NETCONF i

- vrlo je zahtjevno napraviti pravilni i funkcionalni kod za aplikacije.

- Uz NETCONF postoji puno drugih protokola (API) za konfiguraciju i uzimanje podataka s uređaja. Možda je to razlog što proizvođači imaju veliki izbor pa ne rade svi podršku za NETCONF. 
- Primjena NETCONF-a značajno ovisi o čvrstom angažmanu proizvođača na uvođenju NETCONF standarda.

23. pitanje intervjua glasi: "Molimo Vas da izložite svoja dodatna zapažanja i mišljenje vezano uz primjenu NETCONF standarda i povećanje raspoloživosti mrežnih uređaja, a koja nisu obrađena u prethodnim pitanjima:". Dobivena su sljedeća mišljenja i prijedlozi ispitanika:

- NETCONF se vjerojatno pojavio prerano pa je zato i prošlo toliko vremena jer ostali sustavi, alati, organizacije i ljudi nisu bili spremni za njegovu primjenu. Međutim, zadnjih godina su se počeli stjecati uvjeti za veću i masovniju primjenu u budućnosti. Hoće li do toga zaista doći, pokazat će vrijeme.

- Nove generacije mrežnih inženjera koje su odrasle uz Python i XML lakše će prihvatiti NETCONF.

- Budući da korisnici nisu preuzeli tu ulogu da sami automatiziraju svoje mreže, to su počeli raditi proizvođači koji nude već gotove proizvode vezane uz SDN. Neki od tih produkata bazirani su na NETCONF-u, npr. Cisco NSO (Network Service Orchestrator), dok su drugi bazirani na nekim drugim standardnim ili proprietary protokolima.

- Ispitanik navodi sljedeće.:

- Do sada u njihovoj kompaniji nisu koristili NETCONF, no trenutno rade na prvom ozbiljnijem (komercijalnom) projektu implementacije NETCONF-a kod velikih korisnika (MPLS mreža s više od 100 PE usmjernika). Taj ispitanik inače izuzetno cijeni NETCONF standard.

- Primjena NETCONF-a je široko područje i promjena paradigme u načinu konfiguracije servisa.

- Ljudima (krajnjim korisnicima) je problem shvatiti kako se više ne konfiguriraju uređaji, već se konfiguriraju servisi.

\subsubsection{Zaključak}

Na temelju odgovora dobivenih tijekom intervjua sa zaposlenicima partnera u Hrvatskoj može se zaključiti sljedeće: 


\section{Primjena NETCONF standarda kod proizvođača R/S uređaja:}

- NETCONF se najviše koristi (ponuđene vrijednosti su od 0 do 5 , gdje 5 označava $100 \%$ ) kod korisnika na R/S uređajima proizvođača Cisco Systems (prosječna vrijednost odgovora 1,00, korištenje kod 20\% korisnika; std.dev.0,58) i uređajima proizvođača Huawei (prosječna vrijednost odgovora 1,00 (20\%); std.dev. 1,73). Ukupna razina odgovora ispitanika (zaposlenici partnera) je bilježila prosječnu vrijednost $0,61 \mathrm{~s}$ prosječnim odstupanjem od aritmetičke sredine 0,51 što pokazuje vrlo nisku prosječnu implementaciju $(18,8 \%)$ NETCONF standarda na R/S uređajima proizvođača.

- Što se tiče raspoložive dokumentacije i edukacije od strane proizvođača (ponuđene vrijednosti su od 1 do 5 , gdje je 5 potpuno slaganje s tvrdnjom), ispitanici se najviše slažu s tvrdnjom da postoje tečajevi proizvođača za samostalno učenje (CBT, Webinar, i slično) koji u potpunosti podučavaju korisnike uporabi i primjeni NETCONF standarda (prosječna vrijednost odgovora 2,71; std.dev.1,38), dok se najmanje slažu s tvrdnjom da postoje certifikacijski ispiti (prosječna vrijednost odgovora 1,57; std.dev. 0,53). Ukupna razina odgovora ispitanika (zaposlenici partnera) o raspoloživoj NETCONF dokumentaciji i edukaciji proizvođača je bilježila prosječnu vrijednost 2,29 s prosječnim odstupanjem od aritmetičke sredine 1,05.

\section{Primjena NETCONF standarda od strane korisnika u Hrvatskoj:}

- NETCONF se najviše koristi (ponuđene vrijednosti su od 0 do 5 , gdje 5 označava $100 \%$ ) na R/S mrežnim uređajima u mrežama davatelja usluga (prosječna vrijednost odgovora 3,33; korištenje kod 66,6\% partnera; std.dev. 1,15). Ispitanici, pak, ne koriste NETCONF u IoT mrežama na što ni jedan ispitanik nije dao odgovor. Ukupna razina odgovora ispitanika bilježila je prosječnu vrijednost $0,94 \mathrm{~s}$ prosječnim odstupanjem od aritmetičke sredine 0,84 , što pokazuje vrlo nisku prosječnu implementaciju $(18,8 \%)$ NETCONF standarda u različitim vrstama mreža.

- $\mathrm{R} / \mathrm{S}$ uređaji koji su instalirani u mrežama korisnika ispitanika (zaposlenici partnera) najčešće dolaze od proizvođača Cisco (prosječna vrijednost odgovora 4,86; korištenje kod 97,2\% partnera; std.dev.0,38), dok su najrjeđi R/S uređaji od proizvođača Arista 
(prosječna vrijednost odgovora 0,43 , razina korištenja $8,6 \%$, sa standardnom devijacijom 0,53).

- Najvažniji razlozi (ponuđene vrijednosti od 1 do 5 , gdje 5 označava izuzetno važno) za implementaciju NETCONF standarda na R/S uređajima korisnika su (prosječna vrijednost odgovora 4,14; std.dev. 1,46):

○ omogućavanje programabilnosti (automatiziranja),

○ mogućnosti "Backup \& restore" te

○ mogućnost istovremenog i koordiniranog konfiguriranja svih ili više uređaja u mreži.

Najmanje važni razlozi implementacije prema ispitanicima su:

- razlikovanje između konfiguracijskih i operacijskih podataka (prosječna vrijednost 3,43; std.dev. 1,51) i

○ mogućnost parcijalnog konfiguriranja (prosječna vrijednost 3,43; std.dev. $1,27)$

Ukupna prosječna razina razloga implementacija NETCONF standarda na R/S uređajima od strane korisnika ispitanika je 3,79 s prosječnim odstupanjem od aritmetičke sredine 1,33 te je riječ o visokoj razini povećanja $(Z=2,20 ; p=0,028)$.

- Glavni razlog za neimplementaciju NETCONF standarda na R/S uređajima kod korisnika su (ponuđene vrijednosti od 1 do 5 , gdje 5 označava izuzetno važno):

○ nepoznavanje programskih jezika od strane korisnika (prosječna vrijednost odgovora 4,43; std.dev. 0,53).

- nedostupnost na starijim uređajima i operacijskim sustavima (prosječna vrijednost 4,29; std.dev. 0,76).

○ navika korisnika na CLI i OS proizvođača (prosječna vrijednost 4,00; std.dev. $1,00)$.

- proizvođači ne podržavaju sve funkcije pa se ne može iskoristiti većina prednosti standarda (prosječna vrijednost 3,71; std.dev. 1,25). i

○ strah od novih tehnologija (prosječna vrijednost 3,71 ; std.dev. 1,11). 
Najmanje važan razlog neimplementacije NETCONF standarda na uređajima korisnika je da krajnji korisnici koriste RESTCONF kao bolje standardno rješenje od NETCONF-a (prosječna vrijednost odgovora 1,71; std.dev. 0,76).

\section{Poznavanje NETCONF standarda od strane korisnika u Hrvatskoj:}

- U dvadesetom pitanju ispitanici su iskazivali svoje mišljenje o znanju svojih korisnika o NETCONF standardu. Ispitanici su davali svoje ocjene znanja svojih korisnika od 1 (nedovoljno) do 5 (izvrsno). Ispitanici smatraju da njihovi korisnici imaju izrazito nisku razinu znanja o NETCONF standardu što je vidljivo u prosječnim ocjenama za pojedine tvrdnje koje se odnose na znanje korisnika:

o poznavanje prednosti NETCONF protokola u povećanju raspoloživosti mrežnih uređaja (prosječna ocjena 2,00; std.dev. 1,53),

- savladana teoretska znanja o radu NETCONF protokola i razumijevanje njegovih prednosti (prosječna ocjena 1,14; std.dev. 0,38) i

O savladana praktična znanja NETCONF protokola i njegova uporaba (prosječna ocjena 1,00; std.dev. 0,00).

- Ispitanici smatraju da su teoretska znanja njihovih korisnika o NETCONF standardu po pojedinim mogućnostima izrazito niska (ponuđene ocijene od 1 do 5 , gdje 5 označava izvrsno). Korisnici su najviše upoznati s tim da NETCONF standard omogućava programabilnost (automatiziranje) (prosječna ocjena 2,00; std.dev. 1,53). Prosječna razina teorijskog znanja korisnika o NETCONF standardu po pojedinim njegovim mogućnostima iznosi 1,75 s prosječnim odstupanjem od aritmetičke sredine 1,46. Testiranjem nije utvrđeno postojanje statistički značajne razlike u odnosu na vrijednost 1 (nedovoljno; $Z=1,83 ; p=0,068$ ).

- Ispitanici smatraju da su praktična znanja njihovih korisnika o NETCONF standardu po pojedinim mogućnostima izrazito niska (ponuđene ocijene od 1 do 5 , gdje 5 označava izvrsno). Korisnici su najviše upoznati s tim da NETOCONF ima mogućnost istovremenog i koordiniranog konfiguriranja svih ili više uređaja u mreži (prosječna ocjena 1,43 ; std. 0,79). Prosječna razina praktičnog znanja korisnika o NETCONF standardu po pojedinim mogućnostima je 1,29 s prosječnim odstupanjem od 
aritmetičke sredine 0,55. Testiranjem nije utvrđeno postojanje statistički značajne razlike u odnosu na vrijednost 1 (nedovoljno; $Z=1,60 ; p=0,109$ ).

\section{NETCONF i povećanje raspoloživosti R/S uređaja:}

- Što se tiče povećanja raspoloživosti primjenom svojstava NETCONF standarda (ponuđene vrijednosti su od 1 do 5 , gdje je 5 izrazito slaganje), ispitanici su najveću razinu slaganja iskazali na tvrdnju NETCONF kao standard povećava raspoloživost jer omogućava programabilnost (automatiziranje) (prosječna ocjena 5,00; std.dev. 0,00), dok su najnižu razinu slaganja iskazali na tvrdnju NETCONF standard povećava raspoloživost mrežnih uređaja zbog toga što koristi jasnu razliku u strukturi između konfiguracijskih i operacijskih podataka (prosječna ocjena 4,00; std.dev. 0,82). Ukupna razina povećanja raspoloživosti mrežnog uređaja u odnosu na nestandardne metode konfiguriranja (CLI) primjenom različitih svojstava NETCONF standarda je 4,70 s prosječnim odstupanjem od aritmetičke sredine 0,30 te se može donijeti zaključak da je riječ o visokoj razini povećanja $(Z=2,38 ; p=0,018)$.

- Najvišu traženu raspoloživost mreža prema mišljenju ispitanika zahtijevaju (ponuđene vrijednosti su od 1 do 5, gdje 5 označava $100 \%$ raspoloživosti):

○ podatkovni centri korisnika (prosječna vrijednost mišljenja 5,00 (100\%); std.dev. 0,00),

dok po mišljenju ispitanika najnižu raspoloživost zahtijevaju:

○ rezidencijalni korisnici (prosječna vrijednost mišljenja 2,17 $(43,4 \%)$; std. dev.1,33).

- Na dvanaesto pitanje su ispitanici iskazivali svoje mišljenje o visoko raspoloživim mrežama (raspoloživost $\geq 99,9 \%$ ) njihovih korisnika i NETCONF standardu. Ponuđene vrijednosti su od 1 do 5 , gdje 5 označava $100 \%$ raspoloživosti. Prema ispitanicima $80 \%$ njihovih korisnika (prosječna vrijednost odgovora 4,00; std.dev. $1,00)$ ima visoko raspoloživu mrežu (raspoloživost $\geq 99,9 \%$ ). NETCONF u tim visoko raspoloživim mrežama koristi samo $14,6 \%$ (prosječna vrijednost odgovora 0,73 ; std.dev. 0,49) njihovih korisnika, što je vrlo nizak iznos. 


\section{Karakteristike i povećanje primjene NETCONF standarda:}

- Prema mišljenju ispitanika (ponuđena skala od 1 do 5 , gdje je 5 izrazito slaganje) glavni nedostatak NETCONF standarda je taj što je za korištenje NETCONF protokola potrebno poznavati programske jezike (prosječna vrijednost odgovora 3,71; std.dev.0,95), dok se najmanje slažu da je nedostatak mogućnost korištenja nestandardnih modela podataka (prosječna vrijednost odgovora 2,71; std.dev.0,95). Ukupna razina slaganja ispitanika o predloženim nedostacima NETCONF standarda je bilježila prosječnu vrijednost 3,25 s prosječnim odstupanjem od aritmetičke sredine 0,63 .

- U trinaestom pitanju ispitanici su iskazivali svoje mišljenje o različitim tvrdnjama vezanim uz NETCONF standard i povećanje raspoloživosti R/S uređaja (ponuđena skala od 1 do 5 , gdje je 5 izrazito slaganje). Ispitanici se izrazito slažu sa sljedećim tvrdnjama:

○ korištenjem NETCONF standarda povećava se raspoloživost mrežnih uređaja (prosjek 4,71; std.dev. 0,49),

- NETCONF standard bi se trebao više koristiti od strane korisnika zbog povećanja raspoloživosti (prosjek 4,57; std.dev. 0,53),

- NETCONF pomaže korisnicima u radu kada su u mreži prisutni R/S uređaji različitih proizvođača (prosjek 4,43; std. dev.0,53)

- dostupnost NETCONF standarda na uređajima proizvođača je važna za njihovu konkurentnost na tržištu (prosjek 4,43; std.dev. 0,79),

- NETCONF standard bi se trebao više koristiti od strane korisnika na R/S uređajima (prosjek 4,29; std.dev. 0,95),

○ $\operatorname{rad} \mathrm{s}$ nestandardnim CLI sučeljem i njegovim konfiguracijskim datotekama je više „human readable“ nego kada se koristi NETCONF standard (prosjek 4,14; std.dev. 1,07),

dok se vrlo malo slažu s tvrdnjom da je RESTCONF bolje rješenje za konfiguraciju mrežnih uređaja od NETCONF standarda (prosjek 3,00; std.dev.0,00). 
- O implementaciji NETCONF standarda na svim vrstama R/S uređaja četiri se ispitanika $(57,14 \%)$ slaže s tvrdnjom da NETCONF standard treba implementirati na sve vrste R/S uređaja dok se tri ispitanika $(42,86 \%)$ s ponuđenom tvrdnjom ne slaže.

Ispitanici su dali i svoje mišljenje o budućem razvoju i primjeni NETCONF standarda.

$\mathrm{Na}$ temelju odgovora dobivenih tijekom intervjua sa zaposlenicima partnera u Hrvatskoj, kreirana su i pitanja anketnog upitnika za korisnike mrežne opreme u Hrvatskoj. 


\subsection{Dobiveni podaci od ispitanika (anketni upitnik korisnika)}

U ovom su poglavlju prikazani odgovori dobiveni anketnim upitnikom koji su popunili korisnici R/S mrežnih uređaja u Hrvatskoj.

Odgovori su podijeljeni po područjima:

- podaci o korisnicima (od 1. do 6. pitanja anketnog upitnika)

- Podaci o kompanijama korisnika (od 7. do 11. pitanja anketnog upitnika)

- Primjena NETCONF standarda kod proizvođača R/S uređaja (14., 15., 16., 17. i 27. pitanje anketnog upitnika) koja je povezana uz područje ispitivanja hipoteze $\mathrm{H} 2$.

- Primjena NETCONF standarda od strane korisnika u Hrvatskoj (od 18. do 22. pitanja anketnog upitnika) koja je povezana uz područje ispitivanja hipoteze H3.

- Poznavanje NETCONF standarda od strane korisnika u Hrvatskoj (pitanja 12. i 13.) koje je povezano uz područje ispitivanja hipoteze $\mathrm{H} 4$.

- NETCONF i povećanje raspoloživosti R/S uređaja (pitanja 25., 26. i 29.) koje je povezano uz područje ispitivanja hipoteze $\mathrm{H} 1$.

- Karakteristike i povećanje primjene NETCONF standarda (pitanja 23., 24. i 28.) koje pokriva ostala pitanja vezana uz NETCONF standard i povećanje raspoloživosti R/S uređaja.

\subsubsection{Metoda obrade podataka}

U ovom se poglavlju upotrebom metoda tabelarnog prikazivanja prezentira struktura odgovora na anketna pitanja od strane ispitanika (korisnika u Hrvatskoj), dok se upotrebom metoda deskriptivne statistike prezentiraju srednje vrijednosti (aritmetička sredina, medijan i mod) kao i disperzija oko srednjih vrijednosti (standardna devijacija kao prosječno odstupanje od aritmetičke sredine, te inderkvartilni raspon (IQR) kao pokazatelj disperzije oko srednje vrijednosti medijana). Testiranje razlika $u$ odnosu na teorijsku vrijednost provodi se upotrebom Wilcoxonovog testa za jedan nezavisan uzorak. Opravdanost upotrebe Wilcoxonovog testa proizlazi iz ranga obilježja brojčanih vrijednosti koje nemaju normalnu razdiobu, zbog čega nisu zadovoljeni uvjeti za provođenje parametrijskih inačica testa. 
Analiza je rađena u statističkom softveru SPSS 25 te se zaključci donose pri graničnoj signifikantnosti od $5 \%$.

\subsubsection{Podaci o ispitanicima (korisnicima)}

U anketnom upitniku od ispitanika su dobiveni njihovi sljedeći podaci:

- najviši stupanj formalnog obrazovanja vezanog uz računarstvo i ICT (engl. Information Communication Technologies) (1. pitanje anketnog upitnika),

- najviši stupanj položenog certifikata iz računalnih mreža (koji je položen, a ne mora biti aktivan) (2. pitanje anketnog upitnika),

- godine iskustva rada s računalnim mrežama i mrežnim uređajima (3. pitanje anketnog upitnika),

- znanja iz različitih područja i tehnologija računalnih mreža (4. pitanje anketnog upitnika),

- znanja iz programiranja i programskih jezika (5. pitanje anketnog upitnika) i

- na kojim poslovima vezanim uz R/S uređaje rade na svojem radnom mjestu u kompaniji (6. pitanje anketnog upitnika).

Tablica 6-32. Formalno ICT obrazovanje ispitanika (upitnik korisnika)

\begin{tabular}{lcc}
\hline & $\mathbf{N}$ & $\mathbf{\%}$ \\
\hline Završena srednja škola računarskog smjera & 8 & 10,96 \\
\hline Završene 3 godine visoke škole ili fakulteta računarskog smjera & 17 & 23,29 \\
\hline Završenih 4 ili 5 (3+2) godina visoke škole ili fakulteta računarskog smjera & 46 & 63,01 \\
\hline Završen doktorat računarskog smjera & 0 & 0,00 \\
\hline Ništa od gore navedenog & 2 & 2,74 \\
\hline Ukupno & 73 & 100,0 \\
\hline
\end{tabular}

Tablica 6-32. prikazuje najviši stupanj formalnog obrazovanja ispitanika vezanog uz računarstvo i ICT (engl. Information Communication Technologies) iz prvog pitanja anketnog upitnika. Može se vidjeti da (od ukupno 73 ispitanika):

- $23.29 \%$ ispitanika ima završene 3 godine visoke škole ili fakulteta računarskog smjera 
- $63.01 \%$ ispitanika ima završenih 4 ili $5(3+2)$ godina visoke škole ili fakulteta računarskog smjera.

što ukupno znači da $\mathbf{8 6 . 3 \%}$ ispitanika ima završeno više obrazovanje (ili 3 ili 5 godina) vezano za ICT tehnologije.

Slika 6-5. prikazuje graf najvišeg stupnja ICT obrazovanja ispitanika.

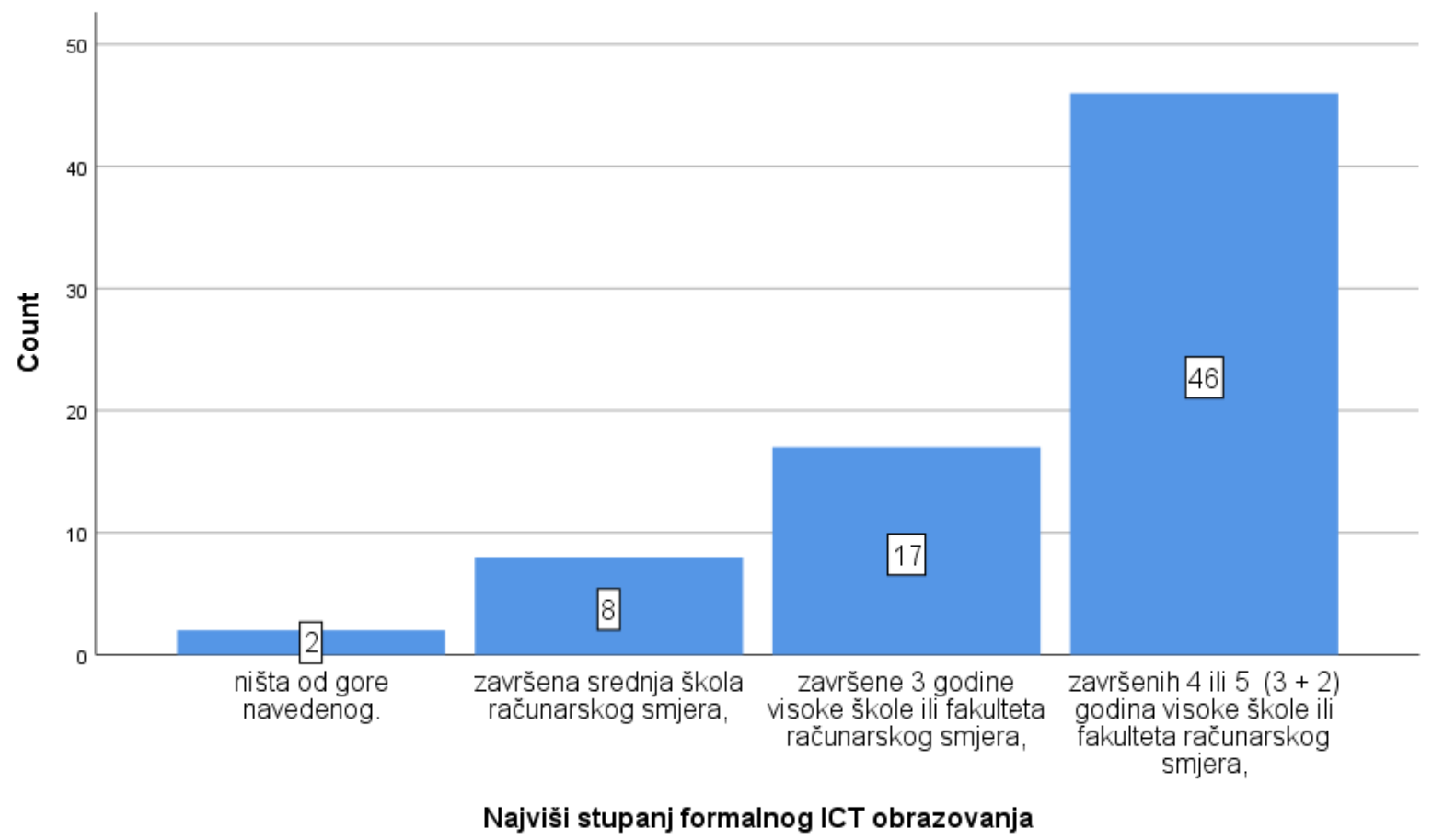

\section{Slika 6-5. Graf formalnog ICT obrazovanje ispitanika (upitnik korisnika)}

Pod rubrikom Napomene jedan je ispitanik naveo da ima završen magisterij znanosti u ICT području, jedan da ima završen VSS netehničkog smjera i jedan da ima završen VSS elektrotehnike.

Može se zaključiti da ispitanici imaju vrlo visoko formalno obrazovanje u ICT području.

Tablica 6-33. prikazuje najviši stupanj položenog certifikata polaznika iz računalnih mreža (koji je položen, a ne mora biti aktivan) iz drugog pitanja anketnog upitnika. Može se vidjeti da (od ukupno 73 ispitanika): 
- 35.6\% ispitanika ima položeni osnovni stupanj (Associate level) certificiranja, na primjer Cisco CCNA, Juniper JNCIA, Huawei HCIA ili odgovarajući drugih proizvođača ili istih proizvođača iz drugih mrežnih tehnologija.

- $37 \%$ ispitanika ima položeni srednji stupanj (Professional level) certificiranja, na primjer Cisco CCNP, Juniper JNCIP, Huawei HCIP ili odgovarajući drugih proizvođača ili istih proizvođača iz drugih mrežnih tehnologija.

- $6.8 \%$ ispitanika ima položeni najviši stupanj (Expert level) certificiranja, na primjer Cisco CCIE, Juniper JNCIE, Huawei HCIE ili odgovarajući drugih proizvođača ili istih proizvođača iz drugih mrežnih tehnologija.

Tablica 6-33. Najviši stupanj položenog certifikata iz računalnih mreža (upitnik korisnika)

\begin{tabular}{|c|c|c|}
\hline & $\mathbf{N}$ & $\%$ \\
\hline Nemam položenih certifikata iz računalnih mreža. & 14 & 19,2 \\
\hline $\begin{array}{l}\text { Osnovni (ASSOCIATE level) } \\
\text { - na primjer Cisco CCNA, Juniper JNCIA, Huawei HCIA ili odgovarajući } \\
\text { drugih proizvođača ili istih proizvođača iz drugih mrežnih tehnologija. }\end{array}$ & 26 & 35,6 \\
\hline $\begin{array}{l}\text { Srednji (PROFESSIONAL level) } \\
\text { • na primjer Cisco CCNP, Juniper JNCIP, Huawei HCIP ili odgovarajući } \\
\text { drugih proizvođača ili istih proizvođača iz drugih mrežnih tehnologija. }\end{array}$ & 27 & 37,0 \\
\hline $\begin{array}{l}\text { Najviši (EXPERT level) } \\
\text { - na primjer Cisco CCIE, Juniper JNCIE, Huawei HCIE ili odgovarajući } \\
\text { drugih proizvođača ili istih proizvođača iz drugih mrežnih tehnologija. }\end{array}$ & 5 & 6,8 \\
\hline Ostalo & 1 & 1,4 \\
\hline Ukupno & 73 & 100,0 \\
\hline
\end{tabular}

Ukupno 79.4\% ispitanika ima položeni certifikat iz računalnih mreža, a 43.8\% ispitanika ima položeni srednji ili najviši stupanj certifikata iz računalnih mreža.

Pod rubrikom Napomene jedan je ispitanik naveo da ima djelomično završeni CCNP certifikat. 
Važno je napomenuti da su neki od razloga zašto neki ispitanici nemaju certifikate iz računalnih mreža sljedeći:

- svoja su znanja o računalnim mrežama stekli kroz formalno obrazovanje, Cisco akademiju (kroz koju se steknu ista znanja, ali se ne polažu certifikati), CBT (Computer Based Training) tečajeve ili druge oblike obrazovanja ili

- rade već dosta dugo vremena s mrežnom opremom i tako su stekli kroz praksu svoja znanja i

- njihovi poslodavci ne traže od svojih zaposlenika polaganje certifikata.

Može se zaključiti da ispitanici imaju vrlo visoki stupanj položenosti certifikata što pokazuje njihovu stručnost u radu s računalnim mrežama i R/S uređajima.

Tablica 6-34. Iskustvo rada s računalnim mrežama (upitnik korisnika)

\begin{tabular}{lcc}
\hline & $\mathbf{N}$ & $\boldsymbol{\%}$ \\
\hline 0 - 5 godina & 19 & 26,03 \\
\hline $5-10$ godina & 17 & 23,29 \\
\hline 10 - 15 godina & 19 & 26,03 \\
\hline 15 - 20 godina & 10 & 13,70 \\
\hline 20 - 25 godina & 2 & 2,74 \\
\hline više od 25 godina & 6 & 8,22 \\
\hline Ukupno & 73 & 100,0 \\
\hline
\end{tabular}

Tablica 6-34. prikazuje godine iskustva rada s računalnim mrežama i mrežnim uređajima (treće pitanje anketnog upitnika).

Može se zaključiti da ispitanici imaju različito radno iskustvo i da je istraživanje pokrilo raspon od mladih stručnjaka do stručnjaka s iskustvom od dvadeset i više godina.

Slika 6-6. prikazuje graf iskustva rada ispitanika s računalnim mrežama. Na grafu se jasno može vidjeti podjednaka zastupljenost ispitanika do 5 godina rada (19), od 5 do 10 godina (17), od 10 do 15 godina (19) i više od 20 godina (18) rada s računalnim mrežama. 


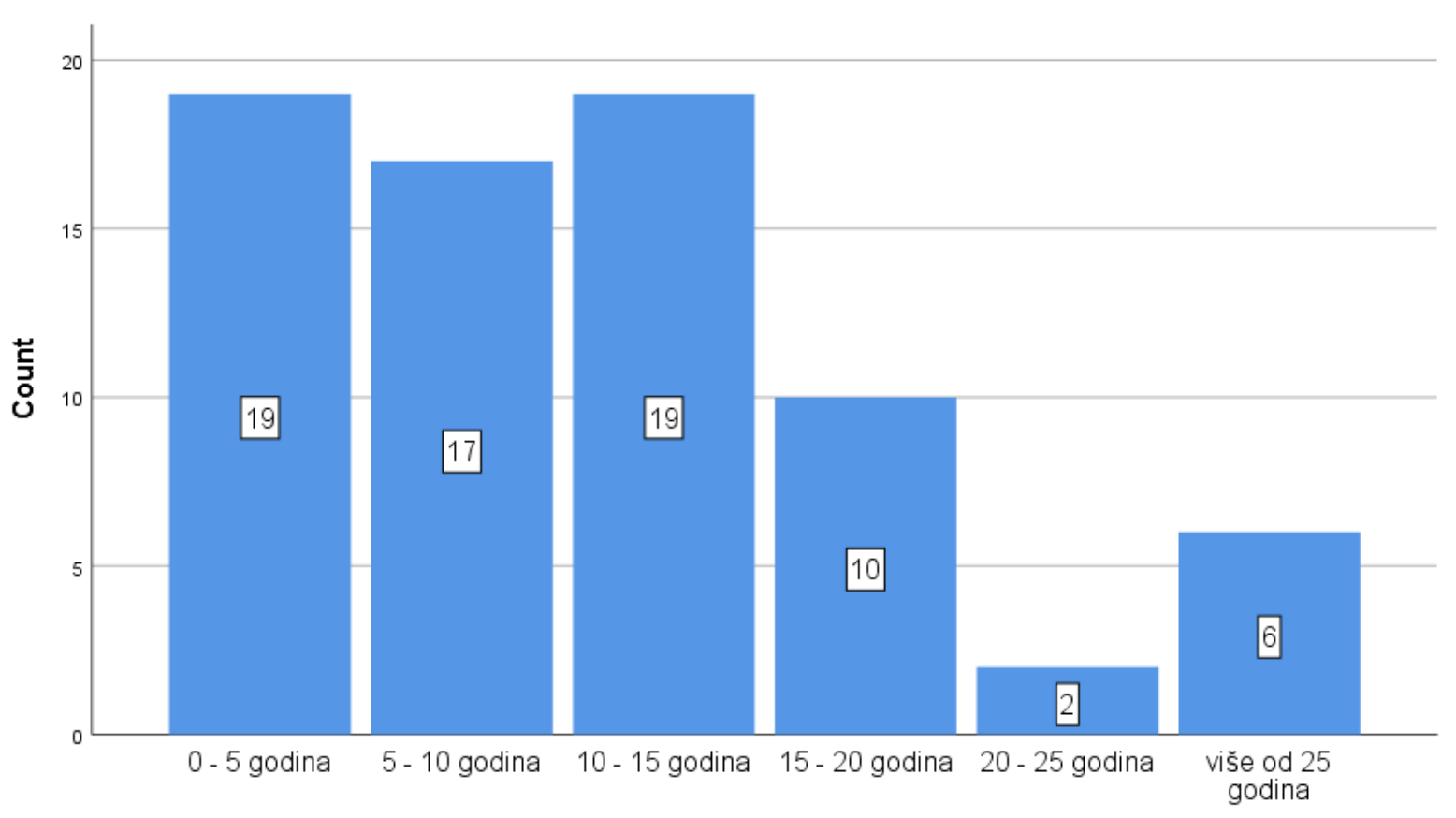

Iskustvo rada s računalnim mrežama

\section{Slika 6-6. Graf iskustva rada s računalnim mrežama (upitnik korisnika)}

Sljedeće, četvrto pitanje odnosi se na razinu znanja ispitanika iz različitih područja i tehnologije računalnih mreža. Ispitanici su iskazivali razinu svoga znanja vrijednostima od 1 do 5, gdje je 1 označavala nedovoljno znanje, a 5 izvrsno znanje.

Testiranje se provodi Wilcoxonovim testom za jedan nezavisan uzorak gdje će se utvrditi postojanje prolazne ocjene na ponuđene tvrdnje samo ako je srednja vrijednost (medijan) veća od 1,00 uz empirijsku p vrijednost manju od 0,05. U slučaju da je empirijska p vrijednost veća od 0,05 , riječ je o neprolaznoj ocjeni (nedovoljan).

Tablica 6-35. prikazuje odgovore na 4. pitanje pomoću deskriptivne statistike razine znanja ispitanika iz različitih područja i tehnologije računalnih mreža.

Ispitanici posjeduju najviše znanja iz tradicionalnih (engl. legacy) tehnologija, koje su već dugo prisutne i prihvaćene:

- $\mathrm{R} / \mathrm{S}$ poduzeća (Enterprise routing/switching): srednja ocjena 3.62,

- $\quad$ sigurnost R/S uređaje i računalnih mreža: srednja ocjena 3.34,

- $\mathrm{R} / \mathrm{S}$ davatelja usluga (Service provider routing/switching): srednja ocjena $3.21 \mathrm{i}$ 
- upravljanje računalnim mrežama (engl. Network management - NM): srednja ocjena 3.19 .

Tablica 6-35. Razine znanja ispitanika iz različitih područja i tehnologija računalnih mreža (upitnik korisnika)

\begin{tabular}{|c|c|c|c|c|c|c|c|c|}
\hline & $\mathrm{N}$ & Prosjek & Std.Dev. & Mod & Medijan & IQR & $\mathrm{Z}$ & $\mathrm{P}^{*}$ \\
\hline $\begin{array}{l}\mathrm{R} / \mathrm{S} \text { poduzeća (Enterprise } \\
\text { routing/switching): } \\
-\mathrm{R} / \mathrm{S} \text { uređaji, protokoli, } \\
\text { način rada, ... }\end{array}$ & 73 & 3,62 & 1,08 & 4,00 & 4,00 & $\begin{array}{l}(3,00- \\
4,00)\end{array}$ & 7,36 & $<0,001$ \\
\hline $\begin{array}{l}\mathrm{R} / \mathrm{S} \text { davatelja usluga } \\
\text { (Service provider } \\
\text { routing/switching): } \\
\text { - } \mathrm{R} / \mathrm{S} \text { uređaji, protokoli, } \\
\text { način rada, ... }\end{array}$ & 73 & 3,21 & 1,11 & 3,00 & 3,00 & $\begin{array}{c}(3,00- \\
4,00)\end{array}$ & 7,22 & $<0,001$ \\
\hline $\begin{array}{l}\text { Podatkovni centri (Data } \\
\text { Center): } \\
\text { - R/S uređaji, protokoli, } \\
\text { način rada, ... }\end{array}$ & 73 & 2,89 & 1,19 & 4,00 & 3,00 & $\begin{array}{l}(2,00- \\
4,00)\end{array}$ & 6,88 & $<0,001$ \\
\hline $\begin{array}{l}\text { Upravljanje računalnim } \\
\text { mrežama (Network } \\
\text { management - NM): } \\
\text { - SNMP protokol, načini } \\
\text { upravljanja R/S uređajima, } \\
\text { i drugo. }\end{array}$ & 73 & 3,19 & 0,95 & 3,00 & 3,00 & $\begin{array}{l}(3,00- \\
4,00)\end{array}$ & 7,42 & $<0,001$ \\
\hline $\begin{array}{l}\text { Sigurnost R/S uređaja i } \\
\text { računalnih mreža }\end{array}$ & 73 & 3,34 & 1,07 & 4,00 & 4,00 & $\begin{array}{c}(3,00- \\
4,00)\end{array}$ & 7,36 & $<0,001$ \\
\hline $\begin{array}{l}\text { Računalstvo u oblaku } \\
\text { (Cloud computing) }\end{array}$ & 73 & 2,53 & 1,08 & 3,00 & 3,00 & $\begin{array}{c}(2,00- \\
3,00) \\
\end{array}$ & 6,78 & $<0,001$ \\
\hline $\begin{array}{l}\text { Softverski definirane } \\
\text { mreže (Software Defined } \\
\text { Networks - SDN) }\end{array}$ & 73 & 2,41 & 1,19 & 3,00 & 2,00 & $\begin{array}{l}(1,00- \\
3,00)\end{array}$ & 6,43 & $<0,001$ \\
\hline $\begin{array}{l}\text { Automatizacija i } \\
\text { programiranje računalnih } \\
\text { mreža (Automation tools } \\
\text { and DevOps) }\end{array}$ & 73 & 2,04 & 1,10 & 1,00 & 2,00 & $\begin{array}{c}(1,00- \\
3,00)\end{array}$ & 5,90 & $<0,001$ \\
\hline Ukupno & 73 & 2,90 & 0,81 & 3,13 & 3,00 & $\begin{array}{l}(2,38- \\
3,50)\end{array}$ & 7,38 & $<0,001$ \\
\hline
\end{tabular}

* Wilcoxonov test za jedan nezavisan uzorak

Manje znanja ispitanici imaju iz novijih područja računalnih mreža koja su se pojavila s tehnologijom virtualizacije mrežnih uređaja prije 15-ak godina i postaju sve važnija u današnjim računalnim mrežama:

- podatkovni centri (engl. Data Center - DC): srednja ocjena 2.89, 
- računalstvo u oblaku (engl. cloud computing): srednja ocjena 2.53 i

- $\quad$ softverski definirane mreže (Software Defined Networks - SDN): srednja ocjena 2.41.

Najmanje znanja ispitanici imaju iz područja automatizacije i programiranje računalnih mreža (srednja ocjena 2.04).

Kreirana je ukupna dimenzija razine znanja kao prosjek odgovora svih tvrdnji. Iz tablice je vidljivo da je prosječna vrijednost znanja ukupne dimenzije razine znanja 2,90 (dobro znanje) s prosječnim odstupanjem od aritmetičke sredine $0,81(Z=7,38, p<0,001)$.

Sam iznos ocjena ispitanika nije toliko važan (zbog uvijek prisutne subjektivnosti kod ocjenjivanja), već je važan odnos dodijeljenih ocjena koji se može koristiti za međusobnu usporedbu po područjima, kao i za kasniju usporedbu s poznavanjem NETCONF standarda.

Sljedeće, peto pitanje odnosi se na razinu znanja ispitanika iz područja programiranja i programskih jezika. Ispitanici su iskazivali razinu svoga znanja vrijednostima od 1 do 5, gdje je 1 označavala nedovoljno znanje, a 5 izvrsno znanje.

Testiranje se provodi Wilcoxonovim testom za jedan nezavisan uzorak gdje će se utvrditi postojanje prolazne ocjene na ponuđene tvrdnje samo ako je srednja vrijednost (medijan) veća od 1,00 uz empirijsku p vrijednost manju od 0,05 . U slučaju da je empirijska p vrijednost veća od 0,05 , riječ je o neprolaznoj ocjeni (nedovoljan).

Tablica 6-36. prikazuje odgovore na 5. pitanje pomoću deskriptivne statistike razine znanja ispitanika iz programiranja i programskih jezika.

Može se vidjeti da ispitanici posjeduju najviše znanja iz:

- općenito programiranje $i$ programski jezici (prosječna razina znanja 2,32; std.dev.1,08)

koja su vjerojatno stečena tijekom formalnog ICT obrazovanja.

Zanimljivo je da ispitanici najmanje znanja imaju iz:

- Perl (prosječna razina znanja 1,41; std.dev.0,91) i

- $\mathrm{Tcl}$ (prosječna razina znanja 1,41; std.dev.0,70) 
koji su jezici korišteni za automatizaciju računalnih mreža na tradicionalan način pomoću skripti i prisutni su kao mrežna tehnologija više od dvadeset godina. Čak $76.71 \%$ ispitanika za Perl i $69.86 \%$ za Tcl smatra da ima nedovoljna znanja o tim jezicima. To pokazuje da ispitanici koji rade s računalnim mrežama rijetko koriste automatizaciju računalnih mreža i na tradicionalan način. To potvrđuje iskustvo iz prakse istraživača da se automatizacija ponekad koristi u ISP mrežama (i to od najiskusnijih ili specijaliziranih mrežnih stručnjaka), a gotovo nikada u mrežama poduzeća.

Tablica 6-36. Razine znanja ispitanika iz programiranja i programskih jezika (upitnik korisnika)

\begin{tabular}{|c|c|c|c|c|c|c|c|c|}
\hline & $\mathrm{N}$ & Prosjek & Std.Dev. & Mod & $\begin{array}{c}\text { Medija } \\
\mathrm{n}\end{array}$ & IQR & $\mathrm{Z}$ & $\mathrm{P}^{*}$ \\
\hline $\begin{array}{l}\text { Općenito programiranje i } \\
\text { programski jezici }\end{array}$ & 73 & 2,32 & 1,08 & 2,00 & 2,00 & $\begin{array}{l}(1,00- \\
3,00)\end{array}$ & 6,51 & $<0,001$ \\
\hline $\mathrm{C} / \mathrm{C}++$ & 73 & 1,88 & 0,96 & 1,00 & 2,00 & $\begin{array}{c}(1,00- \\
2,00)\end{array}$ & 5,83 & $<0,001$ \\
\hline Python & 73 & 2,03 & 1,14 & 1,00 & 2,00 & $\begin{array}{c}(1,00- \\
3,00)\end{array}$ & 5,52 & $<0,001$ \\
\hline Java & 73 & 1,75 & 0,95 & 1,00 & 1,00 & $\begin{array}{l}(1,00- \\
2,00)\end{array}$ & 5,20 & $<0,001$ \\
\hline JavaScript & 73 & 1,52 & 0,93 & 1,00 & 1,00 & $\begin{array}{l}(1,00- \\
2,00)\end{array}$ & 4,32 & $<0,001$ \\
\hline $\begin{array}{l}\text { XML (Extensible Markup } \\
\text { Language) }\end{array}$ & 73 & 1,99 & 1,03 & 2,00 & 2,00 & $\begin{array}{c}(1,00- \\
2,00)\end{array}$ & 6,12 & $<0,001$ \\
\hline $\begin{array}{l}\text { HTML (Hypertext Markup } \\
\text { Language) }\end{array}$ & 73 & 2,10 & 1,09 & 2,00 & 2,00 & $\begin{array}{c}(1,00- \\
3,00)\end{array}$ & 6,19 & $<0,001$ \\
\hline $\begin{array}{l}\text { API (Application- } \\
\text { Programming Interface) }\end{array}$ & 73 & 1,62 & 1,01 & 1,00 & 1,00 & $\begin{array}{l}(1,00- \\
2,00)\end{array}$ & 4,68 & $<0,001$ \\
\hline Perl & 73 & 1,41 & 0,91 & 1,00 & 1,00 & $\begin{array}{c}(1,00- \\
1,00) \\
\end{array}$ & 3,71 & $<0,001$ \\
\hline $\mathrm{Tcl}$ & 73 & 1,41 & 0,70 & 1,00 & 1,00 & $\begin{array}{c}(1,00- \\
2,00)\end{array}$ & 4,29 & $<0,001$ \\
\hline Ukupno & 73 & 1,80 & 0,72 & 1,00 & 1,60 & $\begin{array}{c}(1,30- \\
2,20)\end{array}$ & 7,01 & $<0,001$ \\
\hline
\end{tabular}

* Wilcoxonov test za jedan nezavisan uzorak

Kreirana je ukupna dimenzija razine znanja kao prosjek odgovora svih tvrdnji. Iz tablice je vidljivo da je prosječna vrijednost znanja ukupne dimenzije razine znanja $1,80 \mathrm{~s}$ prosječnim odstupanjem od aritmetičke sredine $0,72(Z=7,01 ; p<0,001)$. 
Tablica 6-37. prikazuje na kojim poslovima vezanim uz R/S uređaje rade ispitanici na svojim radnim mjestima (šesto pitanje anketnog upitnika). Može se vidjeti da ispitanici obavljaju različite vrste poslova vezane uz računalne mreže. To pokazuje da istraživanje ne pokriva samo mrežne stručnjake koji se bave određenom vrstom posla (na primjer edukacijom ili upravljanje timom), već uključuje većinu poslova kojima se bave stručnjaci u ovom području.

Tablica 6-37. Poslovi ispitanika vezani uz $R / S$ uređaje

\begin{tabular}{lcc}
\hline & $\mathbf{N}$ & $\mathbf{\%}$ \\
\hline Dizajn računalne mreže kompanije. & 46 & 63,00 \\
\hline Instalacija i konfiguracija R/S uređaja i računalne mreže. & 51 & 69,86 \\
\hline Dijagnostika (troubleshooting) R/S uređaja i računalne mreže. & 52 & 71,23 \\
\hline Upravljanje i nadzor R/S uređaja i računalne mreže. & 42 & 57,53 \\
\hline Sigurnost R/S uređaja i računalne mreže. & 40 & 54,79 \\
\hline Savjetovanje za poboljšanje i daljnji razvoj računalne mreže. & 43 & 58,90 \\
\hline Prodaja mrežnih usluga i R/S uređaja. & 10 & 13,70 \\
\hline Edukacija o računalnim mrežama i tehnologijama. & 24 & 32,88 \\
\hline Upravljanje tima mrežnih administratora. & 14 & 19,18 \\
\hline Komunikacija i rad s vanjskim partnerima koji održavaju računalnu mrežu. & 30 & 41,10 \\
\hline Sistemski administrator. & 28 & 38,36 \\
\hline Ostalo & 0 & 0,00 \\
\hline
\end{tabular}

Važno je napomenuti da značajan broj ispitanika obavlja i poslove sistemskog administratora. To je posao koji zahtijeva poznavanje računalnih mreža i mrežnih R/S uređaja, ali zahtijeva i značajno poznavanje drugih računalnih uređaja i sustava (operacijski sustavi, krajnji mrežni uređaji, i drugo). Zbog potrebne širine znanja iz različitih ICT područja, sistemski administratori vrlo često imaju samo osnovna znanja iz računalnih mreža.

Ovo je pitanje bilo eliminacijsko za istraživanje: ako su ispitanici odabrali odgovor $\mathrm{Ne}$ radim na poslovima vezanim uz računalne mreže $i R / S$ uređaje njihovi odgovori nisu uključeni u daljnju analizu dobivenih rezultata.

\subsubsection{Podaci o kompanijama ispitanika}

U anketnom upitniku od ispitanika su dobiveni sljedeći podaci o njihovim kompanijama: 
- osnovna djelatnost kompanije zaposlenika (8. pitanje anketnog upitnika),

- tražena raspoloživost mreže kompanije ispitanika (9. pitanje anketnog upitnika),

- od kojih proizvođača dolaze R/S mrežni uređaji i u kojem su postotku instalirani u mreži kompanije ispitanika (10. pitanje anketnog upitnika) i

- postoji li implementacija softverski definirane mreže (SDN) u mreži kompanije ispitanika (11. pitanje anketnog upitnika).

Tablica 6-38. prikazuje osnovnu djelatnost kompanije zaposlenika (osmo pitanje anketnog upitnika).

\section{Tablica 6-38. Osnovna djelatnost kompanije zaposlenika (upitnik korisnika)}

\begin{tabular}{|c|c|c|}
\hline Osnovna djelatnost kompanije & $\mathbf{N}$ & $\%$ \\
\hline $\begin{array}{l}\text { Davatelj usluga (Internet servise provider - ISP) } \\
\text { • na primjer: T-Com (HT), A1, Iskon, Metronet,... }\end{array}$ & 17 & 23,29 \\
\hline $\begin{array}{l}\text { Državna ustanova } \\
\text { • na primjer vojska, policija i slično }\end{array}$ & 6 & 8,22 \\
\hline $\begin{array}{l}\text { Edukacijska ustanova } \\
\text { - na primjer škole, fakulteti i slično }\end{array}$ & 5 & 6,85 \\
\hline $\begin{array}{l}\text { Financijska ustanova } \\
\text { • na primjer banke i slično }\end{array}$ & 3 & 4,11 \\
\hline Podatkovni centar & 1 & 1,37 \\
\hline $\begin{array}{l}\text { Sistem integrator (partner proizvođača mrežne opreme), } \\
\text { • na primjer Combis, CS, King ICT, Kodeks, S\&T, Storm, Verso i drugi }\end{array}$ & 20 & 27,40 \\
\hline $\begin{array}{l}\text { Transport } \\
\bullet \quad \text { na primjer zračne luke, željeznica i slično }\end{array}$ & 2 & 2,74 \\
\hline $\begin{array}{l}\text { Trgovina } \\
\bullet \quad \text { na primjer trgovački lanci, trgovački centri }\end{array}$ & 3 & 4,11 \\
\hline $\begin{array}{l}\text { Zdravstvena ustanova } \\
\text { • na primjer bolnice, ambulante i slično }\end{array}$ & 1 & 1,37 \\
\hline Ostala velika poduzeća (Enterprise) koja nisu gore navedena & 13 & 17,81 \\
\hline Ostala mala i srednja poduzeća (Small Medium Business - SMB) koja nisu gore navedena & 2 & 2,74 \\
\hline Ukupno & 73 & 100,0 \\
\hline
\end{tabular}

Djelatnost kompanije poduzeća može se podijeliti u tri kategorije koje su važne za istraživanje: 
- $\quad$ sistemski integrator (partner proizvođača mrežne opreme): 27.40\% (20 ispitanika)

○ na primjer Combis, CS, King ICT, Kodeks, S\&T, Storm, Verso i drugi

- davatelj usluga (ISP): 23.29\% (17 ispitanika)

○ na primjer: T-Com (HT), A1, Iskon, Metronet i drugi

- poduzeće (engl. Enterprise): 49.31\% (36 ispitanika)

○ na primjer: banka, škola, bolnica, trgovina, obrt i drugi

odnosno:

- partneri: $27.40 \%$ (20 ispitanika)

- $\quad$ krajnji korisnici (ISP i poduzeća zajedno): 72.60\% (53 ispitanika)

Sve gore navedene kompanije imaju veću raspoloživost (minimalno ,tri devetke“), tako da su kao poduzeća uključene državne ustanove, banke i financijske ustanove, podatkovni centri, transport i druga poduzeća.

\begin{tabular}{l|l|l|l|}
\hline $\begin{array}{l}\text { Raspoloživost < } 99 \% \text { (Vrijeme zastoja godišnje } \\
\text { veće od 3,65 dana) }\end{array}$ & $14.12 \%$ & 12 & \\
\hline $\begin{array}{l}\text { Raspoloživost } 99.9 \% \text { (Vrijeme zastoja godišnje } \\
\text { oko 8,76 sati) }\end{array}$ & $30.59 \%$ & 26 & \\
\hline $\begin{array}{l}\text { Raspoloživost 99.99\% (Vrijeme zastoja godišnje } \\
\text { oko } 52,56 \text { minuta) }\end{array}$ & $29.41 \%$ & 25 & \\
\hline $\begin{array}{l}\text { Raspoloživost } 99.999 \% \text { (Vrijeme zastoja } \\
\text { godišnje oko 5,26 minuta) }\end{array}$ & $17.65 \%$ & 15 & \\
\hline $\begin{array}{l}\text { Raspoloživost > 99.9999\% (Vrijeme zastoja } \\
\text { godišnje manje od 31,5 sekundi) }\end{array}$ & $8.24 \%$ & 7 & \\
\hline
\end{tabular}

85

\section{Slika 6-7. Raspoloživost mreže kompanije ispitanika}

Nakon eliminacije nekompletnih anketnih upitnika i odgovora osoba koji se trenutno ne bave računalnim mrežama (6. pitanje anketnog upitnika), preostalo je ukupno 85 anketnih upitnika.

Slika 6-7. prikazuje traženu raspoloživost mreže kompanije ispitanika (deveto pitanje anketnog upitnika). U slučaju da ispitanici rade s više računalnih mreža svoje kompanije ili kompanija svojih korisnika (u slučaju partnera), tražilo se da ispitanici odaberu onu s 
najvećom raspoloživosti, odnosno s najmanjim vremenom zastoja. Cilj ovog pitanja je dobiti informaciju da li ispitanici rade s mrežama visoke raspoloživosti.

Ovo pitanje je eliminacijsko za istraživanje. Za istraživanje primjene NETCONF standarda uvjet je visoka raspoloživost računalnih mreža ispitanika. Za granicu visoke raspoloživosti (prihvatljive minimalne raspoloživosti) od istraživača su određene „tri devetke“ (raspoloživost 99.9\%, odnosno godišnje vrijeme zastoja oko 8.76 sati). Zbog toga su za analiziranje rezultata istraživanja eliminirani odgovori 12 ispitanika (raspoloživost 99\% i manje) pa je preostao broj anketnih upitnika od $\mathbf{7 3}$ ispitanika za analizu rezultata.

Od preostale 73 kompanije koje imaju raspoloživost veću ili jednaku_od „tri devetke“ može se vidjeti:

- gotovo isti broj kompanija ima zahtjev za mrežom raspoloživosti od „tri devetke“ (26 kompanija; 35,62\%) i „četiri devetke“ (25 kompanija; 35,25\%)

- dok 15 poduzeća $(17,55 \%)$ ima zahtjev za mrežom raspoloživosti „četiri devetke“ i

- 7 poduzeća $(9,59 \%)$ ima zahtjev za mrežom raspoloživosti većom ,ppet devetki“.

Iduće, deseto pitanje odnosilo se na primjenu R/S mrežnih uređaja od više proizvođača. Ispitanici su iskazivali mišljenje vrijednostima razreda od 0 do 5 , gdje je 0 označavalo $0 \%$ dok je 5 označavalo $100 \%$.

Testiranje se provodi Wilcoxonovim testom za jedan nezavisan uzorak gdje će se utvrditi postojanje visoke razine upotrebe samo ako je srednja vrijednost (medijan) veća od 3,00 (41\%-60\%) uz empirijsku p vrijednost manju od 0,05. U slučaju da je empirijska p vrijednost veća od 0,05 riječ je o srednjoj razini primjene (41\%-60\%), dok u slučaju da je srednja vrijednost (medijan) manja od 3 (41-60\%) te se utvrdi empirijska p vrijednost manja od 0,05, postoji niska razina upotrebe.

Najveći broj R/S mrežnih uređaja dolazi od proizvođača:

- Cisco Systems (prosječna vrijednost odgovora 3,64; std.dev.1,48),

- Hewlett Packard Enterprise (prosječna vrijednost odgovora 1,04; std.dev.1,39),

- Huawei (prosječna vrijednost odgovora 0,71 ; std.dev.1,30) i

- Juniper Networks (prosječna vrijednost odgovora 0,66; std.dev. 1,11), 
i sa svima njima je obavljen intervju.

Tablica 6-39. prikazuje odgovore na 10. pitanje pomoću deskriptivne statistike.

Tablica 6-39. Primjena R/S uređaja u Hrvatskoj po proizvođačima (upitnik korisnika)

\begin{tabular}{lcccccccc}
\hline & $\mathrm{N}$ & Prosjek & $\begin{array}{c}\text { Std. } \\
\text { dev. }\end{array}$ & Mod & Median & IQR & Z & $\mathrm{P}^{*}$ \\
\hline Arista & 73 & 0,10 & 0,41 & 0,00 & 0,00 & $(0,00-0,00)$ & 8,28 & $<0,001$ \\
\hline Cisco Systems & 73 & 3,67 & 1,48 & 5,00 & 4,00 & $(3,00-5,00)$ & 3,54 & 0,001 \\
\hline Extreme Networks & 73 & 0,34 & 1,07 & 0,00 & 0,00 & $(0,00-0,00)$ & 8,01 & $<0,001$ \\
\hline F5 & 73 & 0,64 & 1,05 & 0,00 & 0,00 & $(0,00-1,00)$ & 7,38 & $<0,001$ \\
\hline $\begin{array}{l}\text { Hewlett Packard } \\
\text { Enterprise (HPE) }\end{array}$ & 73 & 1,04 & 1,39 & 0,00 & 0,00 & $(0,00-2,00)$ & 6,84 & $<0,001$ \\
\hline Huawei & 73 & 0,71 & 1,30 & 0,00 & 0,00 & $(0,00-1,00)$ & 7,32 & $<0,001$ \\
\hline Juniper Networks & 73 & 0,66 & 1,11 & 0,00 & 0,00 & $(0,00-1,00)$ & 7,39 & $<0,001$ \\
\hline Nokia (Alcatel-Lucent) & 73 & 0,14 & 0,42 & 0,00 & 0,00 & $(0,00-0,00)$ & 8,16 & $<0,001$ \\
\hline
\end{tabular}

* Wilcoxonov test za jedan nezavisan uzorak

R/S uređaji u najmanjem broju slučajeva dolaze od proizvođača Arista (prosječna vrijednost odgovora 0,$10 ;$ std.dev.0,41).

Tablica 6-40. prikazuje detaljno rezultate primjene R/S uređaja kod korisnika u Hrvatskoj po proizvođačima (10. pitanje anketnog upitnika). Iz tablice se može vidjeti da najviše ispitanika koristi Cisco (72) R/S uređaje u svojim mrežama, zatim slijede HPE (50), Juniper Networks (50) i drugi.

Za svakog proizvođača izračunati su bodovi prisutnosti na tržištu množenjem stupnja postotka s brojem korisnika koji su odabrali taj stupanj. Tako se, na primjer, za Cisco dobije 268 $(7 * 1+14+7 * 2+12 * 3+14 * 4+31 * 5)$ i odgovarajući postotak $(268 / 541 * 100=49,54 \%)$. Tablica 6-41. prikazuje izračun za sve proizvođače. U tablici se vidi da su četiri proizvođača najzastupljenija kod korisnika: Cisco (49,54\%), HPE (14,05\%), Huawei $(9,61 \%)$ i Juniper Networks $(8,87)$.

Pod Napomene jedan je ispitanik naveo Mikrotik, jedan Fortigate i jedan Fortinet (kao ostale proizvođače koji nisu na listi), dok je jedan ispitanik naveo da koriste isključivo Cisco (što je, kako je naveo, standardizirano po odluci kompanije). 
Tablica 6-40. Primjena R/S uređaja u Hrvatskoj po proizvođačima (rezultati upitnika korisnika)

\begin{tabular}{|c|c|c|c|c|c|c|c|c|c|c|c|c|c|c|}
\hline & \multicolumn{2}{|c|}{$\begin{array}{c}0 \\
0 \%\end{array}$} & \multicolumn{2}{|c|}{$\begin{array}{c}1 \\
1-20 \% \\
\end{array}$} & \multicolumn{2}{|c|}{$\begin{array}{c}2 \\
21-40 \% \\
\end{array}$} & \multicolumn{2}{|c|}{$\begin{array}{c}3 \\
41-60 \% \\
\end{array}$} & \multicolumn{2}{|c|}{$\begin{array}{c}4 \\
61-80 \% \\
\end{array}$} & \multicolumn{2}{|c|}{$\begin{array}{c}5 \\
81-100 \% \\
\end{array}$} & \multicolumn{2}{|c|}{ Ukupno } \\
\hline & $\%$ & $\mathbf{N}$ & $\%$ & $\mathbf{N}$ & $\%$ & $\mathbf{N}$ & $\%$ & $\mathbf{N}$ & $\%$ & $\mathbf{N}$ & $\%$ & $\mathbf{N}$ & $\%$ & $\mathbf{N}$ \\
\hline Arista & 86.84 & 33 & 10.53 & 4 & 0.00 & 0 & 2.63 & 1 & 0.00 & 0 & 0.00 & 0 & 100 & 38 \\
\hline Cisco Systems & 1.39 & 1 & 9.72 & 7 & 9.72 & 7 & 16.67 & 12 & 19.44 & 14 & 43.06 & 31 & 100 & 72 \\
\hline Extreme Networks & 78.05 & 32 & 7.32 & 3 & 2.44 & 1 & 4.88 & 2 & 2.44 & 1 & 4.88 & 2 & 100 & 41 \\
\hline F5 & 43.75 & 21 & 31.25 & 15 & 12.50 & 6 & 10.42 & 5 & 0.00 & 0 & 2.08 & 1 & 100 & 48 \\
\hline $\begin{array}{l}\text { Hewlett Packard } \\
\text { Enterprise }\end{array}$ & 28.00 & 14 & 34.00 & 17 & 12.00 & 6 & 14.00 & 7 & 8.00 & 4 & 4.00 & 2 & 100 & 50 \\
\hline Huawei & 48.89 & 22 & 22.22 & 10 & 6.67 & 3 & 13.33 & 6 & 4.44 & 2 & 4.44 & 2 & 100 & 45 \\
\hline Juniper Networks & 44.00 & 22 & 34.00 & 17 & 14.00 & 7 & 2.00 & 1 & 2.00 & 1 & 4.00 & 2 & 100 & 50 \\
\hline $\begin{array}{l}\text { Nokia (Alcatel- } \\
\text { Lucent) }\end{array}$ & 79.49 & 31 & 15.38 & 6 & 5.13 & 2 & 0.00 & 0 & 0.00 & 0 & 0.00 & 0 & 100 & 39 \\
\hline
\end{tabular}

Tablica 6-41. Proizvođači R/S mrežnih uređaja u Hrvatskoj

\begin{tabular}{lcc}
\hline Proizvođač & \multicolumn{2}{c}{ Prisutnost na tržištu } \\
\hline Arista & Bodovi & Postotak \\
\hline Cisco Systems & 7 & 1,29 \\
\hline Extreme Networks & 268 & 49,54 \\
\hline F5 & 25 & 4,62 \\
\hline Hewlett Packard Enterprise (HPE) & 47 & 8,69 \\
\hline Huawei & 76 & 14,05 \\
\hline Juniper Networks & 52 & 9,61 \\
\hline Nokia (Alcatel-Lucent) & 48 & 8,87 \\
\hline Ukupno: & 18 & 3,33 \\
\hline
\end{tabular}


Tablica 6-42. prikazuje implementaciju softverski definirane mreže (SDN) u mreži kompanije ispitanika (jedanaesto pitanje anketnog upitnika). To može bilo koja vrsta SDN implementacije: SD-WAN, SD-Access ili drugo.

Tablica 6-42. Implementacija softverski definirane mreže (SDN) (upitnik korisnika)

\begin{tabular}{lc|c}
\hline & $\mathbf{N}$ & $\boldsymbol{\%}$ \\
\hline $\mathrm{Da}$ & 15 & 20,55 \\
\hline $\mathrm{Ne}$ & 26 & 35,62 \\
\hline Još ne, ali trenutno razmatramo/testiramo SDN implementaciju & 22 & 30,14 \\
\hline Ne znam & 10 & 13,70 \\
\hline Ukupno & 73 & 100,0 \\
\hline
\end{tabular}

NETCONF protokol je sastavni dio definicije arhitekture SDN standarda definiranog u RFC $7426^{170}$ zbog čega je ovo je pitanje stavljeno u anketni upitnik.

Iz rezultata se može vidjeti da samo $20.55 \%$ ispitanika koristi softverski definirane mreže, dok $30.14 \%$ ispitanika još ne koristi, ali razmatra njegovu primjenu.

\subsubsection{Primjena NETCONF standarda kod proizvođača $R / S$ uređaja}

U ovom poglavlju se razmatra primjena NETCONF standarda od strane proizvođača na svojim R/S uređajima.

Četrnaesto pitanje odnosi se na primjenu NETCONF standarda od strane proizvođača. Ispitanici su iskazivali slaganje s ponuđenom tvrdnjom vrijednostima od -2 do 2 , gdje je -2 označavalo izrazito ne slaganje, a 2 izrazito slaganje s tvrdnjom.

Od 73 ispitanika, njih 9 (12,33\%) je odabralo odgovor Ne znam. Rezultati dobiveni od ostalih ispitanika (64) obrađeni su deskriptivnom statistikom.

Testiranje se provodi Wilcoxonovim testom za jedan nezavisan uzorak gdje će se utvrditi postojanje slaganja ispitanika s tvrdnjom da proizvođači mrežne opreme implementiraju

${ }^{170}$ IETF: RFC 7426 Software-Defined Networking (SDN): Layers and Architecture Terminology, January 2015 
NETCONF standard na svojim uređajima samo ako je srednja vrijednost (medijan) veća od 0,00 uz empirijsku p vrijednost manju od 0,05 . U slučaju da je empirijska p vrijednost veća od 0,05 riječ je o indiferentnom stavu, dok se u slučaju negativne vrijednosti medijana uz empirijsku p vrijednost manju od 0,05 može utvrditi da je riječ o neslaganju.

Tablica 6-43. prikazuje odgovore na 14. pitanje pomoću deskriptivne statistike.

Tablica 6-43. Primjena NETCONF standarda na R/S uređajima proizvođača (upitnik korisnika)

\begin{tabular}{|c|c|c|c|c|c|c|c|c|}
\hline & $\mathrm{N}$ & Prosjek & $\begin{array}{l}\text { Std. } \\
\text { Dev. }\end{array}$ & Mod & Medijan & IQR & $\mathrm{Z}$ & $\mathrm{P} *$ \\
\hline $\begin{array}{l}\text { Proizvođači mrežne } \\
\text { opreme implementiraju } \\
\text { NETCONF standard na } \\
\text { svojim uređajima. }\end{array}$ & 64 & 0,33 & 0,86 & 0,00 & 0,00 & $(0,00-1,00)$ & 2,87 & 0,004 \\
\hline
\end{tabular}

Prosječna razina slaganja s ponuđenom tvrdnjom je 0,33 s prosječnim odstupanjem od aritmetičke sredine 0,86 , što znači da korisnici imaju indiferentan stav.

Petnaesto pitanje anketnog upitnika glasi: „Po Vašem mišljenju u kojem postotku na svojim R/S uređajima različiti proizvođači implementiraju NETCONF standard?“. Ispitanici su iskazivali mišljenje vrijednostima razreda od 0 do 5 , gdje je 0 označavalo $0 \%$, dok je 5 označavalo $100 \%$.

Testiranje se provodi Wilcoxonovim testom za jedan nezavisan uzorak gdje će se utvrditi postojanje visoke razine upotrebe samo ako je srednja vrijednost (medijan) veća od 3,00 (41\%-60\%) uz empirijsku p vrijednost manju od 0,05. U slučaju da je empirijska p vrijednost veća od 0,05 riječ je o srednjoj razini primjene (41\%-60\%), dok u slučaju da je srednja vrijednost (medijan) manja od 3 (41-60\%) te se utvrdi empirijska p vrijednost manja od 0,05, postoji niska razina upotrebe.

Tablica 6-44. prikazuje broj i postotak odgovora „Ne znam“ na 15. pitanje. Visoki postotak odgovora „Ne znam“ u ovom pitanju pokazuje nepoznavanje NETCONF standarda i njegove primjene od strane ispitanika (korisnika). Ostali odgovori su prikazani deskriptivnom statistikom. 
Tablica 6-44. Odgovori „Ne znam“ na 15. pitanje (upitnik korisnika)

\begin{tabular}{|l|c|c|c|c|}
\hline \multirow{2}{*}{} & Ukupan broj odgovora & \multicolumn{2}{|c|}{$\begin{array}{c}\text { Odgovori } \\
\text { "Ne znam" }\end{array}$} & $\begin{array}{c}\text { Broj odgovora za } \\
\text { analizu }\end{array}$ \\
\cline { 2 - 5 } & $\mathbf{N}$ & $\mathbf{\%}$ & $\mathbf{N}$ & $\mathbf{N}$ \\
\hline Arista & 64 & $67.19 \%$ & 43 & 21 \\
\hline Cisco Systems & 72 & $37.50 \%$ & 27 & 45 \\
\hline Extreme Networks & 65 & $64.62 \%$ & 42 & 23 \\
\hline F5 & 65 & $60.00 \%$ & 39 & 26 \\
\hline Hewlett Packard Enterprise & 65 & $61.54 \%$ & 40 & 25 \\
\hline Huawei & 65 & $64.62 \%$ & 42 & 23 \\
\hline Juniper Networks & 66 & $57.58 \%$ & 38 & 28 \\
\hline Nokia (Alcatel-Lucent) & 64 & $70.31 \%$ & 45 & 19 \\
\hline
\end{tabular}

Tablica 6-45. prikazuje odgovore na 15. pitanje pomoću deskriptivne statistike.

Tablica 6-45. Implementacija NETCONF standarda na R/S uređajima različitih proizvođača (upitnik korisnika)

\begin{tabular}{lcccccccc}
\hline & $\mathrm{N}$ & Prosjek & Std.Dev. & Mod & $\begin{array}{c}\text { Med } \\
\text { ijan }\end{array}$ & IQR & Z & $\mathrm{P}^{*}$ \\
\hline Arista & 21 & 1,48 & 1,83 & 0,00 & 1,00 & $(0,00-2,00)$ & 3,08 & 0,002 \\
\hline Cisco Systems & 45 & 2,31 & 1,78 & N/a & 2,00 & $(1,00-4,00)$ & 2,49 & 0,013 \\
\hline Extreme Networks & 23 & 1,22 & 1,59 & 0,00 & 0,00 & $(0,00-2,00)$ & 3,63 & $<0,001$ \\
\hline F5 & 26 & 1,42 & 1,55 & 0,00 & 1,00 & $(0,00-2,00)$ & 3,68 & $<0,001$ \\
\hline $\begin{array}{l}\text { Hewlett Packard } \\
\text { Enterprise (HPE) }\end{array}$ & 25 & 1,36 & 1,50 & 0,00 & 1,00 & $(0,00-2,00)$ & 3,77 & $<0,001$ \\
\hline Huawei & 23 & 1,74 & 1,74 & 0,00 & 1,00 & $(0,00-4,00)$ & 2,99 & 0,003 \\
\hline Juniper Networks & 28 & 2,07 & 1,80 & 0,00 & 2,00 & $(0,00-4,00)$ & 2,61 & 0,009 \\
\hline Nokia (Alcatel-Lucent) & 19 & 1,05 & 1,22 & 0,00 & 1,00 & $(0,00-2,00)$ & 3,64 & $<0,001$ \\
\hline
\end{tabular}

* Wilcoxonov test za jedan nezavisan uzorak

Po mišljenju ispitanika proizvođač Cisco Systems u najvećem postotku (46,2\%) implementira NETCONF standard na svojim R/S uređajima (prosječna vrijednost odgovora 2,31; std.dev.1,78), dok u najmanjem postotku (24,4\%) proizvođač Extreme Networks implementira NETCONF standard na svojim R/S uređajima (prosječna vrijednost odgovora 1,22; std.dev.1,59). 
Šesnaesto pitanje anketnog upitnika glasi: „Podržavaju li proizvođači veću primjenu NETCONF standarda kod korisnika i na koji način?“. Ispitanici su iskazivali slaganje vrijednostima od 1 do 5 , gdje je 1 označavala neslaganje, a 5 potpuno slaganje s tvrdnjom.

Tablica 6-46. Podrška primjene NETCONF standarda od strane proizvođača (rezultati upitnika korisnika)

\begin{tabular}{|c|c|c|c|c|c|c|c|c|c|c|c|c|c|c|}
\hline & \multicolumn{2}{|c|}{ Ne znam } & \multicolumn{2}{|c|}{$\begin{array}{c}1 \\
\mathrm{Ne} \\
\text { slažem } \\
\text { se }\end{array}$} & \multicolumn{2}{|c|}{$\begin{array}{c}2 \\
\text { Malo se } \\
\text { slažem }\end{array}$} & \multicolumn{2}{|c|}{$\begin{array}{c}3 \\
\text { Slažem se }\end{array}$} & \multicolumn{2}{|c|}{$\begin{array}{l}\quad 4 \\
\text { Vrlo se } \\
\text { slažem }\end{array}$} & \multicolumn{2}{|c|}{$\begin{array}{c}5 \\
\text { Potpuno } \\
\text { se slažem }\end{array}$} & \multicolumn{2}{|c|}{ Ukupno } \\
\hline & $N$ & $\%$ & $\mathbf{N}$ & $\%$ & $\mathbf{N}$ & $\%$ & $\mathbf{N}$ & $\%$ & $\mathbf{N}$ & $\%$ & $\mathbf{N}$ & $\%$ & $\mathbf{N}$ & $\%$ \\
\hline $\begin{array}{l}\text { Postoji detaljna dokumentacija } \\
\text { proizvođača koja objašnjava rad } \\
\text { i primjenu NETCONF } \\
\text { standarda na mrežnim } \\
\text { uređajima: upute (manuals), } \\
\text { preporuke za uporabu (white } \\
\text { papers), i slično. }\end{array}$ & 37 & 50,68 & 4 & 5,48 & 12 & 16,44 & 15 & 20,55 & 5 & 6,85 & 0 & 0 & 73 & 100 \\
\hline $\begin{array}{l}\text { Postoje tečajevi proizvođača za } \\
\text { samostalno učenje (CBT, } \\
\text { Webinar, i slično) o NETCONF } \\
\text { protokolu. }\end{array}$ & 38 & 52,05 & 3 & 4,11 & 13 & 17,81 & 15 & 20,55 & 4 & 5,48 & 0 & 0 & 73 & 100 \\
\hline $\begin{array}{l}\text { Postoje organizirani tečajevi } \\
\text { proizvođača koje vode } \\
\text { instruktori o NETCONF } \\
\text { protokolu. }\end{array}$ & 40 & 54,79 & 5 & 6,85 & 14 & 19,18 & 7 & 9,59 & 6 & 8,22 & 1 & 1,37 & 73 & 100 \\
\hline $\begin{array}{l}\text { Postoje certifikacijski ispiti (i } \\
\text { pripadajući tečajevi) } \\
\text { proizvođača koji detaljno } \\
\text { osposobljavaju korisnike } \\
\text { uporabi i primjeni NETCONF } \\
\text { standarda. }\end{array}$ & 42 & 57,53 & 3 & 4,11 & 16 & 21,92 & 10 & 13,7 & 1 & 1,37 & 1 & 1,37 & 73 & 100 \\
\hline $\begin{array}{l}\text { Proizvođači održavaju } \\
\text { prezentacije i radionice } \\
\text { (workshops) o prednostima i } \\
\text { načinu primjene NETCONF } \\
\text { protokola. }\end{array}$ & 41 & 56,16 & 6 & 8,22 & 15 & 20,55 & 7 & 9,59 & 1 & 1,37 & 3 & 4,11 & 73 & 100 \\
\hline
\end{tabular}

Kao granična vrijednost se koristi vrijednost 2,00 gdje u slučaju da vrijednosti slaganja prelaze graničnu vrijednost 2,00 postoji slaganje s ponuđenim tvrdnjama, dok vrijednosti niže od granične vrijednosti 2,00 upućuju na indiferentnost, dok vrijednosti manje od 2 upućuju na neslaganje s ponuđenim tvrdnjama. Testiranje se provodi Wilcoxonovim testom za jedan nezavisan uzorak gdje će se utvrditi postojanje slaganja s ponuđenim tvrdnjama samo ako je srednja vrijednost (medijan) veća od 2,00 uz empirijsku p vrijednost manju od 0,05. U slučaju da je empirijska $p$ vrijednost veća od 0,05 riječ je o indiferentnom stavu, dok u slučaju da je 
srednja vrijednost (medijan) manja od 2 te se utvrdi empirijska p vrijednost manja od 0,05 , postoji neslaganje s ponuđenim tvrdnjama.

Tablica 6-46. prikazuje rezultate odgovora na 16. pitanje anketnog upitnika. Visoki postotak odgovora „Ne znam“ u ovom pitanju pokazuje nepoznavanje NETCONF standarda i njegove primjene od strane ispitanika (korisnika). Ostali odgovori su prikazani deskriptivnom statistikom.

Tablica 6-47. prikazuje odgovore na 16. pitanje pomoću deskriptivne statistike.

Tablica 6-47. Podrška primjene NETCONF standarda od strane proizvođača (upitnik korisnika)

\begin{tabular}{|c|c|c|c|c|c|c|c|c|}
\hline & $\mathrm{N}$ & Prosjek & Std.Dev. & Mod & Medijan & IQR & $\mathrm{Z}$ & $\mathrm{P}^{*}$ \\
\hline $\begin{array}{l}\text { Postoji detaljna dokumentacija } \\
\text { proizvođača koja objašnjava rad i } \\
\text { primjenu NETCONF standarda na } \\
\text { mrežnim uređajima: upute } \\
\text { (manuals), preporuke za uporabu } \\
\text { (white papers), i slično. }\end{array}$ & 36 & 2,58 & 0,87 & 3,00 & 3,00 & $\begin{array}{l}(2,00- \\
3,00)\end{array}$ & 2,62 & 0,009 \\
\hline $\begin{array}{l}\text { Postoje tečajevi proizvođača za } \\
\text { samostalno učenje (CBT, Webinar, } \\
\text { i slično) o NETCONF protokolu. }\end{array}$ & 35 & 2,57 & 0,81 & 3,00 & 3,00 & $\begin{array}{l}(2,00- \\
3,00)\end{array}$ & 2,78 & 0,005 \\
\hline $\begin{array}{l}\text { Postoje organizirani tečajevi } \\
\text { proizvođača koje vode instruktori o } \\
\text { NETCONF protokolu. }\end{array}$ & 33 & 2,52 & 1,06 & 2,00 & 2,00 & $\begin{array}{c}(2,00- \\
3,00)\end{array}$ & 2,40 & 0,017 \\
\hline $\begin{array}{l}\text { Postoje certifikacijski ispiti (i } \\
\text { pripadajući tečajevi) proizvođača } \\
\text { koji detaljno osposobljavaju } \\
\text { korisnike uporabi i primjeni } \\
\text { NETCONF standarda. }\end{array}$ & 31 & 2,39 & 0,84 & 2,00 & 2,00 & $\begin{array}{l}(2,00- \\
3,00)\end{array}$ & 3,23 & 0,001 \\
\hline $\begin{array}{l}\text { Proizvođači održavaju prezentacije } \\
\text { i radionice (workshops) o } \\
\text { prednostima i načinu primjene } \\
\text { NETCONF protokola. }\end{array}$ & 32 & 2,38 & 1,13 & 2,00 & 2,00 & $\begin{array}{l}(2,00- \\
3,00)\end{array}$ & 2,54 & 0,011 \\
\hline Ukupno & 36 & 2,55 & 0,90 & 3,00 & 2,40 & $\begin{array}{c}(2,00- \\
3,00)\end{array}$ & 2,78 & 0,005 \\
\hline
\end{tabular}

* Wilcoxonov test za jedan nezavisan uzorak

Ispitanici su iskazali najveću razinu slaganja na tvrdnju Postoji detaljna dokumentacija proizvođača koja objašnjava rad i primjenu NETCONF standarda na mrežnim uređajima: upute (manuals), preporuke za uporabu (white papers), i slično. (prosječna vrijednost odgovora 2,58, std.dev.0,87), dok su najnižu razinu slaganja iskazali na tvrdnju Proizvođači 
održavaju prezentacije $i$ radionice (workshops) o prednostima i načinu primjene NETCONF protokola. (prosječna vrijednost odgovora 2,38, std.dev.1,13).

Ukupna razina slaganja ispitanika je bilježila prosječnu vrijednost $2,55 \mathrm{~s}$ prosječnim odstupanjem od aritmetičke sredine 0,90 .

Sedamnaesto pitanje anketnog upitnika glasi: „Molim Vas da ocijenite raspoloživu dokumentaciju, edukaciju i certificiranje o NETCONF protokolu po proizvođaču R/S uređaja.“. Ispitanici su ocjenjivali raspoloživu dokumentaciju, edukaciju i certificiranje o NETCONF protokolu po proizvođaču R/S uređaja vrijednostima 1 do 5 , gdje je 1 označavala nedovoljno, a 5 izvrsno.

Tablica 6-48. prikazuje rezultate odgovora na 17. pitanje anketnog upitnika. Visoki postotak odgovora „Ne znam“ u ovom pitanju pokazuje nepoznavanje NETCONF standarda i njegove primjene od strane ispitanika (korisnika). Ostali odgovori su prikazani deskriptivnom statistikom.

Tablica 6-48. Raspoloživa NETCONF dokumentacija i edukacija (rezultati upitnika korisnika)

\begin{tabular}{|c|c|c|c|c|c|c|c|c|c|c|c|c|c|c|}
\hline & \multicolumn{2}{|c|}{ Ne znam } & \multicolumn{2}{|c|}{$\begin{array}{c}1 \\
\text { Nedovoljna } \\
\end{array}$} & \multicolumn{2}{|c|}{$\begin{array}{c}2 \\
\text { Dovoljna } \\
\end{array}$} & \multicolumn{2}{|c|}{$\begin{array}{c}3 \\
\text { Dobra } \\
\end{array}$} & \multicolumn{2}{|c|}{$\begin{array}{c}4 \\
\text { Vrlo dobra } \\
\end{array}$} & \multicolumn{2}{|c|}{$\begin{array}{c}5 \\
\text { Izvrsna } \\
\end{array}$} & \multicolumn{2}{|c|}{ Ukupno } \\
\hline & $N$ & $\%$ & $\mathbf{N}$ & $\%$ & $\mathbf{N}$ & $\%$ & $\mathbf{N}$ & $\%$ & $\mathbf{N}$ & $\%$ & $\mathbf{N}$ & $\%$ & $\mathbf{N}$ & $\%$ \\
\hline Arista & 46 & 69,7 & 6 & 9,09 & 8 & 12,12 & 2 & 3,03 & 3 & 4,55 & 1 & 1,52 & 66 & 100 \\
\hline Cisco Systems & 31 & 43,06 & 5 & 6,94 & 9 & 12,5 & 11 & 15,28 & 11 & 15,28 & 5 & 6,94 & 72 & 100 \\
\hline Extreme Networks & 47 & 69,12 & 6 & 8,82 & 11 & 16,18 & 2 & 2,94 & 1 & 1,47 & 1 & 1,47 & 68 & 100 \\
\hline F5 & 49 & 72,06 & 4 & 5,88 & 9 & 13,24 & 3 & 4,41 & 2 & 2,94 & 1 & 1,47 & 68 & 100 \\
\hline $\begin{array}{l}\text { Hewlett Packard Enterprise } \\
\text { (HPE) }\end{array}$ & 47 & 69,12 & 4 & 5,88 & 9 & 13,24 & 4 & 5,88 & 4 & 5,88 & 0 & 0 & 68 & 100 \\
\hline Huawei & 44 & 64,71 & 5 & 7,35 & 10 & 14,71 & 4 & 5,88 & 3 & 4,41 & 2 & 2,94 & 68 & 100 \\
\hline Juniper Networks & 40 & 57,97 & 7 & 10,14 & 7 & 10,14 & 3 & 4,35 & 8 & 11,59 & 4 & 5,8 & 69 & 100 \\
\hline Nokia (Alcatel-Lucent) & 49 & 73,13 & 6 & 8,96 & 9 & 13,43 & 2 & 2,99 & 1 & 1,49 & 0 & 0 & 67 & 100 \\
\hline
\end{tabular}

Testiranje se provodi Wilcoxonovim testom za jedan nezavisan uzorak gdje će se utvrditi postojanje prolazne ocjene na ponuđene tvrdnje samo ako je srednja vrijednost (medijan) veća od 1,00 uz empirijsku p vrijednost manju od 0,05. U slučaju da je empirijska p vrijednost veća od 0,05 , riječ je o neprolaznoj ocjeni (nedovoljan). 
Tablica 6-49. prikazuje odgovore na 17. pitanje pomoću deskriptivne statistike.

Tablica 6-49. Raspoloživa NETCONF dokumentacija i edukacija (upitnik korisnika)

\begin{tabular}{lcccccccc}
\hline & $\mathrm{N}$ & Prosjek & Std.Dev. & Mod & Medijan & $\mathrm{IQR}$ & $\mathrm{Z}$ & $\mathrm{P}^{*}$ \\
\hline Arista & 20 & 2,25 & 1,21 & 2,00 & 2,00 & $(1,00-3,00)$ & 3,37 & 0,001 \\
\hline Cisco Systems & 41 & 3,05 & 1,22 & N/a & 3,00 & $(2,00-4,00)$ & 5,28 & $<0,001$ \\
\hline Extreme Networks & 21 & 2,05 & 1,02 & 2,00 & 2,00 & $(1,00-2,00)$ & 3,57 & $<0,001$ \\
\hline F5 & 19 & 2,32 & 1,11 & 2,00 & 2,00 & $(2,00-3,00)$ & 3,50 & $<0,001$ \\
\hline $\begin{array}{l}\text { Hewlett Packard Enterprise } \\
\text { (HPE) }\end{array}$ & 21 & 2,38 & 1,02 & 2,00 & 2,00 & $(2,00-3,00)$ & 3,70 & $<0,001$ \\
\hline Huawei & 24 & 2,46 & 1,22 & 2,00 & 2,00 & $(2,00-3,00)$ & 3,90 & $<0,001$ \\
\hline Juniper Networks & 29 & 2,83 & 1,44 & 4,00 & 3,00 & $(2,00-4,00)$ & 4,15 & $<0,001$ \\
\hline Nokia (Alcatel-Lucent) & 18 & 1,89 & 0,83 & 2,00 & 2,00 & $(1,00-2,00)$ & 3,21 & 0,001 \\
\hline Ukupno & 41 & 2,84 & 1,21 & 2,00 & 3,00 & $(2,00-$ & 5,2 & $<0,001$ \\
& & & & & & $4,00)$ & 5 & $<, 001$ \\
\hline
\end{tabular}

* Wilcoxonov test za jedan nezavisan uzorak

Najveću razinu mišljenja ispitanici su iskazali za dokumentaciju, edukaciju i certificiranje o NETCONF protokolu proizvođača R/S uređaja Cisco Systems (prosječna vrijednost odgovora 3,05; std.dev.1,22), dok su najnižu razinu mišljenja iskazali za proizvođača Nokia (AlcatelLucent) (prosječna vrijednost odgovora 1,89; std.dev.0,83).

Ukupna razina dokumentacije i edukacije o NETCONF standardu za sve proizvođače je bilježila prosječnu vrijednost 2,84 s prosječnim odstupanjem od aritmetičke sredine 1,21.

27. pitanje anketnog upitnika glasi: " Na koji način mislite da bi se mogla povećati primjena NETCONF standarda od strane proizvođača?". Ispitanici su iskazivali mišljenje vrijednostima razreda od 1 do 5, gdje je 1 označavalo nevažan razlog, a 5 izuzetno važan razlog.

Testiranje se provodi Wilcoxonovim testom za jedan nezavisan uzorak gdje će se utvrditi postojanje važnosti samo ako je srednja vrijednost (medijan) veća od 2,00 uz empirijsku p vrijednost manju od 0,05 . U slučaju da je empirijska $p$ vrijednost veća od 0,05 riječ je o indiferentnom stavu, dok u slučaju da je srednja vrijednost (medijan) manja od 2 te se utvrdi empirijska p vrijednost manja od 0,05 , postoji nevažnost s ponuđenim tvrdnjama.

Tablica 6-50. prikazuje rezultate odgovora na 27. pitanje anketnog upitnika. Visoki postotak odgovora „Ne znam“ u ovom pitanju pokazuje nepoznavanje NETCONF standarda i njegove 
primjene od strane ispitanika (korisnika). Ostali odgovori prikazani su deskriptivnom statistikom.

Tablica 6-50. Načini povećanja primjene NETCONF standarda od strane proizvođača (rezultati upitnika korisnika)

\begin{tabular}{|c|c|c|c|c|c|c|c|c|c|c|c|c|c|c|}
\hline & \multicolumn{2}{|c|}{ Ne znam } & \multicolumn{2}{|c|}{$\begin{array}{c}1 \\
\text { Nevažno }\end{array}$} & \multicolumn{2}{|c|}{$\begin{array}{c}2 \\
\text { Malo } \\
\text { važno }\end{array}$} & \multicolumn{2}{|c|}{$\begin{array}{c}3 \\
\text { Važno }\end{array}$} & \multicolumn{2}{|c|}{$\begin{array}{c}4 \\
\text { Vrlo } \\
\text { važno } \\
\end{array}$} & \multicolumn{2}{|c|}{$\begin{array}{c}5 \\
\text { Izuzetno } \\
\text { važno } \\
\end{array}$} & \multicolumn{2}{|c|}{ Ukupno } \\
\hline & $N$ & $\%$ & $\mathbf{N}$ & $\%$ & $\mathbf{N}$ & $\%$ & $\mathbf{N}$ & $\%$ & $\mathbf{N}$ & $\%$ & $\mathbf{N}$ & $\%$ & $\mathbf{N}$ & $\%$ \\
\hline $\begin{array}{l}\text { 1. Implementirati NETCONF } \\
\text { na svim vrstama R/S uređaja }\end{array}$ & 18 & 24,66 & 0 & 0 & 4 & 5,48 & 19 & 26,03 & 19 & 26,03 & 13 & 17,81 & 73 & 100 \\
\hline $\begin{array}{l}\text { 2. Povećati informiranje o } \\
\text { teoretskom radu i } \\
\text { prednostima NETCONF } \\
\text { standarda. }\end{array}$ & 17 & 23,29 & 0 & 0 & 7 & 9,59 & 16 & 21,92 & 20 & 27,4 & 13 & 17,81 & 73 & 100 \\
\hline $\begin{array}{l}\text { 3. Povećati informiranje o } \\
\text { praktičnoj primjeni } \\
\text { NETCONF standarda. }\end{array}$ & 17 & 23,29 & 0 & 0 & 4 & 5,48 & 18 & 24,66 & 19 & 26,03 & 15 & 20,55 & 73 & 100 \\
\hline $\begin{array}{l}\text { 4. Povećati informiranje o } \\
\text { primjeni NETCONF } \\
\text { standarda za POVEĆANJE } \\
\text { RASPOLOŽIVOSTI mrežnih } \\
\text { sustava i R/S uređaja. }\end{array}$ & 19 & 26,03 & 0 & 0 & 4 & 5,48 & 15 & 20,55 & 24 & 32,88 & 11 & 15,07 & 73 & 100 \\
\hline $\begin{array}{l}\text { 5. Povećati edukaciju i } \\
\text { informiranje o softverski } \\
\text { definiranim mrežama } \\
\text { (Software Defined Networks } \\
\text { - SDN) }\end{array}$ & 16 & 21,92 & 0 & 0 & 4 & 5,48 & 17 & 23,29 & 22 & 30,14 & 14 & 19,18 & 73 & 100 \\
\hline $\begin{array}{l}\text { 6. Povećati edukaciju i } \\
\text { informiranje o automatizaciji } \\
\text { i programiranju računalnih } \\
\text { mreža (Automation tools and } \\
\text { DevOps) }\end{array}$ & 16 & 21,92 & 0 & 0 & 4 & 5,48 & 15 & 20,55 & 23 & 31,51 & 15 & 20,55 & 73 & 100 \\
\hline $\begin{array}{l}\text { 7. Pojačati edukaciju o } \\
\text { programiranju i programskim } \\
\text { jezicima }\end{array}$ & 15 & 20,55 & 0 & 0 & 6 & 8,22 & 24 & 32,88 & 10 & 13,7 & 18 & 24,66 & 73 & 100 \\
\hline
\end{tabular}

Tablica 6-51. prikazuje odgovore na 27. pitanje pomoću deskriptivne statistike.

Najbolji način za povećanje korištenja NETCONF sadržaja prema mišljenju ispitanika je povećanje edukacije i informiranja o automatizaciji i programiranju računalnih mreža (Automation tools and DevOps) (prosječna vrijednost odgovora 3,86; std.dev. 0,90). 
Tablica 6-51. Načini povećanja primjene NETCONF standarda od strane proizvođača (upitnik korisnika)

\begin{tabular}{|c|c|c|c|c|c|c|c|c|}
\hline & $\mathrm{N}$ & Prosjek & Std.Dev. & Mod & Medijan & IQR & Z & $\mathrm{P}^{*}$ \\
\hline $\begin{array}{l}\text { 1. Implementirati NETCONF } \\
\text { na svim vrstama R/S uređaja - } \\
\text { na primjer od malih SMB } \\
\text { uređaja do velikih ISP uređaja. }\end{array}$ & 55 & 3,75 & 0,91 & $\mathrm{~N} / \mathrm{a}$ & 4,00 & $\begin{array}{c}(3,00- \\
4,00)\end{array}$ & 6,31 & $<0,001$ \\
\hline $\begin{array}{l}\text { 2. Povećati informiranje o } \\
\text { teoretskom radu i prednostima } \\
\text { NETCONF standarda - na } \\
\text { primjer pomoću organiziranih } \\
\text { tečajeva proizvođača, radionica, } \\
\text { CBT, Webinar, i drugo. }\end{array}$ & 56 & 3,70 & 0,97 & 4,00 & 4,00 & $\begin{array}{c}(3,00- \\
4,00)\end{array}$ & 6,18 & $<0,001$ \\
\hline $\begin{array}{l}\text { 3. Povećati informiranje o } \\
\text { praktičnoj primjeni NETCONF } \\
\text { standarda - na primjer } \\
\text { objavljivanje preporuka za } \\
\text { uporabu (white papers) i drugo. }\end{array}$ & 56 & 3,80 & 0,92 & 4,00 & 4,00 & $\begin{array}{l}(3,00- \\
5,00)\end{array}$ & 6,36 & $<0,001$ \\
\hline $\begin{array}{l}\text { 4. Povećati informiranje o } \\
\text { primjeni NETCONF standarda } \\
\text { za POVEĆANJE } \\
\text { RASPOLOŽIVOSTI mrežnih } \\
\text { sustava i R/S uređaja - na } \\
\text { primjer objavljivanje preporuka } \\
\text { za uporabu (white papers) i } \\
\text { drugo. }\end{array}$ & 54 & 3,78 & 0,86 & 4,00 & 4,00 & $\begin{array}{c}(3,00- \\
4,00)\end{array}$ & 6,27 & $<0,001$ \\
\hline $\begin{array}{l}\text { 5. Povećati edukaciju i } \\
\text { informiranje o softverski } \\
\text { definiranim mrežama (Software } \\
\text { Defined Networks - SDN) }\end{array}$ & 57 & 3,81 & 0,90 & 4,00 & 4,00 & $\begin{array}{l}(3,00- \\
4,00)\end{array}$ & 6,43 & $<0,001$ \\
\hline $\begin{array}{l}\text { 6. Povećati edukaciju i } \\
\text { informiranje o automatizaciji i } \\
\text { programiranju računalnih mreža } \\
\text { (Automation tools and DevOps) }\end{array}$ & 57 & 3,86 & 0,90 & 4,00 & 4,00 & $\begin{array}{c}(3,00- \\
5,00)\end{array}$ & 6,34 & $<0,001$ \\
\hline $\begin{array}{l}\text { 7. Pojačati edukaciju o } \\
\text { programiranju i programskim } \\
\text { jezicima }\end{array}$ & 58 & 3,69 & 1,03 & 3,00 & 3,00 & $\begin{array}{c}(3,00- \\
5,00) \\
\end{array}$ & 6,39 & $<0,001$ \\
\hline
\end{tabular}

* Wilcoxonov test za jedan nezavisan uzorak

\subsubsection{Primjena NETCONF standarda od strane korisnika u Hrvatskoj}

U ovom poglavlju se razmatra primjena NETCONF standarda od strane korisnika na svojim $\mathrm{R} / \mathrm{S}$ uređajima.

Osamnaesto pitanje anketnog upitnika glasi: „Da li koristite NETCONF standard na R/S mrežnim uređajima Vaše kompanije?“. 
Slika 6-8. prikazuje odgovore dobivene na 18. pitanje i može se vidjeti da većina kompanija ne koristi NETCONF standard na svojim R/S uređajima (65 kompanija; 89,04\%). NETCONF koristi samo 8 kompanija ispitanika $(10,96 \%)$.

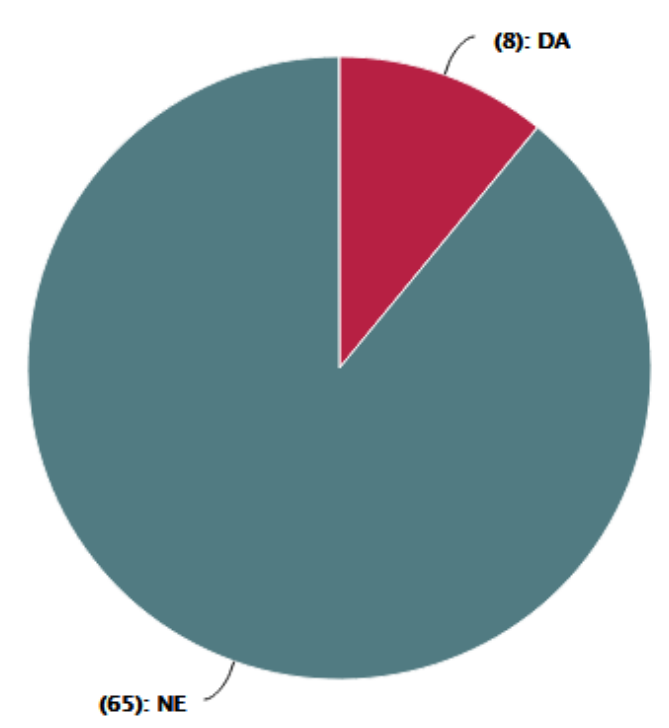

Slika 6-8. Implementacija NETCONF standarda u mreži kompanije ispitanika

Ispitanicima koji su pozitivno odgovorili na ovo pitanje i koji implementiraju NETCONF u mrežama svojih kompanija, odgovarali su i na pitanja 19, 20. i 21., dok su ostali nastavili anketni upitnik s 22. pitanjem.

Devetnaesto pitanje anketnog upitnika glasi: „U kojim vrstama mreža Vaše kompanije koristite NETCONF na R/S mrežnim uređajima i u kojem postotku?“. Na pitanje su odgovarali samo ispitanici koji su potvrdno odgovorili na 18. pitanje. Ispitanici su iskazivali mišljenje vrijednostima razreda od 0 do 5 , gdje je 0 označavalo $0 \%$, dok je 5 označavalo $100 \%$.

Tablica 6-52. prikazuje rezultate odgovora na 19. pitanje anketnog upitnika. Svi ispitanici ne koriste sve vrste mreže kod primjene NETCONF standarda. Broj i postotak ispitanika koji ne koriste određene vrste mreža kod njihove NETCONF implementacije prikazani su u stupcu X. Ostali su odgovori (primjena NETCONF standarda po određenim vrstama mreža) obrađeni i prikazani deskriptivnom statistikom. 
Tablica 6-52. Implementacija NETCONF standarda po vrstama mreža (rezultati upitnika korisnika)

\begin{tabular}{|c|c|c|c|c|c|c|c|c|c|c|c|c|c|c|c|c|}
\hline & \multicolumn{2}{|c|}{$X^{*}$} & \multicolumn{2}{|c|}{$\begin{array}{c}0 \\
0 \%\end{array}$} & \multicolumn{2}{|c|}{$\begin{array}{c}1 \\
1-20 \% \\
\end{array}$} & \multicolumn{2}{|c|}{$\begin{array}{c}2 \\
21-40 \% \\
\end{array}$} & \multicolumn{2}{|c|}{$\begin{array}{c}3 \\
41-60 \% \\
\end{array}$} & \multicolumn{2}{|c|}{$\begin{array}{c}4 \\
61-80 \% \\
\end{array}$} & \multicolumn{2}{|c|}{$\begin{array}{c}5 \\
81-100 \% \\
\end{array}$} & \multicolumn{2}{|c|}{ Ukupno } \\
\hline & $N$ & $\%$ & $\mathbf{N}$ & $\%$ & $\mathbf{N}$ & $\%$ & $\mathbf{N}$ & $\%$ & $\mathbf{N}$ & $\%$ & $\mathbf{N}$ & $\%$ & $\mathbf{N}$ & $\%$ & $\mathbf{N}$ & $\%$ \\
\hline $\begin{array}{l}\text { LAN mreža malih i } \\
\text { srednjih poduzeća } \\
\text { (Small Medium } \\
\text { Business - SMB) }\end{array}$ & 2 & 2,74 & 2 & 2,74 & 0 & 0 & 1 & 1,37 & 1 & 1,37 & 0 & 0 & 2 & 2,74 & 73 & 100 \\
\hline $\begin{array}{l}\text { LAN mreža većih } \\
\text { poduzeća (Enterprise } \\
\text { Networks) }\end{array}$ & 1 & 1,37 & 1 & 1,37 & 0 & 0 & 2 & 2,74 & 0 & 0 & 1 & 1,37 & 3 & 4,11 & 73 & 100 \\
\hline $\begin{array}{l}\text { WAN mreža većih } \\
\text { poduzeća (Enterprise } \\
\text { Networks) }\end{array}$ & 1 & 1,37 & 1 & 1,37 & 0 & 0 & 2 & 2,74 & 1 & 1,37 & 1 & 1,37 & 2 & 2,74 & 73 & 100 \\
\hline $\begin{array}{l}\text { Mreža davatelja } \\
\text { usluga (Internet } \\
\text { servise provider- } \\
\text { ISP) }\end{array}$ & 0 & 0 & 0 & 0 & 2 & 2,74 & 0 & 0 & 1 & 1,37 & 1 & 1,37 & 4 & 5,48 & 73 & 100 \\
\hline $\begin{array}{l}\text { Mreža podatkovnih } \\
\text { centara (Data Center } \\
\text { - DC) }\end{array}$ & 1 & 1,37 & 1 & 1,37 & 1 & 1,37 & 0 & 0 & 1 & 1,37 & 2 & 2,74 & 2 & 2,74 & 73 & 100 \\
\hline $\begin{array}{l}\text { Mreže internet stvari } \\
\text { (IoT) }\end{array}$ & 2 & 2,74 & 3 & 4,11 & 1 & 1,37 & 1 & 1,37 & 0 & 0 & 0 & 0 & 1 & 1,37 & 73 & 100 \\
\hline
\end{tabular}

* Ne koristi se ta vrsta mreže

Testiranje se provodi Wilcoxonovim testom za jedan nezavisan uzorak gdje će se utvrditi postojanje visoke razine upotrebe samo ako je srednja vrijednost (medijan) veća od 3,00 (41\%-60\%) uz empirijsku p vrijednost manju od 0,05. U slučaju da je empirijska p vrijednost veća od 0,05 riječ je o srednjoj razini primjene (41\%-60\%), dok u slučaju da je srednja vrijednost (medijan) manja od 3 (41-60\%) te se utvrdi empirijska p vrijednost manja od 0,05, postoji niska razina upotrebe.

Tablica 6-53. prikazuje odgovore na 19. pitanje pomoću deskriptivne statistike. Podaci u tablici uređeni su od najveće do najmanje prosječne vrijednosti.

Kompanije NETCONF standard najčešće koriste u mrežama davatelja usluga (prosječna vrijednost odgovora 3,63 (72,6\%); std.dev.1,77), dok najrjeđe koriste u mrežama Internet stvari (prosječna vrijednost odgovora 1,33 (26,6\%); std.dev.1,97). 
Tablica 6-53. Implementacija NETCONF standarda po vrstama mreža (upitnik korisnika)

\begin{tabular}{lcccccccc}
\hline & $\mathrm{N}$ & Prosjek & Std.Dev. & Mod & Median & $\mathrm{IQR}$ & $\mathrm{Z}$ & $\mathrm{P} *$ \\
\hline $\begin{array}{l}\text { Mreža davatelja usluga } \\
\text { (Internet Servise Provider }-\end{array}$ & 8 & 3,63 & 1,77 & 5,00 & 4,50 & $(2,00-5,00)$ & 0,90 & 0,366 \\
ISP) & 7 & 3,29 & 1,98 & 5,00 & 4,00 & $(2,00-5,00)$ & 0,61 & 0,607 \\
\hline $\begin{array}{l}\text { LAN mreža većih poduzeća } \\
\text { (Enterprise Networks) }\end{array}$ & 7 & 3,14 & 1,95 & $\mathrm{~N} / \mathrm{a}$ & 4,00 & $(1,00-5,00)$ & 0,11 & 0,915 \\
\hline $\begin{array}{l}\text { Mreža podatkovnih centara } \\
\text { (Data Center - DC) }\end{array}$ & 7 & 3,00 & 1,83 & $\mathrm{~N} / \mathrm{a}$ & 3,00 & $(2,00-5,00)$ & 0,92 & 0,915 \\
\hline $\begin{array}{l}\text { WAN mreža većih poduzeća } \\
\text { (Enterprise Networks) }\end{array}$ & 6 & 2,50 & 2,26 & $\mathrm{~N} / \mathrm{a}$ & 2,50 & $(0,00-5,00)$ & 0,68 & 0,496 \\
\hline $\begin{array}{l}\text { LAN mreža malih i srednjih } \\
\text { poduzeća (Small Medium } \\
\text { Business - SMB) }\end{array}$ & 6 & 1,33 & 1,97 & 0,00 & 0,50 & $(0,00-2,00)$ & 1,70 & 0,089 \\
\hline $\begin{array}{l}\text { Mreže internet stvari (IoT) } \\
\text { * Wilcoxonov test za jedan nezavisan uzorak }\end{array}$ & & & & & & & & \\
\hline
\end{tabular}

Dvadeseto pitanje anketnog upitnika glasi: „Na R/S uređajima kojih proizvođača koristite NETCONF i u kojem postotku u Vašoj kompaniji?“. Ispitanici su iskazivali mišljenje vrijednostima razreda od 0 do 5 , gdje je 0 označavalo $0 \%$, dok je 5 označavalo $100 \%$. Na pitanje su odgovarali samo ispitanici koji su potvrdno odgovorili na 18. pitanje.

\section{Tablica 6-54. Implementacija NETCONF standarda po proizvođačima} (rezultati upitnika korisnika)

\begin{tabular}{|c|c|c|c|c|c|c|c|c|c|c|c|c|c|c|c|c|}
\hline & \multicolumn{2}{|c|}{$X^{*}$} & \multicolumn{2}{|c|}{$\begin{array}{c}0 \\
0 \%\end{array}$} & \multicolumn{2}{|c|}{$\begin{array}{c}1 \\
1-20 \%\end{array}$} & \multicolumn{2}{|c|}{$\begin{array}{c}2 \\
21-40 \%\end{array}$} & \multicolumn{2}{|c|}{$\begin{array}{c}3 \\
41-60 \% \\
\end{array}$} & \multicolumn{2}{|c|}{$\begin{array}{c}4 \\
61-80 \%\end{array}$} & \multicolumn{2}{|c|}{$\begin{array}{c}5 \\
81-100 \%\end{array}$} & \multicolumn{2}{|c|}{ Ukupno } \\
\hline & $\%$ & $N$ & $\%$ & $N$ & $\%$ & $N$ & $\%$ & $N$ & $\%$ & $N$ & $\%$ & $N$ & $\%$ & $N$ & $\%$ & $N$ \\
\hline Arista & 50,00 & 4 & 0,00 & 0 & 0,00 & 0 & 12,50 & 1 & 0,00 & 0 & 25,00 & 2 & 12,50 & 1 & 100 & 8 \\
\hline Cisco Systems & 0,00 & 0 & 0,00 & 0 & 0,00 & 0 & 37,50 & 3 & 0,00 & 0 & 25,00 & 2 & 37,50 & 3 & 100 & 8 \\
\hline Extreme Networks & 62,50 & 5 & 0,00 & 0 & 12,50 & 1 & 12,50 & 1 & 0,00 & 0 & 0,00 & 0 & 12,50 & 1 & 100 & 8 \\
\hline F5 & 50,00 & 4 & 0,00 & 0 & 0,00 & 0 & 25,00 & 2 & 0,00 & 0 & 12,50 & 1 & 12,50 & 1 & 100 & 8 \\
\hline $\begin{array}{l}\text { Hewlett Packard } \\
\text { Enterprise (HPE) }\end{array}$ & 25,00 & 2 & 12,50 & 1 & 0,00 & 0 & 12,50 & 1 & 12,50 & 1 & 12,50 & 1 & 25,00 & 2 & 100 & 8 \\
\hline Huawei & 62,50 & 5 & 12,50 & 1 & 0,00 & 0 & 12,50 & 1 & 12,50 & 1 & 0,00 & 0 & 0,00 & 0 & 100 & 8 \\
\hline Juniper Networks & 25,00 & 2 & 0,00 & 0 & 0,00 & 0 & 25,00 & 2 & 0,00 & 0 & 12,50 & 1 & 37,50 & 3 & 100 & 8 \\
\hline $\begin{array}{l}\text { Nokia (Alcatel- } \\
\text { Lucent) }\end{array}$ & 87,50 & 7 & 0,00 & 0 & 0,00 & 0 & 12,50 & 1 & 0,00 & 0 & 0,00 & 0 & 0,00 & 0 & 100 & 8 \\
\hline
\end{tabular}

* Ne koristi se ta vrsta mreže

Tablica 6-54. prikazuje rezultate odgovora na 20. pitanje anketnog upitnika. Svi ispitanici ne koriste uređaje svih proizvođača kod primjene NETCONF standarda. Broj i postotak ispitanika koji ne koriste određene proizvođače kod njihove NETCONF implementacije 
prikazani su u stupcu X. Ostali su odgovori (primjena NETCONF standarda za određene proizvođače) obrađeni i prikazani deskriptivnom statistikom.

Testiranje se provodi Wilcoxonovim testom za jedan nezavisan uzorak gdje će se utvrditi postojanje visoke razine upotrebe samo ako je srednja vrijednost (medijan) veća od 3,00 (41\%-60\%) uz empirijsku p vrijednost manju od 0,05. U slučaju da je empirijska p vrijednost veća od 0,05 riječ je o srednjoj razini primjene (41\%-60\%), dok u slučaju da je srednja vrijednost (medijan) manja od 3 (41-60\%) te se utvrdi empirijska p vrijednost manja od 0,05, postoji niska razina upotrebe.

Tablica 6-55. prikazuje odgovore na 20. pitanje pomoću deskriptivne statistike.

Tablica 6-55. Implementacija NETCONF standarda po proizvođačima (upitnik korisnika)

\begin{tabular}{lcccccccc}
\hline & $\mathrm{N}$ & Prosjek & Std.Dev. & Mod & Median & IQR & Z & P* \\
\cline { 1 - 5 } Juniper Networks & 6 & 3,83 & 1,47 & 5,00 & 4,50 & $\begin{array}{c}(2,00- \\
5,00)\end{array}$ & 1,39 & 0,163 \\
\hline Arista & 4 & 3,75 & 1,26 & 4,00 & 4,00 & $\begin{array}{c}(3,00- \\
4,50)\end{array}$ & 1,13 & 0,257 \\
\hline Cisco Systems & 8 & 3,63 & 1,41 & N/a & 4,00 & $\begin{array}{c}(2,00- \\
5,00)\end{array}$ & 1,30 & 0,194 \\
\hline F5 & 4 & 3,25 & 1,50 & 2,00 & 3,00 & $\begin{array}{c}(2,00- \\
4,50)\end{array}$ & 0,38 & 0,705 \\
\hline Hewlett Packard Enterprise (HPE) & 6 & 3,17 & 1,94 & 5,00 & 3,50 & $\begin{array}{c}(2,00- \\
5,00)\end{array}$ & 0,27 & 0,785 \\
\hline Extreme Networks & 3 & 2,67 & 2,08 & N/a & 2,00 & $\begin{array}{c}(1,00- \\
5,00)\end{array}$ & 0,27 & 0,785 \\
\hline Nokia (Alcatel-Lucent) & 1 & 2,00 & N/a & 2,00 & 2,00 & $\begin{array}{c}(2,00- \\
2,00)\end{array}$ & 1,00 & 0,317 \\
\hline Huawei & 3 & 1,67 & 1,53 & N/a & 2,00 & $\begin{array}{c}(0,00- \\
3,00)\end{array}$ & 1,34 & 0,180 \\
\hline
\end{tabular}

* Wilcoxonov test za jedan nezavisan uzorak

Najveći broj R/S mrežnih uređaja s NETCONF standardom dolazi od proizvođača Juniper Networks (prosječna vrijednost odgovora 3,83 (76,6\%); std.dev.1,47), dok R/S uređaji u najmanjem broju slučajeva dolaze od proizvođača Huawei (prosječna vrijednost odgovora $1,67(33,4 \%)$; std.dev.1,53).

21. pitanje anketnog upitnika glasi: „Koji su glavni razlozi implementacije NETCONF standarda na R/S mrežnim uređajima Vaše kompanije?“. Na pitanje su odgovarali samo 
ispitanici koji su potvrdno odgovorili na 18. pitanje. Ispitanici su iskazivali mišljenje vrijednostima razreda od 1 do 5 , gdje je 1 označavalo nevažan razlog, a 5 izuzetno važan razlog.

Testiranje se provodi Wilcoxon testom za jedan nezavisan uzorak gdje će se utvrditi postojanje važnosti samo ako je srednja vrijednost (medijan) veća od 2,00 uz empirijsku p vrijednost manju od 0,05 . U slučaju da je empirijska $p$ vrijednost veća od 0,05 riječ je o indiferentnom stavu, dok u slučaju da je srednja vrijednost (medijan) manja od 2 te se utvrdi empirijska p vrijednost manja od 0,05 , postoji nevažnost s ponuđenim tvrdnjama.

Tablica 6-56. prikazuje odgovore na 21. pitanje pomoću deskriptivne statistike. Podaci u tablici su uređeni od najveće do najmanje prosječne vrijednosti.

Tablica 6-56. Razlozi implementacije NETCONF standarda na R/S uređajima (upitnik korisnika)

\begin{tabular}{lcccccccc}
\hline & $\mathrm{N}$ & Prosjek & Std.Dev. & Mod & Medijan & IQR & Z & $\mathrm{P}^{*}$ \\
\hline $\begin{array}{l}\text { „Backup \& restore“ mogućnost } \\
\text { NETCONF-a. }\end{array}$ & 7 & 4,14 & 0,69 & 4,00 & 4,00 & $\begin{array}{c}(4,00- \\
5,00)\end{array}$ & 2,41 & 0,016 \\
\hline $\begin{array}{l}\text { Mogućnost istovremenog i } \\
\text { koordiniranog konfiguriranja } \\
\text { svih ili više uređaja u mreži. }\end{array}$ & 8 & 3,88 & 1,13 & 5,00 & 4,00 & $\begin{array}{c}(3,00- \\
5,00)\end{array}$ & 2,39 & 0,017 \\
\hline $\begin{array}{l}\text { Programabilnost } \\
\text { (automatiziranje) NETCONF-a. }\end{array}$ & 7 & 3,86 & 1,21 & 5,00 & 4,00 & $\begin{array}{c}(3,00- \\
5,00)\end{array}$ & 2,23 & 0,026 \\
\hline $\begin{array}{l}\text { Mogućnost provjere } \\
\text { konfiguracije prije primjene. }\end{array}$ & 8 & 3,75 & 0,89 & 3,00 & 3,50 & $\begin{array}{c}(4,00- \\
4,50)\end{array}$ & 2,56 & 0,011 \\
\hline $\begin{array}{l}\text { NETCONF je standard koji za } \\
\text { sve proizvođače uređaja ima }\end{array}$ & 8 & 3,63 & 1,41 & $\mathrm{~N} / \mathrm{a}$ & 3,50 & $\begin{array}{c}(3,00- \\
5,00)\end{array}$ & 2,21 & 0,027 \\
$\begin{array}{l}\text { stu strukturu komandi i } \\
\text { podataka. }\end{array}$ & 8 & 3,63 & 1,41 & $\mathrm{~N} / \mathrm{a}$ & 3,50 & $\begin{array}{c}(3,00- \\
5,00)\end{array}$ & 2,21 & 0,027 \\
\hline $\begin{array}{l}\text { Mogućnost parcijalnog } \\
\text { konfiguriranja uređaja. }\end{array}$ & 8 & 3,63 & 0,74 & 3,00 & 3,50 & $\begin{array}{c}(4,00- \\
4,00)\end{array}$ & 2,57 & 0,010 \\
\hline $\begin{array}{l}\text { Mogućnost zaključavanja } \\
\text { konfiguracijske datoteke. }\end{array}$ & 8 & 3,25 & 1,75 & 5,00 & 3,50 & $\begin{array}{c}(3,50- \\
5,00)\end{array}$ & 1,71 & 0,086 \\
\hline $\begin{array}{l}\text { Jasna razlika u strukturi između } \\
\text { konfiguracijskih i operacijskih } \\
\text { podataka NETCONF-a. }\end{array}$ & & & & & & & & \\
\hline
\end{tabular}

* Wilcoxonov test za jedan nezavisan uzorak

Najvažniji razlog implementacije NETCONF standarda u mrežnim uređajima kompanija je mogućnost „Backup \& restore“ (prosječna vrijednost odgovora 4,14; std.dev.0,69), dok je 
najmanje važan razlog implementacije jasna razlika u strukturi između konfiguracijskih i operacijskih podataka NETCONF-a (prosječna vrijednost odgovora 3,25; std.dev.1,75).

22. pitanje anketnog upitnika glasi: „Koji su glavni razlozi neimplementacije NETCONF standarda na R/S mrežnim uređajima Vaše kompanije?“. Ispitanici su iskazivali mišljenje vrijednostima razreda od 1 do 5 , gdje je 1 označavalo nevažan razlog, a 5 izuzetno važan razlog.

\section{Tablica 6-57. Razlozi neimplementacije NETCONF standarda na R/S uređajima}

\section{(rezultati upitnika korisnika)}

\begin{tabular}{|c|c|c|c|c|c|c|c|c|c|c|c|c|c|c|}
\hline & \multicolumn{2}{|c|}{ Ne znam } & \multicolumn{2}{|c|}{$\begin{array}{c}1 \\
\text { Nevažno }\end{array}$} & \multicolumn{2}{|c|}{$\begin{array}{c}2 \\
\text { Malo } \\
\text { važno }\end{array}$} & \multicolumn{2}{|c|}{$\begin{array}{c}3 \\
\text { Važno }\end{array}$} & \multicolumn{2}{|c|}{$\begin{array}{c} \\
\text { Vrlo } \\
\text { važno } \\
\end{array}$} & \multicolumn{2}{|c|}{$\begin{array}{c}5 \\
\text { Izuzetno } \\
\text { važno } \\
\end{array}$} & \multicolumn{2}{|c|}{ Ukupno } \\
\hline & $N$ & $\%$ & $\mathbf{N}$ & $\%$ & $\mathbf{N}$ & $\%$ & $\mathbf{N}$ & $\%$ & $\mathbf{N}$ & $\%$ & $\mathbf{N}$ & $\%$ & $\mathbf{N}$ & $\%$ \\
\hline $\begin{array}{l}\text { CLI proizvođača je } \\
\text { jednostavniji od NETCONF } \\
\text { standarda }\end{array}$ & 25 & 34,72 & 10 & 13,89 & 8 & 11,11 & 19 & 26,39 & 5 & 6,94 & 5 & 6,94 & 72 & 100 \\
\hline $\begin{array}{l}\text { NETCONF nije potreban } \\
\text { zbog navike na OS i CLI } \\
\text { proizvođača }\end{array}$ & 18 & 25 & 9 & 12,5 & 7 & 9,72 & 16 & 22,22 & 12 & 16,67 & 10 & 13,89 & 72 & 100 \\
\hline $\begin{array}{l}\text { NETCONF koristi XML } \\
\text { sintaksu koja je } \\
\text { redundantna i opširna što } \\
\text { može zamarati i zbunjivati. }\end{array}$ & 34 & 47,22 & 8 & 11,11 & 15 & 20,83 & 6 & 8,33 & 8 & 11,11 & 1 & 1,39 & 72 & 100 \\
\hline $\begin{array}{l}\text { Koristi se RESTCONF koji } \\
\text { je bolje standardno rješenje } \\
\text { od NETCONF-a }\end{array}$ & 33 & 45,83 & 18 & 25 & 15 & 20,83 & 4 & 5,56 & 1 & 1,39 & 1 & 1,39 & 72 & 100 \\
\hline $\begin{array}{l}\text { NETCONF nije dostupan } \\
\text { na starijim uređajima i } \\
\text { starijem OS koji ga ne } \\
\text { podržavaju }\end{array}$ & 26 & 36,11 & 9 & 12,5 & 8 & 11,11 & 8 & 11,11 & 11 & 15,28 & 10 & 13,89 & 72 & 100 \\
\hline $\begin{array}{l}\text { Nedovoljno poznavanje } \\
\text { programskih jezika. }\end{array}$ & 21 & 29,17 & 9 & 12,5 & 9 & 12,5 & 21 & 29,17 & 6 & 8,33 & 6 & 8,33 & 72 & 100 \\
\hline $\begin{array}{l}\text { Proizvođači ne podržavaju } \\
\text { sve funkcije (Capability), na } \\
\text { primjer „Candidate“, } \\
\text { „Startup“, „Validate“, } \\
\text { „Rollback-on-Error“ i } \\
\text { druge, pa se ne mogu } \\
\text { iskoristiti većina prednosti } \\
\text { standarda. }\end{array}$ & 34 & 47,22 & 9 & 12,5 & 8 & 11,11 & 12 & 16,67 & 4 & 5,56 & 5 & 6,94 & 72 & 100 \\
\hline $\begin{array}{l}\text { Potrebni su dodatni alati (na } \\
\text { primjer NETCONF browser } \\
\text { ili aplikacija u Pythonu) }\end{array}$ & 30 & 41,67 & 14 & 19,44 & 5 & 6,94 & 12 & 16,67 & 7 & 9,72 & 4 & 5,56 & 72 & 100 \\
\hline Strah od novih tehnologija & 20 & 27,78 & 20 & 27,78 & 13 & 18,06 & 8 & 11,11 & 9 & 12,5 & 2 & 2,78 & 72 & 100 \\
\hline
\end{tabular}


Tablica 6-58. Razlozi neimplementacije NETCONF standarda na R/S uređajima (upitnik korisnika)

\begin{tabular}{|c|c|c|c|c|c|c|c|c|}
\hline & $\mathrm{N}$ & Prosjek & Std.Dev. & Mod & $\begin{array}{c}\text { Medij } \\
\text { an }\end{array}$ & IQR & $\mathrm{Z}$ & $\mathrm{p}^{*}$ \\
\hline $\begin{array}{l}\text { NETCONF nije potreban } \\
\text { zbog navike na OS i CLI } \\
\text { proizvođača }\end{array}$ & 54 & 3,13 & 1,33 & 3,00 & 3,00 & $\begin{array}{l}(2,00- \\
4,00)\end{array}$ & 4,84 & $<0,001$ \\
\hline $\begin{array}{l}\text { NETCONF nije dostupan na } \\
\text { starijim uređajima i starijem } \\
\text { OS koji ga ne podržavaju }\end{array}$ & 46 & 3,11 & 1,45 & 4,00 & 3,00 & $\begin{array}{l}(2,00- \\
4,00)\end{array}$ & 2,27 & $<0,001$ \\
\hline $\begin{array}{l}\text { Nedovoljno poznavanje } \\
\text { programskih jezika. }\end{array}$ & 51 & 2,82 & 1,21 & 3,00 & 3,00 & $\begin{array}{l}(2,00- \\
3,00)\end{array}$ & 4,09 & $<0,001$ \\
\hline $\begin{array}{l}\text { CLI proizvođača je } \\
\text { jednostavniji od NETCONF } \\
\text { standarda }\end{array}$ & 47 & 2,72 & 1,23 & 3,00 & 3,00 & $\begin{array}{l}(2,00- \\
3,00)\end{array}$ & 3,53 & $<0,001$ \\
\hline $\begin{array}{l}\text { Proizvođači ne podržavaju } \\
\text { sve funkcije (Capability), na } \\
\text { primjer „Candidate“, } \\
\text { „Startup“, „Validate“, } \\
\text { „Rollback-on-Error“ i druge } \\
\text { pa se ne može iskoristiti } \\
\text { većina prednosti standarda. }\end{array}$ & 38 & 2,68 & 1,32 & 3,00 & 3,00 & $\begin{array}{l}(2,00- \\
3,00)\end{array}$ & 2,87 & 0,004 \\
\hline $\begin{array}{l}\text { Potrebni su dodatni alati (na } \\
\text { primjer NETCONF browser } \\
\text { ili aplikacija u Pythonu) }\end{array}$ & 42 & 2,57 & 1,36 & 1,00 & 3,00 & $\begin{array}{l}(1,00- \\
4,00)\end{array}$ & 2,56 & 0,010 \\
\hline $\begin{array}{l}\text { NETCONF koristi XML } \\
\text { sintaksu koja je redundantna } \\
\text { i opširna što može zamarati i } \\
\text { zbunjivati. }\end{array}$ & 38 & 2,45 & 1,13 & 2,00 & 2,00 & $\begin{array}{l}(2,00- \\
3,00)\end{array}$ & 2,45 & 0,014 \\
\hline Strah od novih tehnologija & 52 & 2,23 & 1,25 & 1,00 & 2,00 & $\begin{array}{l}(1,00- \\
3,00) \\
\end{array}$ & 1,46 & 0,143 \\
\hline $\begin{array}{l}\text { Koristi se RESTCONF koji } \\
\text { je bolje standardno rješenje } \\
\text { od NETCONF-a }\end{array}$ & 39 & 1,77 & 0,93 & 1,00 & 2,00 & $\begin{array}{l}(1,00- \\
2,00)\end{array}$ & 1,80 & 0,072 \\
\hline
\end{tabular}

* Wilcoxonov test za jedan nezavisan uzorak

Testiranje se provodi Wilcoxonovim testom za jedan nezavisan uzorak gdje će se utvrditi postojanje važnosti samo ako je srednja vrijednost (medijan) veća od 2,00 uz empirijsku p vrijednost manju od 0,05 . U slučaju da je empirijska $p$ vrijednost veća od 0,05 riječ je o indiferentnom stavu, dok u slučaju da je srednja vrijednost (medijan) manja od 2 te se utvrdi empirijska p vrijednost manja od 0,05 , postoji nevažnost s ponuđenim tvrdnjama.

Tablica 6-57. prikazuje rezultate odgovora na 22. pitanje anketnog upitnika. Visoki postotak odgovora „Ne znam“ u ovom pitanju pokazuje nepoznavanje NETCONF standarda i njegove 
primjene od strane ispitanika (korisnika). Ostali odgovori su prikazani deskriptivnom statistikom.

Tablica 6-58. prikazuje odgovore na 22. pitanje pomoću deskriptivne statistike. Podaci u tablici su uređeni od najveće do najmanje prosječne vrijednosti.

Glavni razlog neimplementacije NETCONF standarda na uređajima kompanija je tvrdnja NETCONF nije potreban zbog navike na OS i CLI proizvođača (prosječna vrijednost odgovora 3,13; std.dev. 1,33). Najmanje važan razlog neimplementacije NETCONF standarda na uređajima korisnika je da se koristi RESTCONF koji je bolje standardno rješenje od NETCONF-a (prosječna vrijednost odgovora 1,77; std.dev. 0,93).

\subsubsection{Poznavanje NETCONF standarda od strane korisnika u Hrvatskoj}

U ovom poglavlju se razmatra poznavanje mogućnosti NETCONF standarda i njegove primjene.

Dvanaesto pitanje se odnosi na razinu znanja ispitanika o NETCONF standardu. Ispitanici su iskazivali razinu znanja vrijednostima od 1 do 5 , gdje je 1 označavala nedovoljno znanje, dok je 5 označavala izvrsno znanje.

Testiranje se provodi Wilcoxonovim testom za jedan nezavisan uzorak gdje će se utvrditi postojanje prolazne ocjene na ponuđene tvrdnje samo ako je srednja vrijednost (medijan) veća od 1,00 uz empirijsku p vrijednost manju od 0,05 . U slučaju da je empirijska p vrijednost veća od 0,05 , riječ je o neprolaznoj ocjeni (nedovoljan).

Tablica 6-59. prikazuje odgovore na 12. pitanje pomoću deskriptivne statistike.

Ispitanici posjeduju najveću razinu teoretskog o NETCONF protokolu (prosječna vrijednost odgovora 1,90; std.dev.1,00), dok su najmanju razinu znanja iskazali u području praktične primjene NETCONF protokola (prosječna vrijednost odgovora 1,37; std.dev.0,87).

Kreirana je ukupna dimenzija razine znanja kao prosjek odgovora svih tvrdnji. Prosječna vrijednost razine znanja ukupne dimenzije razine znanja je 1,69 s prosječnim odstupanjem od aritmetičke sredine 0,92 . 
Tablica 6-59. Razine znanja ispitanika o NETCONF standardu (upitnik korisnika)

\begin{tabular}{|c|c|c|c|c|c|c|c|c|}
\hline & $\mathrm{N}$ & Prosjek & Std.Dev. & Mod & Median & IQR & $\mathrm{Z}$ & $\mathrm{P}^{*}$ \\
\hline $\begin{array}{l}\text { 1. Savladao sam } \\
\text { TEORETSKA znanja o radu } \\
\text { NETCONF protokola i } \\
\text { razumijem njegove } \\
\text { karakteristike i prednosti. }\end{array}$ & 73 & 1,90 & 1,00 & 1,00 & 2,00 & $\begin{array}{l}(1,00- \\
2,00)\end{array}$ & 5,90 & $<0,001$ \\
\hline $\begin{array}{l}\text { 2. Savladao sam } \\
\text { PRAKTIČNA znanja } \\
\text { NETCONF protokola i } \\
\text { primjenjujem ga s lakoćom. }\end{array}$ & 73 & 1,37 & 0,87 & 1,00 & 1,00 & $\begin{array}{c}(1,00- \\
1,00)\end{array}$ & 3,48 & 0,001 \\
\hline $\begin{array}{l}\text { 3. Poznajem prednosti } \\
\text { NETCONF protokola u } \\
\text { POVEĆANJU } \\
\text { RASPOLOŽIVOSTI R/S } \\
\text { mrežnih uređaja. }\end{array}$ & 73 & 1,81 & 1,10 & 1,00 & 1,00 & $\begin{array}{l}(1,00- \\
2,00)\end{array}$ & 5,11 & $<0,001$ \\
\hline Ukupno & 73 & 1,69 & 0,92 & 1,00 & 1,33 & $\begin{array}{l}(1,00- \\
2,00) \\
\end{array}$ & 5,87 & $<0,001$ \\
\hline
\end{tabular}

* Wilcoxonov test za jedan nezavisan uzorak

Na sljedeće, trinaesto pitanje, ispitanici su iskazivali svoju razinu znanja o svojstvima i mogućnostima NETCONF standarda. Ispitanici su iskazivali razinu znanja vrijednostima od 1 do 5, gdje je 1 označavala nedovoljno znanje, a 5 izvrsno znanje.

Testiranje se provodi Wilcoxon testom za jedan nezavisan uzorak gdje će se utvrditi postojanje prolazne ocjene na ponuđene tvrdnje samo ako je srednja vrijednost (medijan) veća od 1,00 uz empirijsku p vrijednost manju od 0,05 . U slučaju da je empirijska p vrijednost veća od 0,05 , riječ je o neprolaznoj ocjeni (nedovoljan).

Tablica 6-60. prikazuje odgovore na 13. pitanje pomoću deskriptivne statistike.

Ispitanici su najviše upoznati da NETCONF nudi mogućnost istovremenog i koordiniranog konfiguriranja svih ili više uređaja u mreži (prosječna vrijednost odgovora 1,81; std.dev.1,11), dok su najmanje upoznati da NETCONF standard koristi jasnu razliku u strukturi između konfiguracijskih i operacijskih podataka (prosječna vrijednost odgovora 1,68; std.dev. 0,97).

Kreirana je ukupna dimenzija razine znanja iz koje je vidljivo da je prosječna razina znanja ispitanika 1,74 boda s prosječnim odstupanjem od aritmetičke sredine 0,95 . 
Tablica 6-60. Razine znanja ispitanika o svojstvima NETCONF standarda (upitnik korisnika)

\begin{tabular}{|c|c|c|c|c|c|c|c|c|}
\hline & $\mathrm{N}$ & Prosjek & Std.Dev. & Mod & Median & IQR & $\mathrm{Z}$ & $\mathrm{P}^{*}$ \\
\hline $\begin{array}{l}\text { NETCONF kao standardni način } \\
\text { konfiguracije preko udaljenog } \\
\text { pristupa na IP adresu uređaja. }\end{array}$ & 73 & 1,78 & 1,02 & 1,00 & 2,00 & $\begin{array}{l}(1,00- \\
2,00)\end{array}$ & 5,52 & $<0,001$ \\
\hline $\begin{array}{l}\text { NETCONF kao standard koji } \\
\text { omogućava programabilnost } \\
\text { (automatiziranje). }\end{array}$ & 73 & 1,73 & 0,92 & 1,00 & 1,00 & $\begin{array}{l}(1,00- \\
2,00)\end{array}$ & 5,44 & $<0,001$ \\
\hline $\begin{array}{l}\text { NETCONF standard koristi } \\
\text { jasnu razliku u strukturi između } \\
\text { konfiguracijskih i operacijskih } \\
\text { podataka. }\end{array}$ & 73 & 1,68 & 0,97 & 1,00 & 1,00 & $\begin{array}{l}(1,00- \\
2,00)\end{array}$ & 5,10 & $<0,001$ \\
\hline $\begin{array}{l}\text { Mogućnost parcijalnog } \\
\text { konfiguriranja uređaja pomoću } \\
\text { NETCONF standarda. }\end{array}$ & 73 & 1,74 & 0,99 & 1,00 & 1,00 & $\begin{array}{l}(1,00- \\
2,00)\end{array}$ & 5,34 & $<0,001$ \\
\hline $\begin{array}{l}\text { Mogućnost provjere } \\
\text { konfiguracije prije primjene kod } \\
\text { NETCONF načina } \\
\text { konfiguriranja uređaja. }\end{array}$ & 73 & 1,75 & 1,05 & 1,00 & 1,00 & $\begin{array}{l}(1,00- \\
2,00)\end{array}$ & 5,14 & $<0,001$ \\
\hline $\begin{array}{l}\text { Mogućnost zaključavanja } \\
\text { konfiguracijske datoteke koje } \\
\text { nudi NETCONF. }\end{array}$ & 73 & 1,71 & 0,99 & 1,00 & 1,00 & $\begin{array}{l}(1,00- \\
2,00)\end{array}$ & 5,06 & $<0,001$ \\
\hline $\begin{array}{l}\text { „Backup \& restore“ mogućnost } \\
\text { koju nudi NETCONF standard. }\end{array}$ & 73 & 1,73 & 1,00 & 1,00 & 1,00 & $\begin{array}{l}(1,00- \\
2,00) \\
\end{array}$ & 5,15 & $<0,001$ \\
\hline $\begin{array}{l}\text { Mogućnost istovremenog i } \\
\text { koordiniranog konfiguriranja } \\
\text { svih ili više uređaja u mreži. }\end{array}$ & 73 & 1,81 & 1,11 & 1,00 & 1,00 & $\begin{array}{l}(1,00- \\
2,00)\end{array}$ & 5,21 & $<0,001$ \\
\hline Ukupno & 73 & 1,74 & 0,95 & 1,00 & 1,38 & $\begin{array}{l}(1,00- \\
2,00) \\
\end{array}$ & 5,53 & $<0,001$ \\
\hline
\end{tabular}

* Wilcoxonov test za jedan nezavisan uzorak

\subsubsection{NETCONF i povećanje raspoloživosti R/S uređaja}

U ovom poglavlju se razmatra povećanje raspoloživosti mrežnih R/S uređaja pomoću NETCONF standarda (u odnosu na nestandardne metode konfiguriranja).

U 25. pitanju ispitanici su iskazivali svoje mišljenje o NETCONF standardu i povećanju raspoloživosti R/S uređaja.

Ispitanici su iskazivali slaganje s ponuđenim tvrdnjama vrijednostima od -2 do 2 , gdje je -2 označavalo izrazito neslaganje, a 2 izrazito slaganje s tvrdnjom. 
Testiranje se provodi Wilcoxonovim testom za jedan nezavisan uzorak gdje će se utvrditi postojanje slaganja ispitanika $\mathrm{s}$ tvrdnjom da proizvođači mrežne opreme implementiraju NETCONF standard na svojim uređajima samo ako je srednja vrijednost (medijan) veća od 0,00 uz empirijsku p vrijednost manju od 0,05. U slučaju da je empirijska p vrijednost veća od 0,05 riječ je o indiferentnom stavu, dok se u slučaju negativne vrijednosti medijana uz empirijsku p vrijednost manju od 0,05 može utvrditi da je riječ o neslaganju.

Tablica 6-61. prikazuje rezultate odgovora na 25. pitanje anketnog upitnika. Visoki postotak odgovora „Ne znam“ u ovom pitanju pokazuje nepoznavanje NETCONF standarda i njegove primjene od strane ispitanika (korisnika). Ostali odgovori su prikazani deskriptivnom statistikom.

\section{Tablica 6-61. NETCONF standard i povećanje raspoloživosti R/S uređaja} (rezultati upitnika korisnika)

\begin{tabular}{|c|c|c|c|c|c|c|c|c|c|c|c|c|c|c|}
\hline & \multicolumn{2}{|c|}{ Ne znam } & \multicolumn{2}{|c|}{$\begin{array}{c}-2 \\
\text { Izrazito } \\
\text { se NE } \\
\text { slažem } \\
\end{array}$} & \multicolumn{2}{|c|}{$\begin{array}{c}-1 \\
\mathrm{NE} \\
\text { slažem } \\
\text { se }\end{array}$} & \multicolumn{2}{|c|}{$\begin{array}{c}0 \\
\text { Niti se } \\
\text { slažem niti } \\
\text { se ne slažem }\end{array}$} & \multicolumn{2}{|c|}{$\begin{array}{c}1 \\
\text { Slažem se }\end{array}$} & \multicolumn{2}{|c|}{$\begin{array}{c}2 \\
\text { Izrazito } \\
\text { se slažem }\end{array}$} & \multicolumn{2}{|c|}{ Ukupno } \\
\hline & $N$ & $\%$ & $\mathbf{N}$ & $\%$ & $\mathbf{N}$ & $\%$ & $\mathbf{N}$ & $\%$ & $\mathbf{N}$ & $\%$ & $\mathbf{N}$ & $\%$ & $\mathbf{N}$ & $\%$ \\
\hline $\begin{array}{l}\text { 1. Korištenje NETCONF } \\
\text { standarda povećava } \\
\text { raspoloživost mrežnog R/S } \\
\text { uređaja u odnosu na } \\
\text { nestandardne CLI metode } \\
\text { konfiguriranja mrežnih } \\
\text { uređaja (operacijskih sustava } \\
\text { proizvođača opreme). }\end{array}$ & 28 & 38,36 & 2 & 2,74 & 3 & 4,11 & 15 & 20,55 & 21 & 28,77 & 4 & 5,48 & 73 & 100 \\
\hline $\begin{array}{l}\text { 2. NETCONF standard bi se } \\
\text { trebao više koristiti od strane } \\
\text { proizvođača i korisnika na } \\
\mathrm{R} / \mathrm{S} \text { uređajima zbog postizanja } \\
\text { povećanja raspoloživosti } \\
\text { uređaja i sustava. }\end{array}$ & 25 & 34,25 & 2 & 2,74 & 3 & 4,11 & 17 & 23,29 & 22 & 30,14 & 4 & 5,48 & 73 & 100 \\
\hline
\end{tabular}

Tablica 6-62. prikazuje odgovore na 25. pitanje pomoću deskriptivne statistike.

Ispitanici se gotovo podjednako slažu s tvrdnjom Korištenje NETCONF standarda povećava raspoloživost mrežnog $R / S$ uređaja u odnosu na nestandardne CLI metode konfiguriranja mrežnih uređaja (prosječna vrijednost odgovora 0,49; std.dev.0,92), odnosno s tvrdnjom NETCONF standard bi se trebao više koristiti od strane proizvođača $i$ korisnika na R/S 
uređajima zbog postizanja povećanja raspoloživosti uređaja i sustava (prosječna vrijednost odgovora 0,48 ; std.dev.0,90).

Tablica 6-62. NETCONF standard i povećanje raspoloživosti R/S uređaja (upitnik korisnika)

\begin{tabular}{|c|c|c|c|c|c|c|c|c|}
\hline & $\mathrm{N}$ & Prosjek & Std.Dev. & Mod & Median & IQR & Z & $\mathrm{P}^{*}$ \\
\hline $\begin{array}{l}\text { 1. Korištenje NETCONF } \\
\text { standarda povećava } \\
\text { raspoloživost mrežnog R/S } \\
\text { uređaja u odnosu na } \\
\text { nestandardne CLI metode } \\
\text { konfiguriranja mrežnih } \\
\text { uređaja (operacijskih } \\
\text { sustava proizvođača } \\
\text { opreme). }\end{array}$ & 45 & 0,49 & 0,92 & 1,00 & 1,00 & $\begin{array}{c}(0,00- \\
1,00)\end{array}$ & 3,08 & 0,002 \\
\hline $\begin{array}{l}\text { 2. NETCONF standard bi se } \\
\text { trebao više koristiti od } \\
\text { strane proizvođača i } \\
\text { korisnika na R/S uređajima } \\
\text { zbog postizanja povećanja } \\
\text { raspoloživosti uređaja i } \\
\text { sustava. }\end{array}$ & 48 & 0,48 & 0,90 & 1,00 & 1,00 & $\begin{array}{c}(0,00- \\
1,00)\end{array}$ & 3,19 & 0,001 \\
\hline
\end{tabular}

U 26. pitanju su ispitanici iskazivali svoje mišljenje o svojstvima NETCONF standarda i povećanju raspoloživosti R/S uređaja.

Ispitanici su iskazivali slaganje s ponuđenim tvrdnjama vrijednostima od -2 do 2 , gdje je -2 označavalo izrazito neslaganje, a 2 izrazito slaganje s tvrdnjom.

Testiranje se provodi Wilcoxonovim testom za jedan nezavisan uzorak gdje će se utvrditi postojanje slaganja ispitanika s tvrdnjom da proizvođači mrežne opreme implementiraju NETCONF standard na svojim uređajima samo ako je srednja vrijednost (medijan) veća od 0,00 uz empirijsku p vrijednost manju od 0,05. U slučaju da je empirijska p vrijednost veća od 0,05 riječ je o indiferentnom stavu, dok se u slučaju negativne vrijednosti medijana uz empirijsku p vrijednost manju od 0,05 može utvrditi da je riječ o neslaganju.

Tablica 6-63. prikazuje rezultate odgovora na 26. pitanje anketnog upitnika. Visoki postotak odgovora „Ne znam“ u ovom pitanju pokazuje nepoznavanje NETCONF standarda i njegove 
primjene od strane ispitanika (korisnika). Ostali odgovori su prikazani deskriptivnom statistikom.

Tablica 6-63. Svojstva NETCONF standarda i povećanje raspoloživosti R/S uređaja (rezultati upitnika korisnika)

\begin{tabular}{|c|c|c|c|c|c|c|c|c|c|c|c|c|c|c|}
\hline & \multicolumn{2}{|c|}{ Ne znam } & \multicolumn{2}{|c|}{$\begin{array}{c}-2 \\
\text { Izrazito se } \\
\mathrm{NE} \\
\text { slažem }\end{array}$} & \multicolumn{2}{|c|}{$\begin{array}{c}-1 \\
\mathrm{NE} \\
\text { slažem } \\
\text { se }\end{array}$} & \multicolumn{2}{|c|}{$\begin{array}{c}0 \\
\text { Niti se } \\
\text { slažem niti } \\
\text { se ne slažem }\end{array}$} & \multicolumn{2}{|c|}{$\begin{array}{c}1 \\
\text { Slažem se }\end{array}$} & \multicolumn{2}{|c|}{$\begin{array}{l}2 \\
\text { Izrazito se } \\
\text { slažem }\end{array}$} & \multicolumn{2}{|c|}{ Ukupno } \\
\hline & $\%$ & $N$ & $\%$ & $\mathbf{N}$ & $\%$ & $\mathbf{N}$ & $\%$ & $\mathbf{N}$ & $\%$ & $\mathbf{N}$ & $\%$ & $\mathbf{N}$ & $\%$ & $\mathbf{N}$ \\
\hline $\begin{array}{l}\text { Mogućnost istovremenog i } \\
\text { koordiniranog } \\
\text { konfiguriranja svih ili više } \\
\text { uređaja u mreži. }\end{array}$ & 35,62 & 26 & 0,00 & 0 & 1,37 & 1 & 9,59 & 7 & 35,62 & 26 & 17,81 & 13 & 100 & 73 \\
\hline $\begin{array}{l}\text { Mogućnost provjere } \\
\text { konfiguracije prije primjene } \\
\text { kod NETCONF načina } \\
\text { konfiguriranja uređaja. }\end{array}$ & 39,73 & 29 & 0,00 & 0 & 0,00 & 0 & 15,07 & 11 & 30,14 & 22 & 15,07 & 11 & 100 & 73 \\
\hline $\begin{array}{l}\text { NETCONF kao standard } \\
\text { omogućava } \\
\text { programabilnost } \\
\text { (automatiziranje) koja } \\
\text { značajno smanjuje } \\
\text { učestalost ljudske pogreške. }\end{array}$ & 35,62 & 26 & 0,00 & 0 & 2,74 & 2 & 10,96 & 8 & 38,36 & 28 & 12,33 & 9 & 100 & 73 \\
\hline $\begin{array}{l}\text { NETCONF standard za sve } \\
\text { proizvođače uređaja ima } \\
\text { istu (standardnu) strukturu } \\
\text { komandi i podataka. }\end{array}$ & 36,99 & 27 & 0,00 & 0 & 0,00 & 0 & 16,44 & 12 & 36,99 & 27 & 9,59 & 7 & 100 & 73 \\
\hline $\begin{array}{l}\text { „Backup \& restore“ } \\
\text { mogućnost koju nudi } \\
\text { NETCONF standard. }\end{array}$ & 36,99 & 27 & 0,00 & 0 & 2,74 & 2 & 16,44 & 12 & 32,88 & 24 & 10,96 & 8 & 100 & 73 \\
\hline $\begin{array}{l}\text { NETCONF standard koristi } \\
\text { jasnu razliku u strukturi } \\
\text { između konfiguracijskih i } \\
\text { operacijskih podataka. }\end{array}$ & 41,10 & 30 & 0,00 & 0 & 1,37 & 1 & 17,81 & 13 & 30,14 & 22 & 9,59 & 7 & 100 & 73 \\
\hline $\begin{array}{l}\text { Mogućnost zaključavanja } \\
\text { konfiguracijske datoteke } \\
\text { koje nudi NETCONF. }\end{array}$ & 38,36 & 28 & 1,37 & 1 & 0,00 & 0 & 17,81 & 13 & 34,25 & 25 & 8,22 & 6 & 100 & 73 \\
\hline $\begin{array}{l}\text { Mogućnost parcijalnog } \\
\text { konfiguriranja uređaja } \\
\text { pomoću NETCONF } \\
\text { standarda. }\end{array}$ & 39,73 & 29 & 0,00 & 0 & 0,00 & 0 & 20,55 & 15 & 34,25 & 25 & 5,48 & 4 & 100 & 73 \\
\hline
\end{tabular}

Tablica 6-64. prikazuje odgovore na 26. pitanje pomoću deskriptivne statistike. Podaci u tablici su uređeni od najveće do najmanje prosječne vrijednosti. 
Tablica 6-64. Svojstva NETCONF standarda i povećanje raspoloživosti R/S uređaja (upitnik korisnika)

\begin{tabular}{|c|c|c|c|c|c|c|c|c|}
\hline & $\mathrm{N}$ & Prosjek & Std.Dev. & Mod & Median & IQR & $\mathrm{Z}$ & $\mathrm{P}^{*}$ \\
\hline $\begin{array}{l}\text { Mogućnost istovremenog i } \\
\text { koordiniranog konfiguriranja } \\
\text { svih ili više uređaja u mreži. }\end{array}$ & 47 & 1,09 & 0,72 & 1,00 & 1,00 & $\begin{array}{l}(1,00- \\
2,00)\end{array}$ & 5,56 & $<0,001$ \\
\hline $\begin{array}{l}\text { Mogućnost provjere } \\
\text { konfiguracije prije primjene } \\
\text { kod NETCONF načina } \\
\text { konfiguriranja uređaja. }\end{array}$ & 44 & 1,00 & 0,72 & 1,00 & 1,00 & $\begin{array}{c}(0,50- \\
1,50)\end{array}$ & 5,22 & $<0,001$ \\
\hline $\begin{array}{l}\text { NETCONF kao standard } \\
\text { omogućava programabilnost } \\
\text { (automatiziranje) koja značajno } \\
\text { smanjuje učestalost ljudske } \\
\text { pogreške. }\end{array}$ & 47 & 0,94 & 0,73 & 1,00 & 1,00 & $\begin{array}{l}(1,00- \\
1,00)\end{array}$ & 5,32 & $<0,001$ \\
\hline $\begin{array}{l}\text { NETCONF standard za sve } \\
\text { proizvođače uređaja ima istu } \\
\text { (standardnu) strukturu komandi } \\
\text { i podataka. }\end{array}$ & 46 & 0,89 & 0,64 & 1,00 & 1,00 & $\begin{array}{l}(0,00- \\
1,00)\end{array}$ & 5,43 & $<0,001$ \\
\hline $\begin{array}{l}\text { „Backup \& restore“ mogućnost } \\
\text { koju nudi NETCONF standard. }\end{array}$ & 46 & 0,83 & 0,77 & 1,00 & 1,00 & $\begin{array}{c}(0,00- \\
1,00) \\
\end{array}$ & 4,90 & $<0,001$ \\
\hline $\begin{array}{l}\text { NETCONF standard koristi } \\
\text { jasnu razliku u strukturi između } \\
\text { konfiguracijskih i operacijskih } \\
\text { podataka. }\end{array}$ & 43 & 0,81 & 0,73 & 1,00 & 1,00 & $\begin{array}{l}(0,00- \\
1,00)\end{array}$ & 4,81 & $<0,001$ \\
\hline $\begin{array}{l}\text { Mogućnost zaključavanja } \\
\text { konfiguracijske datoteke koje } \\
\text { nudi NETCONF. }\end{array}$ & 45 & 0,78 & 0,77 & 1,00 & 1,00 & $\begin{array}{l}(0,00- \\
1,00)\end{array}$ & 5,67 & $<0,001$ \\
\hline $\begin{array}{l}\text { Mogućnost parcijalnog } \\
\text { konfiguriranja uređaja pomoću } \\
\text { NETCONF standarda. }\end{array}$ & 44 & 0,75 & 0,61 & 1,00 & 1,00 & $\begin{array}{l}(0,00- \\
1,00)\end{array}$ & 5,11 & $<0,001$ \\
\hline Ukupno & 47 & 0,91 & 0,50 & 1,00 & 1,00 & $\begin{array}{c}(0,63- \\
1,03)\end{array}$ & 5,93 & $<0,001$ \\
\hline
\end{tabular}

* Wilcoxonov test za jedan nezavisan uzorak

Ispitanici smatraju da u najvećoj mjeri svojstvo Mogućnost istovremenog $i$ koordiniranog konfiguriranja svih ili više uređaja u mreži pomoću NETCONF standarda omogućava povećanje raspoloživosti mrežnih uređaja (prosječna vrijednost odgovora 1,09; std.dev. 0,72), dok u najmanjoj mjeri raspoloživost povećava mogućnost parcijalnog konfiguriranja uređaja pomoću NETCONF standarda (prosječna vrijednost odgovora 0,75 ; std.dev. 0,61).

Ukupna razina slaganja ispitanika je bilježila prosječnu vrijednost 0,91 s prosječnim odstupanjem od aritmetičke sredine 0,50 . 
29. pitanje anketnog upitnika glasi: "Molim Vas da izložite svoja dodatna zapažanja i mišljenje vezano uz primjenu NETCONF standarda i povećanje raspoloživosti mrežnih uređaja, a koja nisu obrađena u prethodnim pitanjima.". Dobiven je sljedeći odgovor ispitanika:

- „Iskreno, do sad nisam bio upoznat s ovim standardom i njegovim mogućnostima. Kroz prezentaciju i ovaj upitnik sam ostao iznenađen koliko je standard dobro zamišljen i koje su njegove prednosti, ali sam isto tako negativno iznenađen koliko je slabo zastupljen u svakodnevnoj upotrebi.“

\subsubsection{Karakteristike i povećanje primjene NETCONF standarda}

U ovom poglavlju se razmatraju ostale teme o NETCONF standardu (karakteristike, budući razvoj i primjena, i drugo) koje nisu pokrivene u prethodnim pitanjima anketnog upitnika.

23. pitanje anketnog upitnika glasi: „Molim Vas da izrazite svoje mišljenje o nedostacima NETCONF standarda?“. Ispitanici su iskazivali slaganje $\mathrm{s}$ ponuđenim tvrdnjama o nedostatcima NETCONF standarda vrijednostima od -2 do 2, gdje je -2 označavalo izrazito neslaganje, a 2 izrazito slaganje s tvrdnjom.

Tablica 6-65. Nedostatci NETCONF standarda (rezultati upitnika korisnika)

\begin{tabular}{|c|c|c|c|c|c|c|c|c|c|c|c|c|c|c|}
\hline & \multicolumn{2}{|c|}{ Ne znam } & \multicolumn{2}{|c|}{$\begin{array}{c}-2 \\
\text { Izrazito se } \\
\text { NE slažem }\end{array}$} & \multicolumn{2}{|c|}{$\begin{array}{c}-1 \\
\mathrm{NE} \\
\text { slažem se }\end{array}$} & \multicolumn{2}{|c|}{$\begin{array}{c}0 \\
\text { Niti se } \\
\text { slažem niti se } \\
\text { ne slažem }\end{array}$} & \multicolumn{2}{|c|}{$\begin{array}{c}1 \\
\text { Slažem se }\end{array}$} & \multicolumn{2}{|c|}{$\begin{array}{c}2 \\
\text { Izrazito se } \\
\text { slažem }\end{array}$} & \multicolumn{2}{|c|}{ Ukupno } \\
\hline & $N$ & $\%$ & $\mathbf{N}$ & $\%$ & $\mathbf{N}$ & $\%$ & $\mathbf{N}$ & $\%$ & $\mathbf{N}$ & $\%$ & $\mathbf{N}$ & $\%$ & $\mathbf{N}$ & $\%$ \\
\hline $\begin{array}{l}\text { NETCONF standard } \\
\text { koristi XML jezik i } \\
\text { njegovu sintaksu koja je } \\
\text { redundantna i opširna što } \\
\text { može zamarati i zbunjivati. }\end{array}$ & 27 & 36,99 & 2 & 2,74 & 8 & 10,96 & 17 & 23,29 & 16 & 21,92 & 3 & 4,11 & 73 & 100 \\
\hline $\begin{array}{l}\text { Za korištenje NETCONF } \\
\text { protokola potrebno je } \\
\text { poznavanje programskih } \\
\text { jezika. }\end{array}$ & 25 & 34,25 & 1 & 1,37 & 5 & 6,85 & 16 & 21,92 & 19 & 26,03 & 7 & 9,59 & 73 & 100 \\
\hline
\end{tabular}

Testiranje se provodi Wilcoxonovim testom za jedan nezavisan uzorak gdje će se utvrditi postojanje slaganja ispitanika s tvrdnjom da proizvođači mrežne opreme implementiraju NETCONF standard na svojim uređajima samo ako je srednja vrijednost (medijan) veća od 0,00 uz empirijsku p vrijednost manju od 0,05 . U slučaju da je empirijska p vrijednost veća od 
0,05 riječ je o indiferentnom stavu, dok se u slučaju negativne vrijednosti medijana uz empirijsku p vrijednost manju od 0,05 može utvrditi da je riječ o neslaganju.

Tablica 6-65. prikazuje rezultate odgovora na 23. pitanje anketnog upitnika. Visoki postotak odgovora „Ne znam“ u ovom pitanju pokazuje nepoznavanje NETCONF standarda i njegove primjene od strane ispitanika (korisnika). Ostali su odgovori prikazani deskriptivnom statistikom.

Tablica 6-66. prikazuje odgovore na 23. pitanje pomoću deskriptivne statistike.

Tablica 6-66. Nedostaci NETCONF standarda (upitnik korisnika)

\begin{tabular}{|c|c|c|c|c|c|c|c|c|}
\hline & $\mathrm{N}$ & Prosjek & Std.Dev. & Mod & $\begin{array}{c}\text { Medi } \\
\text { an }\end{array}$ & IQR & Z & $\mathrm{P}^{*}$ \\
\hline $\begin{array}{l}\text { NETCONF standard koristi } \\
\text { XML jezik i njegovu sintaksu } \\
\text { koja je redundantna i opširna } \\
\text { stto može zamarati i } \\
\text { zbunjivati. }\end{array}$ & 46 & 0,22 & 0,96 & 0,00 & 0,00 & $\begin{array}{c}(0,00- \\
1,00)\end{array}$ & 1,48 & 0,140 \\
\hline $\begin{array}{l}\text { Za korištenje NETCONF } \\
\text { protokola potrebno je } \\
\text { poznavanje programskih } \\
\text { jezika. }\end{array}$ & 48 & 0,54 & 0,94 & 1,00 & 1,00 & $\begin{array}{c}(0,00- \\
1,00)\end{array}$ & 3,42 & 0,001 \\
\hline
\end{tabular}

* Wilcoxonov test za jedan nezavisan uzorak

Ispitanici se slažu s tvrdnjom da je za korištenje NETCONF protokola potrebno poznavanje programskih jezika (prosječna vrijednost odgovora 0,54; std.dev.0,94), dok su neutralni oko tvrdnje NETCONF standard koristi XML jezik i njegovu sintaksu koja je redundantna $i$ opširna što može zamarati i zbunjivati (prosječna vrijednost odgovora 0,22; std.dev.0,96).

U 24. pitanju su ispitanici iskazivali svoje mišljenje o različitim tvrdnjama vezanim uz NETCONF standard i povećanje raspoloživosti R/S uređaja. Ispitanici su iskazivali slaganje $\mathrm{s}$ ponuđenim tvrdnjama vrijednostima od -2 do 2 , gdje je -2 označavalo izrazito neslaganje, a 2 izrazito slaganje s tvrdnjom.

Testiranje se provodi Wilcoxonovim testom za jedan nezavisan uzorak gdje će se utvrditi postojanje slaganja ispitanika $s$ tvrdnjom da proizvođači mrežne opreme implementiraju NETCONF standard na svojim uređajima samo ako je srednja vrijednost (medijan) veća od 0,00 uz empirijsku p vrijednost manju od 0,05. U slučaju da je empirijska p vrijednost veća od 
0,05 riječ je o indiferentnom stavu, dok se u slučaju negativne vrijednosti medijana uz empirijsku p vrijednost manju od 0,05 može utvrditi da je riječ o neslaganju.

Tablica 6-67. prikazuje rezultate odgovora na 24. pitanje anketnog upitnika. Visoki postotak odgovora „Ne znam“ u ovom pitanju pokazuje nepoznavanje NETCONF standarda i njegove primjene od strane ispitanika (korisnika). Ostali su odgovori prikazani deskriptivnom statistikom.

\section{Tablica 6-67. NETCONF standard i povećanje raspoloživosti R/S uređaja}

\section{(rezultati upitnika korisnika)}

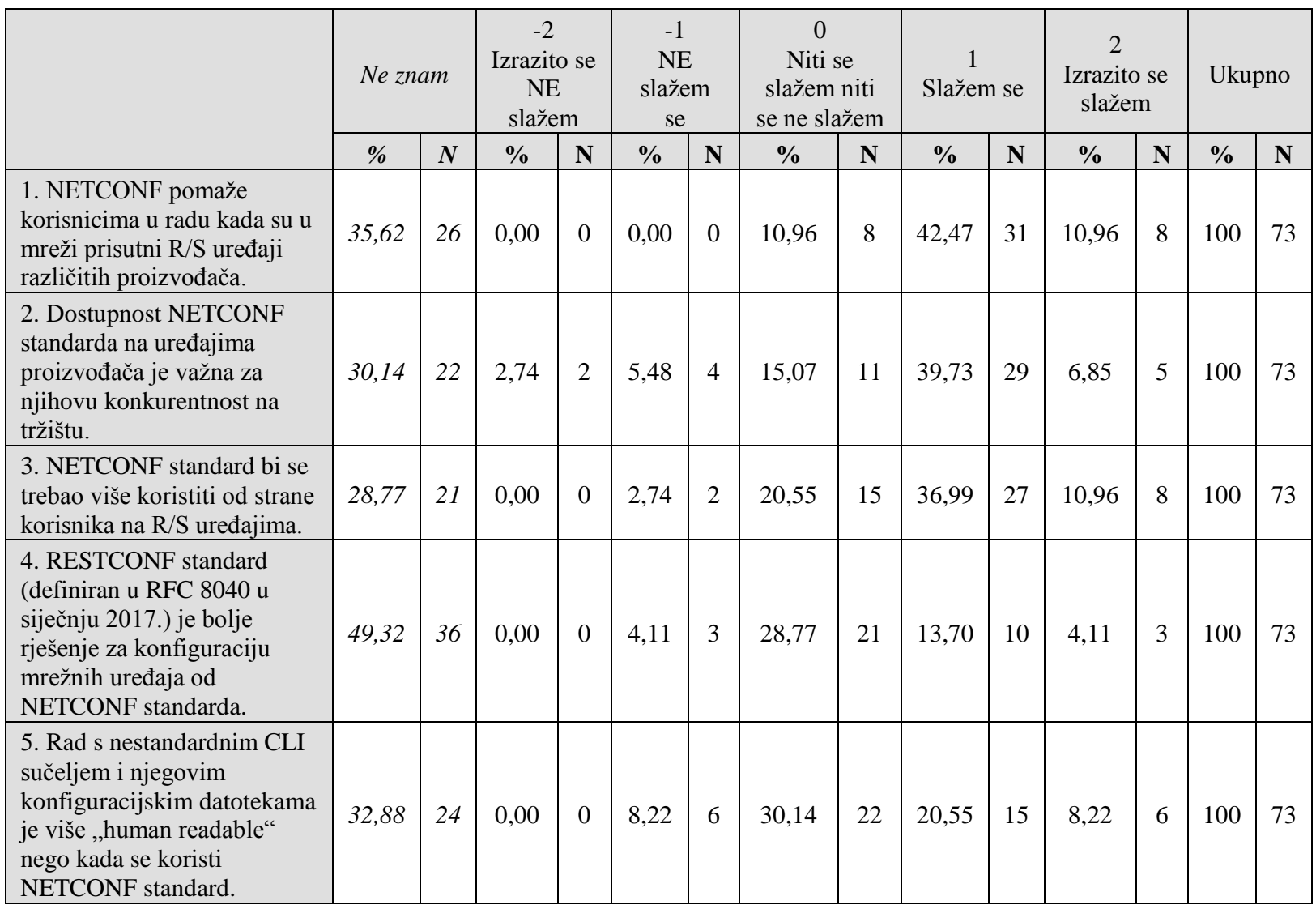

Tablica 6-68. prikazuje odgovore na 24. pitanje pomoću deskriptivne statistike.

Ispitanici su iskazali najveće slaganje s tvrdnjom NETCONF pomaže korisnicima u radu kada su u mreži prisutni $R / S$ uređaji različitih proizvođača (prosječna vrijednost odgovora 1,00; std.dev.0,59), dok se najmanje slažu s tvrdnjom RESTCONF standard (definiran u RFC 8040 
u siječnju 2017.) je bolje rješenje za konfiguraciju mrě̌nih uređaja od NETCONF standarda (prosječna vrijednost odgovora 0,35 std.dev.0,75).

Tablica 6-68. NETCONF standard i povećanje raspoloživosti R/S uređaja (upitnik korisnika)

\begin{tabular}{|c|c|c|c|c|c|c|c|c|}
\hline & $\mathrm{N}$ & Prosjek & $\begin{array}{c}\text { Std.D } \\
\text { ev. }\end{array}$ & Mod & $\begin{array}{c}\text { Medi } \\
\text { jan }\end{array}$ & IQR & Z & $\mathrm{P}^{*}$ \\
\hline $\begin{array}{l}\text { 1. NETCONF pomaže } \\
\text { korisnicima u radu kada su u } \\
\text { mreži prisutni R/S uređaji } \\
\text { različitih proizvođača. }\end{array}$ & 47 & 1,00 & 0,59 & 1,00 & 1,00 & $\begin{array}{c}(1,00- \\
1,00)\end{array}$ & 5,81 & $<0,001$ \\
\hline $\begin{array}{l}\text { 2. Dostupnost NETCONF } \\
\text { standarda na uređajima } \\
\text { proizvođača je važna za njihovu } \\
\text { konkurentnost na tržištu. }\end{array}$ & 51 & 0,61 & 0,92 & 1,00 & 1,00 & $\begin{array}{c}(0,00- \\
1,00)\end{array}$ & 3,88 & $<0,001$ \\
\hline $\begin{array}{l}\text { 3. NETCONF standard bi se } \\
\text { trebao više koristiti od strane } \\
\text { korisnika na R/S uređajima. }\end{array}$ & 52 & 0,79 & 0,75 & 1,00 & 1,00 & $\begin{array}{c}(0,00- \\
1,00)\end{array}$ & 5,16 & $<0,001$ \\
\hline $\begin{array}{l}\text { 4. RESTCONF standard } \\
\text { (definiran u RFC } 8040 \text { u siječnju } \\
\text { 2017.) je bolje rješenje za } \\
\text { konfiguraciju mrežnih uređaja od } \\
\text { NETCONF standarda. }\end{array}$ & 37 & 0,35 & 0,75 & 0,00 & 0,00 & $\begin{array}{c}(0,00- \\
1,00)\end{array}$ & 2,60 & 0,009 \\
\hline $\begin{array}{l}\text { 5. Rad s nestandardnim CLI } \\
\text { sučeljem i njegovim } \\
\text { konfiguracijskim datotekama je } \\
\text { više „human readable“ nego kada } \\
\text { se koristi NETCONF standard. }\end{array}$ & 49 & 0,43 & 0,87 & 0,00 & 0,00 & $\begin{array}{c}(0,00- \\
1,00)\end{array}$ & 3,14 & 0,002 \\
\hline
\end{tabular}

* Wilcoxonov test za jedan nezavisan uzorak

28. pitanje anketnog upitnika glasi: "Na koji način Vi vidite buduću primjenu i razvoj NETCONF standarda?". Odabrani su sljedeći odgovori ispitanika:

- ispitanik navodi da će se standard nastaviti razvijati (u nekom obliku) jer postoji potreba za standardiziranim načinom konfiguriranja i automatiziranja, pogotovo velikih mreža. Uz mrežna znanja svakako je potrebno i poznavanje programskih jezika.

- Drugi ispitanik smatra da će većina proizvođača uvesti vlastita rješenja za SDN poput Cisco ACI ili Cisco DNA iz čisto komercijalnih razloga. Stoga drži da će upotreba standarda poput NETCONF-a postati transparentna za krajnjeg korisnika, odnosno administratora. Malo je vjerojatno da će mrežni administratori dovoljno kvalitetno usvojiti programerske vještine i znanja, a i da će veliki proizvođači mrežne opreme 
poput kompanije Cisco olako "dozvoliti" primjenu nečega što potiče korisnike na multi-vendor okruženja. Stoga misli da će primjena čistog NETCONF standarda ostati više u okvirima service i cloud davatelja usluga ili jako velikih sustava koji posjeduju vlastite razvojne (DevOps) timove.

- Treći ispitanik smatra da NETCONF standard može zaživjeti kao vodeći standard jedino kroz zajednički nastup i promociju vodećih proizvođača opreme. Uglavnom se mrežni administratori sustava drže određenih proizvođača i njihovih sučelja i nisu baš spremni uvoditi promjene. Ovakav pristup vjerojatno odgovara i samim proizvođačima opreme jer na taj način osiguravaju svoju ,publiku“ odnosno korisnike.

- Sljedeći ispitanik vjeruje da bi se NETCONF standard više koristio kada bi proizvođači pružali više informacija i edukacija na tu temu jer bi se time olakšalo i automatiziralo upravljanje mrežom.

- Sljedeći ispitanik smatra da, ako se nastavi ovako, ne vidi buduću primjenu. Misli da je potrebno više popularizirati NETCONF.

- Ispitanik smatra da je to korak u pravom smjeru jer NETCONF ukida ovisnost o jednom proizvođaču (npr. Cisco) u malim i srednjim mrežama, a u podatkovnim centrima i oblačnim će uslugama vjerojatno postati nezamjenjiv.

- Više ispitanika navodi da nije, ili je slabo upoznato s NETCONF protokolom,

\subsubsection{Zaključak}

Na temelju odgovora dobivenih na anketne upitnike korisnika u Hrvatskoj može se zaključiti sljedeće:

\section{Podaci o ispitanicima (korisnicima):}

- Visoki postotak (86.3\%) ispitanika ima završeno više obrazovanje (ili 3 ili 5 godina) vezano za ICT tehnologije.

- Visoki postotak (79.4\%) ispitanika ima položeni certifikat iz računalnih mreža, od kojih 43.8\% ispitanika ima položeni srednji ili najviši stupanj certifikata iz računalnih mreža, što pokazuje njihovu stručnost u radu s računalnim mrežama i R/S uređajima.

- Ispitanici imaju različito radno iskustvo, odnosno istraživanje je pokrilo podjednako raspon od mladih stručnjaka do stručnjaka s iskustvom od petnaest i više godina. 
- Na temelju ocjene svojih znanja iz poznavanje računalnih mreža i uređaja, može se zaključiti da ispitanici imaju najviše znanja iz tradicionalnih područja i tehnologija računalnih mreža ( $\mathrm{R} / \mathrm{S}$ uređaji, sigurnost i upravljanje računalnim mrežama), a najmanje iz područja automatizacije i programiranja računalnih mreža. To pokazuje da ispitanici koji rade s računalnim mrežama rijetko koriste automatizaciju računalnih mreža i na tradicionalan način (pomoću skripti).

- Na temelju ocjene svojih znanja, može se vidjeti da ispitanici imaju relativno nisko znanje iz programiranja (srednja ocjena 1.8). Najviše znanja imaju iz opće teorije programiranja (srednja ocjena 2.32), dok manje znanja imaju o programskim jezicima (HTML, Python, C/C++, i ostali). Ispitanici najmanje znanja imaju iz programskih jezika:

○ Perl (prosječna razina znanja 1,41; std.dev.0,91) i

○ $\mathrm{Tcl}$ (prosječna razina znanja 1,41 ; std.dev.0,70)

koji se koriste za automatizaciju računalnih mreža na tradicionalan način pomoću skripti i prisutni su kao mrežna tehnologija više od dvadeset godina. Čak $76.71 \%$ ispitanika za Perl i $69.86 \%$ za Tcl smatra da ima nedovoljna znanja o tim jezicima. To pokazuje da ispitanici koji rade s računalnim mrežama rijetko koriste automatizaciju računalnih mreža i na tradicionalan način.

- Ispitanici uključeni u ispitivanje obavljaju široki spektar poslova vezanih uz računalne mreže.

\section{Podaci o kompanijama ispitanika:}

- Ispitanici koji su popunili anketni upitnik rade u kompanijama koje su:

○ partneri u iznosu od $27.40 \%$ (20 ispitanika) i

○ krajnji korisnici (ISP i poduzeća zajedno) u iznosu od 72.60\% (53 ispitanika), i oni su uključeni u analizu rezultata.

- Od ukupno 85 ispitanika koji su kompletno popunili anketni upitnik i koji rade na poslovima vezanim uz računalne mreže, njih 12 radi na računalnim mrežama niže raspoloživosti (manje od ,tri devetke“). Zbog toga je za analiziranje rezultata istraživanja preostao broj anketnih upitnika od $\mathbf{7 3}$ ispitanika koji imaju visoku raspoloživost (raspoloživost $\geq 99.9 \%$, odnosno vrijeme zastoja godišnje $\leq 8.76$ sati). 
- Najviše ispitanika koristi Cisco (72) R/S uređaje u svojim mrežama, zatim slijede HPE (50), Juniper Networks (50) i drugi.

- Četiri proizvođača su najviše zastupljena kod korisnika: Cisco (49,54\%), HPE $(14,05 \%)$, Huawei $(9,61 \%)$ i Juniper Networks $(8,87)$.

- Trenutno samo 20.55\% ispitanika koristi softverski definirane mreže (bilo koja vrsta SDN implementacije: SD-WAN, SD-Access ili drugo) u svojim kompanijama.

\section{Primjena NETCONF standarda kod proizvođača R/S uređaja:}

- Visoki postotak odgovora „Ne znam“ u pitanjima što se tiču NETCONF standarda pokazuje nepoznavanje NETCONF standarda i njegove primjene od strane ispitanika (korisnika). Ostali odgovori su prikazani deskriptivnom statistikom.

- Što se tiče primjene NETCONF standarda od strane proizvođača, korisnici imaju neutralan stav (prosječna vrijednost odgovora 0,33; std.dev. 0,86). Ispitanici su iskazivali slaganje $\mathrm{s}$ ponuđenom tvrdnjom vrijednostima od -2 do 2 , gdje je -2 označavalo izrazito neslaganje, a 2 izrazito slaganje s tvrdnjom.

- Prema mišljenju ispitanika proizvođač Cisco Systems u najvećem postotku $(46,2 \%)$ implementira NETCONF standard na svojim R/S uređajima (prosječna vrijednost odgovora 2,31; std.dev.1,78), dok u najmanjem postotku (24,4\%) proizvođač Extreme Networks implementira NETCONF standard na svojim R/S uređajima (prosječna vrijednost 1,22; std.dev.1,59).

- Ispitanici smatraju da proizvođači podržavaju primjenu NETCONF standarda na sljedeći način (ponuđene vrijednosti su od 1 do 5 , gdje je 5 potpuno slaganje $\mathrm{s}$ tvrdnjom):

○ detaljna dokumentacija (prosječna vrijednost 2,58; std.dev. 0,87)

○ tečajevi za samostalno učenje (prosječna vrijednost 2,57; std.dev. 0,81)

○ tečajevi koje vodi instruktori (prosječna vrijednost 2,52; std.dev. 1,06)

○ certifikacijski ispiti (prosječna vrijednost 2,39; std.dev. 0,84)

○ prezentacije i radionice (prosječna vrijednost 2,38; std.dev. 1,13).

Ukupna razina slaganja ispitanika je bilježila prosječnu vrijednost 2,55 s prosječnim odstupanjem od aritmetičke sredine 0,90 . 
- Što se tiče raspoložive dokumentacije i edukacije (ponuđene vrijednosti su od 1 do 5 , gdje je 1 nedovoljno, a 5 izvrsno) ispitanici smatraju da najveću razinu dokumentacije i edukacije o NETCONF protokolu ima proizvođač Cisco Systems (prosječna vrijednost odgovora 3,05; std.dev.1,22), dok najnižu proizvođač Nokia (AlcatelLucent) (prosječna vrijednost odgovora 1,89; std.dev.0,83). Ukupna razina dokumentacije i edukacije o NETCONF standardu za sve proizvođače je bilježila prosječnu vrijednost 2,84 s prosječnim odstupanjem od aritmetičke sredine 1,21.

- 27. pitanje anketnog upitnika glasi: "Na koji način mislite da bi se mogla povećati primjena NETCONF standarda od strane proizvođača?". Ispitanici su iskazivali mišljenje vrijednostima razreda od 1 do 5 , gdje je 1 označavalo nevažan razlog, a 5 izuzetno važan razlog. Prema ispitanicima povećanje NETCONF standarda može se postići na sljedeći način:

- povećanje edukacije i informiranje o automatizaciji i programiranju računalnih mreža (Automation tools and DevOps) (prosječna vrijednost odgovora 3,86; std.dev. 0,90);

- povećanje edukacije i informiranje o softverski definiranim mrežama (prosječna vrijednost odgovora 3,81; std.dev. 0,90);

- povećanje informiranja o praktičnoj primjeni NETCONF standarda ) (prosječna vrijednost odgovora 3,80; std.dev. 0,92);

- povećanje informiranja o primjeni NETCONF standarda za povećanje raspoloživosti mrežnih sustava i R/S uređaja (prosječna vrijednost odgovora 3,78; std.dev. 0,86);

- implementiranje NETCONF standarda na svim vrstama R/S uređaja ) (prosječna vrijednost odgovora 3,75; std.dev. 0,91);

- povećanje informiranja o teoretskom radu i prednostima NETCONF ) (prosječna vrijednost odgovora 3,70; std.dev. 0,97);

○ povećati edukaciju o programiranju i programskim jezicima ) (prosječna vrijednost odgovora 3,69; std.dev. 1,03). 


\section{Primjena NETCONF standarda od strane korisnika u Hrvatskoj:}

- Visoki postotak odgovora „Ne znam“ u pitanjima što se tiču NETCONF standarda pokazuje nepoznavanje NETCONF standarda i njegove primjene od strane ispitanika (korisnika). Ostali su odgovori prikazani deskriptivnom statistikom.

- Od 73 ispitanika, NETCONF koristi samo 8 kompanija ispitanika $(10,96 \%)$, a ne koristi 65 kompanija (89,04\%). Podaci o osam kompanija koje koriste NETCONF su sljedeći:

- NETCONF se najviše koristi (ponuđene vrijednosti su od 0 do 5 , gdje 5 označava $100 \%$ ) na R/S mrežnim uređajima u:

- mrežama davatelja usluga (prosječna vrijednost odgovora 3,63 (72,6\%); std.dev. 1,77),

- LAN mrežama većih poduzeća (prosječna vrijednost odgovora 3,29 $(65,8 \%)$; std.dev. 1,98),

- mrežama podatkovnih centara (prosječna vrijednost odgovora 3,14 $(62,8 \%)$; std.dev. 1,95),

- WAN mrežama većih poduzeća (prosječna vrijednost odgovora 3,00 (60\%); std.dev. 1,83).

dok se najrjeđe koriste u mrežama Internet stvari (prosječna vrijednost odgovora 1,33 (26,6\%); std.dev.1,97).

- $U$ tih osam kompanija, najveći broj $\mathrm{R} / \mathrm{S}$ mrežnih uređaja $\mathrm{s}$ NETCONF standardom dolazi od proizvođača Juniper Networks (prosječna vrijednost odgovora 3,83; std.dev.1,47), dok R/S uređaji u najmanjem broju slučajeva dolaze od proizvođača Huawei (prosječna vrijednost odgovora 1,67; std.dev.1,53).

- Najvažniji razlozi (ponuđene vrijednosti od 1 do 5 , gdje 5 označava izuzetno važno) za implementaciju NETCONF standarda na R/S uređajima korisnika su:

- „Backup \& restore“ mogućnost (prosječna vrijednost 4,14; std.dev. $0,69)$,

- mogućnost istovremenog i koordiniranog konfiguriranja svih ili više uređaja u mreži (prosječna vrijednost 3,88; std.dev. 1,13) , 
- programabilnost (automatiziranje) NETCONF-a (prosječna vrijednost 3,86; std.dev. 1,21),

- mogućnost provjere konfiguracije prije primjene (prosječna vrijednost 3,75; std.dev. 0,89),

- ista struktura komandi i podataka (prosječna vrijednost 3,63; std.dev. $1,41)$,

- mogućnost parcijalnog konfiguriranja uređaja (prosječna vrijednost 3,63; std.dev. 1,41),

- mogućnost zaključavanja konfiguracijske datoteke (prosječna vrijednost 3,63; std.dev. 0,74),

a najmanje važan razlog implementacije prema ispitanicima je:

- jasna razlika u strukturi između konfiguracijskih i operacijskih podataka NETCONF-a (prosječna vrijednost 3,25; std.dev. 1,75).

- Glavni razlozi za neimplementaciju NETCONF standarda na R/S uređajima kod korisnika su (ponuđene vrijednosti od 1 do 5 , gdje 5 označava izuzetno važno):

- navika korisnika na OS i CLI proizvođača (prosječna vrijednost odgovora 3,13; std.dev. 1,33),

○ nedostupnost na starijim uređajima i operacijskim sustavima (prosječna vrijednost odgovora 3,11; std.dev. 1,45),

○ nepoznavanje programskih jezika (prosječna vrijednost odgovora 2,82; std.dev. $1,21)$,

○ CLI proizvođača je jednostavniji od NETCONF standarda (prosječna vrijednost odgovora 2,72; std.dev1,23),

- proizvođači ne podržavaju sve funkcije (Capability) NETCONF-a pa se ne mogu iskoristiti većina prednosti standarda (prosječna vrijednost odgovora 2,68; std.dev. 1,32),

○ potrebni su dodatni alati (prosječna vrijednost odgovora 2,57; std.dev. 1,36). (na primjer NETCONF browser ili aplikacija u Pythonu) ,

- NETCONF koristi XML sintaksu koja je redundantna i opširna (prosječna vrijednost odgovora 2,45; std.dev. 1,13), 
○ strah od novih tehnologija (prosječna vrijednost odgovora 2,23; std.dev. 1,25).

dok se ne slažu da je razlog neimplementacije tvrdnja:

○ RESTCONF je bolje standardno rješenje od NETCONF-a (prosječna vrijednost odgovora 1,77 ; std.dev. 0,93 ),

\section{Poznavanje NETCONF standarda od strane korisnika u Hrvatskoj:}

- U dvadesetom pitanju su ispitanici iskazivali mišljenje o svom znanju o NETCONF standardu. Ispitanici su davali ocjene svoga znanja od 1 (nedovoljno) do 5 (izvrsno). Ispitanici smatraju da imaju izrazito nisku razinu znanja o NETCONF standardu što je vidljivo po prosječnim ocjenama za pojedine tvrdnje koje se odnose na znanje korisnika:

- savladana teoretska znanja o radu NETCONF protokola i razumijevanje njegovih prednosti (prosječna ocjena 1,90; std.dev. 1,00),

○ poznavanje prednosti NETCONF protokola u povećanju raspoloživosti mrežnih uređaja (prosječna ocjena 1,81; std.dev. 1,10) i

- savladana praktična znanja NETCONF protokola i njegova uporaba (prosječna ocjena 1,37; std.dev. 0,87).

Kreirana je ukupna dimenzija razine znanja kao prosjek odgovora svih tvrdnji i iznosi vrlo niskih 1,69 s prosječnim odstupanjem od aritmetičke sredine 0,92 .

- Ispitanici smatraju da su njihova znanja o NETCONF standardu po pojedinim mogućnostima vrlo niska (ponuđene ocjene od 1 do 5 , gdje 5 označava izvrsno). Ispitanici su najviše upoznati da NETCONF nudi mogućnost istovremenog i koordiniranog konfiguriranja svih ili više uređaja u mreži (prosječna vrijednost odgovora 1,81; std.dev.1,11), dok su najmanje upoznati da NETCONF standard koristi jasnu razliku u strukturi između konfiguracijskih i operacijskih podataka (prosječna vrijednost odgovora 1,68; std.dev. 0,97). Kreirana je ukupna dimenzija razine znanja iz koje je vidljivo da je prosječna razina znanja ispitanika 1,74 boda s prosječnim odstupanjem od aritmetičke sredine 0,95 . 


\section{NETCONF i povećanje raspoloživosti R/S uređaja:}

- Visoki postotak odgovora „Ne znam“ u pitanjima što se tiču NETCONF standarda pokazuje nepoznavanje NETCONF standarda i njegove primjene od strane ispitanika (korisnika). Ostali odgovori su prikazani deskriptivnom statistikom.

- U 25. pitanju su ispitanici iskazivali svoje mišljenje o NETCONF standardu i povećanju raspoloživosti $\mathrm{R} / \mathrm{S}$ uređaja. Ispitanici su iskazivali slaganje s ponuđenim tvrdnjama vrijednostima od -2 do 2 , gdje je -2 označavalo izrazito neslaganje, a 2 izrazito slaganje s tvrdnjom. Ispitanici se slažu s tvrdnjama:

- Korištenje NETCONF standarda povećava raspoloživost mrežnog $R / S$ uređaja u odnosu na nestandardne CLI metode konfiguriranja mrežnih uređaja (prosječna vrijednost odgovora 0,49; std.dev.0,92) i

- NETCONF standard bi se trebao više koristiti od strane proizvođača $i$ korisnika na $R / S$ uređajima zbog postizanja povećanja raspoloživosti uređaja $i$ sustava (prosječna vrijednost odgovora 0,48; std.dev.0,90).

- Što se tiče povećanja raspoloživosti primjenom svojstava NETCONF standarda (ponuđene vrijednosti od -2 do 2, gdje je -2 označavalo izrazito neslaganje, a 2 izrazito slaganje), ispitanici smatraju da u najvećoj mjeri mogućnost istovremenog i koordiniranog konfiguriranja svih ili više uređaja u mreži pomoću NETCONF standarda omogućava povećanje raspoloživosti mrežnih uređaja (prosječna vrijednost odgovora 1,09; std.dev. 0,72), dok u najmanjoj mjeri raspoloživost povećava mogućnost parcijalnog konfiguriranja uređaja pomoću NETCONF standarda (prosječna vrijednost odgovora 0,75 ; std.dev. 0,61). Ukupna razina slaganja ispitanika je bilježila prosječnu vrijednost 0,91 s prosječnim odstupanjem od aritmetičke sredine 0,50 .

\section{Karakteristike i povećanje primjene NETCONF standarda:}

- Visoki postotak odgovora „Ne znam“ u pitanjima što se tiču NETCONF standarda pokazuje nepoznavanje NETCONF standarda i njegove primjene od strane ispitanika (korisnika). Ostali odgovori su prikazani deskriptivnom statistikom.

- Prema mišljenju ispitanika (ponuđene vrijednosti od -2 do 2, gdje je -2 označavalo izrazito neslaganje, a 2 izrazito slaganje) nedostatak NETCONF standarda je: 
○ za korištenje NETCONF protokola je potrebno poznavanje programskih jezika (prosječna vrijednost odgovora 0,54 ; std.dev.0,94),

dok su neutralni oko tvrdnje:

- NETCONF standard koristi XML jezik i njegovu sintaksu koja je redundantna $i$ opširna što može zamarati $i$ zbunjivati (prosječna vrijednost odgovora 0,22 ; std.dev.0,96).

- U 24. pitanju su ispitanici iskazivali svoje mišljenje o različitim tvrdnjama vezanim uz NETCONF standard i povećanje raspoloživosti R/S uređaja (ponuđena skala od -2 do 2, gdje je -2 označavalo izrazito neslaganje, a 2 izrazito slaganje s tvrdnjom). Ispitanici se slažu sa sljedećim tvrdnjama:

- NETCONF pomaže korisnicima u radu kada su u mreži prisutni $R / S$ uređaji različitih proizvođača (prosječna vrijednost odgovora 1,00; std.dev.0,59).

- NETCONF standard bi se trebao više koristiti od strane korisnika na R/S uređajima (prosječna vrijednost odgovora 0,79 ; std.dev. 0,75).

- Dostupnost NETCONF standarda na uređajima proizvođača je važna za njihovu konkurentnost na tržištu (prosječna vrijednost odgovora 0,61; std.dev. 0,92).

- Rad s nestandardnim CLI sučeljem i njegovim konfiguracijskim datotekama je više „human readable“ nego kada se koristi NETCONF standard (prosječna vrijednost odgovora 0,43; std.dev.0,87).

- RESTCONF standard (definiran u RFC 8040 u siječnju 2017.) je bolje rješenje za konfiguraciju mrežnih uređaja od NETCONF standarda (prosječna vrijednost odgovora 0,35 ; std.dev. 0,75 ).

Ispitanici su dali i svoje mišljenje o budućem razvoju i primjeni NETCONF standarda. 


\section{Usporedba i dodatna analiza dobivenih rezultata istraživanja}

U ovom će se poglavlju napraviti usporedba dobivenih rezultata različitim metodama istraživanja i od različitih ispitanika (zaposlenici proizvođača, zaposlenici partnera i korisnici u Hrvatskoj).

Zbog preglednosti prikaza rezultata koristi se SWOT (Strengths, Weaknesses, Opportunities, Threats) analiza NETCONF standarda.

U tablicama su paralelno prikazani rezultati dobivenih odgovora na ista pitanja, ali od različitih vrsta ispitanika (proizvođača, partnera i korisnika). Iako je broj ispitanika od strane proizvođača (5) i partnera (7) puno manji od korisnika (73), odgovori proizvođača i partnera imaju veći značaj i ,težinu“ zbog većeg iskustva, znanja i informacija koje oni imaju zbog rada s većim brojem korisnika. Ipak, mišljenje korisnika je izuzetno važno, jer zbog njih se i razvija određena tehnologija i oni na kraju odlučuju da li je nešto vrijedno ili nije.

\section{PREDNOSTI:}

- Svojstva NETCONF standarda pružaju dodatne mogućnosti i prednosti u odnosu na nestandardni CLI pristup konfiguriranja R/S mrežnih uređaja.

- Svojstva NETCONF standarda su objašnjena u poglavlju 5.1.1.Svojstva NETCONF standarda za povećanje raspoloživosti.

- Mišljenje ispitanika i razlozi implementacije NETCONF standarda su obrađeni i prikazani u:

- 6. pitanju intervjua za proizvođače (Tablica 6-11. prikazuje rezultate; skala od 1 do 5 , gdje je 1 nevažno, dok je 5 izuzetno važno);

- 7. pitanju intervjua za partnere (Tablica 6-22. prikazuje rezultate; skala od 1 do 5 , gdje je 1 nevažno, dok je 5 izuzetno važno);

- 21. pitanju upitnika za korisnike (Tablica 6-56. prikazuje rezultate; skala od 1 do 5 , gdje je 1 nevažno, dok je 5 izuzetno važno). 
Tablica 7-1. Razlozi implementacije NETCONF standarda na R/S uređajima (usporedni prikaz)

\begin{tabular}{|c|c|c|c|c|c|c|c|c|c|}
\hline & \multicolumn{3}{|c|}{ Proizvođači } & \multicolumn{3}{|c|}{ Partneri } & \multicolumn{3}{|c|}{ Korisnici } \\
\hline & $\mathrm{N}$ & Prosjek & Std.Dev. & $\mathrm{N}$ & Prosjek & Std. Dev. & $\mathrm{N}$ & Prosjek & Std. Dev. \\
\hline $\begin{array}{l}\text { „Backup \& restore“ } \\
\text { mogućnost koju nudi } \\
\text { NETCONF standard. }\end{array}$ & 5 & 4,80 & 0,45 & 7 & 4,14 & 1,46 & 7 & 4,14 & 0,69 \\
\hline $\begin{array}{l}\text { Mogućnost istovremenog i } \\
\text { koordiniranog } \\
\text { konfiguriranja svih ili više } \\
\text { uređaja u mreži. }\end{array}$ & 5 & 4,80 & 0,45 & 7 & 4,14 & 1,46 & 8 & 3,88 & 1,13 \\
\hline $\begin{array}{l}\text { Mogućnost parcijalnog } \\
\text { konfiguriranja uređaja } \\
\text { pomoću NETCONF } \\
\text { standarda. }\end{array}$ & 5 & 5,00 & 0,00 & 7 & 3,43 & 1,27 & 8 & 3,63 & 1,41 \\
\hline $\begin{array}{l}\text { Mogućnost provjere } \\
\text { konfiguracije prije } \\
\text { primjene kod NETCONF } \\
\text { načina konfiguriranja } \\
\text { uređaja. }\end{array}$ & 5 & 5,00 & 0,00 & 7 & 3,71 & 1,38 & 8 & 3,75 & 0,89 \\
\hline $\begin{array}{l}\text { Mogućnost zaključavanja } \\
\text { konfiguracijske datoteke } \\
\text { koje nudi NETCONF. }\end{array}$ & 5 & 4,60 & 0,89 & 7 & 3,71 & 1,50 & 8 & 3,63 & 0,74 \\
\hline $\begin{array}{l}\text { NETCONF kao standard } \\
\text { koji omogućava } \\
\text { programabilnost } \\
\text { (automatiziranje) koja } \\
\text { značajno smanjuje } \\
\text { učestalost ljudske pogreške. }\end{array}$ & 5 & 4,80 & 0,45 & 7 & 4,14 & 1,46 & 7 & 3,86 & 1,21 \\
\hline $\begin{array}{l}\text { NETCONF kao standardni } \\
\text { način konfiguracije preko } \\
\text { udaljenog pristupa na IP } \\
\text { adresu uređaja zato jer je za } \\
\text { sve proizvođače ista } \\
\text { struktura komandi i } \\
\text { podataka. }\end{array}$ & 5 & 4,80 & 0,45 & 7 & 3,57 & 1,40 & 8 & 3,63 & 1,41 \\
\hline $\begin{array}{l}\text { NETCONF standard koristi } \\
\text { jasnu razliku u strukturi } \\
\text { između konfiguracijskih i } \\
\text { operacijskih podataka. }\end{array}$ & 5 & 4,80 & 0,45 & 7 & 3,43 & 1,51 & 8 & 3,25 & 1,75 \\
\hline
\end{tabular}

○ Tablica 7-1. prikazuje usporedni pregled rezultata (broj ispitanika N, prosječnu vrijednost i standardnu devijaciju) dobivenih od sve tri vrste ispitanika. Iz tablice se može vidjeti sljedeće:

- sva predložena svojstva NETCONF standarda su visoko ocijenjena kao značajne prednosti i razlozi implementacije na R/S uređajima. 
- Zaposlenici proizvođača su dali izrazito veće ocjene svojstvima NETCONF standarda. To se može objasniti njihovim boljim poznavanjem NETCONF standarda, a time su i svjesniji njegovih prednosti i mogućnosti primjene.

- Svojstva NETCONF standarda povećavaju raspoloživost $\mathrm{R} / \mathrm{S}$ mrežnih uređaja.

- Svojstva NETCONF standarda su objašnjena u poglavlju 5.1.1.Svojstva NETCONF standarda za povećanje raspoloživosti.

- Mišljenja ispitanika o povećanju raspoloživosti pomoću svojstava NETCONF standarda su obrađena i prikazana u:

- 4. pitanju intervjua za proizvođače (Tablica 6-14. prikazuje rezultate; skala od 1 do 5 , gdje je 1 izrazito neslaganje, a 5 izrazito slaganje $s$ tvrdnjom);

- 3. pitanju intervjua za partnere (Tablica 6-27. prikazuje rezultate; skala od 1 do 5 , gdje je 1 izrazito neslaganje, a 5 izrazito slaganje $\mathrm{s}$ tvrdnjom);

- 26. pitanju upitnika za korisnike (Tablica 6-62. prikazuje rezultate; skala od -2 do 2, gdje -2 označava izrazito neslaganje, a 2 izrazito slaganje s tvrdnjom).

○ Tablica 7-2. prikazuje usporedni pregled rezultata (broj ispitanika N, prosječnu vrijednost i standardnu devijaciju) dobivenih od sve tri vrste ispitanika. Korištene su dvije različite skale: od 1 do 5 (proizvođači i partneri) i od -2 do 2 (korisnici), ali se rezultati mogu usporediti. Iz tablice se može vidjeti sljedeće:

- ispitanici su sva predložena svojstva NETCONF standarda izrazito visoko ocijenili i smatraju da značajno povećavaju raspoloživost $\mathrm{R} / \mathrm{S}$ uređaja.

- Zaposlenici proizvođača i partnera su dali izrazito veće ocjene svojstvima NETCONF standarda u odnosu na korisnike. Velik broj korisnika je odgovorio s Ne znam i Niti se slažem niti se ne slažem što pokazuje njihovo nedovoljno poznavanje NETCONF standarda i njegovih prednosti. 
Tablica 7-2. NETCONF standard i povećanje raspoloživosti

(usporedni prikaz)

\begin{tabular}{|c|c|c|c|c|c|c|c|c|c|}
\hline & \multicolumn{3}{|c|}{$\begin{array}{c}\text { Proizvođači } \\
\text { (skala od } 1 \text { do } 5)\end{array}$} & \multicolumn{3}{|c|}{$\begin{array}{c}\text { Partneri } \\
\text { (skala od } 1 \text { do 5) }\end{array}$} & \multicolumn{3}{|c|}{$\begin{array}{c}\text { Korisnici } \\
\text { (skala od }-2 \text { do 2) }\end{array}$} \\
\hline & $\mathrm{N}$ & Prosjek & Std.Dev. & $\mathrm{N}$ & Prosjek & Std. Dev. & $\mathrm{N}$ & Prosjek & Std. Dev. \\
\hline $\begin{array}{l}\text { „Backup \& restore“ mogućnost koju } \\
\text { nudi NETCONF standard povećava } \\
\text { raspoloživost mrežnih uređaja. }\end{array}$ & 5 & 4,80 & 0,45 & 7 & 4,86 & 0,38 & 46 & 0,83 & 0,77 \\
\hline $\begin{array}{l}\text { Mogućnost istovremenog i } \\
\text { koordiniranog konfiguriranja svih ili } \\
\text { više uređaja u mreži koje nudi } \\
\text { NETCONF povećava raspoloživost } \\
\text { mrežnih uređaja. }\end{array}$ & 5 & 4,80 & 0,45 & 7 & 4,71 & 0,49 & 47 & 1,09 & 0,72 \\
\hline $\begin{array}{l}\text { Mogućnost parcijalnog } \\
\text { konfiguriranja uređaja pomoću } \\
\text { NETCONF standarda povećava } \\
\text { raspoloživost mrežnih uređaja. }\end{array}$ & 5 & 5,00 & 0,00 & 7 & 4,86 & 0,38 & 44 & 0,75 & 0,61 \\
\hline $\begin{array}{l}\text { Mogućnost provjere konfiguracije } \\
\text { prije primjene kod NETCONF načina } \\
\text { konfiguriranja uređaja povećava } \\
\text { raspoloživost mrežnih uređaja. }\end{array}$ & 5 & 4,80 & 0,45 & 7 & 4,86 & 0,38 & 44 & 1,00 & 0,72 \\
\hline $\begin{array}{l}\text { Mogućnost zaključavanja } \\
\text { konfiguracijske datoteke koje nudi } \\
\text { NETCONF povećava raspoloživost } \\
\text { mrežnih uređaja. }\end{array}$ & 5 & 4,60 & 0,55 & 7 & 4,71 & 0,49 & 45 & 0,78 & 0,77 \\
\hline $\begin{array}{l}\text { NETCONF kao standard povećava } \\
\text { raspoloživost jer omogućava } \\
\text { programabilnost (automatiziranje) } \\
\text { konfiguriranja mrežnih uređaja koja } \\
\text { značajno smanjuje učestalost ljudske } \\
\text { pogreške. }\end{array}$ & 5 & 4,80 & 0,45 & 7 & 5,00 & 0,00 & 47 & 0,94 & 0,73 \\
\hline $\begin{array}{l}\text { NETCONF kao standardni način } \\
\text { konfiguracije preko udaljenog } \\
\text { pristupa na IP adresu uređaja } \\
\text { povećava raspoloživost mrežnih } \\
\text { uređaja zato jer je za sve proizvođače } \\
\text { ista struktura komandi i podataka }\end{array}$ & 5 & 4,60 & 0,55 & 7 & 4,57 & 0,53 & 46 & 0,89 & 0,64 \\
\hline $\begin{array}{l}\text { NETCONF standard povećava } \\
\text { raspoloživost mrežnih uređaja zbog } \\
\text { toga što koristi jasnu razliku u } \\
\text { strukturi između konfiguracijskih i } \\
\text { operacijskih podataka }\end{array}$ & 5 & 4,60 & 0,55 & 7 & 4,00 & 0,82 & 43 & 0,81 & 0,73 \\
\hline Ukupno & 5 & 4,75 & 0,34 & 7 & 4,70 & 0,30 & 47 & 0,91 & 0,50 \\
\hline
\end{tabular}

\section{- Dodatne prednosti NETCONF standarda.}

- Mišljenja ispitanika o dodatnim prednostima i karakteristikama NETCONF standarda su obrađena i prikazana u: 
- 10. pitanju intervjua za proizvođače (Tablica 6-16. prikazuje rezultate; skala od 1 do 5 , gdje je 1 izrazito neslaganje, a 5 izrazito slaganje $\mathrm{s}$ tvrdnjom);

- 13. pitanju intervjua za partnere (Tablica 6-31. prikazuje rezultate; skala od 1 do 5 , gdje je 1 izrazito neslaganje, a 5 izrazito slaganje $\mathrm{s}$ tvrdnjom);

- 24. i 25. pitanju upitnika za korisnike (Tablica 6-68. i Tablica 6-61. prikazuju rezultate; skala od -2 do 2 , gdje je -2 označavalo izrazito neslaganje, a 2 izrazito slaganje s tvrdnjom).

Tablica 7-3. NETCONF standard i povećanje raspoloživosti R/S uređaja (usporedni prikaz)

\begin{tabular}{|c|c|c|c|c|c|c|c|c|c|}
\hline & \multicolumn{3}{|c|}{$\begin{array}{c}\text { Proizvođači } \\
\text { (skala od } 1 \text { do 5) }\end{array}$} & \multicolumn{3}{|c|}{$\begin{array}{c}\text { Partneri } \\
\text { (skala od } 1 \text { do 5) }\end{array}$} & \multicolumn{3}{|c|}{$\begin{array}{c}\text { Korisnici } \\
\text { (skala od -2 do 2) }\end{array}$} \\
\hline & $\mathrm{N}$ & Prosjek & Std.Dev. & $\mathrm{N}$ & Prosjek & Std.Dev. & $\mathrm{N}$ & Prosjek & Std.Dev. \\
\hline $\begin{array}{l}\text { Dostupnost NETCONF } \\
\text { standarda na uređajima } \\
\text { proizvođača je važna za } \\
\text { njihovu konkurentnost na } \\
\text { tržištu. }\end{array}$ & 5 & 4,80 & 0,45 & 7 & 4,43 & 0,79 & 51 & 0,61 & 0,92 \\
\hline $\begin{array}{l}\text { NETCONF standard bi se } \\
\text { trebao više koristiti od strane } \\
\text { korisnika na R/S uređajima. }\end{array}$ & 5 & 4,80 & 0,45 & 7 & 4,29 & 0,95 & 52 & 0,79 & 0,75 \\
\hline $\begin{array}{l}\text { Korištenjem NETCONF } \\
\text { standarda povećava se } \\
\text { raspoloživost mrežnih uređaja i } \\
\text { sustava. }\end{array}$ & 5 & 4,80 & 0,45 & 7 & 4,71 & 0,49 & 45 & 0,49 & 0,92 \\
\hline $\begin{array}{l}\text { NETCONF standard bi se } \\
\text { trebao više koristiti od strane } \\
\text { korisnika na R/S uređajima da } \\
\text { bi povećali raspoloživost } \\
\text { uređaja i sustava. }\end{array}$ & 5 & 4,80 & 0,45 & 7 & 4,57 & 0,53 & 48 & 0,48 & 0,90 \\
\hline $\begin{array}{l}\text { NETCONF pomaže } \\
\text { korisnicima u radu kada su u } \\
\text { mreži prisutni R/S uređaji } \\
\text { različitih proizvođača }\end{array}$ & - & - & - & 7 & 4,43 & 0,53 & 47 & 1,00 & 0,59 \\
\hline
\end{tabular}

○ Tablica 7-3. prikazuje usporedni pregled rezultata (broj ispitanika N, prosječnu vrijednost i standardnu devijaciju) dobivenih od sve tri vrste ispitanika. Korištene su dvije različite skale: od 1 do 5 (proizvođači i partneri) i od -2 do 2 (korisnici), ali se rezultati mogu usporediti. Iz tablice se može vidjeti sljedeće: 
- ispitanici su predložene tvrdnje o NETCONF standardu izrazito visoko ocijenili i smatraju da su značajne prednosti NETCONF standarda.

- Zaposlenici proizvođača i partnera su dali izrazito veće ocjene predloženim tvrdnjama u odnosu na korisnike. Veliki broj korisnika je odgovorio s Ne znam i Niti se slažem niti se ne slažem što pokazuje njihovo nedovoljno poznavanje NETCONF standarda i njegovih prednosti.

\section{- Postoji dovoljna i raspoloživa dokumentacija i edukacija o NETCONF} standardu.

- Mišljenja ispitanika o raspoloživoj dokumentaciji i edukaciji o NETCONF standardu su obrađena i prikazana u:

- 9. pitanju intervjua za proizvođače (Tablica 6-13. prikazuje rezultate; skala od 1 do 5 , gdje 1 označava neslaganje s tvrdnjom, a 5 potpuno slaganje s tvrdnjom);

- 10. pitanju intervjua za partnere (Tablica 6-19. prikazuje rezultate; skala od 1 do 5 , gdje 1 označava neslaganje s tvrdnjom, a 5 potpuno slaganje s tvrdnjom);

- 16. pitanju upitnika za korisnike (Tablica 6-49. prikazuje rezultate; skala od 1 do 5 , gdje 1 označava neslaganje s tvrdnjom, a 5 potpuno slaganje s tvrdnjom).

○ Tablica 7-4. prikazuje usporedni pregled rezultata (broj ispitanika N, prosječnu vrijednost i standardnu devijaciju) dobivenih od sve tri vrste ispitanika. Iz tablice se može vidjeti sljedeće:

- proizvođači smatraju da postoji detaljna dokumentacija i edukacija, a partneri i korisnici se s tim slažu (ali u značajno manjem omjeru).

- Istraživač smatra da je dokumentacija i edukacija dovoljno detaljna i dostupna, a da je uzrok nedovoljnog znanja korisnika njihova neinformiranost o prednostima NETCONF standarda. 
○ Dostupnost dokumentacije i edukacije su važan preduvjet za brzo širenje znanja o NETCONF standardu i bliskim tehnologijama.

Tablica 7-4. Raspoloživa dokumentacija i edukacija o NETCONF standardu (usporedni prikaz)

\begin{tabular}{|c|c|c|c|c|c|c|c|c|c|}
\hline & \multicolumn{3}{|c|}{ Proizvođači } & \multicolumn{3}{|c|}{ Partneri } & \multicolumn{3}{|c|}{ Korisnici } \\
\hline & $\mathrm{N}$ & Prosjek & Std.Dev. & $\mathrm{N}$ & Prosjek & Std.Dev. & $\mathrm{N}$ & Prosjek & Std.Dev. \\
\hline $\begin{array}{l}\text { Postoji detaljna dokumentacija } \\
\text { koja objašnjava rad i primjenu } \\
\text { NETCONF standarda na } \\
\text { mrežnim uređajima Vašeg } \\
\text { proizvođača: upute (manuals), } \\
\text { preporuke za uporabu (white } \\
\text { papers), i slično. }\end{array}$ & 5 & 4,80 & 0,45 & 7 & 2,29 & 1,38 & 36 & 2,58 & 0,87 \\
\hline $\begin{array}{l}\text { Postoje tečajevi za samostalno } \\
\text { učenje (CBT, Webinar, i slično) } \\
\text { koji u potpunosti podučavaju } \\
\text { korisnike uporabi i primjeni } \\
\text { NETCONF standarda na } \\
\text { mrežnim uređajima Vašeg } \\
\text { proizvođača. }\end{array}$ & 5 & 4,60 & 0,89 & 7 & 2,71 & 1,38 & 35 & 2,57 & 0,81 \\
\hline $\begin{array}{l}\text { Postoje organizirani tečajevi } \\
\text { vođeni od instruktora koji } \\
\text { detaljno podučavaju korisnike } \\
\text { uporabi i primjeni NETCONF } \\
\text { standarda na mrežnim uređajima } \\
\text { Vašeg proizvođača. }\end{array}$ & 5 & 4,40 & 1,34 & 7 & 2,57 & 1,62 & 33 & 2,52 & 1,06 \\
\hline $\begin{array}{l}\text { Postoje certifikacijski ispiti (i } \\
\text { pripadajući tečajevi) koji detaljno } \\
\text { osposobljavaju korisnike uporabi } \\
\text { i primjeni NETCONF standarda } \\
\text { na mrežnim uređajima Vašeg } \\
\text { proizvođača. }\end{array}$ & 5 & 4,20 & 1,79 & 7 & 1,57 & 0,53 & 31 & 2,39 & 0,84 \\
\hline Ukupno & 5 & 4,50 & 1,12 & 7 & 2,29 & 1,05 & 32 & 2,38 & 1,13 \\
\hline
\end{tabular}

- NETCONF standard je izrazito robustan i kvalitetno osmišljen i izrađen protokol (kao što je prikazano i objašnjeno u poglavlju 4.2. Osnovna svojstva $i$ prednosti NETCONF standarda).

- NETCONF standard daje mogućnost jednostavnog proširenja protokola, na primjer podatkovnih modela i funkcija (prikazano i objašnjeno u poglavlju 4.2. Osnovna svojstva i prednosti NETCONF standarda).

- NETCONF prikaz podataka je čitljiv, za razliku od SNMP standarda (prikazano i objašnjeno u poglavlju 5.1. Usporedba metoda konfiguriranja mrežnih uređaja). Slika 
5-1. prikazuje usporedbu konfiguriranja uređaja pomoću NETCONF i SNMP standarda.

- NETCONF je transaction-based protokol, što mu je daje veliku prednost u odnosu na CLI. NETCONF je stateful protokol i dovodi sistem u definirano (željeno) stanje ili ga vraća u prethodno stanje. Zbog toga se ne može dogoditi polovična konfiguracija R/S uređaja. Ovo svojstvo omogućava i istovremenu konfiguraciju više mrežnih uređaja pomoću transakcija (prikazano i objašnjeno u poglavlju 5.1. Usporedba metoda konfiguriranja mrežnih uređaja). Detaljan primjer takve konfiguracije je prikazan i u samom NETCONF standardu RFC $6241^{171}$.

\section{NEDOSTATCI:}

- Razlozi neimplementacije NETCONF standarda se mogu smatrati njegovim nedostacima.

- Mišljenje ispitanika i razlozi neimplementacije NETCONF standarda su obrađeni i prikazani u:

- 7. pitanju intervjua za proizvođače (Tablica 6-12. prikazuje rezultate; skala od 1 do 5 , gdje 1 označava nevažno, dok 5 označava izuzetno važno);

- 8. pitanju intervjua za partnere (Tablica 6-23. prikazuje rezultate; skala od 1 do 5 , gdje 1 označava nevažno, dok 5 označava izuzetno važno);

- 22. pitanju upitnika za korisnike (Tablica 6-58. prikazuje rezultate; skala od 1 do 5 , gdje 1 označava nevažno, dok 5 označava izuzetno važno).

${ }^{171}$ IETF RFC 6241 Network Configuration Protocol (NETCONF) (2011) https://tools.ietf.org/html/rfc6241 (21.1.2019), 106-111. 
Tablica 7-5. Razlozi neimplementacije NETCONF standarda na R/S uređajima (usporedni prikaz)

\begin{tabular}{|c|c|c|c|c|c|c|c|c|c|}
\hline & \multicolumn{3}{|c|}{ Proizvođači } & \multicolumn{3}{|c|}{ Partneri } & \multicolumn{3}{|c|}{ Korisnici } \\
\hline & $\mathrm{N}$ & Prosjek & Std.Dev. & $\mathrm{N}$ & Prosjek & Std. Dev. & $\mathrm{N}$ & Prosjek & Std. Dev. \\
\hline $\begin{array}{l}\text { 1. CLI proizvođača je } \\
\text { jednostavniji od } \\
\text { NETCONF standarda }\end{array}$ & 5 & 1,80 & 1,30 & 7 & 2,57 & 1,27 & 47 & 2,72 & 1,23 \\
\hline $\begin{array}{l}\text { 2. NETCONF nije potreban } \\
\text { jer su krajnji korisnici } \\
\text { navikli na OS i CLI } \\
\text { proizvođača }\end{array}$ & 5 & 2,80 & 1,64 & 7 & 4,00 & 1,00 & 54 & 3,13 & 1,33 \\
\hline $\begin{array}{l}\text { 3. NETCONF koristi XML } \\
\text { sintaksu koja je } \\
\text { redundantna i opširna što } \\
\text { može zamarati i zbunjivati } \\
\text { korisnika. }\end{array}$ & 5 & 2,20 & 1,30 & 7 & 2,29 & 1,60 & 38 & 2,45 & 1,13 \\
\hline $\begin{array}{l}\text { 4. NETCONF ne daje } \\
\text { dovoljno prednosti da bi se } \\
\text { implementirao }\end{array}$ & 5 & 1,60 & 1,34 & - & - & - & - & - & - \\
\hline $\begin{array}{l}\text { 5. NETCONF nije } \\
\text { prihvaćen od korisnika i } \\
\text { rijetko se koristi }\end{array}$ & 5 & 3,20 & 1,48 & - & - & - & - & - & - \\
\hline $\begin{array}{l}\text { 6. Koristimo RESTCONF } \\
\text { koji je bolje standardno } \\
\text { rješenje od NETCONF-a }\end{array}$ & 5 & 1,40 & 0,55 & 7 & 1,71 & 0,76 & 39 & 1,77 & 0,93 \\
\hline $\begin{array}{l}\text { 6. NETCONF nije } \\
\text { dostupan na starijim } \\
\text { uređajima i starijem OS } \\
\text { koji ga ne podržavaju }\end{array}$ & - & - & - & 7 & 4,29 & 0,76 & 46 & 3,11 & 1,45 \\
\hline $\begin{array}{l}\text { 7. Nepoznavanje } \\
\text { programskih jezika od } \\
\text { strane korisnika }\end{array}$ & - & - & - & 7 & 4,43 & 0,53 & 51 & 2,82 & 1,21 \\
\hline $\begin{array}{l}\text { 8. Proizvođači ne } \\
\text { podržavaju sve funkcije } \\
\text { (capability), na primjer } \\
\text { "Candidate“, „Startup“, } \\
\text { "Validate“, „Rollback-on- } \\
\text { Error“ i druge pa se ne } \\
\text { može iskoristiti većina } \\
\text { prednosti standarda. }\end{array}$ & - & - & - & 7 & 3,71 & 1,25 & 38 & 2,68 & 1,32 \\
\hline $\begin{array}{l}\text { 9. Potrebni dodatni alati (na } \\
\text { primjer NETCONF } \\
\text { browser ili aplikacija u } \\
\text { Pythonu) }\end{array}$ & - & - & - & 7 & 3,00 & 1,29 & 42 & 2,57 & 1,36 \\
\hline $\begin{array}{l}\text { 10. Strah od novih } \\
\text { tehnologija }\end{array}$ & - & - & - & 7 & 3,71 & 1,11 & 52 & 2,23 & 1,25 \\
\hline
\end{tabular}

○ Tablica 7-5. prikazuje usporedni pregled rezultata (broj ispitanika N, prosječnu vrijednost i standardnu devijaciju) dobivenih od sve tri vrste ispitanika. Iz tablice se može vidjeti sljedeće: 
○ Najvažniji uzroci neimplementacije (s najvećim ocjenama važnosti od strane ispitanika) su sljedeći:

- nepoznavanje programskih jezika od strane korisnika,

- NETCONF nije dostupan na starijim uređajima i starijem OS koji ga ne podržavaju,

- strah korisnika od novih tehnologija,

- NETCONF nije potreban jer su krajnji korisnici navikli na OS i CLI proizvođača.

○ Iz gore navedenih uzroka može se vidjeti da je većina nedostataka povezana s navikama mrežnih administratora i vremenu koje je potrebno da se prihvate promjene, tako da se ne moraju vidjeti kao pravi nedostaci NETCONF standarda.

- Istraživač smatra da je osnovni nedostatak NETCONF standarda:

- proizvođači ne podržavaju sve funkcije (capability).

○ Ostali predloženi uzroci neimplementacije su dobili niske ocjene važnosti.

- Predloženi nedostaci NETCONF standarda su ocijenjeni od strane ispitanika.

- Mišljenje ispitanika o predloženim nedostacima NETCONF standarda su obrađeni i prikazani u:

- 8. pitanju intervjua za proizvođače (Tablica 6-15. prikazuje rezultate; skala od 1 do 5 , gdje 1 označava neslaganje $\mathrm{s}$ tvrdnjom, a 5 potpuno slaganje s tvrdnjom);

- 9. pitanju intervjua za partnere (Tablica 6-30. prikazuje rezultate; skala od 1 do 5 , gdje 1 označava neslaganje s tvrdnjom, a 5 potpuno slaganje s tvrdnjom);

- 23. pitanju upitnika za korisnike (Tablica 6-66. prikazuje rezultate; skala od -2 do 2 , gdje -2 označava izrazito neslaganje, a 2 izrazito slaganje s tvrdnjom);

- Tablica 7-6. prikazuje usporedni pregled rezultata (broj ispitanika N, prosječnu vrijednost i standardnu devijaciju) dobivenih od sve tri vrste ispitanika. Korištene su dvije različite skale: od 1 do 5 (proizvođači i partneri) i od -2 do 2 (korisnici), ali se rezultati mogu usporediti. Iz tablice se može vidjeti sljedeće: 
○ svi predloženi nedostaci su dobili niske ili srednje ocjene važnosti od strane ispitanika.

○ Najvažniji nedostaci (s najvećim ocjenama važnosti od strane ispitanika) su sljedeći:

- NETCONF standard daje mogućnost proizvođačima da ne podržavaju sve funkcije (capability),

- NETCONF standard koristi XML jezik i njegovu sintaksu koja je redundantna i opširna što može zamarati i zbunjivati korisnika.

Tablica 7-6. Nedostaci NETCONF standarda (usporedni prikaz)

\begin{tabular}{|c|c|c|c|c|c|c|c|c|c|}
\hline & \multicolumn{3}{|c|}{$\begin{array}{c}\text { Proizvođači } \\
\text { (skala od } 1 \text { do 5) }\end{array}$} & \multicolumn{3}{|c|}{$\begin{array}{c}\text { Partneri } \\
\text { (skala od } 1 \text { do 5) }\end{array}$} & \multicolumn{3}{|c|}{$\begin{array}{c}\text { Korisnici } \\
\text { (skala od } \mathbf{- 2} \text { do 2) }\end{array}$} \\
\hline & $\mathrm{N}$ & Prosjek & Std.Dev. & $\mathrm{N}$ & Prosjek & Std.Dev. & $\mathrm{N}$ & Prosjek & Std.Dev \\
\hline $\begin{array}{l}\text { 1. NETCONF standard daje } \\
\text { mogućnost proizvođačima da ne } \\
\text { podržavaju sve funkcije } \\
\text { (capability), na primjer } \\
\text { "Candidate“, „Startup“, } \\
\text { "Validate“, „Rollback-on-Error“ i } \\
\text { druge pa se ne može iskoristiti } \\
\text { većina prednosti standarda. }\end{array}$ & 5 & 3,00 & 1,00 & 7 & 3,43 & 1,27 & - & - & - \\
\hline $\begin{array}{l}\text { 2. NETCONF standard daje } \\
\text { mogućnost da se koriste } \\
\text { nestandardni (proprietary) } \\
\text { modeli podataka (data models). }\end{array}$ & 5 & 2,40 & 1,14 & 7 & 3,14 & 1,07 & - & - & - \\
\hline $\begin{array}{l}\text { 3. NETCONF standard daje } \\
\text { mogućnost da se definiraju i } \\
\text { koriste nestandardne } \\
\text { (proprietary) funkcije } \\
\text { (capabilities). }\end{array}$ & 5 & 2,00 & 0,71 & 7 & 2,71 & 0,95 & - & - & - \\
\hline $\begin{array}{l}\text { 4. NETCONF standard koristi } \\
\text { XML jezik i njegovu sintaksu } \\
\text { koja je redundantna i opširna što } \\
\text { može zamarati i zbunjivati } \\
\text { korisnika. }\end{array}$ & 5 & 2,60 & 0,89 & 7 & 3,43 & 1,51 & 46 & 0,22 & 0,96 \\
\hline $\begin{array}{l}\text { 5. Za korištenje NETCONF } \\
\text { protokola potrebno je poznavanje } \\
\text { programskih jezika. }\end{array}$ & 5 & 2,00 & 0,71 & 7 & 3,71 & 0,95 & 48 & 0,54 & 0,94 \\
\hline
\end{tabular}

\section{- Dodatni nedostaci NETCONF standarda.}

- Mišljenja ispitanika o dodatnim nedostacima NETCONF standarda su obrađena i prikazana u: 
- 10. pitanju intervjua za proizvođače (Tablica 6-16. prikazuje rezultate; skala od 1 do 5 , gdje je 1 izrazito neslaganje, a 5 izrazito slaganje $s$ tvrdnjom);

- 13. pitanju intervjua za partnere (Tablica 6-31. prikazuje rezultate; skala od 1 do 5 , gdje je 1 izrazito neslaganje, a 5 izrazito slaganje $\mathrm{s}$ tvrdnjom);

- 24. i 25. pitanju upitnika za korisnike (Tablica 6-68. i Tablica 6-61. prikazuju rezultate; skala od -2 do 2 , gdje je -2 označavalo izrazito neslaganje, a 2 izrazito slaganje s tvrdnjom).

○ Tablica 7-7. prikazuje usporedni pregled rezultata (broj ispitanika N, prosječnu vrijednost i standardnu devijaciju) dobivenih od sve tri vrste ispitanika. Korištene su dvije različite skale: od 1 do 5 (proizvođači i partneri) i od -2 do 2 (korisnici), ali se rezultati mogu usporediti. Iz tablice se može vidjeti sljedeće:

- ispitanici se dosta slažu s tvrdnjom da je rad s nestandardnim CLI sučeljem više „human readable“, dok se umjereno slažu da je RESTCONF bolje rješenje od NETCONF standarda. Oba nedostatka NETCONF standarda su povezana s jednostavnošću uporabe, odnosno koliko ispitanici smatraju da je user-friendly.

Tablica 7-7. Dodatni nedostatci NETCONF standarda (usporedni prikaz)

\begin{tabular}{|c|c|c|c|c|c|c|c|c|c|}
\hline & \multicolumn{3}{|c|}{$\begin{array}{c}\text { Proizvođači } \\
\text { (skala od } 1 \text { do 5) }\end{array}$} & \multicolumn{3}{|c|}{$\begin{array}{c}\text { Partneri } \\
\text { (skala od } 1 \text { do 5) }\end{array}$} & \multicolumn{3}{|c|}{$\begin{array}{c}\text { Korisnici } \\
\text { (skala od }-2 \text { do } 2)\end{array}$} \\
\hline & $\mathrm{N}$ & Prosjek & Std.Dev. & $\mathrm{N}$ & Prosjek & Std.Dev. & $\mathrm{N}$ & Prosjek & Std.Dev. \\
\hline $\begin{array}{l}\text { RESTCONF standard } \\
\text { (definiran u RFC } 8040 \text { u } \\
\text { siječnju 2017.) je bolje rješenje } \\
\text { za konfiguraciju mrežnih } \\
\text { uređaja od NETCONF } \\
\text { standarda. }\end{array}$ & 5 & 3,00 & 0,71 & 7 & 3,00 & 0,00 & 37 & 0,35 & 0,75 \\
\hline $\begin{array}{l}\text { Rad s nestandardnim CLI } \\
\text { sučeljem i njegovim } \\
\text { konfiguracijskim datotekama je } \\
\text { više „human readable“ nego } \\
\text { kada se koristi NETCONF } \\
\text { standard. }\end{array}$ & - & - & - & 7 & 4,14 & 1,07 & 49 & 0,43 & 0,87 \\
\hline
\end{tabular}


- NETCONF ne omogućava direktni pristup preko lokalnog konzolnog pristupa, već je uvijek prvo potrebno konfigurirati uređaj (dodijeliti IP adresu i aktivirati NETCONF i SSH protokole na uređaju) da bi se NETCONF mogao koristiti. Ta početna konfiguracija uređaja izvršava se pomoću CLI komandi i OS sustava proizvođača opreme, a nakon toga se uređaj može dalje konfigurirati pomoću NETCONF standarda spajanjem preko udaljenog pristupa na IP adresu uređaja (objašnjeno u poglavlju 5.1. Usporedba metoda konfiguriranja mrežnih uređaja). Dakle, NETCONF potpuno ne zamjenjuje nestandardni CLI pristup. Ipak, NETCONF uporabu CLI pristupa može smanjiti na samo nekoliko komandi koje su potrebne za inicijalnu konfiguraciju ili se može primjenjivati ZTP (Zero Touch Provisioning) ili slični pristupi. S druge strane, trenutno korisnici često koriste NETCONF za automatiziranje konfiguriranja R/S uređaja, a ne kao standard koji zamjenjuje CLI nestandardni pristup.

- NETCONF standard daje mogućnost proizvođačima da ne podržavaju sve funkcije (capability), na primjer „Candidate“, „Startup“, „Validate“, „Rollback-onError“" $i$ druge pa se ne može iskoristiti većina prednosti NETCONF standarda. To su kao nedostatak prepoznali i ispitanici, iako neki smatraju da bi ova karakteristika NETCONF-a mogla biti i njegova prednost (jer pruža fleksibilnost implementacije). U poglavlju 5.3.Testiranje funkcija NETCONF standarda u laboratoriju prikazani su rezultati napravljenog laboratorijskog testa (testirano je 5 različitih R/S uređaja od tri najveća proizvođača) gdje se vidi da:

○ svi uređaji podržavaju samo:base 1.0 funkciju,

○ ni jedan uređaj ne podržava sve dostupne funkcije NETCONF protokola,

○ uređaji različitih proizvođača ne podržavaju iste funkcije pa čak i

- različiti uređaji istog proizvođača ne podržavaju iste funkcije.

To može biti vrlo frustrirajuće za korisnike, koji iako imaju R/S uređaje koji podržavaju NETCONF standard, ne mogu od njih dobiti sva svojstva koja povećavaju raspoloživost. 


\section{PRILIKE:}

- NETCONF standard je za sada implementiran samo na R/S uređajima nekih vrsta mreža. Zbog toga postoji veliki prostor za proširenje primjene.

- Mišljenja ispitanika o implementaciji NETCONF standarda na R/S uređajima određenih vrsta mreža su obrađena i prikazana u:

- 5. pitanju intervjua za proizvođače (Tablica 6-10. prikazuje rezultate; skala od 0 do 5 , gdje 0 označava $0 \%$, dok 5 označava $100 \%$ );

- 4. pitanju intervjua za partnere (Tablica 6-17. prikazuje rezultate; skala od 0 do 5 , gdje 0 označava $0 \%$, dok 5 označava $100 \%$ );

- 19. pitanju upitnika za korisnike (Tablica 6-52. prikazuje rezultate; skala od 0 do 5 , gdje 0 označava $0 \%$, dok 5 označava $100 \%$ ).

Tablica 7-8. Implementacija NETCONF standarda na R/S uređajima po vrstama mreža (usporedni prikaz)

\begin{tabular}{|c|c|c|c|c|c|c|c|c|c|}
\hline & \multicolumn{3}{|c|}{ Proizvođači } & \multicolumn{3}{|c|}{ Partneri } & \multicolumn{3}{|c|}{ Korisnici } \\
\hline & $\mathrm{N}$ & Prosjek & Std.Dev. & $\mathrm{N}$ & Prosjek & Std. Dev. & $\mathrm{N}$ & Prosjek & Std. Dev. \\
\hline $\begin{array}{l}\text { LAN mreže malih i srednjih } \\
\text { poduzeća (Small Medium } \\
\text { Business - SMB) }\end{array}$ & 4 & 3,50 & 2,38 & 7 & 0,14 & 0,38 & 6 & 2,50 & 2,26 \\
\hline $\begin{array}{l}\text { LAN mreže većih poduzeća } \\
\text { (Enterprise Networks) }\end{array}$ & 5 & 3,20 & 2,05 & 7 & 0,71 & 0,49 & 7 & 3,29 & 1,98 \\
\hline $\begin{array}{l}\text { Mreže davatelja usluga (Internet } \\
\text { Servise Provider-ISP) }\end{array}$ & 4 & 4,75 & 0,50 & 3 & 3,33 & 1,15 & 8 & 3,63 & 1,77 \\
\hline Mreže internet stvari (IoT) & 4 & 2,25 & 2,06 & 4 & 0,00 & 0,00 & 6 & 1,33 & 1,97 \\
\hline $\begin{array}{l}\text { Mreže podatkovnih centara (Data } \\
\text { Center - DC) }\end{array}$ & 5 & 4,60 & 0,89 & 6 & 1,50 & 1,05 & 7 & 3,14 & 1,95 \\
\hline $\begin{array}{l}\text { WAN mreže većih poduzeća } \\
\text { (Enterprise Networks) }\end{array}$ & 5 & 4,20 & 1,30 & 7 & 0,57 & 0,53 & 7 & 3,00 & 1,83 \\
\hline
\end{tabular}

○ Tablica 7-8. prikazuje usporedni pregled rezultata (broj ispitanika N, prosječnu vrijednost i standardnu devijaciju) dobivenih od sve tri vrste ispitanika. Iz tablice se može vidjeti sljedeće: 
- ocjene partnera su značajno niže u odnosu na korisnike. Razlog je što su u ovom pitanju sudjelovali samo korisnici koji implementiraju NETCONF, dok su partneri davali ocjene za sve svoje korisnike.

- Proizvođači su implementirali NETCONF standard na većini svojih uređaja za ISP, DC i WAN mreže. Postoji značajna mogućnost povećanja implementacije za ostale uređaje, a posebno za SMB uređaje (na primjer za ISP upravljane usluge) i IoT tehnologiju.

- Proizvođači su implementirali NETCONF standard na svojim R/S uređajima puno više nego ih korisnici koriste na svojim uređajima. Postoji značajna mogućnost širenja primjene NETCONF standarda kod korisnika.

- Korisnici za sada implementiraju NETCONF standard samo na nekim R/S uređajima proizvođača. Postoji veliki prostor za proširenje primjene.

- Mišljenja ispitanika o implementaciji NETCONF standarda na R/S uređajima određenih proizvođača su obrađena i prikazana u:

- 6. pitanju intervjua za partnere (Tablica 6-20. prikazuje rezultate; skala od 0 do 5 , gdje 0 označava $0 \%$, dok 5 označava 100\%);

- 15. pitanju upitnika za korisnike (Tablica 6-43. prikazuje rezultate; skala od 0 do 5 , gdje 0 označava $0 \%$, dok 5 označava $100 \%$ ).

Tablica 7-9. Primjena NETCONF standarda na R/S uređajima korisnika (usporedni prikaz)

\begin{tabular}{lcccccc}
\hline & \multicolumn{2}{c}{ Partneri } & \multicolumn{3}{c}{ Korisnici } \\
& N & Prosjek & Std.Dev. & N & Prosjek & Std.Dev. \\
\hline Arista & 3 & 0,33 & 0,58 & 21 & 1,48 & 1,83 \\
\hline Cisco Systems & 7 & 1,00 & 0,58 & 45 & 2,31 & 1,78 \\
\hline Extreme Networks & 2 & 0,00 & 0,00 & 23 & 1,22 & 1,59 \\
\hline F5 & 4 & 0,75 & 0,96 & 26 & 1,42 & 1,55 \\
\hline Hewlett Packard & 6 & 0,17 & 0,41 & 25 & 1,36 & 1,50 \\
\hline Enterprise & 5 & 1,00 & 1,73 & 23 & 1,74 & 1,74 \\
\hline Huawei & 4 & 0,75 & 0,96 & 28 & 2,07 & 1,80 \\
\hline Juniper Networks & - & - & - & 19 & 1,05 & 1,22 \\
\hline Nokia (Alcatel-Lucent) & & & & & & \\
\hline
\end{tabular}


○ Tablica 7-9. prikazuje usporedni pregled rezultata (broj ispitanika N, prosječnu vrijednost i standardnu devijaciju) dobivenih od dvije vrste ispitanika (partneri i korisnici). Iz tablice se može vidjeti sljedeće:

- korisnici vrlo malo implementiraju NETCONF standard na svojim uređajima različitih proizvođača. Postoji značajna mogućnost širenja primjene NETCONF standarda kod korisnika.

- Korisnici su izrazili svoje mišljenje o načinima povećanja primjene NETCONF standarda.

- Mišljenja ispitanika o implementaciji NETCONF standarda na R/S uređajima određenih proizvođača su obrađena i prikazana u:

- 27. pitanju upitnika za korisnike (Tablica 7-10. prikazuje rezultate; skala od 1 do 5 , gdje 1 označava nevažan razlog, a 5 izuzetno važan razlog).

○ Načini povećanja primjene su ukratko:

- povećanje promocije (edukacije i informiranja) NETCONF-a i povezanih tehnologija (automatizacija, SDN mreže, programiranje) i

- implementacija NETCONF standarda na svim vrstama R/S uređaja (posebno na SMB uređajima i ISP upravljanim uslugama).

Tablica 7-10. Načini povećanja primjene NETCONF standarda od strane proizvođača (upitnik korisnika)

\begin{tabular}{|c|c|c|c|}
\hline & $\mathrm{N}$ & Prosjek & Std.Dev. \\
\hline $\begin{array}{l}\text { Povećati edukaciju i informiranje o automatizaciji i programiranju računalnih mreža } \\
\text { (Automation tools and DevOps) }\end{array}$ & 57 & 3,86 & 0,90 \\
\hline $\begin{array}{l}\text { Povećati edukaciju i informiranje o softverski definiranim mrežama (Software Defined } \\
\text { Networks - SDN) }\end{array}$ & 57 & 3,81 & 0,90 \\
\hline $\begin{array}{l}\text { Povećati informiranje o praktičnoj primjeni NETCONF standarda - na primjer } \\
\text { objavljivanje preporuka za uporabu (white papers) i drugo. }\end{array}$ & 56 & 3,80 & 0,92 \\
\hline $\begin{array}{l}\text { Povećati informiranje o primjeni NETCONF standarda za POVEĆANJE } \\
\text { RASPOLOŽIVOSTI mrežnih sustava i R/S uređaja - na primjer objavljivanje preporuka } \\
\text { za uporabu (white papers) i drugo. }\end{array}$ & 54 & 3,78 & 0,86 \\
\hline $\begin{array}{l}\text { Implementirati NETCONF na svim vrstama R/S uređaja - na primjer od malih SMB } \\
\text { uređaja do velikih ISP uređaja. }\end{array}$ & 55 & 3,75 & 0,91 \\
\hline $\begin{array}{l}\text { Povećati informiranje o teoretskom radu i prednostima NETCONF standarda - na primjer } \\
\text { pomoću organiziranih tečajeva proizvođača, radionica, CBT, Webinar, i drugo. }\end{array}$ & 56 & 3,70 & 0,97 \\
\hline Pojačati edukaciju o programiranju i programskim jezicima & 58 & 3,69 & 1,03 \\
\hline
\end{tabular}


○ Tablica 7-10. prikazuje rezultate odgovora korisnika. Odgovori su uređeni od najvažnijeg do najmanje važnog načina povećanja primjene NETCONF standarda.

- Primjena NETCONF-a od strane korisnika je trenutno izuzetno niska. Slika 6-8. prikazuje odgovore korisnika dobivene na 18. pitanje anketnog upitnika i može se vidjeti da većina kompanija (od ukupno 73 kompanija ispitanika) ne koristi NETCONF standard na svojim R/S uređajima (65 kompanija; 89,04\%). NETCONF koristi samo 8 kompanija ispitanika (10,96\%).

- Korisnici imaju vrlo visoki postotak visoko raspoloživih mreža i trenutno se u njima vrlo malo koristi NETCONF. Tablica 6-29. prikazuje rezultate 12. pitanja intervjua za partnere gdje se vidi da $80 \%$ korisnika (skala od 0 do 5 gdje 5 iznosi $100 \%$; srednja vrijednost 4,00; standardna devijacija 1,00) ima mreže visoke raspoloživosti ( $\geq 99,9 \%$ ) i da samo 14,2\% (skala od 0 do 5 gdje 5 iznosi 100\%; srednja vrijednost 0,71 ; standardna devijacija 0,49 ) korisnika u svojim mrežama upotrebljava NETCONF. Ova vrijednost dobivena od partnera $(14,2 \%)$ vrlo je blizu odgovoru samih korisnika koji iznosi gore navedenih 10,96\%). To pokazuje da postoji veliki prostor za proširenje primjene NETCONF-a kod korisnika, ali i prijetnju da ako do širenja primjene ne dođe, postoji opasnost da će umjesto NETCONF-a biti implementirano neko drugo rješenje.

- U zadnjih nekoliko godina došlo je do značajne potrebe za promjenom u upravljanju $\mathrm{R} / \mathrm{S}$ uređajima uzrokovane virtualizacijom i mobilnošću današnjih mreža pa su nastale softverski definirane mreže $(\mathrm{SDN})$. Softverski definirane mreže termin je za paradigmu programabilnih mreža. NETCONF je važan sastavni dio SDN arhitekture (kako je definirano u RFC 7426), a SDN se sve više primjenjuje. Korisnici koji koriste SDN mreže, vrlo često primjenjuju i NETCONF protokol (kao sastavni dio SDN proizvoda), a da toga nisu ni svjesni. NETCONF izvršava svoje funkcije u pozadini i prikriven je SDN korisničkom aplikacijom. SDN i njegova primjena su prikazani u poglavlju 2.6.Trendovi u upravljanju mrežnim uređajima: SDN mreže.

- Tijekom intervjua jedan ispitanik (zaposlenik partnera u Hrvatskoj) naveo je mogućnost brisanja konfiguracije, odnosno uklanjanje konfiguracije (engl. change 
management) na R/S uređaju, kao značajno svojstvo NETCONF standarda. Nakon prestanka rada usluge, konfiguracije na uređajima treba obrisati ili dovesti u prethodno stanje. To je ogromni trenutni operativni problem SP-a, a rješenje je moguće pomoću SDN-a (i NETCONF protokola).

- Ostali prijedlozi ispitanika za povećanje primjene NETCONF-a su sljedeći:

○ uvođenje više cjelovitih sustava za nadzor i konfiguraciju mrežne opreme koji bi u pozadini koristili NETCONF.

○ Implementacija u IoT tehnologijama.

○ Proizvođači trebaju više inzistirati na korištenju NETCONF standarda.

- Povećana primjena bi se postigla pomoću organizacije interesne udruge (foruma) za NETCONF protokol.

○ Potreban je angažman proizvođača u pružanju podrške korištenja NETCONF-a na novoj opremi te pružanju migracijske strategije prema NETCONF-u.

- Poboljšanje NETCONF standarda prelaskom sa XML u JSON format koji je više "human readable" i sve više standard koji potiskuje XML.

- Poboljšanje standarda vezanih uz NETCONF: brža standardizacija temeljnih servisa (na primjer MPLS VPN treba konfigurirati na isti način kod svih proizvođača opreme).

- Značajno se mijenja pristup upravljanju računalnim mrežama: više se ne konfiguriraju uređaji, već se konfiguriraju servisi.

- Automatizacija servisa će se temeljiti na NETCONF-u. Mogućnost povezivanja $\mathrm{s}$ umjetnom inteligencijom (kada stroj počne automatski konfigurirati servise, a u to će se sigurno uključiti umjetna inteligencija).

\section{PRIJETNJE:}

- Korisnici vrlo malo poznaju NETCONF standard.

- Mišljenja ispitanika o znanju korisnika o NETCONF standardu su obrađena i prikazana u: 
- 20. pitanju intervjua za partnere (Tablica 6-24. prikazuje rezultate; skala od 1 do 5, gdje 1 označava nedovoljno, a 5 izvrsno znanje);

- 12. pitanju upitnika za korisnike (Tablica 6-59. prikazuje rezultate; skala od 1 do 5 , gdje 1 označava nedovoljno, a 5 izvrsno znanje).

○ Tablica 7-11. prikazuje usporedni pregled rezultata (broj ispitanika N, prosječnu vrijednost i standardnu devijaciju) dobivenih od dvije vrste ispitanika (partneri i korisnici). Iz tablice se može vidjeti sljedeće:

- korisnici vrlo malo poznaju NETCONF standard (teoretski, praktično i u svrhu povećanja raspoloživosti $R / S$ uređaja);

- partneri svojim korisnicima daju nižu ocjenu o poznavanju NETCONFa u odnosu kako korisnici ocjenjuju sami sebe.

Tablica 7-11. Znanje korisnika o NETCONF standardu (usporedni prikaz)

\begin{tabular}{lcccccc}
\hline & \multicolumn{2}{c}{ Partneri } & & \multicolumn{2}{c}{ Korisnici } \\
& $\mathrm{N}$ & Prosjek & Std.Dev. & $\mathrm{N}$ & Prosjek & Std.Dev. \\
\hline $\begin{array}{l}\text { 1. Savladana teoretska znanja o radu NETCONF } \\
\text { protokola i razumiju njegove karakteristike i } \\
\text { prednosti }\end{array}$ & 7 & 1,14 & 0,38 & 73 & 1,90 & 1,00 \\
\hline $\begin{array}{l}\text { 2. Savladana praktična znanja NETCONF } \\
\text { protokola i koriste ga s lakoćom }\end{array}$ & 7 & 1,00 & 0,00 & 73 & 1,37 & 0,87 \\
\hline $\begin{array}{l}\text { 3. Poznavanje prednosti NETCONF protokola u } \\
\text { povećanju raspoloživosti mrežnih uređaja }\end{array}$ & 7 & 2,00 & 1,53 & 73 & 1,81 & 1,10 \\
\hline
\end{tabular}

\section{- Korisnici imaju izrazito nisko znanje o mogućnostima NETCONF standarda.}

- Mišljenja ispitanika o znanju korisnika o NETCONF standardu su obrađena i prikazana u:

- 21. pitanju intervjua (teoretska znanja) za partnere (Tablica 6-25. prikazuje rezultate; skala od 1 do 5 , gdje 1 označava nedovoljno, a 5 izvrsno znanje);

- 22. pitanju intervjua (praktična znanja) za partnere (Tablica 6-26. prikazuje rezultate; skala od 1 do 5 , gdje 1 označava nedovoljno, a 5 izvrsno znanje).

- 13. pitanju upitnika za korisnike (Tablica 6-60. prikazuje rezultate; skala od 1 do 5, gdje 1 označava nedovoljno, a 5 izvrsno znanje). 
○ Tablica 7-12. prikazuje usporedni pregled rezultata (broj ispitanika N, prosječnu vrijednost i standardnu devijaciju) dobivenih od dvije vrste ispitanika (partneri i korisnici). Iz tablice se može vidjeti sljedeće:

- i partneri i korisnici se slažu da korisnici imaju izrazito niska znanja o mogućnostima NETCONF standarda;

- partneri smatraju da njihovi korisnici imaju značajno manja praktična znanja od teoretskih;

- partneri svojim korisnicima daju podjednake ocjene o niskom poznavanju NETCONF-a u odnosu kako korisnici ocjenjuju sami sebe.

\section{Tablica 7-12. Znanja korisnika o mogućnostima NETCONF standarda}

(usporedni prikaz)

\begin{tabular}{|c|c|c|c|c|c|c|c|c|c|}
\hline & \multicolumn{3}{|c|}{$\begin{array}{c}\text { Partneri } \\
\text { (teoretska znanja) }\end{array}$} & \multicolumn{3}{|c|}{$\begin{array}{c}\text { Partneri } \\
\text { (praktična znanja) }\end{array}$} & \multicolumn{3}{|c|}{$\begin{array}{c}\text { Korisnici } \\
\text { (teoretska i praktična } \\
\text { znanja) }\end{array}$} \\
\hline & $\mathrm{N}$ & Prosjek & $\begin{array}{l}\text { Std. } \\
\text { Dev. }\end{array}$ & $\mathrm{N}$ & Prosjek & $\begin{array}{l}\text { Std. } \\
\text { Dev. }\end{array}$ & $\mathrm{N}$ & Prosjek & $\begin{array}{l}\text { Std. } \\
\text { Dev. }\end{array}$ \\
\hline $\begin{array}{l}\text { „Backup \& restore“ mogućnost } \\
\text { koju nudi NETCONF standard. }\end{array}$ & 7 & 1,71 & 1,50 & 7 & 1,29 & 0,76 & 73 & 1,73 & 1,00 \\
\hline $\begin{array}{l}\text { Mogućnost istovremenog i } \\
\text { koordiniranog konfiguriranja svih } \\
\text { ili više uređaja u mreži. }\end{array}$ & 7 & 1,86 & 1,46 & 7 & 1,43 & 0,79 & 73 & 1,81 & 1,11 \\
\hline $\begin{array}{l}\text { Mogućnost parcijalnog } \\
\text { konfiguriranja uređaja pomoću } \\
\text { NETCONF standarda. }\end{array}$ & 7 & 1,71 & 1,50 & 7 & 1,29 & 0,49 & 73 & 1,74 & 0,99 \\
\hline $\begin{array}{l}\text { Mogućnost provjere } \\
\text { konfiguracije prije primjene kod } \\
\text { NETCONF načina konfiguriranja } \\
\text { uređaja. }\end{array}$ & 7 & 1,57 & 1,51 & 7 & 1,29 & 0,76 & 73 & 1,75 & 1,05 \\
\hline $\begin{array}{l}\text { Mogućnost zaključavanja } \\
\text { konfiguracijske datoteke koje } \\
\text { nudi NETCONF. }\end{array}$ & 7 & 1,57 & 1,51 & 7 & 1,29 & 0,76 & 73 & 1,71 & 0,99 \\
\hline $\begin{array}{l}\text { NETCONF kao standard koji } \\
\text { omogućava programabilnost } \\
\text { (automatiziranje). }\end{array}$ & 7 & 2,00 & 1,53 & 7 & 1,29 & 0,49 & 73 & 1,73 & 0,92 \\
\hline $\begin{array}{l}\text { NETCONF kao standardni način } \\
\text { konfiguracije preko udaljenog } \\
\text { pristupa na IP adresu uređaja }\end{array}$ & 7 & 1,86 & 1,46 & 7 & 1,29 & 0,49 & 73 & 1,78 & 1,02 \\
\hline $\begin{array}{l}\text { NETCONF standard koristi jasnu } \\
\text { razliku u strukturi između } \\
\text { konfiguracijskih i operacijskih } \\
\text { podataka. }\end{array}$ & 7 & 1,71 & 1,50 & 7 & 1,14 & 0,38 & 73 & 1,68 & 0,97 \\
\hline Ukupno & 7 & 1,75 & 1,46 & 7 & 1,29 & 0,55 & 73 & 1,74 & 0,95 \\
\hline
\end{tabular}


- Korisnici uglavnom malo znaju da je NETCONF standard raspoloživ na R/S uređajima. Tablica 6-43. prikazuje rezultate 14. pitanja anketnog upitnika za korisnike gdje se vidi da korisnici vrlo malo znaju da proizvođači mrežne opreme implementiraju NETCONF standard na svojim uređajima (skala od -2 do 2, gdje je -2 izrazito neslaganje, a 2 izrazito slaganje s tvrdnjom; srednja vrijednost 0,33 ; standardna devijacija 0,86 ).

- Većina proizvođača ne podržava NETCONF standard na svim svojim uređajima i OS verzijama. U razgovorima s zaposlenicima proizvođača dobivene su informacije da samo Juniper podržava NETCONF na svim uređajima, dok ostali proizvođači NETCONF implementiraju samo na nekim svojim uređajima. Podrška nekog uređaja za NETCONF ovisi o parametrima tog uređaja (vrsta uređaja, model uređaja, vrsta operacijskog sustava, verzija operacijskog sustava, grupa podržanih funkcionalnosti operacijskog sustava). Zbog čestih promjena tih parametara vrlo je složeno odrediti koji mrežni uređaji podržavaju NETCONF i u kojoj verziji softvera, a rezultati se skoro svakodnevno mijenjaju (objašnjeno u poglavlju 5.2. Informacije proizvođača o implementaciji NETCONF standarda).

- Razvijaju se alternativna i slična rješenja (kao na primjer RESTCONF i gRPC) koja su jednostavnija korisnicima za uporabu (ukratko prikazano u poglavlju 5.4.Alternativna rješenja). RESTCONF standard je jednostavniji jer omogućava API sučelje koje je usklađeno s ostalim API sučeljima web aplikacija, ali trenutno nema sva napredna svojstva NETCONF standarda. RESTCONF koristi JSON format podataka koji se često koristi u programske svrhe i teži biti razumljiviji od XML formata. Korisnici vole jednostavnost uporabe. Ipak, IETF $^{172}$ i Cisco ${ }^{173}$ ne smatraju da je RESTCONF zamjena za NETCONF, već da se mogu oba standarda koristiti, ovisno o trenutnoj situaciji i zahtjevima (potrebama) korisnika.

- Korisnici imaju vrlo mala znanja o programiranju i automatiziranju računalnih mreža. Mrežni administratori nisu često upoznati s programskim jezicima. Mišljenja ispitanika o njihovom poznavanju programiranja i programskih jezika su obrađena $i$

\footnotetext{
${ }^{172}$ IETF RFC 8040 RESTCONF Protocol (2017) https://tools.ietf.org/html/rfc8040 (15.8.2019).

${ }^{173}$ Cisco DevNet: RESTCONF https://developer.cisco.com/learning/modules/intro-device-level-interfaces/introrestconf/step/2 (20.8.2019)
} 
prikazana u 5. pitanju anketnog upitnika (Tablica 6-36. prikazuje rezultate; skala od 1 do 5, gdje 1 označava nedovoljno, a 5 izvrsno znanje). Može se vidjeti da ispitanici posjeduju najviše znanja iz:

○ općenito programiranje i programski jezici (prosječna razina znanja 2,32; std.dev.1,08)

koja su vjerojatno stečena tijekom formalnog ICT obrazovanja. Zanimljivo je da ispitanici najmanje znanja imaju iz:

○ Perl (prosječna razina znanja 1,41; std.dev.0,91) i

○ Tcl (prosječna razina znanja 1,41; std.dev.0,70)

koji su jezici korišteni za automatizaciju računalnih mreža na tradicionalan način pomoću skripti i prisutni su kao mrežna tehnologija više od dvadeset godina. Čak $76.71 \%$ ispitanika za Perl i $69.86 \%$ za Tcl smatra da ima nedovoljna znanja o tim jezicima. To pokazuje da ispitanici koji rade s računalnim mrežama rijetko koriste programiranje i automatizaciju računalnih mreža i na tradicionalan način. To potvrđuje iskustvo iz prakse istraživača da se automatizacija ponekad koristi u ISP mrežama (i to od najiskusnijih ili specijaliziranih mrežnih stručnjaka), a gotovo nikada u mrežama poduzeća.

- Zapažanja ispitanika su sljedeća:

○ u ovom trenutku NETCONF zahtijeva znanja korisnika i iz mrežnih tehnologija i iz programiranja. Oba područja su vrlo široka i različita po sadržaju, pa je vrlo zahtjevno imati dovoljno znanja iz oba područja. Ipak, razvijaju se aplikacije koje mrežni administratori mogu koristiti za NETCONF bez poznavanja programiranja. 


\section{Testiranje hipoteza}

U ovom se dijelu rada testiraju postavljene hipoteze istraživanja upotrebom Hi kvadrat $\left(\chi^{2}\right)$ testa. Hi kvadrat testom testira se razlika u strukturi odgovora gdje se u slučaju empirijske p vrijednosti manje od 5\% $(0,05)$ može utvrditi da jedna skupina odgovora prevladava u populaciji, dok se u suprotnom donosi zaključak da je u populaciji podjednaka zastupljenost obje odabrane grupe odgovora.

Analiza je rađena u statističkom softveru SPSS 25 te se zaključci donose pri graničnoj razini signifikantnosti od $5 \%$.

\subsection{NETCONF i povećanje raspoloživosti (H1)}

Prva hipoteza glasi (H1): NETCONF standard povećava raspoloživost mrežnog uređaja u odnosu na nestandardne metode konfiguriranja mrežnih uređaja.

Ova se hipoteza testira na osnovi mišljenja korisnika prikupljenog pomoću anketnog upitnika (pitanje $25.1 \mathrm{u}$ anketnom upitniku). Pitanje je glasilo: „Slažete li se sa sljedećom tvrdnjom: korištenje NETCONF standarda povećava raspoloživost mrežnog R/S uređaja u odnosu na nestandardne CLI metode konfiguriranja mrežnih uređaja (operacijskih sustava proizvođača opreme)?“. Tablica 8-1. prikazuje odgovore korisnika na to pitanje.

Odgovori ispitanika su grupirani u dvije skupine slaganja (Ne i $D a$ ), dok su odgovori ispitanika koji nisu imali svoj stav ispušteni iz testiranja (odgovorili su s Ne znam ili Niti se slažem niti se ne slažem). 
Tablica 8-1. NETCONF i povećanje raspoloživosti (25.1 pitanje anketnog upitnika)

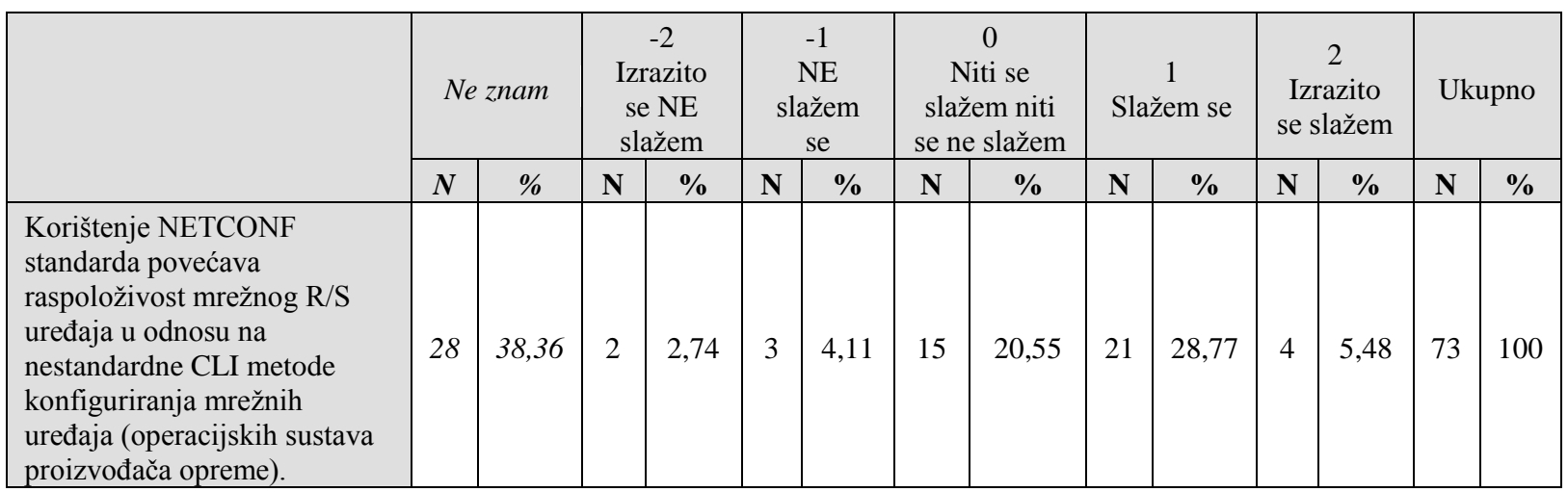

Hipoteza se testira upotrebom $\mathrm{Hi}$ kvadrat $\left(\chi^{2}\right)$ testa kojim se provjerava razlika $\mathrm{u}$ zastupljenosti odgovora u odnosu na jednaku preraspodjelu (50\% odgovora $\mathrm{Ne}$ i $50 \%$ odgovora $D a)$. U slučaju da je empirijska p vrijednost manja od 5\% $(0,05)$, utvrđuje se da prevladava odgovor u populaciji korisnika koji ima veći \% zastupljenosti među ispitanicima. Ukoliko je empirijska p vrijednost veća od 0,05 donosi se zaključak da razdioba odgovora $\mathrm{Ne}$ i $D a$ u populaciji ne odstupa statistički značajno od omjera $50 \%$ naspram $50 \%$.

Tablica 8-2. prikazuje Hi kvadrat $\left(\chi^{2}\right)$ test ove hipoteze.

Tablica 8-2. Testiranje 1. hipoteze

Korištenje NETCONF standarda povećava raspoloživost mrežnog R/S uređaja u odnosu na nestandardne CLI metode konfiguriranja mrežnih uređaja (operacijskih $\chi^{2} \quad \mathrm{p}^{*}$ sustava proizvođača opreme).

\begin{tabular}{lccll}
\hline $\mathrm{Ne}$ & 5 & $16,67 \%$ & \multirow{2}{*}{$13,33<0,001$} \\
\hline $\mathrm{Da}$ & 25 & $83,33 \%$ & & \\
\hline Ukupno & 30 & $100,00 \%$ & & \\
\hline$* \chi^{2}$ test & & & &
\end{tabular}

Iz tablice se može utvrditi da je za 25 veći broj ispitanika koji su iskazali slaganje na tvrdnju da korištenje NETCONF standarda povećava raspoloživost mrežnog $R / S$ uređaja u odnosu na nestandardne CLI metode konfiguriranja mrežnih uređaja (operacijskih sustava proizvođača opreme) u odnosu na broj ispitanika koji se nisu složili s tvrdnjom. Ispitanici koji nisu imali izražen stav su ispušteni iz testiranja. Testiranjem je utvrđeno da postoji razlika u 
zastupljenosti slaganja s ponuđenom tvrdnjom u odnosu na broj ispitanika koji nisu iskazali slaganje. $\left(\chi^{2}=13,33\right.$; empirijska p vrijednost $\left.<0,001\right)$.

Slijedom rezultata provedenog testa može se donijeti zaključak da se hipoteza H1 kojom se pretpostavlja da korištenje NETCONF standarda povećava raspoloživost mrežnog $R / S$ uređaja u odnosu na nestandardne CLI metode konfiguriranja mrežnih uređaja prihvaća kao istinita.

\subsection{Primjena NETCONF standarda od proizvođača R/S uređaja (H2)}

Druga hipoteza glasi (H2): proizvođači mrežne opreme ne implementiraju NETCONF standard na svojim uređajima.

Ova se hipoteza testira na osnovi mišljenja korisnika prikupljenog pomoću anketnog upitnika (14. pitanje u anketnom upitniku). Pitanje je glasilo: „Slažete li se sa sljedećom tvrdnjom: proizvođači mrežne opreme implementiraju NETCONF standard na svojim uređajima?““. Tablica 8-3. prikazuje odgovore korisnika na to pitanje.

\section{Tablica 8-3. Implementacija NETCONF standarda od proizvođača (14. pitanje anketnog upitnika)}

\begin{tabular}{|c|c|c|c|c|c|c|c|c|c|c|c|c|c|c|}
\hline & \multicolumn{2}{|c|}{ Ne znam } & \multicolumn{2}{|c|}{$\begin{array}{c}-2 \\
\text { Izrazito se } \\
\mathrm{NE} \\
\text { slažem }\end{array}$} & \multicolumn{2}{|c|}{$\stackrel{-1}{\text { NE slažem se }}$} & \multicolumn{2}{|c|}{$\begin{array}{c}0 \\
\text { Niti se slažem } \\
\text { niti se ne } \\
\text { slažem }\end{array}$} & \multicolumn{2}{|c|}{$\begin{array}{c}1 \\
\text { Slažem se }\end{array}$} & \multicolumn{2}{|c|}{$\begin{array}{l}2 \\
\text { Izrazito se } \\
\text { slažem }\end{array}$} & \multicolumn{2}{|c|}{ Ukupno } \\
\hline & $\%$ & $\mathbf{N}$ & $\%$ & $\mathbf{N}$ & $\%$ & $\mathbf{N}$ & $\%$ & $\mathbf{N}$ & $\%$ & $\mathbf{N}$ & $\%$ & $\mathbf{N}$ & $\%$ & $\mathbf{N}$ \\
\hline $\begin{array}{l}\text { Proizvođači mrežne } \\
\text { opreme implementiraju } \\
\text { NETCONF standard na } \\
\text { svojim uređajima. }\end{array}$ & 12,33 & 9 & 1.37 & 1 & 10,96 & 8 & 39,73 & 29 & 28,77 & 21 & 6,85 & 5 & 100 & 5 \\
\hline
\end{tabular}

Odgovori ispitanika su grupirani u dvije skupine slaganja (Ne i $D a$ ), dok su odgovori ispitanika koji nisu imali svoj stav ispušteni iz testiranja (odgovorili su s Ne znam ili Niti se slažem niti se ne slažem). 
Hipoteza se testira upotrebom $\mathrm{Hi}$ kvadrat $\left(\chi^{2}\right)$ testa kojim se provjerava razlika $\mathrm{u}$ zastupljenosti odgovora u odnosu na jednaku preraspodjelu (50\% odgovora $\mathrm{Ne}$ i 50\% odgovora $D a)$. U slučaju da je empirijska p vrijednost manja od 5\% $(0,05)$, utvrđuje se da prevladava odgovor u populaciji korisnika koji ima veći \% zastupljenosti među ispitanicima. Ukoliko je empirijska p vrijednost veća od 0,05 donosi se zaključak da razdioba odgovora $\mathrm{Ne}$ i $\mathrm{Da}$ u populaciji ne odstupa statistički značajno od omjera $50 \%$ naspram $50 \%$.

Tablica 8-4. prikazuje Hi kvadrat test $\left(\chi^{2}\right)$ ove hipoteze.

Tablica 8-4. Testiranje 2. hipoteze

\begin{tabular}{|c|c|c|c|c|}
\hline \multicolumn{3}{|c|}{$\begin{array}{l}\text { Proizvođači mrežne opreme implementiraju } \\
\text { NETCONF standard na svojim uređajima. }\end{array}$} & $\chi^{2}$ & $\mathrm{p}^{*}$ \\
\hline $\mathrm{Ne}$ & 9 & $25,71 \%$ & \multirow{2}{*}{8,26} & \multirow{2}{*}{$<0,001$} \\
\hline $\mathrm{Da}$ & 26 & $74,29 \%$ & & \\
\hline Ukupno & 35 & $100,00 \%$ & & \\
\hline
\end{tabular}

Iz tablice se može utvrditi da je za 17 veći broj ispitanika koji su iskazali slaganje za tvrdnju da proizvođači mrežne opreme implementiraju NETCONF standard na svojim uređajima $\mathrm{u}$ odnosu na broj ispitanika koji se nisu složili s tvrdnjom. Ispitanici koji nisu imali izražen stav ispušteni su iz testiranja. Testiranjem je utvrđeno da postoji razlika u zastupljenosti slaganja s ponuđenom tvrdnjom $\mathrm{u}$ odnosu na broj ispitanika koji nisu iskazali slaganje. $\left(\chi^{2}=8,26\right.$; empirijska $\mathrm{p}$ vrijednost $<0,001)$, odnosno u populaciji će prevladavati slaganje s ponuđenom tvrdnjom.

Slijedom rezultata provedenog testa može se donijeti zaključak da se hipoteza H2 kojom se pretpostavlja da proizvođači mrežne opreme ne implementiraju NETCONF standard na svojim uređajima odbacuje kao neistinita.

Objašnjenje dobivenog rezultata je sljedeće: hipoteza je postavljena prije dvije do tri godine, a zadnjih se nekoliko godina događaju značajne promjene u području upravljanja računalnim mrežama i NETCONF (kao dio softverski definiranih mreža) se sve više implementira na R/S uređajima od strane proizvođača mrežne opreme. 


\subsection{Primjena NETCONF standarda u kompaniji korisnika (H3)}

Treća hipoteza glasi (H3): korisnici mrežne opreme ne implementiraju NETCONF standard na svojim mrežnim uređajima.

Ova se hipoteza testira na osnovi mišljenja korisnika prikupljenog pomoću anketnog upitnika (18. pitanje u anketnom upitniku). Pitanje je glasilo: „Da li koristite NETCONF standard na R/S (Router/Switch) mrežnim uređajima Vaše kompanije?“. Tablica 8-5. prikazuje odgovore korisnika na to pitanje.

Tablica 8-5. Implementacija NETCONF standarda od korisnika (18. pitanje anketnog upitnika)

\begin{tabular}{lc|c}
\hline & $\mathbf{N}$ & $\boldsymbol{\%}$ \\
\hline DA & 8 & 10,96 \\
\hline NE & 65 & 89,04 \\
\hline Ukupno & 73 & 100,0 \\
\hline
\end{tabular}

Hipoteza se testira upotrebom $\mathrm{Hi}$ kvadrat $\left(\chi^{2}\right)$ testa kojim se provjerava razlika $\mathrm{u}$ zastupljenosti odgovora $\mathrm{u}$ odnosu na jednaku preraspodjelu (50\% odgovora $\mathrm{Ne}$ i 50\% odgovora $D a)$. U slučaju da je empirijska p vrijednost manja od 5\% $(0,05)$, utvrđuje se da prevladava odgovor u populaciji korisnika koji ima veći \% zastupljenosti među ispitanicima. Ukoliko je empirijska p vrijednost veća od 0,05 donosi se zaključak da razdioba odgovora $\mathrm{Ne}$ i $D a$ u populaciji ne odstupa statistički značajno od omjera 50\% naspram 50\%.

Tablica 8-6. Testiranje 3. hipoteze

\begin{tabular}{|c|c|c|c|c|}
\hline \multicolumn{3}{|c|}{$\begin{array}{l}\text { Da li koristite NETCONF standard na R/S mrežnim } \\
\text { uređajima Vaše kompanije? }\end{array}$} & $\chi^{2}$ & $\mathrm{p}^{*}$ \\
\hline $\mathrm{Ne}$ & 65,00 & $89,04 \%$ & \multirow{2}{*}{44,51} & \multirow{2}{*}{$<0,001$} \\
\hline $\mathrm{Da}$ & 8,00 & $10,96 \%$ & & \\
\hline Ukupno & 73 & $100,00 \%$ & & \\
\hline
\end{tabular}

Tablica 8-6. prikazuje Hi kvadrat $\left(\chi^{2}\right)$ test ove hipoteze. 
Iz tablice se može utvrditi da je za 57 veći broj ispitanika koji su dali negativan odgovor na pitanje koristi li se NETCONF standard na R/S mrežnim uređajima u njihovoj kompaniji.

Testiranjem je utvrđeno da postoji razlika u zastupljenosti poduzeća koja koriste i koja ne koriste NETCONF standard na R/S mrežnim uređajima. $\left(\chi^{2}=44,51\right.$; empirijska $p$ vrijednost $<0,001$ ), odnosno u populaciji će prevladavati slaganje s ponuđenom tvrdnjom.

Slijedom rezultata provedenog testa može se donijeti zaključak da se hipoteza H3 kojom se pretpostavlja da korisnici mrežne opreme ne implementiraju NETCONF standard na svojim mrežnim uređajima prihvaća kao istinita.

\subsection{Poznavanje NETCONF standarda od strane korisnika (H4)}

Četvrta hipoteza glasi (H4): korisnici nedovoljno poznaju prednosti NETCONF standarda u povećanju raspoloživosti mrežnih uređaja.

Ova se hipoteza testira na osnovi mišljenja korisnika prikupljenog pomoću anketnog upitnika (pitanje 12.3 u anketnom upitniku). Pitanje je glasilo: „Molimo Vas da ocijenite Vaše znanje: poznajete li prednosti NETCONF protokola u povećanju raspoloživosti $\mathrm{R} / \mathrm{S}$ mrežnih uređaja.“. Tablica 8-7. prikazuje odgovore korisnika na to pitanje.

Tablica 8-7. Poznavanje NETCONF standarda od strane korisnika (12.3 pitanje anketnog upitnika)

\begin{tabular}{|c|c|c|c|c|c|c|c|c|c|c|c|c|}
\hline & \multicolumn{2}{|c|}{$\begin{array}{c}1 \\
\text { Nedovoljno }\end{array}$} & \multicolumn{2}{|c|}{$\begin{array}{c}2 \\
\text { Dovoljno }\end{array}$} & \multicolumn{2}{|c|}{$\begin{array}{c}3 \\
\text { Dobro }\end{array}$} & \multicolumn{2}{|c|}{$\begin{array}{c}4 \\
\text { Vrlo dobro }\end{array}$} & \multicolumn{2}{|c|}{$\begin{array}{c}5 \\
\text { Izvrsno }\end{array}$} & \multicolumn{2}{|c|}{ Ukupno } \\
\hline & $\%$ & $N$ & $\%$ & $N$ & $\%$ & $N$ & $\%$ & $N$ & $\%$ & $N$ & $\%$ & $N$ \\
\hline $\begin{array}{l}\text { Poznajem prednosti NETCONF } \\
\text { protokola u POVEĆANJU } \\
\text { RASPOLOŽIVOSTI R/S mrežnih } \\
\text { uređaja. }\end{array}$ & 54,79 & 40 & 21,92 & 16 & 15,07 & 11 & 4,11 & 3 & 4,11 & 3 & 73 & 100 \\
\hline
\end{tabular}


Odgovori ispitanika grupirani su u dvije skupine: skupina $N e$ koja je sebi za svoje znanje dala ocjenu nedovoljan (1), i skupinu Da koja je sebi za svoje znanje dala dovoljan (2) ili veću ocjenu.

Hipoteza se testira upotrebom $\mathrm{Hi}$ kvadrat $\left(\chi^{2}\right)$ testa kojim se provjerava razlika $\mathrm{u}$ zastupljenosti odgovora $\mathrm{u}$ odnosu na jednaku preraspodjelu (50\% odgovora $\mathrm{Ne}$ i 50\% odgovora $D a)$. U slučaju da je empirijska p vrijednost manja od 5\% $(0,05)$, utvrđuje se da prevladava odgovor u populaciji korisnika koji ima veći \% zastupljenosti među ispitanicima. Ukoliko je empirijska p vrijednost veća od 0,05 donosi se zaključak da razdioba odgovora $\mathrm{Ne}$ i $D a$ u populaciji ne odstupa statistički značajno od omjera 50\% naspram 50\%.

Tablica 8-8. prikazuje Hi kvadrat test $\left(\chi^{2}\right)$ ove hipoteze.

Tablica 8-8. Testiranje 4. hipoteze

\begin{tabular}{|c|c|c|c|c|}
\hline \multicolumn{3}{|c|}{$\begin{array}{l}\text { Poznajem prednosti NETCONF protokola u povećanju } \\
\text { raspoloživosti R/S mrežnih uređaja }\end{array}$} & $\chi^{2}$ & $\mathrm{p}^{*}$ \\
\hline $\mathrm{Ne}$ & 40,00 & $54,79 \%$ & \multirow{2}{*}{0,67} & \multirow{2}{*}{0,413} \\
\hline $\mathrm{Da}$ & 33,00 & $45,21 \%$ & & \\
\hline Ukupno & 73 & $100,00 \%$ & & \\
\hline
\end{tabular}

Iz tablice se može utvrditi da je za 7 veći broj ispitanika koji su iskazali nedovoljno znanje o prednosti NETCONF protokola u povećanju raspoloživosti R/S mrežnih uređaja.

Testiranjem nije utvrđena razlika u zastupljenosti korisnika NETCONF standarda koji imaju nedovoljno i koji imaju barem dovoljno znanje o povećanju raspoloživosti R/S mrežnih uređaja poduzeća $\left(\chi^{2}=0,67\right.$; empirijska $\mathrm{p}$ vrijednost $=0,413$ ), odnosno u populaciji polovica ljudi ima nedovoljno znanje, dok druga polovica ima dovoljno znanje.

Slijedom rezultata provedenog testa $(p>0,05)$ može se donijeti zaključak da se hipoteza H4 kojom se pretpostavlja da korisnici nedovoljno poznaju prednosti NETCONF standarda $u$ povećanju raspoloživosti mrežnih uređaja odbacuje kao neistinita.

Iako je hipoteza odbačena kao neistinita, istraživanje je pokazalo da je razina znanja korisnika o poznavanju prednosti NETCONF standardu u povećanju raspoloživosti R/S mrežnih uređaja vrlo niska u usporedbi sa znanjem korisnika iz ostalih područja računalnih mreža. 


\section{Tablica 8-9. Razine znanja ispitanika iz različitih područja i tehnologija računalnih mreža (4. pitanje upitnika korisnika)}

\begin{tabular}{lccc}
\hline & $\mathrm{N}$ & Prosjek & Std.Dev. \\
\hline $\begin{array}{l}\text { R/S poduzeća (Enterprise routing/switching): } \\
\text { - R/S uređaji, protokoli, način rada, .. }\end{array}$ & 73 & 3,62 & 1,08 \\
\hline $\begin{array}{l}\text { R/S davatelja usluga (Service provider routing/switching): } \\
\text { - R/S uređaji, protokoli, način rada, .. }\end{array}$ & 73 & 3,21 & 1,11 \\
\hline $\begin{array}{l}\text { Podatkovni centri (Data Center): } \\
\text { - R/S uređaji, protokoli, način rada, ... }\end{array}$ & 73 & 2,89 & 1,19 \\
\hline $\begin{array}{l}\text { Upravljanje računalnim mrežama (Network management - NM): } \\
\text { - SNMP protokol, načini upravljanja R/S uređajima, i drugo. }\end{array}$ & 73 & 3,19 & 0,95 \\
\hline $\begin{array}{l}\text { Sigurnost R/S uređaja i računalnih mreža } \\
\text { Računalstvo u oblaku (Cloud computing) }\end{array}$ & 73 & 3,34 & 1,07 \\
\hline Softverski definirane mreže (Software Defined Networks - SDN) & 73 & 2,53 & 1,08 \\
\hline $\begin{array}{l}\text { Automatizacija i programiranje računalnih mreža (Automation tools and } \\
\text { DevOps) }\end{array}$ & 73 & 2,41 & 1,19 \\
\hline Ukupno & 73 & 2,04 & 1,10 \\
\hline
\end{tabular}

Tablica 8-10. Razine znanja ispitanika o NETCONF standardu

(12. pitanje upitnika korisnika)

\begin{tabular}{lccc}
\hline & $\mathrm{N}$ & Prosjek \\
\hline $\begin{array}{l}\text { 1. Savladao sam TEORETSKA znanja o radu NETCONF protokola i } \\
\text { razumijem njegove karakteristike i prednosti. }\end{array}$ & 73 & 1,90 & 1,00 \\
\hline $\begin{array}{l}\text { 2. Savladao sam PRAKTIČNA znanja NETCONF protokola i primjenjujem } \\
\text { ga s lakoćom. }\end{array}$ & 73 & 1,37 & 0,87 \\
\hline $\begin{array}{l}\text { 3. Poznajem prednosti NETCONF protokola u POVEĆANJU } \\
\text { RASPOLOŽIVOSTI R/S mrežnih uređaja. }\end{array}$ & 73 & 1,81 & 1,10 \\
\hline Ukupno & 73 & 1,69 & 0,92 \\
\hline
\end{tabular}

Tablica 8-9. i Tablica 8-10. pokazuju sljedeće:

- znanja korisnika o prednostima NETCONF standarda u povećanju raspoloživosti R/S uređaja (prosječna ocjena 1,81; std. 1,10) izrazito su manja od znanja iz općih područja računalnih mreža:

○ R/S poduzeća (Enterprise routing/switching) (prosječna ocjena 3,62; std. $1,08)$,

- sigurnost R/S uređaja i računalnih mreža (prosječna ocjena 3,34; std. 1,07),

- R/S davatelja usluga (Service provider routing/switching) (prosječna ocjena $3,21 ;$ std. 1,11$)$, 
○ upravljanje računalnim mrežama (Network management - NM) (prosječna ocjena 3,19 ; std. 0,95$)$,

- znanja korisnika o prednostima NETCONF standarda u povećanju raspoloživosti (prosječna ocjena 1,81; std. 1,10) manja su od znanja tehnologija koje su povezane uz NETCONF:

O softverski definirane mreže (Software Defined Networks - SDN) (prosječna ocjena 2,41; std. 1,19),

○ automatizacija i programiranje računalnih mreža (Automation tools and DevOps) (prosječna ocjena 2,04; std. 1,10),

Važno je napomenuti da su oba navedena područja nastala nekoliko godina poslije NETCONF standarda.

- ukupna znanja korisnika iz NETCONF standarda (prosječna ocjena 1,69; std. 0,92) značajno su manja od ukupnih znanja iz različitih područja računalnih mreža (prosječna ocjena 2,90; std. 0,81).

Sve to pokazuje nisku razinu znanja korisnika o NETCONF protokolu, iako je NETCONF standard raspoloživ korisnicima već više od dvanaest godina (od 2006. godine).

\subsection{Zaključak}

Slijedom rezultata i provedenih testova u ovom poglavlju može se zaključiti sljedeće:

- hipoteza H1 kojom se pretpostavlja da korištenje NETCONF standarda povećava raspoloživost mrežnog $R / S$ uređaja u odnosu na nestandardne CLI metode konfiguriranja mrežnih uređaja prihvaća se kao istinita.

- Hipoteza H2 kojom se pretpostavlja da proizvođači mrežne opreme ne implementiraju NETCONF standard na svojim uređajima odbacuje se kao neistinita.

- Hipoteza H3 kojom se pretpostavlja da korisnici mrežne opreme ne implementiraju NETCONF standard na svojim mrežnim uređajima prihvaća se kao istinita.

- Hipoteza H4 kojom se pretpostavlja da korisnici nedovoljno poznaju prednosti NETCONF standarda u povećanju raspoloživosti mrežnih uređaja odbacuje se kao neistinita. Iako je ova hipoteza odbačena kao neistinita, istraživanje je pokazalo da je 
razina znanja korisnika o poznavanju prednosti NETCONF standardu u povećanju raspoloživosti R/S mrežnih uređaja vrlo niska u usporedbi sa znanjem korisnika iz ostalih područja računalnih mreža. 


\section{Zaključak}

IETF $^{174}$ je definirao NETCONF (Network Configuration Protocol) standard u RFC $4741^{175}$ u prosincu 2006. godine. NETCONF je nastao na temelju zahtjeva mrežnih operatora (koji su definirani u RFC 3535 u lipnju 2002. godine) za standardnim protokolom za konfiguriranje mrežnih uređaja. NETCONF je zatim poboljšan u lipnju 2011. godine u RFC 6241 koji je trenutno aktivan standard.

NETCONF definira mehanizme instaliranja, manipulacije i brisanja konfiguracije mrežnih uređaja. NETCONF koristi RPC poruke, SSH za prijenos poruka između servera i klijenta, ima definiran svoj skup operacija i koristi YANG za modeliranje podataka. NETCONF definira inicijalni osnovni skup operacija i dodatne funkcije (engl. capabilities). Te funkcije su dodatne sposobnosti NETCONF uređaja (klijenta i servera) koje mrežni uređaji mogu, ali ne moraju implementirati.

NETCONF standard je nastao $u$ namjeri da se zamjeni nestandardni CLI pristup konfiguriranja mrežnih uređaja i pruže mogućnosti koje SNMP standard nema. SNMP prikaz podataka nije čitljiv i zbog toga se izuzetno rijetko koristi za konfiguriranje mrežnih uređaja, već se uglavnom SNMP upotrebljava za nadzor. Nestandardne CLI komande i ispis rezultata $\mathrm{R} / \mathrm{S}^{176}$ uređaja različiti su za svakog proizvođača i njegov OS koji koristi, što onemogućava automatiziranje i programabilnost mrežnog upravljanja. U sklopu sekundarnog istraživanja ovog rada napravljena je usporedba između CLI, SNMP i NETCONF pristupa konfiguriranju $\mathrm{R} / \mathrm{S}$ uređaja ${ }^{177}$.

\footnotetext{
${ }^{174}$ IETF (Internet Engineering Task Force) je svjetska standardna organizacija koja definira veliku većinu standarda za Internet i računalne mreže.

${ }^{175}$ RFC (Request For Comment) je dokument (standard) definiran od standardne organizacije IETF.

${ }^{176} \mathrm{R} / \mathrm{S}$ je skraćenica (router/switch, na hrv. usmjernik/preklopnik) koja se često koristi u računalnim mrežama i označava dvije vrste najčešćih mrežnih uređaja koji čine osnovu svake računalne mreže.

${ }^{177}$ Slika 5-1. u poglavlju 5.1.Usporedba metoda konfiguriranja mrežnih uređaja
} 
Na temelju sekundarnog istraživanja provedenog u prvom dijelu rada, definirana su osnovna svojstva (mogućnosti) NETCONF protokola kojima se povećava kvaliteta mrežnog upravljanja (Tablica 9-1.)

\section{Tablica 9-1. Svojstva NETCONF protokola}

\begin{tabular}{|c|}
\hline $\begin{array}{l}\text { NETCONF kao standardni način konfiguracije preko udaljenog pristupa na IP adresu uređaja } \\
\text { gdje je za sve proizvođače ista struktura komandi i podataka. }\end{array}$ \\
\hline $\begin{array}{l}\text { NETCONF kao standard omogućava programabilnost (automatiziranje) koja značajno smanjuje } \\
\text { učestalost ljudske pogreške. }\end{array}$ \\
\hline $\begin{array}{l}\text { NETCONF standard koristi jasnu razliku u strukturi između konfiguracijskih i operacijskih } \\
\text { podataka. }\end{array}$ \\
\hline $\begin{array}{l}\text { Mogućnost parcijalnog konfiguriranja uređaja pomoću NETCONF standarda } \\
\text { - NETCONF postiže pomoću XML jezika i „,XML subtree filtering “ funkcije) }\end{array}$ \\
\hline $\begin{array}{l}\text { Mogućnost provjere konfiguracije prije primjene kod NETCONF načina konfiguriranja uređaja. } \\
\text { - NETCONF postiže provjeru konfiguracijske datoteke pomoću funkcije <validate> }\end{array}$ \\
\hline $\begin{array}{l}\text { Mogućnost zaključavanja konfiguracijske datoteke koje nudi NETCONF. } \\
\text { • NETCONF pomoću operacija „lock“ i „,unlock“ onemogućava istovremenu promjenu } \\
\text { konfiguracijske datoteke iz više izvora (na primjer istovremena druga NETCONF sesija, } \\
\text { CLI pristup ili pristup pomoću SNMP protokola). }\end{array}$ \\
\hline $\begin{array}{l}\text { „Backup \& restore“ mogućnost koju nudi NETCONF standard. } \\
\text { - NETCONF postiže pomoću (1) manipulacije konfiguracijskih datoteka (<running〉, } \\
\langle\text { candidate >, 〈startup > i backup) i (2) pomoću funkcije „Rollback-on-Error“. }\end{array}$ \\
\hline
\end{tabular}

Prikazana svojstva NETCONF protokola mogu povećati raspoloživost R/S uređaja. Pojam raspoloživost (engl. availability) u području računalnih sustava i mreža određuje zahtjev da računalni sustav bude raspoloživ za pristup autoriziranim korisnicima, odnosno da se smanji vrijeme zastoja (neželjeni prekid rada uređaja). Raspoloživost je jedan od triju osnovnih zahtjeva mreža (uz tajnost i integritet) za sigurnost računalnih sustava i mreža.

Novi trendovi razvoja računalnih uređaja i mreža (virtualizacija, centralizacija i mobilnost uređaja) su osnovica nastanka računalstva u oblaku koji sve češće koristi arhitekturu softverski definiranih mreža za upravljanje računalnim mrežama. SDN nudi programabilni pristup upravljanja računalnim mrežama i omogućava efikasniju i jednostavniju instalaciju, upravljanje i praćenje stanja računalnih mreža. Budući da se SDN pristup mrežnom upravljanju brzo razvijao i nastajao iz različitih izvora, IETF je objavio RFC 7426 u siječnju 
2015. u kojem je napravio pregled i sistematizaciju razvoja SDN arhitekture te definirao smjernice za budući razvoj. NETCONF je jedan od osnovnih protokola na kojima se bazira SDN arhitektura definirana u RFC 7426. SDN ima izuzetno veliki utjecaj na današnji razvoj računalnih mreža i uvodi značajne promjene.

IETF je u RFC 6632 napravio klasifikaciju protokola mrežnog upravljanja i pozicionirao ih u tradicionalni FCAPS model. NETCONF je definiran i u toj tradicionalnoj arhitekturi kao osnovni protokol (uz SNMP) za konfiguriranje mrežnih uređaja.

Uvrštavanje NETCONF-a u obje arhitekture (tradicionalnu i noviju SDN) pokazuje da je NETCONF od strane IETF organizacije prepoznat kao optimalan sadašnji, ali i budući osnovni protokol za konfiguriranje mrežnih uređaja.

Trenutni status NETCONF RFC 6410 standarda je "predložen”, a da bi prešao u najviši nivo (status "Internet standard", kakav ima i SNMP) trebala bi postojati široka upotreba tog standarda u praksi od strane korisnika, odnosno RFC treba biti prihvaćen u svakodnevnoj primjeni. Korisnici (mrežni administratori, sistemski inženjeri, arhitekti mrežnih sustava i drugi) odabirom i instalacijom nekog protokola u svojim mrežama određuju važnost i zrelost RFC standarda.

U primarnom istraživanju u ovom radu prikazuje se kolika je stvarna prihvaćenost i primjena NETCONF standarda $u$ današnjim mrežama u Hrvatskoj i koliki je utjecaj NETCONF standarda na povećanje raspoloživosti mrežnih R/S uređaja. Odabir ispitanika i primarno istraživanje u ovom radu su izvedeni kako je određeno i planirano u Prijavi teme doktorskog rada.

Primarno je istraživanje provedeno u tri dijela ${ }^{178}$ :

- polustrukturirani intervju s odabranim svjetskim proizvođačima mrežne opreme. Odabrani su najveći proizvođači (Cisco, HPE, Juniper i Huawei) koji zajedno pokrivaju $82 \%$ tržišta usmjernika i preklopnika u Hrvatskoj. Obavljeno je pet intervjua

\footnotetext{
178 Slika 6-1. prikazuje međusobni odnos proizvođača, partnera i krajnjih korisnika, a Tablica 6-8. prikazuje detaljnije informacije o odabiru ispitanika i njihovih kompanija za istraživanje poglavlje 6.1. Vrste i odabir ispitanika za istraživanje.
} 
sa specijaliziranim inženjerima koji posjeduju najvišu razinu znanja i iskustva za R/S uređaje i tehnologije u svojim kompanijama za područje Hrvatske i regiju.

- Polustrukturirani intervju s odabranim partnerima proizvođača mrežne opreme u Hrvatskoj. Obavljen je intervju s ukupno 7 od 11 najvećih partnera proizvođača mrežne opreme u Hrvatskoj, odnosno s njihovim specijaliziranim inženjerima (s jednim za svakog odabranog partnera) koji posjeduju najviši nivo znanja i iskustva za $\mathrm{R} / \mathrm{S}$ uređaje i tehnologije u svojim kompanijama.

- Strukturirani anketni upitnik za korisnike (partnere i krajnje korisnike) mrežnih uređaja u Hrvatskoj. Odabrani su zaposlenici kompanija u Hrvatskoj koji imaju ili održavaju veće ili važnije računalne mreže u Hrvatskoj. Svi ispitanici (ukupno 73) su (a) korisnici mrežne opreme koji poznaju R/S tehnologiju i rade s R/S uređajima (na različitim vrstama poslova) i (b) koji rade u Hrvatskoj s računalnim mrežama i R/S opremom koja zahtijeva veću raspoloživost (raspoloživost $\geq 99.9 \%$, odnosno vrijeme zastoja godišnje $\leq 8.76$ sati). Ispitanici koji su popunili anketni upitnik rade $\mathrm{u}$ kompanijama koje su partneri u iznosu od 27.40\% (20 ispitanika) i krajnji korisnici (ISP i poduzeća zajedno) u iznosu od 72.60\% (53 ispitanika). Krajnji korisnici rade u kompanijama koje zahtijevaju visoku raspoloživost njihovih računalnih mreža (raspoloživost $\geq 99.9 \%$ ) kao što internetski davatelji usluga, financijske ustanove, državne ustanove i drugi ${ }^{179}$.

Zbog preglednosti, dobiveni rezultati su prikazani za svaku vrstu ispitanika (proizvođači, partneri i korisnici) u četiri dijela: (a) primjena NETCONF standarda kod proizvođača, (b) primjena NETCONF standarda kod korisnika, (c) poznavanje NETCONF standarda od strane korisnika i (d) NETCONF i povećanje raspoloživosti R/S uređaja. Osim toga prikazani su podaci o ispitanicima (korisnicima) i njihovim kompanijama dobiveni anketnim upitnikom. Većina dobivenih rezultata $\mathrm{u}$ radu je testirana upotrebom Wilcoxonovog testa i prezentirana upotrebom metoda deskriptivne statistike.

Sve se vrste ispitanika izrazito slažu da svojstva NETCONF standarda (Tablica 9-1.) pružaju dodatne mogućnosti i prednosti u odnosu na nestandardni CLI pristup konfiguriranja R/S

\footnotetext{
${ }^{179}$ Tablica 6-38. u poglavlju 6.4.Dobiveni podaci od ispitanika (anketni upitnik korisnika).
} 
mrežnih uređaja ${ }^{180}$. Također se izrazito slažu da ta svojstva NETCONF standarda povećavaju raspoloživost R/S mrežnih uređaja ${ }^{181}$. Ispitanici se izrazito slažu i sa sljedećim tvrdnjama ${ }^{182}$ :

- dostupnost NETCONF standarda na uređajima proizvođača važna je za njihovu konkurentnost na tržištu.

- NETCONF standard bi se trebao više koristiti od strane korisnika na R/S uređajima.

- Korištenjem NETCONF standarda povećava se raspoloživost mrežnih uređaja i sustava.

- NETCONF standard bi se trebao više koristiti od strane korisnika na R/S uređajima da bi povećali raspoloživost uređaja i sustava.

- NETCONF pomaže korisnicima u radu kada su u mreži prisutni R/S uređaji različitih proizvođača.

Proizvođači smatraju da postoji dovoljna i raspoloživa dokumentacija i edukacija o NETCONF standardu, a partneri i korisnici se s tim slažu (ali u značajno manjem omjeru) ${ }^{183}$.

Važno je napomenuti da je u sekundarnom istraživanju pokazano da je NETCONF standard izrazito robustan i kvalitetno osmišljen i izrađen protokol te da, po potrebi, pruža mogućnost jednostavnog proširenja protokola (na primjer podatkovnih modela ili funkcija) ${ }^{184}$.

Osim toga, NETCONF je transaction-based protokol, što mu je daje veliku prednost u odnosu na CLI. Drugim riječima, NETCONF je stateful protokol i dovodi sistem u definirano (željeno) stanje ili ga vraća u prethodno stanje. Zbog toga se ne može dogoditi polovična konfiguracija R/S uređaja. Ova karakteristika NETCONF-a omogućava istovremenu konfiguraciju više mrežnih uređaja i uzrok je nekoliko svojstava koje prikazuje Tablica 9-1.

Prema odgovorima ispitanika uzroci neimplementacije NETCONF standarda su sljedeći ${ }^{185}$ :

- nepoznavanje programskih jezika od strane korisnika,

- NETCONF nije dostupan na starijim uređajima i starijem OS koji ga ne podržavaju,

\footnotetext{
${ }^{180}$ Tablica 7-1. u poglavlju 7. Usporedba i dodatna analiza dobivenih rezultata istraživanja.

${ }^{181}$ Tablica 7-2. u poglavlju 7. Usporedba i dodatna analiza dobivenih rezultata istraživanja.

182 Tablica 7-3. u poglavlju 7. Usporedba i dodatna analiza dobivenih rezultata istraživanja.

${ }^{183}$ Tablica 7-4. u poglavlju 7. Usporedba $i$ dodatna analiza dobivenih rezultata istraživanja.

${ }^{184}$ Objašnjeno u poglavlju 7. Usporedba i dodatna analiza dobivenih rezultata istraživanja

${ }^{185}$ Tablica 7-5. u poglavlju 7. Usporedba i dodatna analiza dobivenih rezultata istraživanja.
} 
- strah korisnika od novih tehnologija,

- NETCONF nije potreban jer su krajnji korisnici navikli na OS i CLI proizvođača.

Iz gore navedenih uzroka može se vidjeti da je većina nedostataka povezana s navikama mrežnih administratora i vremenu koje je potrebno da se prihvate promjene, tako da se ne moraju smatrati kao pravi nedostaci NETCONF standarda.

Kao nedostatak ispitanici smatraju i činjenicu da NETCONF standard koristi XML jezik i njegovu sintaksu (koja je redundantna i opširna što može zamarati i zbunjivati korisnika) ${ }^{186}$, odnosno da je rad s nestandardnim CLI sučeljem više „human readable“6187. Ispitanici se umjereno slažu i s tvrdnjom da je RESTCONF bolje rješenje od NETCONF standarda ${ }^{188}$. Sva ova tri nedostatka NETCONF standarda su povezana s (ne)jednostavnošću uporabe, odnosno ispitanici smatraju da NETCONF nije dovoljno user-friendly protokol.

NETCONF standard daje mogućnost proizvođačima da ne podržavaju sve funkcije (na primjer „Candidate“, „Startup“, „Validate“, „Rollback-on-Error“ i druge) pa se u tim slučajevima ne može iskoristiti većina prednosti NETCONF standarda. To su kao nedostatak prepoznali i ispitanici ${ }^{189}$, iako neki smatraju da bi ova karakteristika NETCONF standarda mogla biti i njegova prednost (jer pruža fleksibilnost implementacije). U poglavlju sekundarnog istraživanja 5.3.Testiranje funkcija NETCONF standarda u laboratoriju prikazani su rezultati napravljenog laboratorijskog testa (testirano je 5 različitih R/S uređaja od tri najveća proizvođača) gdje se vidi da:

- svi uređaji podržavaju samo:base1.0 funkciju,

- ni jedan uređaj ne podržava sve dostupne funkcije NETCONF protokola,

- uređaji različitih proizvođača ne podržavaju iste funkcije pa čak i

- različiti uređaji istog proizvođača ne podržavaju iste funkcije.

To može biti vrlo frustrirajuće za korisnike, koji iako imaju R/S uređaje koji podržavaju NETCONF standard, ne mogu od njih dobiti sva svojstva koja povećavaju raspoloživost.

\footnotetext{
${ }^{186}$ Tablica 7-6. u poglavlju 7. Usporedba i dodatna analiza dobivenih rezultata istraživanja.

${ }^{187}$ Tablica 7-7. u poglavlju 7. Usporedba i dodatna analiza dobivenih rezultata istraživanja.

${ }^{188}$ Isto.

189 Tablica 7-6. u poglavlju 7. Usporedba i dodatna analiza dobivenih rezultata istraživanja.
} 
NETCONF ne omogućava direktni pristup preko lokalnog konzolnog pristupa, već je uvijek prvo potrebno konfigurirati uređaj (dodijeliti IP adresu i aktivirati NETCONF i SSH protokole na uređaju) da bi se NETCONF mogao koristiti. Ta početna konfiguracija uređaja izvršava se pomoću CLI komandi i OS sustava proizvođača opreme, a nakon toga se može dalje konfigurirati uređaj pomoću NETCONF standarda spajanjem preko udaljenog pristupa na IP adresu uređaja ${ }^{190}$. To znači da NETCONF ne može potpuno zamijeniti nestandardni CLI pristup. Ipak, NETCONF uporabu CLI pristupa može smanjiti na samo nekoliko komandi koje su potrebne za inicijalnu konfiguraciju ili se može primjenjivati ZTP (Zero Touch Provisioning) ili slični pristupi. Trenutno korisnici najčešće koriste NETCONF za automatiziranje konfiguriranja $\mathrm{R} / \mathrm{S}$ uređaja, a ne kao standard koji zamjenjuje CLI nestandardni pristup.

NETCONF standard je za sada implementiran samo na R/S uređajima nekih vrsta mreža i zbog toga postoji veliki prostor za proširenje primjene. Proizvođači su implementirali NETCONF standard na većini svojih uređaja za ISP, DC i WAN mreže. Postoji značajna mogućnost povećanja implementacije za ostale uređaje, a posebno za SMB uređaje (na primjer za ISP upravljane usluge) i IoT tehnologiju ${ }^{191}$.

Primjena NETCONF standarda od strane korisnika je trenutno izuzetno niska. Korisnici vrlo malo implementiraju NETCONF standard na svojim uređajima različitih proizvođača ${ }^{192}$. Rezultati anketnog upitnika ${ }^{193}$ pokazuju da većina kompanija (od ukupno 73 kompanije ispitanika) ne koristi NETCONF standard na svojim R/S uređajima (65 kompanija; 89,04\%). NETCONF koristi samo 8 kompanija ispitanika (10,96\%). Zbog toga postoji značajna mogućnost širenja primjene NETCONF standarda kod korisnika.

Korisnici imaju vrlo visoki postotak visoko raspoloživih mreža i trenutno se u njima vrlo malo koristi NETCONF. Rezultati intervjua za partnere ${ }^{194}$ pokazuju da $80 \%$ korisnika ima mreže visoke raspoloživosti ( $(99,9 \%)$, a da samo $14,2 \%$ korisnika u svojim mrežama upotrebljava NETCONF. Ova vrijednost dobivena od partnera $(14,2 \%)$ vrlo je blizu odgovoru

\footnotetext{
${ }^{190}$ Objašnjeno u poglavlju 5.1. Usporedba metoda konfiguriranja mrežnih uređaja.

191 Tablica 7-8. u poglavlju 7. Usporedba i dodatna analiza dobivenih rezultata istraživanja.

192 Tablica 7-9. u poglavlju 7. Usporedba i dodatna analiza dobivenih rezultata istraživanja.

${ }^{193}$ Slika 6-8. (18. pitanje) u poglavlju 6.4. Dobiveni podaci od ispitanika (anketni upitnik korisnika).

194 Tablica 6-29. (12. pitanje) u poglavlju. 6.3. Dobiveni podaci od ispitanika (intervju s partnerima)
} 
samih korisnika $(10,96 \%)^{195}$. To pokazuje da postoji veliki prostor za proširenje primjene NETCONF standarda kod korisnika, ali i prijetnju da ako do širenja primjene ne dođe, postoji opasnost da će umjesto NETCONF-a biti implementirano neko drugo rješenje.

U zadnjih nekoliko godina došlo je do značajne potrebe za promjenom u upravljanju R/S uređajima uzrokovane virtualizacijom i mobilnošću današnjih mreža pa su nastale softverski definirane mreže (SDN). Softverski definirane mreže je termin za paradigmu programabilnih mreža. NETCONF je važan sastavni dio SDN arhitekture (kako je definirano u RFC 7426), a SDN se sve više primjenjuje. Korisnici koji koriste SDN mreže, vrlo često primjenjuju i NETCONF protokol (kao sastavni dio SDN proizvoda), a da toga nisu ni svjesni. NETCONF izvršava svoje funkcije u pozadini i prikriven je SDN korisničkom aplikacijom ${ }^{196}$.

Korisnici su izrazili svoje mišljenje o načinima povećanja primjene NETCONF standarda i smatraju da bi proizvođači trebali (a) povećati promociju (edukaciju i informiranje) o NETCONF standardu i povezanim tehnologijama (automatizacija, SDN mreže, programiranje) i (b) implementirati NETCONF standard na svim vrstama R/S uređaja (posebno na SMB uređajima i ISP upravljanim uslugama) ${ }^{197}$.

Tijekom intervjua jedan je ispitanik (zaposlenik partnera u Hrvatskoj s izrazito puno iskustva) naveo mogućnost brisanja konfiguracije na R/S uređaja kao značajno svojstvo NETCONF standarda. Nakon prestanka rada usluge, konfiguracije na uređajima treba obrisati ili dovesti u prethodno stanje. To je ogromni trenutni operativni problem SP-a, a rješenje je moguće pomoću SDN-a (i NETCONF protokola).

Korisnici vrlo malo poznaju NETCONF standard što je velika prijetnja za njegov opstanak. Korisnici imaju izuzetno mala znanja (teoretsko, praktično i u svrhu povećanja raspoloživosti $\mathrm{R} / \mathrm{S}$ uređaja) o NETCONF standardu ${ }^{198}$. Također, korisnici imaju izrazito nisko znanje o svojstvima NETCONF standarda ${ }^{199}$ i njegovim mogućnostima (Tablica 9-1.). Što je izuzetno

\footnotetext{
195 Slika 6-8. (18. pitanje) u poglavlju 6.4. Dobiveni podaci od ispitanika (anketni upitnik korisnika).

${ }^{196}$ SDN i njegova primjena su prikazani u poglavlju 2.6.Trendovi u upravljanju mrežnim uređajima: SDN mreže.

197 Tablica 7-10. u poglavlju 7. Usporedba i dodatna analiza dobivenih rezultata istraživanja.

198 Tablica 7-11. u poglavlju 7. Usporedba i dodatna analiza dobivenih rezultata istraživanja.

${ }^{199}$ Tablica 7-12. u poglavlju 7. Usporedba i dodatna analiza dobivenih rezultata istraživanja.
} 
loše, korisnici rijetko znaju da je NETCONF standard raspoloživ na R/S uređajima ${ }^{200}$ i da ga mogu koristiti. Važno je napomenuti da su inženjeri vrlo često specijalizirani u jednom od dva velika područja primjene R/S uređaja: ISP ili Enterprise. Ispitanici koje rade u ISP području imaju veća znanja i iskustva o NETCONF standardu, dok ispitanici u Enterprise mrežama puno manje (zbog rjeđe primjene i manje potrebe korisnika) ${ }^{201}$.

Većina proizvođača ne podržava NETCONF standard na svim svojim uređajima i OS verzijama. Podrška nekog uređaja za NETCONF ovisi o parametrima tog uređaja (vrsta uređaja, model uređaja, vrsta operacijskog sustava, verzija operacijskog sustava, grupa podržanih funkcionalnosti operacijskog sustava). Zbog čestih promjena tih parametara, vrlo je složeno odrediti koji mrežni uređaji podržavaju NETCONF i u kojoj verziji softvera, a rezultati se skoro svakodnevno mijenjaju ${ }^{202}$.

Korisnici imaju vrlo mala znanja o programiranju i automatiziranju računalnih mreža. Mrežni administratori nisu često upoznati s programskim jezicima ${ }^{203}$. Istraživanje je pokazalo da korisnici posjeduju najviše znanja iz područja općeg programiranja koja su vjerojatno stečena tijekom formalnog ICT obrazovanja, dok imaju puno manja znanja iz ostalih područja programiranja. Zanimljivo je da ispitanici najmanje znanja imaju iz Perl i Tcl programskih jezika koji se koriste za automatizaciju računalnih mreža na tradicionalan način pomoću skripti i prisutni su kao mrežna tehnologija više od dvadeset godina. Čak $76.71 \%$ ispitanika za Perl i $69.86 \%$ za Tcl smatra da ima nedovoljna znanja o tim jezicima. To pokazuje da ispitanici koji rade s računalnim mrežama rijetko koriste programiranje i automatizaciju računalnih mreža i na tradicionalan način.

Područje automatiziranja i programiranja računalnih mreža izuzetno je aktivno i brzo se razvija posljednjih godina. Tako je na primjer Cisco uspostavio DevNet tim koji na svojim stranicama daje detaljne besplatne informacije o različitim MDP tehnologijama, a dostupna je

\footnotetext{
${ }^{200}$ Tablica 6-43. (14. pitanje) u poglavlju 6.4. Dobiveni podaci od ispitanika (anketni upitnik korisnika).

201 Podaci dobiveni tokom intervvjua s proizvođačima i partnerima, na primjer 4. pitanje u poglavlju 6.3.Dobiveni podaci od ispitanika (intervju s partnerima)

${ }^{202}$ Objašnjeno u poglavlju 5.2. Informacije proizvođača o implementaciji NETCONF standarda.

${ }^{203}$ Tablica 6-36. (5. pitanje) u poglavlju 6.4. Dobiveni podaci od ispitanika (anketni upitnik korisnika)..
} 
i oprema na kojoj se može raditi laboratorijsko testiranje ${ }^{204}$. Razvijaju se alternativna i slična rješenja kao NETCONF (kao na primjer RESTCONF i gRPC) koja su korisnicima jednostavnija za uporabu ${ }^{205}$. RESTCONF standard je jednostavniji jer omogućava API sučelje koje je usklađeno s ostalim API sučeljima web aplikacija, ali trenutno nema sva napredna svojstva NETCONF standarda. RESTCONF koristi JSON format podataka koji se često koristi u programske svrhe i teži biti razumljiviji od XML formata. Korisnici vole jednostavnost uporabe. Ipak, $\operatorname{IETF}^{206}$ i $\mathrm{Cisco}^{207}$ ne smatraju da je RESTCONF zamjena za NETCONF, već da se oba standarda mogu koristiti, ovisno o trenutnoj situaciji i zahtjevima (potrebama) korisnika.

Testirane su postavljene hipoteze istraživanja upotrebom Hi kvadrat $\left(\chi^{2}\right)$ testa. Hi kvadrat testom testirala se razlika u strukturi odgovora gdje se u slučaju empirijske p vrijednosti manje od 5\% $(0,05)$ moglo utvrditi da jedna skupina odgovora prevladava u populaciji, dok se u suprotnom donosi zaključak da je u populaciji podjednaka zastupljenost obje odabrane grupe odgovora. Analiza je rađena u statističkom softveru SPSS 25 te se zaključci donose pri graničnoj razini signifikantnosti od 5\%. Dobiveni su sljedeći rezultati ${ }^{208}$ :

- hipoteza H1 kojom se pretpostavlja da korištenje NETCONF standarda povećava raspoloživost mrežnog $R / S$ uređaja u odnosu na nestandardne CLI metode konfiguriranja mrežnih uređaja prihvaća se kao istinita.

- Hipoteza H2 kojom se pretpostavlja da proizvođači mrežne opreme ne implementiraju NETCONF standard na svojim uređajima odbacuje se kao neistinita.

- Hipoteza H3 kojom se pretpostavlja da korisnici mrežne opreme ne implementiraju NETCONF standard na svojim mrežnim uređajima prihvaća se kao istinita.

- Hipoteza H4 kojom se pretpostavlja da korisnici nedovoljno poznaju prednosti NETCONF standarda u povećanju raspoloživosti mrežnih uređaja odbacuje se kao neistinita. Iako je ova hipoteza odbačena kao neistinita, istraživanje je pokazalo da je

\footnotetext{
${ }^{204}$ Cisco DevNet: Cisco APIs, SDKs, Sandbox and Community for Cisco Developers:, https://developer.cisco.com/ (20.5.2019)

${ }^{205}$ Ukratko prikazano u poglavlju 5.4.Alternativna rješenja.

${ }^{206}$ IETF RFC 8040 RESTCONF Protocol (2017) https://tools.ietf.org/html/rfc8040 (15.8.2019).

${ }^{207}$ Cisco DevNet: RESTCONF https://developer.cisco.com/learning/modules/intro-device-level-interfaces/introrestconf/step/2 (20.8.2019).

${ }^{208}$ Testiranje hipoteza je detaljno objašnjeno u poglavlju 8. Testiranje hipoteza.
} 
razina znanja korisnika o poznavanju prednosti NETCONF standardu u povećanju raspoloživosti R/S mrežnih uređaja vrlo niska u usporedbi sa znanjem korisnika iz ostalih područja računalnih mreža.

Važno je i napomenuti da u trenutku nastanka zahtjeva za NETCONF standardom (RFC 3535 u lipnju 2002. godine) i u trenutku njegovog nastanka (RFC 4741 u prosincu 2006. godine), virtualizacija računalnih uređaja i računalstvo u oblaku bili su tek u svom začetku. Iako je početno zamišljen kao zamjena za nestandardni CLI pristup, danas se NETCONF uglavnom koristi za automatiziranje i programabilnost upravljanja računalnih mreža i kao sastavni dio SDN rješenja.

Buduće istraživanje vezano uz NETCONF može biti prošireno na druge zemlje (na primjer na Europsku uniju). Isto tako, u istraživanje se mogu uključiti i druga slična rješenja (na primjer primjena RESTCONF standarda) ili primjena SDN tehnologija u Hrvatskoj ili EU. 


\section{Prilog 1: Pitanja intervjua za proizvođače opreme}

1. Molimo zaokružite koliko imate godina iskustva rada s računalnim mrežama $i$ mrežnim uređajima.
a. 0 - 5 godina
b. 5 - 10 godina
c. 10 - 15 godina
d. 15 - 20 godina
e. 20 - 25 godina
f. više od 25 godina

2. Molimo zaokružite koji je najviši stupanj Vašeg certifikata iz računalnih mreža koji ste položili (ne mora biti aktivan)

a. Nemam položenih certifikata iz računalnih mreža ili imam niže od osnovnih

- na primjer Cisco CCENT ili odgovarajući drugih proizvođača

b. Osnovni (Associate level)

- na primjer Cisco CCNA, Juniper JNCIA, Huawei HCIA ili odgovarajući drugih proizvođača ili istih proizvođača iz drugih mrežnih tehnologija.

c. Srednji (Professional level)

- na primjer Cisco CCNP, Juniper JNCIP, Huawei HCIP ili odgovarajući drugih proizvođača ili istih proizvođača iz drugih mrežnih tehnologija.

d. Najviši (Expert level)

- na primjer Cisco CCIE, Juniper JNCIE, Huawei HCIE ili odgovarajući drugih proizvođača ili istih proizvođača iz drugih mrežnih tehnologija.

e. Ostalo

3. Implementira li Vaša kompanija NETCONF standard definiran u RFC?

DA NE

ZAPAŽANJA: 
4. Povećava li NETCONF standard raspoloživost mrežnih uređaja u odnosu na nestandardne metode konfiguriranja (CLI) koje koriste proizvođači sa svojim operacijskim sustavima (na primjer JUNOS, IOS, EXOS, itd.) i na koji način?

\begin{tabular}{|cccccc|}
\hline \multicolumn{7}{|c|}{ NETCONF standard povećava raspoloživost mrežnog uređaja u odnosu na nestandardne } \\
metode konfiguriranja (CLI)?
\end{tabular}

\begin{tabular}{|c|c|c|c|c|c|c|c|}
\hline 1. & $\begin{array}{l}\text { NETCONF kao standardni način konfiguracije preko udaljenog } \\
\text { pristupa na IP adresu uređaja povećava raspoloživost mrežnih } \\
\text { uređaja zato jer je za sve proizvođače ista struktura komandi i } \\
\text { podataka. }\end{array}$ & $\mathrm{N}$ & 1 & 2 & 3 & 4 & 5 \\
\hline 2. & $\begin{array}{l}\text { NETCONF kao standard povećava raspoloživost jer omogućava } \\
\text { programabilnost (automatiziranje) konfiguriranja mrežnih uređaja } \\
\text { koja značajno smanjuje učestalost ljudske pogreške. }\end{array}$ & $\mathrm{N}$ & 1 & 2 & 3 & 4 & 5 \\
\hline 3. & $\begin{array}{l}\text { NETCONF standard povećava raspoloživost mrežnih uređaja zbog } \\
\text { toga što koristi jasnu razliku u strukturi između konfiguracijskih i } \\
\text { operacijskih podataka. }\end{array}$ & $\mathrm{N}$ & 1 & 2 & 3 & 4 & 5 \\
\hline 4. & $\begin{array}{l}\text { Mogućnost parcijalnog konfiguriranja* uređaja pomoću } \\
\text { NETCONF standarda povećava raspoloživost mrežnih uređaja. } \\
\text { *NETCONF postiže pomoću XML jezika i „XML subtree filtering“ } \\
\text { funkcije }\end{array}$ & $\mathrm{N}$ & 1 & 2 & 3 & 4 & 5 \\
\hline 5. & $\begin{array}{l}\text { Mogućnost provjere konfiguracije prije primjene* kod NETCONF } \\
\text { načina konfiguriranja uređaja povećava raspoloživost mrežnih } \\
\text { uređaja. } \\
\text { *NETCONF postiže provjeru konfiguracijske datoteke pomoću } \\
\text { funkcije <validate> }\end{array}$ & $\mathrm{N}$ & 1 & 2 & 3 & 4 & \\
\hline 6. & $\begin{array}{l}\text { Mogućnost zaključavanja konfiguracijske datoteke* koje nudi } \\
\text { NETCONF povećava raspoloživost mrežnih uređaja. } \\
\text { *NETCONF pomoću operacija „lock“ i ,unlock“ onemogućava } \\
\text { istovremenu promjenu konfiguracijske datoteke iz više izvora (na } \\
\text { primjer istovremena druga NETCONF sesija, CLI pristup ili pristup } \\
\text { pomoću SNMP protokola). }\end{array}$ & $\mathrm{N}$ & 1 & 2 & 3 & 4 & \\
\hline 7. & $\begin{array}{l}\text { „Backup \& restore“** mogućnost koju nudi NETCONF standard } \\
\text { povećava raspoloživost mrežnih uređaja. } \\
\text { *NETCONF postiže pomoću (1) manipulacije konfiguracijskih } \\
\text { datoteka (<running>, <candidate>, <startup> i backup) i (2) pomoću } \\
\text { funkcije „Rollback-on-Error“. }\end{array}$ & $\mathrm{N}$ & 1 & 2 & 3 & 4 & f \\
\hline 8. & $\begin{array}{l}\text { Mogućnost istovremenog i koordiniranog konfiguriranja svih ili } \\
\text { više uređaja* u mreži koje nudi NETCONF povećava raspoloživost } \\
\text { mrežnih uređaja. }\end{array}$ & $\mathrm{N}$ & 1 & 2 & 3 & 4 & \\
\hline
\end{tabular}




\begin{tabular}{|c|l|c|c|c|c|c|c|}
\hline & $\begin{array}{l}\text { *NETCONF postiže pomoću manipulacije konfiguracijskih datoteka } \\
(<\text { running }>,<\text { candidate }>,<\text { startup }>\mathrm{i} \text { backup }) \mathrm{i} \text { pomoću operacija } \\
, \text { lock“ } \mathrm{i}, \text {,unlock“. }\end{array}$ & $\mathrm{N}$ & 1 & 2 & 3 & 4 & 5 \\
\hline 9. & Nešto drugo (molimo navedite) & & & & & & \\
\hline
\end{tabular}

ZAPAŽANJA:: 
5. U kojim vrstama mreža je NETCONF implementiran na R/S (router/switch) uređajima i u kojem postotku od strane Vaše kompanije?

\begin{tabular}{|ccccccc|}
\hline \multicolumn{7}{|c|}{ Implementacija NETCONF standarda na mrežnim uređajima od strane proizvođača } \\
X & Molimo označite svoj stav o navedenim & tvrdnjama, pri čemu je: & \\
& 0 & 1 & 2 & 3 & 4 & 5 \\
(Ne znam jer & $0 \%$ & $1-20 \%$ & $21-40 \%$ & $41-60 \%$ & $61-80 \%$ & $81-100 \%$ \\
trenutno ne radim s & implementira se & & & & & \\
tim vrstama mreža) & NETCONF) & & & & & \\
\hline
\end{tabular}

\begin{tabular}{|c|c|c|c|c|c|c|c|c|}
\hline 1. & $\begin{array}{l}\text { LAN mreže malih i srednjih poduzeća (Small Medium Business - } \\
\text { SMB) }\end{array}$ & $\mathrm{X}$ & 0 & 1 & 2 & 3 & 4 & 5 \\
\hline 2. & LAN mreže većih poduzeća (Enterprise Networks) & $\mathrm{X}$ & 0 & 1 & 2 & 3 & 4 & 5 \\
\hline 3. & WAN mreže većih poduzeća (Enterprise Networks) & $\mathrm{X}$ & 0 & 1 & 2 & 3 & 4 & 5 \\
\hline 4. & $\begin{array}{l}\text { Mreže davatelja usluga (Internet servise provider - ISP)* } \\
\text { *Uključuje sve vrste ISP mreža, na primjer broadband, bežične, } \\
\text { core, access, ... }\end{array}$ & $\mathrm{X}$ & 0 & 1 & 2 & 3 & 4 & 5 \\
\hline 5. & Mreže podatkovnih centara (Data Center - DC) & $\mathrm{X}$ & 0 & 1 & 2 & 3 & 4 & 5 \\
\hline 6. & Mreže internet stvari (IoT) & $\mathrm{X}$ & 0 & 1 & 2 & 3 & 4 & 5 \\
\hline 7. & Nešto drugo (molimo navedite) & $\mathrm{X}$ & 0 & 1 & 2 & 3 & 4 & 5 \\
\hline 8. & Nešto drugo (molimo navedite) & $\mathrm{X}$ & 0 & 1 & 2 & 3 & 4 & 5 \\
\hline 9. & Nešto drugo (molimo navedite) & $\mathrm{X}$ & 0 & 1 & 2 & 3 & 4 & 5 \\
\hline 10. & Nešto drugo (molimo navedite) & $\mathrm{X}$ & 0 & 1 & 2 & 3 & 4 & 5 \\
\hline
\end{tabular}

ZAPAŽANJA: 
6. Koji su glavni razlozi implementacije NETCONF standarda na R/S mrežnim uređajima Vaše kompanije?

\begin{tabular}{|ccccc|}
\hline \multicolumn{5}{|c|}{ Razlozi implementacija NETCONF standarda na mrežnim uređajima od strane proizvođača } \\
\hline \multicolumn{7}{c}{ Molimo označite svoje mišljenje, pri čemu je: } \\
1 & 2 & 3 & 4 & 5 \\
Nevažno & Malo važno & Važno & Vrlo važno & Izuzetno važno \\
\hline
\end{tabular}

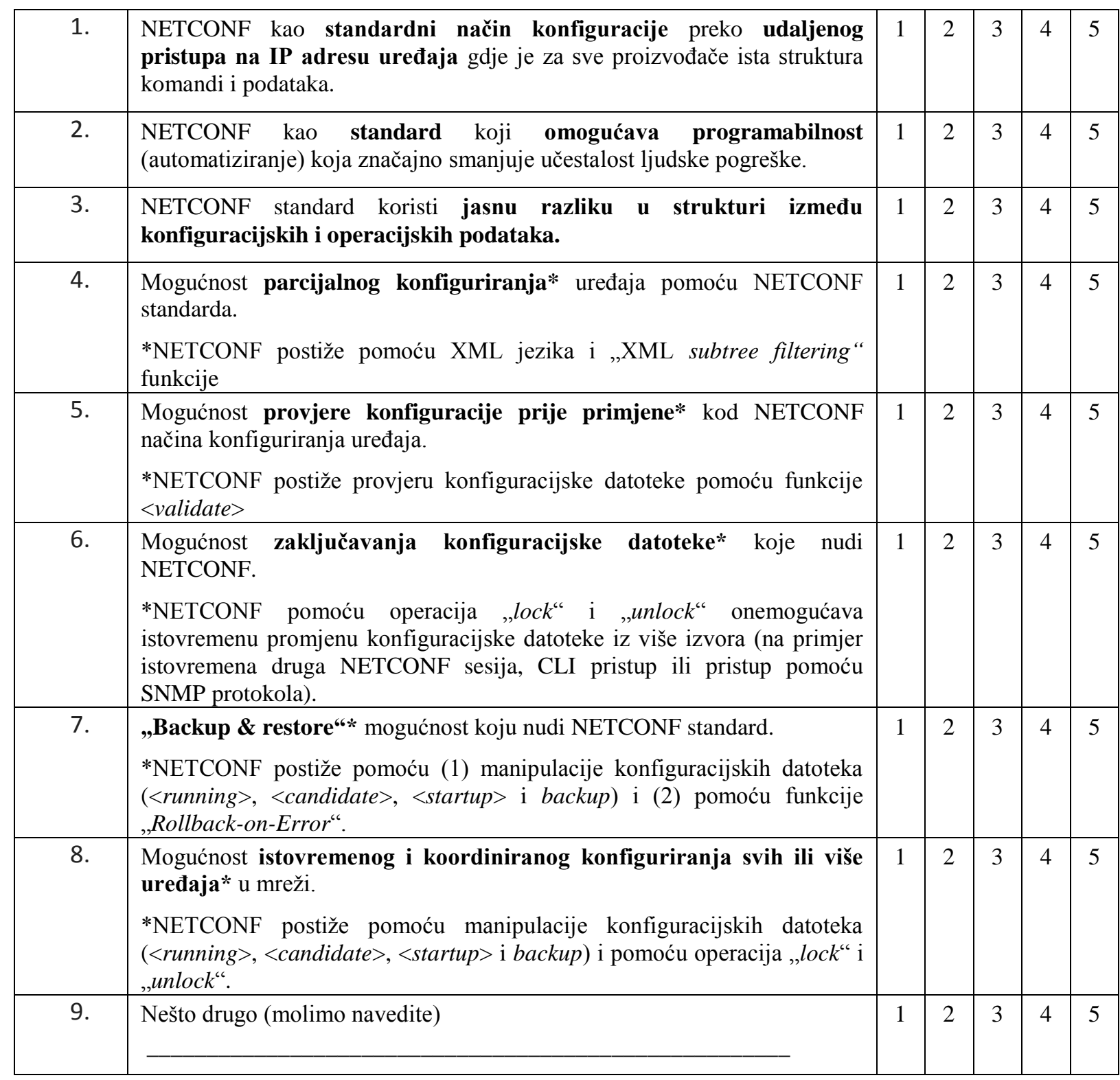


7. Koji su glavni razlozi neimplementacije NETCONF standarda na R/S mrežnim uređajima Vaše kompanije?

\begin{tabular}{|c|cccc|}
\hline \multicolumn{7}{|c|}{ Razlozi neimplementacija NETCONF standarda na mrežnim uređajima od strane proizvođača } \\
1 \\
1
\end{tabular}

\begin{tabular}{|c|l|c|c|c|c|c|}
\hline 1. & Naš CLI je jednostavniji od NETCONF standarda & 1 & 2 & 3 & 4 & 5 \\
\hline 2. & NETCONF nije potreban jer naši korisnici su navikli na naš OS i CLI & 1 & 2 & 3 & 4 & 5 \\
\hline 3. & $\begin{array}{l}\text { NETCONF koristi XML sintaksu koja je redundantna i opširna što može } \\
\text { zamarati i zbunjivati korisnika. }\end{array}$ & 1 & 2 & 3 & 4 & 5 \\
\hline 4. & NETCONF ne daje dovoljno prednosti da bi se implementirao & 1 & 2 & 3 & 4 & 5 \\
\hline 5. & NETCONF nije prihvaćen od korisnika i rijetko se koristi & 1 & 2 & 3 & 4 & 5 \\
\hline 6. & Koristimo RESTCONF koji je bolje standardno rješenje od NETCONF-a & 1 & 2 & 3 & 4 & 5 \\
\hline 7. & Nešto drugo (molimo navedite) & 1 & 2 & 3 & 4 & 5 \\
\hline 8. & Nešto drugo (molimo navedite) & 1 & 2 & 3 & 4 & 5 \\
\hline 9. & Nešto drugo (molimo navedite) & 1 & 2 & 3 & 4 & 5 \\
\hline 10. & Nešto drugo (molimo navedite) & 1 & 2 & 3 & 4 & 5 \\
\hline
\end{tabular}


8. Molimo Vas da izrazite svoje mišljenje o nedostacima NETCONF standarda?

\begin{tabular}{|c|c|c|c|c|}
\hline \multicolumn{5}{|c|}{ Nedostaci NETCONF standarda } \\
\hline \multicolumn{5}{|c|}{ Molimo označite svoje mišljenje, pri čemu je: } \\
\hline 1 & 2 & 3 & 4 & 5 \\
\hline Izrazito se NE slažem & NE slažem se & $\begin{array}{l}\text { Niti se slažem niti se ne } \\
\text { slažem }\end{array}$ & Slažem se & Izrazito se slažem \\
\hline
\end{tabular}

\begin{tabular}{|c|l|c|c|c|c|c|}
\hline 1. & $\begin{array}{l}\text { NETCONF standard daje mogućnost proizvođačima da ne podržavaju } \\
\text { sve funkcije (capability), na primjer „,Candidate“, ,Startup“, ,Validate, } \\
\text { „Rollback-on-Error“ } \mathrm{i} \text { druge pa se ne mogu iskoristiti većina prednosti } \\
\text { standarda. } \\
\text { ZAPAŽANJA: }\end{array}$ & 2 & 3 & 4 & 5 \\
\hline 2. & $\begin{array}{l}\text { NETCONF standard daje mogućnost da se koriste nestandardni } \\
\text { (proprietary) modeli podataka (data models). } \\
\text { ZAPAŽANJA: }\end{array}$ & 1 & 2 & 3 & 4 & 5 \\
\hline 3. & $\begin{array}{l}\text { NETCONF standard daje mogućnost da se definiraju i koriste } \\
\text { nestandardne (proprietary) funkcije (capabilities). } \\
\text { ZAPAŽANJA:__ je }\end{array}$ & 1 & 2 & 3 & 4 & 5 \\
\hline 4. & $\begin{array}{l}\text { NETCONF standard koristi XML jezik i njegovu sintaksu koja je } \\
\text { redundantna i opširna što može zamarati i zbunjivati korisnika. } \\
\text { ZAPAŽANJA: }\end{array}$ & 2 & 3 & 4 & 5 \\
\hline 5. & $\begin{array}{l}\text { Za korištenje NETCONF protokola potrebno je poznavanje programskih } \\
\text { jezika. } \\
\text { ZAPAŽANJA: }\end{array}$ & 1 & 2 & 4 & 5 \\
\hline
\end{tabular}

ZAPAŽANJA: 
9. Slažete li se sa sljedećim tvrdnjama?

\section{Raspoloživa dokumentacija i edukacija o primjeni i korištenju NETCONF standarda od strane proizvođača opreme}

Molimo označite svoj stav, pri čemu je:

1

Ne slažem se
2

Malo se slažem
3

Slažem se
4

Vrlo se

slažem
5

Potpuno se slažem

\begin{tabular}{|c|l|c|c|c|c|c|}
\hline 1. & $\begin{array}{l}\text { Postoji detaljna dokumentacija koja objašnjava rad i primjenu NETCONF } \\
\text { standarda na mrežnim uređajima Vašeg proizvođača: upute (manuals), } \\
\text { preporuke za uporabu (white papers), i slično. } \\
\text { ZAPAŽANJA: }\end{array}$ & 2 & 3 & 4 & 5 \\
\hline 2. & $\begin{array}{l}\text { Postoje tečajevi za samostalno učenje (CBT, Webinar, i slično) koji u } \\
\text { potpunosti podučavaju korisnike uporabi i primjeni NETCONF standarda } \\
\text { na mrežnim uređajima Vašeg proizvođača. } \\
\text { ZAPAŽANJA: }\end{array}$ & 2 & 3 & 4 & 5 \\
\hline 3. & $\begin{array}{l}\text { Postoje organizirani tečajevi vođeni od instruktora koji detaljno } \\
\text { podučavaju korisnike uporabi i primjeni NETCONF standarda na mrežnim } \\
\text { uređajima Vašeg proizvođača. } \\
\text { ZAPAŽANJA: }\end{array}$ & 2 & 3 & 4 & 5 \\
\hline 4. & $\begin{array}{l}\text { Postoje certifikacijski ispiti (i pripadajući tečajevi) koji detaljno } \\
\text { osposobljavaju korisnike uporabi i primjeni NETCONF standarda na } \\
\text { mrežnim uređajima Vašeg proizvođača. } \\
\text { ZAPAŽANJA: }\end{array}$ & 2 & 3 & 4 & 5 \\
\hline
\end{tabular}

ZAPAŽANJA: 
10. Slažete li se sa sljedećim tvrdnjama?

\begin{tabular}{|c|c|c|c|c|}
\hline & & Ostala pitanja & & \\
\hline & Mo & označite svoj stav, pri če & & \\
\hline & 2 & 3 & 4 & 5 \\
\hline Izrazito se NE slažem & NE slažem se & $\begin{array}{l}\text { Niti se slažem niti se ne } \\
\text { slažem }\end{array}$ & Slažem se & Izrazito se slažem \\
\hline
\end{tabular}

\begin{tabular}{|c|l|c|c|c|c|c|}
\hline 1. & $\begin{array}{l}\text { Primjena NETCONF standarda na R/S uređajima našeg proizvođača je } \\
\text { važna za konkurentnost na tržištu. } \\
\text { ZAPAŽANJA: }\end{array}$ & 2 & 3 & 4 & 5 \\
\hline 2. & $\begin{array}{l}\text { NETCONF standard bi se trebao više koristiti od strane Vaših korisnika na } \\
\text { R/S uređajima. } \\
\text { ZAPAŽANJA: }\end{array}$ & 1 & 2 & 3 & 4 & 5 \\
\hline 3. & $\begin{array}{l}\text { Korištenjem NETCONF standarda povećava se raspoloživost mrežnih } \\
\text { uređaja i sustava. } \\
\text { ZAPAŽANJA: }\end{array}$ & 1 & 2 & 3 & 4 & 5 \\
\hline 4. & $\begin{array}{l}\text { NETCONF standard bi se trebao više koristiti od strane Vaših korisnika na } \\
\text { R/S uređajima da bi povećali raspoloživost uređaja i sustava. } \\
\text { ZAPAŽANJA: }\end{array}$ & 1 & 2 & 3 & 4 & 5 \\
\hline 5. & $\begin{array}{l}\text { RESTCONF standard (definiran u RFC 8040 u siječnju 2017.) je bolje } \\
\text { rješenje za konfiguraciju mrežnih uređaja od NETCONF standarda. } \\
\text { ZAPAŽANJA: }\end{array}$ & 1 & 2 & 3 & 4 & 5 \\
\hline
\end{tabular}

\section{ZAPAŽANJA:}

11. Slažete li se s tvrdnjom da sve vrste R/S uređaja (na primjer od malih SMB uređaja do velikih ISP uređaja) trebaju imati implementiran NETCONF standarda?
DA
$\mathrm{NE}$

\section{ZAPAŽANJA:}


12. Na koji način mislite da bi se mogla povećati primjena NETCONF standarda?

13. Na koji način mislite da bi se mogao poboljšati NETCONF standard?

14. Na koji način Vi vidite buduću primjenu i razvoj NETCONF standarda?

15. Molimo Vas da izložite svoja dodatna zapažanja i mišljenje vezana uz primjenu NETCONF standarda, a koja nisu obrađena u prethodnim pitanjima:

16. Molimo Vas da izložite svoja dodatna zapažanja i mišljenje vezana uz primjenu NETCONF standarda i povećanje raspoloživosti mrežnih uređaja, a koja nisu obrađena u prethodnim pitanjima:

17. Imate li Vi kakvih pitanja za mene ili dodatnih opažanja? 


\section{Prilog 2: Pitanja intervjua za partnere u Hrvatskoj}

1. Molimo zaokružite koliko imate godina iskustva rada $\mathbf{s}$ računalnim mrežama $\mathrm{i}$ mrežnim uređajima.
a. 0 - 5 godina
b. 5 - 10 godina
c. 10 - 15 godina
d. 15 - 20 godina
e. 20 - 25 godina
f. više od 25 godina

2. Molimo zaokružite koji je najviši stupanj Vašeg certifikata iz računalnih mreža koji ste položili (ne mora biti aktivan)

a. Nemam položenih certifikata iz računalnih mreža ili imam niže od osnovnih

- na primjer Cisco CCENT ili odgovarajući drugih proizvođača

b. Osnovni (Associate level)

- na primjer Cisco CCNA, Juniper JNCIA, Huawei HCIA ili odgovarajući drugih proizvođača ili istih proizvođača iz drugih mrežnih tehnologija.

c. Srednji (Professional level)

- na primjer Cisco CCNP, Juniper JNCIP, Huawei HCIP ili odgovarajući drugih proizvođača ili istih proizvođača iz drugih mrežnih tehnologija.

d. Najviši (Expert level)

- na primjer Cisco CCIE, Juniper JNCIE, Huawei HCIE ili odgovarajući drugih proizvođača ili istih proizvođača iz drugih mrežnih tehnologija.

e. Ostalo 
3. Povećava li NETCONF standard raspoloživost mrežnih uređaja u odnosu na nestandardne metode konfiguriranja (CLI) koje koriste proizvođači sa svojim operacijskim sustavima (na primjer JUNOS, IOS, EXOS, i dr.) i na koji način?

\begin{tabular}{|cccccc|}
\hline \multicolumn{6}{|c|}{ NETCONF standard povećava raspoloživost mrežnog uređaja u odnosu na nestandardne } \\
metode konfiguriranja (CLI)?
\end{tabular}

\begin{tabular}{|c|c|c|c|c|c|c|c|}
\hline 1. & $\begin{array}{l}\text { NETCONF kao standardni način konfiguracije preko udaljenog } \\
\text { pristupa na IP adresu uređaja povećava raspoloživost mrežnih } \\
\text { uređaja zato jer je za sve proizvođače ista struktura komandi i } \\
\text { podataka. }\end{array}$ & $\mathrm{N}$ & 1 & 2 & 3 & 4 & 5 \\
\hline 2. & $\begin{array}{l}\text { NETCONF kao standard povećava raspoloživost jer omogućava } \\
\text { programabilnost (automatiziranje) konfiguriranja mrežnih uređaja } \\
\text { koja značajno smanjuje učestalost ljudske pogreške. }\end{array}$ & $\mathrm{N}$ & 1 & 2 & 3 & 4 & 5 \\
\hline 3. & $\begin{array}{l}\text { NETCONF standard povećava raspoloživost mrežnih uređaja zbog } \\
\text { toga što koristi jasnu razliku u strukturi između konfiguracijskih i } \\
\text { operacijskih podataka. }\end{array}$ & $\mathrm{N}$ & 1 & 2 & 3 & 4 & 5 \\
\hline 4. & $\begin{array}{l}\text { Mogućnost parcijalnog konfiguriranja* uređaja pomoću NETCONF } \\
\text { standarda povećava raspoloživost mrežnih uređaja. } \\
\text { *NETCONF postiže pomoću XML jezika i „XML subtree filtering“ } \\
\text { funkcije }\end{array}$ & $\mathrm{N}$ & 1 & 2 & 3 & 4 & 5 \\
\hline 5. & $\begin{array}{l}\text { Mogućnost provjere konfiguracije prije primjene* kod NETCONF } \\
\text { načina konfiguriranja uređaja povećava raspoloživost mrežnih uređaja. } \\
\text { *NETCONF postiže provjeru konfiguracijske datoteke pomoću } \\
\text { funkcije }\langle\text { validate }>\end{array}$ & $\mathrm{N}$ & 1 & 2 & 3 & 4 & 5 \\
\hline 6. & $\begin{array}{l}\text { Mogućnost zaključavanja konfiguracijske datoteke* koje nudi } \\
\text { NETCONF povećava raspoloživost mrežnih uređaja. } \\
\text { *NETCONF pomoću operacija „lock“ i ,unlock“ onemogućava } \\
\text { istovremenu promjenu konfiguracijske datoteke iz više izvora (na } \\
\text { primjer istovremena druga NETCONF sesija, CLI pristup ili pristup } \\
\text { pomoću SNMP protokola). }\end{array}$ & $\mathrm{N}$ & 1 & 2 & 3 & 4 & 5 \\
\hline 7. & $\begin{array}{l}\text { „Backup \& restore“** mogućnost koju nudi NETCONF standard } \\
\text { povećava raspoloživost mrežnih uređaja. } \\
\text { *NETCONF postiže pomoću (1) manipulacije konfiguracijskih } \\
\text { datoteka (<running >, <candidate }>,<\text { startup }>\text { i backup) i (2) pomoću } \\
\text { funkcije „,Rollback-on-Error“. }\end{array}$ & $\mathrm{N}$ & 1 & 2 & 3 & 4 & 5 \\
\hline
\end{tabular}




\begin{tabular}{|c|c|c|c|c|c|c|c|}
\hline 8. & $\begin{array}{l}\text { Mogućnost istovremenog i koordiniranog konfiguriranja svih ili } \\
\text { više uređaja* u mreži koje nudi NETCONF povećava raspoloživost } \\
\text { mrežnih uređaja. } \\
\text { *NETCONF postiže pomoću manipulacije konfiguracijskih datoteka } \\
(<\text { running }>\text {, <candidate >, <startup > i backup) i pomoću operacija } \\
\text { „lock“ i ,unlock“. }\end{array}$ & $\mathrm{N}$ & 1 & 2 & 3 & 4 & 5 \\
\hline 9. & Nešto drugo (molimo navedite) & $\mathrm{N}$ & 1 & 2 & 3 & 4 & 5 \\
\hline
\end{tabular}

ZAPAŽANJA:: 
4. U kojim vrstama mreža koristite NETCONF na R/S (router/switch) mrežnim uređajima i u kojem postotku od strane Vaših korisnika?

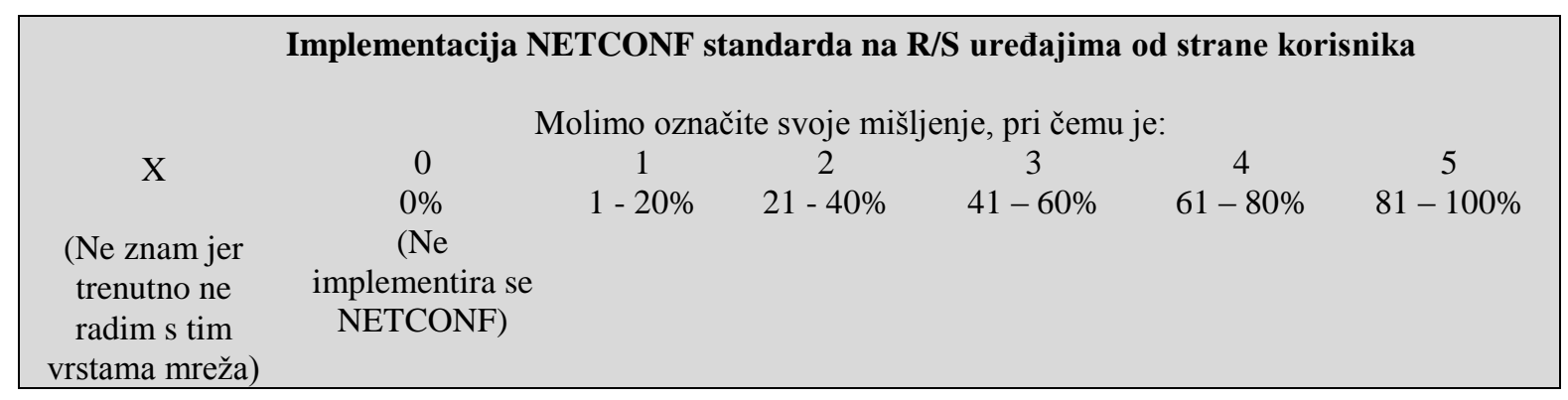

\begin{tabular}{|c|c|c|c|c|c|c|c|c|}
\hline 1. & $\begin{array}{l}\text { LAN mreže malih i srednjih poduzeća (Small Medium Business - } \\
\text { SMB) }\end{array}$ & $\mathrm{X}$ & 0 & 1 & 2 & 3 & 4 & 5 \\
\hline 2. & LAN mreže većih poduzeća (Enterprise Networks) & $\mathrm{X}$ & 0 & 1 & 2 & 3 & 4 & 5 \\
\hline 3. & WAN mreže većih poduzeća (Enterprise Networks) & $\mathrm{X}$ & 0 & 1 & 2 & 3 & 4 & 5 \\
\hline 4. & $\begin{array}{l}\text { Mreže davatelja usluga (Internet servise provider - ISP)* } \\
\text { *Uključuje sve vrste ISP mreža, na primjer broadband, bežične, } \\
\text { core, access, ... }\end{array}$ & $\mathrm{X}$ & 0 & 1 & 2 & 3 & 4 & 5 \\
\hline 5. & Mreže podatkovnih centara (Data Center - DC) & $\mathrm{X}$ & 0 & 1 & 2 & 3 & 4 & 5 \\
\hline 6. & Mreže internet stvari (IoT) & $\mathrm{X}$ & 0 & 1 & 2 & 3 & 4 & 5 \\
\hline 7. & Nešto drugo (molimo navedite) & $\mathrm{X}$ & 0 & 1 & 2 & 3 & 4 & 5 \\
\hline 8. & Nešto drugo (molimo navedite) & $\mathrm{X}$ & 0 & 1 & 2 & 3 & 4 & 5 \\
\hline 9. & Nešto drugo (molimo navedite) & $\mathrm{X}$ & 0 & 1 & 2 & 3 & 4 & 5 \\
\hline 10. & Nešto drugo (molimo navedite) & $\mathrm{X}$ & 0 & 1 & 2 & 3 & 4 & 5 \\
\hline
\end{tabular}

ZAPAŽANJA: 
5. Od kojih proizvođača dolaze R/S (router/switch) mrežni uređaji i u kojem postotku su instalirani u mrežama Vaših korisnika?

\section{Primjena R/S mrežnih uređaja od više proizvođača}

Molimo označite svoje mišljenje, pri čemu je:

$\begin{array}{cccccc}0 & 1 & 2 & 3 & 4 & 5 \\ 0 \% & 1-20 \% & 21-40 \% & 41-60 \% & 61-80 \% & 81-100 \%\end{array}$

(Ne implementira)

\begin{tabular}{|c|l|c|c|c|c|c|c|}
\hline 1. & Arista & 0 & 1 & 2 & 3 & 4 & 5 \\
\hline 2. & Cisco Systems & 0 & 1 & 2 & 3 & 4 & 5 \\
\hline 3. & Extreme Networks & 0 & 1 & 2 & 3 & 4 & 5 \\
\hline 4. & F5 & 0 & 1 & 2 & 3 & 4 & 5 \\
\hline 5. & Hewlett Packard Enterprise & 0 & 1 & 2 & 3 & 4 & 5 \\
\hline 6. & Huawei & 0 & 1 & 2 & 3 & 4 & 5 \\
\hline 7. & Juniper Networks & 0 & 1 & 2 & 3 & 4 & 5 \\
\hline 8. & & 0 & 1 & 2 & 3 & 4 & 5 \\
\hline 9. & & 0 & 1 & 2 & 3 & 4 & 5 \\
\hline 10. & & 0 & 1 & 2 & 3 & 4 & 5 \\
\hline
\end{tabular}

ZAPAŽANJA: 
6. Na R/S (router/switch) uređajima kojih proizvođača koristite NETCONF i u kojem postotku?

\begin{tabular}{|c|c|c|c|c|c|c|}
\hline & \multicolumn{6}{|c|}{ Primjena NETCONF standarda na R/S uređajima proizvođača od strane korisnika } \\
\hline \multicolumn{7}{|c|}{ Molimo označite svoje mišljenje, pri čemu je: } \\
\hline $\mathrm{X}$ & $\begin{array}{c}0 \\
0 \%\end{array}$ & 1 & 2 & 3 & $\begin{array}{c}4 \\
61-80 \%\end{array}$ & $\begin{array}{l}5 \\
81-100 \%\end{array}$ \\
\hline $\begin{array}{l}\text { (Ne koristi se } \\
\text { oprema od tog } \\
\text { proizvođača u } \\
\text { mreži) }\end{array}$ & $\begin{array}{c}0 \% \\
\text { (Ne implementira } \\
\text { se NETCONF) }\end{array}$ & $1-20 \%$ & $21-40 \%$ & $41-60 \%$ & $61-80 \%$ & $81-100 \%$ \\
\hline
\end{tabular}

\begin{tabular}{|c|l|c|c|c|c|c|c|c|}
\hline 1. & Arista & $X$ & 0 & 1 & 2 & 3 & 4 & 5 \\
\hline 2. & Cisco Systems & $X$ & 0 & 1 & 2 & 3 & 4 & 5 \\
\hline 3. & Extreme Networks & $X$ & 0 & 1 & 2 & 3 & 4 & 5 \\
\hline 4. & F5 & $X$ & 0 & 1 & 2 & 3 & 4 & 5 \\
\hline 5. & Hewlett Packard Enterprise & $X$ & 0 & 1 & 2 & 3 & 4 & 5 \\
\hline 6. & Huawei & $X$ & 0 & 1 & 2 & 3 & 4 & 5 \\
\hline 7. & Juniper Networks & $X$ & 0 & 1 & 2 & 3 & 4 & 5 \\
\hline 8. & & $X$ & 0 & 1 & 2 & 3 & 4 & 5 \\
\hline 9. & & $X$ & 0 & 1 & 2 & 3 & 4 & 5 \\
\hline 10. & & $X$ & 0 & 1 & 2 & 3 & 4 & 5 \\
\hline
\end{tabular}

ZAPAŽANJA: 
7. Koji su glavni razlozi implementacije NETCONF standarda na R/S mrežnim uređajima Vaših korisnika?

\begin{tabular}{|cccccc|}
\hline \multicolumn{7}{|c|}{ Razlozi implementacija NETCONF standarda na R/S uređajima od strane korisnika } \\
\multicolumn{7}{|c}{ Molimo označite svoje mišljenje, pri čemu je: } \\
1 & 2 & 3 & 4 & 5 \\
Nevažno & Malo važno & Važno & Vrlo važno & Izuzetno važno \\
\hline
\end{tabular}

\begin{tabular}{|c|c|c|c|c|c|c|}
\hline 1. & $\begin{array}{l}\text { NETCONF kao standardni način konfiguracije preko udaljenog } \\
\text { pristupa na IP adresu uređaja gdje je za sve proizvođače ista } \\
\text { struktura komandi i podataka. }\end{array}$ & 1 & 2 & 3 & 4 & 5 \\
\hline 2. & $\begin{array}{l}\text { NETCONF kao standard jer omogućava programabilnost } \\
\text { (automatiziranje) koja značajno smanjuje učestalost ljudske pogreške. }\end{array}$ & 1 & 2 & 3 & 4 & 5 \\
\hline 3. & $\begin{array}{l}\text { NETCONF standard koristi jasnu razliku u strukturi između } \\
\text { konfiguracijskih i operacijskih podataka. }\end{array}$ & 1 & 2 & 3 & 4 & 5 \\
\hline 4. & $\begin{array}{l}\text { Mogućnost parcijalnog konfiguriranja* uređaja pomoću NETCONF } \\
\text { standarda. } \\
\text { *NETCONF postiže pomoću XML jezika i „XML subtree filtering“ } \\
\text { funkcije }\end{array}$ & 1 & 2 & 3 & 4 & $J$ \\
\hline 5. & $\begin{array}{l}\text { Mogućnost provjere konfiguracije prije primjene* kod NETCONF } \\
\text { načina konfiguriranja uređaja. } \\
\text { *NETCONF postiže provjeru konfiguracijske datoteke pomoću } \\
\text { funkcije }\langle\text { validate }>\end{array}$ & 1 & 2 & 3 & 4 & 5 \\
\hline 6. & $\begin{array}{l}\text { Mogućnost zaključavanja konfiguracijske datoteke* koje nudi } \\
\text { NETCONF. } \\
\text { *NETCONF pomoću operacija „lock“ i „,unlock“ onemogućava } \\
\text { istovremenu promjenu konfiguracijske datoteke iz više izvora (na } \\
\text { primjer istovremena druga NETCONF sesija, CLI pristup ili pristup } \\
\text { pomoću SNMP protokola). }\end{array}$ & 1 & 2 & 3 & 4 & 5 \\
\hline 7. & $\begin{array}{l}\text { „Backup \& restore““* mogućnost koju nudi NETCONF standard. } \\
\text { *NETCONF postiže pomoću (1) manipulacije konfiguracijskih } \\
\text { datoteka (<running }>,<\text { candidate }\rangle,<\text { startup }>\text { i backup) i (2) pomoću } \\
\text { funkcije „Rollback-on-Error“. }\end{array}$ & 1 & 2 & 3 & 4 & 5 \\
\hline 8. & $\begin{array}{l}\text { Mogućnost istovremenog i koordiniranog konfiguriranja svih ili } \\
\text { više uređaja* u mreži. } \\
\text { *NETCONF postiže pomoću manipulacije konfiguracijskih datoteka } \\
(<\text { running >, <candidate>, <startup > i backup) i pomoću operacija } \\
\text { „lock" i , ,unlock“. }\end{array}$ & 1 & 2 & 3 & 4 & 5 \\
\hline 9. & Nešto drugo (molimo navedite) & 1 & 2 & 3 & 4 & \\
\hline
\end{tabular}


8. Koji su glavni razlozi neimplementacije NETCONF standarda na R/S mrežnim uređajima Vaših korisnika?

\begin{tabular}{|cccccc|}
\hline \multicolumn{5}{|c|}{ Razlozi neimplementacija NETCONF standarda na R/S uređajima od strane korisnika } \\
\multicolumn{7}{|c}{ Molimo označite svoje mišljenje, pri čemu je: } \\
11 & 2 & 3 & 4 & 5 \\
Nevažno & Malo važno & Važno & Vrlo važno & Izuzetno važno \\
\hline
\end{tabular}

\begin{tabular}{|c|c|c|c|c|c|c|}
\hline 1. & CLI proizvođača je jednostavniji od NETCONF standarda & 1 & 2 & 3 & 4 & 5 \\
\hline 2. & $\begin{array}{l}\text { NETCONF nije potreban jer su krajnji korisnici navikli na OS i CLI } \\
\text { proizvođača }\end{array}$ & 1 & 2 & 3 & 4 & 5 \\
\hline 3. & $\begin{array}{l}\text { NETCONF koristi XML sintaksu koja je redundantna i opširna što } \\
\text { može zamarati i zbunjivati korisnika. }\end{array}$ & 1 & 2 & 3 & 4 & 5 \\
\hline 4. & $\begin{array}{l}\text { Krajnji korisnici koriste RESTCONF koji je bolje standardno rješenje } \\
\text { od NETCONF-a }\end{array}$ & 1 & 2 & 3 & 4 & 5 \\
\hline 5. & $\begin{array}{l}\text { NETCONF nije dostupan na starijim uređajima i starijem OS koji ga ne } \\
\text { podržavaju }\end{array}$ & 1 & 2 & 3 & 4 & 5 \\
\hline 6. & Nepoznavanje programskih jezika od strane korisnika & 1 & 2 & 3 & 4 & 5 \\
\hline 7. & $\begin{array}{l}\text { Proizvođači ne podržavaju sve funkcije (capability), na primjer } \\
\text { „Candidate“, „Startup“, ,Validate“, ,Rollback-on-Error" i druge pa se } \\
\text { ne može iskoristiti većina prednosti standarda. }\end{array}$ & 1 & 2 & 3 & 4 & 5 \\
\hline 8. & $\begin{array}{l}\text { Potrebni dodatni alati (na primjer NETCONF browser ili aplikacija u } \\
\text { Pythonu) }\end{array}$ & 1 & 2 & 3 & 4 & 5 \\
\hline 9. & Strah od novih tehnologija & 1 & 2 & 3 & 4 & 5 \\
\hline 10. & Nešto drugo (molimo navedite) & 1 & 2 & 3 & 4 & 5 \\
\hline
\end{tabular}

ZAPAŽANJA: 
9. Molimo Vas da izrazite svoje mišljenje o nedostacima NETCONF standarda?

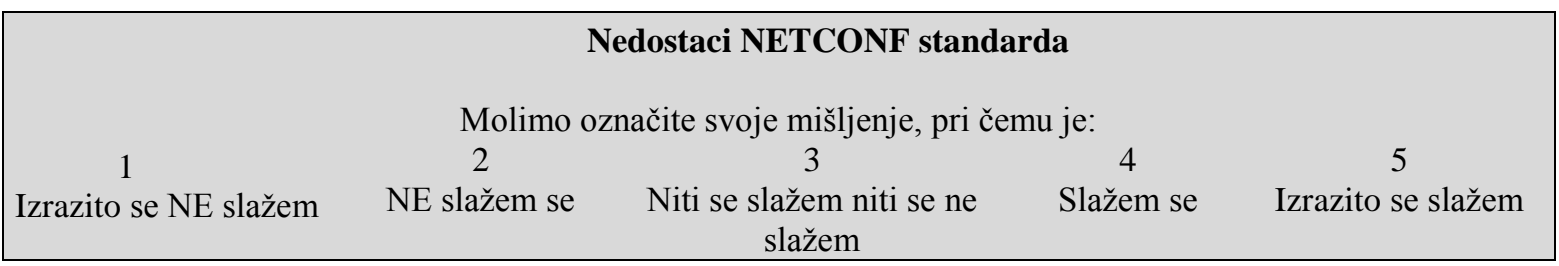

\begin{tabular}{|c|c|c|c|c|c|c|}
\hline 1. & $\begin{array}{l}\text { NETCONF standard daje mogućnost proizvođačima da ne podržavaju } \\
\text { sve funkcije (capability), na primjer "Candidate“, "Startup“, } \\
\text { „Validate“, „Rollback-on-Error“ i druge pa se ne može iskoristiti } \\
\text { većina prednosti standarda. } \\
\text { ZAPAŽANJA: }\end{array}$ & 1 & 2 & 3 & 4 & 5 \\
\hline 2. & $\begin{array}{l}\text { NETCONF standard daje mogućnost da se koriste nestandardni } \\
\text { (proprietary) modeli podataka (data models). } \\
\text { ZAPAŽANJA: }\end{array}$ & 1 & 2 & 3 & 4 & 5 \\
\hline 3. & $\begin{array}{l}\text { NETCONF standard daje mogućnost da se definiraju i koriste } \\
\text { nestandardne (proprietary) funkcije (capabilities). } \\
\text { ZAPAŽANJA: }\end{array}$ & 1 & 2 & 3 & 4 & 5 \\
\hline 4. & $\begin{array}{l}\text { NETCONF standard koristi XML jezik i njegovu sintaksu koja je } \\
\text { redundantna i opširna što može zamarati i zbunjivati korisnika. } \\
\text { ZAPAŽANJA: }\end{array}$ & 1 & 2 & 3 & 4 & 5 \\
\hline 5. & $\begin{array}{l}\text { Za korištenje NETCONF protokola potrebno je poznavanje } \\
\text { programskih jezika. } \\
\text { ZAPAŽANJA: }\end{array}$ & 1 & 2 & 3 & 4 & 5 \\
\hline
\end{tabular}

ZAPAŽANJA: 
10. Slažete li se sa sljedećim tvrdnjama?

\begin{tabular}{|c|cccc|}
\hline \multicolumn{4}{|c|}{ Raspoloživa dokumentacija i edukacija o primjeni i korištenju NETCONF standarda od } \\
strane proizvođača opreme
\end{tabular}

\begin{tabular}{|c|c|c|c|c|c|c|}
\hline 1. & $\begin{array}{l}\text { Postoji detaljna dokumentacija proizvođača koja objašnjava rad i } \\
\text { primjenu NETCONF standarda na mrežnim uređajima: upute } \\
\text { (manuals), preporuke za uporabu (white papers), i slično. } \\
\text { ZAPAŽANJA: }\end{array}$ & 1 & 2 & 3 & 4 & 5 \\
\hline 2. & $\begin{array}{l}\text { Postoje tečajevi proizvođača za samostalno učenje (CBT, Webinar, i } \\
\text { slično) koji u potpunosti podučavaju korisnike uporabi i primjeni } \\
\text { NETCONF standarda na mrežnim uređajima. } \\
\text { ZAPAŽANJA: }\end{array}$ & 1 & 2 & 3 & 4 & 5 \\
\hline 3. & $\begin{array}{l}\text { Postoje organizirani tečajevi proizvođača vođeni od instruktora koji } \\
\text { detaljno podučavaju korisnike uporabi i primjeni NETCONF standarda } \\
\text { na mrežnim uređajima. } \\
\text { ZAPAŽANJA: }\end{array}$ & 1 & 2 & 3 & 4 & 5 \\
\hline 4. & $\begin{array}{l}\text { Postoje certifikacijski ispiti (i pripadajući tečajevi) proizvođača koji } \\
\text { detaljno osposobljavaju korisnike uporabi i primjeni NETCONF } \\
\text { standarda na mrežnim uređajima. } \\
\text { ZAPAŽANJA: }\end{array}$ & 1 & 2 & 3 & 4 & 5 \\
\hline
\end{tabular}


11. Koji postotak po vrstama mreža Vaših korisnika po Vašem mišljenju zahtijeva raspoloživost jednaku ili veću od ,tri devetke“ ( $\geq$ raspoloživosti od 99,9\%),odnosno vrijeme zastoja manje od 8,76 sati godišnje ili 43,2 minute mjesečno ili 10,1 minutu tjedno)?

\section{Visoko raspoložive mreže korisnika}

Molimo označite svoje mišljenje, pri čemu je:

$\begin{array}{cccccc}0 & 1 & 2 & 3 & 4 & 5 \\ 0 \% & 1-20 \% & 21-40 \% & 41-60 \% & 61-80 \% & 81-100 \%\end{array}$

\begin{tabular}{|c|c|c|c|c|c|c|c|}
\hline 1. & Financijske ustanove (banke i slično) & 0 & 1 & 2 & 3 & 4 & 5 \\
\hline 2. & Podatkovni centri & 0 & 1 & 2 & 3 & 4 & 5 \\
\hline 3. & Internet davatelji usluga (na primjer $\mathrm{T}$-com, $\mathrm{A} 1, \ldots$ ) & 0 & 1 & 2 & 3 & 4 & 5 \\
\hline 4. & Medijske ustanove (TV, radio, časopisi, ....) & 0 & 1 & 2 & 3 & 4 & 5 \\
\hline 5. & Edukacijske ustanove (škole, fakulteti, ...) & 0 & 1 & 2 & 3 & 4 & 5 \\
\hline 6. & Trgovine (trgovački lanci, trgovački centri, ...) & 0 & 1 & 2 & 3 & 4 & 5 \\
\hline 7. & On-line trgovine (e-kupi, „ulaznice.hr“, ...) & 0 & 1 & 2 & 3 & 4 & 5 \\
\hline 8. & Transport (zračne luke, željeznica, ...) & 0 & 1 & 2 & 3 & 4 & 5 \\
\hline 9. & Zdravstvene ustanove (bolnice, ambulante, ...) & 0 & 1 & 2 & 3 & 4 & 5 \\
\hline 10. & Državne ustanove (vojska, policija, ...) & 0 & 1 & 2 & 3 & 4 & 5 \\
\hline 11. & Rezidencijalni (kućni) korisnici & 0 & 1 & 2 & 3 & 4 & 5 \\
\hline 12. & Mala i srednja poduzeća (Small Medium Business - SMB) & 0 & 1 & 2 & 3 & 4 & 5 \\
\hline 13. & & & & & & & \\
\hline
\end{tabular}

ZAPAŽANJA: 
12. Molim Vas da odgovorite na pitanja o visoko raspoloživim mrežama (jednaku ili veću od ,tri devetke“) i NETCONF-u?

\begin{tabular}{|cccccc|}
\hline \multicolumn{5}{c|}{ Visoko raspoložive mreže korisnika i NETCONF } \\
\\
\hline \multicolumn{7}{|c}{ Molimo označite svoje mišljenje, pri čemu je: } \\
$0 \%$ & 1 & 2 & 3 & 4 & 5 \\
& $1-20 \%$ & $21-40 \%$ & $41-60 \%$ & $61-80 \%$ & $81-100 \%$ \\
\hline
\end{tabular}

\begin{tabular}{|c|l|c|c|c|c|c|c|}
\hline 1. & $\begin{array}{l}\text { Koji postotak Vaših korisnika ima visoko raspoložive mreže } \\
\text { (jednaku ili veću od ,tri devetke“)? }\end{array}$ & 1 & 2 & 3 & 4 & 5 \\
\hline 2. & $\begin{array}{l}\text { Koji postotak R/S uređaja Vaših korisnika koristi NETCONF za } \\
\text { konfiguriranje u mrežama visoke raspoloživosti (jednaku ili veću od } \\
\text {,tri devetke“)? }\end{array}$ & 0 & 1 & 2 & 3 & 4 & 5 \\
\hline 3. & \multicolumn{1}{|l}{} & 0 & 1 & 2 & 3 & 4 & 5 \\
\hline
\end{tabular}

ZAPAŽANJA: 
13. Slažete li se sa sljedećim tvrdnjama?

\begin{tabular}{|ccccc|}
\hline \multicolumn{4}{c|}{ Ostala pitanja } \\
\\
\multicolumn{4}{|c}{ Molimo označite svoje mišljenje, pri čemu je: } & \\
1 & 2 & 3 & 4 & 5 \\
Izrazito se NE slažem & NE slažem se & Niti se slažem niti se ne & Slažem se & Izrazito se slažem \\
\hline
\end{tabular}

\begin{tabular}{|c|c|c|c|c|c|c|}
\hline 1. & $\begin{array}{l}\text { NETCONF pomaže korisnicima u radu kada su u mreži prisutni R/S } \\
\text { uređaji različith proizvođača. } \\
\text { ZAPAŽANJA: }\end{array}$ & 1 & 2 & 3 & 4 & 5 \\
\hline 2. & $\begin{array}{l}\text { Dostupnost NETCONF standarda na uređajima proizvođača je važna za } \\
\text { njihovu konkurentnost na tržištu. } \\
\text { ZAPAŽANJA: }\end{array}$ & 1 & 2 & 3 & 4 & 5 \\
\hline 3. & $\begin{array}{l}\text { NETCONF standard bi se trebao više koristiti od strane Vaših korisnika } \\
\text { na R/S uređajima. } \\
\text { ZAPAŽANJA: }\end{array}$ & 1 & 2 & 3 & 4 & 5 \\
\hline 4. & $\begin{array}{l}\text { Korištenjem NETCONF standarda povećava se raspoloživost mrežnih } \\
\text { uređaja i sustava. } \\
\text { ZAPAŽANJA: }\end{array}$ & 1 & 2 & 3 & 4 & 5 \\
\hline 5. & $\begin{array}{l}\text { NETCONF standard bi se trebao više koristiti od strane Vaših korisnika } \\
\text { na R/S uređajima da bi povećali raspoloživost uređaja i sustava. } \\
\text { ZAPAŽANJA: }\end{array}$ & 1 & 2 & 3 & 4 & 5 \\
\hline 6. & $\begin{array}{l}\text { RESTCONF standard (definiran u RFC } 8040 \text { u siječnju 2017.) je bolje } \\
\text { rješenje za konfiguraciju mrežnih uređaja od NETCONF standarda. } \\
\text { ZAPAŽANJA: }\end{array}$ & 1 & 2 & 3 & 4 & 5 \\
\hline 7. & $\begin{array}{l}\text { Rad s nestandardnim CLI sučeljem i njegovim konfiguracijskim } \\
\text { datotekama je više „,human readable“ nego kada se koristi NETCONF } \\
\text { standard. } \\
\text { ZAPAŽANJA: }\end{array}$ & 1 & 2 & 3 & 4 & 5 \\
\hline
\end{tabular}


ZAPAŽANJA:

14. Slažete li se s tvrdnjom da sve vrste R/S uređaja (na primjer od malih SMB uređaja do velikih ISP uređaja) trebaju imati implementiran NETCONF standarda?

DA

\section{NE}

ZAPAŽANJA:

15. Na koji način mislite da bi se mogla povećati primjena NETCONF standarda?

16. Na koji način mislite da bi se mogao poboljšati NETCONF standard?

17. Na koji način Vi vidite buduću primjenu i razvoj NETCONF standarda?

18. Molimo Vas da izložite svoja dodatna zapažanja i mišljenje vezana uz primjenu NETCONF standarda, a koja nisu obrađena u prethodnim pitanjima:

19. Molimo Vas da izložite svoja dodatna zapažanja i mišljenje vezana uz primjenu NETCONF standarda i povećanje raspoloživosti mrežnih uređaja, a koja nisu obrađena u prethodnim pitanjima: 
20. Molimo Vas da ocijenite znanje Vaših korisnika o NETCONF standardu?

\begin{tabular}{|cccccc|}
\hline \multicolumn{4}{c|}{ Razina znanja korisnika o NETCONF standardu } \\
\\
\multicolumn{4}{c}{ Molimo označite svoje mišljenje, pri čemu je: } \\
1 & 2 & 3 & 4 & 5 & Izvrsno \\
\hline
\end{tabular}

\begin{tabular}{|c|c|c|c|c|c|c|}
\hline 1. & $\begin{array}{l}\text { Savladana teoretska znanja o radu NETCONF protokola i razumiju } \\
\text { njegove karakteristike i prednosti } \\
\text { ZAPAŽANJA: }\end{array}$ & 1 & 2 & 3 & 4 & 5 \\
\hline 2. & $\begin{array}{l}\text { Savladana praktična znanja NETCONF protokola i koriste ga s } \\
\text { lakoćom } \\
\text { ZAPAŽANJA: }\end{array}$ & 1 & 2 & 3 & 4 & 5 \\
\hline 3. & $\begin{array}{l}\text { Poznavanje prednosti NETCONF } \text { protokola } \text { u povećanju } \\
\text { raspoloživosti mrežnih uređaja } \\
\text { ZAPAŽANJA: }\end{array}$ & 1 & 2 & 3 & 4 & 5 \\
\hline 4. & & 1 & 2 & 3 & 4 & 5 \\
\hline
\end{tabular}

ZAPAŽANJA: 
21. Molimo Vas da ocijenite teorijsko znanje Vaših korisnika o NETCONF standardu po pojedinim funkcijama?

\begin{tabular}{|c|cccc|}
\hline \multicolumn{5}{|c|}{ Razina teorijskog znanja korisnika o NETCONF standardu po pojedinim funkcijama } \\
\multicolumn{7}{|c}{ Molimo označite svoje mišljenje, pri čemu je: } \\
1 & 2 & 3 & 4 & 5 \\
Nedovoljno & Dovoljno & Dobro & Vrlo dobro & Izvrsno \\
\hline
\end{tabular}

\begin{tabular}{|c|c|c|c|c|c|c|}
\hline 1. & $\begin{array}{l}\text { NETCONF kao standardni način konfiguracije preko udaljenog } \\
\text { pristupa na IP adresu uređaja }\end{array}$ & 1 & 2 & 3 & 4 & 5 \\
\hline 2. & $\begin{array}{lrrrrr}\text { NETCONF kao } & \text { standard } & \text { koji } & \text { omogućava } & \text { programabilnost } \\
\text { (automatiziranje). } & & & & \end{array}$ & 1 & 2 & 3 & 4 & 5 \\
\hline 3. & $\begin{array}{l}\text { NETCONF standard koristi jasnu razliku u strukturi između } \\
\text { konfiguracijskih i operacijskih podataka. }\end{array}$ & 1 & 2 & 3 & 4 & 5 \\
\hline 4. & $\begin{array}{l}\text { Mogućnost parcijalnog konfiguriranja* uređaja pomoću NETCONF } \\
\text { standarda. } \\
\text { *NETCONF postiže pomoću XML jezika i „XML subtree filtering“ } \\
\text { funkcije }\end{array}$ & 1 & 2 & 3 & 4 & 5 \\
\hline 5. & $\begin{array}{l}\text { Mogućnost provjere konfiguracije prije primjene* kod NETCONF } \\
\text { načina konfiguriranja uređaja. } \\
\text { *NETCONF postiže provjeru konfiguracijske datoteke pomoću } \\
\text { funkcije <validate> }\end{array}$ & 1 & 2 & 3 & 4 & 5 \\
\hline 6. & $\begin{array}{l}\text { Mogućnost zaključavanja konfiguracijske datoteke* koje nudi } \\
\text { NETCONF. } \\
\text { *NETCONF pomoću operacija „lock“ i „,unlock“ onemogućava } \\
\text { istovremenu promjenu konfiguracijske datoteke iz više izvora (na } \\
\text { primjer istovremena druga NETCONF sesija, CLI pristup ili pristup } \\
\text { pomoću SNMP protokola). }\end{array}$ & 1 & 2 & 3 & 4 & 5 \\
\hline 7. & $\begin{array}{l}\text { „Backup \& restore }{ }^{6 *} \text { mogućnost koju nudi NETCONF standard. } \\
\text { *NETCONF postiže pomoću (1) manipulacije konfiguracijskih } \\
\text { datoteka (<running >, <candidate>, <startup > i backup) i (2) pomoću } \\
\text { funkcije „Rollback-on-Error“. }\end{array}$ & 1 & 2 & 3 & 4 & 5 \\
\hline 8. & $\begin{array}{l}\text { Mogućnost istovremenog i koordiniranog konfiguriranja svih ili } \\
\text { više uređaja* u mreži. } \\
\text { *NETCONF postiže pomoću manipulacije konfiguracijskih datoteka } \\
(\langle\text { running }>\text {, <candidate>, <startup > i backup }) \text { i pomoću operacija } \\
\text { „lock“ } \mathrm{i}, \text {,unlock“. }\end{array}$ & 1 & 2 & 3 & 4 & \\
\hline
\end{tabular}

ZAPAŽANJA: 
22. Molimo Vas da ocijenite praktično znanje Vaših korisnika o NETCONF standardu po pojedinim funkcijama?

\begin{tabular}{|c|cccc|}
\hline \multicolumn{6}{|c|}{ Razina praktičnog znanja korisnika o NETCONF standardu po pojedinim funkcijama } \\
\multicolumn{7}{|c}{ Molimo označite svoje mišljenje, pri čemu je: } \\
1 & 2 & 3 & 4 & 5 \\
Nedovoljno & Dovoljno & Dobro & Vrlo dobro & Izvrsno \\
\hline
\end{tabular}

\begin{tabular}{|c|c|c|c|c|c|c|}
\hline 1. & $\begin{array}{l}\text { NETCONF kao standardni način konfiguracije preko udaljenog } \\
\text { pristupa na IP adresu uređaja }\end{array}$ & 1 & 2 & 3 & 4 & 5 \\
\hline 2. & $\begin{array}{lrrrrr}\text { NETCONF kao } & \text { standard } & \text { koji } & \text { omogućava } & \text { programabilnost } \\
\text { (automatiziranje). } & & & & \end{array}$ & 1 & 2 & 3 & 4 & 5 \\
\hline 3. & $\begin{array}{l}\text { NETCONF standard koristi jasnu razliku u strukturi između } \\
\text { konfiguracijskih i operacijskih podataka. }\end{array}$ & 1 & 2 & 3 & 4 & 5 \\
\hline 4. & $\begin{array}{l}\text { Mogućnost parcijalnog konfiguriranja* uređaja pomoću NETCONF } \\
\text { standarda. } \\
\text { *NETCONF postiže pomoću XML jezika i „XML subtree filtering“ } \\
\text { funkcije }\end{array}$ & 1 & 2 & 3 & 4 & 5 \\
\hline 5. & $\begin{array}{l}\text { Mogućnost provjere konfiguracije prije primjene* kod NETCONF } \\
\text { načina konfiguriranja uređaja. } \\
\text { *NETCONF postiže provjeru konfiguracijske datoteke pomoću } \\
\text { funkcije <validate> }\end{array}$ & 1 & 2 & 3 & 4 & 5 \\
\hline 6. & $\begin{array}{l}\text { Mogućnost zaključavanja konfiguracijske datoteke* koje nudi } \\
\text { NETCONF. } \\
\text { *NETCONF pomoću operacija „lock“ i „,unlock“ onemogućava } \\
\text { istovremenu promjenu konfiguracijske datoteke iz više izvora (na } \\
\text { primjer istovremena druga NETCONF sesija, CLI pristup ili pristup } \\
\text { pomoću SNMP protokola). }\end{array}$ & 1 & 2 & 3 & 4 & 5 \\
\hline 7. & $\begin{array}{l}\text { „Backup \& restore }{ }^{6 *} \text { mogućnost koju nudi NETCONF standard. } \\
\text { *NETCONF postiže pomoću (1) manipulacije konfiguracijskih } \\
\text { datoteka (<running >, <candidate>, <startup > i backup) i (2) pomoću } \\
\text { funkcije „Rollback-on-Error“. }\end{array}$ & 1 & 2 & 3 & 4 & 5 \\
\hline 8. & $\begin{array}{l}\text { Mogućnost istovremenog i koordiniranog konfiguriranja svih ili } \\
\text { više uređaja* u mreži. } \\
\text { *NETCONF postiže pomoću manipulacije konfiguracijskih datoteka } \\
(\langle\text { running }>\text {, <candidate>, <startup > i backup }) \text { i pomoću operacija } \\
\text { „lock“ } \mathrm{i}, \text {,unlock“. }\end{array}$ & 1 & 2 & 3 & 4 & \\
\hline
\end{tabular}

ZAPAŽANJA: 
23. Imate li Vi kakvih pitanja za mene ili dodatnih zapažanja? 


\section{Prilog 3: Pitanja anketnog upitnika za krajnje korisnike u Hrvatskoj}

\section{Osobni podaci}

1. *Molimo ${ }^{209}$ zaokružite svoj najviši stupanj formalnog obrazovanja vezanog uz računarstvo i ICT (Information Communication Technologies).

a. završena srednja škola računarskog smjera

b. završene 3 godine visoke škole ili fakulteta računarskog smjera.

c. završenih 4 ili $5(3+2)$ godina visoke škole ili fakulteta računarskog smjera.

d. završen doktorat računarskog smjera.

e. ništa od gore navedenog.

\section{NAPOMENA::}

2. *Molimo zaokružite koji je najviši stupanj Vašeg položenog certifikata iz računalnih mreža koji ste položili (ne mora biti aktivan)

a. Nemam položenih certifikata iz računalnih mreža

b. Osnovni (Associate level)

- na primjer Cisco CCNA, Juniper JNCIA, Huawei HCIA ili odgovarajući drugih proizvođača ili istih proizvođača iz drugih mrežnih tehnologija.

c. Srednji (Professional level)

- na primjer Cisco CCNP, Juniper JNCIP, Huawei HCIP ili odgovarajući drugih proizvođača ili istih proizvođača iz drugih mrežnih tehnologija.

d. Najviši (Expert level)

- na primjer Cisco CCIE, Juniper JNCIE, Huawei HCIE ili odgovarajući drugih proizvođača ili istih proizvođača iz drugih mrežnih tehnologija.

e. Ostalo

\footnotetext{
${ }^{209}$ Pitanja s * u anketnom upitniku su s obaveznim odgovorom.
} 
3. *Molimo zaokružite koliko imate godina iskustva rada $\mathbf{s}$ računalnim mrežama i mrežnim uređajima.
a. 0 - 5 godina
b. 5 - 10 godina
c. 10 - 15 godina
d. 15 - 20 godina
e. 20 - 25 godina
f. više od 25 godina 
4. *Molimo Vas da ocijenite svoja znanja iz različitih područja i tehnologija računalnih mreža.

\begin{tabular}{|c|c|c|c|c|}
\hline \multicolumn{5}{|c|}{ Razina Vašeg znanja iz različitih područja i tehnologija računalnih mreža } \\
\hline \multicolumn{5}{|c|}{ Molimo označite svoje mišljenje, pri čemu je: } \\
\hline 1 & 2 & 3 & 4 & 5 \\
\hline Nedovoljno & Dovoljno & Dobro & Vrlo dobro & Izvrsno \\
\hline
\end{tabular}

\begin{tabular}{|c|l|c|c|c|c|c|}
\hline 1. & $\begin{array}{l}\text { R/S poduzeća (Enterprise routing/switching): R/S uređaji, protokoli, } \\
\text { način rada, i drugo. }\end{array}$ & 1 & 2 & 4 & 5 \\
\hline 2. & $\begin{array}{l}\text { R/S davatelja usluga (Service provider routing/switching): R/S uređaji, } \\
\text { protokoli, način rada, i drugo. }\end{array}$ & 1 & 2 & 3 & 4 & 5 \\
\hline 3. & $\begin{array}{l}\text { Podatkovni centri (Data Center): R/S uređaji, protokoli, način rada, i } \\
\text { drugo. }\end{array}$ & 1 & 2 & 3 & 4 & 5 \\
\hline 4. & $\begin{array}{l}\text { Upravljanje računalnim mrežama (Network management - NM): SNMP } \\
\text { protokol, načini upravljanja R/S uređajima, i drugo. }\end{array}$ & 1 & 2 & 3 & 4 & 5 \\
\hline 5. & $\begin{array}{l}\text { Sigurnost R/S uređaje i računalnih mreža } \\
6 .\end{array}$ & 1 & 2 & 3 & 4 & 5 \\
\hline 7. & Računalstvo u oblaku (Cloud computing) & 1 & 2 & 3 & 4 & 5 \\
\hline 8. & $\begin{array}{l}\text { Softverski definirane mreže (Software Defined Networks - SDN) } \\
\text { Automatizacija i programiranje računalnih mreža (Automation tools } \\
\text { and DevOps) }\end{array}$ & 1 & 2 & 3 & 4 & 5 \\
\hline
\end{tabular}


5. *Molimo Vas da ocijenite svoja znanja iz programiranja i programskih jezika.

\begin{tabular}{|c|c|c|c|c|}
\hline \multicolumn{5}{|c|}{ Razina znanja iz programiranja i programskih jezika } \\
\hline \multicolumn{5}{|c|}{ Molimo označite svoje mišljenje, pri čemu je: } \\
\hline 1 & 2 & 3 & 4 & 5 \\
\hline Nedovolino & Dovoljno & Dobro & Vrlo dobro & Izvrsno \\
\hline
\end{tabular}

\begin{tabular}{|c|l|c|c|c|c|c|}
\hline 1. & Općenito programiranje i programski jezici & 1 & 2 & 3 & 4 & 5 \\
\hline 2. & C/C++ & 1 & 2 & 3 & 4 & 5 \\
\hline 3. & Python & 1 & 2 & 3 & 4 & 5 \\
\hline 4. & Java & 1 & 2 & 3 & 4 & 5 \\
\hline 5. & JavaScript & 1 & 2 & 3 & 4 & 5 \\
\hline 6. & XML (Extensible Markup Language) & 1 & 2 & 3 & 4 & 5 \\
\hline 7. & HTML (Hypertext Markup Language) & 1 & 2 & 3 & 4 & 5 \\
\hline 8. & API (Application-Programming Interface) & 1 & 2 & 3 & 4 & 5 \\
\hline 9. & Perl & 1 & 2 & 3 & 4 & 5 \\
\hline 10. & Tcl & 1 & 2 & 3 & 4 & 5 \\
\hline
\end{tabular}


6. *Na kojim poslovima vezanim uz $\mathrm{R} / \mathrm{S}$ uređaje radite na svome radnom mjestu u kompaniji? (moguće više odgovora)

a. Dizajn računalne mreže kompanije.

b. Instalacija i konfiguracija $\mathrm{R} / \mathrm{S}$ uređaja i računalne mreže.

c. Dijagnostika (troubleshooting) R/S uređaja i računalne mreže.

d. Upravljanje i nadzor R/S uređaja i računalne mreže.

e. Sigurnost R/S uređaja i računalne mreže.

f. Savjetovanje za poboljšanje i daljnji razvoj računalne mreže.

g. Prodaja mrežnih usluga i R/S uređaja.

h. Edukacija o računalnim mrežama i tehnologijama.

i. Upravljanje tima mrežnih administratora.

j. Komunikacija i rad s vanjskim partnerima koji održavaju računalnu mrežu Vaše kompanije.

k. Sistemski administrator.

1. Nešto drugo:

m. Ne radim na poslovima vezanim uz računalne mreže i R/S uređaje.

\section{Podaci o Vašoj kompaniji}

7. * Da li je kompanija u kojoj radite:

a. Poduzeće (Enterprise)

- $\quad$ na primjer: banka, škola, bolnica, trgovina, obrt, ...

b. Davatelj usluga (Internet servise provider - ISP)

- na primjer: T-Com (HT), A1, Iskon, Metronet,... 


\section{8. Što najbliže opisuje osnovnu djelatnost Vaše kompanije?}

\section{Osnovna djelatnost Vaše kompanije?}

Molimo označite jedan odgovor:

\begin{tabular}{|c|c|}
\hline 1. & Internet davatelj usluga (Internet Service Provider - ISP), na primjer T-Com, A1, i drugi. \\
\hline 2. & Podatkovni centar \\
\hline 3. & $\begin{array}{l}\text { Sistem integrator (partner proizvođača mrežne opreme), na primjer Combis, CS, King ICT, } \\
\text { Kodeks, S\&T, Storm, Verso i drugi) }\end{array}$ \\
\hline 4. & Financijska ustanova (banke i slično) \\
\hline 5. & Transport (zračne luke, željeznica, ...) \\
\hline 6. & Zdravstvena ustanova (bolnice, ambulante, ...) \\
\hline 7. & Državna ustanova (vojska, policija, ...) \\
\hline 8. & Edukacijska ustanova (škole, fakulteti, ...) \\
\hline 9. & On-line trgovina ili usluga (e-kupi, „ulaznice.hr“, ...) \\
\hline 10. & Medijska ustanova (TV, radio, časopisi, ....) \\
\hline 11. & Turizam (hoteli, turističke agencije, ...) \\
\hline 12. & Trgovina (trgovački lanci, trgovački centri, ...) \\
\hline 13. & Ostala velika poduzeća (Enterprise) koja nisu gore navedena \\
\hline 14. & Ostala mala i srednja poduzeća (Small Medium Business - SMB) koja nisu gore navedena \\
\hline 15. & Nešto drugo (molimo navedite) \\
\hline
\end{tabular}


9. *Koja je tražena raspoloživost mreže Vaše kompanije?

(Napomena 1: kratak uvod u raspoloživost je prikazan na slici)

(Napomena 2: ako postoji više vrsta mreža, odaberite onu s najvećom raspoloživosti, odnosno s najmanjim vremenom zastoja)
a. Raspoloživost $\leq 99 \%$
(Vrijeme zastoja godišnje $\geq 3,65$ dana)
b. Raspoloživost $99.9 \%$
(Vrijeme zastoja godišnje oko 8,76 sati)
c. Raspoloživost $99.99 \%$
(Vrijeme zastoja godišnje oko 52,56 minuta)
d. Raspoloživost $99.999 \%$
(Vrijeme zastoja godišnje oko 5,26 minuta)
e. Raspoloživost $\geq 99.9999 \%$
(Vrijeme zastoja godišnje manja od 31,5 sekundi)

10. Od kojih proizvođača dolaze R/S (router/switch) mrežni uređaji i u kojem postotku su instalirani u mreži Vaše kompanije?

\section{Primjena R/S mrežnih uređaja od više proizvođača}

Molimo označite svoje mišljenje, pri čemu je:

$\begin{array}{cccccc}0 & 1 & 2 & 3 & 4 & 5 \\ 0 \% & 1-20 \% & 21-40 \% & 41-60 \% & 61-80 \% & 81-100 \%\end{array}$

(Ne implementira)

\begin{tabular}{|c|l|c|c|c|c|c|c|}
\hline 1. & Arista & 0 & 1 & 2 & 3 & 4 & 5 \\
\hline 2. & Cisco Systems & 0 & 1 & 2 & 3 & 4 & 5 \\
\hline 3. & Extreme Networks & 0 & 1 & 2 & 3 & 4 & 5 \\
\hline 4. & F5 & 0 & 1 & 2 & 3 & 4 & 5 \\
\hline 5. & Hewlett Packard Enterprise & 0 & 1 & 2 & 3 & 4 & 5 \\
\hline 6. & Huawei & 0 & 1 & 2 & 3 & 4 & 5 \\
\hline 7. & Juniper Networks & 0 & 1 & 2 & 3 & 4 & 5 \\
\hline 8. & Nokia (Alcatel-Lucent) & 0 & 1 & 2 & 3 & 4 & 5 \\
\hline
\end{tabular}

ZAPAŽANJA: 
11. Da li imate implementaciju softverski definirane mreže (SDN) u mreži Vaše kompanije (bilo koja vrsta implementacije: SD-WAN, SD-Access ili drugo ...)?
a) $\mathrm{Da}$
b) $\mathrm{Ne}$
c) Još ne, ali trenutno razmatramo/testiramo SDN implementaciju
d) Ne znam

\section{Poznavanje NETCONF standarda (H4)}

12. * Molimo Vas da ocijenite svoje znanje o NETCONF standardu?

\begin{tabular}{|c|c|c|c|c|}
\hline \multicolumn{5}{|c|}{ Razina znanja korisnika o NETCONF standardu } \\
\hline \multicolumn{5}{|c|}{ Molimo označite svoje mišljenje, pri čemu je: } \\
\hline 1 & 2 & 3 & 4 & 5 \\
\hline Nedovoljno & Dovoljno & Dobro & Vrlo dobro & Izvrsno \\
\hline
\end{tabular}

\begin{tabular}{|c|l|c|c|c|c|c|}
\hline 1. & $\begin{array}{l}\text { Savladao sam teoretska znanja o radu NETCONF protokola i } \\
\text { razumijem njegove karakteristike i prednosti. }\end{array}$ & 2 & 3 & 4 & 5 \\
\hline 2. & $\begin{array}{l}\text { Savladao sam praktična znanja NETCONF protokola i primjenjujem } \\
\text { ga s lakoćom. }\end{array}$ & 2 & 3 & 4 & 5 \\
\hline 3. & $\begin{array}{l}\text { Poznajem prednosti NETCONF protokola u povećanju } \\
\text { raspoloživosti R/S mrežnih uređaja. }\end{array}$ & 2 & 3 & 4 & 5 \\
\hline
\end{tabular}


13. *Molimo Vas da ocijenite svoje znanje o NETCONF standardu po pojedinim funkcijama koje povećavaju raspoloživost R/S uređaja?

\begin{tabular}{|ccccc|}
\hline \multicolumn{5}{|c|}{ Razina znanja korisnika o NETCONF standardu po pojedinim funkcijama } \\
\multicolumn{7}{|c}{ Molimo označite svoje mišljenje, pri čemu je: } \\
1 & 2 & 3 & 4 & 5 \\
Nedovoljno & Dovoljno & Dobro & Vrlo dobro & Izvrsno \\
\hline
\end{tabular}

\begin{tabular}{|c|c|c|c|c|c|c|}
\hline 1. & $\begin{array}{l}\text { NETCONF kao standardni način konfiguracije preko udaljenog } \\
\text { pristupa na IP adresu uređaja }\end{array}$ & 1 & 2 & 3 & 4 & 5 \\
\hline 2. & $\begin{array}{lrlll}\text { NETCONF kao } & \text { standard } & \text { koji } & \text { omogućava } & \text { programabilnost } \\
\text { (automatiziranje). }\end{array}$ & 1 & 2 & 3 & 4 & 5 \\
\hline 3. & $\begin{array}{l}\text { NETCONF standard koristi jasnu razliku u strukturi između } \\
\text { konfiguracijskih i operacijskih podataka. }\end{array}$ & 1 & 2 & 3 & 4 & 5 \\
\hline 4. & $\begin{array}{l}\text { Mogućnost parcijalnog konfiguriranja* uređaja pomoću NETCONF } \\
\text { standarda. } \\
\text { *NETCONF postiže pomoću XML jezika i „XML subtree filtering““ } \\
\text { funkcije }\end{array}$ & 1 & 2 & 3 & 4 & 5 \\
\hline 5. & $\begin{array}{l}\text { Mogućnost provjere konfiguracije prije primjene* kod NETCONF } \\
\text { načina konfiguriranja uređaja. } \\
\text { *NETCONF postiže provjeru konfiguracijske datoteke pomoću } \\
\text { funkcije }\langle\text { validate }>\end{array}$ & 1 & 2 & 3 & 4 & 5 \\
\hline 6. & $\begin{array}{l}\text { Mogućnost zaključavanja konfiguracijske datoteke* koje nudi } \\
\text { NETCONF. } \\
\text { *NETCONF pomoću operacija „lock“ i „,unlock“ onemogućava } \\
\text { istovremenu promjenu konfiguracijske datoteke iz više izvora (na } \\
\text { primjer istovremena druga NETCONF sesija, CLI pristup ili pristup } \\
\text { pomoću SNMP protokola). }\end{array}$ & 1 & 2 & 3 & 4 & 5 \\
\hline 7. & $\begin{array}{l}\text { „Backup \& restore“** mogućnost koju nudi NETCONF standard. } \\
\text { *NETCONF postiže pomoću (1) manipulacije konfiguracijskih } \\
\text { datoteka (<running>, <candidate>, <startup> i backup) i (2) pomoću } \\
\text { funkcije „Rollback-on-Error“. }\end{array}$ & 1 & 2 & 3 & 4 & 5 \\
\hline 8. & 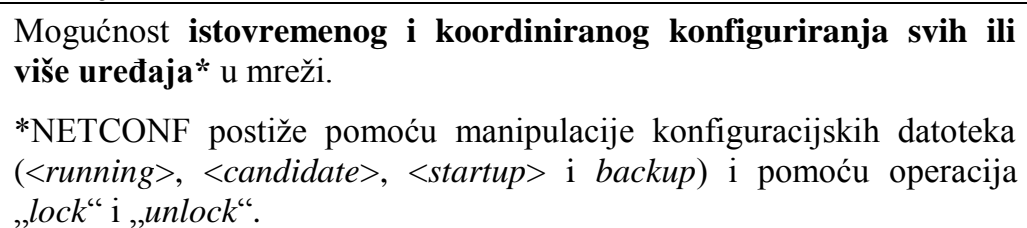 & 1 & 2 & 3 & 4 & 5 \\
\hline
\end{tabular}

ZAPAŽANJA: 


\section{Primjena NETCONF standarda od proizvođača R/S uređaja (H2)}

14. *Slažete li se sa sljedećim tvrdnjama?

\begin{tabular}{|cccccc|}
\hline \multicolumn{5}{|c|}{ Primjena NETCONF standarda na R/S uređajima proizvođača } \\
$\mathrm{N}$ & -2 & Molimo označite svoje mišljenje, pri čemu je: & 1 & 2 \\
Ne znam & Izrazito se NE & NE slažem se & Niti se slažem & Slažem se & Izrazito se \\
(Ne poznajem & slažem & & niti se ne & & slažem \\
dovoljno & & slažem & \\
NETCONF da bih & & & \\
mogao odgovoriti) & & & \\
\hline
\end{tabular}

\begin{tabular}{|l|l|l|l|l|l|l|l|}
1. & $\begin{array}{l}\text { Proizvođači mrežne opreme implementiraju NETCONF } \\
\text { standard na svojim uređajima. }\end{array}$ & $\mathrm{N}$ & 1 & 2 & 3 & 4 & 5 \\
\hline
\end{tabular}


15. Po Vašem mišljenju u kojem postotku na svojim R/S uređajima različiti proizvođači implementiraju NETCONF standard?

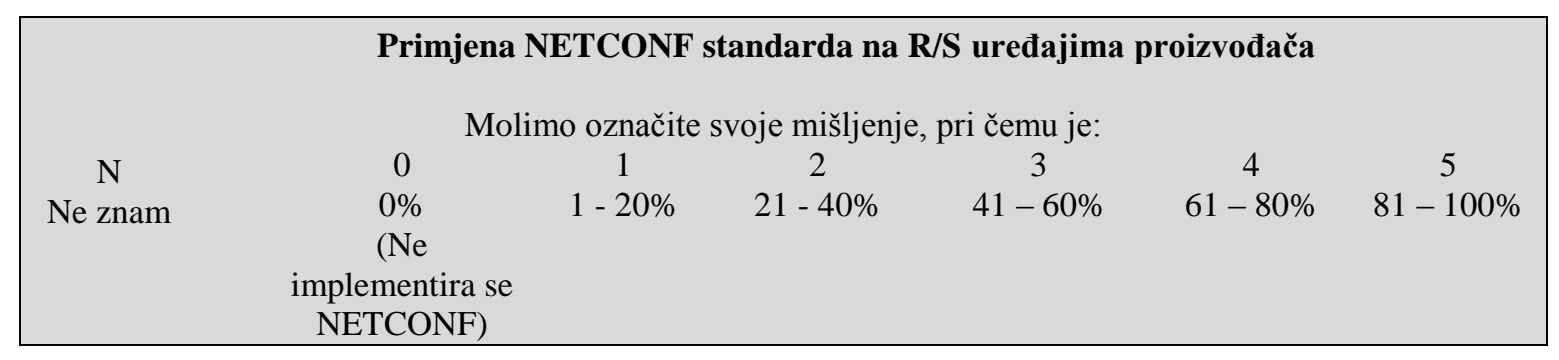

\begin{tabular}{|r|l|c|c|c|c|c|c|c|}
\hline 1. & Arista & $\mathrm{N}$ & 0 & 1 & 2 & 3 & 4 & 5 \\
\hline 2. & Cisco Systems & $\mathrm{N}$ & 0 & 1 & 2 & 3 & 4 & 5 \\
\hline 3. & Extreme Networks & $\mathrm{N}$ & 0 & 1 & 2 & 3 & 4 & 5 \\
\hline 4. & F5 & $\mathrm{N}$ & 0 & 1 & 2 & 3 & 4 & 5 \\
\hline 5. & Hewlett Packard Enterprise (HPE) & $\mathrm{N}$ & 0 & 1 & 2 & 3 & 4 & 5 \\
\hline 6. & Huawei & $\mathrm{N}$ & 0 & 1 & 2 & 3 & 4 & 5 \\
\hline 7. & Juniper Networks & $\mathrm{N}$ & 0 & 1 & 2 & 3 & 4 & 5 \\
\hline 8. & Nokia (Alcatel-Lucent) & $\mathrm{N}$ & 0 & 1 & 2 & 3 & 4 & 5 \\
\hline
\end{tabular}


16. *Podržavaju li proizvođači veću primjenu NETCONF standarda kod korisnika i na koji način?

\begin{tabular}{|cccccc|}
\hline \multicolumn{7}{|c|}{ Podrška primjene NETCONF standarda od strane proizvođača } \\
N & 1 & Molimo označite svoje mišljenje, pri čemu je: & 4 & 5 \\
Ne znam & Ne slažem se & Malo se slažem & Slažem se & Vrlo se slažem & $\begin{array}{c}\text { Potpuno se } \\
\text { slažem }\end{array}$ \\
\hline
\end{tabular}

\begin{tabular}{|c|l|c|c|c|c|c|c|}
\hline 1. & $\begin{array}{l}\text { Postoji detaljna dokumentacija proizvođača koja objašnjava rad i } \\
\text { primjenu NETCONF standarda na mrežnim uređajima: upute } \\
\text { (manuals), preporuke za uporabu (white papers), } \mathrm{i} \text { slično. }\end{array}$ & 1 & 2 & 3 & 4 & 5 \\
\hline 2. & $\begin{array}{l}\text { Postoje tečajevi proizvođača za samostalno učenje (CBT, } \\
\text { Webinar, i slično) o NETCONF protokolu. }\end{array}$ & 1 & 2 & 3 & 4 & 5 \\
\hline 3. & $\begin{array}{l}\text { Postoje organizirani tečajevi proizvođača koje vode instruktori o } \\
\text { NETCONF protokolu. }\end{array}$ & $\mathrm{N}$ & 1 & 2 & 3 & 4 & 5 \\
\hline 4. & $\begin{array}{l}\text { Postoje certifikacijski ispiti (i pripadajući tečajevi) proizvođača } \\
\text { koji detaljno osposobljavaju korisnike uporabi i primjeni } \\
\text { NETCONF standarda na mrežnim uređajima. }\end{array}$ & 1 & 2 & 3 & 4 & 5 \\
\hline 5. & $\begin{array}{l}\text { Proizvođači održavaju prezentacije i radionice (workshops) o } \\
\text { prednostima i načinu primjene NETCONF protokola. }\end{array}$ & $\mathrm{N}$ & 2 & 3 & 4 & 5 \\
\hline
\end{tabular}

ZAPAŽANJA: 
17. Molimo Vas da ocijenite raspoloživu dokumentaciju, edukaciju i certificiranje o NETCONF protokolu po proizvođaču R/S uređaja.

\begin{tabular}{|cccccc|}
\hline \multicolumn{7}{|c|}{ Raspoloživa dokumentacija i edukacija o primjeni i korištenju NETCONF standarda od } \\
strane proizvođača opreme
\end{tabular}

\begin{tabular}{|c|l|c|c|c|c|c|c|}
\hline 1. & Arista & $\mathrm{N}$ & 1 & 2 & 3 & 4 & 5 \\
\hline 2. & Cisco Systems & $\mathrm{N}$ & 1 & 2 & 3 & 4 & 5 \\
\hline 3. & Extreme Networks & $\mathrm{N}$ & 1 & 2 & 3 & 4 & 5 \\
\hline 4. & F5 & $\mathrm{N}$ & 1 & 2 & 3 & 4 & 5 \\
\hline 5. & Hewlett Packard Enterprise & $\mathrm{N}$ & 1 & 2 & 3 & 4 & 5 \\
\hline 6. & Huawei & $\mathrm{N}$ & 1 & 2 & 3 & 4 & 5 \\
\hline 7. & Juniper Networks & $\mathrm{N}$ & 1 & 2 & 3 & 4 & 5 \\
\hline 8. & Nokia (Alcatel-Lucent) & $\mathrm{N}$ & 1 & 2 & 3 & 4 & 5 \\
\hline
\end{tabular}




\section{Primjena NETCONF standarda u Vašoj kompaniji (H3)}

18. *Da li koristite NETCONF standard na R/S (router/switch) mrežnim uređajima Vaše kompanije?

a. Da (napomena: u slučaju ovog odgovora nastavlja se s 19. pitanjem)

b. Ne (napomena: u slučaju ovog odgovora nastavlja se s 22. pitanjem)

19. *U kojim vrstama mreža Vaše kompanije koristite NETCONF na R/S (router/switch) mrežnim uređajima i u kojem postotku?

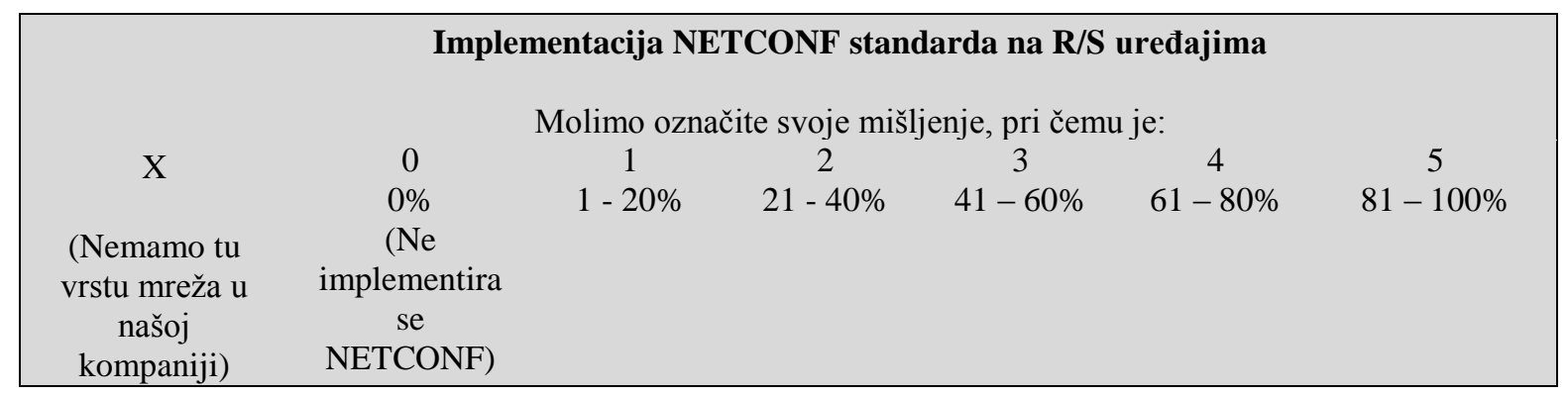

\begin{tabular}{|c|c|c|c|c|c|c|c|c|}
\hline 1. & $\begin{array}{l}\text { LAN mreža malih i srednjih poduzeća (Small Medium Business - } \\
\text { SMB) }\end{array}$ & $\mathrm{X}$ & 0 & 1 & 2 & 3 & 4 & 5 \\
\hline 2. & LAN mreža većih poduzeća (Enterprise Networks) & $\mathrm{X}$ & 0 & 1 & 2 & 3 & 4 & 5 \\
\hline 3. & WAN mreža većih poduzeća (Enterprise Networks) & $\mathrm{X}$ & 0 & 1 & 2 & 3 & 4 & 5 \\
\hline 4. & $\begin{array}{l}\text { Mreža davatelja usluga (Internet servise provider }- \text { ISP)* } \\
\text { *Uključuje sve vrste ISP mreža, na primjer broadband, bežične, } \\
\text { core, access,... }\end{array}$ & $\mathrm{X}$ & 0 & 1 & 2 & 3 & 4 & 5 \\
\hline 5. & Mreža podatkovnih centara (Data Center - DC) & $\mathrm{X}$ & 0 & 1 & 2 & 3 & 4 & 5 \\
\hline 6. & Mreže internet stvari (IoT) & $\mathrm{X}$ & 0 & 1 & 2 & 3 & 4 & 5 \\
\hline
\end{tabular}


20. Na R/S (router/switch) uređajima kojih proizvođača koristite NETCONF i u kojem postotku u Vašoj kompaniji?

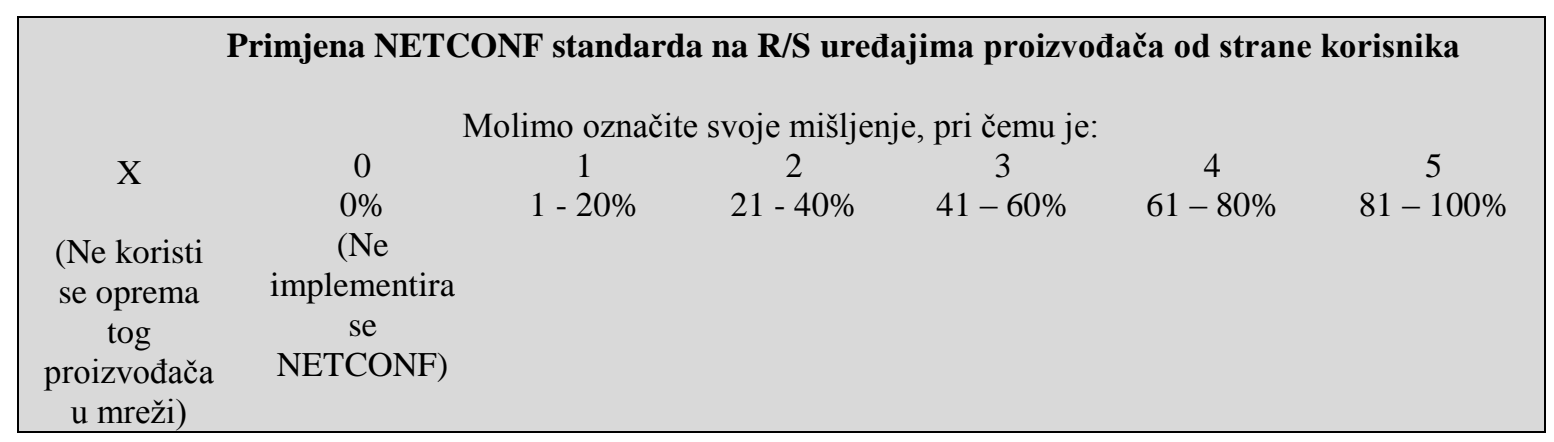

\begin{tabular}{|c|l|c|c|c|c|c|c|c|}
\hline 1. & Arista & $\mathrm{X}$ & 0 & 1 & 2 & 3 & 4 & 5 \\
\hline 2. & Cisco Systems & $\mathrm{X}$ & 0 & 1 & 2 & 3 & 4 & 5 \\
\hline 3. & Extreme Networks & $\mathrm{X}$ & 0 & 1 & 2 & 3 & 4 & 5 \\
\hline 4. & F5 & $\mathrm{X}$ & 0 & 1 & 2 & 3 & 4 & 5 \\
\hline 5. & Hewlett Packard Enterprise (HPE) & $\mathrm{X}$ & 0 & 1 & 2 & 3 & 4 & 5 \\
\hline 6. & Huawei & $\mathrm{X}$ & 0 & 1 & 2 & 3 & 4 & 5 \\
\hline 7. & Juniper Networks & $\mathrm{X}$ & 0 & 1 & 2 & 3 & 4 & 5 \\
\hline 8. & Nokia (Alcatel-Lucent) & $\mathrm{X}$ & 0 & 1 & 2 & 3 & 4 & 5 \\
\hline
\end{tabular}


21. Koji su glavni razlozi implementacije NETCONF standarda na R/S mrežnim uređajima Vaše kompanije?

\begin{tabular}{|cccccc|}
\hline \multicolumn{7}{|c|}{ Razlozi implementacija NETCONF standarda na R/S uređajima od strane korisnika } \\
N & 1 & Molimo označite svoje mišljenje, pri čemu je: \\
Ne znam & Nevažno & Malo važno & Važno & Vrlo važno & Izuzetno važno \\
\hline
\end{tabular}

\begin{tabular}{|c|c|c|c|c|c|c|c|}
\hline 1. & $\begin{array}{l}\text { NETCONF kao standardni način konfiguracije preko } \\
\text { udaljenog pristupa na IP adresu uređaja gdje je za sve } \\
\text { proizvođače ista (standardna) struktura komandi i podataka. }\end{array}$ & $\mathrm{N}$ & 1 & 2 & 3 & 4 & 5 \\
\hline 2. & $\begin{array}{l}\text { NETCONF kao standard omogućava programabilnost } \\
\text { (automatiziranje) koja značajno smanjuje učestalost ljudske } \\
\text { pogreške. }\end{array}$ & $\mathrm{N}$ & 1 & 2 & 3 & 4 & 5 \\
\hline 3. & $\begin{array}{l}\text { NETCONF standard koristi jasnu razliku u strukturi između } \\
\text { konfiguracijskih i operacijskih podataka. }\end{array}$ & $\mathrm{N}$ & 1 & 2 & 3 & 4 & 5 \\
\hline 4. & $\begin{array}{l}\text { Mogućnost parcijalnog konfiguriranja* uređaja pomoću } \\
\text { NETCONF standarda. } \\
\text { *NETCONF postiže pomoću XML jezika i „XML subtree } \\
\text { filtering“ funkcije }\end{array}$ & $\mathrm{N}$ & 1 & 2 & 3 & 4 & 5 \\
\hline 5. & $\begin{array}{l}\text { Mogućnost provjere konfiguracije prije primjene* kod } \\
\text { NETCONF načina konfiguriranja uređaja. } \\
\text { *NETCONF postiže provjeru konfiguracijske datoteke pomoću } \\
\text { funkcije <validate> }\end{array}$ & $\mathrm{N}$ & 1 & 2 & 3 & 4 & 5 \\
\hline 6. & $\begin{array}{l}\text { Mogućnost zaključavanja konfiguracijske datoteke* koje } \\
\text { nudi NETCONF. } \\
\text { *NETCONF pomoću operacija „lock“ i „,unlock“ onemogućava } \\
\text { istovremenu promjenu konfiguracijske datoteke iz više izvora } \\
\text { (na primjer istovremena druga NETCONF sesija, CLI pristup ili } \\
\text { pristup pomoću SNMP protokola). }\end{array}$ & $\mathrm{N}$ & 1 & 2 & 3 & 4 & 5 \\
\hline 7. & $\begin{array}{l}\text { „Backup \& } \text { restore }^{6 * *} \text { mogućnost koju nudi NETCONF } \\
\text { standard. } \\
\text { *NETCONF postiže pomoću (1) manipulacije konfiguracijskih } \\
\text { datoteka (<running>, <candidate>, <startup> i backup) i (2) } \\
\text { pomoću funkcije ,Rollback-on-Error“. }\end{array}$ & $\mathrm{N}$ & 1 & 2 & 3 & 4 & 5 \\
\hline 8. & 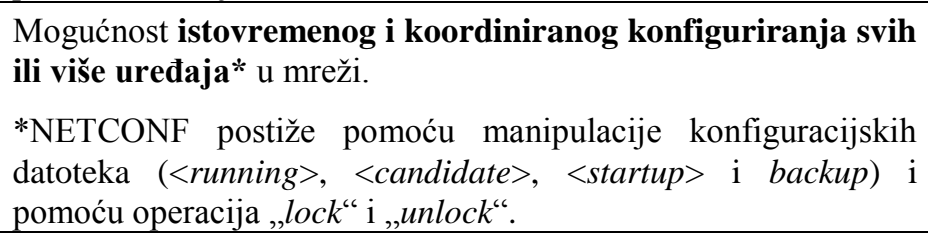 & $\mathrm{N}$ & 1 & 2 & 3 & 4 & 5 \\
\hline 9. & Nešto drugo (molimo navedite) & $\mathrm{N}$ & 1 & 2 & 3 & 4 & 5 \\
\hline
\end{tabular}


22. Koji su glavni razlozi neimplementacije NETCONF standarda na R/S mrežnim uređajima Vaše kompanije?

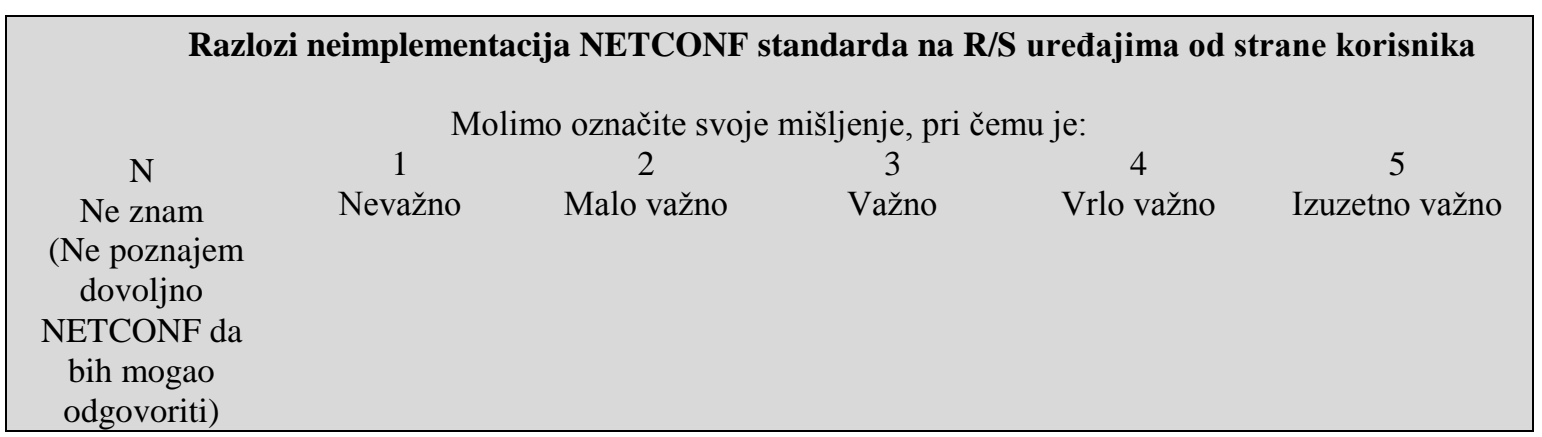

\begin{tabular}{|c|c|c|c|c|c|c|c|}
\hline 1. & CLI proizvođača je jednostavniji od NETCONF standarda & $\mathrm{N}$ & 1 & 2 & 3 & 4 & 5 \\
\hline 2. & NETCONF nije potreban zbog navike na OS i CLI proizvođača & $\mathrm{N}$ & 1 & 2 & 3 & 4 & 5 \\
\hline 3. & $\begin{array}{l}\text { NETCONF koristi XML sintaksu koja je redundantna i opširna } \\
\text { što može zamarati i zbunjivati. }\end{array}$ & $\mathrm{N}$ & 1 & 2 & 3 & 4 & 5 \\
\hline 4. & $\begin{array}{l}\text { Koristi se RESTCONF koji je bolje standardno rješenje od } \\
\text { NETCONF-a }\end{array}$ & $\mathrm{N}$ & 1 & 2 & 3 & 4 & 5 \\
\hline 5. & $\begin{array}{l}\text { NETCONF nije dostupan na starijim uređajima i starijem OS } \\
\text { koji ga ne podržavaju }\end{array}$ & $\mathrm{N}$ & 1 & 2 & 3 & 4 & 5 \\
\hline 6. & Nedovoljno poznavanje programskih jezika. & $\mathrm{N}$ & 1 & 2 & 3 & 4 & 5 \\
\hline 7. & $\begin{array}{l}\text { Proizvođači ne podržavaju sve funkcije (capability), na primjer } \\
\text { „Candidate“, „Startup“, „Validate“, „Rollback-on-Error“ i } \\
\text { druge, pa se ne mogu iskoristiti većina prednosti standarda. }\end{array}$ & $\mathrm{N}$ & 1 & 2 & 3 & 4 & 5 \\
\hline 8. & $\begin{array}{l}\text { Potrebni dodatni alati (na primjer NETCONF browser ili } \\
\text { aplikacija u Pythonu) }\end{array}$ & $\mathrm{N}$ & 1 & 2 & 3 & 4 & 5 \\
\hline 9. & Strah od novih tehnologija & $\mathrm{N}$ & 1 & 2 & 3 & 4 & 5 \\
\hline 10. & Nešto drugo (molimo navedite) & $\mathrm{N}$ & 1 & 2 & 3 & 4 & 5 \\
\hline
\end{tabular}




\section{Vaše mišljenje o NETCONF standardu}

23. Molimo Vas da izrazite svoje mišljenje o nedostacima NETCONF standarda?

\begin{tabular}{|cccccc|}
\hline \multicolumn{5}{c|}{ Nedostaci NETCONF standarda } \\
& \multicolumn{5}{c|}{ Molimo označite svoje mišljenje, pri čemu je: } \\
$\mathrm{N}$ & 1 & 2 & 3 & 4 & 5 \\
Ne znam & Izrazito se NE & NE slažem se & Niti se slažem niti & Slažem se & Izrazito se \\
(Ne poznajem & slažem & se ne slažem & slažem \\
dovoljno & & & \\
NETCONF da & & & \\
bih mogao & & & \\
odgovoriti) & & & \\
\hline
\end{tabular}

\begin{tabular}{|c|l|c|c|c|c|c|c|}
\hline 1. & $\begin{array}{l}\text { NETCONF standard koristi XML jezik i njegovu sintaksu koja je } \\
\text { redundantna i opširna što može zamarati i zbunjivati. }\end{array}$ & 1 & 2 & 3 & 4 & 5 \\
\hline 2. & $\begin{array}{l}\text { Za korištenje NETCONF protokola potrebno je poznavanje } \\
\text { programskih jezika. }\end{array}$ & $\mathrm{N}$ & 2 & 3 & 4 & 5 \\
\hline
\end{tabular}

ZAPAŽANJA: 
24. Slažete li se sa sljedećim tvrdnjama?

\section{Ostala pitanja (primjena NETCONF standarda)}

Molimo označite svoje mišljenje, pri čemu je:

$\mathrm{N}$

Ne znam

(Ne poznajem

dovoljno

NETCONF da

bih mogao

odgovoriti)

\begin{tabular}{|c|l|c|c|c|c|c|c|}
\hline 1. & $\begin{array}{l}\text { NETCONF pomaže korisnicima u radu kada su u mreži prisutni } \\
\text { R/S uređaji različitih proizvođača. }\end{array}$ & 1 & 2 & 3 & 4 & 5 \\
\hline 2. & $\begin{array}{l}\text { Dostupnost NETCONF standarda na uređajima proizvođača je } \\
\text { važna za njihovu konkurentnost na tržištu. }\end{array}$ & 1 & 2 & 3 & 4 & 5 \\
\hline 3. & $\begin{array}{l}\text { NETCONF standard bi se trebao više koristiti od strane } \\
\text { korisnika na R/S uređajima. }\end{array}$ & $\mathrm{N}$ & 1 & 2 & 3 & 4 & 5 \\
\hline 4. & $\begin{array}{l}\text { RESTCONF standard (definiran u RFC 8040 u siječnju 2017.) je } \\
\text { bolje rješenje za konfiguraciju mrežnih uređaja od NETCONF } \\
\text { standarda. }\end{array}$ & 1 & 2 & 3 & 4 & 5 \\
\hline 5. & $\begin{array}{l}\text { Rad s nestandardnim CLI sučeljem i njegovim konfiguracijskim } \\
\text { datotekama je više ,human readable“ nego kada se koristi } \\
\text { NETCONF standard. }\end{array}$ & 1 & 2 & 3 & 4 & 5 \\
\hline
\end{tabular}

\section{ZAPAŽANJA:}




\section{NETCONF i povećanje raspoloživosti (H1)}

25. *Slažete li se sa sljedećim tvrdnjama?

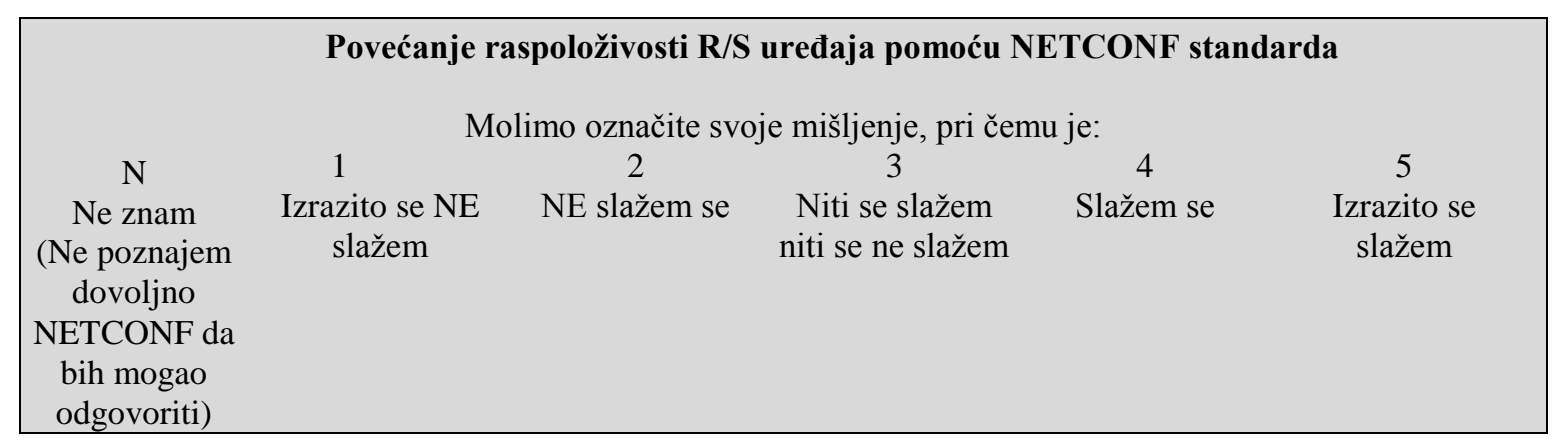

\begin{tabular}{|c|l|c|c|c|c|c|c|}
\hline 1. & $\begin{array}{l}\text { Korištenje NETCONF standarda povećava raspoloživost } \\
\text { mrežnog R/S uređaja u odnosu na nestandardne CLI metode } \\
\text { konfiguriranja mrežnih uređaja (operacijskih sustava } \\
\text { proizvođača opreme). }\end{array}$ & 1 & 2 & 3 & 4 & 5 \\
\hline 2. & $\begin{array}{l}\text { NETCONF standard bi se trebao više koristiti od strane } \\
\text { proizvođača i korisnika na R/S uređajima zbog postizanja } \\
\text { povećanja raspoloživosti uređaja i sustava. }\end{array}$ & 1 & 2 & 3 & 4 & 5 \\
\hline
\end{tabular}


26. *Pomoću kojih svojih funkcija NETCONF standard povećava raspoloživost mrežnih $\mathrm{R} / \mathrm{S}$ uređaja?

\begin{tabular}{|cccccc|}
\hline \multicolumn{5}{c|}{ Povećanje raspoloživosti po funkcijama NETCONF standarda } \\
Molimo označite svoj stav o navedenim tvrdnjama, pri čemu je: & 4 \\
$\mathrm{~N}$ & 1 & 2 & 3 & 4 \\
Ne znam & Izrazito se NE & NE slažem se & Niti se slažem & Slažem se & Izrazito se \\
(Ne poznajem & slažem & & niti se ne & & \\
dovoljno & & slažem & \\
NETCONF da \\
bih mogao \\
odgovoriti)
\end{tabular}

\begin{tabular}{|c|l|c|c|c|c|c|c|}
\hline 1. & $\begin{array}{l}\text { NETCONF kao standardni način konfiguracije preko udaljenog } \\
\text { pristupa na IP adresu uređaja povećava raspoloživost mrežnih } \\
\text { uređaja zato jer je za sve proizvođače ista (standardna) struktura } \\
\text { komandi i podataka. }\end{array}$ & 1 & 2 & 3 & 4 & 5 \\
\hline 2. & $\begin{array}{l}\text { NETCONF kao standard povećava raspoloživost jer omogućava } \\
\text { programabilnost (automatiziranje) konfiguriranja mrežnih uređaja } \\
\text { koja značajno smanjuje učestalost ljudske pogreške. }\end{array}$ & $\mathrm{N}$ & 1 & 2 & 3 & 4 & 5 \\
\hline 3. & $\begin{array}{l}\text { NETCONF standard povećava raspoloživost mrežnih uređaja zbog } \\
\text { toga što koristi jasnu razliku u strukturi između } \\
\text { konfiguracijskih i operacijskih podataka. }\end{array}$ & $\mathrm{N}$ & 1 & 2 & 3 & 4 & 5 \\
\hline 4. & $\begin{array}{l}\text { Mogućnost parcijalnog konfiguriranja* uređaja pomoću } \\
\text { NETCONF standarda povećava raspoloživost mrežnih uređaja. } \\
\text { *NETCONF postiže pomoću XML jezika i „XML subtree } \\
\text { filtering“ funkcije }\end{array}$ & $\mathrm{N}$ & 1 & 2 & 3 & 4 & 5 \\
\hline 5. & $\begin{array}{l}\text { Mogućnost provjere konfiguracije prije primjene* kod } \\
\text { NETCONF načina konfiguriranja uređaja povećava raspoloživost } \\
\text { mrežnih uređaja. } \\
\text { *NETCONF postiže provjeru konfiguracijske datoteke pomoću } \\
\text { funkcije <validate> }\end{array}$ & 1 & 2 & 3 & 4 & 5 \\
\hline 6. & $\begin{array}{l}\text { Mogućnost zaključavanja konfiguracijske datoteke* koje nudi } \\
\text { NETCONF povećava raspoloživost mrežnih uređaja. } \\
\text { *NETCONF pomoću operacija ,lock“ i ,unlock“ onemogućava } \\
\text { istovremenu promjenu konfiguracijske datoteke iz više izvora (na } \\
\text { primjer istovremena druga NETCONF sesija, CLI pristup ili } \\
\text { pristup pomoću SNMP protokola). }\end{array}$ & 1 & 2 & 3 & 4 & 5 \\
\hline 7. & $\begin{array}{l}\text { „Backup \& restore“* mogućnost koju nudi NETCONF standard } \\
\text { povećava raspoloživost mrežnih uređaja. } \\
\text { *NETCONF postiže pomoću (1) manipulacije konfiguracijskih } \\
\text { datoteka (<running>, <candidate>, <startup> i backup) i (2) } \\
\text { pomoću funkcije „Rollback-on-Error“. }\end{array}$ & $\mathrm{N}$ & 1 & 2 & 3 & 4 & 5 \\
\hline
\end{tabular}




\begin{tabular}{|c|l|c|c|c|c|c|c|}
\hline 8. & $\begin{array}{l}\text { Mogućnost istovremenog i koordiniranog konfiguriranja svih } \\
\text { ili više uređaja* u mreži koje nudi NETCONF povećava } \\
\text { raspoloživost mrežnih uređaja. } \\
\text { *NETCONF postiže pomoću manipulacije konfiguracijskih } \\
\text { datoteka (<running>, <candidate>, <startup> i backup) i pomoću } \\
\text { operacija, ,lock“ i, ,unlock“. }\end{array}$ & 1 & 2 & 3 & 4 & 5 \\
\hline 9. & \begin{tabular}{l} 
Nešto drugo (molimo navedite) \\
\hline
\end{tabular} & $\mathrm{N}$ & 1 & 2 & 3 & 4 & 5 \\
\hline
\end{tabular}

ZAPAŽANJA:: 


\section{Povećanje primjene i poboljšanje NETCONF standarda}

27. *Na koji način mislite da bi se mogla povećati primjena NETCONF standarda od strane proizvođača?

\begin{tabular}{|cccccc|}
\hline \multicolumn{7}{c|}{ Kako proizvođači mogu povećati primjenu NETCONF standarda? } \\
Molimo označite svoje mišljenje, pri čemu je: \\
$\mathrm{N}$ & 1 & 2 & 3 & 4 & 5 \\
Ne znam & Nevažno & Malo važno & Važno & Vrlo važno & Izuzetno važno \\
\hline
\end{tabular}

\begin{tabular}{|c|l|c|c|c|c|c|c|}
\hline 1. & $\begin{array}{l}\text { Implementirati NETCONF na svim vrstama R/S uređaja (na } \\
\text { primjer od malih SMB uređaja do velikih ISP uređaja) }\end{array}$ & 1 & 2 & 3 & 4 & 5 \\
\hline 2. & $\begin{array}{l}\text { Povećati informiranje o teoretskom radu i prednostima NETCONF } \\
\text { standarda (na primjer pomoću organiziranih tečajeva proizvođača, } \\
\text { radionica, CBT, Webinar, i drugo). }\end{array}$ & 1 & 2 & 3 & 4 & 5 \\
\hline 3. & $\begin{array}{l}\text { Povećati informiranje o praktičnoj primjeni NETCONF standarda } \\
\text { (na primjer objavljivanje preporuka za uporabu (white papers) i } \\
\text { drugo). }\end{array}$ & 1 & 2 & 3 & 4 & 5 \\
\hline 4. & $\begin{array}{l}\text { Povećati informiranje o primjeni NETCONF standarda za } \\
\text { povećanje raspoloživosti R/S mrežnih uređaja i sustava (na } \\
\text { primjer objavljivanje preporuka za uporabu (white papers) i } \\
\text { drugo). }\end{array}$ & 1 & 2 & 3 & 4 & 5 \\
\hline 5. & $\begin{array}{l}\text { Povećati edukaciju i informiranje o softverski definiranim } \\
\text { mrežama (Software Defined Networks - SDN) }\end{array}$ & $\mathrm{N}$ & 1 & 2 & 3 & 4 & 5 \\
\hline 6. & $\begin{array}{l}\text { Povećati edukaciju i informiranje o automatizaciji i programiranju } \\
\text { računalnih mreža (Automation tools and DevOps) }\end{array}$ & $\mathrm{N}$ & 1 & 2 & 3 & 4 & 5 \\
\hline 7. & $\begin{array}{l}\text { Pojačati edukaciju o programiranju i programskim jezicima } \\
8 .\end{array}$ & $\mathrm{N}$ & 1 & 2 & 3 & 4 & 5 \\
\hline Nešto drugo (molimo navedite) & & & & & \\
\hline
\end{tabular}


28. Na koji način Vi vidite buduću primjenu i razvoj NETCONF standarda?

29. Molim Vas da izložite svoja dodatna zapažanja i mišljenje vezano uz primjenu NETCONF standarda i povećanje raspoloživosti mrežnih uređaja, a koja nisu obrađena u prethodnim pitanjima:

\section{Vaši kontakt-podaci}

30. Ako želite da Vam se na e-mail adresu pošalju rezultati istraživanja, molim Vas da upišete svoju e-mail adresu:

31. Ova anketa je anonimna. Ipak, ako želite, možete ostaviti svoje osobne podatke:

- Ime i prezime:

- $\quad$ Poduzeće:

- Radno mjesto:

- Mobitel: 


\section{Literatura}

1. Alcatel-Lucent Enterprise SDN Strategy, https://www.al-enterprise.com//media/assets/internet/documents/network-strategy-whitepaper-en.pdf, (21.3.2019).

2. Alcatel-Lucent Enterprise SDN, https://www.alenterprise.com/en/perspectives/strategies/software-defined-networking, (21.3.2019).

3. Arista SDN, https://www.arista.com/en/solutions/software-defined-networking, (21.3.2019).

4. Availability, https://en.wikipedia.org/wiki/Availability (10.5.2019)

5. Bajpai, V., Schönwälder, J. 2014. NETCONF Interoperability Lab, Conference paper, 14th IEEE/IFIP Network Operations and Management Symposium (NOMS 2014), At Krakow, Poland.

6. Big Switch Networks Big CLoud Fabric, https://www.bigswitch.com/products/bigcloud-fabric, (21.3.2019).

7. Campbell, A., De Meer, H., Kounavis, M., Miki, K., Vicente, J., and D. Villela, 1992. A Survey of Programmable Networks, ACM SIGCOMM Computer Communication Review, Volume 29, Issue 2, 7-23.

8. Chowdhury, N. and R. Boutaba, 2009. Network Virtualization:State of the Art and Research Challenges, Communications Magazine, IEEE, Volume 47, Issue 7, pp. 2026.

9. Cisco Zero Touch Provisioning, https://www.cisco.com/c/en/us/td/docs/switches/lan/catalyst3850/software/release/165/configuration_guide/prog/b_165_prog_3850_cg/zero_touch_provisioning.pdf (15.8.2019).

10. Cisco ACI infrastruktura, https://www.cisco.com/c/en/us/solutions/data-centervirtualization/application-centric-infrastructure/index.html\# stickynav=4 (21.3.2019).

11. Cisco ACI, https://www.cisco.com/c/dam/en/us/solutions/collateral/data-centervirtualization/application-centric-infrastructure/esg-lab-validation-aci.pdf (21.3.2019). 
12. Cisco Campus Network for High Availability Design Guide (2008)

http://www.cisco.com/en/US/docs/solutions/Enterprise/Campus/HA_campus_DG/haca mpusdg.html\#wp1108817 (10.1.2012.)

13. Cisco CCNA Routing/switching course, Cisco Academy v4.0 e-learning (2009.), https://www.netacad.com/ (11.05.2012).

14. Cisco DevNet: Cisco APIs, SDKs, Sandbox and Community for Cisco Developers:, https://developer.cisco.com/ (20.5.2019)

15. Cisco DevNet: JSON https://developer.cisco.com/learning/help (20.8.2019)

16. Cisco DevNet: Model Driven Programmability https://developer.cisco.com/site/standard-network-devices/ (15.8.2019).

17. Cisco DevNet: RESTCONF https://developer.cisco.com/learning/modules/intro-devicelevel-interfaces/intro-restconf/step/2 (20.8.2019)

18. Cisco Feature Navigator https://cfn.cloudapps.cisco.com/ITDIT/CFN/jsp/index.jsp (17.08.2019)

19. Cisco Feature Navigator: NETCONF https://cfn.cloudapps.cisco.com/ITDIT/CFN/jsp/by-feature-technology.jsp (17.08.2019).

20. Cisco Systems www.cisco.com (21.1.2019).

21. Cisco Systems 2018. DevNet Series Network Programmability with YANG, NETCONF and RESTCONF, Cisco Academy e-learning.

22. Cisco Systems, Preston Hank (2018) NETCONF, RESTCONF, YANG Demos, API versus CLI (2. part) https://www.youtube.com/watch?v=o3CaEaVfCP0 (20.1.2019)

23. Cisco Systems, Preston Hank (2018) YANG, NETCONF, RESTCONF Demos. Which Cisco devices are supported? (1. part) https://www.youtube.com/watch?v=cooE3wZ7O4I (20.1.2019)

24. Cisco Systems: Cisco CCNA Routing/switching course, Cisco Academy v6.0 e-learning (2017.), https://www.netacad.com/ (20.10.2018).

25. Cisco Systems: Partner Ecosystem, https://www.cisco.com/c/en/us/solutions/partnerecosystem.html (20.1.2019) 
26. Cisco Validated Designs

http://www.cisco.com/en/US/solutions/ns340/ns414/ns742/ns741/networking solutions _products_genericcontent0900aecd80601e22.html, (10.1.2012.)

27. Cisco: Find a Cisco Partner

https://locatr.cloudapps.cisco.com/WWChannels/LOCATR/openBasicSearch.do (25.01.2019).

28. Cisco: Select, Premier, and Gold Certifications

https://www.cisco.com/c/en/us/partners/partner-with-cisco/channel-partnerprogram/certifications/select-premier-gold.html (16.08.2010).

29. Clemm, A. 2006. Network management fundamentals, Cisco Press

30. Dell SDN Solution, http://i.dell.com/sites/doccontent/business/largebusiness/en/Documents/Dell-Networking-SDN-Solutions-Guide.pdf, (21.3.2019).

31. Deveriya, A. 2005. Network Administrators Survival Guide, Cisco Press, ISBN: 158705-211-3.

32. DevOps, https://en.wikipedia.org/wiki/DevOps (20.8.2019).

33. Dye, M., McDonald, R., Ruf, A. 2007. Network Fundamentals, CCNA Exploration Companion Guide, Cisco Press.

34. Easy-feedback: NETCONF Protocol: Interview (vendors) (2019) https://indivsurvey.com/customer/survey/1176497 (10.06.2019).

35. Easy-feedback: Upitnik o NETCONF protokolu (2019.) https://indivsurvey.com/customer/survey/1175461 (10.06.2019).

36. Extreme Networks ExtremeControl, https://www.extremenetworks.com/product/extremecontrol/, (21.3.2019).

37. Extreme Networks SDN, https://iamnetworks.net/2017/01/09/extreme-networksextremecontrol-sdn/ (21.3.2019).

38. F5 BIG-I, https://www.f5.com/products/automation-and-orchestration/big-iq, (21.3.2019).

39. F5 SDN, https://f5.com/solutions/software-defined-networking, (21.3.2019).

40. Floodlight applications, http://www.projectfloodlight.org/download, (21.3.2019).

41. Floodlight, http://www.projectfloodlight.org/floodlight, (21.3.2019). 
42. Franetić F., Valenčić, D. 2019 Nadzor i upravljanje računalne mreže davatelja usluga, Zbornik radova, 12. Međunarodna konferencija "Dani kriznog upravljanja“, Veleučilište Velika Gorica, Šibenik.

43. Galac M., Valenčić D.. 2015. Trendovi u izgradnji podatkovnih centara u Hrvatskoj, Proceedings of the 38th International Convention, Croatian Society for Information and Communication Technology, Electronics and Microelectronics - MIPRO, Rijeka.

44. Geng, H. 2015. Data Center Handbook, Wiley, ISBN 978-1-118-43663-9.

45. Greenberg, A., Hjalmtysson, G., Maltz, D., Myers, A., Rexford, J., Xie, G., Yan, H., Zhan, J., and H. Zhang, 2005. A CleanSlate 4D Approach to Network Control and Management, ACM SIGCOMM Computer Communication Review, Volume 35, Issue 5, pp. 41-54.

46. Halsall, F. 1995. Data Communications, Computer Networks and Open Systems, 4th Edition, Addison Wesley.

47. Harris, S. 2013. CISSP all-in-one exam guide, McGraw-Hill, Inc., 6th ed.

48. Hewlett Packard Enterprise SDN Controller, https://community.hpe.com/t5/SoftwareDefined-Networking/bd-p/sdn-discussions\#.XHPUQqB7nb0, (21.3.2019).

49. High Availability, https://en.wikipedia.org/wiki/High_availability (10.5.2019)

50. Huawei www.huawei.com (21.1.2019).

51. Huawei SDN, https://e.huawei.com/en/solutions/technical/sdn, (21.3.2019).

52. Hunnebeck, L. 2011. ITIL Service Design, The Stationery Office 2nd edition.

53. IANA: Network Configuration Protocol (NETCONF) Capability URNs (2019) https://www.iana.org/assignments/netconf-capability-urns/netconf-capability-urns.xml, (20.5.2019)

54. IBM Global Service: Improving Systems Availability (1998) http://www.cs.cmu.edu/ priya/hawht.pdf (10.1.2012.)

55. IDC, Worldwide Ethernet Switch and Router 3Q15 Market Share Update (2016), https://www.idc.com/getdoc.jsp?containerId=US40444915 (10.05.2016)

56. IETF Datatracker, ttps://datatracker.ietf.org/doc/search?name=NETCONF\&sort=\&rfcs=on \&activedrafts=0 $\mathrm{n} \& \mathrm{by}=$ group \&group $=(15.8 .2019)$

57. IETF Documents, https://tools.ietf.org/html/ (20.5.2019) 
58. IETF NETCONF Wiki, https://trac.ietf.org/trac/netconf/wiki (16.08.2010)

59. IETF RFC 1350 THE TFTP PROTOCOL (REVISION 2) (1985), https://tools.ietf.org/html/rfc1350 (11.3.2019).

60. IETF RFC 3411 An Architecture for Describing Simple Network Management Protocol (SNMP) Management Frameworks (2002), https://tools.ietf.org/html/rfc3411 (21.10.2010).

61. IETF RFC 3535 Overview of the 2002 IAB Network Management Workshop (2002), https://tools.ietf.org/html/rfc3535 (21.1.2019).

62. IETF RFC 3553 An IETF URN Sub-namespace for Registered Protocol Parameters (2003) https://tools.ietf.org/html/rfc3553 (21.3.2019).

63. IETF RFC 3954 Cisco Systems NetFlow Services Export Version 9 (2004), https://tools.ietf.org/html/rfc3954 (11.3.2019).

64. IETF RFC 4253 The Secure Shell (SSH) Transport Layer Protocol (2006), https://tools.ietf.org/html/rfc4253 (21.1.2019).

65. IETF RFC 4502 Remote Network Monitoring Management Information Base Version 2 (2006), https://tools.ietf.org/html/rfc4502 (11.3.2019).

66. IETF RFC 5277 NETCONF Event Notifications (2008), https://tools.ietf.org/html/rfc5277 (21.1.2019).

67. IETF RFC 5424 The Syslog Protocol (2009), https://tools.ietf.org/html/rfc5424 (11.3.2019).

68. IETF RFC 6020 YANG - A Data Modeling Language for the Network Configuration Protocol (NETCONF) (2010) https://tools.ietf.org/html/rfc6020 (21.1.2019).

69. IETF RFC 6021 Common YANG Data Types (2010) https://tools.ietf.org/html/rfc6021 (21.1.2019).

70. IETF RFC 6022 YANG Module for NETCONF Monitoring (2010) https://tools.ietf.org/html/rfc6022 (21.1.2019).

71. IETF RFC 6241 Network Configuration Protocol (NETCONF) (2011) https://tools.ietf.org/html/rfc6241 (21.1.2019).

72. IETF RFC 5717 Partial Lock Remote Procedure Call (RPC) for NETCONF (2009) https://tools.ietf.org/html/rfc5717 (21.1.2019). 
73. IETF RFC 6410 Reducing the Standards Track to Two Maturity Levels (2011) https://tools.ietf.org/html/rfc6410 (21.1.2019).

74. IETF RFC 6632 An Overview of the IETF Network Management Standards (2012) https://tools.ietf.org/html/rfc6632 (21.1.2019).

75. IETF RFC 6632 An Overview of the IETF Network Management Standards (2012), https://tools.ietf.org/html/rfc6632 (21.04.2019).

76. IETF RFC 7011 Specification of the IP Flow Information Export (IPFIX) Protocol for the Exchange of Flow Information (2013), https://tools.ietf.org/html/rfc7011 (11.3.2019).

77. IETF RFC 7149 Software-Defined Networking: A Perspective from within a Service Provider Environment (2014), https://tools.ietf.org/html/rfc7149 (21.01.2019).

78. IETF RFC 7158 The JavaScript Object Notation (JSON) Data Interchange Format (2013) https://tools.ietf.org/html/rfc7158 (15.8.2019).

79. IETF RFC 7426 Software-Defined Networking (SDN): Layers and Architecture Terminology (2015) https://tools.ietf.org/html/rfc7426 (21.1.2019).

80. IETF RFC 8040 RESTCONF Protocol (2017) https://tools.ietf.org/html/rfc8040 (15.8.2019).

81. IETF RFC 854 Telnet Protocol Specification (1983), https://tools.ietf.org/html/rfc854 (21.1.2019).

82. IETF RFC 959 FILE TRANSFER PROTOCOL (FTP) (1985), https://tools.ietf.org/html/rfc959 (11.3.2019).

83. IETF RFC početna web stranica http://www.ietf.org/rfc.html (11.10.2018).

84. IETF: RFC 4741 Network Configuration Protocol (NETCONF) (2006), https://tools.ietf.org/html/rfc4741 (21.1.2019).

85. Juniper Networks Contrail Networking, https://www.juniper.net/us/en/productsservices/sdn/contrail/contrail-networking/, (21.3.2019).

86. Juniper SDN Controller Data Sheet, https://www.juniper.net/assets/us/en/local/pdf/datasheets/1000521-en.pdf (21.3.2019). 
87. Juniper Zero Touch Provisioning https://www.juniper.net/documentation/en_US/junos/topics/topic-map/zero-touchprovision.html\#id-zero-touch-provisioning (15.8.2019).

88. Kažović D., Valenčić D., Radošević I. 2016. Primjena ITIL standarda u upravljanju kriznim situacijama IT sustava, Zbornik radova, 11. Međunarodna konferencija "Dani kriznog upravljanja“, Veleučilište Velika Gorica, Velika Gorica

89. Lebinac V., Valenčić D. 2013. Računalne mreže, izdavač Veleučilište Velika Gorica, ISBN 978-953-7716-45-5.

90. Marković S., Valenčić D., Valić B. 2018. Visoka raspoloživost preklopnika u troslojnom hijerarhijskom modelu računalnih mreža, Zbornik radova, 11. Međunarodna konferencija "Dani kriznog upravljanja“, Veleučilište Velika Gorica, Velika Gorica, 2018., znanstveni rad.

91. Marquis, H. The Paradox of the 9s (2006), ITSM Solutions, http://www.itsmsolutions.com/newsletters/DITYvol2iss47.htm (10.1.2012.)

92. McKeown, N., Anderson, T., Balakrishnan, H., Parulkar, G., Peterson, L., Rexford, J., Shenker, S., and J. Turner, 2008. OpenFlow: Enabling Innovation in Campus Networks, ACM SIGCOMM Computer Communication Review, Volume 38, Issue 2, pp. 69-74.

93. Menken, I. 2011. Itil® Foundation Complete Certification Kit - Study Book and eLearning Program - 4th edition, Publisher: Emereo Pty Ltd.

94. MG-SOFT NETCONF and YANG applications, https://www.mgsoft.si/mgProductsNetConf.html, (15.8.2019).

95. Moberg C. Introduction to NETCONF and YANG (2011) https://www.slideshare.net/cmoberg/a-30minute-introduction-to-netconf-and-yang (20.10.2018).

96. NETCONF central, http://netconfcentral.org/ (15.8.2019).

97. Netflow, https://en.wikipedia.org/wiki/NetFlow (21.1.2019).

98. NIST (US National Institute of Standards and Technology) Glossary, under NIST SP 800-113 (2008.), https://csrc.nist.gov/glossary/term/availability (11.05.2019).

99. Odom, W., Healy, R., Donohue, D. 2009. CCIE Routing and Switching Certification Guide, Cisco Press.

100. ONF, https://www.opennetworking.org/ (15.8.2019). 
101. Open Networking Foundation 2012. Software-defined networking: The new norm for networks ONF White Paper.

102. OpenConfig, http://www.openconfig.net/ (15.8.2019).

103. OpenFlow, https://en.wikipedia.org/wiki/OpenFlow (21.3.2019)

104. Petz, B., Kolesarić, V., Ivanec, D. (2012) Petzova statistika. Osnovne statističke metode za nematematičare, Naklada Slap.

105. Piedad, F., Hawkins, M. 2000. High Availability: Design, Techniques, and Processes, Prentice Hall.

106. Pupovac, V. 2019. Primjena funkcija NETCONF standarda, diplomski rad (u izradi, mentor D. Valenčić), Veleučilište Velika Gorica.

107. Schiesser, R. 2010. IT Systems Management, Pearson Education. 2nd edition, ISBN-13: 978-0-137-02506-0.

108. Schmidt, K. 2006. High availability and disaster recovery: concepts, design, implementation, Springer Science \& Business Media, ISBN-13 978-3-540-24460-8.

109. SDx Central: https://www.sdxcentral.com/ (20.1.2019).

110. Stallings, W. 2003. Data and computer communications, Fifth Edition, Pearson Education, Inc., Pearson Prentice Hall.

111. Stallings,W. Software-Defined Networks and OpenFlow (2013)

https://www.cisco.com/c/en/us/about/press/internet-protocol-journal/back-issues/tablecontents-59/161-sdn.html (20.1.2019).

112. Stevens, R. 1996. TCP/IP Illustrated, Volume 1: The Protocols, Addison Wesley, ebook.

113. Tail-f Systems: NETCONF Tutorial: https://www.slideshare.net/tailfsystems/04netconf-tutorial?next_slideshow=3 (10.2.2019.)

114. Tail-f Systems: NETCONF and YANG Tutorial part 1a: NETCONF and YANG Overview (2014) https://www.youtube.com/watch?v=Vr4kB1_6fLQ (10.1.2016.)

115. Tail-f Systems: NETCONF and YANG Tutorial part 1b: Relation to SDN (2014) https://www.youtube.com/watch?v=m6spTjQyTEo (10.1.2016.)

116. Tail-f Systems: NETCONF and YANG Tutorial part 2: NETCONF (2014) https://www.youtube.com/watch?v=xoPZO1N-x38 (10.1.2016.) 
117. Tail-f Systems: NETCONF and YANG Tutorial part 3: YANG (2014) https://www.youtube.com/watch?v=33VBb6N4yOY\&t=523s (10.1.2016.)

118. Tail-f Systems: NETCONF Tutorial, https://www.slideshare.net/tailfsystems/04$\underline{\text { netconf-tutorial?next_slideshow }=3}$ (20.10.2018).

119. Tail-f Systems: Why NETCONF? (2014) https://www.youtube.com/watch?v=HBvpHd49-o (10.1.2016).

120. Tanenbaum, A. 2003. Computer Networks, Fourth Edition, Prentice Hall, e-book.

121. Techtarget: Data center network design moves from tree to leaf (2013) https://searchdatacenter.techtarget.com/feature/Data-center-network-design-movesfrom-tree-to-leaf (21.01.2019).

122. Telecommunications Management Network, https://en.wikipedia.org/wiki/Telecommunications_Management_Network (21.04.2019).

123. Tkalac Verčič A., Sinčić Ćorić D., Pološki Vokić N. (2010) Priručnik za metodologiju istraživačkog rada - Kako osmisliti, provesti i opisati znanstveno i stručno istraživanje, M.E.P. d.o.o., Zagreb.

124. Valenčić D., Ćavar I., Lebinac V. 2012. Provedba oporavka od katastrofe u računalstvu u oblaku, Zbornik radova, 5. Međunarodna konferencija "Dani kriznog upravljanja“, Veleučilište Velika Gorica, Velika Gorica, str. 675 - 693, ISBN 978-953-7716-31-8., znanstveni rad.

125. Valenčić D., Ćavar I., Zimet J. 2012. Visoka raspoloživost računalnih mreža, Zbornik radova, 5. Međunarodna konferencija "Dani kriznog upravljanja“, Veleučilište Velika Gorica, Velika Gorica, str. 695 - 719, ISBN 978-953-7716-31-8., znanstveni rad.

126. Valenčić D., Lebinac V., Skendžić A. 2013. Developments and current trends in Ethernet technology, Proceedings of the 36th International Convention, Croatian Society for Information and Communication Technology, Electronics and Microelectronics - MIPRO, Rijeka, str. 507 - 512, ISBN: 978-953-233-074-8.

127. Valenčić D., Mateljan V. 2019. Implementation of NETCONF Protocol, Proceedings of the 42nd International Convention, Croatian Society for Information and Communication Technology, Electronics and Microelectronics - MIPRO, Rijeka. 
128. Valenčić D., Valić B. 2019. Usmjernici i preklopnici: osnovni protokoli i konfiguracija, izdavač Veleučilište Velika Gorica, ISBN 978-953-7716-88-2, (u tisku).

129. Valić B., Valenčić D. 2019. OpenDayLight kontroler u softverski definiranoj mreži, Zbornik radova, 12. Međunarodna konferencija "Dani kriznog upravljanja“, Veleučilište Velika Gorica, Šibenik.

130. VMware NSX https://www.vmware.com/products/nsx.html, (21.3.2019).

131. Zelenika, R. (2011) Metodologija i tehnologija izrade znanstvenog i stručnog djela, 5. izmijenjeno i dopunjeno izdanje, Impresum: SBN 978-953-6148-98-1 (cjelina). 


\section{Popis slika}

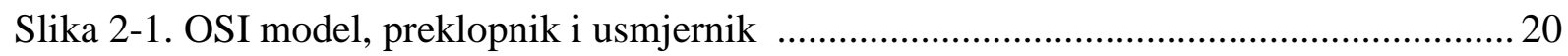

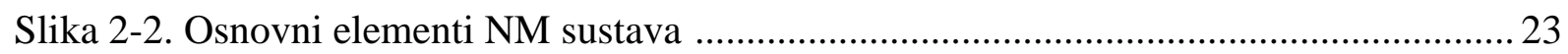

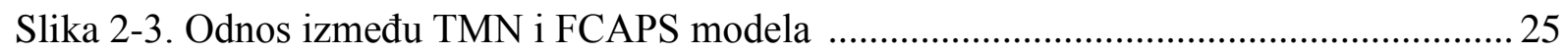

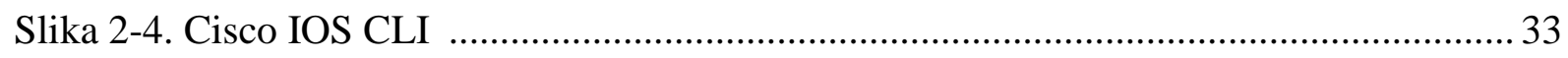

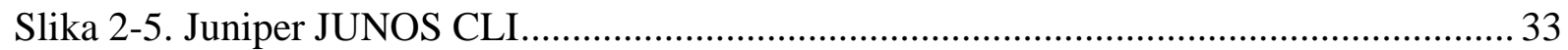

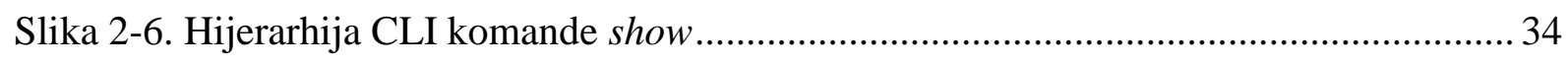

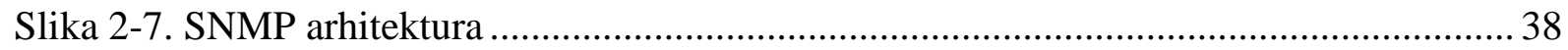

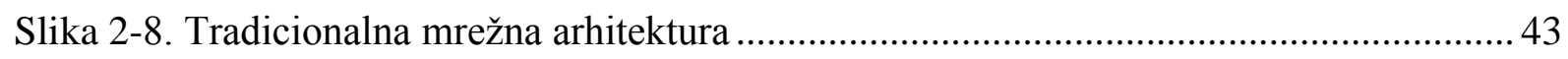

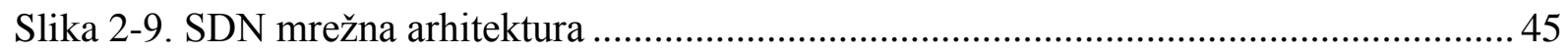

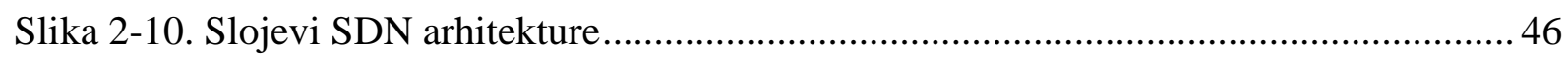

Slika 2-11. Primjer OpenFlow skupa instrukcija ............................................................... 51

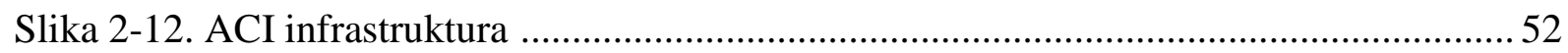

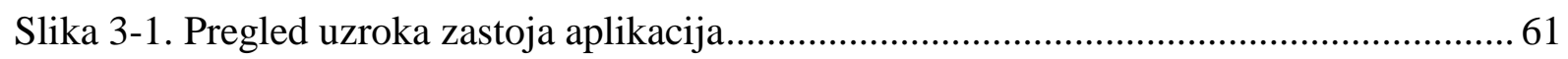

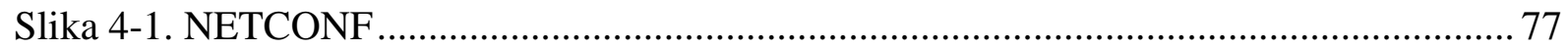

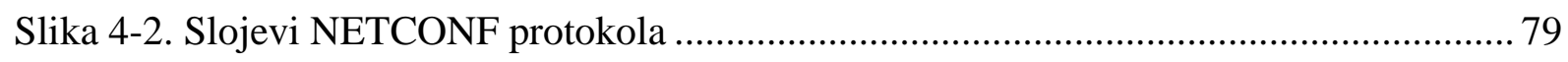

Slika 4-3. Primjer implementacije NETCONF protokola ....................................................... 80

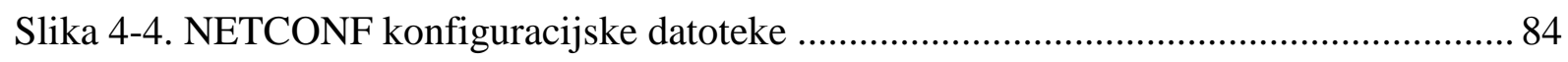

Slika 4-5. FCAPS i protokoli mrežnog upravljanja ............................................................. 91

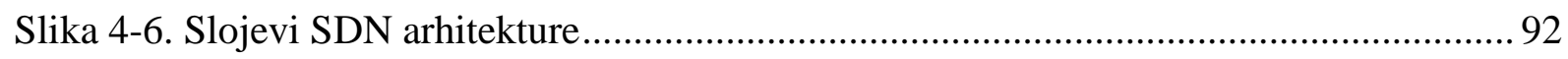

Slika 5-1. Usporedba metoda konfiguriranja mrežnih uređaja ............................................ 97

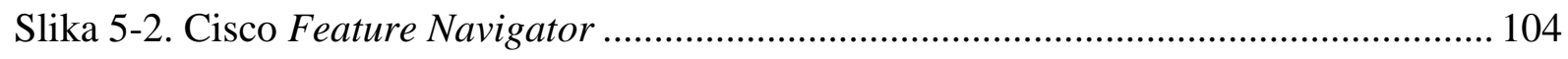

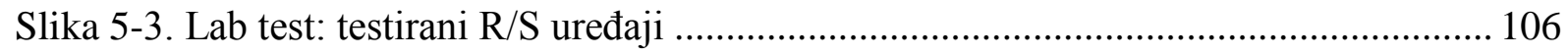

Slika 5-4. Rezultati testa: podržane NETCONF funkcije na uređajima ............................... 107 
Slika 6-1. Odnos proizvođača, partnera i krajnjih korisnika 113

Slika 6-2. Proizvođači R/S mrežnih uređaja u svijetu...... 115

Slika 6-3. Proizvođači R/S mrežnih uređaja u Hrvatskoj.... 115

Slika 6-4. Implementacija NETCONF standarda na svim vrstama R/S uređaja (intervju partneri) 175

Slika 6-5. Graf formalnog ICT obrazovanje ispitanika (upitnik korisnika) 187

Slika 6-6. Graf iskustva rada s računalnim mrežama (upitnik korisnika) 190

Slika 6-7. Raspoloživost mreže kompanije ispitanika ..... 196

Slika 6-8. Implementacija NETCONF standarda u mreži kompanije ispitanika 209 


\section{Popis tablica}

Tablica 2-1. Usporedba osnovnih JUNOS i IOS naredbi.................................................... 37

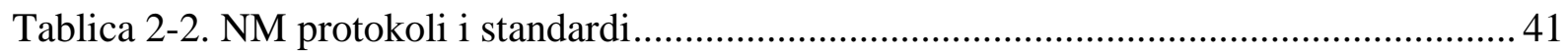

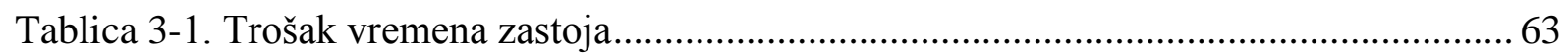

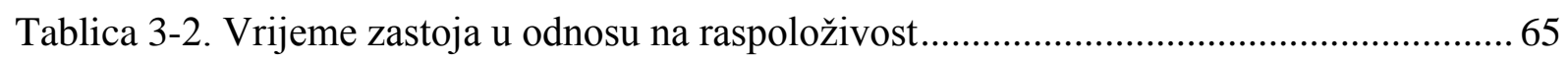

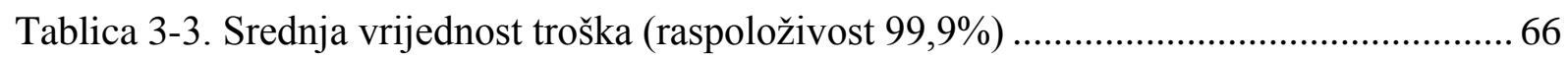

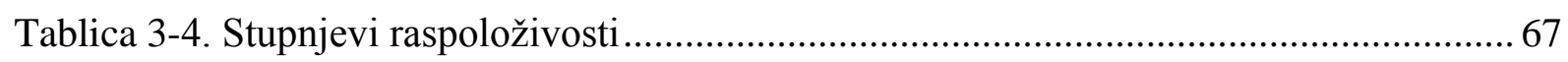

Tablica 4-1. Osnovne operacije NETCONF protokola ........................................................ 81

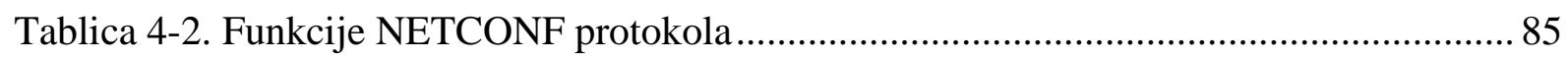

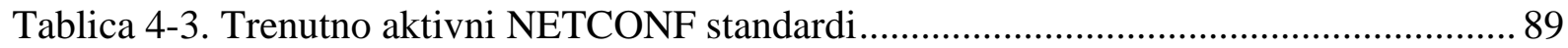

Tablica 4-4. Primjeri implementacije NETCONF protokola ............................................... 94

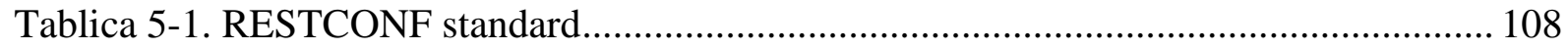

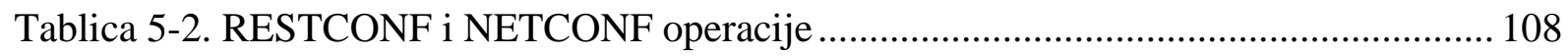

Tablica 6-1. Proizvođači R/S mrežnih uređaja u Hrvatskoj ................................................ 116

Tablica 6-2. Godine iskustva rada s računalnim mrežama (intervju proizvođači)................. 117

Tablica 6-3. Najviši stupanj certifikata iz računalnih mreža (intervju proizvođači)............. 117

Tablica 6-4. Primjena R/S mrežnih uređaja po proizvođačima (rezultati intervju partneri). 119

Tablica 6-5. R/S uređaji kod korisnika (ocjena njihovog partnera) ................................... 120

Tablica 6-6. Godine iskustva rada s računalnim mrežama (intervju partneri) ....................... 121

Tablica 6-7. Najviši stupanj certifikata iz računalnih mreža (intervju partneri) .................. 121

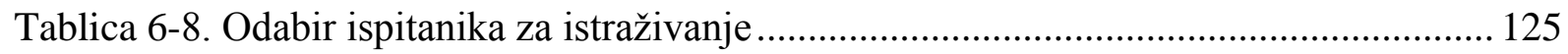

Tablica 6-9. Implementacija NETCONF standarda (intervju proizvođači) ......................... 127

Tablica 6-10. Implementacija NETCONF standarda na R/S uređajima po vrstama mreža

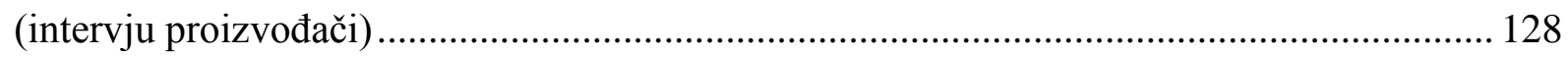


Tablica 6-11. Razlozi implementacije NETCONF standarda na R/S uređajima (intervju proizvođači) 130

Tablica 6-12. Razlozi neimplementacije NETCONF standarda na R/S uređajima (intervju proizvođači)

Tablica 6-13. Raspoloživa dokumentacija i edukacija o NETCONF standardu (intervju proizvođači)

Tablica 6-14. NETCONF standard i povećanje raspoloživosti (intervju proizvođači).......... 136

Tablica 6-15. Nedostatci NETCONF standarda (intervju proizvođači). 138

Tablica 6-16. NETCONF standard i povećanje raspoloživosti R/S uređaja (intervju proizvođači)

Tablica 6-17. Implementacija NETCONF standarda na svim vrstama R/S uređaja (intervju proizvođači)

Tablica 6-18. Primjena NETCONF standarda na R/S uređajima korisnika (intervju partneri) 150

Tablica 6-19. Raspoloživa dokumentacija i edukacija o NETCONF standardu (intervju partneri)

Tablica 6-20. Implementacija NETCONF standarda na R/S uređajima od strane korisnika (intervju partneri)

Tablica 6-21. Primjena R/S mrežnih uređaja po proizvođačima (intervju partneri)

Tablica 6-22. Razlozi implementacije NETCONF standarda na R/S uređajima korisnika (intervju partneri)

Tablica 6-23. Razlozi neimplementacije NETCONF standarda na R/S uređajima korisnika (intervju partneri) 159

Tablica 6-24. Znanje korisnika o NETCONF standardu (intervju partneri) 161

Tablica 6-25. Teoretska znanja korisnika o NETCONF standardu (intervju partneri) 162

Tablica 6-26. Praktična znanja korisnika o NETCONF standardu (intervju partneri). 164

Tablica 6-27. Povećanje raspoloživosti pomoću NETCONF standarda (intervju partneri)... 166

Tablica 6-28. Visoko raspoložive mreže korisnika (intervju partneri) 168

Tablica 6-29. Visoko raspoložive mreže korisnika i NETCONF (intervju partneri)..... 169 
Tablica 6-30. Nedostatci NETCONF standarda (intervju partneri) 171

Tablica 6-31. NETCONF standard i povećanje raspoloživosti R/S uređaja (intervju partneri)

Tablica 6-32. Formalno ICT obrazovanje ispitanika (upitnik korisnika). 186

Tablica 6-33. Najviši stupanj položenog certifikata iz računalnih mreža (upitnik korisnika) 188

Tablica 6-34. Iskustvo rada s računalnim mrežama (upitnik korisnika) 189

Tablica 6-35. Razine znanja ispitanika iz različitih područja i tehnologija računalnih mreža (upitnik korisnika) 191

Tablica 6-36. Razine znanja ispitanika iz programiranja i programskih jezika (upitnik korisnika) 193

Tablica 6-37. Poslovi ispitanika vezani uz R/S uređaje. 194

Tablica 6-38. Osnovna djelatnost kompanije zaposlenika (upitnik korisnika) 195

Tablica 6-39. Primjena R/S uređaja u Hrvatskoj po proizvođačima (upitnik korisnika) 198

Tablica 6-40. Primjena R/S uređaja u Hrvatskoj po proizvođačima (rezultati upitnika korisnika) 199

Tablica 6-41. Proizvođači R/S mrežnih uređaja u Hrvatskoj 199

Tablica 6-42. Implementacija softverski definirane mreže (SDN) (upitnik korisnika) 200

Tablica 6-43. Primjena NETCONF standarda na R/S uređajima proizvođača (upitnik korisnika) 201

Tablica 6-44. Odgovori „Ne znam“ na 15. pitanje (upitnik korisnika) 202

Tablica 6-45. Implementacija NETCONF standarda na R/S uređajima različitih proizvođača (upitnik korisnika). 202

Tablica 6-46. Podrška primjene NETCONF standarda od strane proizvođača (rezultati upitnika korisnika). 203

Tablica 6-47. Podrška primjene NETCONF standarda od strane proizvođača (upitnik korisnika) 204

Tablica 6-48. Raspoloživa NETCONF dokumentacija i edukacija (rezultati upitnika korisnika) 205 
Tablica 6-49. Raspoloživa NETCONF dokumentacija i edukacija (upitnik korisnika) 206

Tablica 6-50. Načini povećanja primjene NETCONF standarda od strane proizvođača (rezultati upitnika korisnika) 207

Tablica 6-51. Načini povećanja primjene NETCONF standarda od strane proizvođača (upitnik korisnika) 208

Tablica 6-52. Implementacija NETCONF standarda po vrstama mreža (rezultati upitnika korisnika) 210

Tablica 6-53. Implementacija NETCONF standarda po vrstama mreža (upitnik korisnika). 211 Tablica 6-54. Implementacija NETCONF standarda po proizvođačima (rezultati upitnika korisnika) 211

Tablica 6-55. Implementacija NETCONF standarda po proizvođačima (upitnik korisnika) 212 Tablica 6-56. Razlozi implementacije NETCONF standarda na R/S uređajima (upitnik korisnika)

Tablica 6-57. Razlozi neimplementacije NETCONF standarda na R/S uređajima (rezultati upitnika korisnika). 214

Tablica 6-58. Razlozi neimplementacije NETCONF standarda na R/S uređajima (upitnik korisnika) 215

Tablica 6-59. Razine znanja ispitanika o NETCONF standardu (upitnik korisnika). 217

Tablica 6-60. Razine znanja ispitanika o svojstvima NETCONF standarda (upitnik korisnika) 218

Tablica 6-61. NETCONF standard i povećanje raspoloživosti R/S uređaja (rezultati upitnika korisnika). 219

Tablica 6-62. NETCONF standard i povećanje raspoloživosti R/S uređaja (upitnik korisnika) 220

Tablica 6-63. Svojstva NETCONF standarda i povećanje raspoloživosti R/S uređaja (rezultati upitnika korisnika). 221

Tablica 6-64. Svojstva NETCONF standarda i povećanje raspoloživosti R/S uređaja (upitnik korisnika) 222

Tablica 6-65. Nedostatci NETCONF standarda (rezultati upitnika korisnika) 223 
Tablica 6-66. Nedostaci NETCONF standarda (upitnik korisnika) 224

Tablica 6-67. NETCONF standard i povećanje raspoloživosti R/S uređaja (rezultati upitnika korisnika) 225

Tablica 6-68. NETCONF standard i povećanje raspoloživosti R/S uređaja (upitnik korisnika) 226

Tablica 7-1. Razlozi implementacije NETCONF standarda na R/S uređajima (usporedni prikaz). 237

Tablica 7-2. NETCONF standard i povećanje raspoloživosti (usporedni prikaz) 239

Tablica 7-3. NETCONF standard i povećanje raspoloživosti R/S uređaja (usporedni prikaz) 240

Tablica 7-4. Raspoloživa dokumentacija i edukacija o NETCONF standardu (usporedni prikaz)

Tablica 7-5. Razlozi neimplementacije NETCONF standarda na R/S uređajima (usporedni prikaz). 244

Tablica 7-6. Nedostaci NETCONF standarda (usporedni prikaz) 246

Tablica 7-7. Dodatni nedostatci NETCONF standarda (usporedni prikaz) 247

Tablica 7-8. Implementacija NETCONF standarda na R/S uređajima po vrstama mreža (usporedni prikaz)

Tablica 7-9. Primjena NETCONF standarda na R/S uređajima korisnika (usporedni prikaz) 250

Tablica 7-10. Načini povećanja primjene NETCONF standarda od strane proizvođača (upitnik korisnika). 251

Tablica 7-11. Znanje korisnika o NETCONF standardu (usporedni prikaz) 254

Tablica 7-12. Znanja korisnika o mogućnostima NETCONF standarda (usporedni prikaz). 255 Tablica 8-1. NETCONF i povećanje raspoloživosti (25.1 pitanje anketnog upitnika) .......... 259

Tablica 8-2. Testiranje 1. hipoteze 259

Tablica 8-3. Implementacija NETCONF standarda od proizvođača (14. pitanje anketnog upitnika) 260

Tablica 8-4. Testiranje 2. hipoteze 261 
Tablica 8-5. Implementacija NETCONF standarda od korisnika (18. pitanje anketnog

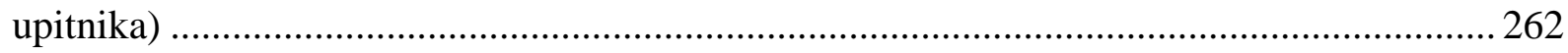

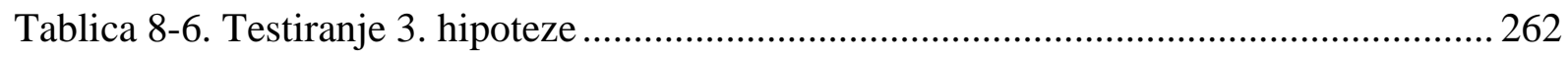

Tablica 8-7. Poznavanje NETCONF standarda od strane korisnika (12.3 pitanje anketnog

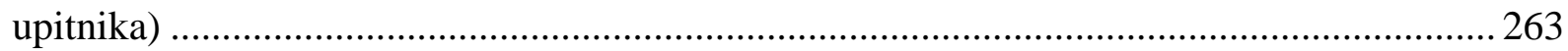

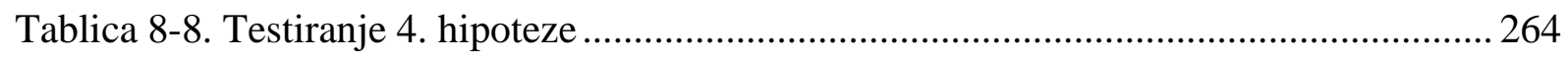

Tablica 8-9. Razine znanja ispitanika iz različitih područja i tehnologija računalnih mreža (4.

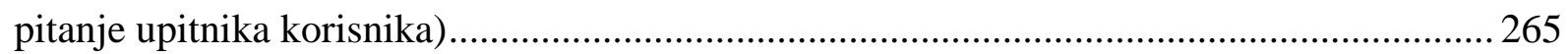

Tablica 8-10. Razine znanja ispitanika o NETCONF standardu (12. pitanje upitnika

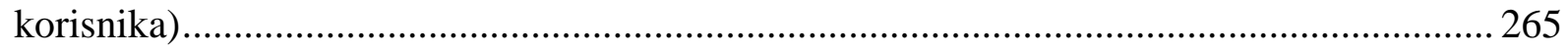

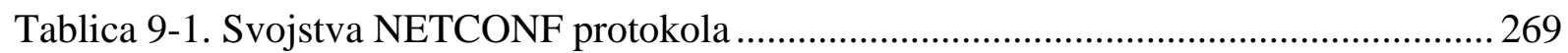




\title{
Popis hrvatskih naziva za osnovne pojmove računalnih mreža na engleskom jeziku
}

\author{
Hrvatski naziv: \\ aplikacijska ravnina \\ aplikacijski sloj \\ aplikacijsko programsko sučelje \\ autentikacija \\ balansiranje opterećenja \\ cjelovitost podataka \\ čitljiv \\ davatelj usluga \\ definiranje strukture okvira \\ distribucijski sloj \\ dolazeći promet \\ fizički sloj \\ grafičko korisničko sučelje \\ grupa protokola \\ grupa servera \\ informacijska tehnologija \\ informacijsko-komunikacijske tehnologije \\ internet stvari \\ internetski davatelj usluga

\section{Engleski naziv:} \\ Application Plane - AP \\ application layer \\ Application Programming Interface - API \\ authentication \\ load balancing \\ data integrity \\ human readable \\ Service Provider - SP \\ framing \\ distribution layer \\ inbound traffic \\ physical layer \\ Graphical User Interface - GUI \\ protocol suite \\ server cluster \\ Information Technology - IT \\ Information and Communication Technology \\ - ICT \\ Internet of Things - IoT \\ Internet Service Proveder - ISP
}




\begin{tabular}{|c|c|}
\hline jedinstvene točke prekida & Single Point of Failure - SPoF \\
\hline jedinstveni identifikator resursa & Uniform Resource Identifier - URI \\
\hline jednostavno korisniku za uporabu & user-friendly \\
\hline jezgreni sloj & core layer \\
\hline komandno korisničko sučelje & Command Line Interface - CLI \\
\hline komandno orijentiran & command/task oriented \\
\hline koncentrator & hub \\
\hline konfiguracijska datoteka & configuration datastore \\
\hline konfiguracijski podaci & configuration dana \\
\hline kontrola pristup mediju & Media Access Control - MAC \\
\hline kontrola prometnih tokova & flow control \\
\hline kontrola pogreške & error control \\
\hline kontrolna ravnina & Control Plane - CP \\
\hline konzistentnost konfiguracije & configuration consistency \\
\hline konzola & console \\
\hline krajnji uređaj & end device \\
\hline logiranje poruka & message logging \\
\hline manji gubitak & minor outages \\
\hline među-procesna komunikacija & Inter-Process Communication - IPC \\
\hline model podataka & data model \\
\hline mrežni čvor & network node \\
\hline mrežni sloj & network layer \\
\hline nacrt dokumenta & draft document \\
\hline nadzor mreža & network monitoring \\
\hline nadzor na daljinu & Remote Network Monitoring - RMON \\
\hline neprekidan rad & continuous processing \\
\hline neprekidnost poslovanja & Business Continuity - BC \\
\hline neraspoloživ & unavailable \\
\hline
\end{tabular}




\begin{tabular}{|c|c|}
\hline NETCONF funkcija & NETCONF capability \\
\hline normalna komercijalna raspoloživost & normal commercial availability \\
\hline odlazeći promet & outbound traffic \\
\hline operacijski sloj & operations layer \\
\hline operacijski sustav & Operating System - OS \\
\hline operativna ravnina & Operational Plane - OP \\
\hline oporavak od katastrofe & Disaster Recovery - DR \\
\hline otpornost na grešku & fault resilient \\
\hline otvoreni koda & open source \\
\hline otvoreni sustav & open system \\
\hline podaci notifikacije & notification dana \\
\hline podaci stanja & state data \\
\hline podatkovna ravnina & Forwarding Plane - FP \\
\hline podatkovni centar & data center \\
\hline podatkovni sloj & data link layer \\
\hline podatkovno orijentiran & data-oriented \\
\hline poduzeće & enterprise \\
\hline poslovno upravljanje & business management \\
\hline poslužitelj & server \\
\hline posredovni uređaj & intermediate device \\
\hline predefinirana putanja & default route \\
\hline predložak & template \\
\hline predloženi standard & proposed standard \\
\hline prekid & interruption \\
\hline preklapanje & switching \\
\hline preklopnik & switch \\
\hline preuzeti & fetch \\
\hline prezentacijski sloj & presentation layer \\
\hline
\end{tabular}




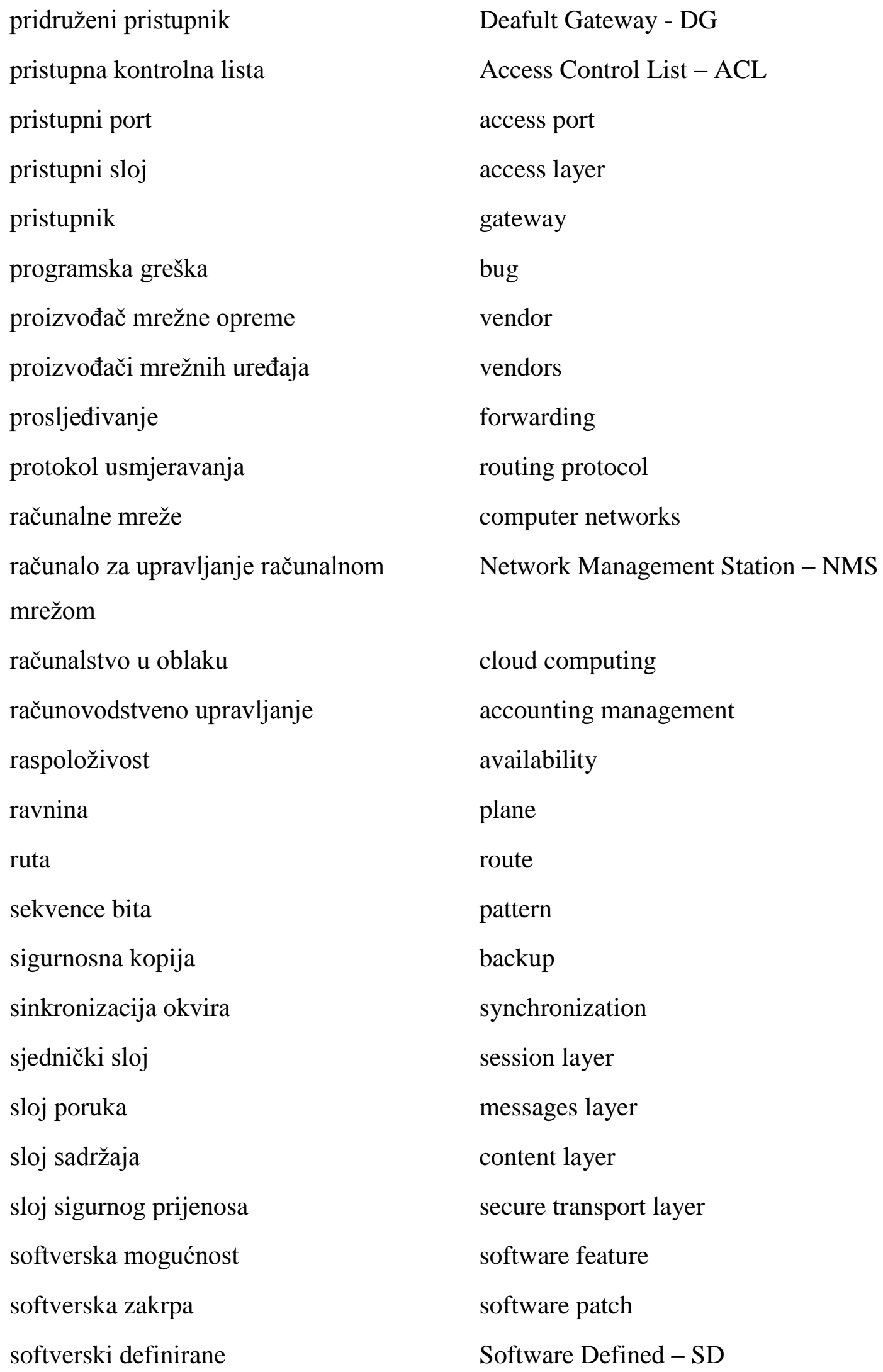

pridruženi pristupnik

pristupna kontrolna lista

pristupni port

pristupni sloj

pristupnik

programska greška

proizvođač mrežne opreme

proizvođači mrežnih uređaja

prosljeđivanje

protokol usmjeravanja

računalne mreže

računalo za upravljanje računalnom

mrežom

računalstvo u oblaku

računovodstveno upravljanje

raspoloživost

ravnina

ruta

sekvence bita

sigurnosna kopija

sinkronizacija okvira

sjednički sloj

sloj poruka

sloj sadržaja

sloj sigurnog prijenosa

softverska mogućnost

softverska zakrpa

softverski definirane

Deafult Gateway - DG

Access Control List - ACL

access port

access layer

gateway

bug

vendor

vendors

forwarding

routing protocol

computer networks

Network Management Station - NMS

cloud computing

accounting management

availability

plane

route

pattern

backup

synchronization

session layer

messages layer

content layer

secure transport layer

software feature

software patch

Software Defined - SD 


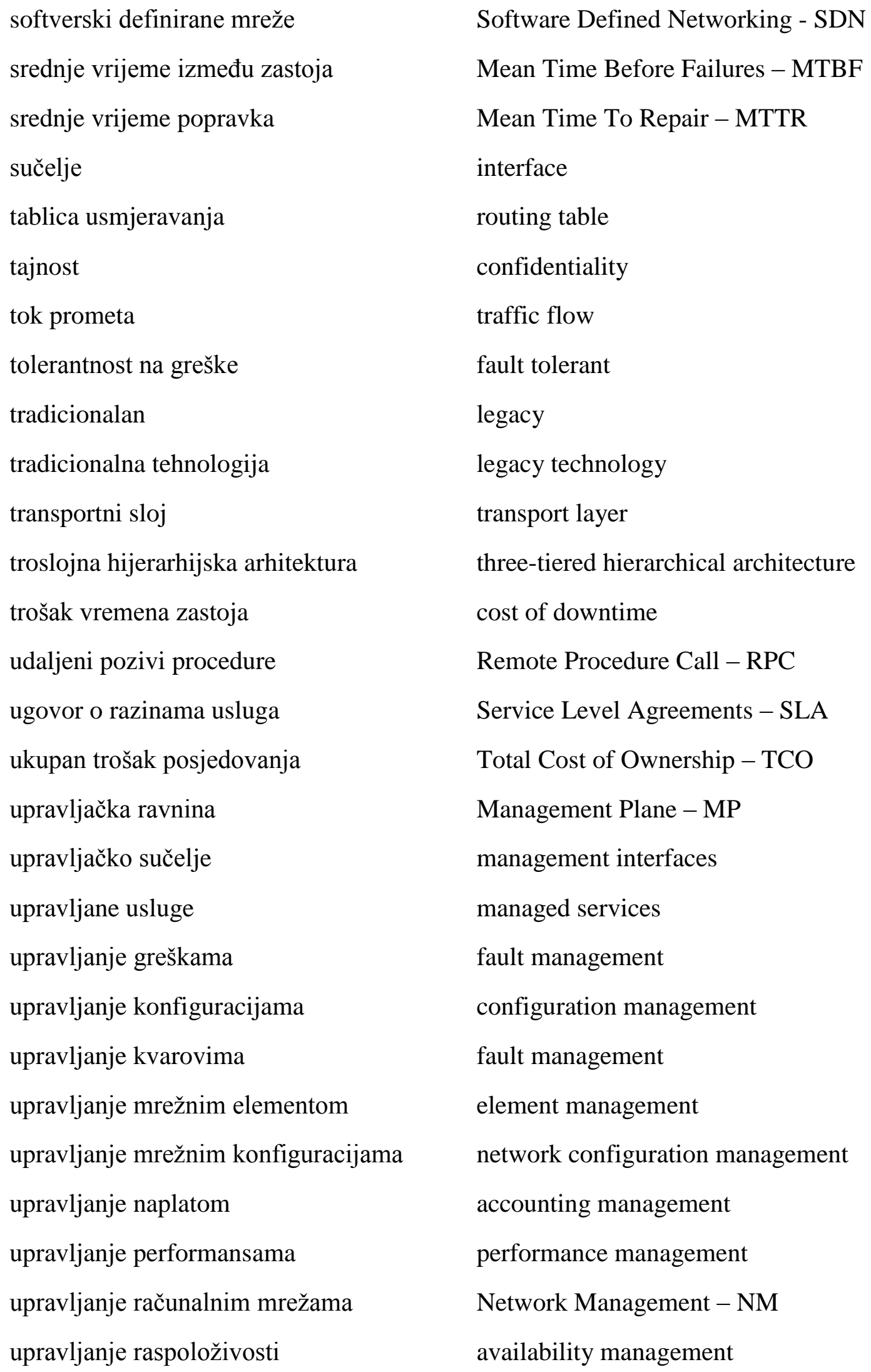




$\begin{array}{ll}\text { upravljanje sigurnošću } & \text { security management } \\ \text { upravljanje uslugama informacijske } & \text { Information Technology Service Management } \\ \text { tehnologije } & \text { - ITSM } \\ \text { upravljanje uslugom } & \text { service management } \\ \text { uređaji u pripremi } & \text { standby equipment } \\ \text { usmjeravanje } & \text { routing } \\ \text { usmjernik } & \text { router } \\ \text { vatrozid } & \text { firewall } \\ \text { virtualizacija mrežnih funkcija } & \text { Network Functions Virtualization - NFV } \\ \text { virtualni terminal } & \text { Virtual Terminal - VT } \\ \text { visoka raspoloživost } & \text { High Availability - HA } \\ \text { vlasnički (nestandardni) } & \text { proprietary } \\ \text { vrijeme zastoja } & \text { downtime } \\ \text { vrste podataka } & \text { data types } \\ \text { zeleno umrežavanje } & \text { green networking } \\ \text { znakovno komandno korisničko sučelje } & \text { character-based command-line interface } \\ \text { zrnatost } & \text { granularity }\end{array}$




\section{Popis kratica i akronima}

\begin{tabular}{|c|c|}
\hline Kratica: & Značenje: \\
\hline ACI & Application Centric Infrastructure \\
\hline ACL & Access Control Lists \\
\hline ANSI & American National Standards Institute \\
\hline AP & Application Plane \\
\hline API & Application Programming Interface \\
\hline APIC & Application Policy Infrastructure Controller \\
\hline ASF & Apache Software Foundation \\
\hline ASN.1 & Abstract Syntax Notation One \\
\hline $\mathrm{BC}$ & Business Continuity \\
\hline BER & Basic Encoding Rules \\
\hline BGP & Border Gateway Protocol \\
\hline CAL & Control Abstraction Layer \\
\hline CIA & Confidentiality, Integrity, Availability \\
\hline CLI & Comand Line Interface \\
\hline $\mathrm{CP}$ & Control Plane \\
\hline CPSI & Control-Plane Southbound Interface \\
\hline CPU & Central Processing Unit \\
\hline DAL & Device and resource Abstraction Layer \\
\hline DevOps & Development and Operations \\
\hline DR & Default Route \\
\hline DR & Disaster Recovery \\
\hline EIA & Electronic Industries Alliance \\
\hline
\end{tabular}


EIA/TIA

EIGRP

EXOS

FCAPS

FP

FTP

FTPd

GUI

HA

HPE

HSRP

HTML

HTTP

HTTPS

IANA

ICMP

ICT

IEC

IEEE

IETF

IGP

IOS

IoT

IP

IPC

IPFIX

IPv4
The Electronics Industry Alliance/Telecommunications Industry

Association

Enhanced Interior Gateway Routing Protocol

Extreme Operating System

Fault, Configuration, Accounting, Performance, Security

Forwarding Plane

File Transfer Protocol

FTP Daemon

Graphical User Interface

High Availability

Hewlett Packard Enterprise

Hot Standby Router Protocol

HyperText Markup Language

Hypertext Transfer Protocol

HTTP Secure

Internet Assigned Numbers Authority

Internet Control Message Protocol

Information and Communication Technologies

International Electrotechnical Commission

Institute of Electrical and Electronics Engineers

Internet Engineering Task Force

Interior Gateway Protocols

Internetwork Operating System

Internet of Things

Internet Protocol

Inter-Process Communication

Internet Protocol Flow Information Export

IP version 4 
IPv6

ISO

ISP

IT

ITIL

ITSM

ITU

JSON

JUNOS

L2

L3

L4

LAN

MAC

MAL

MAN

MDP

MIB

MP

MPSI

MTBF

MTTR

NETCONF

NFV

NM

NMS

NSAL

NSF
IP version 6

International Organization for Standardization

Internet Service Provider

Information Technology

Information Technology Infrastructure Library

Information Technology Service Management

International Telecommunication Union

JavaScript Object Notation

Juniper Operating System

Layer 2 (OSI model)

Layer 3 (OSI model)

Layer 4 (OSI model)

Local Area Network

Medium Access Control

Management Abstraction Layer

Metropolitan Area Network

Model Driven Programmability

Management Information Base

Management Plane

Management-Plane Southbound Interface

Mean Time Before Failures

Mean Time To Repair

Network Configuration Protocol

Network Functions Virtualization

Network Management

Network Management System

Network Services Abstraction Layer

Nonstop Forwarding 


\begin{tabular}{|c|c|}
\hline ONF & Open Networking Foundation \\
\hline $\mathrm{OP}$ & Operational Plane \\
\hline OS & Operating System \\
\hline OSI & Open System Interconnection \\
\hline OSPF & Open Shortest Path First \\
\hline PDU & Protocol Data Unit \\
\hline PSTN & Public Switched Telephone Network \\
\hline QoS & Quality of Service \\
\hline $\mathrm{R} / \mathrm{S}$ & Router/Switch \\
\hline RFC & Request For Comment \\
\hline $\mathrm{RPC}$ & Remote Procedure Call \\
\hline RSTP & Rapid Spanning Tree Protocol \\
\hline RT & Routing table \\
\hline SD & Software Defined \\
\hline SDDN & Software-Defined Data Center \\
\hline SDN & Software Defined Networking \\
\hline SLA & Service Level Agreements \\
\hline SNMP & Simple Network Management Protocol \\
\hline SNMPv3 & Simple Network Management Protocol version 3 \\
\hline SP & Service Provider \\
\hline SP & Source Port \\
\hline SPoF & Single Point of Failure \\
\hline SSH & Secure Shell \\
\hline SSH & Secure Shell Protocol \\
\hline SSL & Secure Sockets Layer \\
\hline SSO & Stateful Switchover \\
\hline TCO & Total Cost of Ownership \\
\hline TCP & Transmission Control Protocol \\
\hline
\end{tabular}


telnetd

TFTP

TIA

TLS

TMN

UDLD

UDP

URI

URL

USD

VDC

VLAN

$\mathrm{VM}$

VoIP

VRRP

VT

WAN

WDM

WLAN

WWW

XHTTP

XID

XML

XPath

YANG

ZTP
Telnet Daemon

Trivial File Transfer Protocol

Telecommunications Industry Association

Transport Layer Security

Telecommunications Management Network

Unidirectional Link Detection

User Datagram Protocol

Uniform Resource Identifier

Uniform Resource Locator

United States Dollar

Virtual Data Center

Virtual LAN

Virtual Machines

Voice over IP

Virtual Router Redundancy Protocol

Virtual Terminal

Wide Area Network

Wave Division Multiplex

Wireless Local Area Network

World Wide Web

Extended Hypertext Transfer Protocol

Exchange Identification

Extensible Markup Language

XML Path Language

Yet Another Next Generation

Zero Touch Provisioning 


\section{Životopis}

\section{Davorin Valenčić}

Rođen je 28.05.1963. u Osijeku. Osnovnu i srednju školu završio je u Osijeku.

Obrazovanje (kronološki od novijeg k starijem datumu):

- Magistar informatičkih znanosti - završen CEFRIEL (Sveučilište "Politecnico di Milano", Italija) poslijediplomski znanstveni studij Informatike, istraživačko područje Transmisijski sustavi, rujan 1991. - lipanj 1992.

- Diplomirani inženjer elektrotehnike - završen Elektrotehnički fakultet (Sveučilište u Zagrebu), smjer Telekomunikacije i informatika, rujan 1983. - veljača 1989.

Radna mjesta (kronološki od novijeg k starijem datumu):

- Veleučilište Velika Gorica (VVG), radno mjesto Viši predavač visoke škole i voditelj Cisco akademije za mrežne tehnologije, travanj 2011. - do danas.

- Honorarni ICT konzultant i povremeni predavač (predmet „Računalne mreže“ i drugi predmeti vezani uz Informacijske i komunikacijske tehnologije) na različitim visokim školama: u RH (RITEH u Rijeci, VSITE Zagreb i Visokoj školi primijenjenog računarstva u Zagrebu), svibanj 2004. - do danas.

- Veleučilište "Nikola Tesla" (Gospić), radno mjesto predavač visoke škole i pročelnik Poslovnog odjela, studeni 2007. - ožujak 2011.

- “Cisco Systems” (Zagreb), radno mjesto Sistem-inženjera za mrežne tehnologije, srpanj 2006. - listopad 2007. 
- "Extreme Networks" (Utrecht, Nizozemska), radno mjesto Senior-inženjera u Europskom eskalacijskom centru, svibanj 2002. - travanj 2004.

- "Energis N.V." (Rotterdam, Nizozemska), radno mjesto Senior Datacom inženjer u Timu za dizajn i inženjering, listopad 2001. - travanj 2002.

- "Cisco Systems Int. BV" (Amsterdam, Nizozemska), radno mjesto inženjera konzultanta za mreže u Timu za napredne mrežne usluge, ožujak1999. - rujan 2001.

- “3Com Corporation” (Nieuwegein, Nizozemska), radno mjesto inženjera tehničke podrške u Timu za mreže računala u 3Comovom europskom centru za tehničku podršku, siječanj 1996 - veljača 1999.

- "Zucchetti srl” (Lodi, Italija), radno mjesto menadžera za razvoj telekomunikacijskih usluga, lipanj 1992. - prosinac 1995.

- "HPT“ Hrvatske Telekomunikacije (Osijek, Hrvatska), radno mjesto inženjera za komutaciju u Odjelu za razvoj, rujan 1989. - rujan 1991.

\section{Certifikati:}

- Cisco Certified Internetworking Expert in R/S - Routing and Switching (CCIE \#6511) - od 26. studenog 2000. (aktivan)

- Cisco Certified Academy Instructor (CCAI) - CCNA, CCNA Security, CCNP - od 15. srpnja 2009. (aktivan)

- Certified Cisco Systems Instructor (CCSI) - od 15. svibnja 2009.

- $\quad$ Extreme Networks Specialist (ENS) - od lipnja 2002.

- Juniper Networks Certified Internet Specialist (JNCIS-M) - od 20. prosinca 2001.

\section{Nagrade i priznanja:}


- 2014. godine: priznanje za najbolje provođenje CCNA programa (“CCNA Curricula Excellence”) u 30 zemalja (u konkurenciji oko 1800 Cisco akademija ) srednje Europe, Rusije i CIS-a (zemalja istočne Europe).

- 2015., 2014. i 2012. godine: status ekspertnog instruktora Cisco mrežne akademije (engl. Expert Level instructor excellence) - po rezultatima među 10\% najboljih instruktora Cisco akademije u svijetu.

- 2013. godine: status naprednog instruktora Cisco mrežne akademije (engl. Advanced Level instructor excellence) - po rezultatima među 25\% najboljih instruktora Cisco akademije u svijetu.

\section{Objavljeni radovi}

Objavljena su dva udžbenika:

1. Valenčić D., Valić B. 2019. Usmjernici i preklopnici: osnovni protokoli $i$ konfiguracija, izdavač Veleučilište Velika Gorica, ISBN 978-953-7716-88-2, (u tisku).

2. Lebinac V., Valenčić D. 2013. Računalne mreže, izdavač Veleučilište Velika Gorica, ISBN 978-953-7716-45-5.

Objavljeno je oko 25 znanstvenih radova i radova na međunarodnim konferencija, od kojih su sljedeći radovi u području teme doktorskog rada:

1. Valenčić D., Mateljan V. 2019. Implementation of NETCONF Protocol, Proceedings of the 42nd International Convention, Croatian Society for Information and Communication Technology, Electronics and Microelectronics MIPRO, Rijeka, (članak, znanstveni).

2. Franetić F., Valenčić, D. 2019 Nadzor i upravljanje računalne mreže davatelja usluga, Zbornik radova, 12. Međunarodna konferencija "Dani kriznog upravljanja“, Veleučilište Velika Gorica, Šibenik. 
3. Valić B., Valenčić D. 2019. OpenDayLight kontroler u softverski definiranoj mreži, Zbornik radova, 12. Međunarodna konferencija "Dani kriznog upravljanja“, Veleučilište Velika Gorica, Šibenik.

4. Marković S., Valenčić D., Valić B. 2018. Visoka raspoloživost preklopnika u troslojnom hijerarhijskom modelu računalnih mreža, Zbornik radova, 11. Međunarodna konferencija "Dani kriznog upravljanja“, Veleučilište Velika Gorica, Velika Gorica, 2018., (pregledni rad, znanstveni).

5. Gaća K., Valenčić D., Kažović D. 2017. Identificiranje rizika projekta proširenja javne bežične mreže grada Zagreba, Zbornik radova, 10. Međunarodna konferencija "Dani kriznog upravljanja“, Veleučilište Velika Gorica, Velika Gorica, znanstveni rad, str. 460-473, Zagreb, 2017., ISBN: 978-953-7716-77-6.

6. Valenčić D., Čulina B., Hruška T. 2016. Zaštita računalnih mrežnih uređaja pomoću pristupnih lista $i$ modalne logike, Zbornik radova, 9. Međunarodna konferencija "Dani kriznog upravljanja“, Split, (pregledni rad, znanstveni).

7. Kažović D., Valenčić, D., Radošević, I. 2016. Primjena ITIL standarda $u$ upravljanju kriznim situacijama IT sustava, Zbornik radova, 11. Međunarodna konferencija "Dani kriznog upravljanja“, Veleučilište Velika Gorica, Velika Gorica.

8. Galac M., Valenčić D.. 2015. Trendovi u izgradnji podatkovnih centara $u$ Hrvatskoj, Proceedings of the 38th International Convention, Croatian Society for Information and Communication Technology, Electronics and Microelectronics MIPRO, Rijeka, (članak, znanstveni).

9. Marinić Z, Valenčić D., Radošević I. 2014. FHRP protokoli za visoku dostupnost $i$ izbjegavanje katastrofe u lokalnim računalnim mrežama, Zbornik radova, 7. Međunarodna konferencija "Dani kriznog upravljanja“, Veleučilište Velika Gorica, Velika Gorica, 2014., str. 1441 - 1456, ISBN 978-953-7716-56-1.

10. Valenčić D., Lebinac V., Skendžić A. 2013. Developments and current trends in Ethernet technology, Proceedings of the 36th International Convention, Croatian Society for Information and Communication Technology, Electronics and Microelectronics - MIPRO, Rijeka, str. 507 - 512, ISBN: 978-953-233-074-8, (članak, znanstveni). 
11. Kažović D., Valenčić D. 2013. Upravljanje kriznim situacijama kao dio uspješnog projektnog upravljanja, Zbornik radova, 6. Međunarodna konferencija "Dani kriznog upravljanja“, Veleučilište Velika Gorica, Velika Gorica, str. 598-616, Zagreb., ISBN: 978-953-7716-18-9

12. Valenčić D., Kažović D., Radovan A. 2013. OpenProj - open source softverski alat za upravljanje IT projektima, Proceedings of the 36th International Convention, Croatian Society for Information and Communication Technology, Electronics and Microelectronics - MIPRO, Rijeka, 2013. str. 987 - 991, ISBN: 978-953-233-074-8, (članak, znanstveni).

13. Ivanković D., Valenčić D. 2013. Primjena POE i VDI tehnologija za povećanje raspoloživosti IT sustava u kriznim situacijama, Zbornik radova, VI. Međunarodna konferencija "Dani kriznog upravljanja“, Veleučilište Velika Gorica, Velika Gorica, 2013., znanstveni rad, str. 1393-1409, Zagreb, ISBN: 978-953-7716-18-9.

14. Kažović D., Valenčić D. 2013. Using Microsoft Project for Project Management in Non-Governmental Organisations, Proceedings of the 36th International Convention, Croatian Society for Information and Communication Technology, Electronics and Microelectronics - MIPRO, Rijeka, str. 811 - 814, ISBN: 978-953233-074-8, (članak, znanstveni).

15. Valenčić D., Ćavar I., Lebinac V. 2012. Provedba oporavka od katastrofe u računalstvu u oblaku, Zbornik radova, 5. Međunarodna konferencija "Dani kriznog upravljanja“،, Veleučilište Velika Gorica, Velika Gorica, str. 675 - 693, ISBN 978-953-7716-31-8., (pregledni rad, znanstveni).

16. Valenčić D., Ćavar I., Zimet J. 2012. Visoka raspoloživost računalnih mreža, Zbornik radova, 5. Međunarodna konferencija "Dani kriznog upravljanja“, Veleučilište Velika Gorica, Velika Gorica, str. 695 - 719, ISBN 978-953-771631-8., (pregledni rad, znanstveni).

17. Cavar, I., Valencic, D. 2011. Applicability of Analytical Tree Search Algorithms in Network Routing, Annals of DAAAM for 2011 \& Proceedings of the 22nd International DAAAM Symposium, ISBN 978-3-901509-83-4, ISSN 1726-9679, str. 1319-1320, DAAAM International, Vienna, Austria, (članak, znanstveni). 